\title{
Demography and health in early medieval Maastricht: Prosopographical observations on two cemeteries
}

Citation for published version (APA):

Panhuysen, R. G. A. M. (2005). Demography and health in early medieval Maastricht: Prosopographical observations on two cemeteries. [Doctoral Thesis, Maastricht University]. Maastricht University. https://doi.org/10.26481/dis.20051215rp

Document status and date:

Published: 01/01/2005

DOI:

10.26481/dis.20051215rp

Document Version:

Publisher's PDF, also known as Version of record

\section{Please check the document version of this publication:}

- A submitted manuscript is the version of the article upon submission and before peer-review. There can be important differences between the submitted version and the official published version of record.

People interested in the research are advised to contact the author for the final version of the publication, or visit the DOI to the publisher's website.

- The final author version and the galley proof are versions of the publication after peer review.

- The final published version features the final layout of the paper including the volume, issue and page numbers.

Link to publication

\footnotetext{
General rights rights.

- You may freely distribute the URL identifying the publication in the public portal. please follow below link for the End User Agreement:

www.umlib.nl/taverne-license

Take down policy

If you believe that this document breaches copyright please contact us at:

repository@maastrichtuniversity.nl

providing details and we will investigate your claim.
}

Copyright and moral rights for the publications made accessible in the public portal are retained by the authors and/or other copyright owners and it is a condition of accessing publications that users recognise and abide by the legal requirements associated with these

- Users may download and print one copy of any publication from the public portal for the purpose of private study or research.

- You may not further distribute the material or use it for any profit-making activity or commercial gain

If the publication is distributed under the terms of Article $25 \mathrm{fa}$ of the Dutch Copyright Act, indicated by the "Taverne" license above, 
Demography and health in early medieval Maastricht

Prosopographical observations on two cemeteries 

Demogrophy and health In eard) medieval Marst richt

\section{Prosopographica observations on wo centeterites}

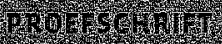

7.t.

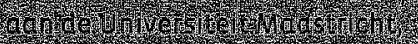
5.717.6.

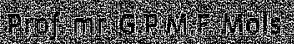

tw

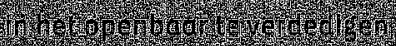

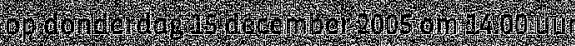
16)
}

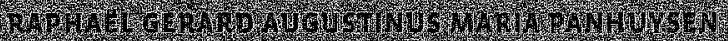




\section{ironing}

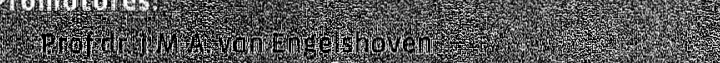
7r 1 (6)

\section{Throndrats}

사.

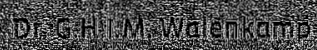

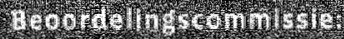

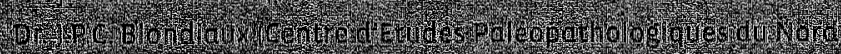

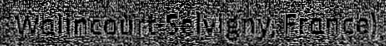

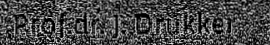

T(6)

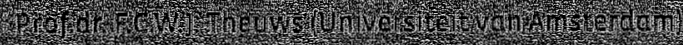


Voor Marijke

(28 mei 1938 - 24 jul 1998) 


\section{Contents}

\section{Introduction}

2 Historical and archaeological setting Geography and prehistory

Late Roman Maastricht (circa 300-480 AD)

Merovingian Maastricht (circa 480-700 AD)

The Frankish revolution

Merovingian Madstricht as a regional centre

The archeoology

Caralingian Maastricht (circa 700950 AD)

From Austrasia to Lotharingia

Mastricht and the Arrulfing pippinid dyrasty

Central place

The archaeology

\section{Archeological description of the} Servaas and Boschstraat site

Cemeteries in late Roman and early medieval Maastricht

Graphic representation of the cemeteries

Grave types

History of the Servaas church site

Topography

Periodisation of the Servads site

The cella phase (circa 350-480 AD)

Deweloment of the late Roman cemetery

Cella memoriate

Grave types, grave goods and skeletal

arrangement

cemetery layout
28
The templum phase (circa $480-700 \mathrm{AD}$ )

Combinuation of the cemetery

The construction of a templum magnum

Grave types

Grave goods

Cemetery llayout

The bosilica phase (eirca 700-950)

The construction of the basitca

The date of the basilica

Grove types and cemetery layout

Boschstraat site

Excavation history

Topogrophy

A merowingian settement and cemetery

Grave types and cemetery layoul

orientation of the inhunation graves

Grave goods

Resume Boschstractionste

Skeletal arrangement of the burials

Typo-chronology of grave types at the

Servaas church site

The ciassification of individuals by

burial status

\section{Material: survival and recovery of the} human skeletal remains

Recovery procedures

Laboratory procedures

Calculation of completeness rates and recovery percentages 
Number of individuals and completeness $\quad 120$

Relative survival and recovery $\quad 123$

Preservation of bone tissue 126

Relative survival and recovery: results $\quad 128$

Taphonomic properties of burial types $\quad 29$

Bone loss caused by human activity

Consequences of variation in relative survival and recovery

Differential loss of nonadul skeletons

Differential lass of skelletal elements

Consequences for further analys is

Conclusions

5. Methods

Physical anthropological methods

Determination of sex

Estimation of age at death

stature estimation

Population variability in non-metric traits

Paleopathology

Dentition

Data registration and statistical analysis

\section{Results}

Demography

Sex

Sexratio

Agre:

Non adults

Aduilts
Age distribution in intervals

158

Mean age at death 159

Population variability

Cronial measurements 263

Post-cranial measurements 2163

Stature estimation $\quad 968$

Non-metrical variation $\quad 170$ 
7 Dlscussion 213

Introduction 214

General characteristics of physical

anthropological and paleopathological

data

$\operatorname{sex}$

Age at death

Age of non adults

Agge of odull trs

Stature

Metric and non-metric variation

The effect of stress and disease

pathology

considerations regarding the

representativeness of the skeletal remains 223

The composition of the orignal popuation 224

The cella phase 226

Plysical antropoloty and paleppathology 228

Aralysis a the ostatogical dalain context 233

Conctistion:

The templum phase

Rejerence populations

Prysical antropology and pateopathology

Spatial distribution

conclusion

The basillica phase

Referenesopulations

physical antropology ard paleopathology
Spatiol distribution 260

Conclusion 265

The Bosichstraat cemetery 266

Reference populations 267

Physical antropology and paleopathology 267

Health 272

Spatial distribution 275

Conclusion 277

Preferential burhal and funerary migration $\quad 277$

The Servas church sice 279

The Boschstraat site $\quad 280$

Complementary cemeteries in Manstricht 282

Diachronic chages in life conditions at the Servatius cemetery in Marastricht 293

The cella templum transition 285

The templumbasilica transition 287

Status related differences in health 288

8 Concllusion 293 

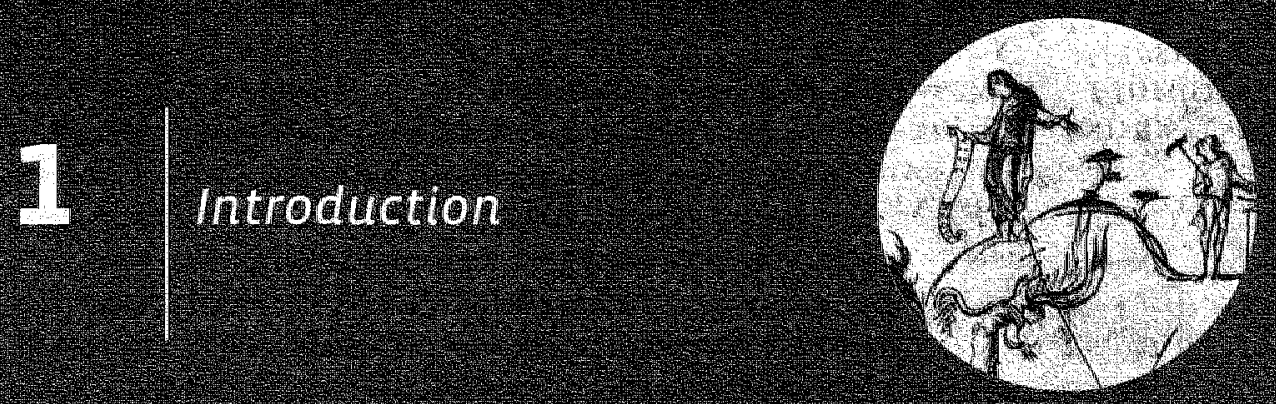


\section{1 Introduction}

In 634 AD the deacon Grimo from Verdun made his will. Among the many beneficiaries named in his testament, we find the "lepers of Maastricht" to whom he donated one of his possessions." Gemerally, this is interpreted as a donation ta a leper house or a xenodochium. In the early medieval period a xenodochium was a hospital or hospice for foreigners, pilgrims, paupers and the sick. This remark in Grimo"s testament informs us about the presence of leprosin in Maastricht and it suggests there was organised care for these lepers. Grimo's testament is one of the oldest textual sources of information on the health of the inhabitants of Maastricht. For the early medieval period a few glimpses are all there is ${ }^{3}$ In this respect Maastricht, an important centre during the early medieval period, is not an exception. Despite the adwances that have been made in the historiography of early medieval Europe, we still know little about the actual living conditions and health situation during that period. The aim of this study is to learn more about the living conditions of the early medieval inhabitants of Maastricht. Because of the scarcity of written sources, it was necessary to consult an alternative type of source: human skeletal remains.

Since the beginning of the twentieth century the way historians approach the past has changed considerably. Next to traditional topics like religious and political history, man as an individual or as a member of a group has moved to the centre of attention. Gradually interest in dailly life, in man's fears, joys and other aspects has grown. The study of history now often includes elements of disciplines like sociology, economy, cultural anthropology or psychology. At the same time a change took place in the type of sources that are used. Texts are nolonger the sole source of information. Paintings, buildings, works of art, also every-day objects and archaeoliogical findings contribute to the image of the past. Still, even in the best cases, when it comes to a description of living conditions in early medieval Europe, most theories are based on circumstantial evidence or extrapolation. For the early medieval period written and other types of sources tell us little about biological aspects of life, like child mortality, mean age at death, propulation growth, status related differences in health, etc. Moreover, the sources on these

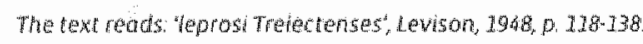

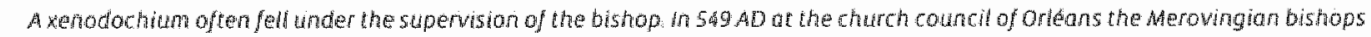
issued a canom indicating that the organisotion of the care for the siak and imprisoned was considered to be one of the episcapal

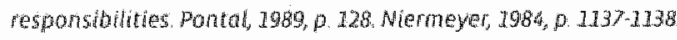

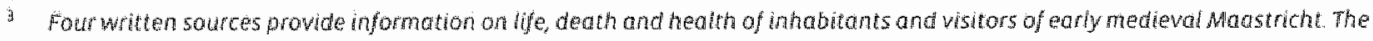
didest source is group of five in scribed christion tombstones on these stones from the ffith and sixth centuries AD in severat cases

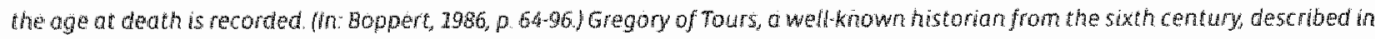
Mis historian libridecen the death of bishop serwatius Gregory writes that the bishop suffered from a slight fever when he arrived

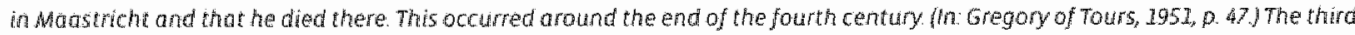

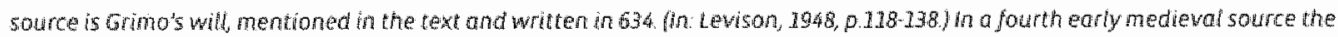

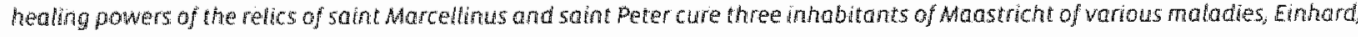
$1987,0.2614$ 
subjects are not only scarce, they are also not available for every region. Because of the unequal geographical distribution and paucity of data discerning geographical and chronological variation is almost impossible.

No wonder that leafing through handbooks and monographs on the early mediewal perlod we find little about the biological aspect of history. Most authors of reference works on early medieval Europe only dedicate some general remarks to demography or health. Others avold the topic altogether. ${ }^{4}$ Those that endeavour to discuss biological matters come across serious difficulties. An example of the problem can be found in George Duby's: 'The early growth of the European economy", originally published in 1973. When he argued that famine remained a permaneint threat in Europe during the seventh and eighth century, Duby used as evidence a written source mentioning a great famine among the Gavls in 580 AD and mortality figures calculated for tenth and eleventh century Hungarians. ${ }^{5}$ This illustrates the scarcity of sources and especially the lack of physical anthropological data at the time. Duby had to extrapolate these findings to the period of his interest and he implicitly considered evidence from Hungary representative for the whole of Europe. Nevertheless, his decision to use skeletal data can be regarded as an early application of osteoarchaeological data in mainstream history.

Duby's example has nat been followed on a large scale in the historiography of early medieval Europe. This is not the result of a lack of skeletall data. Human skeletons have been studied methodically since the nineteenth century. Traditionally, anthropometry and racial differences were the principal topics: Since the second World War, physical anthropologists and palaeopathologists increasingly focus their osteological studies on the conditions of life in the past: They collect demogiraphical information and try to determine the health situation of ancient populations. Because of a lack of communication between the disciplines, the influence of recent physical anthropological and palaeopathological investigations an historical literature has been limited. Such studies had more effect on archaeologicall literature. Several archaeological monographs on specific sites include physical anthropological data in an appendix. "Physical anthropological reports are also published in arehaeological journals." Because human sketetal remains are often presented in exhibitions, various exhibition catalogues devote some pages to the results of physical anthropological and.

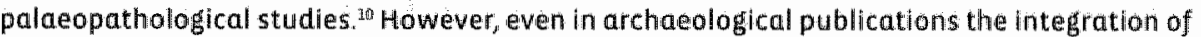

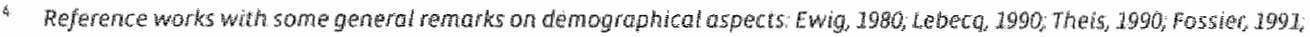

Mckiterick 1995.

Duby 1979,29

Eg. see introductory in Roberts, 1995 and Aufderheide, 1998.

R. Pantuysen, $1995,0.263-266$.

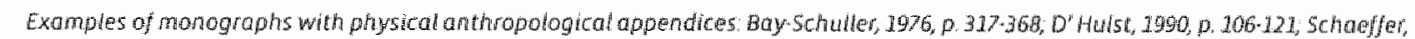
1963.

9. E. Plet et al, $1990,0.3-140$ jonssenj, $1970,0.2942$

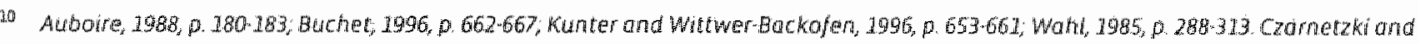
coworkers organised an exhibition that was exclusively dewored to the study of early medieval tuman remans czamerkit al 1989. 
archaeologica findings and osteological data is a process that still seems to be in its initial stage.:

As indicated above, historians have hardly used skeletal data as a genuine source of Information on liwing conditions in early medieval Europe. Until now historians have sought the answer to questions of demography and health in documentapy sources (E. Carolingian polyptychsl and field dato (E.g. the size of houses and settlements or the extent of land used for agriculture) skeletal data of er an opportunity to extend our knowledge of the living conditions in early medieval Europe. Excavated human remains are a direct source of information on matters of demagraphy and health. ${ }^{33}$ Physical anthropological and palaeopathological investigation of these remains can produce reliable data for the study of the demographical situation and the occurrence of disease and trouma. For the early medieval period in particular, with its scarcity of written sources, a combination of skeletal, archaeological and historical data has great potential. Especially, since thumerous inhumations are often found at Merovingian and Carolimgian sites.

Like other places in the region, Maastricht is not rich in documentary sources on living conditions in the early middle Ages. ${ }^{\text {It }}$ Excavations of early medieval cemeteries in and around Maastricht however, have unearthed an alternative source. In the past fifty years considerable numbers of human skeletons from this perlad have been brought to hight by archaeolagists. The related archaeological findings and historhcal sources provide sufficient information to categorise many of these inthumations according to periad and some even by social class. Thus these skeletons are an excellent source to study diachronic and status-related differences in health and living conditions. What is special in this case is the fact that we have the opportunity to study different groups of skeletons that come from one place. So we can rule out the possibility that variation among populations is related to geographical differences. For this study, human remains found at two sites were examined. The graves at the first site, the Servaas church site, range from the second half of the fourth century until the eighteenth century. However, the majority of indiwiduals were buried there between the sixth and tenth century. These graves can be considered as typical "ad sanctos" burials, since they were all interred. around the supposed grave of Saint Servatius. Those at the second site, the Boschstraat site, date from the seventh and eighth centurles. A total of 336 skeletons from both cemeteries was examined. This study will focus on the 238 individuals that could securely be ascribed to one of

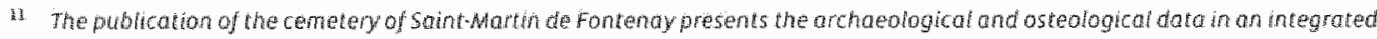

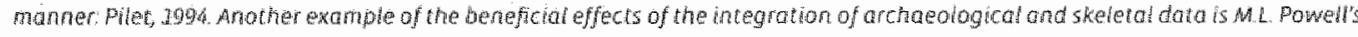

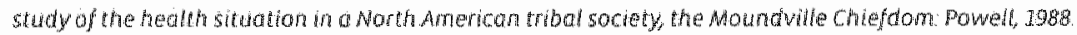
This does not mean that there is wo therawe on this subtect. Articles ard conference procedings hawe indicated the porentat of an

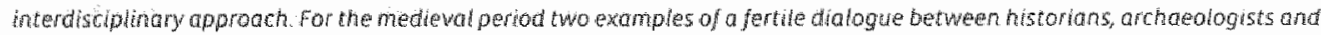

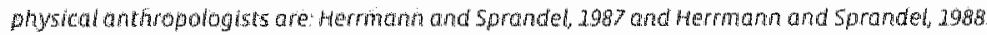

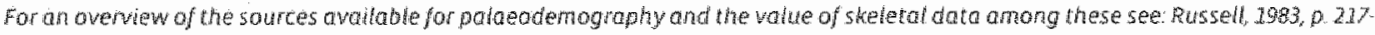
229 and Herlihy $199 \%, p, 1 \%$

14. In an owerview of all written soures relating to Mastrich between 359 and 923 AD van Dmmeren caunted 51 written sources contointing some information on Wictstritht Van ommeren, 199. 
the three periods between circa 350 and $950 \mathrm{AD}$. The number of 238 individuals incorporated in our study is rather meagre for a time span of six centuries. However, we must keep in mind that at the time settlements were much smaller. For early medieval Maastricht we have no evidence that allows for a reliable estimate of the total number of inhabitants. When we juxtapose the investigated skeletons with the estimated number of deaths in Maastricht our sample might represent around one per cent of the total number of deaths in Maastricht. Despite their small number, skeletons from the late Roman period (circa 350 480 AD) are incorporated because they were relatively well preserved and ylelded sufficient data to provide a good starting point for the study of demogiraphical developments. Human skeletal remains dated between 480 and 950 AD were found in larger amounts, allowing for statistical analysis of possible variation.

Skeletons from later periads were found in small numbers and were ingeneral poorly preserved. Consequently, these skeletal remains were not considered appropriate ta represent the period between 950 and $1800 \mathrm{AD}$.

The first objective of this study was to collect evidence of the variation in health and disease patterns in the early medieval population. Secondly, these descriptive data were used to analyse the presence of status-related variation or chronological developments in demography and health. In addition, the characteristics of the spatial distribution of individuals were examined to learin more about the processes that determined the layout of the cemeteries. With this approach it is hoped to find answers for site-specific issues like: the presence of special burial areas for children ar women; the existence of clusters of graves for family members or social groups; the effectiveness of the prohibition on burial inside the church. In this sense the physical anthropological and palaeopathological data may be considered prosopographical observations. To evaluate the situation in Maastricht it was considered useful to compare the Maastricht populations with other early medieval skeletal series. Standard physical anthropological methods were used to collect demographical data, like sex, age, stature, metric and non-metric variation. Health-related data, e.g. Harris lines, degenerative changes and fractures, were evaluated in co-operation with a group of medical speciallsts. The archaeological findings were studied for an assessment of the status of the graves and the dating of the inhumations. The results of this assessment were used to categorise the skeletal datci by period and status. All skeletons were described and their features were recorded in reports per site. ${ }^{.5}$. As this study focuses on the comparison of populations, the description and discussion of skeletal data has been limited to those data that were available for a sufficient number of individuals. This means that comparisan by statistical methods had the potential to produce significant results. Or, in the case of trauma for example, the skeletal data should be illustrative and representative for a population.

some aspects of the arrangement of this book resemble the edition and publication of a written source. In chapter two the context of our source, the excavalted human remains, is described. This consists of an overview of the geographical situation and the historical and archaeological developments in and around Maastrictit from the late koman period to the end of the tenth century. Archaeological details on the Servaas site and Boschstraat site are given in

15 Rantussen, 2005 and $R$, Panhusen, 20056 
the third chapter which reviews the chronological and social classification of the graves. A detailed description of the material aspects of a manuscript is a standard and necessary component of the edition of a written text. In the same way describing the condition of the skeletal remains that were avallable for study is usefull in our case. Therefore, the quantity and quality of the skeletal material and the possible effects of post-depositional processes are discussed in chapter four. Chapter five summarises the physical anthropalogical and paldeopiathological methods. In chapter six the results of this investigation are presented. The discussion of a selection of results, considered important for the purpose of our study, can be found in chapter seven. A comparison will be made for the various aspects by group and by period. In the same chapter the spatial distribution of the sexes, age groups and pathollogical and other characteristics are analysed. The last chapter recapitulates the conclusions from the previous chapters.

The table of contents of this book illustrates that it mot only is intended as a publication of the physical anthropological evidence but also as an attempt to evaluate the information from this type of source. For this purpose, methods and data from three disciplines: history, archaeology and physical anthropology have been used. Each of these has a separate scientific approach, terminology and literature. The interaction of the various disciplines opens up a plethora of possible variables and topics to compare and discuss. This mecessitated a selection of those topics which had the best potential to provide information on possible variation in demography and health. In this respect, child mortality, growth, age at death, stature, arthropathies, dental pathology and infectious disease and a limited number of metric and nonmetric variables were considered the most promising. of course, the study of a limited number of skeletons from one place will not yield canclusive evidence for a whole region and period. Still, if this study demonstrates that the integration of data and methods culminates in a better knowledge of living conditions in early medieval Maasticht and if, through its results, this study cain contribute to the acceptance and wider use of skeletal remains as a valuable historical: source, then it will have fulfilled its goal. 


\section{Historical and setting}

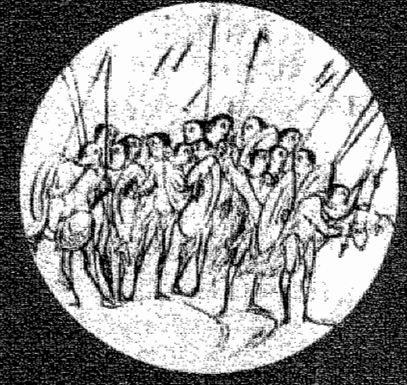




\section{Historical and archaeological setting}

In recent years archaeological excavations and critical evaluations of written sources have lead. to a resurgence of the debate on early medieval Maastricht. This debate has focused on topics related to saint servatius and the role of the church and aristocracy in the development of Maastricht. The framework of this study does not allow for an in depth discussion of all questions concerning the late Roman and early medieval history of Madastricht. Presented here is an overview of the developments in late Roman and early medieval Mastricht based on available historical hiterature. References to a more camplete account of the historical and archaeological developments can be found in the text below. Van Ommeren's compilation of the available documentary sources concerning Maastricht between 359 and 923 AD shows that written sources are relatively scarce.1.7 Fortunately, during the last 50 years archaeological excavations at early medieval si tes in Maastricht have brought to light a substantial set of data. These data cannot completely compensate for the shortage of documentary evidence. Use and interpretation of the data from excavations is hampered since few of these excavations have been analysed or published in full. " Still, the information discliosed by these excavations has helped to elucidate some aspects of the early medieval history of Maastricht.

The periodisation in this chapter was set by local and regional developments and the situation at the investigated burial sites. With reference to the late Roman period (circa $300-480$ $\mathrm{AD}$ ) there is no difference to most traditional divisions. For the caesura between the following Meravingian and Caralingian periad the year $700 \mathrm{AD}$ was chosen. Around this time the Arnulfing-Pippinid dynasty, the ancestors of Charlemagne, began to establish their authority in the middle Meuse valiey, the part of the Frankish teritory to which Mastricht belonged. ${ }^{\text {on }}$ Alt though officially the Merowingian kings still ruled the whole territory of the Franks, there are

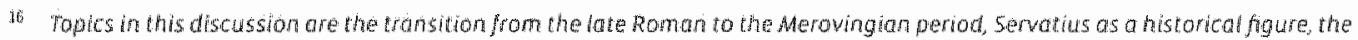
duw

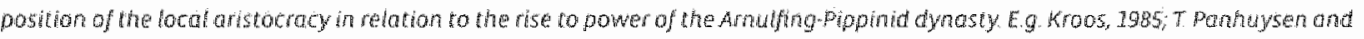

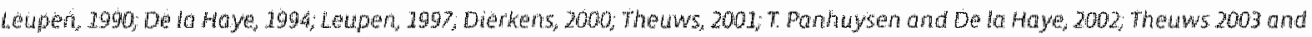

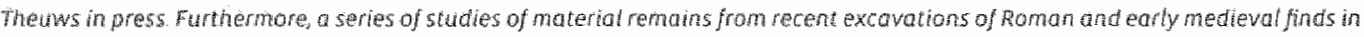

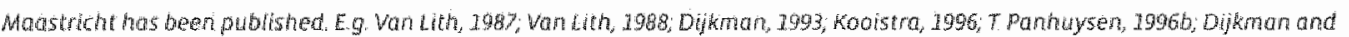
Enynck, 1998 , Bakels and bijknan, 2000

Wan Omineren, 1991

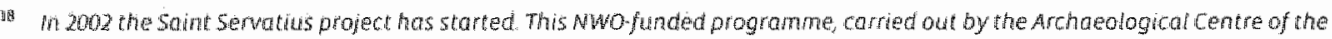

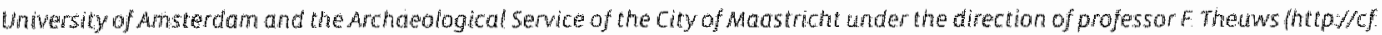

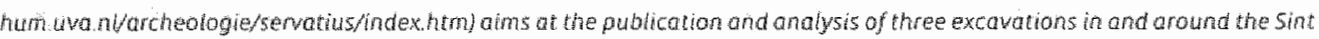
sentaskerk

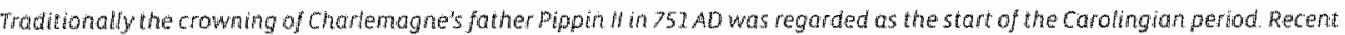
reference work more and more consider the years around 700 AD as the caestu between the periods As far as the historical aspects

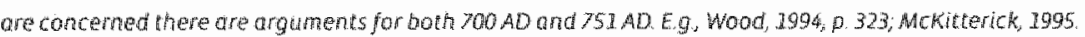


reasons to assume that the forefathers of charlemagne started to expand their influence in the middle Meuse valley around $700 \mathrm{AD}$. The archaeology of Maastricht supports the view that the situation changed around the start of the eighth century. From circa $700 \mathrm{AD}$ ecelesiastical building activities suggest the adwent of a new era, which is also reflected in a transformation in burial customs.

\section{GEOGRAPHY AND PREHISTORY}

The landscape

Nowadays Maastricht is the capital of the province Limburg, the southernmost piravince of the Netherlands. In the west the city borders directly on Belglum and in the east Germany is less than 30 kilometres away. The present frontiers are comparatively modern. Until the nineteenth century these national borders had little effect on the course of history in Maastricht During the first millemnium after Christ, the developments in Maastricht were closely rellated to events in nearby 'Belgian' and 'German' regions and places like Tangeren, Liège, Aachen, Jupille, Herstal and Stavelat-Malmédy. In fact the four regions that today co-operate in the Euregio Meuse. Rhine cover an area that prowides a suitable geographical frame for the history of Madstricht and its surroundings. ${ }^{2}$ Because Maastricht is situated in the northern foothills of the Ardennes, there is more variation in ellevation than farther north in the Netherlands. ${ }^{22}$ The city is situated on the banks of the River Meuse, which runs from the south to the north. South of the city the river valley is relatively narrow; to the narth the valley becomes broad and shallow. During the last two million years the rise of the Ardennes highlands has caused a shift of the riverbed of the Meuse from the east to the west over a distance of circa 25 kilometres. This process has resulted in a "terraced" structure of the landscape east and west of Maastricht (see figure 2-1).

At present the elevation of the city is between 48 and 52 metres above standardised sea level (in Dutch "Noirmatil Amsterdams Peil" further mentioned as NAP). In the easit, southwest and west middle and high terraces surround the city. In the east the rise of the terrain is comparatively gradual. The eastern and southeastern terraces, which slope upward from circa 60 metres to 150 metres above NAP, are foothills of the highlands of the Ardennes and the Eifel. On the left bank of the Meuse the middle and high terrace are closer to the river and the city. At that side of the river the middle terrace of Caberg even extends into the medieval city. Also near to the centre is the high terace of Sint-Pletersberg (110 metres above NAP). The River jeker approaches Maastricht from the south-west and flows between the high terrace of sintPietersberg and the city. When the Jeker reaches the almost horizontal terrain of the Meuse valley, it splits up into several branches. Before they flow into the Meuse all of these branches are united again. in the past the separate streams of the jeker created a marshy area at the southern limits of Maastricht.

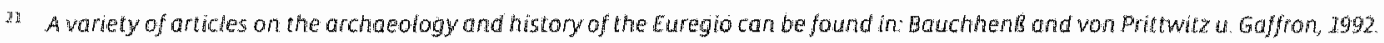

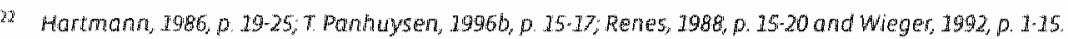




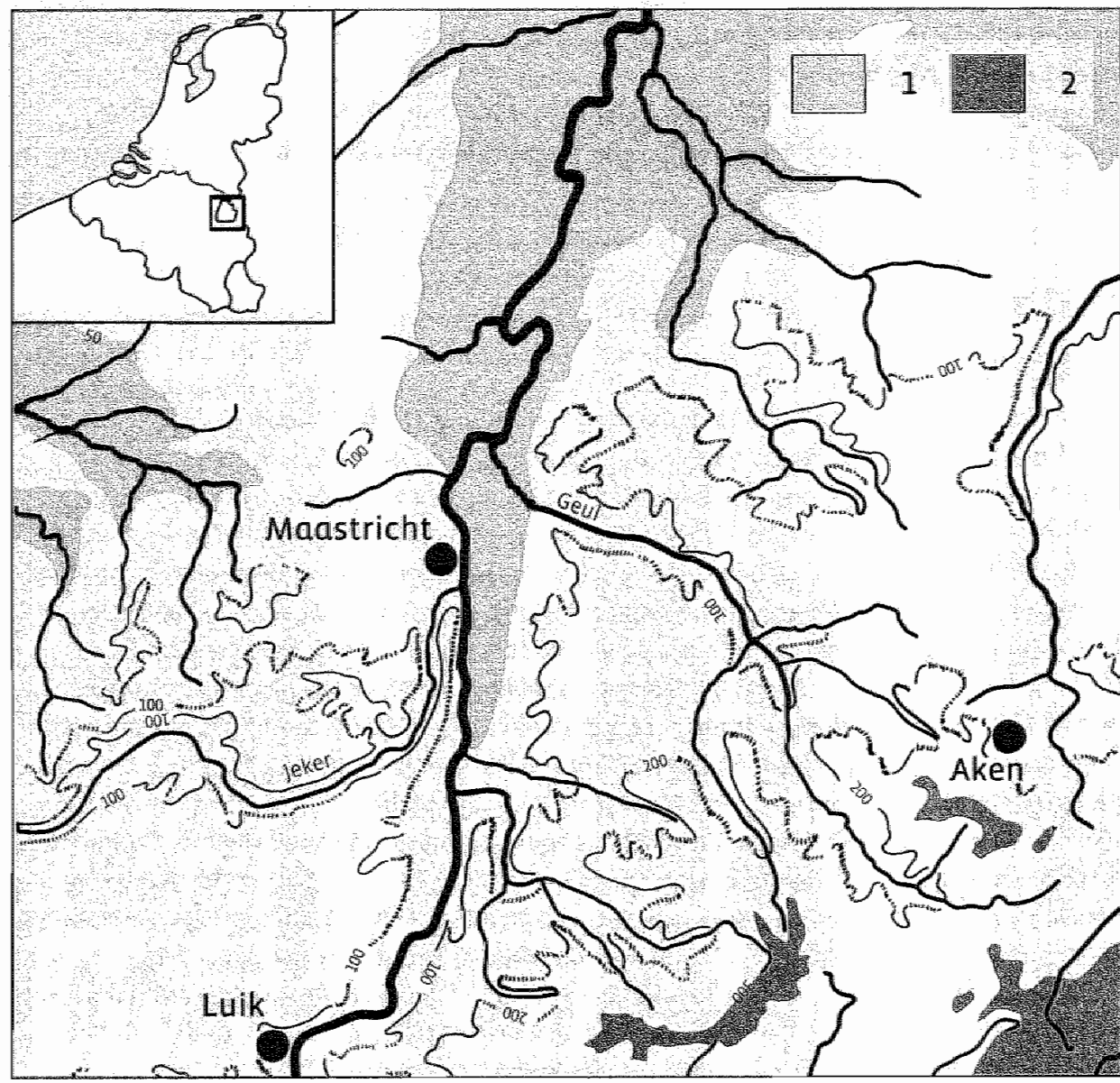

FIGURE 21 the landscope of Moastricht and enwirons. I = under 50 metres obove WAP; $2=$ between 300 and 600 metres above NAP (after T Panhuysen, 2996h; p. 16!

\section{Natural resiources}

The strategic position of Macstricht on the banks of the River Meuse determined the development of the settlement. At least since Roman times were goods transportted via this river. Because it crossed geographical obstacles like the Ardennes the Meuse was a major route of transportation in the region. ${ }^{23}$ In Maastricht a road, built by the Romans following an eastwesterly trajectory, crossed the south-north oriented waterway. Other contributing factors to the development of Maastricht were the presence of fertile soils, raw materials for building, and clay for pottery. Maastricht's soil consilsts of loamy river sediments. On higher grounds eroded 
loessiall deposits are common. Genuine un-eroded loess is found on the middle and high terraces. ${ }^{33}$ The first farmers in the region settled around $5300 \mathrm{BC}$ in the east of Limburg on loess soils. Later as agricultural tools improved, the more fertile river sediments in the valley of the Meuse were preferred. For a long period the valley of the Meuise and its tributaries were the most densely settled and cultivated area in the region. The loess soils on the more remote higher terrace southeast of Maastricht remained largely uninhabited until the twelf th century $\mathrm{AD}_{\mathrm{B}}{ }^{25}$ The fertile soil was not the only natural resaurce avalable in the area around Madastricht. For building purposes the population of Maastricht had at its disposal: marl la soft type of limestone), silex and calcium oxide concentrations (a raw material for the production of mortar found in the marsh among the streams of the Jeker). The presence of clay deposits among the river sediments favoured the local production of pottery: Ceramic vessels were produced in the river valley at least as early as $500 \mathrm{BC}{ }^{26}$ The discovery of four pottery kilns from the Merovinglan period, on the site of a nineteen th century ceramic factory, provided further proof of the amplie opportunities for the local production of ceramics.

\section{The earliest human habitation in the Maastricht area}

Human activity is attested within the present city limits from as early as 250,000 years before present. ${ }^{2 B}$ Remains from vorious younger prehistofic cultures have been excavated in recent: years. ${ }^{29}$ Archaeological findings, relating to the period immediately before the appearance of the Romans, indicate that the area morth of the confluence of the Meuse and Jeker was inlihabited during the late Iron $\mathrm{Age}_{\mathrm{j}}$ viz, since the end of the first century $\mathrm{BC}$. From the beginning of the Roman period the traces of habitation become more intensive. A raad following an eastwesterly trajectory was the most prominent feature of Roman Maastricht. Before the road appraached the riverbank it seems to have made two right-angle turns. In the vicinity of the present-day Vrijthof the road was positioned on a causeway of circa 10 metres wide and 2 metres above the original surface. The route through Maastricht connected two important Roman administrative centres: Baway in the west and Cologne in the east. Mast likely the road was constructed under Agrippa in the second decade BC ${ }^{\text {at }}$ At an early stage a bridge was built to facilitate the passage over the river Meuse. On the basis of the dendrochronological dating of wooden remains of the bridge it was assumed that there were at least three building phases.

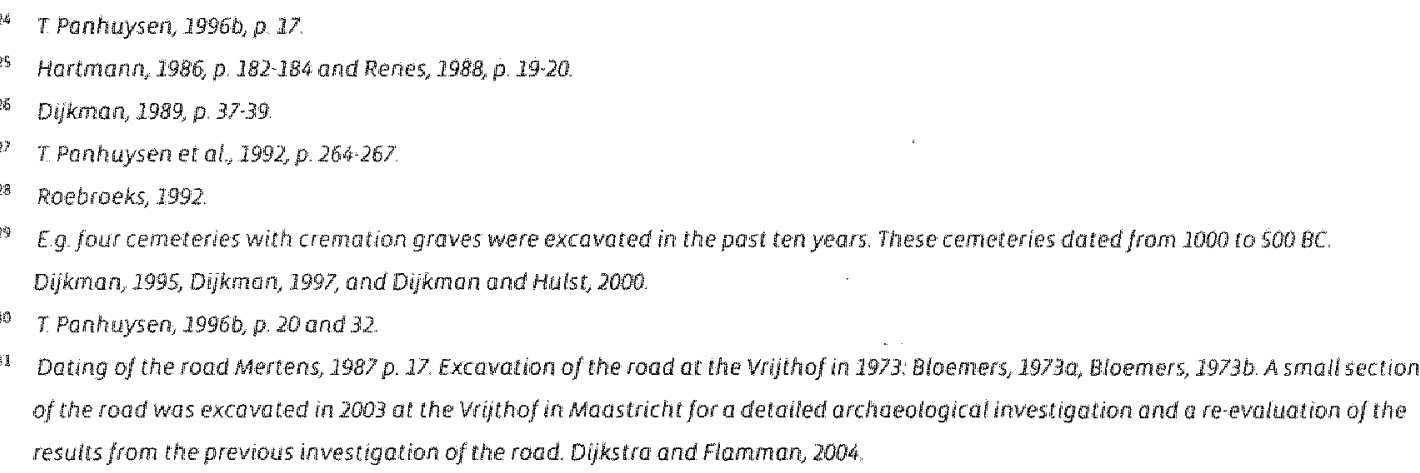


The oldest construction phase dated from the first century AD. ${ }^{32}$ Most of the traces of habitation on bath sides of the river have been discovered around the main Raman road and other intersecting roads. The local circumstances in the flat terrain adjacent to the river were not very favourable for a permanent settlement. At many locations elevation of the terrain was necessary to create suitable conditions for housing. No buildings from the first century, except some funerary monuments, appear to have been constructed of stone. During the first century most structures must have been made of perishable materials. Later, in the second and third centuries $\mathrm{AD}$; several buildings of stone were erected. Most of them were concentrated in a. small area along the river. Among building complexes in this zone the remains of a sanctuary and public baths have been excavated. ${ }^{33}$

Numerous fragments of funerary monuments from the first to the third century inform us about the function of the settlement. In a monograph on this category of finds T. Panhuysen analysed the remains of these monuments in relation to the topography of Roman Maastricht. According to his view, the monuments were placed to commemorate rich veterans of the Roman army, wealthy landowners and merchants from Maastricht and the surrounding willae. The combined evidence suggests Maastricht was a centre of trade and possibly had administrative functions as well. ${ }^{34}$ Also it served as a central place for the numerous willae in the river valley and along the roads. Around $270 \mathrm{AD}$ the scene changed abruptly. Archaeological evidence indicates the settlement was almost completely demolished. At this time Germanic peoples migrated from the east into the Roman empire. Little is known about the precise cause of the devastation of Madstricht or its fate in the sixty years between circa 270 and $330 \mathrm{AD}$. Because of its strategic position at a river clossing it is unlikely that the place was completely deserted for long. There are some indications that around $270 \mathrm{AD}$ a provisional wall was built to create a place of refuge. ${ }^{\text {ss }}$

LATE ROMAN MAASTRICHT (CIRCA 300-480 AD)

\section{Topography}

Intensive building activities mark the beginning of the late Roman period in Maastricht. In the second quarter of the fourth century the central area of the Roman settlement was cleared and surrounded by a stone wall of circa 170 by 90 metres, strengthened with ten towers ${ }^{36}$ In the literature this stronghold is often designated as a castrum. ${ }^{37}$ The fortification of Maastricht is symptomatic of the restoration of Roman authority in the provinces at the perimeter of the

32 T. Panhuysen, 19960, p. 22-25; wo5. 2002

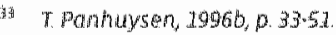

3. T. Ponhusen, 29960, 0.443.

35 T. Ponhuysen, 19966 , p. 250; T. Panhuyser, $19960,0.121226$

Dendrochronologicat doting of ock piles that ance supported the riwerside walls showed that the wowd came from trees felled in the

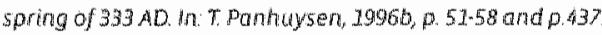


empire. It also stresses the military function of Madstricht as a stronghold on a crossroads of strategically important routes of transportation.

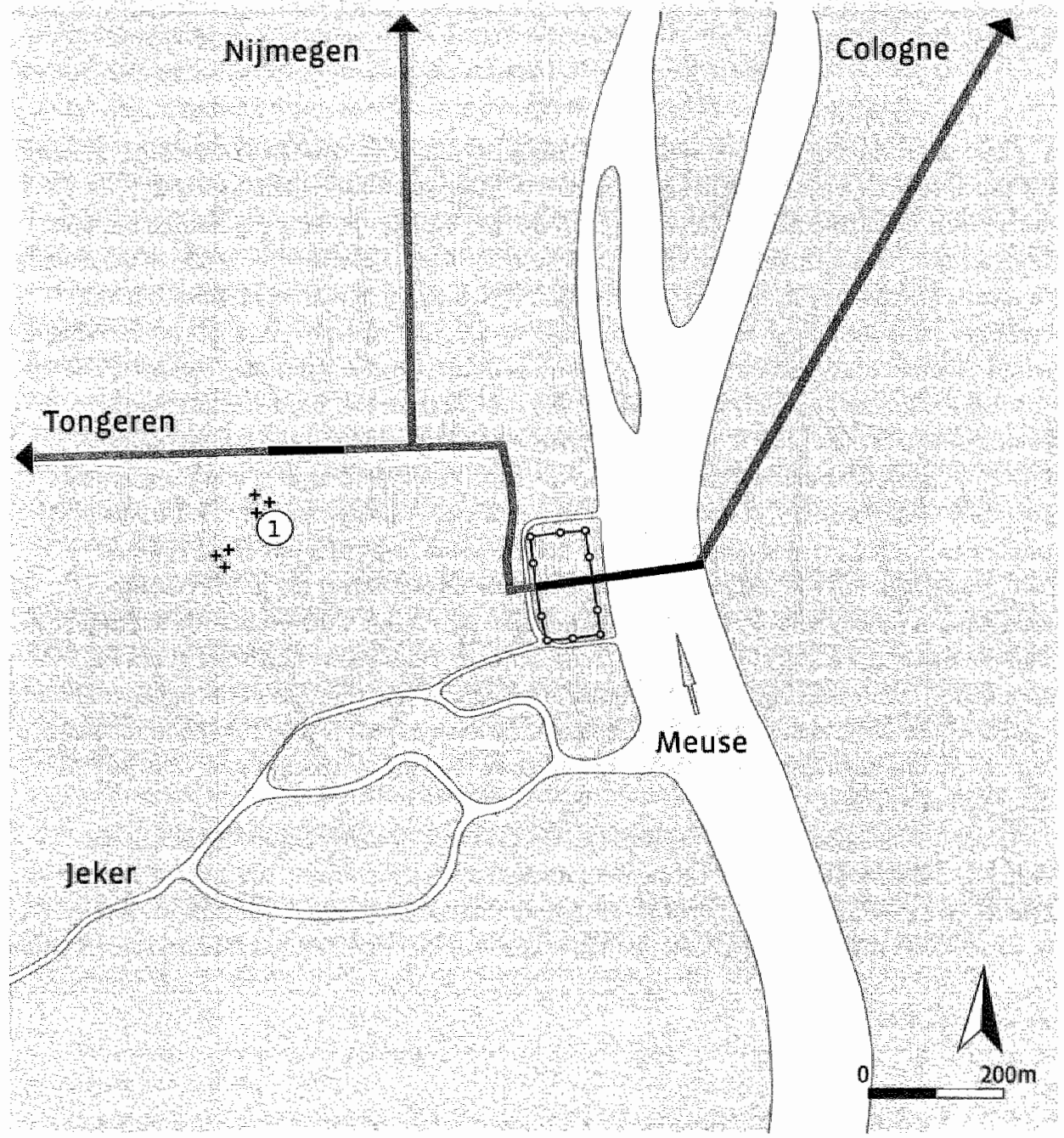

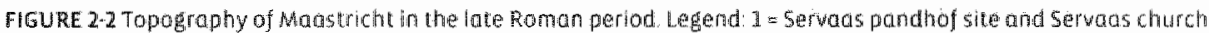

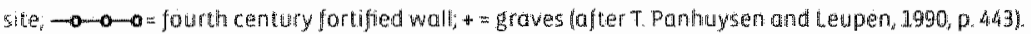

The topography of late Roman Maastricht was dominated by the same elements that had previously determined the layout of Maastricht. The roads and bidge remained in use and still formed the framework around which Maastricht evolved. On the left bank, the walled centre of 
the settlement protected the approach to the bridge. Analogous to other fortified river crossings, it is possible that a smaller fortification guarded the bridge on the right bank ${ }^{39}$ Not only inside the fortified centre but also around the walls and allong the roads traces of intensive habitation were excavated.

\section{The ddvent of Christianity}

The spread of Christianity is a new phenomenon in the late Roman province Germania Secunda, the province to which Maastricht belonged at that time. Historical evidence for the Christianisation of Maastricht comes in part from the writings of Gregory of Tours, a bishop of Tours (France) writing in the sixth century. He describes how Servatius, the bishop of the diocese Tongeren, died on his way to Maastricht. According to Gregory, Serwatius was interred at a cemetery along the Roman road. ${ }^{* 0}$ Gregory gives no date for this event and there are no reliable written sources that mention the year of Servatius' death. However, from the records of church councils it is known Servatius was active around the middle of the fourth century, and is mentioned for the first time in $343 \mathrm{AD}$. In $359 \mathrm{AD}$ he is mentioned for the last time. ${ }^{\text {i3 }}$ Most historians assume he died before the end of the fourth century. Gregory's story concerning Servatius' visit to Maastricht and his burial near that place are interpreted as indicative of the presence of Christians in Maastricht. It is possible that Gregary's account of the death of Servatius echoes more or less the actual events in the second half of the fourth century. Nevertheless he was writing more than two hundred years later. Theuws recently has argued that the tale of the burial of Servatius in Maastricht may have been a construct of bishop Monulphus. Monulphus was a contemporary of Gregory of Tours and the burial of Servatius in Maastricht cauld have been used to legitimate the transfer of the bishop"s see from Tongeren to Maastricht and aid in the promotion of the church he built in Maastricht as the centre of the Saint Servatius cult. ${ }^{\text {s }}$

The only solid and contemporary proof for the presence of Christians in Mastricht are christian grave stones found at excavations and as building material in the present sint Servaas church. Five gravestones with Christian decorations and texts have been documented as spalia in the walls and as archaeolagical finds in the subsoil of the church of sint servaas church. These

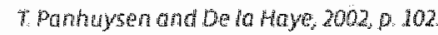

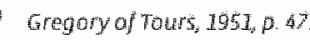

in Brennecke. 1986
}

43 The time of death of Serwatus is stil the subject of debate. Sine the seventeenth century the year 3 a AD has been designated as the year of his death However, as indicated there is ho written source to support this. Recent introductions to the discussion can be

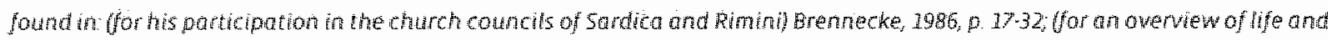

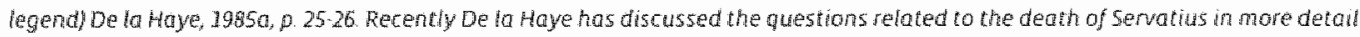
and he seems to have changed of opinion. In this articte De lo Haye argues that there may have been wo persons by the name of Senatius one of these may hove died in the fifth century De la Hoye, 2994, p. 528. A critcal review af the ewidence and literature concerving the historic figure of Servatius and the development of Maastrich during the Roman and early medieval period is presented in t Pantuysen and De la Haye, 2002 
gravestones dated from the fifth and sixth centuries $\mathrm{AD}$. The archoeological record provides further indications in support of a rather early presence of Christians in Maastricht. Changes in the burial custom in the fourth century AD may be associated with the arrival of Christianity. During the first three centuries after Christ, cremation graves were the prevalent type of burial in and around Maastricht and often grave-goods were present in these graves. ${ }^{45}$ From the fourth century on, inhumation graves without grave-goods became the standard type of burial." The largest number of inhumation graves was found at a cemetery situated south of the Roman road to Tongeren. As will be discussed in more detall in the next chapter this cemetery is also the place where Servatius was buried according to Gregory of Tours. The fourth century graves found at this site were all inhumation graves. The inhumations in the graves were placed with the head to the west and feet to the east and several were without grave-goods. The combination of these three characteristics suggests they were Christian burials. Excavations inside the fortified centre of Maastricht provided another hint of the arriwal af christianity. In this central area the archaeolagists found Samian ware (a comparatively luxurious type of pottery) decorated with Christian symbols. Judging from their context these finds date from the fifth and the first half of the sixth century. The fact that many fragments of this specific type of Samian ware were concentrated in the area where the episcopal church was supposedly situated, could be associated with the presence of Christians. ${ }^{\text {at }}$

During the late Raman period Maastricht belonged to the civitas Tungrorum; a district within the province Germania Secunda. Nearby Tongeren, a large urban centre 18 kllometres west of Maastricht, was the capital of this district at the time. As the capital of the civitas the city gave its name to the diocese and was probably the major residence of the bishop. In the fourth century Tongeren decreased in size, the length of the walls around the city was reduced from 4500 to 2800 metres. For the fifth century few traces of habitation have been found in Tongeren. Recent excavations inside the present church of Our Lady in Tongeren have brought to light the remnants of a church that might date from the fifth century. Altogether, the impression is that the size and importance of Tongeren gradually declined. Until now the exact reason for the waning of Tongeren is unknown. Depopulation and the abandonment of settlements and villiae are recorded for many places in the northern provinces. A higher mortality duie to violent incursions of Germanic peoples, migration to safer areas or the deportation of ensiaved

44 Boppert, 1986 , p. 64.95

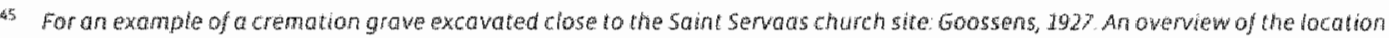
and grave types from the first to the third century AD see. TP Panhysen and De la Haye 2002 , 100 for an introduction to the shift from cremation burials to inhumation buriats and the possible associotion with chistianty see Morris, 1992 , p. 52-69 and p. 206-208. Excavations at four sites have yielded groves from this cemetery the Pandhof site Timmers, 1955 , soeters, 2989 , whe whithof site

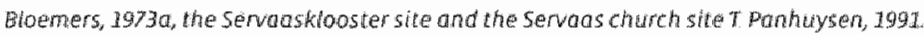
Dikman, 1993 , p. $129-172$, especially p. 258

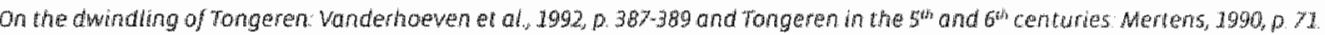
Recently in Wonderhoeven, 2002, 0.85 
inhabitants are often mentiomed as causes that led to a reduction of inhabited places. ${ }^{50}$ It has also been suggested that effective birth control may have contributed to a lower child rate in the Roman period Around the middle of the third century the depopulation seems to have affected the northern provinces of the Roman Empire. With this in mind, the invasions and forced migrations in the second half of the third and in the fourth century can also be regarded as a result af the population decline. For Maastricht nothing indicates that the population decreased. on the contrary, traces of continuous habitation since the fourth century have been found and the settlement area may even have been enlarged. ${ }^{53}$ It is possible that already by the late Romari period some of the urban and religious functions of Tongeren were transferred to Madustricht. As will be indicated below the developments in the sixth century support this theory, but for the fifth century there is no substantial evidence.

\section{Economy}

Our knowledge of the economical circumstances in late Roman Manstricht is limited. As a port and a central place for willae in the region, trade would have been impartant for the local economy. Most of these villae in the river valley and along the Roman road were focused on agriculture. In the third century the first wave of Germanic immigrants caused a disruption of occupation and production at many villae. Furthermore this caused a decline in the number of settlements. ${ }^{54}$ Excavations have further shown that in the fourth century the grounds and sometimes buildings of mast willae were re-used. Maastricht appears to have been one of the surwiving or reviving central places where the agricultural products from the remaining villae could be traded. ${ }^{\text {s. }}$ This idea is corroborated by the excavation of a large rectangullar Roman

5f Werner, $7973,0.289$. The scarcity of sautces and their geagraphicat dispersion impedes progress in the field of historical demography As a result no reliabte figures are avaloble on the size of the poputation and population density in the fate Roman period parkin, 1992, 2. 60466

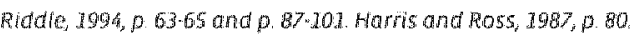

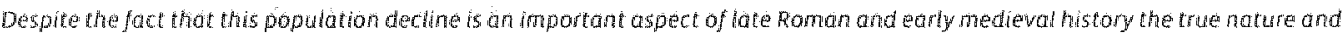

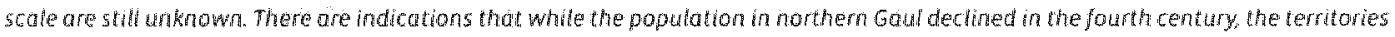
an the rght bonk of the Rhine saw no decrease in population it cannot be excluded that these fronkish grounds were aven

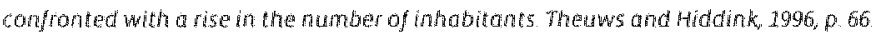

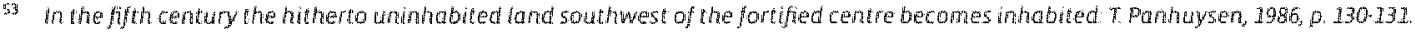

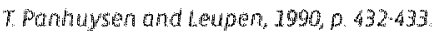

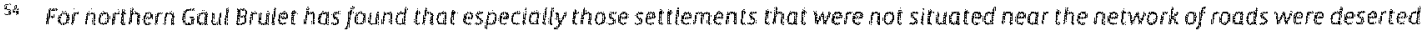

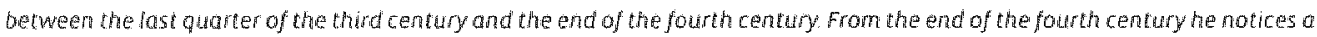

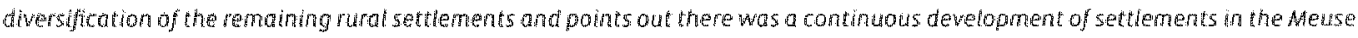

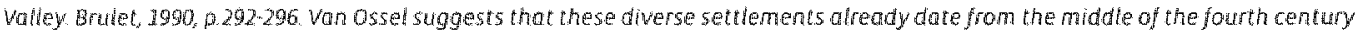
ADand were new foundations adapted to the changing areamstances Van Dssel, $1992,0.171284$

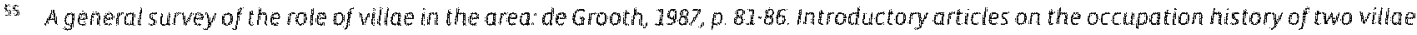
in whe region indicote what happened in the rurat area around Mastricht. For Neenaren Reakern a villa of moderata size a few

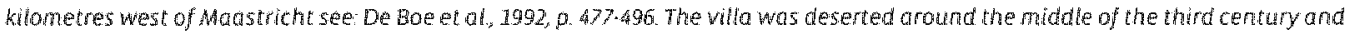

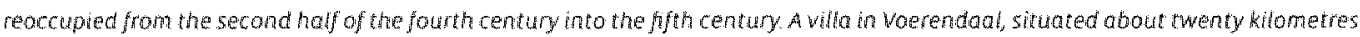


building within the walled centre of fourth century Maastricht. Most likely this is a horretum i building designed for the storage of grain, often found in a military context. ${ }^{\text {s }}$ Ceramics and. glass from areas like northern France were excavated in Maastricht, showing the existence of long distance exchange in the first three centuries $A D$. ${ }^{7}$ Trade intensity possibly diminished in the fourth and fifth centuries due to the depopulation of other cities and rural areas. There are no reasons to assume production and commerce came to a halt entirely. The local manufacture of Samian ware, attested for the fifth century, also suggests there was at least a reglonal market for more luxurious products. 5.8

\section{The inhabitants}

Judging from the transformation of Maastricht into a stronghold the Romans must have felt that the strategical sittation had changed. Nollonger could they leave Maastricht; on the crossroads of an important waterway and the route that connected Cologne with its Roman hinterland, without solid protection. In the fourth century Cologne, the capital of the province Germania Secunda, faced a growing population of Germanic tribes along the eastern border of the prowince. ${ }^{59}$ Traditionally historians assume that most "barbarians" entered the Roman Empire either as laeti or as foederati Laeti were people of Germanic origin who were captured during military actions mostly in the late third and early fourth century. They were forced to work as farmers in depopulated areas and had military duties as well. Foederati were groups or sometimes whole tribes who settled within the empire as federates. Often they formed units in the auxiliary army, under the leadersh ip of their awn rulers. ${ }^{60}$ Although other Germanic tribes passed through the northern part of the empire, the Franks were the most prominent tribe to settle in the area. Traditionally they were divided in two main groups: the Rhine Franks and the Salian Franks. ${ }^{61}$ The Rhine Franks lived in the fourth century on the right bank of the Rhine. During the same period the Salian Franks settled within the Roman Empire. In 35.8 AD emperar

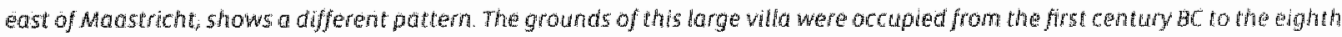
rentury AD in Willems, 192, p. $526-534$.

T. Ponhuysen, 1996b, 0. 5961, Bakels and Dijknan, $2000, p .27$

Difknan, 1992, p 375,376

Dikmian, $2992,368-370$

Thewws ond Hiddink, $1996,0.66$

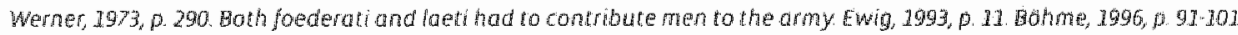

In contrast to the Solian Franks, who seem to have formed one tribe, the Rhine franks were a conglomerate of tribes that had settled in the lower Rhine region. Today the distinction between Rhine and salian frants is considered to be af hthle relewance. older written

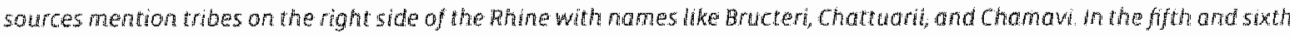
centuries the tribes west of the Rhine accur in the sonrces as Ripuario, Masuorit, Hasbanienses. These names were often as sociated

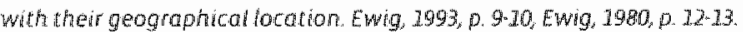


Jullian $(355-361 \mathrm{AD})^{62}$ allowed the Salian Franks to remain in Toxandria, a region circa 50 kilometres northwest of Maastricht. ${ }^{33}$

No unequivocal archaeological evidence for the presence of persons from Germanic origin has been found for fourth century Masastricht. In the fourth century after three centuries of Roman presence the population in and around the fortification may still have consisted mostly of Gallo-Ramans. When exactiy the first Germanic people settled in Marastricht can only be learned from archaeological findings or from future provenance studies of the human skeletal remains. The aldest indication for the presence of people of Germanic origin in Maastricht comes from a Christian gravestone inseribed with a Germanic name. According to W. Boppert this stone was placed in the second half of the fifth or the early sixth century. A second gravestone dates from the sixth century. The names on these stones, Alwuefa and Felegaridus show that either people of Germanic origin were buried in Maastricht, or Germanic names were in usage by the local population of Maastricht. ${ }^{5}$ In both cases this accurrence of Germanic names makes it plausible that at least by the end of the fifth century people of Germanic arigin had settled in or around Maastricht. Support for this assumption comes from a grave excavated close to the place where the gravestones have been found. Ypey has shown that the decoration of the sword sheath found in this grave typologically belongs to a group found mainly in the present Belglan province of Namur. He dates the object, decorated with a human head between stylised birdheads, to the second half of the fifth century and mentions that the decoration is considered of Germanic origin. ${ }^{56}$ Still, the find of such an object cannot be considered absolute proof of the ethnic affiliation of the individual in the grave.

Altogether, the archaeological evidence does not resolve the matter of the actual arrival of people of Germanic origim. Both the tombstones, the re-emergence of grave-goods and the ethnic context of these grave-goods suggest individuals of Germanic origin were buried in Maastricht by the end of the fifth century. Still, the evidence is indirect and the Germanic names and grave goods may also indicate a change in fashion or an adaptation to the fact that Germanic groups acquired administrative control over the region. on the other hand the above-mentioned finds of Samian ware suggest local culture was also continued at least to the fifth century. The traditional assumption that ethnic groups might be recognised on the basis of grave goods and anthropometrical data seems highly unlikely. In view of the evidence that Germanic people entered the empire as farmers or soldiers from as early as the end of the third century, we may assume that they mixed with the Gallo-Roman poptlation long before the end of the fifth

tha In this study for widely known hwstorical higures anghicised personal nomes wibl be used whenever avaloble. For less well known persons latin names will be used fif possite, the years when a person was in function will be placed behnd hisher name between brackets, when arson is mentoned in the text for the first time.

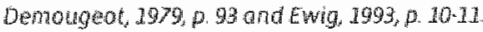

Ba

65 Recenty the name Boto was added the the of Germanic names from Maastriche This name was mentioned on a sword found in an early Merowingion grave and is though ta be the name of the owner of the sword Dikman, 2003. Ypey, 1985, p. 6.9. in the same article Ypey (p. 2-6) describes a bronze decoration from a bett, doting from the midde of the fifth century Unjortunate by this find from Moostriche was not found in an archoological context. 
century. Therefore, it is plausible that a heterogeneous population with Gallo-Roman and Germanic elements populated Madstricht. The long history of contact among these three ethnic groups, their mobility and possibly their own heterogeneity make it highly unlikely that separate ethnic groups would be recognisable through using traditional anthropological methods. Biamolecular methods and isotope analysis provide a better chance to study the provenance and genetic relations of the inhabitants of Maastricht. First generation immigrants could theoretically be recognised by studying the isotopic ratios in their bones and teeth, which is expected to be of a different signature than of persons living on the same site since birth. Detailed analysis of the ancient DNA might also shed light on the genetic composition of the population.

With respect to the social structure of the population of Maastricht we have to rely on archae logical findings. At the time of the construction of the fortification Maastricht may have been a military settlement. However, indications, other than the defensive walls and towers have never been found. There were few finds of military equipment, too few to suggest the permanent presence of military units. This might imply that Maastricht became a centre with a civilian population soon after its fortification. Sametimes an impression of the social stratification and ethnic composition can be obtained from the study af grave-goods and grave types. For late Roman Maastricht however, the prevalling customs seem to hamper such an analysis of the graves. Probably under Christian influence the inclusion of grave-goods became almost obsolete among the Gallo-Roman population. Untill now, only one cemetery from this period has been excavated. Parts of this cemetery have been found at three sites in and around the Salnt Servaas church and monastery. Late Roman graves found at these sites have yielded few grave-goods and showed little wariation in grave typie. Thus the cemetery provides no insight into social differentiation. ${ }^{67}$ Inscribed giravestones found at late Roman cemeteries $s_{j}$ for example in the province Belgica Prima, give the impression that people of all sorts were buried at Christian cemeteries. ${ }^{68}$ Morris concludes that the less privileged generally appear to be underrepresented on the gravestones. This could be an indication that people were buried at different cemeteries according to social status, but it does not rule out the possibility that they were buried at the same cemeteries. For Maastricht Soeters and T. Panhuysen assumed that the cemetery at the site of the Saint Servatius church and monastery was used to bury the "traditional Roman population and the new Germanic elite"."

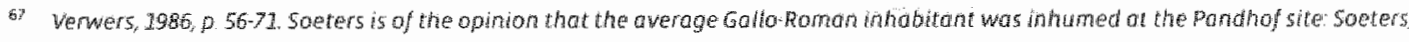
$1989, p$ d6.

wa Guthier, $29 \% 5$, pussim

is Morris, 1992, p. $164-165$.

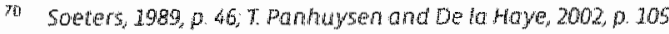




\section{THE FRANKISH REVOLUTION}

Not the deposition of emperor Romulus Augustulus in $476 \mathrm{AD}_{A}$ but the accession of Clovis (481-511 AD) in 481 AD as king of the Salian Franks best marks the beginning of a new era in northwestern Europe. Clovis reign laid the foundation for the Frankish kingdom; a political entity that would determine the course of European history in the following centuries. This kingdom was not created overnight. It was a consequence of the disintegration process of the Roman governmental system in the West. This had started decades before the enthronement of Clovis. After the murder of Emperor Valentinian III in 454 AD Raman authority gradually lost its grip on remote provinces ${ }_{n}$ as it was no longer able to defend the limits of the empire. The dissolution process did not proceed at the same pace in every part of the empire, but region after region detached. Sometimes a pro forma dependency on the Roman Empilire was continued. Several new rulers based their authority on the investment with high Roman offices. In the province of Germania Secunda the transition of authority into the hands of the Franks seems to have occurred without much turmoil.

This placid revolution was probably facilitated by the lons presence of Germanic inhabitants in the area. As indicated above since the third century Germanic groups and individuals of various tribes had settled in the northern provinces. As a result of this, the Franks, originally living east of the Rhime, are supposed to have easily integrated with the Gallo-Roman and Germanic population living west of the Rhine. Araund 440 AD they already dominated the rural areas in the provinces Germania Secunda, Belgica Prima and the northern half of Germania Prima. ${ }^{71}$ After the middle of the fifth century they seem to have established themselves in urban centres as well. At that time the Frankish elite completed the gradual take-over of secular authority. Their territory occurs in the sources as Francia rinensis." Mastricht also belonged to Francia rinensis. Just like Namur and Dinant it was situated on the western border. The southern limit of Francla rinens is lay around Mainz and Toul. To the east the border was formed by the lands right of the Rhine, from whence the Rhine Franks came. In the north their territory ended with the Betuwe. ${ }^{2}$ Gregory of Tours, writing about the settlement of the Franks in the lands west of the Rhine, clescribes how they appointed kings in the various pagi and civitates. Ewig interprets his remarks as an indication that in the second half of the fifth century the political landscape of Francia rinensis consisted of a collection of small kingdoms. 50-called regales or "petty kings" ruled territorles that covered former Roman administrative units like civitates and pagl. At an early stage there also was a tendency to concentrate power over larger reglons. Colog ne, the ancient Roman metropolis, apparently surpassed the other kingdoms and became

Both Brulet and wan ossel have noticed the appearance of a different type of settlement in this area that remained in use into the early medieval period Brulet, 1990 and van 0sse, 2992 . It seems plausible that these new settements with activites in the manufacture of meral, anter objects, portery and glass were a consequence of the intensification of habitation. Ewig. 1980,0 . 910

E. ENig, $1993,0.16$ 
the central place from where Francia rinensis was ruled. Around the end of the fifth century Calogne was the residence of the only known king of Francia rinensis, siglbert.

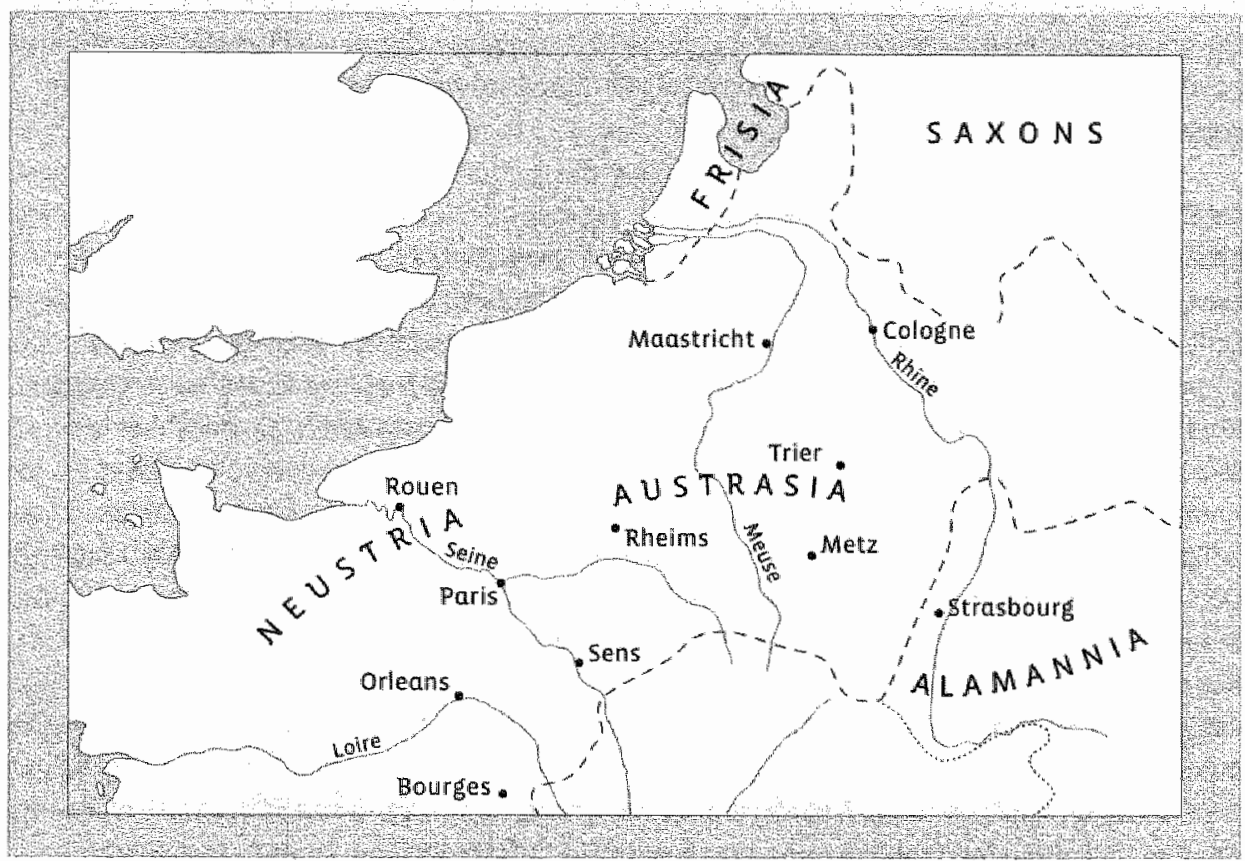

FlGUPE 2-3 The central and northern part of the Frankish kirggaom, C $600 \mathrm{AD}$.

Between 509 and 511 AD machinations of king Clovis of the Salian Franks (482-511 AD) led to the murder of both king Sigibert of Francia rinensis and Sigibert's son Chloderic. This resulted in Chavis' usurpation of the throne in Francia rinensis. ${ }^{\text {?t5 }}$. With this manaeuvre Clovis united the territories of the Franks. Soon after the unification of the two frankish kingdoms Clovis died. After his death the kingdom was divided among his sons. The various parts were reunited after the extinction of the respective branches of the family. This occurred several times during the Merovingian period. As all divisions were followed by re-unification, francia rinensis remained a part of the Frankish kingdom until the dissolution of the Carolinglan Empire in the ninth century. Between $482 \mathrm{AD}$ and $639 \mathrm{AD}$ the political history of the Merovingian kingdom was dominated by the kings and their entourage. After the death of Dagobert $1(638 / 9)$ the influence of the maior domus, originally a high official at the royal court, increased until this dignitary prevailed over the king. By the end of the seventh century the Arnulfing-Pippinid family acquired enough authority to use the office of maior domus to rule the whole Frankish kingdom. Around that time the northern part of the kingdam consisted of two large regions: Neustria and 
Austrasia. Neustria was the heartland of the Merovingian dymasty, consisting of the Seine valley and Northern France. The other region Austrasia was a political entity that had developed in the eastern part of the Frankish kingdom. It consisted of the territories of Francia rinensis. Despite the ethnically mixed population, a sense of unity had evolved in this part of the kingdiom. This development lead to Austrasia becoming a counterweight to Neustria around the end of the sixth century.

\section{MEROVINGIAN MAASTRIGHT AS A REGIONRL CENTRE}

The assessment of the position of Maastricht during the period of Frankish settlement in the territories west of the Rhine remains troublesome. Reliable documentary sources are missing. Only since the second half of the sixth century does Maastricht appear in the dacumentary sources. On the basis of these sources we may assume that Maastricht was a regional centre in Austrasia, with religious and administrative functions. This is illustrated by the fact that two Merovingian kings hell meetings in Maastricht at which they issued new laws or charters. ${ }^{p}$ Another marker of a regional centre in the Merovingian periad was the presence of a mint. Subsequent moneyers minted colns in Maastricht, establishing next to Rheims and Metz, one of the three major mints in Austrasia ${ }^{28}$ Judging from the more than 160 coins recovered from Maastricht and the relatively long series of 12 moneyers working in Maastricht, it was the most important mint in northwestern Europe. In the seventh century two of the moneyers who worked in Maastricht, Rimoaldus and Madelinus, minted virtually identical coins both in Maastricht and Dorestad. Wood has suggested that the mint in Dorestad, a large centre of trade circa 175 kilometres north of Maastricht, may have been subordinate to Maastricht. ${ }^{32}$ Another indication for a central role were the visits of the Merovingian kings to Maastricht. ${ }^{32}$ Given the fact that Merovingian kings visited Maastricht it is possible that a palatium existed in Maastricht or its immediate surroundings in Merovingian times. Hitherto no trace of such a building complex has been found.

\section{The bishops of Maastricht}

Beside the visits of kings, the presence of bishops in Maastricht also qualifies the city as a prominent centre in the reglon. The exact moment when the bishops made Maastricht their

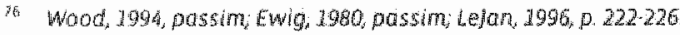

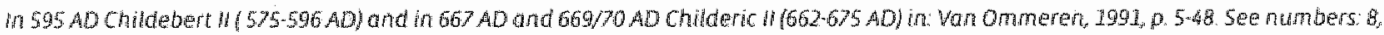
27.28

Grierson and Biackburn, $1992,0.135$ presence of a palatium. Grierson and Blackburn, 1991 1 $136-137$. Pol has shown that this interpretation of these letters on the coins of Gadefredus was inconect. 
main residence cannot be determined. Medieval chroniclers of the diocese interpreted Servatius travel to Maastricht as a relocation of the episcopal see. According to them the bishop's see remained in Maastricht from the end of the fourth century until the eighth century, when the bishops moved to nearby Liegge. It is difficult to discern fact from fiction in the avallable written sources: Therefore, modern historians have doubts about the transferral of the episcopal see and the medieval list of bishops of Maastricht ${ }^{\text {at }}$ On the list of bishops appears the symbolic number of twenty-one names. Many of these seem to have been legendary personages. Only the existence of eleven bishops can be corroborated by documentary sources. The first bishop wha is mentioned in a reliable source after servatius is bishop falco at the beginning of the sixth century. Shortly after Falco, bishop Domitianus must have been in office as a bishop of Maastricht. Domitianus attended a church council in Clermont in $535 . A D$. For circa 170 years between Servatius and Domitianus we have no reliable information on the names and numbers of bishops or where they resided. Like in other dioceses, the episcopal see may have been vacant from time to time during the fifth and first half of the sixth century." The hazy situation concerning the episcopacy does not imply a breach in Christianity in Maastricht. Inscribed tombstones and indirect indications like Christian symbols on locally produced ceramics bear witness to the presence of a Christian community ${ }^{\text {as }}$

A remark added after Domitianus' name on the list of bishops wha attended the church council of Clermont is the first indication that the Merovingian bishops of the diocese Tongeren resided in Maastricht. Later sources even indicate a change in the name of the diocese and write about the "bishop of Maastricht" ${ }^{\text {" }}$ Maastricht was certainly not the only residence of the bishops, they also resided and some were even inhumed in places like Dinant, Namur and Huy.9.9.

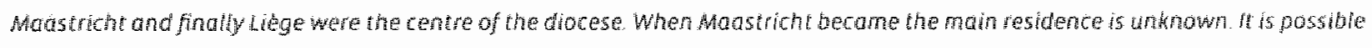

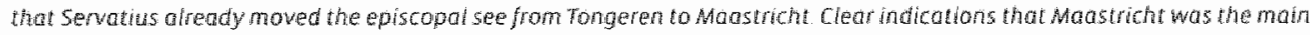

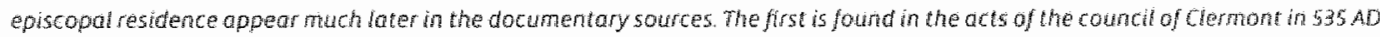

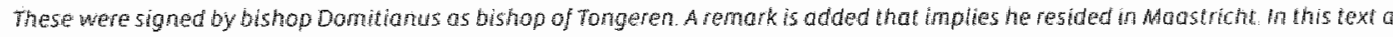

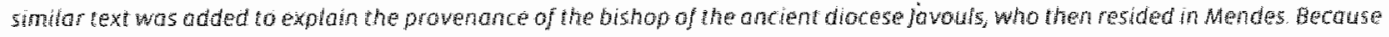

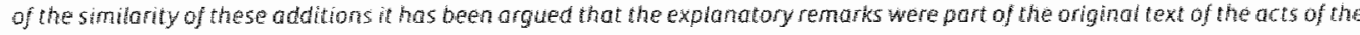

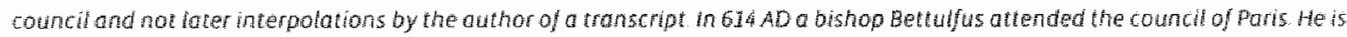

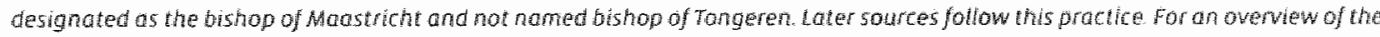

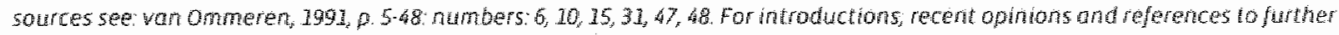

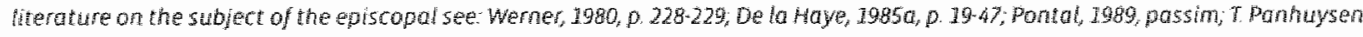

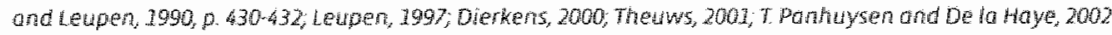

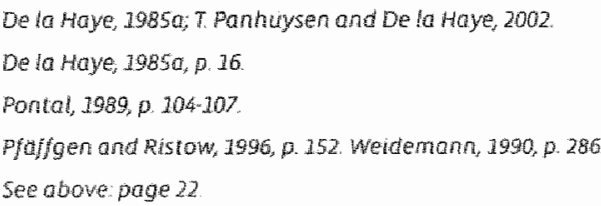


The changed name of the diocese suggests Maastricht was the principal residence of the bishops at the time. Maastricht probably remained the principal episcopal centre in the diocese until bishop Hubertus (703/706-727 AD) arranged the transilation of the corpse of his predecessor Lambertus from Maastricht to Liege. Thus Hubertus initiated a process which would eventually lead to the transfer of the episcopal see to Liege. What the infuence of the bishops on Maastricht was during the two hundred years before this transfer is hard to tell. Many saurces only mention the presence or existence of the subsequent bishops. Few texts also describe the deeds of these bishopis in Madstricht. These texts note that bishop Monulphus (between circa $549.590 \mathrm{AD}$ ) built a church near the grave of Servatius. ${ }^{97}$ Later the description of the life of bishop Lambertus informs us that bishop Lambert was educated in the entourage of his predecessor bishop Theodardus (around $670 \mathrm{AD}$ ). This may be seen as an indication of the presence of a cathedral school in the entourage of the bishop. ${ }^{3}$

\section{An administrative centre}

The teritarial division of the former civitas Tungrorum and its function in the administration is unclear for the early Merovingian period Developments in other civitates show that these remained important in the administrative system, especially as taxation districts. Each civitas was governed from a central city, where the king's officials resided and archives were kept. Often it was also the seat of the comes or graphio, the highest authority in the civitas, who was probably invested with judicial and military duties. ${ }^{95}$ The presence and activities of bishops, the presence of a venerated tomb of a saint and a funerary church in combination with the visits of kings and the minting of coins indicate that Maastricht was an important regional centre in the Merovingian period. At the same time, neighbouring Tongeren seems to have dwindled to a size that was incompatible with the functions of the centre of a civitas. Recent finds have shown that a church was built and various locations were used as a cemetery indicating Tongeren was not completely cleserted during, the fifth and sixth centuries. ${ }^{95}$ More activity was noticed in Maastricht during the same period. Maastricht appears to be the best candidate to have

Wha Lardiberti. (1919), p. 355

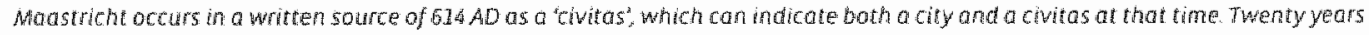
loter the wit of Grimo mentions the extstence of a Tongrinse territorio. This suggests there sitil was a notion of the ancievt civitas

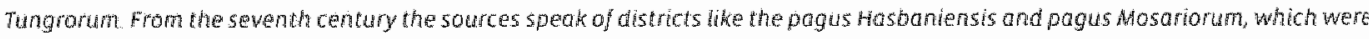
situated in the region around wastricht These pagi originated in the Astavingian perod.

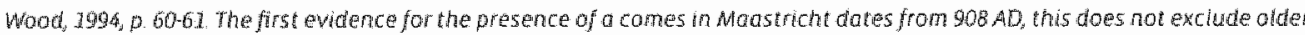
origins for this function. in fact in the eighth century hagiography of 5 t. Lambertus, bishop of waositricht, Lambertus fother bs designated as proeses in Maastricht. The meaning of this tole in the sewenth or eighth century is rather ambiguous. In generat it

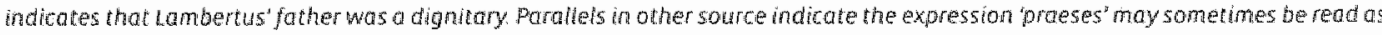

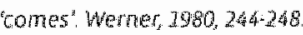


substituted Tongeren as the central place in the region. ${ }^{97}$ in the treaty of Meerssen (870 AD) a "districtus Trectis" is mentioned Several authors have interpreted this as an indication that Maastricht was the centre of a Merowingian district.

\section{THE ARCHAEOLOGY}

Reflections of the prominent position of Maastricht can be found in the archaeologlcal record. An important aspect of the archaeology of Maastricht is the continuity between the late Roman and the Merovingian period. Unlike other places, there are no signs of an intertuption in habitation between the twa periods. Another new development is the growth of the inhabited area. If Maastricht did not already have urban qualities in the late Roman period, it most likely acquired an "urban status" in the Merovingian period, hence the denomination urbs treiectinsis, "the city of Maastricht", in the written sources from this time. ${ }^{.9}$

\section{Continuous habitation}

Continuity of habitation, industrial activity and inhumation were found at several sites in Maastricht. At the Derlon site the stratigraphy revealed that the walls of the fortification remained visible until the end of the Caralingian period. During the Merovingian period the remainder of these Roman walls enclosed a space that is characterised by a very sllow stratigraphical build-up since the end of the fifth century. Around the same time a thick layer was formed during the Merovingian period. T. Panhuysen interprets this as an indication that the space inside the fortification was used for formal activities by religious or secular authorities. ${ }^{101}$ The southern half of the fortification in particular may have been used for ecclesiastical purposes. Most fragments of ceramics, decorated with Christian matifs, were found in that area. In all likelihood this was the part of Maastricht where the bishop and his entourage may have dwelt and where the oldest church can be expected Contemporaneous intensiwe habitation around the fortification caused a rapid growth of the layers in the stratigraphy. Other locations that show continued occupation during the fifth century are: Jodenstraat site, Grote Staat area, and Hondstraat site. ${ }^{162}$ For the next century there are indications that the inhabited area around the fortification and the roads expanded. New sites with traces of habitation or human activity in the sixth century are the Mabro site, Rijksarchief site and on the right bank of the Meuse the Rechtstraat site. ${ }^{103}$ Also a little further away from the fortification, new centres of activity emerged, adding to the image of expansion in Meravingian Maastricht. Approximately two kilometres south of the fortification at the Lage Kanaddilk site

\footnotetext{
Wrimer' 2980 , P. $24 \%$

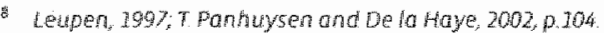

gs Gregory of Tours, $1986,5.72 \%$

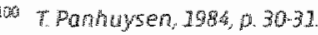

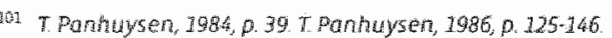

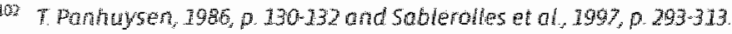

105 T. Ponhuysen, 1984, p. 71 .
} 


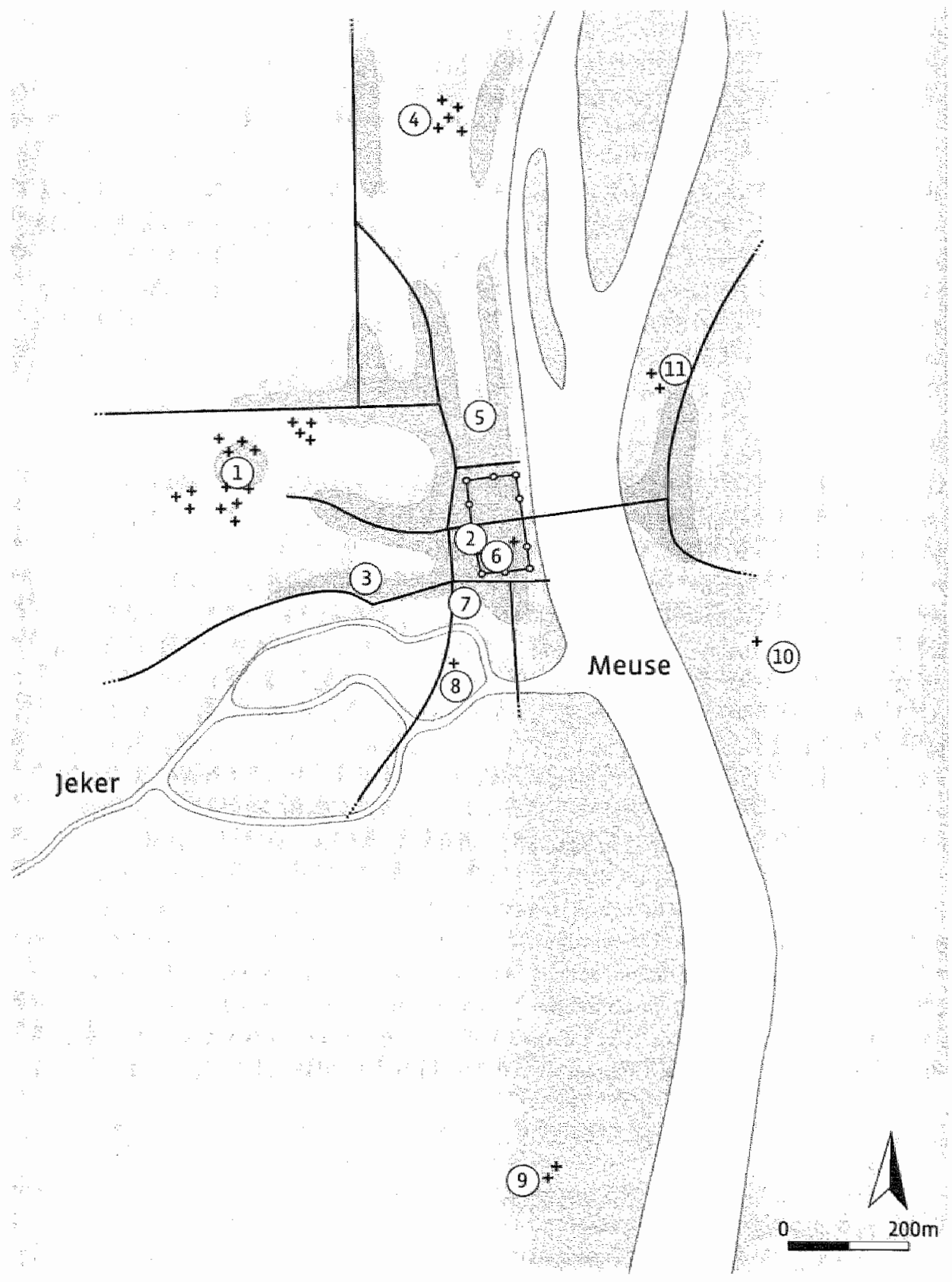

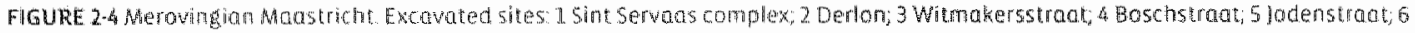

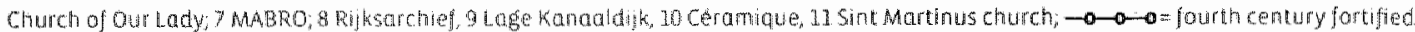

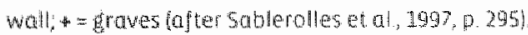


traces of habitation from the sixth and seventh centuries were excavated ${ }^{104}$ Closer to the fortification, 600 metres north, at the Boschstraat site the excavated dirt pits suggest the presence of a small settlement that originated in the seventh century. ${ }^{195}$

\section{Merovingian building activities}

Beside a few traces of the construction of houses of a more perishable nature in the aforementioned areas, there are also buildings in stone. Inherited from the Romans were the bridge and the fortification. The bridge supposedly functioned until the thirteenth century. 10 . Recently the remaining foundations of the bridge in the riverbed have been examined and surveyed. Surprisingly, no evidence was found for repair works or renewal of the foundations of the bridge after the fourth century. As indicated above, the remnants of the walls of the fortification remained visible untill the end of the Carolingian period. Some stone buildings constructed for the first time during this period have also been excavated. At the Serwans church site the remains of a church built adjacent to the grave of Servatius were recovered. There is little doubt that this church was the 'templum magnum' built by bishop Manulphus in the second half of the sixth century to replace a wooden oratory. around the stone-built church at the Servaas Pandhof site and the Servaas 5 tiftskapel site probably serwed ecclesiastical purposes as well. They may either have housed a religious community, ar accommodated the bishop and his entourage. This is an issue that will be hard to resolve as there is no documentary evidence for the existence of a religious community in Maastricht before the first half of the eight century, nor is it clear where the bishop's quarters were.

Four more buildings with a public function may have existed in Merovingian Maastricht. Some of these could have been executed in stone. A good candidate would be the old church of the Christian community in Maastricht. This church supposedly stood in the southeastern corner of the fortification. Today, a Romanesque church stands at that location, but there are indications that the present 'Church of Our Lady' replaced an older predecessor, Ino If ever there was a separate building to function as a palatium in Merovingian times it has not been stated in any of the written source nar has its position been indicated by archaeological findings.

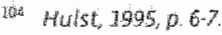

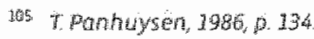

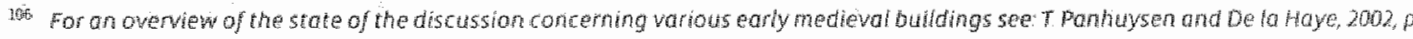
205.75

To7 T Panhusers ond Leupen, $1990,0.436-437$

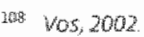

Gregory of Tours, 1985, p. 790

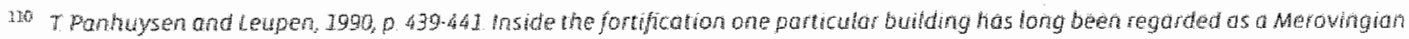

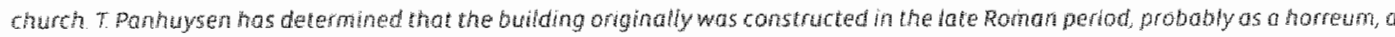

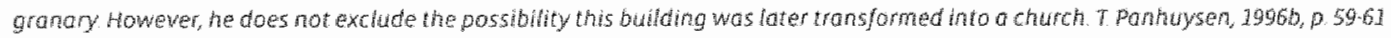

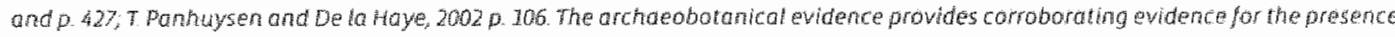
of a horreum Bokes and Dijkman, 2000, p.25.
} 
Furthermore there is the facility for the lepers of Maastricht, in all likelihood a xenodochium, mentioned in Grimo's will. Bishop Domitianus may well have founded such a xenodochium some time after 549 AD. For in that year Domitionus attended the Church council of arleans. On this accasion Merovingian bishops not only issued canons that made the care for the sick and poor one of the episcopal responsibilities, they also confirmed the creation of a xenodochium in Lyons. This meeting may well have set an example for the bishops how to provide for the needy. If indeed such a xenodochium was built in Madstricht, one of the places to expect such a facilfy would be in the vicinity of the monastic buildings found at the Servaas site. For a last building with a public function we again have to rely on assumptions and extrapoliations. Close to the east bank of the Meuse stands a church that is dedicated to St. Martin. Churches under the patronage of St. Martin often date from the early medieval period because Martin was considered the patron saint of the Franks. Furthermore, not wholly reliable reports mention the presence of Merovingian graves south of the present church. Based on this flimsy evidence the existence of a Merovingian church at the location of the present church of Saint Martin has been suggested. ${ }^{3 x}$

\section{Production centre}

At almost all sites in Merovingian Maastricht remains of the local manufacture of goods like glass beads, pottery, antler cambs and various types of metalwork were found. ${ }^{113}$ Figure 2-4 presents an overview of the distribution of these ind strial activities in Merovingian Maastricht. The scale of production and the variety of crafts is exceptional for the Merovingian period. ${ }^{23}$ Maastricht appears to have been a major production centre of goods for a local and regional market. The excawation of pottery from Maastricht's kilns on sites as far as 180 killometres to the north attested to Maastricht's role as a production centre. ${ }^{215}$ This is also in agreement with Macistricht's rolle as an important mint in Austrasia and the widespread use of its colns. With respect to food some data have been collected in recent years. Kooistra investigated 68 soil samples from late Roman and Merovingian sites in Mastricht. She did not find unequivocal evidence concerning agricul tural production in Moastricht and surroundings. However, within the boundaries of the fortification traces of food processing and storage were found. A pit containing the charred remains of spelt, a type of wheat, was found at the Wolfsstraat site. The contents of this pit dated from the seventh century $A D$. We can only speculate about the reasons for the presence of storage of grain in the centre of Maostricht. It is tempting to assume a connection with the secular ar ecclesiastical authorities within the fortification. Maybe the wheat was collected as tax, or it came from church property. Storage for trading purposes cannot be iruled out either, but this would be expected in other areas of Maastricht. Evidence of

13 Pontal, 1989 , p 128; Wood 1994, p 105

in T Ponhuysen and Letpen, 1990, p $460-441$

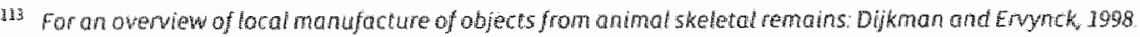

It Sablerollas et al, 2997, p $293-323$

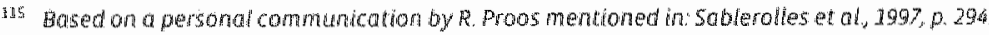

wo A second pit mas found in the wmediate suroundings: kooistra, $1996,0.27969$. 
food storage is also important in light of the physical anthropological investigation. It implies the presence of quantities of food arriving in Maastricht, possibly from its environs. This was a necessary provision to sustain a larger community. And it may possibly have guaranteed the presence of food during periods of food shortage. Further information concerning the vegetable constituents of diet in Maastricht was collected from various late Romon and early medieval sites. Bakels and Dijkman found that during the first millennium AD there was, in general, little diachronic change in the variety of grain, vegetables and fruit on hand for consumption. ${ }^{1 .}$

\section{Cemeteries}

The increase in inhabited areas is paralleled by a growth in the number of cemeteries and the number of recovered inhumations during the Merovingian period. The existing late Roman cemetery at the sites of the Servaas complex remained an important burial place. All around the Servaas church, which stands at the centre of this complex, people were inhumed. (Parts of this cemetery were excavated at the Servaas Pandhof site, Servaasklooster site, stiftskapel site, the Servaas church site and possibly the Vrijthof silte.) Precious grave-goods, found in some of these graves and grave types, like monumental tuff stone sarcophagi, illustrate the above average social pasition of a considerable proportion of these individuals. It is assumed that the presence of the supposed grave of Saint Servatius attracted "ad sanctum" burials. Leiss information is available about ather Merovingian cemeteries in Maastricht. Inside the fortification walls a few graves from the Merovingian period were recently excavated at the Onze Lieve Vrouwekerk site. ${ }^{138}$ These graves were probably located close to the old church that was used by the Christian community of Maastricht since the late Roman period. New burial places originated at several locations around the inhabited area and near various settlements in the vicinity. At the Vrijthof site, close to the Servaas complex, a separate cemetery came into existence. Some 150 graves dating from the sixth and seventh centuries were excavated at this site. ${ }^{\text {129 }}$ Approximately a century later a smaller cemetery was created at the Boschstrant site, which was used during the seventh and early eighth centuriesfor the burial of at least 54 people. Other new cemeteries were excavated at the Lage Kanaaldijk site, the Ceramique site and in Borgharen facemetery originating at the site of a Raman villa). ${ }^{22}$ Not far from Mastricht in Belgium lles the Merovingian cemetery of Rosmeer. The results of the excavation were published in 1970 , with a contribution by danssens on the physical anthropology and palaeopathology. ${ }^{\text {jax }}$ For some cemeteries there are no hard data avallable; their existence is inferred from older written reports on the presence of graves and grave goods. There is information that there were also Merovingian cemeteries on the flanks of a hill to the southwest of Maastricht, locally known as the Sint Pietersberg. ${ }^{m}$ on the right bank, the area around the church of Saint Martin is thought

\footnotetext{
wis Boketsand Dykmar, 2000 .

L T ponhugen and de la Haye 2002 p 105.

is Blomers, 19730, p. $53 \% 54$.

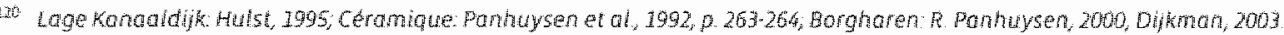

In: Jansens, 2970

in $T$ pontuysen, 1986, p. 135
} 
to be the location of a Merovingian cemetery. ${ }^{325}$ As indicated above, most cemeteries show a change in the burial custom. Unlike the sober late Roman graves, a considerable nu mber of graves from the sixth and seventh centuries contained grave-goods. Various objects such as like utensils, jewellery and weapons were found in the graves. The wariation in the use of graven goods both among and within the cemeteries allows us insight into the composition of the population at the time.

\section{The Merovingian population}

\section{Population growth}

Many places in the region show a distuption or a decrease in occupation between the fifth and first half of the seventh century. However, this trend is not present in all areas; in the region around Maastricht some sites hawe shown that certain areas went through a phase of population increase. 2 . Deteriorating climatological conditions, migrations and epidemies may have been interacting causes that lead to the depopulation of other settlements. A general recovery is visible from the second half of the seventh century. space and the increasing number of burials indicate that Maastricht started to grow earlier, around the end of the fifth century. Whether this growth was a result of immigration or natural population increase remains to be determined. At least the archaeological evidence suggests that immigration was an important factor. Contemporaneous with Maastricht's expansion we find more and more signs of Germanic influences like the custom of grave-goods and the occurrence of Germanic names on tombstones. In part, this may be a consequence of a popularisation of the culture of the new elite. However, it is likelly that the "Germanisation" is also the result of an influx of people of Frankish origin. Therefore, the buried population of this period would have consisted of a mix of Gallo-Romans and Germanic people who lived in Maastricht and surrounding settlements since the late Roman period and a group of Frankish newcomers, arriving by the end of the fifth century. t may be that towards the middle or end of the Merovingian period Maastricht also witnessed the emigration of a proportion of its population. With regard to this theuws signals a repopulation of the territories northwest of Maastricht starting around the middle of the sixth century. ${ }^{325}$ Most of the new settlements had thes with Austrasian ecclesiastical institutions. Therefore, he assumes the new possessions were founded by Austrasian nobility and populated by people from nearby settlements. ${ }^{12 \%}$ For cemetery sites nearer to Maastricht the same trend was found. Heymans' study of the

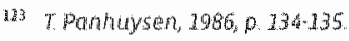

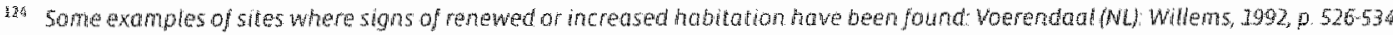

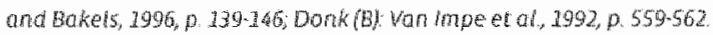

125 Verhulse, $1995,0.48$.

126 Theliws 1988, p 162.

1.7 Theunt 1988,0127 
cemeteries in the Belgian province Limburg also reveded that most burial sites originated around the middle of the sixth century. ${ }^{\mathrm{ng}}$

\section{Social order}

The advent of the new Frankish inhabitants would have altered the social order in Maasteicht and environs. From Salian law, a sixth century codification of Frankish law, we know Merowingian societylegally consisted of three sacial orders determined by birth: the freemen or liberi, the half-free or liberti and the unfree or servi. This simple three-ranked system was however only the basis of a far more intricate social order. By law special positions were acknowledged to various groups of people like servants of the king, men at arms and artisans. This created opportunities for social mobility. E.g, serwants of the king could be recruited from all three orders, allowing the unfree to rise to high positions. Another way for the unfree and half-free to acquire enhanced legal pratection and possibly a better sacial position was through craftsmanship. Next to the worldly social order, the church appears to have had its owm hierarchy. The ecclesiastical hierarchy may also have provided the means to rise in society.

Through the Frankish laws we are informed about the theoretical social order, however, we know ittle about its effect on society. Further anallysis of cemetery finds from the region is expected to inform us better on the structure and mechanisms of Merowingian society. Still, the available information provides some clues for the analysis of Merovingian society. Narrative and historlographical sources for example show the existence of nobility in the area. A new local or regional elite emerged and the tuffstone sarcophagi and precious grave goods found at the Servaas sites show they may have adopted the custom of being buried close to the presumed grave of Servatius. Within the Merovingian social order, the elite was mainly recruited from the class of the freemen. What their exact position was in comparison to other sociall groups has yet to be established. For the Meuse-Demer-Schelde region Theuws assumes that the differences among the various social orders were not so large that it became de facto a dual system with an elite and a substrate agricultural population ${ }^{130}$ Mastricht's cemeteries seem to represent various layers of soclety and therefore offer the opport unity to examine the effect of social differentiation on the living conditions.

In general iwing conditions seem to have been good, after all the growth of Madstricht and its emergence as a centre of praduction and trade suggest the city experienced a period of economic growth. However, rapid expansion, if unaccompanied by a proportional increase in food-production, may incidentally have led to what verhulst has named "accidents of growth": famine. ${ }^{131}$ Another threat for people living together in larger numbers was the occurrence of epidemics. Although there is no written evidence that lorge-scale plagues reached northwestern Europe during the Merovingian period, we caninot entirely rule out the possibility. The presence of "lepers" in Marastricht suggests that at least some inhabitants suffered from diseases.

12. Heymans, 1978 , p.66134.

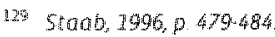

1090) Theuws, 1988

131 Vethulst, 1995, p 4. 
Violence seems to have been a common element of Merovingian politics. To what extent the inhabitants of Maastricht were expased to violence cannot be learned from written sources. Here again the study of human remains may provide some insight.

\section{CAROLINGIAN MAASTRICHT (CIRCA 700-950 AD)}

\section{FROM AUSTRASIA TO LOTHARINGIA}

Since Pippin $11(+714 \mathrm{AD})$, the forefathers of Charlemagne held the function of maior domus almost continuously arid ruled in Austrasia practically without interference from the Merovingian king. In 751 AD the politics of the Arnulfing Pippinid family culminated in a situation that allowed the maiar domus Pippin $I I(+768$ AD) to depose king Childeric Ill and become king himself. ${ }^{372}$ Charlemagne (768-814 AD) succeeded his father Pippin and he extended the Frankish kingdom and welded it into a cultural unity that would long survive its political unity. In agreement with Frankish custom afl carolingian rulers divided the kingdom among their sons. Charles himself made plans to divide his empire among his three sons in 807 AD. As only one son outlived him these plans were newer put into practice. Apparently the prowision of all sons with a part of the heritage was considered more important than keeping the empire together. The frailty of the political unity would come to light after the death of charlemagne's son and successor, Louis the Plous (814-840 AD). In 843 AD at the treaty of Verdun the Frankish empire was split into three parts and divided among the sons of Louis. The eldest son, Lothar (H 855 AD), acquired the "Middle Kingidom", a lang territory from Frisia in the north to ltaly in the south comprising both the "crown jewels" Aachen and Rome. The death of Lothar again led to a division of the 'Middle Kingdom'. On this occasion his son Lothar II ( 869 AD) came into

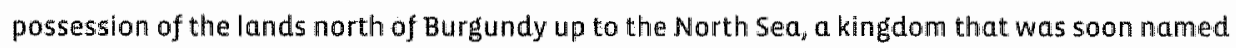
after its ruler, the regnum Lotharil or Lotharingia. When Lothar II died without a legitimate heir his uncles laid claims to his territory. In 870 AD Charles the Bald and Louis the German met to divide Lathar"s kingdom between the two of them. This partition, known as the treaty of Meerssen, Ignored both the linguistic frontier and the sense of unity that was emerging in Lotharingla. In the north, the Meuse became the border between the West Frankish Kingdom and the East frankish Kingdom. ${ }^{234}$ The treaty of Meerssen did not provide a dejinitive

137 Wood, 190.4, passim.

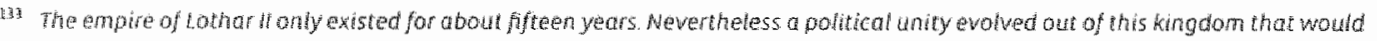

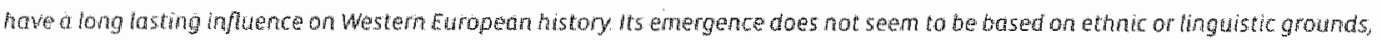

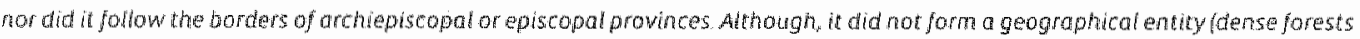
the the Ardennes must have been serious obstacles and bariers, wnifying elements were the old chtes and settements atong the two

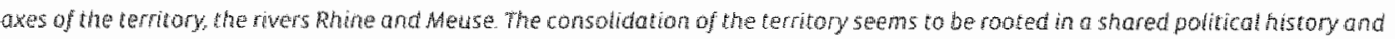
struture, which revolved around the river valteys the orgins of this sense of unity possibly dated from the pertod bejore the carodinglan Empire

134 Netson, 1995,1910141 and Fred $1995,0.142 .168$ 
arrangement of hegemony over Lotharingia. For almost sixty years sovereignty over Lotharingia was a matter of dispute between the East and West Frankish Kingiom.

Conflicts between the various rulers of the Carolingian dynasties and Viking raids, which had become a recurring scourge since the early ninth century, appear to have weakened the supremacy of the kings, thus creating, opportunities for the regional nobility to expand their authority in various parts of the kingdom. Between the end of the ninth and the middle of the tenth century an increasing number of counts and dukes appear in the documentaly sources. In Lotharingia the nobillity seems to have profited from the ambiguous situation in which neither the West nor East Frankish kings succeeded in gaining effective control over the territory: Between 895.900 AD the regnum Lotharii was rewived and temporarily became a separate kingdom under the rule of king Zwentibold ${ }^{13}$ Only through the politics of the East Frankish king, Henry the Fowler (911-936 AD), and his son Otto I (936-973 AD) was the larger part of Lotharingia incorparated in the East Frankish Kingdom.

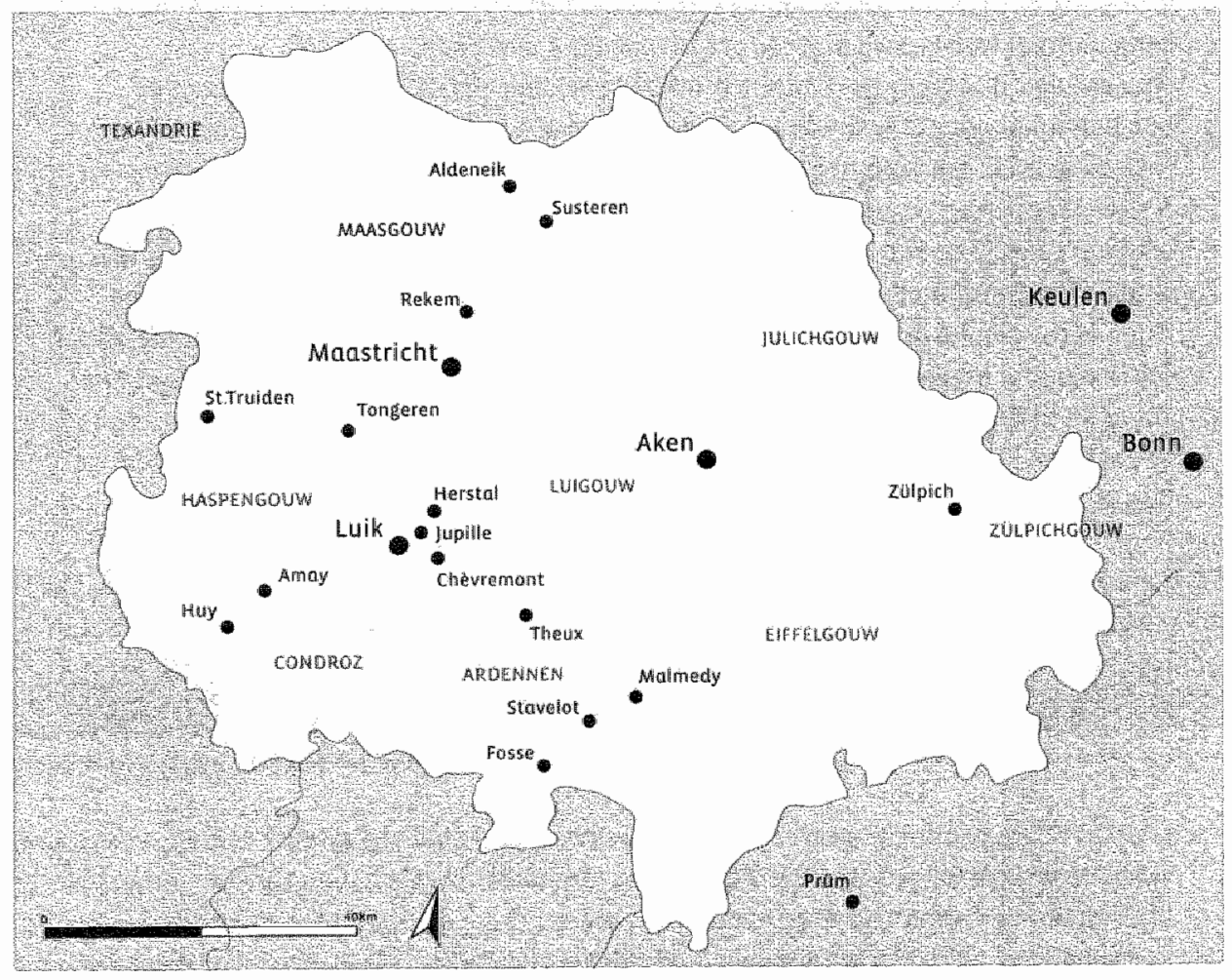

FlGURE 25 manstricht and surrounding places in the Carohingion periad.

135 Zwentibold was an ullegitinate son of Anulf (887-899. A.D), the ruter of the East fronkish Kingdom. 


\section{MAASTRICHT AND THE APWULFING PIPBIND DYNASTY}

Several af the most important possessions of the forefathers of Charlemagne, the ArnulfingPippinid family, were situated near Maastricht. From the beginning of the eighth century the time of Pippin II $(+714 . \mathrm{AD})$, their presence in the area is evident. Mary of the places they often visited, the palatii of Herstal and Jupille, the stronghold Chevvremont and later Charlemagne's residence in Aachen, all lay within a radius of forty kilometres from Maastricht. This region, the middie Meuse region, was also the area whence the Arnulfing Pippinid family recruited its: supporters, ${ }^{236}$ Documentary evidence of a passible connection between Maastricht and the Carolingian rulers is scarce and indirect. Their ties with the religious community around the rove of $5 t$. Servatius are the clearest sign of their involvement with Maastricht. Before the eight century the religious community seems to have been ruled by the bishops. Werner assumes that during the eighth century the Carolingians succeeded in gaining control over this institution. ${ }^{33}$ An indication of a link with the court of Charlemagne is the appointment of Alcuin, an intimate of Charlemagne, as abbot of the Saint Servatius monastery in Maastricht. Later the lay-abbot Einhard, another well-known protégé of Charlemagne, succeeded Alcuin. "133

After the death of Louis the Plous in $B 40 A D$ the evidence of personal involvement of Carolingian rulers with Maastricht becomes more specific. As decided by the treaty of Verdun (843 AD) Maastricht fell within the borders of the empire of Lothar I. During the winth century the term 'near Maastricht' occurs often in the sources to indicate a place of venue for the Carolinglan kings. ${ }^{129}$ Not all of these meetings actually took place, but one of them acquired some fame as it resulted in the treaty of Meerssen. ${ }^{2 * 16}$ in 870 AD this treaty determined the partition of the empire of Lothar ill between his two uncles. Thenceforth Maastricht became a. city on the border between the West Frankish Kingdom and the East Frankish Kingdom. The Annals of St. Bertin mention that Charles the Bald received the abbey of St. Servatius as a result of the partition. ${ }^{13 t}$ Who acquired authority over the rest of Maastricht is not evident from the sources, It is not unlikely though that the arrangement implied that the rest of Manstricht also fell under the rule of Charles the Bald. ${ }^{122}$ After 870 AD Maastricht and immediate surroundings remained a place where Charles the Bald would arrange important meetings. In 872 for example he sailed down the Meuse to meet two viking chiefs and to accept one of them as his vassal. Ten years after the treaty of Meerssen, Maastricht changed hands again. At the treaty of Ribemont In $880 \mathrm{AD}$, Louis the Younger, the East Frankish king (876-882) acquired the territories and

36 Werner, $1960,09.49$

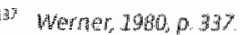

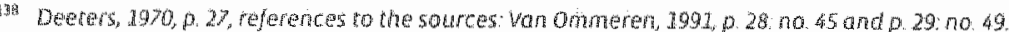

Wan ormered, $1901,34-36$

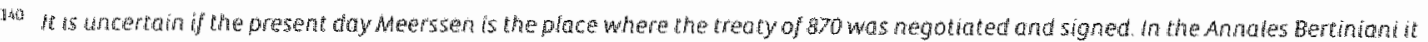
is reloted that the reatment was signed along the wewse holfway between Meers sen and herstal whot would be somewhere

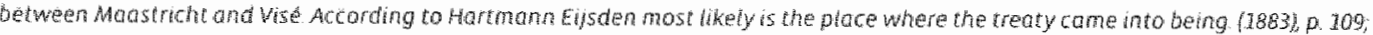
Hathona, $7986,0.141-142$

is.

W.42 Thetins 2004 in press 


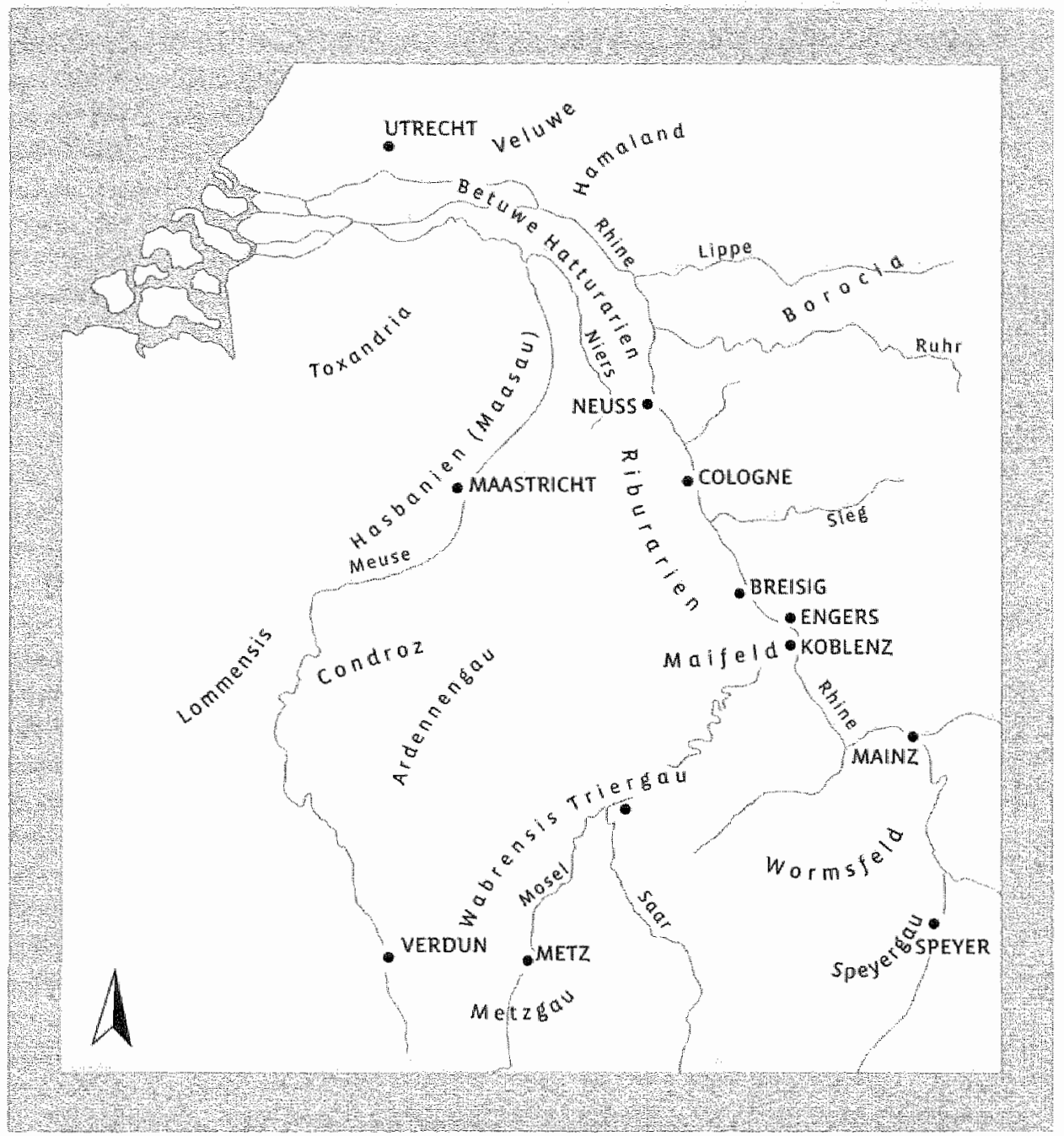

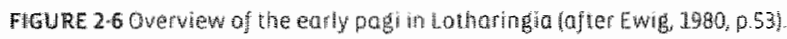

possessions which Charles the Bald had received in $870 \mathrm{AD}$. The year following the treaty of Ribemont the Vikings raided Maastricht and a period of unrest seems to take a start. New partitions and rapid political changes in the West and East Frankish Kingdoms created an unstable political climate in which rapidly moving viking bands became a serious threat to places inland, which had hitherto remained unharmed.

As in other regions of the Carolingian Kingdams, in Lotharingia too, political instability led to the ascent of the lacal nobility. One of them, Ragrar Longneck ( 915 AD), may have had his base

14 Emg, 1980,293 
in the region around Maastricht. He probably descended from Gilbert $\|^{12}$, who is mentioned with the titte of 'comes Mansuariorum' ${ }^{\text {iss }}$ Nonn has argued that this title implies he was invested with athority in the whole Meuse region. ${ }^{2 a 6}$ Ragnar seems to have succeded his father as a count in at least two pagi, "counties' that formed a part of the Meuse region. He held this office in two territories not for from Mastricht: the pagus Hasbaniensis and the comitatus Maselant. Ragmar first appears in the sources around 880 AD when he is involved in the defence of Lotharingia against Viking raids. ${ }^{\text {* }}$ His battles with the Nordic invaders continued until circa $886 \mathrm{AD}$; apparently his military skills increased his prestige. After the threat of the Vikings had waned Ragnar became one of the noblemen whose alliance was essential for every king who intended to govern Lotharingia. Around the beginning of the tenth century Ragnar had acquired an impressive amount of possessions and benefices, widely dispersed over Lotharingia. Among these were important monasteries like those of Stavelot-Malmedy, Echternach and the St. Maximinian abbey in Trier. Ragnar also gained authority over the monastery of St. Servatius in Maastricht. According to a graphic description by Richerus of Reims the West Frankish king, Charles $\mathrm{N}$ the Simple (898-922 AD) attended the funeral of Raginar around the end of $915 \mathrm{AD}$. $^{145}$ Ragnar's son Gllbert II (circa 915-939 AD) succeeded his father in most of his functions. In the following years conflicts arose between Gilbert ll and Charles the Simple and an opposing

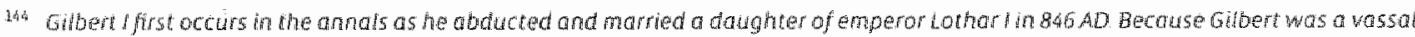

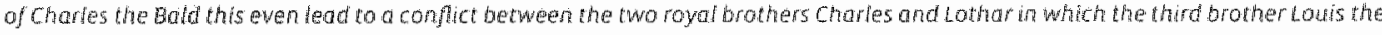
Cerman tried to mediate. Armales Fuldenses, $19991,0.36-38$

1.5 Nithord, 2907 , p. 31 .

$1 \%$ Nonn, $3993,0.99$

14. Fxact boundories are not known for these pagf the pogus Hosbantensis consisted of territoriws to the west and southwest of

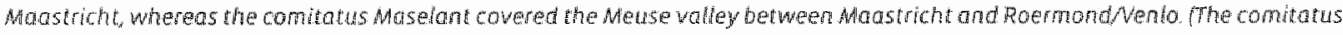
Maseiant should not be canfused whth the larger romitatus Mansuarorum, Maselant seems to have been a part of the larger the

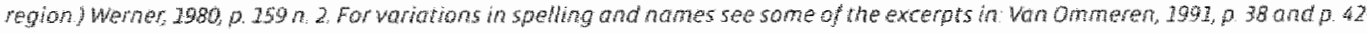
43

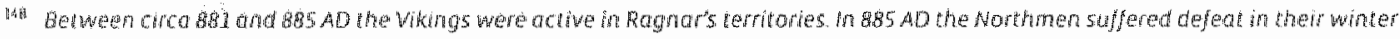

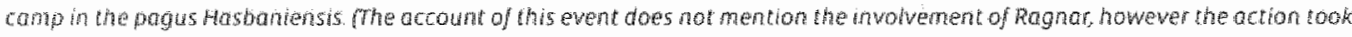

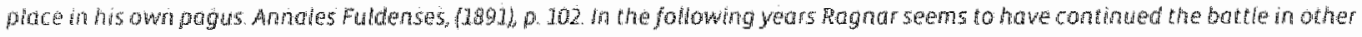
regions. one interesting account mentions that he was coptured by the Vitugs and was freed in exchange for the th beration of twatwe

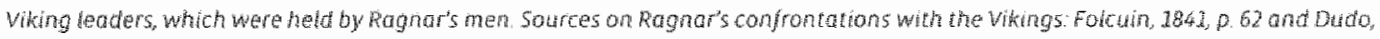
1665. $150 \cdot 151$

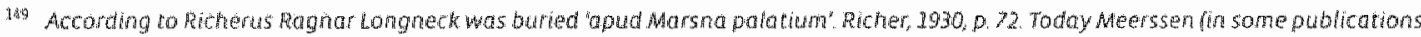

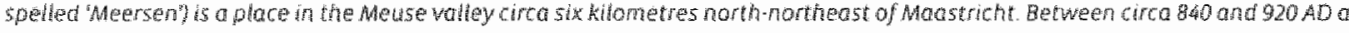

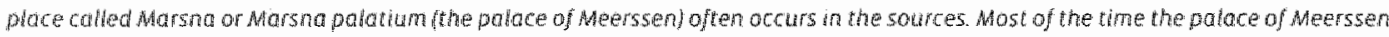
is mentioned to describe ewents that took place 'apud' the palace, meaning hear or hext to a place and fess often though in' a

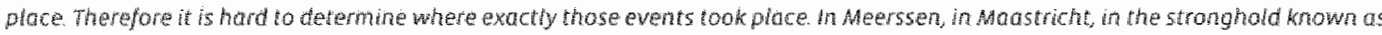
Harburc in other places in the ared known or uhknown, or in the open space? The palace of Meerssen itself emerges in the sources

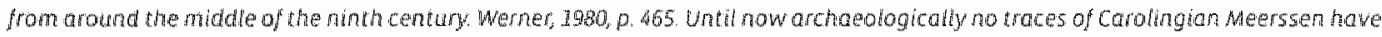
been thancovered. 
Lotharingian family. Despite this antagonism Gilbert 11 managed to gradually increase his authority in Lotharingia. An intricate web of alliances and the possession of two strategically placed strongholds close to Masstricht allowed him to stay in control. Around 925 AD he allied with the East Frankish king Henry the Fowler. This allowed him ta consolidate his power and he officially became duke of Lotharingia. His marriage with Gerberga, a daughter of Henry the Fowler, symbolised his eminent position and the permanent nature of the alliance with Henry. Charters and annals show that Gilbert 11 was an active ruler. in the sou th of Lotharingia he directed the construction of strongholds. He stimulated a reform movement in the Lotharingian manasteries. When in 936 AD otto I succeeded his father as king of the East Frankish kingdom, Gilbert II participated in the crowning ceremonies. Soon after atto's enthronement the king was confronted with a rebellion of East Frankish nobles. His brather Henry also participated in this uprising. Gibert long avoided becoming involved in the conflict. When asked for his support by otto in $938 \mathrm{AD}$ he refused and decided to join the opposition. Returning from a military expedition in Saxania he encountered supporters of king otto by Andernach on the Rhine. There he drowned while crossing the river. ${ }^{150}$

The lives of Ragnar and Gilbert Il are discussed here in some detail because of their connection with Maastricht. Maastricht was situated in the middle of the pagi they ruled. Their mast important strongholds, in which they retreated at times of danger, Chèvremont and Harburc, were located on a short distance to the south and north of Maustricht. Both Ragnar and Gilbert. Il seem to have been very determined to become and remain lay-abbot of the Saint Servatius monastery. For Ragnar more explicit clues of a link with Maastricht are missing " the case of Gilbert II there are more indications he resided in Maastricht. Jocundus, an eleventh century author, extensively describes Gilbert's activities in Maastricht. ${ }^{252}$ Although Jocundus certainly mixed fact and fiction in his writings, his stories were based on information he collected locally. About Gilbert 11 he explicitly writes that he resided in Maastricht; he also mentions the duke built a new wall around the monastery of Saint Servatius and the palace. ${ }^{1.53}$ Furthermore jocundus writes that Gilbert was buried in the Saint Servatius church in

1:50 Pantuysen, 1989 , passim

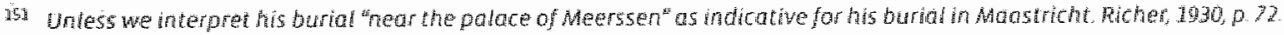

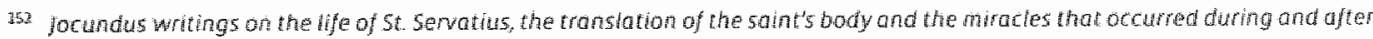

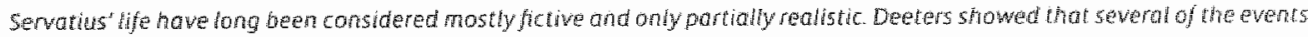
Jocundus described mere alsa mentioned in other sources, implying that wh should nat discard all of the informaton Jow undus has to

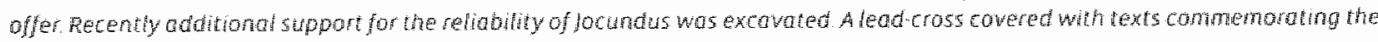
life and death of prowost tumbertus (a contemponary of locundus) was found at the servas churct ste the text on the cross

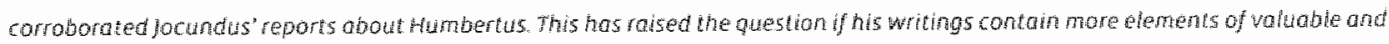

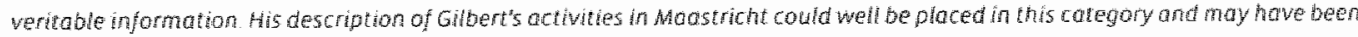

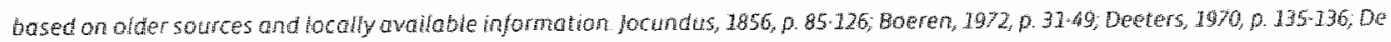
la Haye, 1988, p. 327328: T. Ponthusen, 1988, p. 159 163.

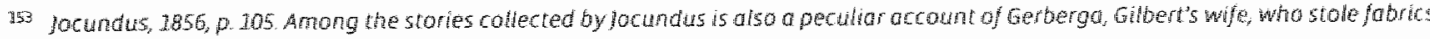
from the treasure of sain semotis and later raturned these remoretuly. 
Maastricht. ${ }^{3}$ Jocundus probably dramatised the life of Gibert II and his wife, but it is likelly that the essence, namely the presence of Gilbert II in Maastricht, was no fabrication.

CENTRAL PUCE

Although the exact role of Maastricht in many developments is unclear we may infer that the city was situated in the centre of the region where the fate of Lotharingla was repeatedy played out ys in review of the abovementioned developments it has been concluded that the region around Maastur icht was first essential for the rise of the Carolinglan family and later a crucial region for the control over Latharingia. ${ }^{156}$ A strong economy moy well have contributed to this situation. Documentary sources show Maastricht remained a significant mercantile centre. Signs of this were the toll collection, a weekly market and the accounts in the written sources suggesting Maastricht was a crowded port of trade. ${ }^{157}$ Carolingian coinage also confirms the continuity af Macstricht's strong economic position. Coins were minted in Maastricht for almost all Carolinglan rulers who exercised authority over the region: Charlemagne, Louis the pious, Lothar I, Lothar II, Lowis the German and Charles III the fat. ${ }^{\text {.5n }}$ Gilbert II also issued cains bearing. his name. (A duke with colnage in his own name is a rarity in the early tenth century.) In the context of practically continuous ininting activities in Maastricht there are reasons to assume that Gill bert's coinage was also minted in Maastricht. is in general it may be concluded that Maastricht retalined a central position in the regional economy and politics.

\section{RELIGIOUS LIHE}

The ecclesiastical situation changed when bishop Lambert was murdered in Liège, between 703 and $705 \mathrm{AD} .160 \mathrm{His}$ body was brought to Maastricht and buried there. Lambert's successor bishop Hubert (703/706-727 AD) decided to rebury Lambert in Liege in a church specially built for that purpose. ${ }^{4(1)}$ There he promoted the veneration of the 'martyred' bishop. Through a gradual process, not visible in the documentary sources, the transition of the episcopal see from Maastricht to Lieg gas completed. Werner among others tried to establish the causes for Hubert's decision, but the could not find a conclusive answer. The nearness to the Carollingian

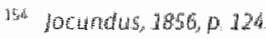

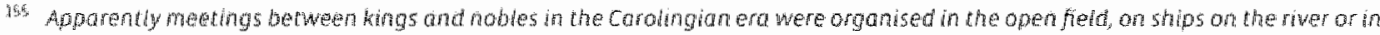

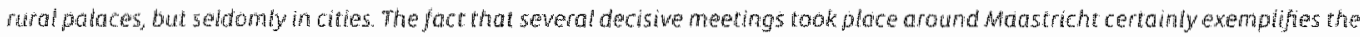

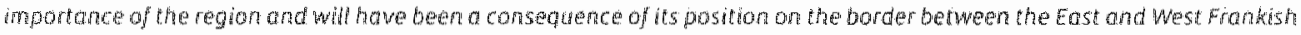
kivodom.

15\% Wernet $1980,0,981-486$

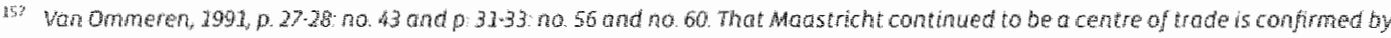
coins on which Aastricht is mentiond as "N PORTO TRIECTO. "Porto is a term used for centres of trade Grierson and Badkbum. $1991,0.199$

Is: Grierson and Backbum, 1991, p. 29\%, p.20\%, p.27, p.227, p.235

Fis Fere, $197 \%$, por 89

atro werner 1980, p 268-273

sti Dela Haye, 2002, p.1.1 
palaces of Herstal and Jupille and Hubert's own predllection for the place may have contributed to the transfer of the episcopal see. ${ }^{\text {it }}$

How the movement of the episcopal household to Liege affected the ecclesiastical institutions in Mastricht remains speculative. ${ }^{153}$ Around the same time as Hubert initialised the move to Liẻge the ol dest allusion to the monastery of Saint Servatius occurs in the Gesta Fontanellensis. ${ }^{1.4}$ The history of the monastery Fontanelle describes how a certain Wando was sent into exile (between 719-747 AD) to the monastery of saint servatius. Since the end of the eighth century the monastery increasingly appears in the written sources, often in relation to possessions of the abbey. In the following years the Saint Servatius monastery acquired properties in various regions of Lotharingid. ${ }^{165}$ Whether ar not the Saint Servatus monastery was a monastic or a canonical community has long been the subject of debate. The second known abbot was Einhard, who was also a lay-abbot of two other canonical communities in Ghent. Einhard remained in function during the reign of Louis the Pious when it was considered objectionable that lay-abbots governed monastic communities, while there was no objection against lay-abbots for canonical communities. Far the tenth century there is decisive evidence for their secular status in a charter of $946 \mathrm{AD}$, mentioning the 'canonici loci S. Servaci'." Therefore, Deeters assumption that the monastery of Saint Servatius began as a canonical community seems most plausible. ${ }^{15 z}$

\section{THEARCHAEOLOGY}

In the archaeolagical record the Caralingian period is represented by building activities and inhumations. Few ather traces are available. In Maastricht the remains of the Caroling ilan period appear to have suffered most from subsequent developments. Expansion and intensification of the urban occupation has on many sites disturbed the archaealogical record to the Carolingian levels. The impression from the written sources that Maastricht remained a crowded and important centre of trade can neither be confirmed nor refuted by archaeological evidence.

\section{A Carolingian centre of trade}

From an archaeological perspective, Caralingian Maastricht remains rather elusive. Apart from some larger structures and cemeteries little is known about housing and production activities. $A$ bridge over the Meuse survived throughout the Carolingian period and remnants of the fortification seem to have been wisible until the end of the Carolingian periad. By then the

\$1: Worner 1980, 2802282

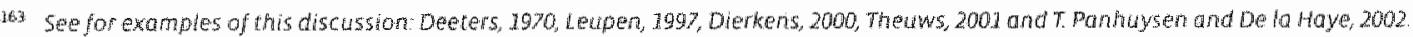

$17936)$ p. 24

1 lis Devers, 1970 , passim.

1.6. wompoth, 1935,160

16 Desters, 19:0 p 28.29 
remainder of the walls were delapidated to use the stone for new buildings. ${ }^{268}$ From the beginning of the eighth century there are traces of temporary habitation inside the fortification. T. Panhuysen assumes these may have housed travelling traders and craftsmen. ${ }^{\text {IEg }}$ The continued presence of craftsmen in Maastricht is confirmed by the excavated fragments of moulds for bronze objects from the eighth century. The production of objects of antler and bone, an important local craft in the Merovingian period, seems to have ended before the Carolingian period. At the Mabro-site few traces of the early Carallingian period were found. This changes by the end of the carolingian period, in the tenth century, when timbered houses were constructed on this spot. ${ }^{12}$ Construction works of a different nature were uncovered at the Servads church silte. There a larger church, richly decorated with coloured glass, mosaics and sculptured elements replaced the Merovingian templum magnum. ${ }^{3 / 2}$ in comparison with the Merovinglan period the information is much scantier. However, the historical and numismatic evidence suggest Maastricht remained a place of considerable economic, political and ecclesiastical importance.

\section{Cemeteries}

The Carolingian burial custom differs from the Merovingian in two aspects. Gradually the isolated burial grounds were deserted. By the end of the eighth century interment took place almost exclusively at cemeteries around a church or chapel. ${ }^{133}$ As churches and chapels were not as numerous and widespread as burial sites, this must generally have led to a reduction of the number of cemeteries. Consequently, at the remaining cemeteries this resulted in inreased inhumations. Excavations have proved the continuity of inhumations into the Carolingian period for the Servaas church and the Pandhof site. In Maastricht an example of a cemetery that was discontinued is the Boschstraat cemetery. This cemetery seems to have become obsalete around the middle of the eighth century. Carolingian inhumations differed in another aspect from Merovinglan inhumations. The practice of placing goods in the graves rapidly declined in the Carolingian period. In this respect the Maastricht cemeteries follow this trend. By the end of the seventh century neither precious mor simple grave-goods were enclosed in the graves.

The continuation of the cemetery at the Lage Kanaaldijk site seems surprising, as there is no church reported at the site for the Carolingian period. ${ }^{174}$ However, careful inspection of the

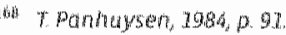

$16936 \mathrm{den}, 3839$

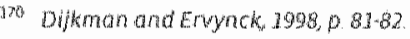

jol bidfem 109

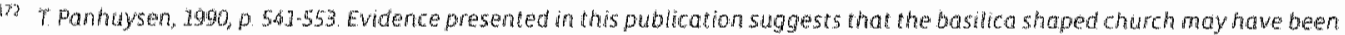
constructed fround he wh of the seventh century or the early eighth century.

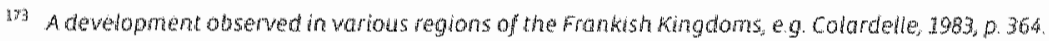

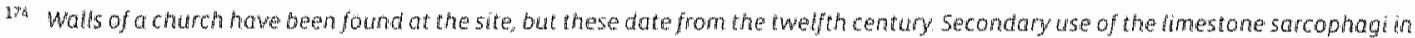
relation with the thet th century church is whikely as sevarat of the sarcophagi were dated as carolingion because of the stratigraphich hevdence Hulst, 1905 , p. 78 
layout of the Carolingian cemetery shows a church may have existed at the shte. If so this church would have been constructed of perishable materials as no substantial traces were recovered during recent excavations. The only indication for the possibility of a Carolingian church at this site comes from the placement of four limestone sarcophagi. These sorcophagi were placed in groups of two rows with the head in the west and the feet in the east; the sarcophagi were placed in line: the footend of the westernmost against the head end of the ecsternmost ${ }^{13}$

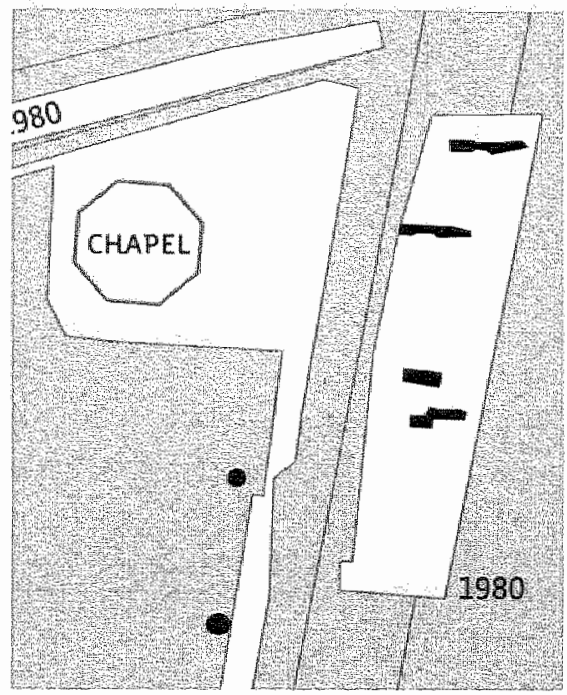

FIGURE 2-7 A detait of the excawation plarn of the Lage Kanoadinik ste Two lines of two sarcophag are depicted to the right of the octogond chapel fafter Huls 1995$)$.

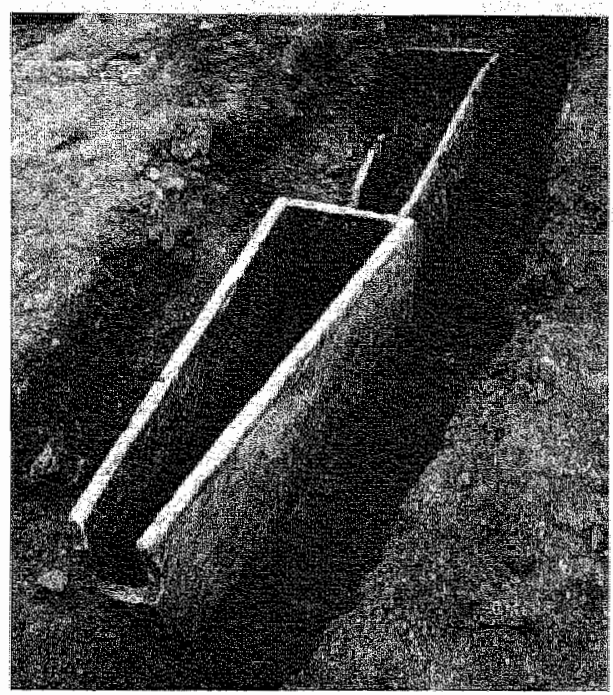

FIGURE 20 Two limestone sar cophagl jound at flat Lage Konnaldijk site: la andogy with the findings ot the Servoas church site these sarcophagi appear to be placed alorig a wall Assuming that the sarcophag were placed on the outside of the church the wall would howe been on the right stae of the sarcophage (photograph: city of Maastrictid

At the Servaas church site the same type of sarcophagus was often found in a comparable situation. There it could be established that all sarcophagi, which were placed in line, were positioned aiong a wall of a basilica shaped church.

From the position of the two scrcophagi in the sou th it can be deduced they were placed on the south side of a wall. This wall may either have been on outside wall or an inside wall separating an aisle from a nave. The distance between the two lines of sarcophagl was approximately five metres, which seems more fitting for an aisle then a nave, but then it may have been a small church. Additional support for the hypothesis of the existence of a church or chapel at this site can be deduced from the position of the Carolinglian inhumations that were

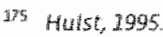


not interred in sarcophagi. These are found south of the two lines of sarcophagi. This would place them outside a possible church, which is a phenomenon that was also observed at the Servaas church site. At this site trench or coffin graves were predominantly placed outside the Carolinglian church. In total inineteen sarcophagi of limestone have been excavated in this area, only five during modern excavations. Sarcophagi may be considered as expensive graves. Most likely burial in a sarcophagus was a priwilege reserved for people of a higher social position. At. this cemetery sarcophagi seem to have been relatively abundant. ${ }^{176}$. Who were buried at the Lage Kanaaldijk site will be difficult to determine. For a correct analysis of the inhumations it is impontant to consider that the apparent the vicinity of the grave of Saint Servatius was not the only attractive place as a last resting-place for representatives of the local elite. ${ }^{\text {"r }}$

\section{The Caralingian population}

In the historical literature it is assiumed that from the second half of the seventh century onwards the European population increased. Demographical analysis of Caralingian polyptychs shows an estimated growth of $1 \%$ for the eighth and ninth centuries, leading to a doubling of the population on some of these estates in a time span of half ta one and a half centuries. Whether the population of Maastricht increased as well could not be determined on the basis of the inhabited space. Einhard writes around $830 \mathrm{AD}$ about Maastricht in his times that it had many irihabitants, predominantly merchants. ${ }^{\text {ing }}$ Maybe the physical anthropological data will yleld some information on the demographical tendencies in Carolingian Maastricht. With respect to the social order it is difficult to determine any developments in Maastricht. Persons dependent of the Saint Servatius monastery appear in two written sources. ${ }^{120}$ These persons seem to live in Maastricht. This suggests that a proportion of the inhabitants of Maastricht were unfree and half-free personnel of the monastery. Whether the differences in social position were also associated with differences in health conditions has to be analysed. The same holds true for the possible impact of violence surrounding the murder of bishop Lambert in the early eighth century, the Viking raids in the second half of the ninth century and possibly the conflicts among the various factions in Lotharingia during the first half of the tenth century.

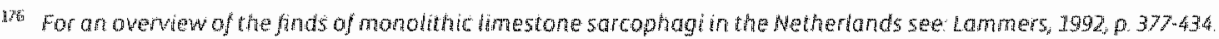

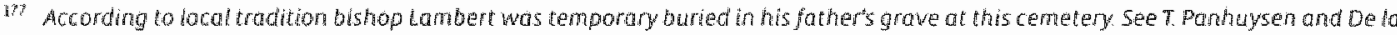
Haryes 2002

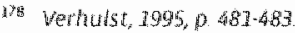

17g Einhard, $280 \%$, p. 261

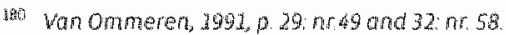


- Archaeological description of the Servaas and Boschstraat sites

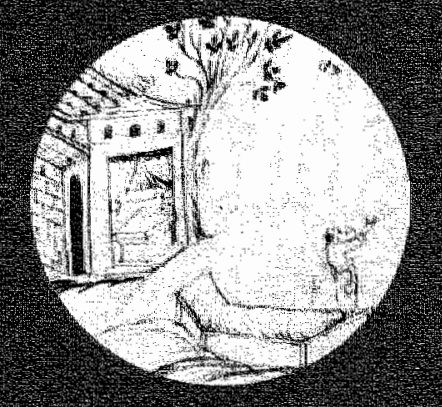




\section{Archaeological description of the Servaas and Boschstraat site}

This chapter will describe the archaeological context of the two sites with human remains examined in this study: the Servaas church site and the Boschstradt site. ${ }^{\text {an: }}$ Both sites are situated in the present city centre of Maastricht. The history of the Serwas site as a burial place started in the late Roman period (300-480 AD). During the Merowingian (480-700 AD) and Carolingian (700-950 AD) period the area evalved into an ecclesiastical and administrative centre of reglonal importance. Large numbers of graves surrounded the church and adjoining monastic buildings. After the construction of a Romanesque church (consecrated in 1039) the number of burlals inside the church decreased significantly. From that time on people were buried in places like the Stifts chapel (chapel of the canons) and around the Romanesque church. In comparison with the Servaas church site, the cemetery at the Boschstraat site was small. Furthermore, it was in use for a relatively short time span, wiz. from the seventh to the beginning of the eighth century AD.

\section{CEMETERIES IN LATE ROMAN AND EARLY MEDIEVAL MAASTRICHT}

Among the most noticeable remains of Maastricht's history between 350 and 950 AD are warious burial sites in and around the present city. Hitherto sections of at least nine late Roman and early medieval cemeteries have been excavated in Maastricht. These cemeteries vary in size and character. Some, like the burial site at the Ceramique site, may have been simall, comprising only a few graves; while a site such as the excavated sections of the Servaas cemetery comprised at least 900 graves (Figure 3-13). Three out of nine cemeterles were found to be associated with a church $_{\AA}$ namely the Servaas cemetery, the Church of Our Lady burials and the Lage Kancaldijk cemetery. The cemeteries also varied with respect to their geographical distribution. Burials at sites like the Serwas cemetery, the Vrijthof, the Church of Our Lady and probably the Ceramique site were positioned close to the living quarters in and around the former Roman settlement. Whereas, burials at sites like the Boschstraat, the Lage Kanaaldialk, the Heukelstraat and Borgharen probably were associated with separate settlements.

toi This chaper is based on publications presenting the pretininary results of several excavations and two reports Referefices to published information can be found the erdnotes. All available data on the graves and disturbed inhumations at both sites were collected in two reports. R. Pahhuys 2005 , R. Parhuysen, $2005 b$

T. Parhuysen has suggested that inside the church the number of butals was atready reduced since 813 AD and later, when a concrete floor was laid. Parhusen, persenal communication 2004. 


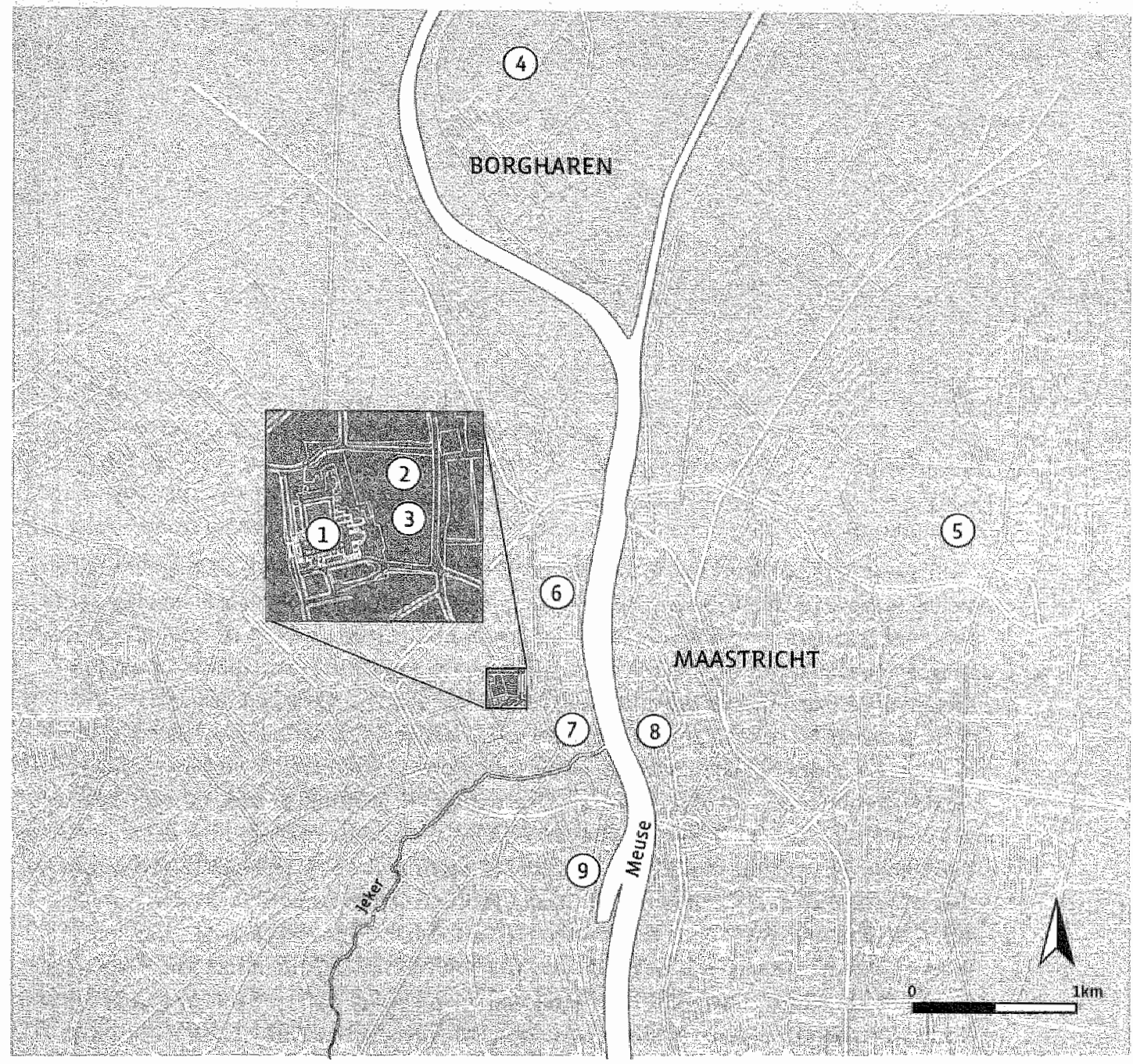

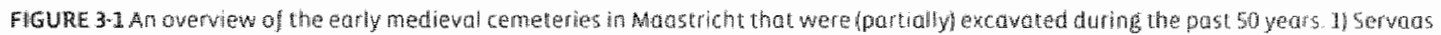

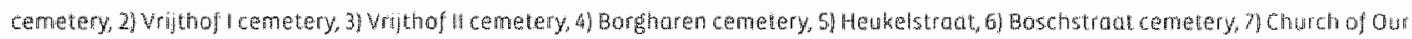

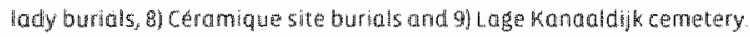




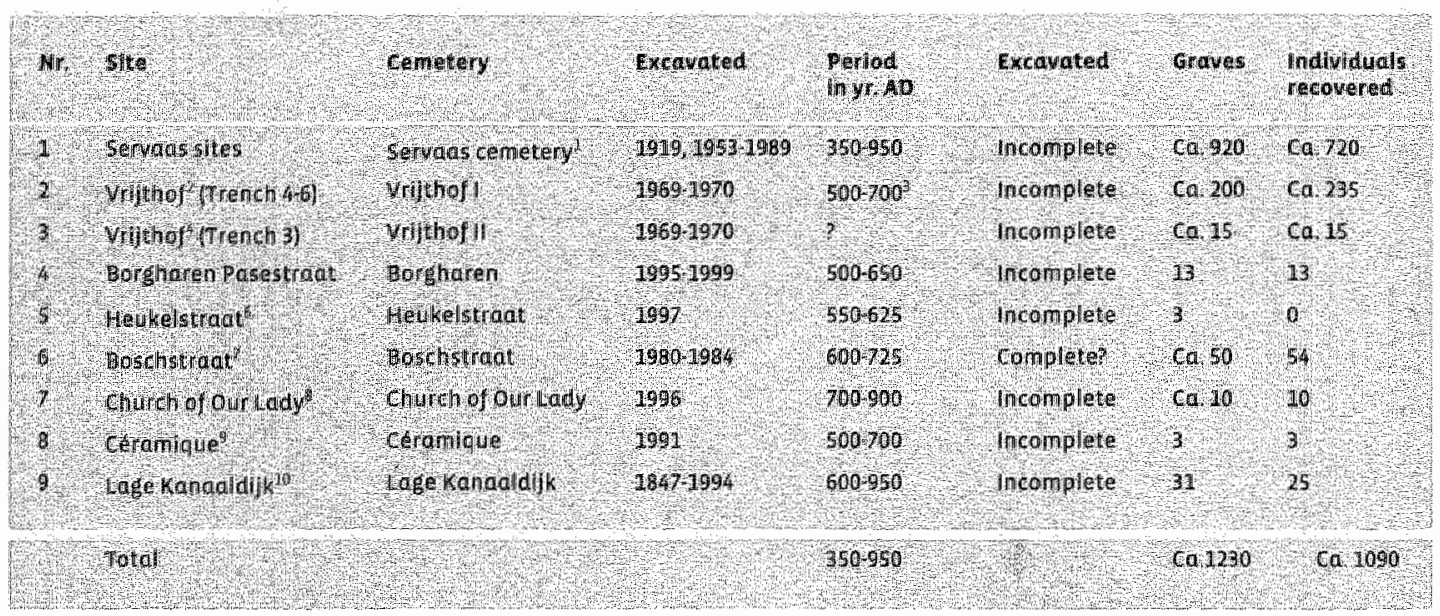

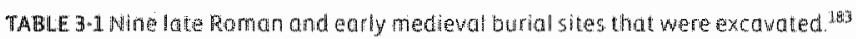

In the burial sites excavated in the past fifty years a total of circa 1230 lete Roman and early medieval graves were excavated. Historical information and archaeological finds suggest the existence of more early medieval cemeterles in and around Mastricht. The two sites in this study were mainly chosen from the available skeletal series for practical reasons. Both the Servaas church and the Boschstraat sites had been excavated quite recently and the accompanying documentation was complete and available in Madstricht. Furthermore, the number of individuals and the state of preserwation of the skeletal remains appeared to be suitable for the collection of sufficient physical anthropological and palaeopathological data and would allow comparisons between the two sites. Other skeletal series from excavations like the Pandhof site and the Vrijt thof site consisted of large numbers of individuals. However, at the time this study started the material and documentation of these excovations were stored at different locations. These older excavations had been carried out using less rigorous documentation methods. This was especially true for the Vrifthof excavation, which was in part a rescue excavation. ${ }^{185}$ Therefore, the skeletal remains excavated at the Servaas church site and the Boschstruat site seemed to be the best option to collect data on life conditions in early medieval Maastricht.

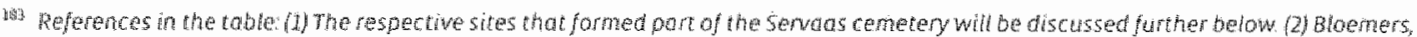

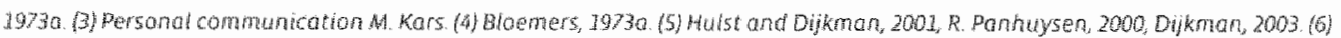

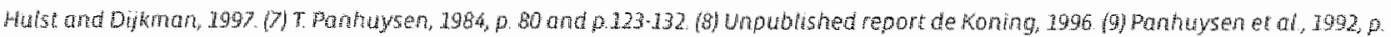

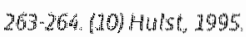

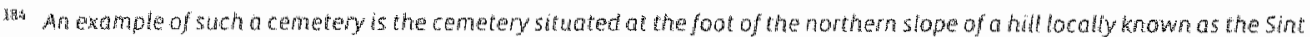

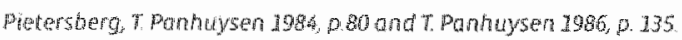

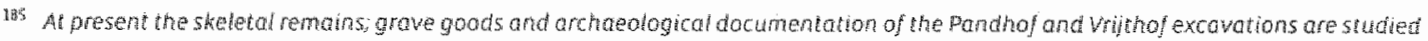
with in the framework of the sing servotwits project 


\section{GRAPHIC REPRESENTATION OF THE CEMETERIES}

An important tool for the analysis of the burial customs at the two cemeteries is the spatial analysis of the distribution of graves within the cemetery. For this purpose a set of digital maps. was made. On these maps standardised symbols of fixed size depict all grave types and the find spots of disarticulated bone. The length of each adult grave on the maps is either 1.80 metres (trench graves and coffins) or 1.97 metres (all other inhumations). Children's graves are represented by smaller symbols, scaled down to about 75 to 30 per cent of the size of graves of adult individuals. Maps of the Servaas church site also display the remnants of buildings, e. churches, chapels and monastic structures. Since the original walls were seldom found, reconstructions based on the remainirg robber trenches are shown. These trenches were often wider than the original walls. On the map this could lead to difficulties in discerning the graves below the walls which antedated the construction of the walls, from those which had been dug against these walls ungeneral graves that antedated the various buildings or phases can be recognised on the maps as walls or robber trenches (trenches dug to extract building material from derelict walls and foundations) intersect them complettely. Unless stated otherwise, all excavation plans and maps are shown with the north approximately at the top of the page. As scales of the drawings may vary, fulers of 10 or 50 metres are included in the maps.

\section{GRAVETYPES}

Various classifications of grave types have been published. medieval western Europe depends among other factors on the condition of the local soll and the avallability of materials to construct graves. Therefore, mast classifications are developed to fit the situation in a single cemetery or a geagraphical region. From the existing classifications $B$ grave types were selected to categorise the burials from the servar church site and the Boschstraat site (see figure 3*2). A ninth category was used to indicate disarticulated human remains. The grave types encountered at the two sites are described below. (Dimensions mentioned in all descriptions indicate the mean length and width of the interior of graves of adult individuals. Because very few graves were intact and the original level was rarely preserved, it was not possible to calculate representative averages for the deptlh of the graves belaw the surface level at the time of burial.)

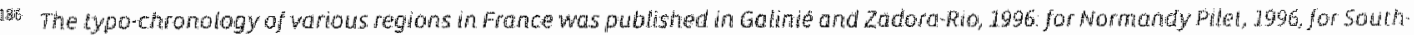

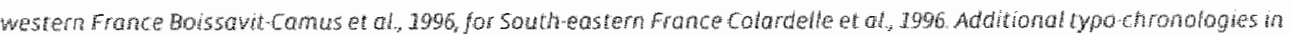

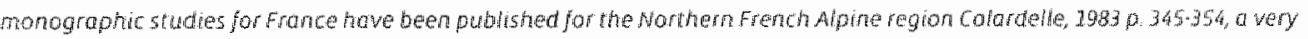

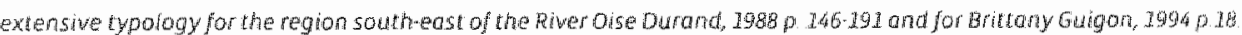




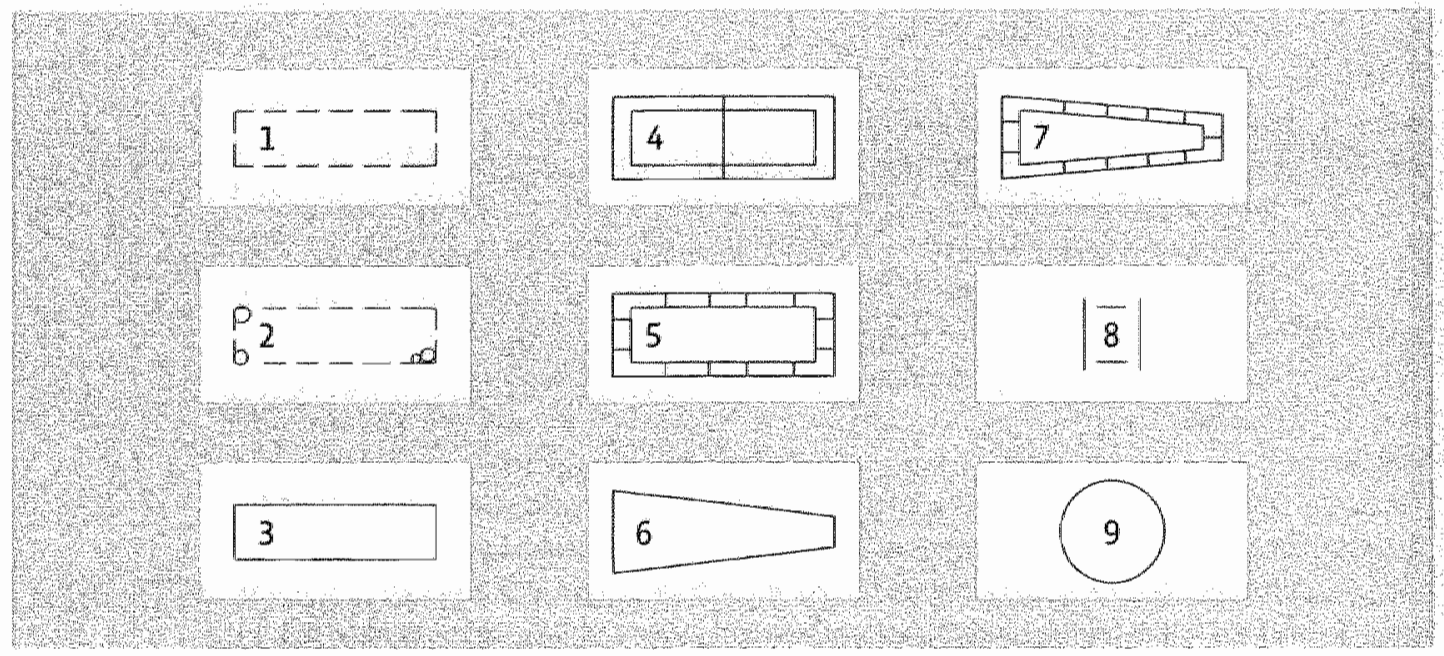

FHGUPE 3-2 Symbols used to depict grave types and redeposited bone on nops of the Sarvas church and Boschstrad

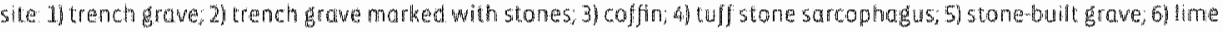
stone sarcophagus;) stonebuit tomb (trapezoid variety) 8) tile grave and gh disanticutated bone

\section{Trench graves}

Trench graves were rectangular or oblong grave cuts, often recognisable by a difference in colour between the grave fill and the undilsturbed soill. In several cases even the traces of a grave cut were missing, leaving the articulated skeleton as the only indication for the existence of a grave. In fact trench graves are categorised as such because of the absence of evidence for the use of a wooden coffin. Therefore, it has to be considered that some of the graves which looked like trench graves were actually coffin graves in which the wooden parts had completely decomposed. However, as will be demonstrated in the following chapter, analysis of the preservation of skeletal material shows a different decomposition pattern for trench graves in comparison to coffin burials. Therefore, it seems probable that mast trench grawes and wooden coffins could be correctly categorised. Additional support for the distinction between trenches and wooden coffins comes from the position in which some of the skeletons were found. in several trench graves skeletons were lying with their legs splayed or their arms at a distance from the thorax (Figure 3-4). Boddington described similar inhumations and understandably inferred that this skeletal arrangement is not compatible with inhumation in a narrow coffin. since most wooden coffins were rather narrow, a splayed position of the arms and/or legs was considered an indication that these individuals had probably been buried in trench graves. ${ }^{398}$ The position of the extremities is not indicative of the type of grave in all cases. Regarding burials with the arms close to the body and the legs close together often it could not be determined whether individuals were buried in coffin graves or in trench graves. Archaeological 


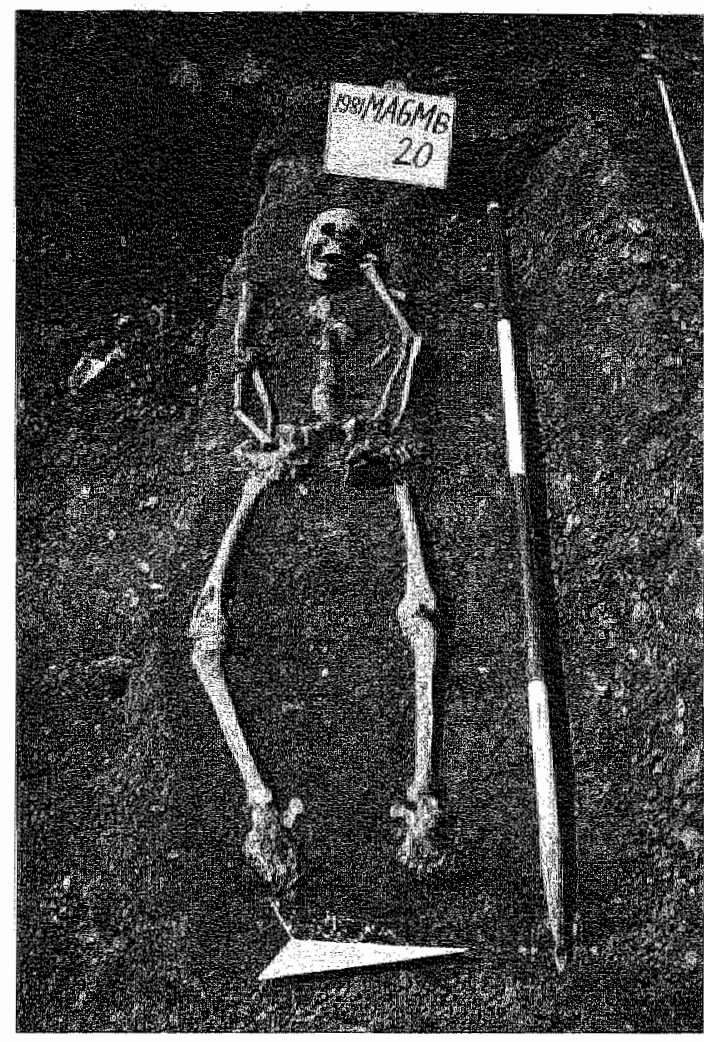

FIGURE 3-3 Servad church site, grave j12, trench grave. The individual was burted with the upper extremitien agoinst on an the thomand the lower axtremites foirly close to eachother (Photograph: city of maastriching

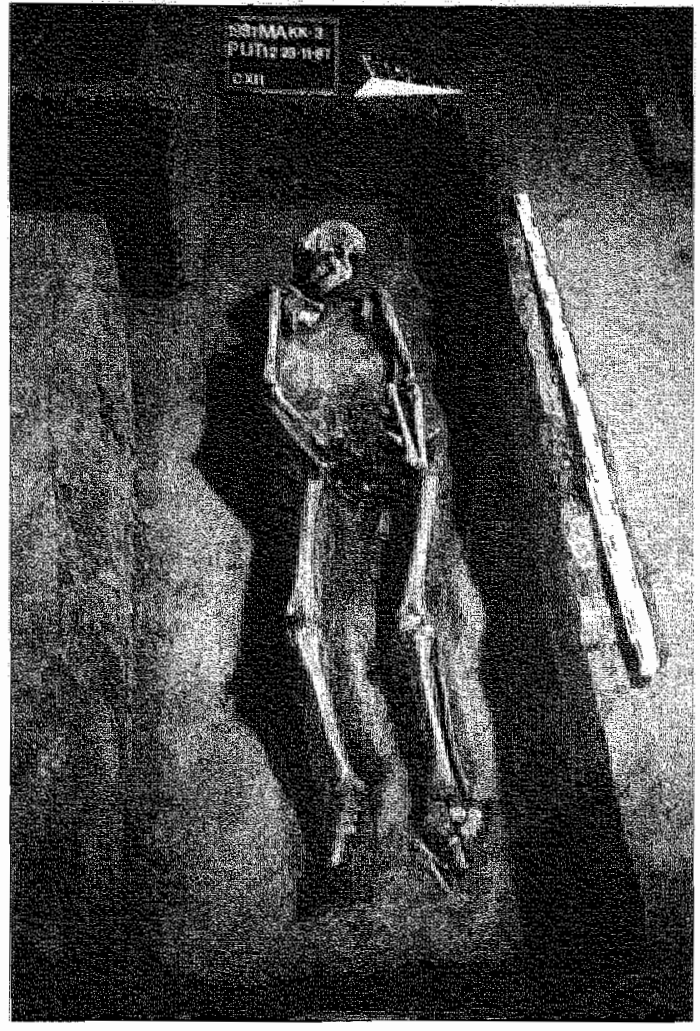

FIGURE 3-4 Boschstrad site, trench grave The inäidutual was butied with the upper extremities agcingt or alang the thorax and the lower extremities splayed (Pholobraply city of waostrichd.

evidence and illuminated manuscripts show that the wrapping of corpses in cloth was common ${ }^{2}$ Such individuals wrapped in clath and buried in a trench graves could resemble inhumations in narrow coffins after complete decomposition of the coffin.

Trench graves were common at both sites: in total 115 trench graves were excavated, 78 at the Servaas church site and 37 at the Boschstraat site. Trench and coffin graves were found in the same areas of the cemeteries. With respect to the average size of the graves, a difference was noted between the Servaas church site and the Boschstraat site. In general the trench graves of adult individuals at the Servaas church site were slightly narrower but considerably longer than thase at the Boschstraat site. At the Servaas church site trench graves were $205 \mathrm{~cm}$ long and $55 \mathrm{~cm}$ wide. Those at the Boschstraat site measured 180 by $60 \mathrm{~cm}$. 
TREMCH GRAVS MAKRED WITH STONES

Small in mbers of stones were found at the head and/or foot end of six trench grawes at the Boschstrat site Because of the presence of these stones and the central position in the cemetery of two of these graves this was considered a separate type of trench grave.

Comparable graves were not found at the Servaas church site. Recent investigations of the Whithof cemetery have showil that this grave type was in use at this cemetery. At the Boschstraat site the number of stones varied from 1 to 18 . Most of the stones were positioned at the head and foot end of the graves. As was described by Rosieux it is possible that these stones may originally hawe been placed as grove markers at the surface. ${ }^{190}$ With an average length of $195 \mathrm{~cm}$ and a width of $60 \mathrm{~cm}$, these graves were larger than the common trench graves at the Boschstraat site. Two out af six of these graves accupled a central position in the cemetery.

\section{WOODEN COFFINS}

Graves were classiffed as a wooden coffin grave if one or more of the following features were associated with the grave: remains of wood; coffin nails; a distinct rectangular or trapezoid discoloration of the soil. No differentiation could be made between burial on a wooden board, graves framed by wooden boards without the use of nails (a formwork) and proper wooden coffins constructed from at least 6 wooden planks and fixed with nails and coffin fittings. ${ }^{23} \mathrm{No}$ evidence for the use of wooden boards was found and iron coffin nails were present in almost half the number of wooden coffin graves. Therefore we assume that the major part of the graves categorised as wooden coffins were typical wooden coffins. One burial at the Servaas church site may possibly have been a wooden grave chamber. This is a specific type of wooden coffin characterised by a relatively large width and sometimes by interior divisions in the grave. ${ }^{192}$ Transwerse wooden beams under large wooden coffins, regularly found at other early medieval cemeteries, were not discovered at any of the two sites. ${ }^{13}$ At the Serva as church site 31 graves were categorised as wooden coffins. In sixteen of these burials iron nails were found. Only two wooden coffins were recognised at the Boschstraat site. On average wooden coffins measured circa 200 by $60 \mathrm{~cm}$.

Hat Gitad in Trefort 1996,123124

191 For a destiption of formwork and coffin growes sed Henrion and Hund, 1996

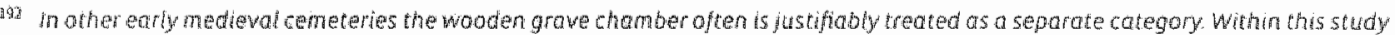

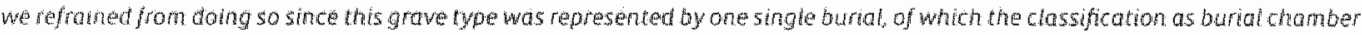
was not unequimotal Fumbermare in aspects like bonepresentetion and chances of recovery wooden chambers were probably similar to woodin coffins.

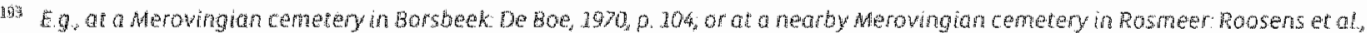
1976, p. 20.11 and p. 29.30 . 


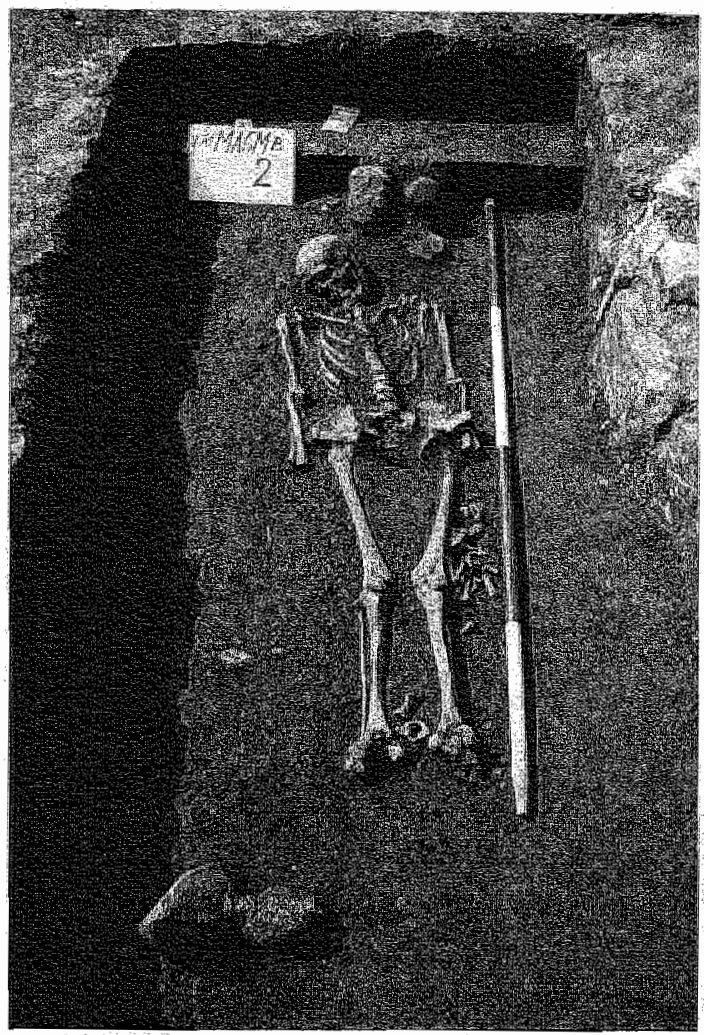

FIGURE 3.5 Boschstrat site, a trenth grawe with stones at the head and foot end At the foot end a ceramic wessel was found. The singller bomes of the hond and feet and the atos were displaced duning excavation Photograph Ciy of Mastricht

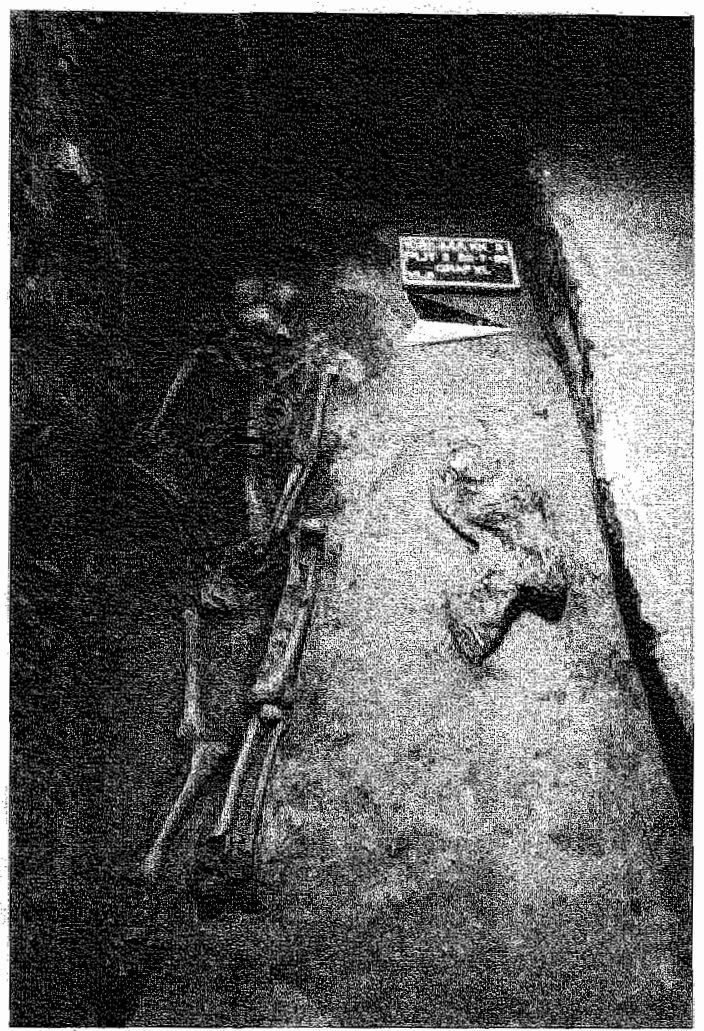

FlGURe 3-6 Serwas church site, aldrge colfh containing the

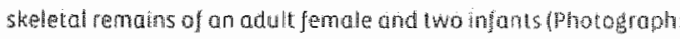
Cicy of Monstictit

\section{SARCOPHAG OF TUFF STONE}

In Maastricht sarcophagi made of volcanic tufa or tulff stone were found exclusively at the Servaas church and Pandhof site. ${ }^{\text {iga }}$ In Maastricht these sarcophagi were generally composed of four parts, two for the bottom and wo for the lid of the sarcophagus. These parts fit together and were probably hewn from one black of stone and later sawn in two to facilitate the transport of the sarcophagus and its deposition in the burial pit. Generally the two halves of the calfin lid were sealed with a strip of lead and the space between the bottom of the sarcophagus and the covering lid was sometimes filled with mortar. Inside the Servalas church seven graves of this type were found. In two cases the roof shaped cover, also made of tuff stone was still in

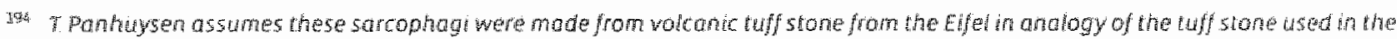

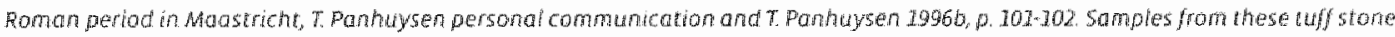
sarcophogi have not yet been examined for provendnce 
place. This type of burial displayed similarities to late Roman sarcophagi and is found on sites dating from the late Roman to the Merovingian periad. The average interion dimensions were 180 by $50 \mathrm{~cm}$ in at least one of these tuff stane sarcophogi coffin nals were found, indicating that the deceased was placed iniside the sarcophagus in a wooden coffin. At the Pandhof site just north of the Servaas church site a relatively large number of these sarcophag was found (at least 10 tuff stone sarcophagi). No tuff stone sarcophagi were found at the Vrijthof site. This type of sarcophagus was not a cammon finding in early medieval cemeteries. An example of a site in the region where several tuff stone sarcophagl were excawated is the Sankt Severin church in cologne.

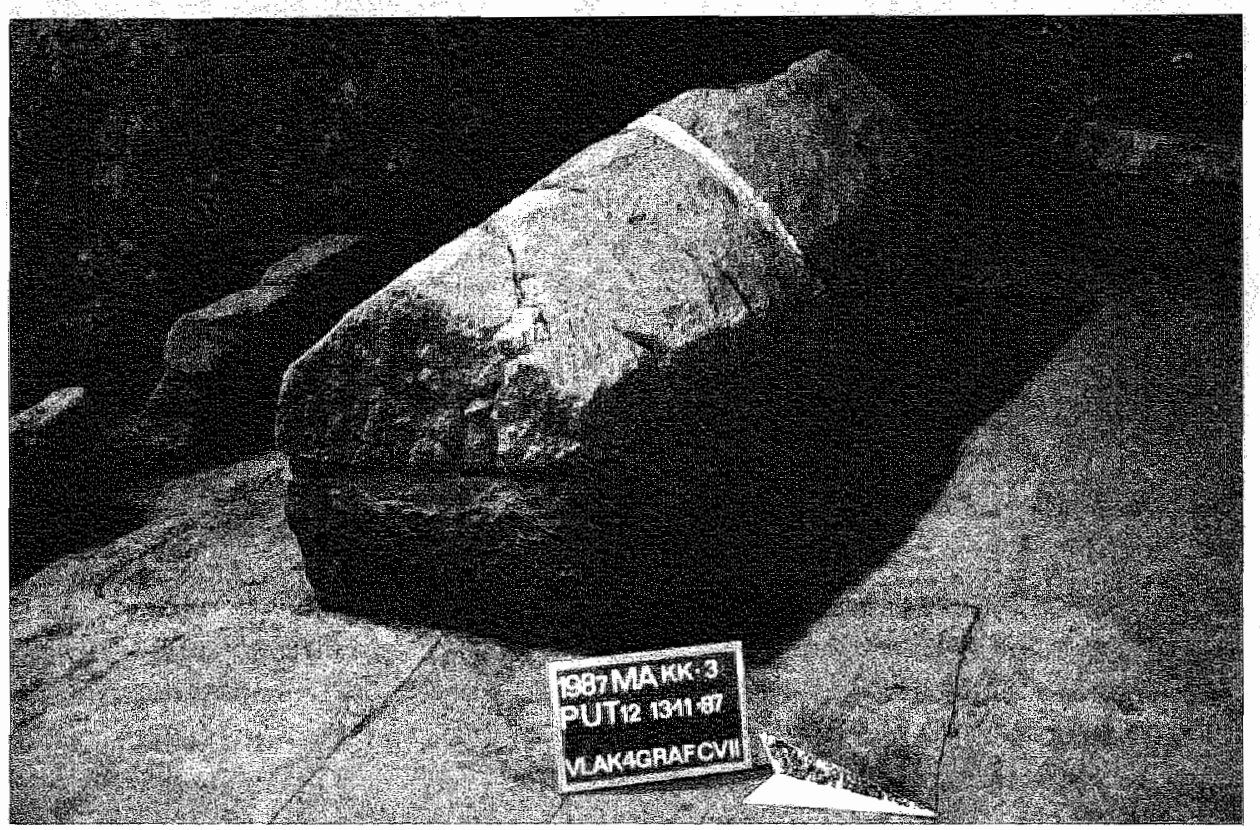

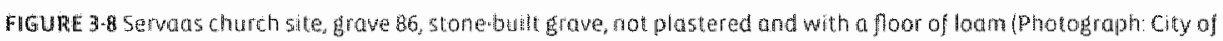
Mcastricht.

\section{STONE BULT GRAVES}

Stone-built graves were mostly constructed from roughly hewn quarry stone, carboniferous sandstone and flint. Several of these graves had red or white pllastered walls. Often the floor consisted of the loam on the bottom of the grave cut, in some instances the floor was paved with fragments of ceramic tilles. At the Servadas church site 43 graves of this type were excavated, not

las Foffoen, 1992 , volume $20.326-32 \%$, ard volume 2 passim.

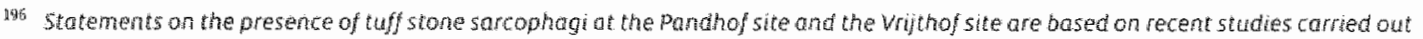
in the context of the saint Servatus Project.

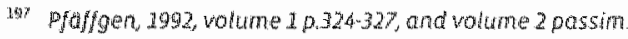


one was found at the Boschstraat site. Stone-buit graves measured approximately 185 by 55 centimetres. None of these graves was found with an intact cover. Therefore, it remaned unclear what kind of material was used to cover these graves. Most likely large slabs of stone served as a coverng lid. However, the possibility that wooden covers were used cannot be ruled out.

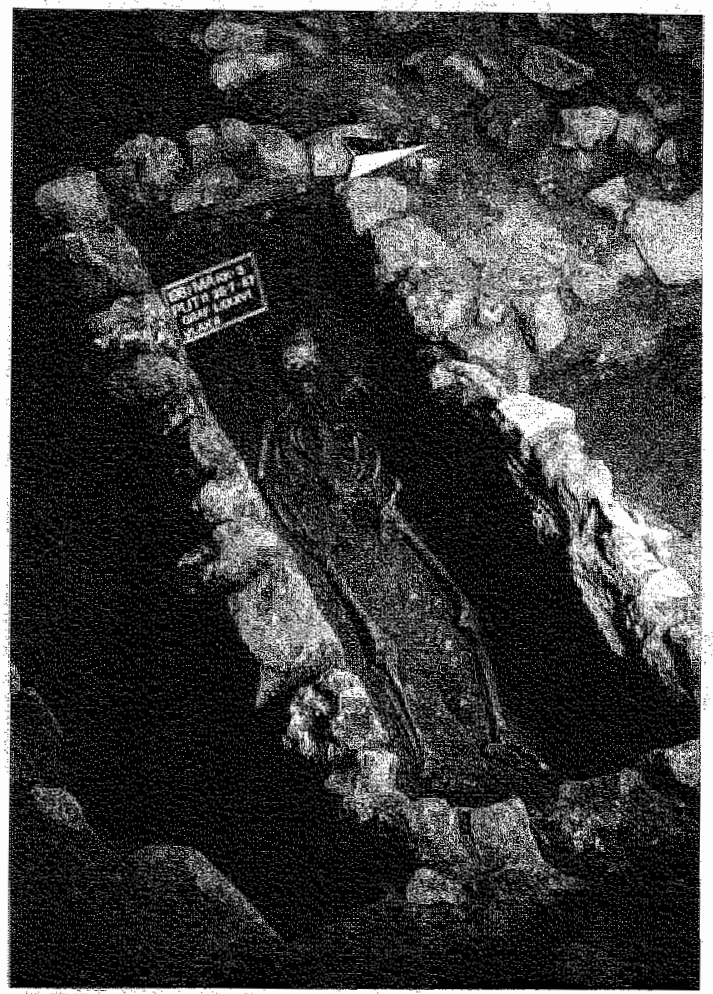

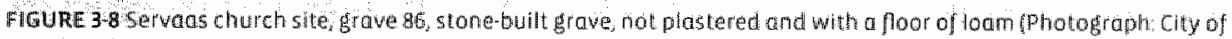
Matstricht)

\section{SARCOPHAGI OF LIMESTONE}

Like the tuff stone sarcophagi and stone-built graves, sarcophagi of Jurassic limestone were anly found at the Servaas site and not at the Boschstraat site. At the Pandhof site fust north of the Servaas church site at least another 7 limestone sarcophagi were excavated. All sarcophagi of limestone at the Servaas church site were hewn out of one piece of stone. In several cases a fitting cover was found in its original position. Some sarcophagi were covered with a reused stone lid. In those cases the cover did not exactly match the coffin. All of the 3.6 limestone sarcophagi were trapezoid in shape. Their mean interior length was $180 \mathrm{~cm}$. The mean width

This aption is also suggested for the more recent stone-buht graves found at 5 t Andrew, York stroud ond hemp. 1993. p. 153 
was $50 \mathrm{~cm}$ at the head and $25 \mathrm{~cm}$ at the foot. At least 7 or more limestone sarcophagi were found during the Pandhof excavation; one or two sarcophagi were found at the Vrijthof site. Lammers studied a large series of limestone sarcophagi from Maastricht, within the framework of a study of fimestone sarcophagi from the upper Meuse Valley. ${ }^{29 y}$ In this study he also published the results of a petrographic study of the composition and possible provenance of the sarcophagi by c. Overweel. Most sarcophagi from Maastricht were made from a type of limestone that was vacuolair or spongy oolith. Overweel suggests the area of provenance of most of the Maastricht sarcophagi was probably situated along the upper course of the River Meuse, between Savonnieres and Chemery (France). According to Lammers' study Maastricht is the place with the largest number of limestone sarcophagi and the Servaas church site is the silte where most sarcophagl have been excavated hitherto.

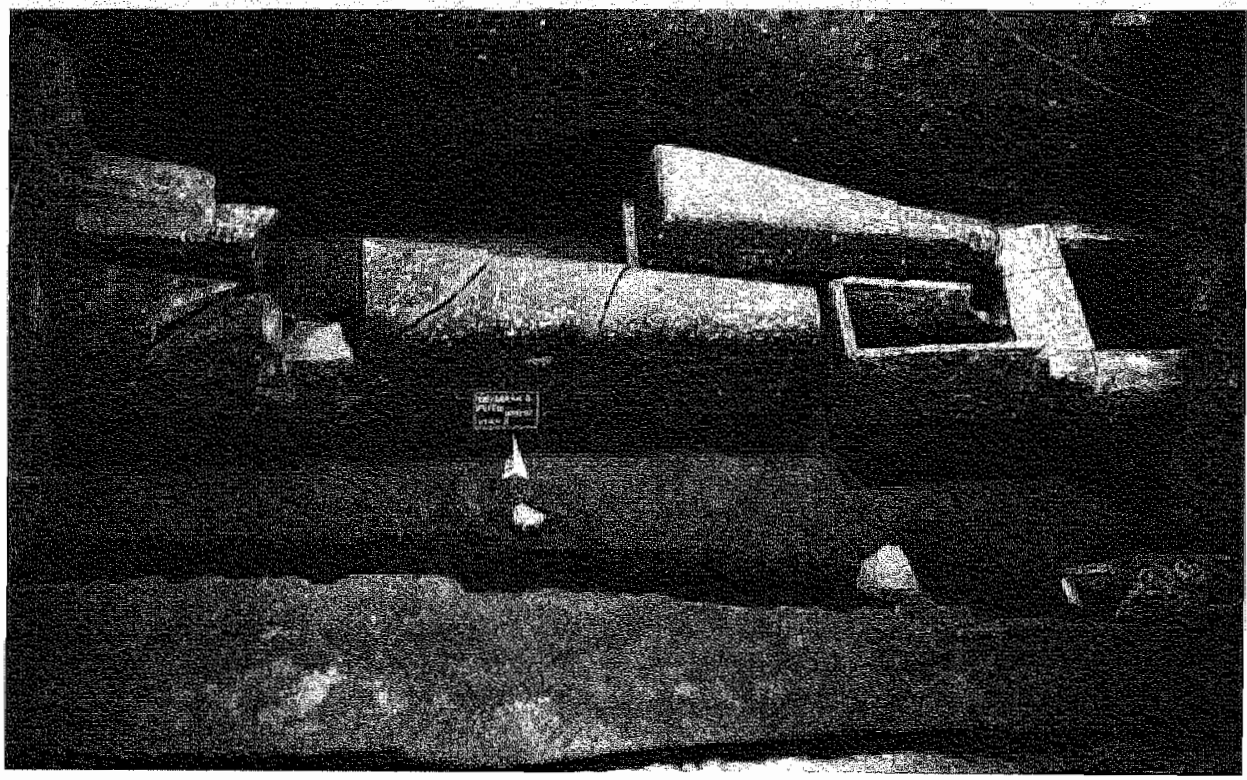

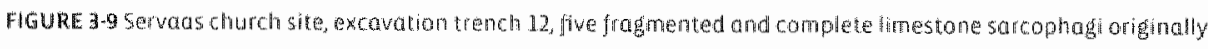

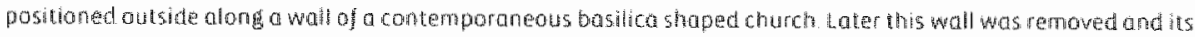

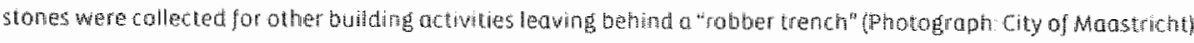

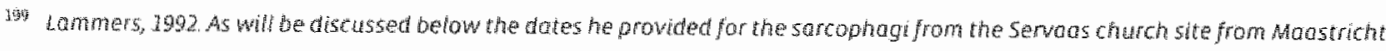
have to berevised on the bests of the results of the carbon ab dating.

wamers, $196,2,0.40$.

301 Lammers 1992 


\section{STONE-BULTTOMBS}

Seven stone-built graves with an interior length exceeding $200 \mathrm{~cm}$ were categorised as stone buift tombs The shape of these tombs could be either rectangular or trapezold. Like stone buit graves, the stone-built tombs were constructed mostly with qualry stone and flint in some cases local Maastricht cretaceous limestone was used as a construction material. Apart from the size and the use of limestone this type of grave differed from other stone-built graves due to the greater thickness of the walls. Often these stone-built tombs had a floor consisting of the same materialls as the walls. Fragments of any covering lids were now found. All seven stone. built tombs were found at the Servaas church site. The average dimensions of these tombs were $220 \mathrm{~cm}$ by $55 \mathrm{~cm}$.

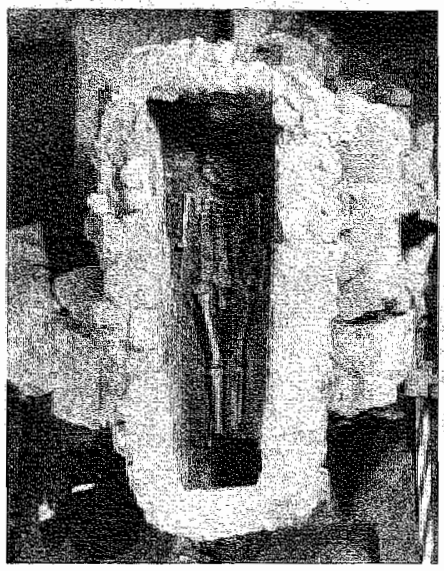

FIGURE 310 Servatas thumeh site, grave 1 , stone-buitt tomb (Photography City of Mastricht)

\section{THLE GRAVES}

One tile grave was found at the Servaas site, four vertically placed ceramic tiles created a rectangular space. Two tiles were placed at the southerin side, in the west no tile was found. Within this confined space the articulated skeletal remains of a child were buried (see figure 3-11). At the pandhof site seven tile graves were excavated. ${ }^{\text {tol }}$

\section{DESARTICULATED HUMAHU RMANS}

At both sites disarticulated bones were recovered from disturbed burials, In some cases old graves were deliberately used as charnel deposits composed of skeletal material that was found during early medieval building activities. At the Servaas site remains of at least 97 individuals were not found as articulated skeletons in situ. Inhumations at the Boschstraat site were less often disturbed. At that site the bones of 10 individuals could not be associated with any particular grave. 


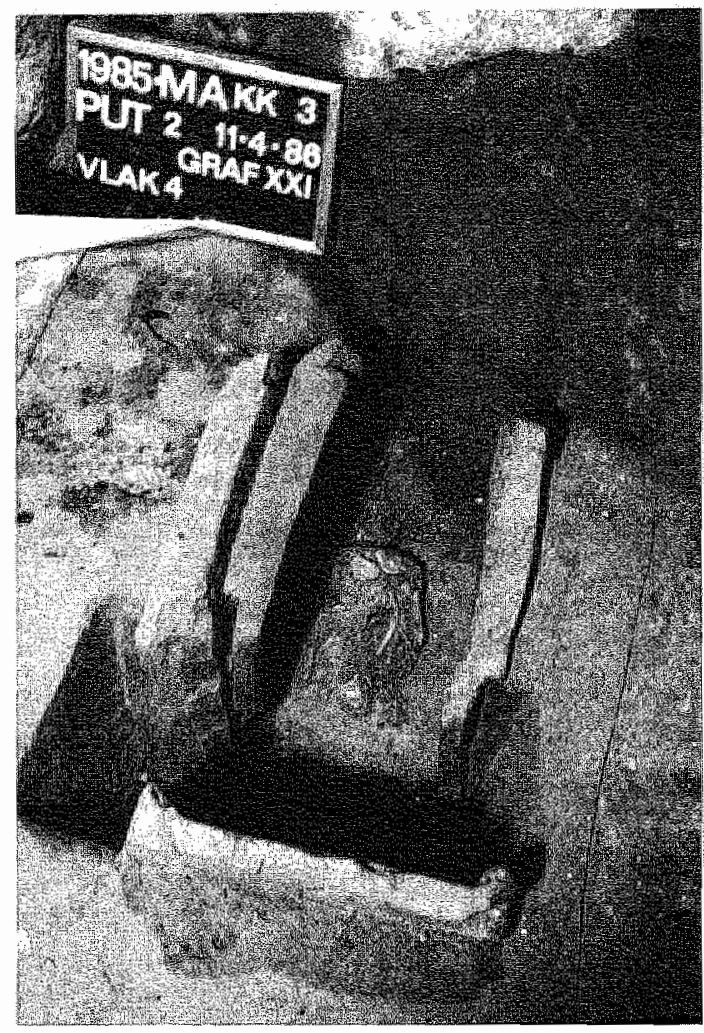

FIGURE 3-11 Servad church site, grave $2 \mathrm{~d}_{2}$, hle grave, constructed of fou roof hiles, containing the seletal remains of a young child (Photograph city of Macstrichty.

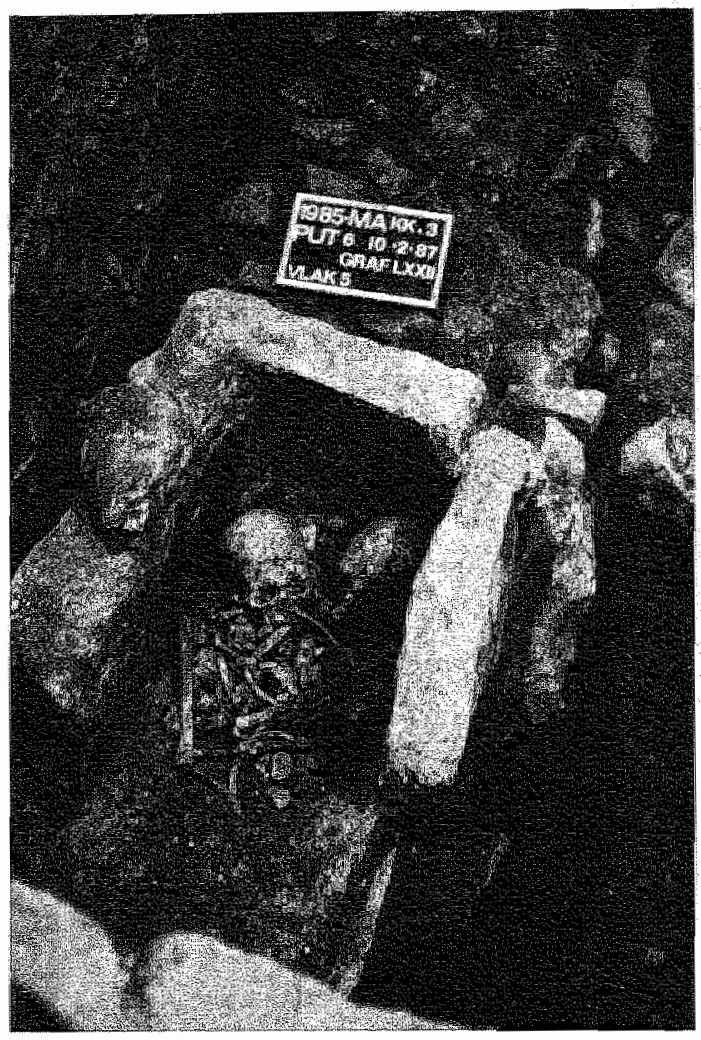

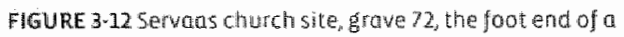
largely clemolished stone buit tomb containing the skeletal remoins of disturbed graves. Recognisatie on the photograph are two skulls; long gones wetebrae and ribs. Since the grawe was intersected by a loundation wall of the present churgh the sketeral remains were probably collected and placed in this grave during bulding achivias felated to the construction of the Komaresque phase of the present church Photograph Cily of Magstirint

\section{HISTORY OF THE SERVAAS CHURCH SITE}

The present Servaas church dominates the Vrijthaf, the central square of Maastricht. Its long and rich history has attracted treasure diggers and scholars alike. ${ }^{203}$ From the beginning of the twentieth century on, interest in the past church and monastery prompted small-scaled archaeologicah investigations.

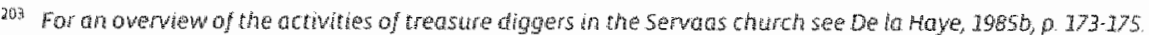

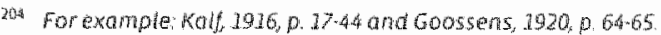




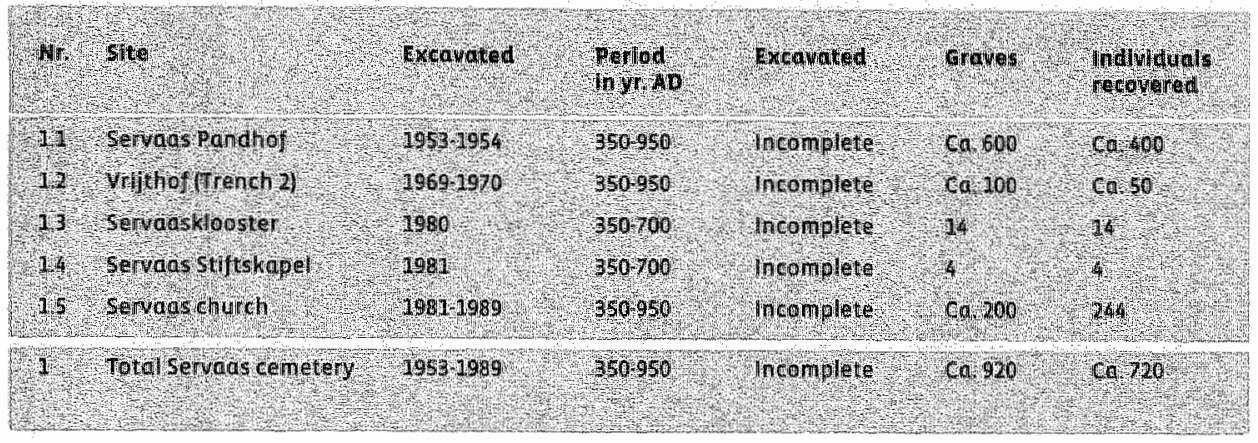

TABLE 3-2 Excavated sections of the Servads cemetery lonly late Roman and early medieval burals were included

The State Service for Archaeological Investigations (ROB) carried out systematic excavations in the building complex of the 'Sint Servads'. In $1953-54$ eight excavation trenches were dug in the cloister next to the church. Since then, the excavation has been known as the Servads Pandhof site (indicated as 1.1 in figure 3-13). ${ }^{205}$ This excavation was the first to uncover a large series of burials from the Servaas cemetery. During later excavations of the State Service for Archaealogical Investigations, in 1969 and 1970 on the adjacent Vrijthof, one of the excavation trenches, namely trench 2; encompassed another section of the Servaas cemetery (indicated as 12 in Figure 3-13). ${ }^{20}$ one of the first excavations carried out by the Archaeological service of Maastricht was situated just west of the Servaas church. At this site, known as the Servaaskloaster site, several early medieval graves from the Servaas cemetery were documented in 1980 (indicated as 1.3 in Figure 3-13).207 In 1981 the Archaeological Service of Maastricht investigated the Servaas Stiftskapel site (a chapel for the chapter of canons dated to the end of the eleventh century AD, adjacent to the Servads church; indicated as $1.4 \mathrm{in} \mathrm{Figure}$ 3-13) ${ }^{300}$ At the deepest level of this excavation four Merovingian graves were uncovered which were also a part of the Servaas cemetery. Despite these archaeological investigations, knowledge of the earliest history of the church itself was limited until excavations inside the church started in 1985 (excavations indicated as 1.5 in Figure 3-13). Bisy Because of planned reconstruction works, and the installation of under floor heating, the soll below the church floar would be severely disturbed. An archaeological investigation was therefore imperative.

\footnotetext{
Wh Gazena ond Ypey, 1956 , Werwers, 3986 and Saeters, 1989

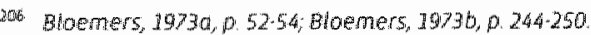

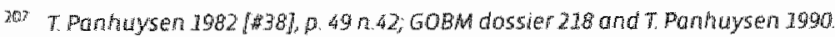

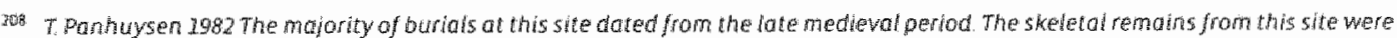
studied by lansser and Maot, 1999

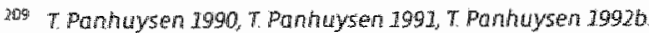




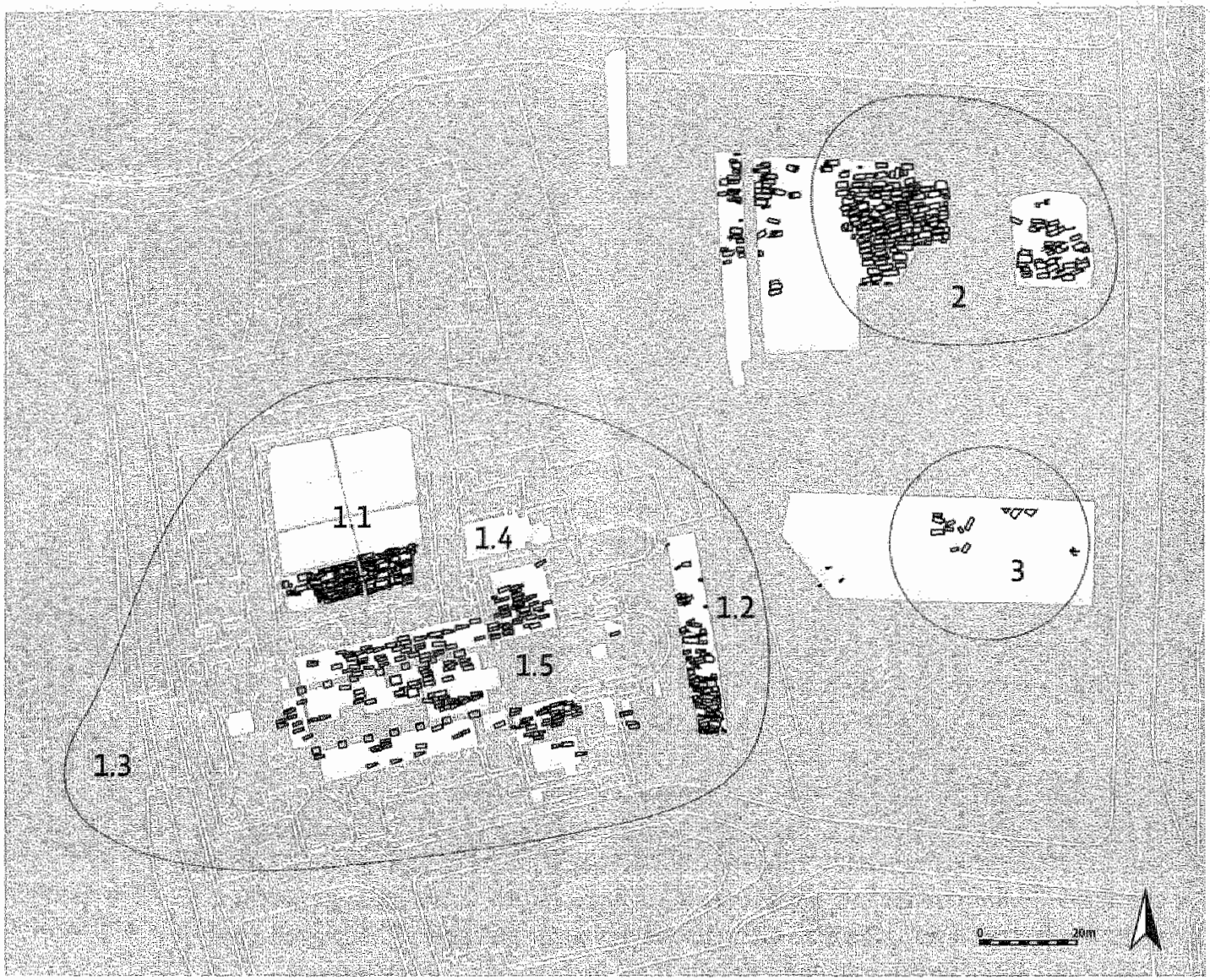

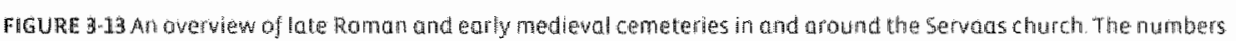

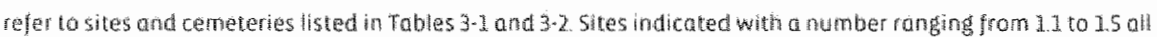
excovated sections of the iarge servous cemetery This figure is based on dota collected by the cuthor and preliminary Gata from the saint seventus project

Between 1985 and 1989 the Archaeological Service of the city of Maastricht dug 38 excavation trenches, mostly inside the present church building (Figure 3-14). ${ }^{20}$ The site comprised an area of approximately 800 square metres. The excavation team manually removed nearly 2,000 cubic metres of soll to document 4,400 square metres of surface area and profiles. ${ }^{22}$ Until now only interim reports and a short first analysis of the results have been issued. ${ }^{212}$ For a full evaluation

210 and trench 8 , 34 and 35 were dug outside the church.

nin $r$ Pahuysen $1992 b$, passim

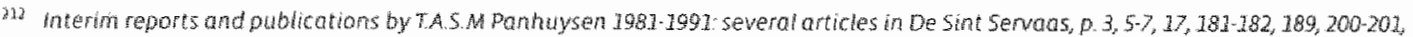

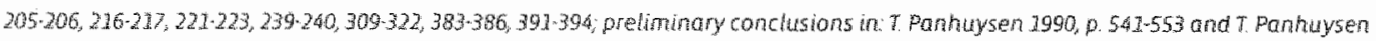


of the development of the Servaas church site it is necessary to include the awailable information from the above listed excavations in the vicinity.

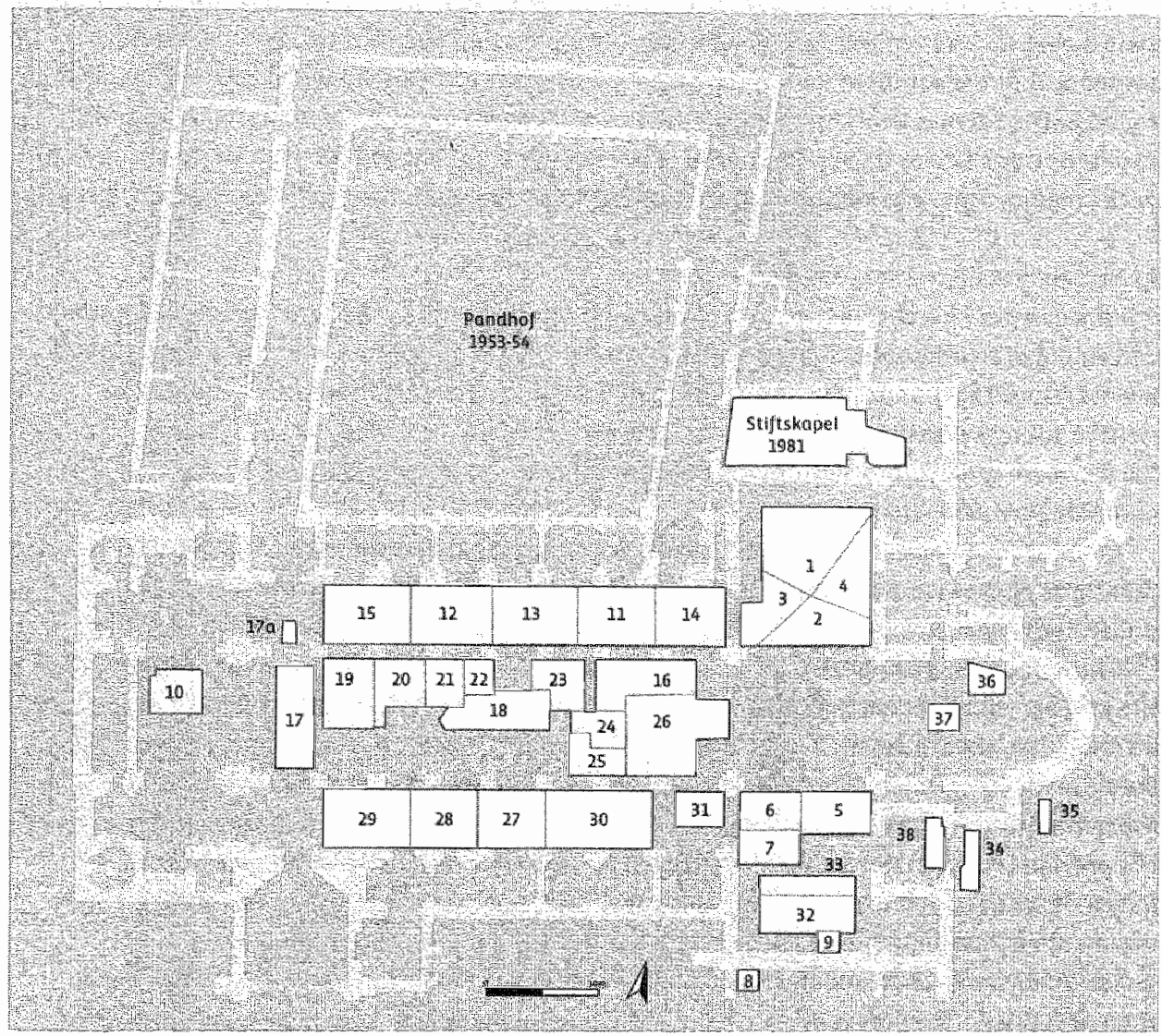

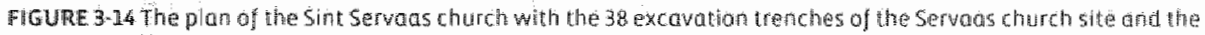
botion of wo excavations within the same buhling complex.

\section{TOPOGRAPHY}

The excavated area of the Siervaas church site lay on a small pratrusion of the western middle terrace, along the valley of the Meuse. The early medieval grave with the highest porition was excavated in trench 12. Since the bottom of the grave was situated at 5170 metres above Normal Amsterdam Level (NAP) the original surface was probably at least above 52.00 metres above NAP. Within a relatively short distance to the east the level slopes circa 5 metres down. ${ }^{23}$

1991, 1524 . Unpublishedrepont on the burids by R. G.M. Pantidysen R Panhuyseri, 20050

2as This is calculated from the difference between the bot tom of the highes grawe in trench 12 at 5 . 70 metres above wap and the bottom of grave 203 in trench 36 , which was situated at aporoximately th 60 metres above NAP. 
It has been assumed that a branch of the river jeker flowed through the lower southern area of the Vrij thaf, creating a humid marsh-like terrain. ${ }^{23}$ However, the first results of the saint Servatius project indicate that the middle of the Vrijthof was used as a burial ground at some time during the first millennium. In addition, the excawation documentation provides no evidence that the southern part of the Vrijthof was still marshy in the Roman period. ${ }^{2}$.5 The soil found at the Servaas church site and in the surrounding area was loess-loam. An important aspect of this site was its position south of the Roman road that connected the city of Tongeren with Calogne. This road was positioned on an artificial bank runining from the west to the east.

\section{PERIODISATION OF THE SERVAAS SITE}

For the Servaas church site a relative chronology was devised based on archaeological findings consisting of stratigraphical evidence and datable objects associated with the graves. A few events related to the construction of the religious complex at this site were mentioned in written sources providing a means to calibrate the relative chronology at some points. Furthermore radiacarbon dating was applied to increase our understanding of the chronological developments (Table 3.3)

In the archiaeological record four phases were recognised between circa 350 and 1800 AD. The first three phases were each named after a building that was considered characteristic for the phase: the "cella phase" (circa 350-480 AD), the "templum phase" (circa 480-700 AD) and the "basilica phase" (circa 700-950 AD). ${ }^{216}$ The fourth phase was named the "Geldulphus phase" after the provost who directed the construction works of the present church. As indicated in the intraduction, the inhumations associated with the fourth phase are beyond the scope of this study. Archaeollagical findings show that the first three phases also roughly corresponded with the periodisation of the late Roman, the Merovingian and the Carolingian period as described in the previous chapter. However, since they did not correspond exactly with these historical phases it was decided to use the chronology derived from the building phases. Neither radiocarbon dates nor grave goods provided exact dates in years $A D$ for the transition from one phase to the next. Consequently many of the dates in this study are of a more relative nature than absolute." The graves and the human skeletal remains were dated because of their association with the building phases. Some graves could be dated within periods of fifty years because of well-datable grave goods. In most cases the archaeological evidence simply allowed for the attribution to one of the aforementioned phases.

\footnotetext{
T. Panhaysen 1982 p 5255

15 Personial commenication M. Dijkstra, 2004

T. Ponhusen 1990 and Thombusen 1991

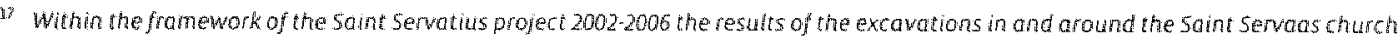
are being coltected in a large database. Fur themore an attempt is made to refine the doting of the warious phases on the basis of

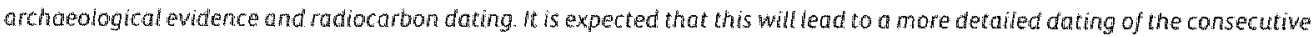
phases.
} 


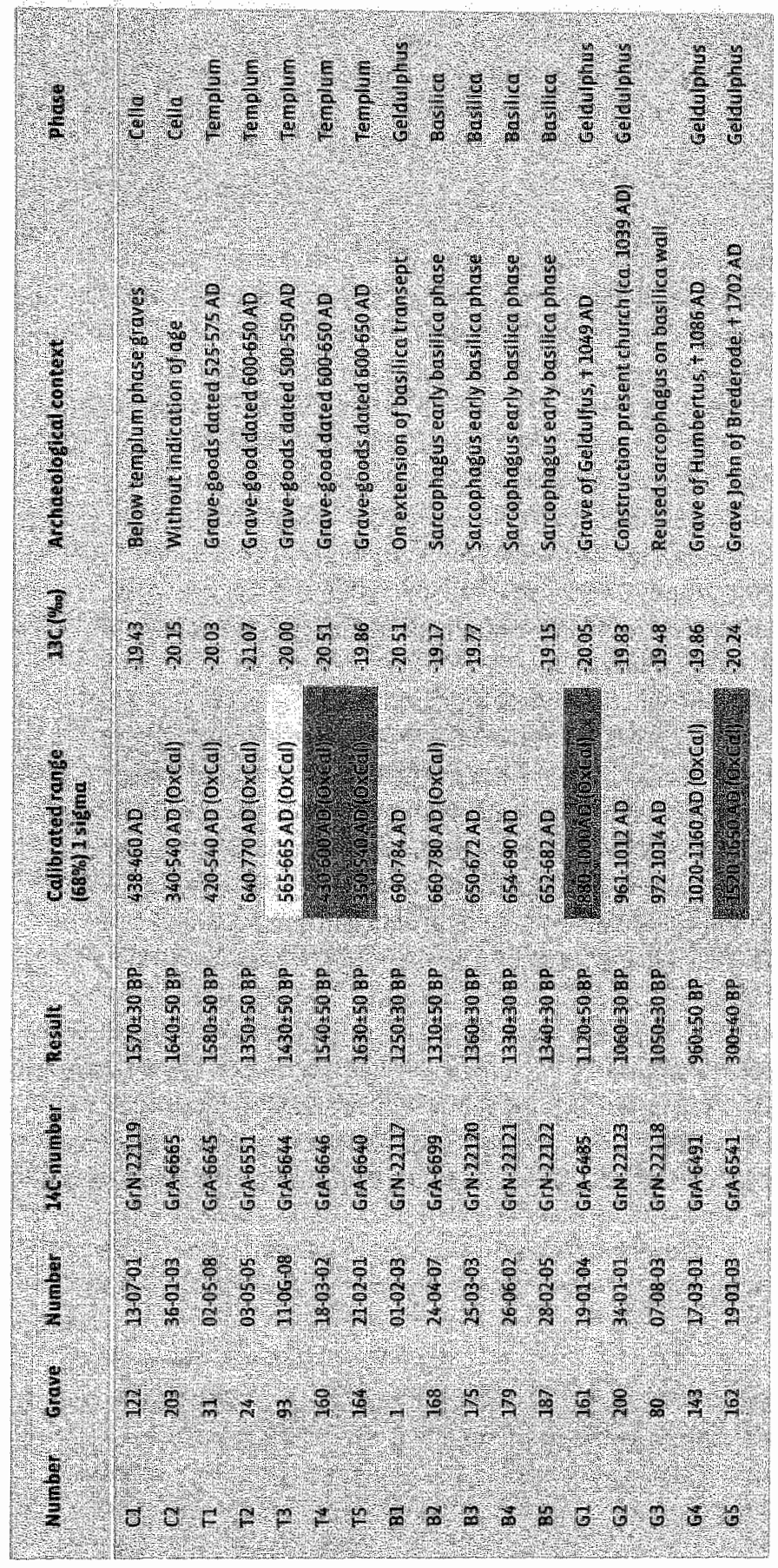

TABLE 3-3 Carbon 14 dates from 17 human bane sairpies from the serwas church exerwaton, ordered by bullding phase calbrated ranges printed in a dark shade were older, those in a light strate were younger tham experted according to the archaedogical context (All samples ware andlysed at the Centre for isotopic Resedrch; Groningen the Netheirlands. 
Seventee human bone samples Jrom intumation graves were selected for radiocarbon dating whe samples were chosen ather because they were considered representative for a particulur phase or were expected to be of use to date the period of transition between wo phases. Eight samples were selected because associated grave goods provided a specific indication concerning the calendar date of the time of burtal. 23: This last sample category may provide information on the valdity of ridiocarbon dates. Three of the calculated intervals were in accordance with the expected dates. The calculated intervals of five of these radiocarbon dates proved to be older than the intervals expected an the basis of the grave finds. Two burials with a lead cross, prawiding an exact date of death, had radiocar bon dates that were circa 150 and 60 years older than expected. Another two burials, dated by the grave goods had radiocarbon dates circa 200 and 200 years alder. Only one burial had a radiocarbon date that was younger than expected, viz. circa 100 years. What caused these differences is af importance for a carrect application of ${ }^{34} \mathrm{C}$ dates in the chronology of the Servaas church site. It is concervable that the archaeological dating of the burial and its grave goods was flawed. Such inaccuracies can only be corrected by a thorough re-examination of grave finds and stratigraphical evidence that is currently undertaken within the framework of the Saint Servatius project. However, it should be taken into consideration that reservoir effects were also a possible cause of bias in the radiocarbon dates.

Recently more attention has been paid to reservor effects in radiocarbon dating. Radiocarbon dating is based on the presence of ${ }^{24} \mathrm{C}$, which is formed high in the atmosphere. Beccuse of the constant uptake of ${ }^{14} \mathrm{C}$ during life the amount of ${ }^{\text {IC }} \mathrm{C}$ in the tissue of living individuals is ideally in equilibrium with the ${ }^{24} \mathrm{C}$ content of atmospheric $\mathrm{CO}_{\mathrm{x}}$. At the time of death the incorporation of atmospheric ${ }^{14} \mathrm{C}$ in the tissue of the organism ends. Carbon 14 is unstable and radioactive, which causes the amount of ${ }^{34} \mathrm{C}$ to decrease at a known rate from the time of death. Measurement of the remaining ${ }^{24} \mathrm{C}$ allows for the calculation of a radiocarbon date. However, inorganic environments like seawater and freshwater form a reservair of ${ }^{14} \mathrm{C}$ in which the amount of ${ }^{\mathrm{B}} \mathrm{C}$ generally is much lower tham in the atmosphere. The consumption of organic material from these surroundings will lead to a lower uptake of " $\mathrm{C}$ in the organism, which will bias the radiocarbon dating of such organisms. E. E. due to the uptake of carban lower in ${ }^{14} \mathrm{C}$ from a freshwater environment, fishes and other organisms caught allive today may yield a radiocarbon date indicating the organism was 1500 years old. A substantial consumption of such organisms by thumans will also lead to radiocarbon dates that are older than the actual date of the individual as

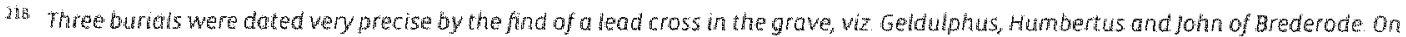

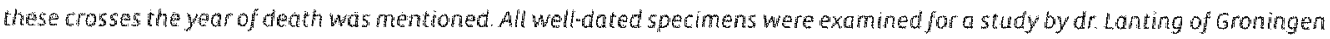

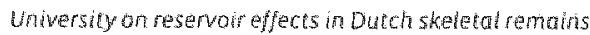

zis tantingand wan der pliche, 1996 . 


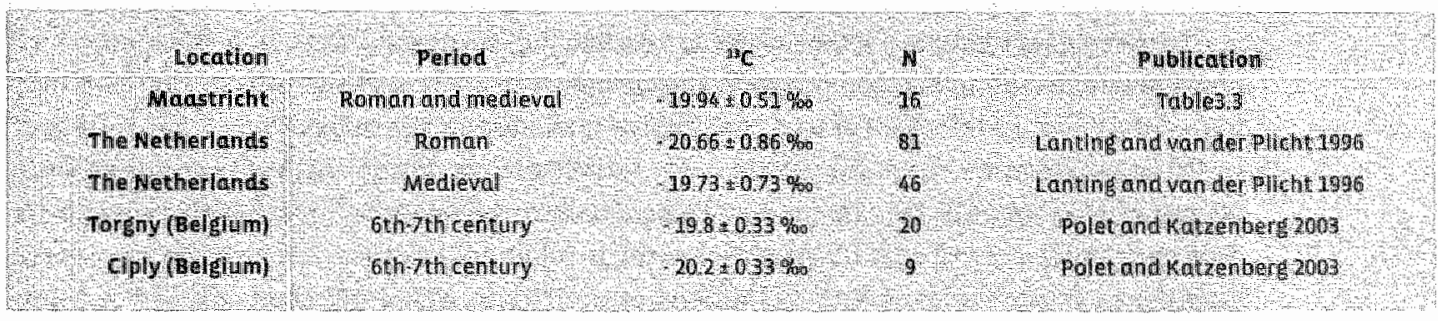

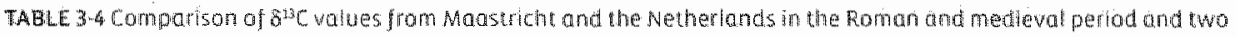
Merawngian cemeteries from Torgny and ciply.

Generally reservoir effects are caused by the consumption of considerable amounts of fish and shallfish, containing less ${ }^{14} \mathrm{C}$ than atmospheric $\mathrm{CO}_{2^{2}}$. For the consumption of sea fish the $\delta^{13} \mathrm{C}$ values provide an indication whether this may have been an important constituent of the diet. ${ }^{220}$ The consumption of large amounts of sea fish would have resulted in less negative $\delta^{2} \mathrm{C}$ walues in the samples. The mean $\delta^{33} \mathrm{C}$ value for Maastricht is lower than the value calculated for Roman samples from The Netherlands but higher than the medieval samples as calculated by Lanting and van der plicht. The difference among the samples is small, 12 out of 16 samples from the Servaas site have a $\delta^{13} \mathrm{C}$ value within one standard deviation of the mean calculated for the Roman period. Lanting and van der Plicht 5 uggest that the diachronic shift in the $\delta^{13} \mathrm{C}$ values they found might have been the result of an increase in the consumption of sea fish in the medieval period because of christian dietary instructions. ${ }^{2.2}$ However, in the case of Maastricht the distance from the sea renders it unlikely that sea fish was an important dietary constituent. ${ }^{222}$ Furthermore no diachronic trend is recognisable in the $\delta^{23} \mathrm{C}$ values. Given its bocation on the banks of the river Meuse it is possible, even likely that freshwater fish was an

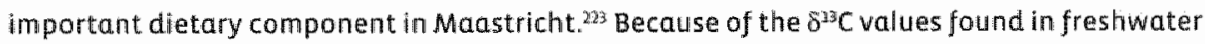
fish one would expect that $\tilde{\delta}^{\mathrm{x}} \mathrm{C}$ values of its consumers would be more negative. ${ }^{224}$ A diachironic trend in that direction is not recognisable in our $\delta^{13} \mathrm{C}$ values. Consequently the $8^{13} \mathrm{C}$ values provide no indication for large dietary changes in late Roman and early medieval Macastricht. Comparison of the $\delta^{i s} \mathrm{C}$ values of Mastricht with data collected by polet and Katzenberg for two Merovingian cemeteries in Belgitum shows considerable agreement between these sites. Measurement of the ${ }^{15} \mathrm{~N}$ values for the same samples allowed polet and Katzenberg to infer that marine fish was not an important component of diet at these inland sites. ${ }^{25}$

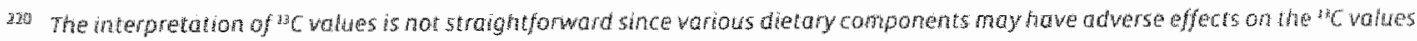

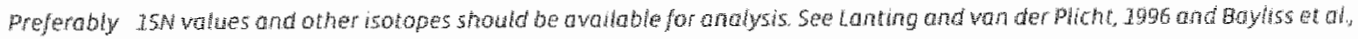
2004 :

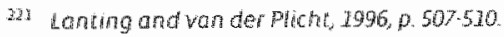

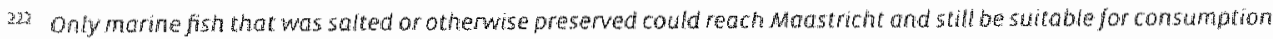

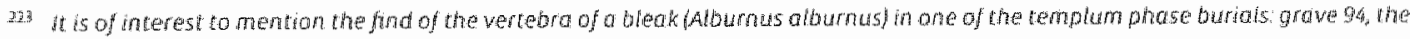
grave of the socalled rich lady".

22 seetable 2 in tantha and vander plicht 1996

22 polet and kotrenterg, $2003,0.530$ 
The discrepancy between radiocarbon and archaeological dates in the case of the five abovementioned burfals can be considered as an indication that reservoir effects may lead to bias in the dates of individual graves. In the case of four burials the radiocarbon dates were 200 to 100 years older than the expected dates. Nevertheless, there are no reasons to assume that all radiocarbon dates have to be corrected. Three radiocarbon dates of graves with a specific date matched fairly well with the expected dates, In addition the other nine radiocarbon dates, determined to test the chronology at the Servaas church site, were in agreement with the dates expected for each phase and the sequence of dates seems to be in agreement with the stratigraphical relations. The radiocarbon dates referring to the cella, templum and basilica phase will be discussed in the separate sections on each phase. More research on the possible impact of diet-related reservoir effects on the Servaas church radiocarbon dates is necessary. Such research should include other isotopes like nitrogen to establish a more refined view of dietary components and possible dietary changes in Maestricht.

\section{THE CELLA PHASE (CIRCA 350-480 AD)}

\section{DEVELOPMENT OF THE LATE ROMAN CEMETERY}

The first traces of human activity found at the Servaas church site and environs are related to mortuary practices. The oldest graves in the area around the Servaas church site were excavated near the southern side of the Roman road. Best documented is a tille grave containing cremated remains, found by Goossens in a street called Sint Servaasklooster near the Keizer Karelplein in 1926 . According to Goossens this grave, from the middle of the third century $A_{\text {, }}$ belonged to a larger cemetery along the Roman road. ${ }^{226}$ Towards the end of the Roman period inhumations replaced the cremation graves as the preferred grave type in Maastricht. ${ }^{2 a y}$ No cremation grawes were found at the Servaas church site, the Servaas Pandhof site or the Vrijthof site. Probably the origin of the Roman cemetery was situated north or north-west of these sites and nearer to the Roman raad. The oldest inhumation graves in the area have been found at the Servaas Pandhof site, although a few graves may possibly date from the third century AD. The oldest securely dated burials were (on the basis of grave goods) from the first half of the fourth century $\mathrm{AD}$. The Roman cemetery extended towards the Servaas church site and the

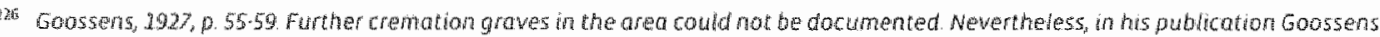
mentions six mare locations where Roman finds were discavered, which may well have been grove goods see also t. Panhuysen 19960 p. $64 \% 3$

2. In other pats of the Netherlands cremation continued to be a common practice well into the Aerowinglan period The shift from cremations to inhumations as the common type of buria in the Roman provinces has been much discussed Authough the shift is visibue in the whole Roman empire there is a wide wartety in local ritud and the chronotogy of the process see for example Morris, 1992, 1. 3.69, and Koch, $1996,0.723$

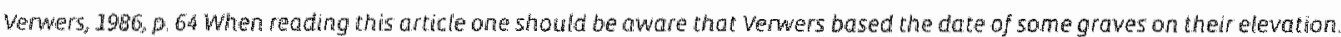
Dating on the basis of the elevotion of the grave is not possible at this site since the cemetery is partatiy lying on a slope. Furthermore, it has been established hat several early medieval graves were buried at the same level as hate Roman burials 
Servacasklooster site. According to T. Panhuysen the oldest graves these sites date from approximately the second half of the fourth century $\mathrm{AD}$, therefore they are considered of late Roman date. ${ }^{229}$ Older Roman burials have not been found at the Servaas church site or the Servaasklooster site. The cella phase was dated to the late Roman period because of the absence of older Roman finds and the presence of late Roman finds like coins and fragments of Samian ware. ${ }^{330}$

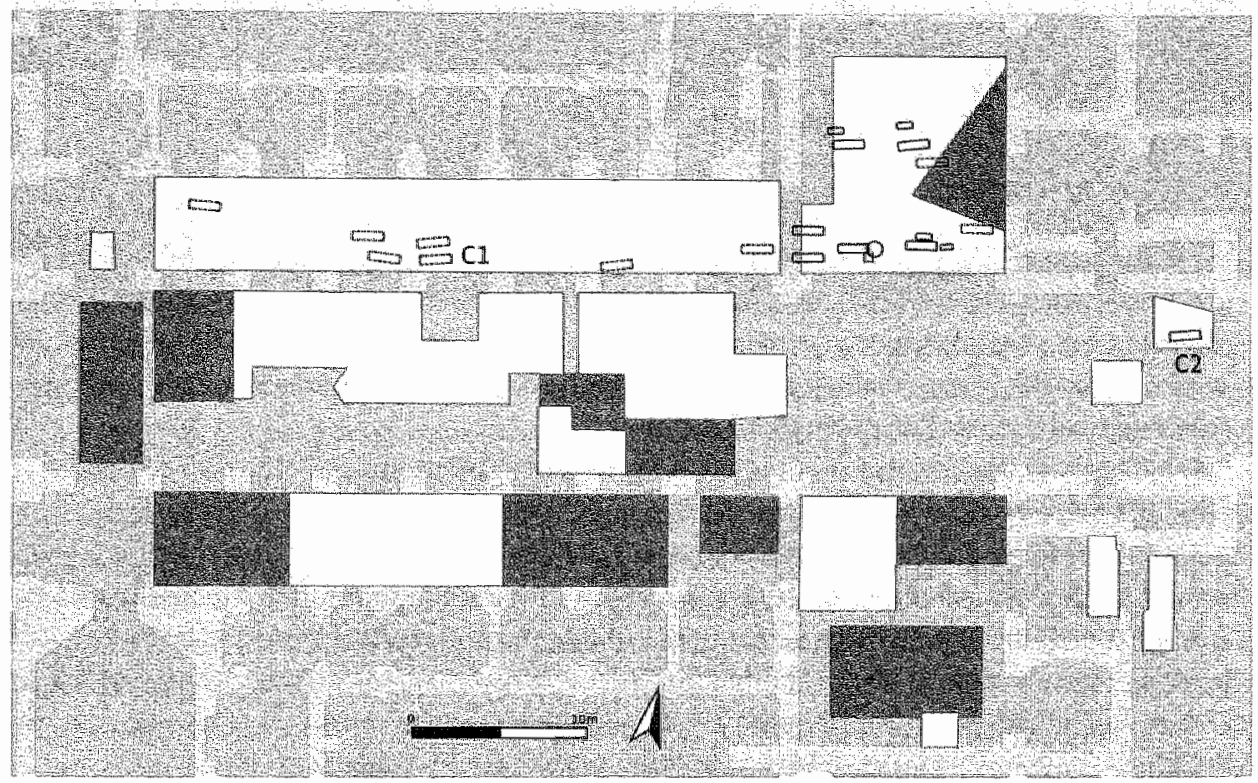

FIGURE 3-15 tnhumations from the cella phase. Darker shades indicate excavation trenches that were excavated less

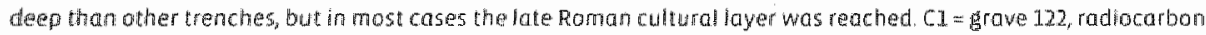

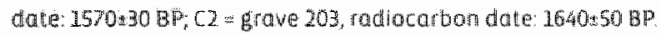

At the Servads church site all cella phase inhumations were found in the northern part of the excavated area. Although the level with the oldest recognisable traces of human activities was not explored in every excavation trench, it is likely that the distribution pattern of burials and finds reflects the actual situation of use during the cella phase. Finds of Samian ware, dating. from the late Roman period, were also found exclusively in the northern part of the site. ${ }^{3 a}$ Furthermore, traces of Roman activities and graves were absent in those sou thern excavation trenchs which were explored down to the level at which Roman finds might be expected. The

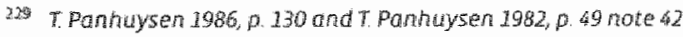

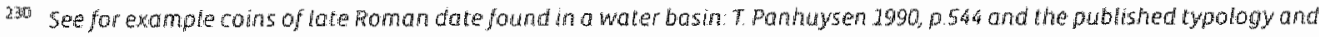
distribution of fragmens of late Roman Samian wore from variaus sites in thastricht, including the senoas church site, Dighan. 1993 .

an Personal communication W Dikman 
cella phase burial lying at the lowest elevation and easternmost location, was excavated at 46.50 + NAP, marked with C2 in Figure 3-15. In nearby trench 2 of the vijthof excavation, slightly further east of the Servaas church, no burials were found at the same level. All graves in trench? of the Wrijthof excavation were found at $47.13+$ NAP or above. At present no dates are avallable for these graves. The natural elevation of the teirain was characterised by a downwards slope from west to east. Therefore, it seems unlikely that the graves positioned at $47.13+$ NAP and above in trench 2 mere late Roman. In that case the easternmost cella phase burial inside the church represents the eastern margin of the cella phase cemetery. Because of this position at the margin of the cemetery and the absence of finds from older Roman phases it seems probable that the graves at the margin consisted solely of late Roman graves. In which case they represent the last phase of geagraphical expansion of the Roman cemetery which originated near the Roman road and in time expanded in a southern direction. This would mean that graves from the beginning of the cemetery were situated to the north close to the Roman road. Later burials (at least a selection) were positioned at the margins of the cemetery, which gradually expanded in a southerly direction. The twa radiocarbon dates (C1 and $\mathrm{C} 2$ in Figure 3-15) from the cella phase would fit this trend, since the calibrated date range for these samples centred around the first half of the fifth century.

As indicated in the previous chapter, the continuity of habitation during the fifth century is often difficult to perceive in late Roman settlements in north-western Europe. For the late Raman cemetery recovered at the Servaas church site, the Servaas Pandhof site and the Serwaasklonster site, a number of arguments suggest that the site continued to be used as a cemetery during the fifth century. As mentioned above, the radlocarbon dates suggest that people were buried here in the first half of the fifth century. Other indications for burial at the Servaas cemetery during the fifth century are grave goods found at the Pandhof and the Servaasklooster sites ${ }^{332}$ and the presence of fifth to sixth century gravestones. ${ }^{233}$

\section{CELAAMEMORIAE}

Among the inhumations at the late Roman cemetery the remains of a small building were found. It was excavated in the centre of the present church. The rectangular floor plan with exterior dimensions of 4.30 by 3.90 metres had walls of worked quarry stone. Because of its shape, size and position on the periphery of the late Roman cemetery the building could be identified as a mausoleum or cella memariae. ${ }^{23 / 5}$ The entrance to this building was situated in the northern wall, facing the Roman road that passed at a distance of circa 100 metres. No traces of a late Roman grave or an original floor level were found inside the building due to the disturbing effects of

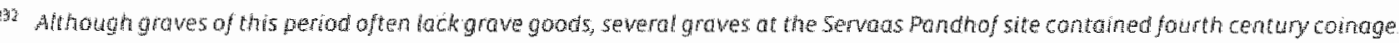

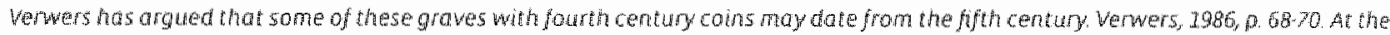
Serwaskboster siten one of the graves contaned a sword sheath that could be dated by the decorative elements as a pdece from the midrle of the fot contury Ypey 1985,69

23 Gopert, 1986

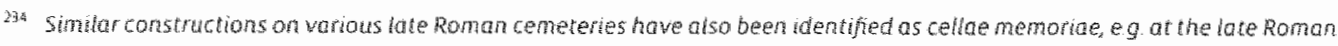

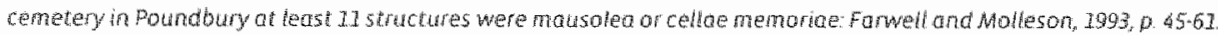



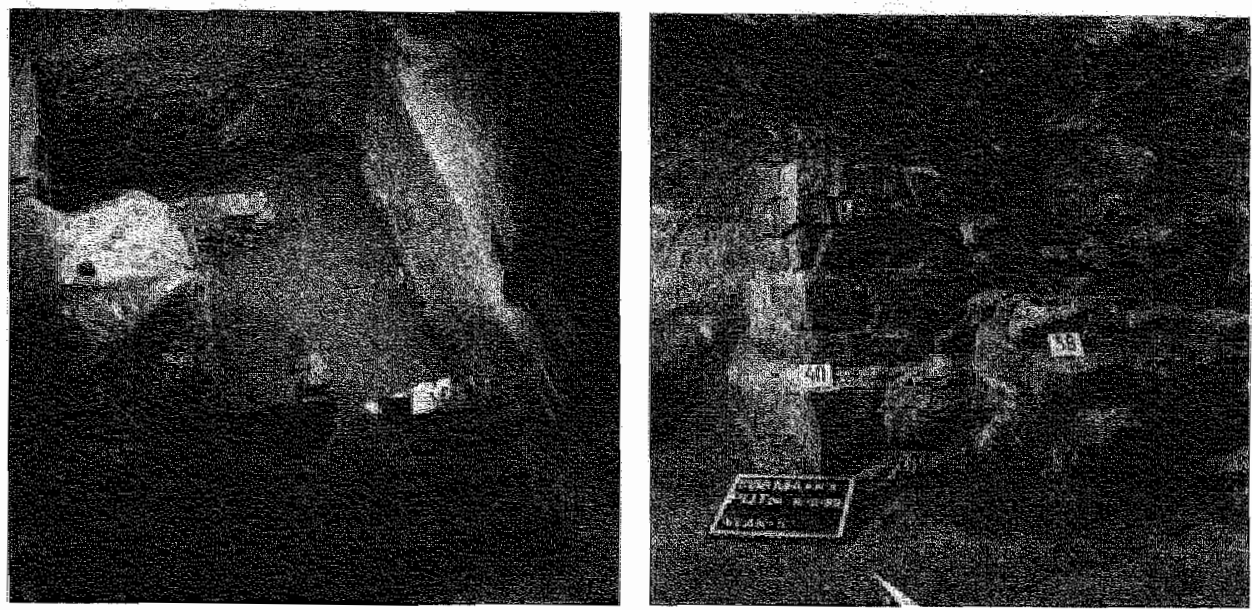

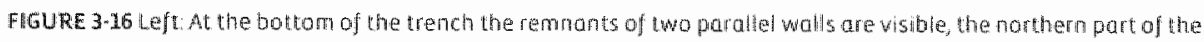

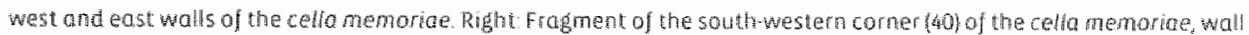

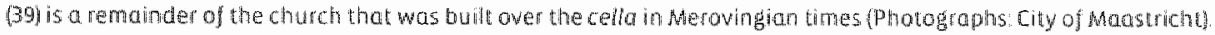

later burial activities. On the outside near the entrance of the building a floor level was found that appeared to represent the original level at the time of the construction of the cella. The above ground section of the walls of the cella started at circa 50.90 above NAP. Next to the southern wall of the cella archaeologists unearthed a late Roman water basin, made of opus signinum, a type of concrete made of crushed tiles consolidated with mortar. The recovered remains of this basin were found at a lower level, between 50.15 and 50.30 metres above NAP. The excavating archaealogist T. Panhulysen has interpreted this basin as a possible baptismal basin associated with the cella memoriae. ${ }^{235}$ Dating of the cella and the basin was based on the material tised for the construction, the shape and dimensions of the building and two coins found at the bottom of the adjacent basin dating from the last decades of the fourth century $A D$. The terminus post quem deduced from these coins is $379 \mathrm{AD}$ and the terminus ante quem was the demolition of the cella which took place at the latest in the seventh century." Hitherto no other stone-built constructions of the late Roman period were found at the Servaas church site, at the Servads Pandhof site or any of the ather surrounding sites.

Since its discovery the cella memoriae has become an important element in the disicussion concerning the authenticity of the tradition that bishop Servatius was buried in Mcastricht and the development of the Servaas manastery. "Gregory of Tours" account of Servatius" burial in Maastricht and the subsequent construction of churches and burial activities have long been considered evidence for the burial of Servatius at the site of the present servaas church. The position of the cella matches with the description of the grave of bishop Servatius in the works

\footnotetext{
25 T. Panhysen 199, p.28-19

3:6. Tombusen 1990, 5.54

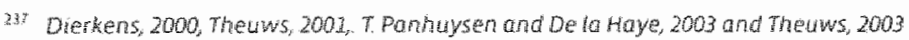


of Gregory of Tours. According to this bishop writing towards the end of the sixth century, Servatius died while he was visiting Maastricht. Gregory mentions that the bishop was buried "next to the public road". "3he archaeological dating of the cella around $400 \mathrm{AD}$, could correspond with the period in which servatius died: supposedly sometime after 359 AD when he attended the Council of Rimini. In the sixth century a church was bullt just east of the location of the cella memoriae and later the location of the cella was incorporated in this church. Also the two subsequent churches included the focation of the cella. ${ }^{239}$ Further indications that local traditions considered this spot central to the cult of saint servatius was the creation of a monastery dedicated to servatius and written sources such as the writings of jocundus. ${ }^{\text {tio }}$ However, the earliest indications that Servatius was buried in Maastricht date from the end of the sixth century, two hundred years after his death. Undisputed evidence that Servatius was buried at the excavated Roman cemetery is lacking. Nevertheless, the construction of three churches at the location of the cella memoriae, in combination with the written sources show that from the sixth century on local tradition considered this spot as the burial place of servatius.

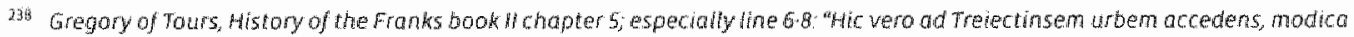

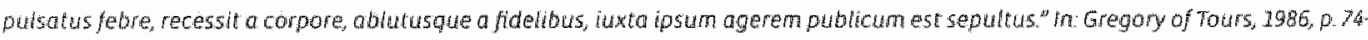

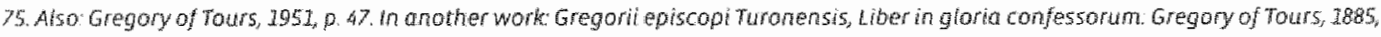

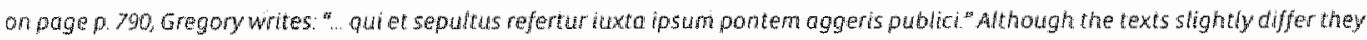
have always been interpred in the some sense from bath texts it was understood that senatius was bured next to the raad. Actually the wording of the second text seems to provide additional information that fits very well with the location of the cella

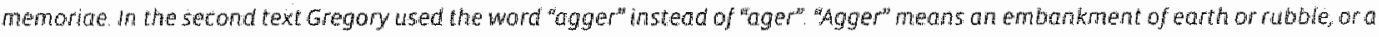
road Here it is ased in combination with the word "public", the gentive of "publica", which according wo Niermeyer can be transiated

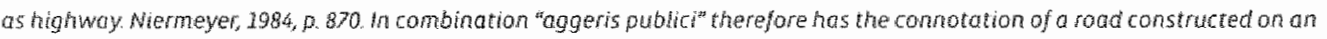
embamkment. Excawations at the writhof site have confrmed the presence of a Roman road an an enbankment. Atout hundred

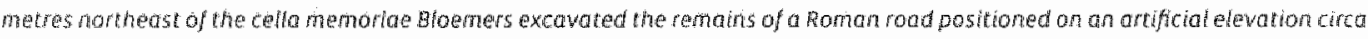

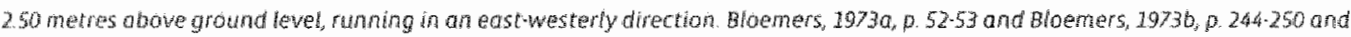

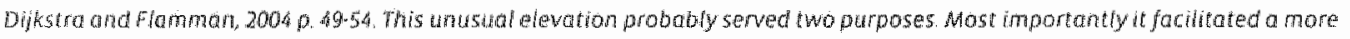
gradual ascent or descent of the slope in the tewain that warked the beginning of the middle terrace Another purpose of the

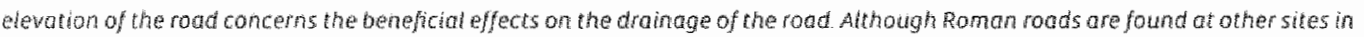

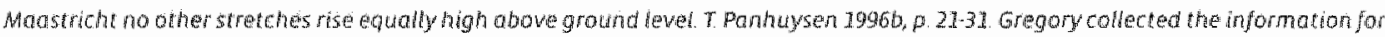

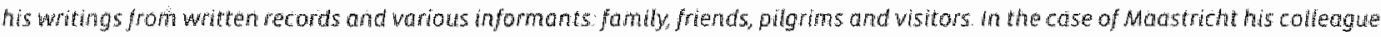

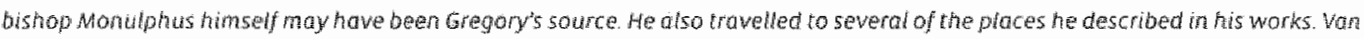

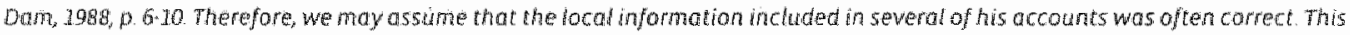
suggests that around the end of the sixth century the topography of the ste where tow assumed that servatus was buried according Gregory was similer to the find situation surrounding the cella memoride.

In the present church one can stit wist a grawe of Servatis fust east of the central crypt which bears witness lo the continuance of

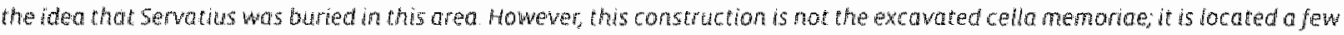
metres east of the cutio.

Jat pocundus 3556 
GRAVE TYPES, GRAVE GOODS AND SKELETAI ARRANGEMENT

Twenty-one graves were assigned to the cella phase. Most grave cuts were dug in the matural loess-toam deposit. in the eastern part of the cemetery the skeletons in four graves were partially subsided, sugiesting that the soil had previously been disturbed in that area ${ }^{\text {2ul }}$ Among the graves of this phase one tile grave was found. Rectangular traces in the soil and a few associated iron nalls indicated the presence of wooden coffins in ten graves. Ten inhumations seem to have been deposited in trench graves. Mast of the trenches and coffin graves of this phase were relatively large. Adult burials were circa $65 \mathrm{~cm}$ wide and were more than 2 metres long. Those of children measured circa $30 \mathrm{~cm}$ in width, with strong variation in length. ${ }^{3 / 2}$ Girave 40 was a wooden coffin with the dimensions of a grave chamber, measuring 2.40 by 1.20 metres. This coffin contained the remains of three individuals: one adult and two young children. At the Servaas Pandhof site wooden coffins and trench graves were also found, only in larger numbers. ${ }^{24}$ Some of the gravestones found in the area of the Servaas cemetery dated from the fifth century and therefore may have originated from cella phase graves.

No grave-goods were found in graves of the cella phase. As there were no obvious traces of grave robbery, there is no reason to assume this is the result of theft. Apparently it was not customary for the persons who buried their dead in this section to place non-perishable grave goods in the graves. In other parts of the late Roman cemetery, at the Servaasklooster site, some younger graves of the fifth century contained grave goods. ${ }^{244}$ Possible explanations for the absence of grave goods at the section of the Servaas church site may be a diachronic change in burial customs. Another options was that it was indicative of a difference in social status.

\section{CEMETERY LAYOUT}

As indicated above, the inhumations at the Servaas church site belonged to a larger cemetery. Parts of this cemetery were unearthed at the Servaas Pandhof site and the Servaasklooster site. ${ }^{245}$ The late Roman graves of the Servaas church site were situated at the southern boundary of this large cemetery. Although the cella memoriae became the central point for the building and burial activities of the following periods, no late Roman graves were found in its immedlate vicinity. Because no formal cemetery limits could be discerned, it remains hitherto unknown what determined the layout of this part of the cemetery. ${ }^{266}$ All graves were oriented west-east, with the head to the west. There may have been an association between the grave type and the position at the cemetery. Trench graves for example were found only to the north and northwest of the cella. Whereas, all wooden coffin graves were cancentrated mortheast of the cella. No intercutting of graves was found for the interments of this phase. This suggests that enough

\footnotetext{
2a. Graves $12,76,39$ and 60

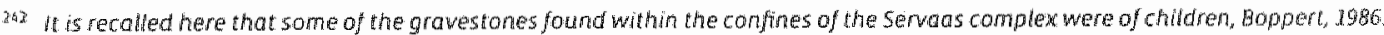

3.5 Soeters, $1989,22.24$

24.5 Ypeys 1985

24s No lote Roman graves were found at the Servas Stifchapel ste, the vrithof ste or the Theater site.

245 A detaled and integrated study of the koman inhumations ar the Servads pandhof site the Servaaklooster site and the Servalas church site may in the future prowide more information about the aetiology and evolut ton of the ceretery.
} 
space was avallable and that graves probably remained visible during the whole period. Although most of the graves were concentrated in two areas, evident clusters of graves could not be recoginised.

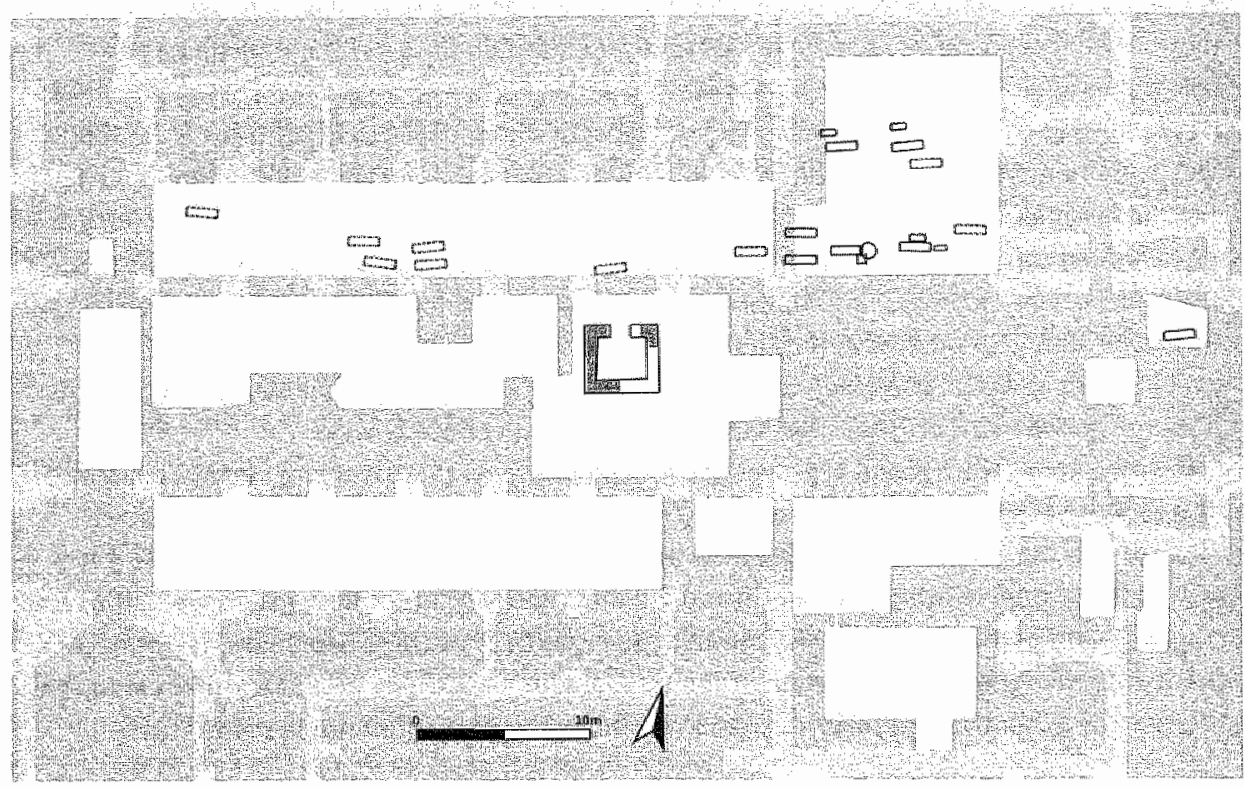

FIGURE 3-17 Cella phase position of the clla memoriae and the layour of the cemerery

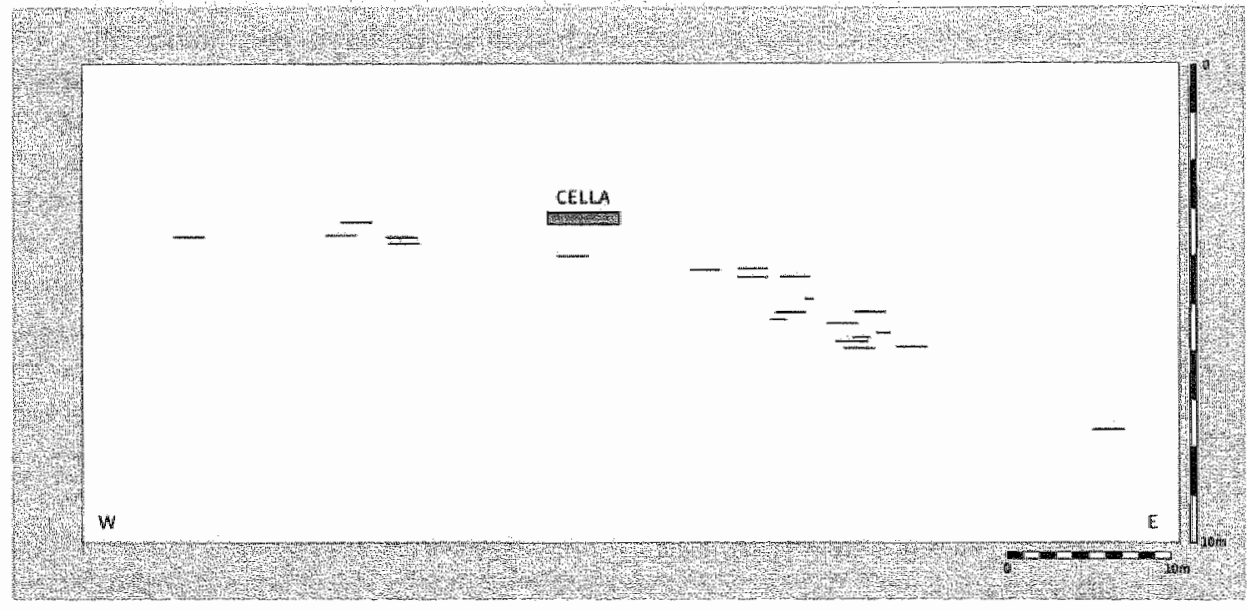

FIGURE 3-18 Cross section of the cemetery of the cellia phase Note that diffenent scales were used for horizontal and vertical projection. Wisible is a decrease in elevation of the graves from west to east 
A cross section of the cemetery of the cella phase shows how the depth of burial is determined by the natural elevation of the terrain. In the west the graves lay almost on the same level. There the grave with the highest position was found at 50.94 metres above NAP. East of the cella the terirain clearly slopes down. Grove 203 , the easternmost inhumation was found at an elevation of 46.61 metres above NAP. The cella is depicted in the middle, apparently it stood near the edge of the western middle terrace. Also the burials at the Pandhof site were positioned allong the edge of this terrace. As a result the height above NAP cannot be used to date the graves at these sites as Verwers attempted to do for the Pandhof site. ${ }^{24 y}$ Morevover, artificial elevation and diachranic variation in depth of burial all caused various graves from younger periods to be buried at lower heights above NAP than oider burials. Elevation of the terrain may even have occurred as early as the cella phase. In the eastern part of trench 2 and 3 some skeletons had partially subsided in southeastern direction. The setuing of the soll after artificial elevation of the terrain may have caused this. This effect was onlly found in a few graves suggesting only small sections of the terrain were raised. lt cannot be excluded that the subsiding of skeletons was limited to a few graves lying an top of older pits.

THE TEMPLUM PHASE (CIRCA 480-700 AD)

\section{CONTINUATION OF THE CEMETERY}

Before a templum magnum was constructed, giving its name to this phase, burial activities continued at the Servaas church site. Therefore, not the construction of the templum but the use of tuff stone sarcophagi and the reintroduction of grave-goods mark the beginning of a mew phase at the Servaas site cemetery, which coincided with the beginning of the Merovingian period. Grave goods found in these sarcophagi were dated between 480 and 550 AD. All seven sarcophagi of tuff stone were lacated west and northwest of the cella. Farther north, at the Servaas Pandhof site at least ten tuff stone sarcophagi were also discovered. ${ }^{2 \alpha s}$ These tuff stone sarcophagi are an exceptional series of burials. Only at a few sites have these massive sarcophagi been found and the number of recovered sarcophagi at the 5ervalas cemetery is remarkably high. Because of the costs that were involved in the production and transport of such sarcophagl and the precious grave goods found in some of them it is assumed that these were reserved for burials of high social status. Besides these sarcophagi, seven other graves were attributed to the earliest phase of the Merovingian cemetery. The distribution pattern of the 14 graves was similar to that of the Late Roman cemetery (Figure 3-19). Only one grave attributed to the early Merowingian period was found south-east of the cella. Moreover, the early templum phase graves north and north-west of the cella were buried at approximately the same level as the late Roman graves. This suggests that during the early Merovingian period the

34: verwers, 1980

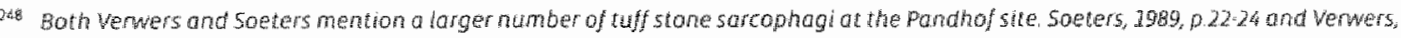
1986, 61 However, a recent study of the excavation plans carred out with the framework of the Saint Servatius projer indtated that only 10 tuff stone sorcophagi were found in sim. 


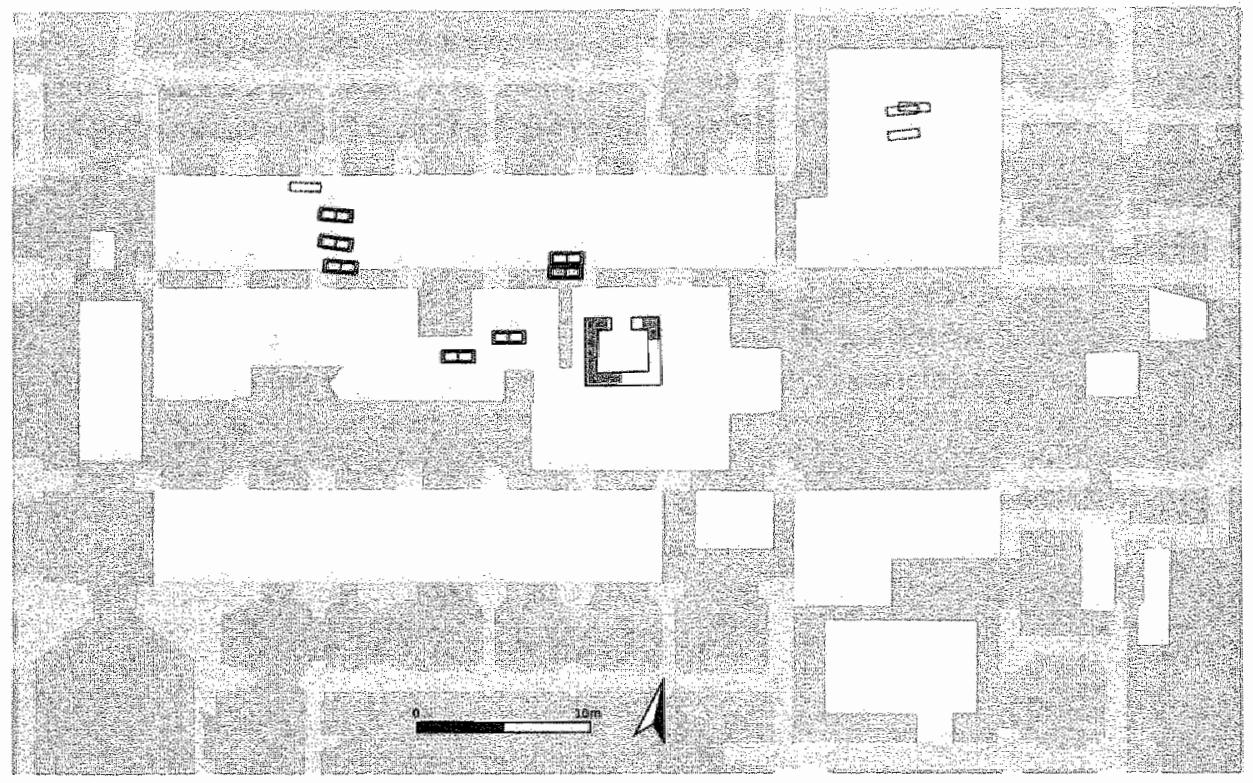

FIGURE 3.19 Templum phase the oldest Nerovingian graves depicted together with the late Roman cello memoriae.

lay-out of the cemetery did not change noticeably. Inscribed gravestones, mentioned above, provided further evidence for continuation of burial practices. Four inscribed gravestones from the fifth and sixth centuries had been reused for building material of the present church. A fifth gravestone was found at the Servaas Pandhof site. The inscriptions and Iconography shawed that these gravestones originally marked the graves of Christians from the late Roman and the early years of the Merovingian period, thus linking the cella and templum phases. ${ }^{24}$

\section{THE CONSTRUCTION OF A TEMPLUM MAGNUM}

In his book "Glory of the confessiors" Gregory of Tours dedicated a chapter to Servatius to inform his readers about two issues. Firstly he describes the miracles that occurred at the site of Servatius" grave. Secondly he mentions the construction of an impressive church (a "templum magnum") in a manner that indicates this event took place during Gregory's lifetime. According to Gregory"s description, bishop Monulphus built this templum magnum to replace a wooden oratory that stood next to the grave of bishop Servatius. The contrast Gregory created in his text strongly suggests that the new church had a more permanent character and was probably built of stone. Gregory added that the remains of Saint Servatius were "translated into this church" ${ }_{250}$ He did not specifically indicate whether the remains were collected from the grave or the old wooden church to be translated to the new church. However, Gregory's description of a wooden church next to, or on the grave of Servatius seems to imply that Servatius still was buried in his

349 soppert, 1986, p. 64.96

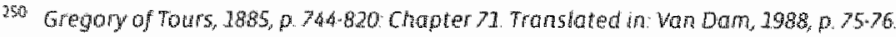


grawe at the time of the construction of the new church. Gregory did not mention any date for these events. According to van Dam ${ }_{n}$ Gregory callected the stories during his life (between ca. $538 / 539$ and 594 ) and edited most of the last version in the winter $0.587 .588 .{ }^{253}$ Therefore, the terminus ante quem for the building of the templum magnum and the translation of saint. Servatius by Monulphus is circa 588 AD. A clear terminus post quem is not avaliable. Bishop Monulphus is generally held to be a contemporary of Gregory and his episcopacy has been ascribed to the second half of the sixth century " This limits the period in which Monulphus could have built a new church to between 550 and 588 AD.

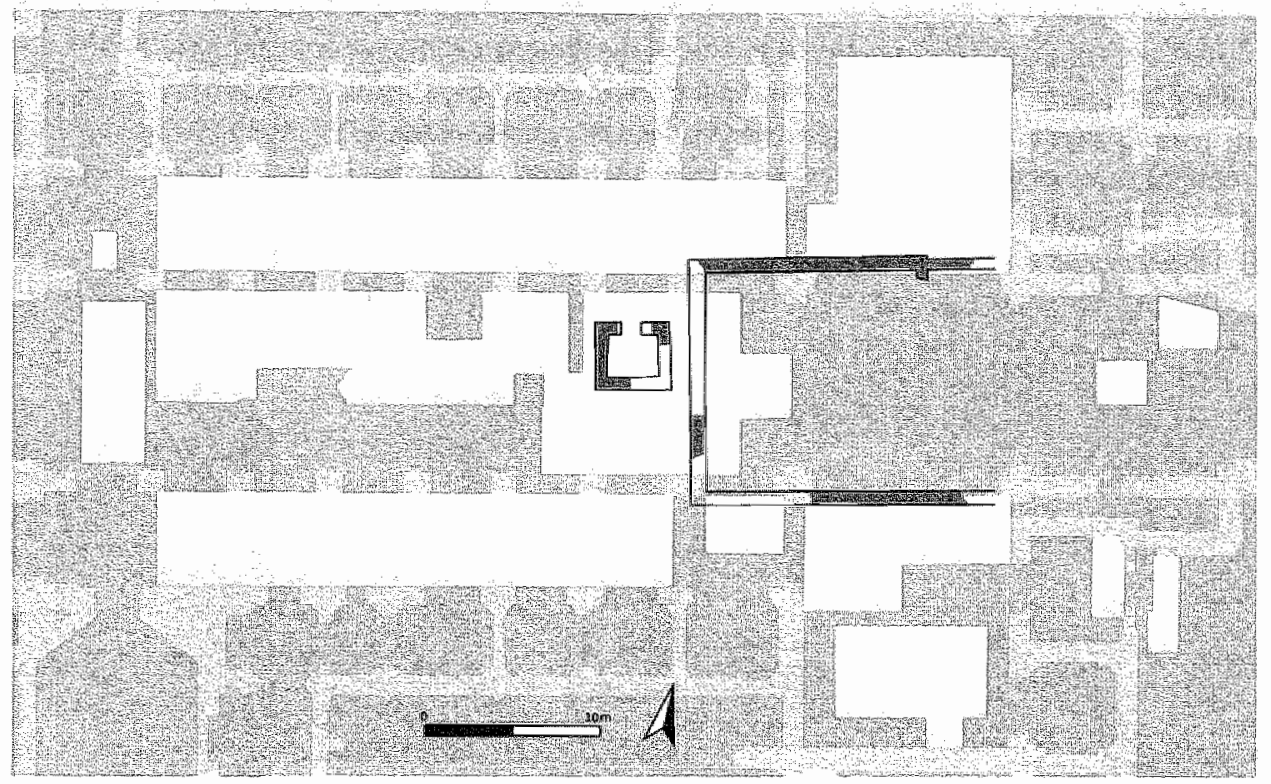

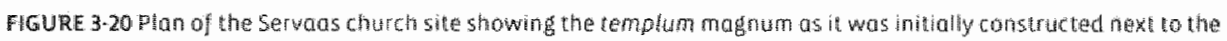
cella menariad the reconstruction of the eastem part is reconstructed after the example from contemporary churenes:

During the excavation inside the present church, remnants of the templum magnum were uncovered. A few meters east of the cella memoriae archaeologists excavated foundations and robber trenches of a rectangular building approximately 15 metres wide. As later building activities had disturbed the eastern end of this edifice, assessing its length was not possible. The remaining fragments of the north and south walls have a length of circa 17 metres. Because of its position and the related findings, this building has been identified as the templum magnum of Momulphus. ${ }^{253}$ Other fragments of walls, found farther north at the Stiftskapel site

\footnotetext{
35. Whath, $2988,0.6 \cdot 5$

x5. Delo Haye 7985 , p a De Moreau, 1940, p. 35-35.

253 T. Pinnuysen 1991
} 
and the Servaas Pandhof site, are probably the remainder of residential buildings of a monastic community or the entourage of the bishop. Below the walls of the magnum templum graves from the fifth century $A D$ were found, providing a terminus post quem. A terminus ante quem is less evident, although several graves containing grave-goods from the sixth and seventh centurles were associated with this structure. The archaeological evidence indicates that at the beginning of the Merovingian period the cella memoriae may still have been wisible. This would fit the description by Gregory of Tours that Servatius' grave was situated next to a wooden oratory that was replaced by the templum magnum. ${ }^{25}$ Remains of a wooden oratory were not found at the Servaas church site. To deduce the position of the wooden oratory from the distribution of the graves from the beginning of the templum phase is hardly feasible. At first glance the position of graves does not suggest these were placed inside or around a building (Figure 3-19j. East of the cella no graves have been found but in that area only small sections could be excavated. Therefore, it is not possible to determine whether the wooden oratory was once situated in the same location as the templum or somewhere else.

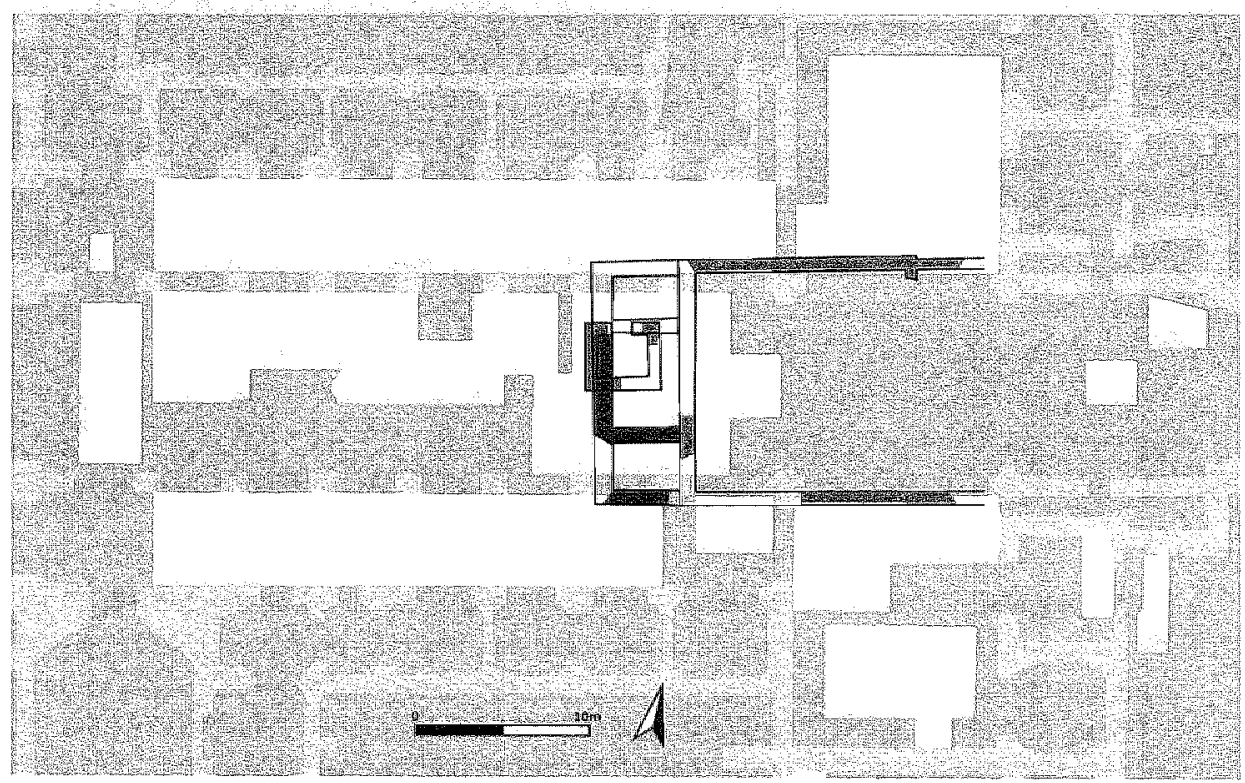

FIGURE 3-21 Templuri phase the extension of the templum magnum i= darker shade) almost completely covered the stite of the cella, For the construetion of this extension remains of the walls of the cella were used as a foundation.

During or after the secand quarter of the seventh century the Merovingian church was enlarged. At that time an extension was built at the western end, adding five metres to the tatal length. As a result, the lacation of the former cella memoriae fell largely within the walls of the

25: T. ponhuysen 1982 
templum magnum, ${ }^{256}$ If the cella had not been dismantled earlier, it must have been demolished for the construction of the extension of the templum.

In the present chronology of the templum phase radiocarbon dates (Table 3-3) cannot contribulte to a refined sequence of events. In general the dates fit in the established chronolagy. Discrepancies between the radiocarbon dates and the provisional dates based on grave finds should first be further analysed. As indicated above, reservoir effects may have led to radiocarbon dates that were too old. Ongoing work on the stratigraphical developments and a detailed study of the grave finds will in the future provide more evidence whether ar not the radiocarbon dates are affected by reserwoir effects.

\section{GRUVE THPES}

Despite the fact that all tuff stone sarcophagi probably antedated the construction of the templum, they were still attributed to the templum phase because of the accompanying grave goods. The grave goods in graves 31,88 and 94 clearly place the tuff stone sarcophagi and assaciated graves in the early Meravingian tradition and dates them in the first half of the sixth century $A D$. Of the seven graves of this type at the Servaas church site, two had remained intact until the moment of excavation. All others were severely disturbed or even demolished by later
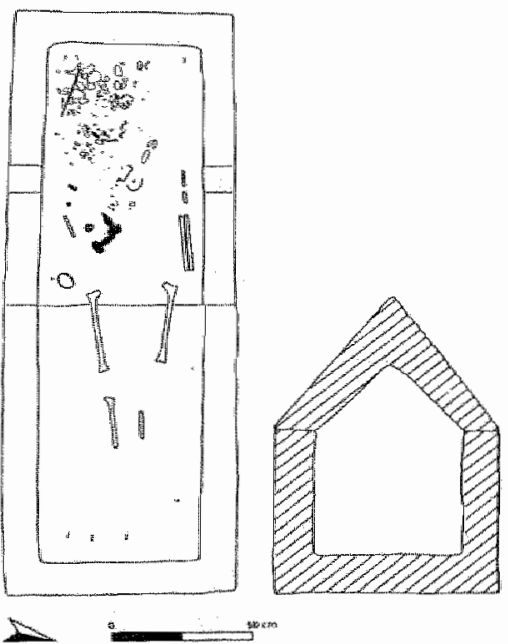

FIGURE 3-22 An overview of the skeleton and objects in grave 94 and a cross section of this tuff stone sarcophagus. Grawe g4, along the walts of the siarcophagus the coffin nats are wistbie as small black bhaped abjects. The grave goods were mostly found in the upper haly of the sarcophagus Their position whthin the space denarcated by the coffin nats suges th that arighally these finds were placed inside or on top of the wooden coffiri Recognisable are, from the top to the midde the hoirpin, two fibulae and the bracelet (Drawing Crty of Maastrictury

burial activities and construction works. In one of the intact graves (grave 94) iron nalls, positioned along the sides of the grave, indicated that a wooden coffin was used to bury the person inside the sarcophagus. In the works of Gregory of Tours there are indications that some stone sarcophagi were placed above ground. ${ }^{23}$ The tuff stone sarcophagi at the Serwans church

20 T. Penhuysen 1990 , p. $544-545$

25? Wan Dam, 2988, see oiso Effros, 1997 . 
site were found at the same elevation as late Roman inhumations in coffins. Therefore, we may conclude that these sarcophagi were not placed at ground level.

After the construction of the templum magnum stone-built graves became the most popular grave type. The stone-built graves appear to have replaced the tuff stone sarcophagl. The majority was constructed close to the templum. Several used the wall of the church or ather graves as one of the sidewalls of the grave. ${ }^{35}$ All thirty-nine graves of this type were dated to the middle and later Merovingian period. Iron mails, found in three stone-built graves, indicate that wooden coffins were probably placed in at least a number of these graves. A special wariety of this type was the twin grave. Four twin graves were recovered (Figure 3-26). They were either buift as one grave with two compartments or as two separate graves positioned very clase to each other. Trench graves were common during the templum phase. At the Servaas church site twenty-three trench graves were excavated. Wooden coffins were less common; nineteen graves were identified as burials in wooden coffins. In comparison with the tuff stone sarcophagi and the stone-built graves the trench graves and colfin graves were often placed at a greater distance from the church. However, they were also found among the stone-built graves as well as in separate clusters.

\section{GRAVE GOODS}

Various graves from the templum phase contained objects like knives, keys, boxes, pottery, glass, Jewelry, belt sets and fibulae. in this respect, the burials were consistent with a widespread practice in early medieval Europe to place abjects and possibly food and drink in a grave. The interpretation of this practice is the subject of debate. Traditionally the objects were considered the personal possessions of the deceased. Recent interpretations focus at the display of objects in the grave as part of a statement of the persons arranging the buriall. ${ }^{259}$ At the time the data for this study were collected the restoration and andysis of the grave goods was not yet completed. ${ }^{250}$ Therefore, it was not possible to evaluate the quality, quantity and significance of grave goods in detail. Here only a few general observations will be presented. For thirty-three graves information on grave gaods was available. Originally more graves would have contained grave goods. Due to disturbances by later construction works and burial activities a large number of the graves were disturbed and their contents dispersed in the soil. Many grave goods were found in elewation layers and near demolished graves. It is possible that people carrying out construction works incidentally removed grave goods. However, no evidence for the deliberate looting of graves was visible at the Serwas church site. At the Pandhof site at least one clear case of grave theft was recorded. ${ }^{\text {gat }}$

sthe terdency at Merovingian ceneteries to construct graves that were in physical contact with lolder bundings was described by

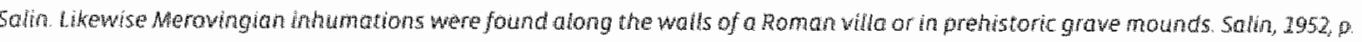
$15-21$

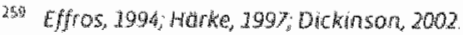

2hin The sudy of the grave goods from the Samt Servas site is phnmed for 2005 and will be undertaken by wh Kars within the framewowk of the saint Servatius propect.

36. In trench 1 a robber pit had been dug to colfect grave goods from a tuff stone sarcophogus and a limestone sarcophagus. 


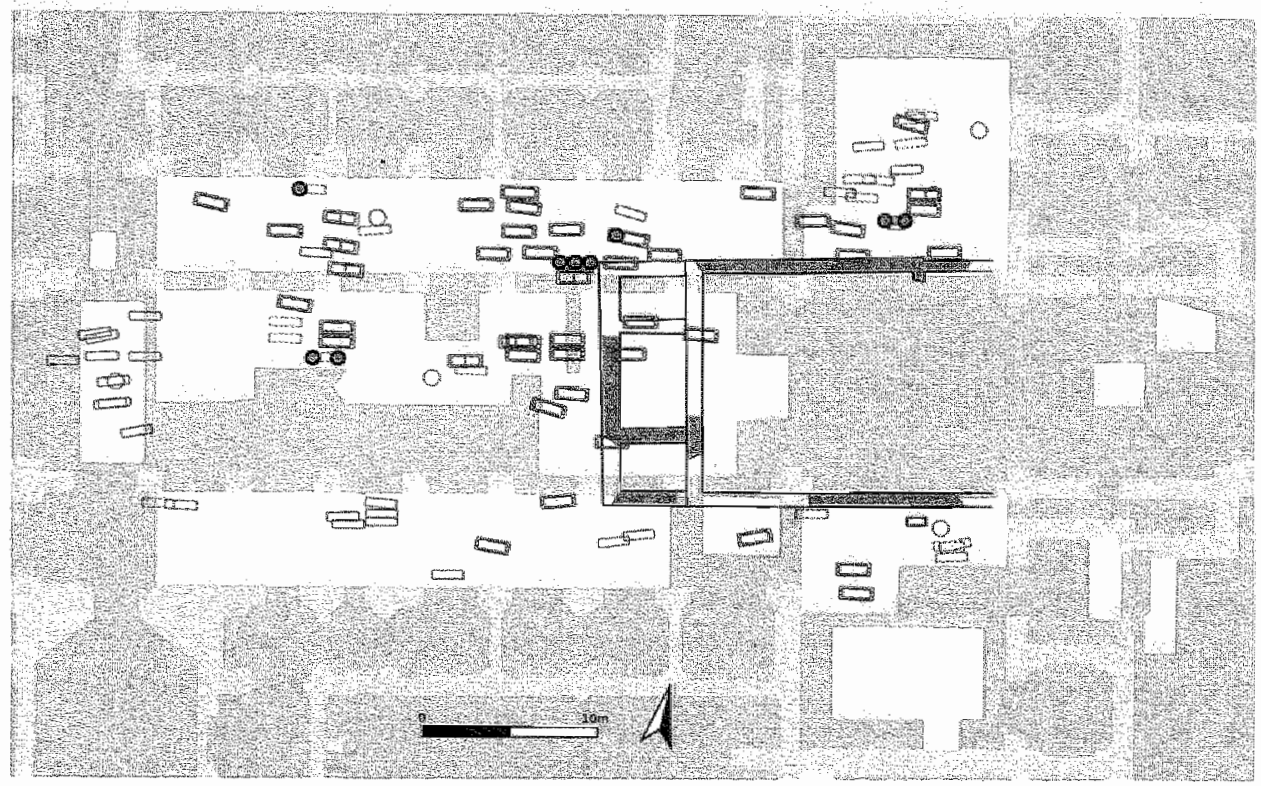

FIGURE 3-23 Temphum phase focation of five graves with exceptional grave goons

Because of the above-mentioned post depositional disturbances our view of the frequency and quality of grave goods is considerably abscured. From sixteen graves one abject was recovered, six graves held two objects and eleven contained three or more grave-goods. Most of the objects date from the sixth century $A D$, the rest from the seventh century $A D$. After the seventh century the custom to deposit grave goods appears to have became obsolete at the Servaas church site. A broad variety of grave goods was found ranging from simple knives and Iron flints to lavishly decorated belt-fittirigs and golden brooches. Mast of the richer assemblages came from graves of wamen. Precious grave goods with a male connotation were also found; only some of these could be ascribed to a specific grave.

Some examples of grave goods found in situ will be presented below. The nature of these grave goods corrobarates the idea, already evoked by the presence of tuff stone sarcophagi, that indiwidualls of high status were buried in this section of the Serwaas cemetery. Grave $94_{i}$ a tuff stone sarcophagus, contained by far the largest number and most valuable grave goods. Inside the sarcophagus, archaeologists discovered numerous precious objects, which clearly showed it was the grave of a distinguished woman. Judging by the necklace with gold pendants, gilded brooches and clasps, a silver hairpin and bracelet, this was the grave of a woman of the Merowingian elite. ${ }^{262}$ In comparison to contemporary graves, traditionally associated with royal status, the grave goods of grave 94 were only slightly less abundant. The other tuff stome sarcophagus that was found intact and unopened contained no grave goods. Apparently not all

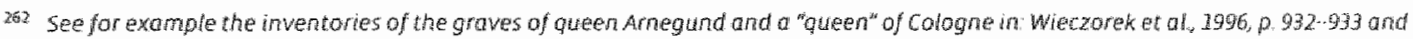
936939 
prestigious graves contained grave goods. Vice versa, not anly people buried in sarcophagi were bestowed with precious grave-goods. Assemblages of valuable objects like jewellery, a small bronze plated coffin or gold brocade were occasionally found in a wooden coffin or trench grave. ${ }^{253}$ The find of gold brocade in grave 164 , a trench grave, was an indication for the burial of persons of high status in less elaborate grave types. Gold brocade was also found also at another section of the Servaas cemetery, viz. at the Pandhof site ${ }^{26}$ in the Byzantine Empire dressing in clothes with gald brocade was reserved for members of the imperial court and high officials. 2 . Therefore, when found in contemporary western European cemeteries this fabric is generally considered a symbol of high social status. ${ }^{256}$

\section{CEMETERY LAYOUT}

As mentioned above, all but one of the graves of the beginning of the templum phase were found in the same area as the inhumations of the cella phase. The graves from the cella phase were not specifically orientated towards the cella memoriae. In the early templum phase this changed, four tuff stone sarcophagi were pasitioned within close range of the cella memoriae. Slightly further to the west three of these sarcophagi were placed in line (from north to south). At least another 10 tuff stone sarcophagil were found at the Servaas Pandhaf site. During the early templum phase the centre of the cemetery still seems to have been situated in the area to the north. After the construction of the templum magnum at the cemetery, the number of burials in the area around the church increased and the focus of the cemetery seems to have shifted. From that moment, people were also buried in the southern half of the excavated area. Still, less thain a third of the 88 graves were found in the southern part of the area of the Servaas church site. Most of the graves were found west and north of the church. The later construction of crypts disturbed the section inside the templum magnum. ${ }^{3 \text { C }}$ Consequently it was not possible to determine if people had been buried within the templum.

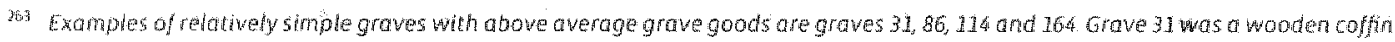

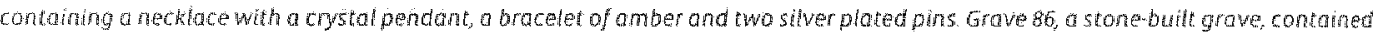

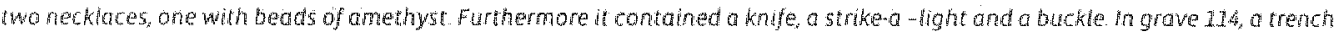

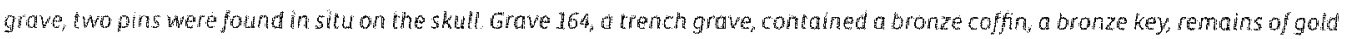
brocade on the skufl and a bone comb.

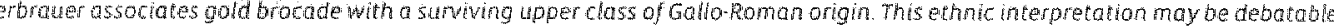

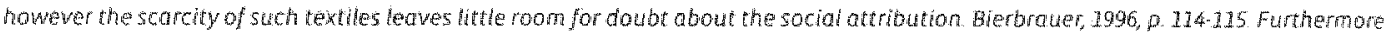

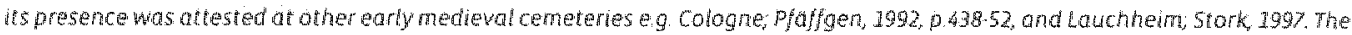
fabric appears to occu both in the graves of males and females, pfafgen, 1992 p.4512 


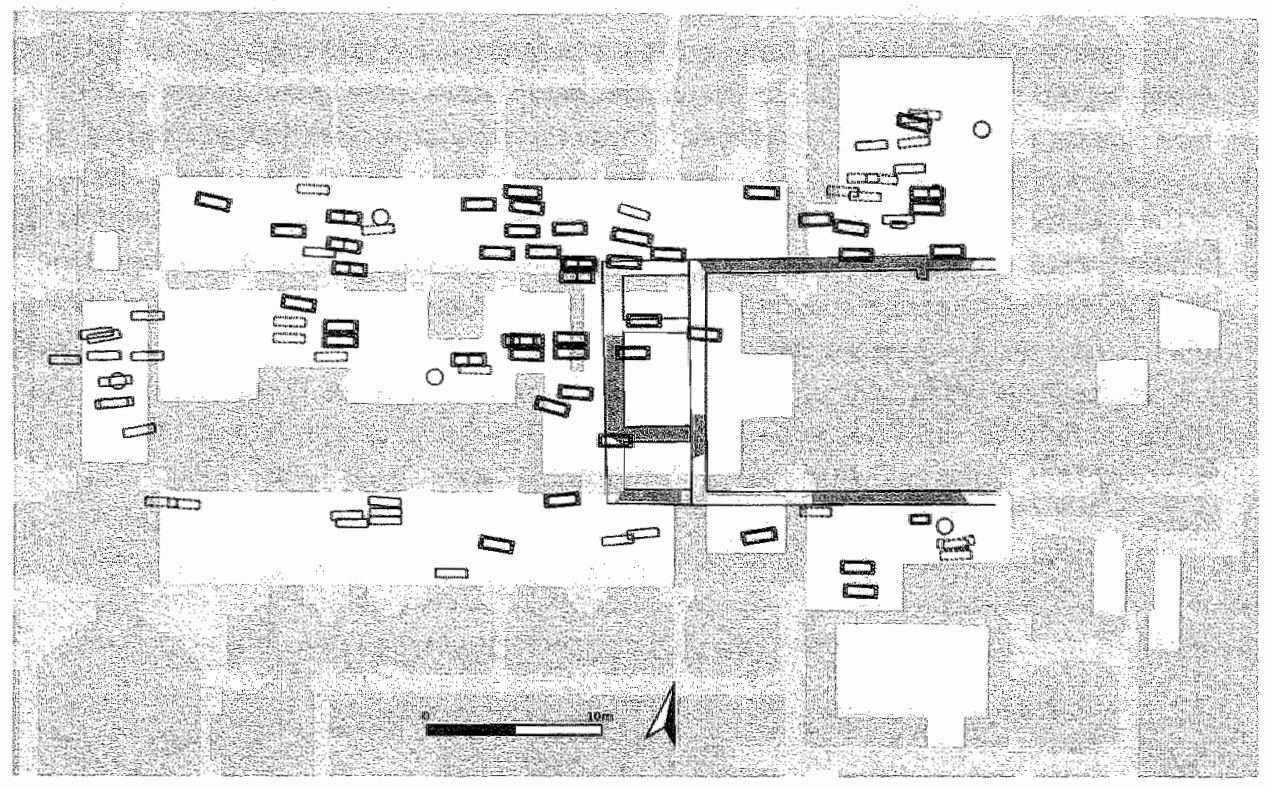

FIGURE 324 Templum phase layout of the cemeters.

Marked cemetery boundaries were not found. As mentioned, excavations at the Servaas Pandhof site showed that the Meravingian cemetery extended to the north side of the cloister. ${ }^{263}$ In the northeast ${ }_{j}$ the cemetery stretched at least to the 5 tiftskapel site. ${ }^{269}$ And at the Servaras church site the easternmost graves were situated in trenches $1 ; 2$ and 5 of the servaas site. The preliminary results of the conalysis of burials in trench 2 of the Vrijthof excawations indicate that further east in the area around the apse of the present church no graves with grave goods from the Merovingian period were found. Although little information could be collected on the relation between these trenches and trenchi 2 of the Vrijthof excavations it is possible that during the templum phase the cemetery boundary fell within this area. In the southern half of the Servaas church excavation the density of burials decreases, which might suggest the cemetery neared its boundaries in this direction. Hitherto we had no information on the distribution of burials south of the Servaas church site. In the west, burials are found in clusters without a sign that the border of the cemetery was near. Also at the Servaasklooster site a few graves from the Merowingian period were excavated. These may have belonged to the same cemetery as those at the Servaas church site. ${ }^{27}$ All graves of the templum phase were oriented with the heads in the west and feet in the east. Their alignment varies between 260 and 289 degrees. The alignment of some graves correspands with the orientation of the walls of the templum magnum; other graves slightly deviated from this alignment.

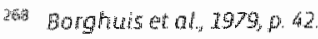

2.69 T. Parturysen $1982,0.52 .53$

27 T panhuysen 1982, p. 49 note 42
} 
A gradual chronological development from the cemetery would most likely have resulted in an even horizontal distribution of the graves. Unlike the horizontal stratigraphy visible in Merovingian Reihengraberfelder, the templum phase cemetery appears to have evolved in anather way. Not only were many graves concentrated around the church, they were also placed in clusters. Within these clusters fincidental intercuting of gravers occurred. As far as could be determined, the clusters had no formal borders. Therefore, they were only recognisable from visudil inspection of the site plan. Four larger clusters were recoginised. The graves within these clusters dated from the whole Merovingian period. It could not be determined whether the late Roman graves found within some clusters were also part of these groups. The continuous use of the samellimited plots suggested that a form of spatial planning existed. In general the clusters displayed a higher density of inthumations in the centre. Based on the present evidence the clusters were thought to represent cemetery areas used by specific groups of individuals. As to what kind of groups the areas were allotted to, we have no other sources than the graves and their contents. Possible factors that may have determined the composition of the clusters could have been social status, member ship of a religious community, secular functions or kinship.

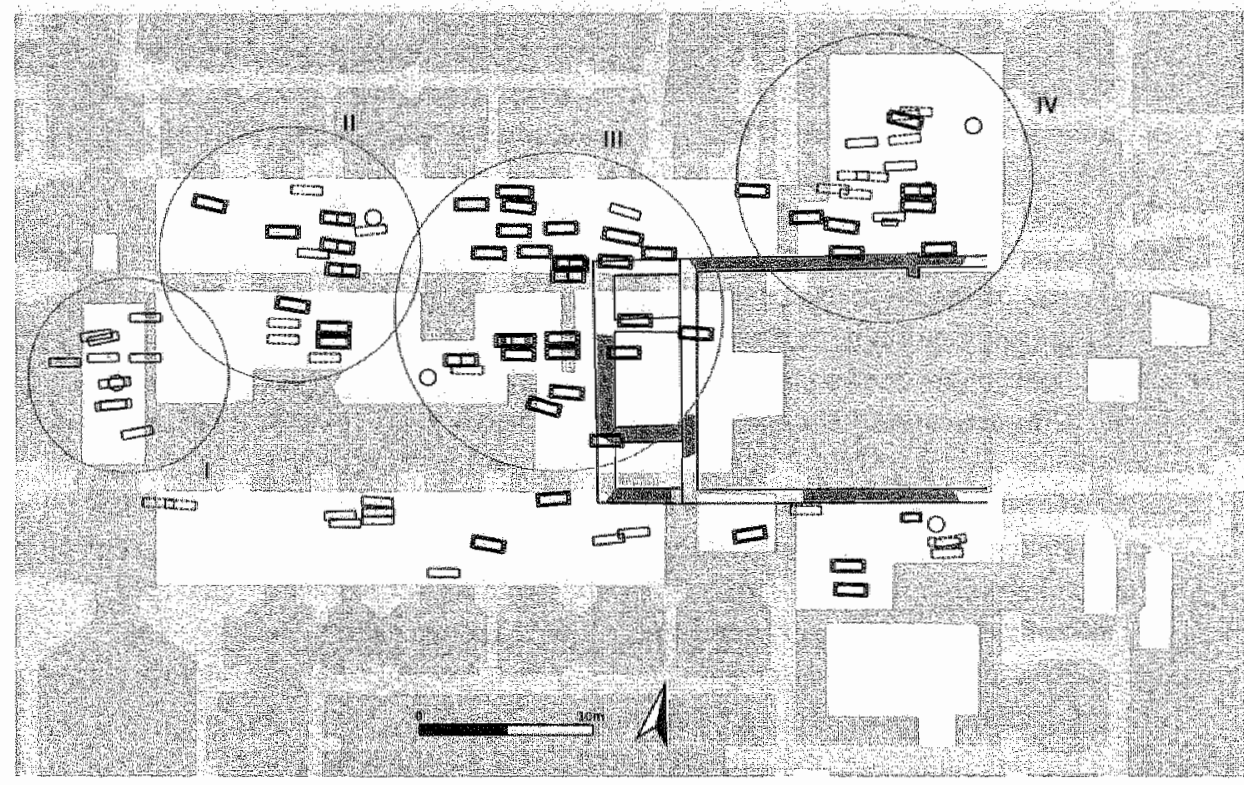

FIGURE 3.25 Templum phase: posinion of clusters I to IV.

Cluster I was the westernmost group, consisting of 10 graves dug at a distance of circa 30 metres from the templum magnum. The grave types in this cluster were much simpler than in the other clusters: either trench graves or wooden coffins. Cluster I was the anly cluster in which none of the graves contained precious grave goods. Closer to the church cluster II was found. approximately at 20 metres west-north-west. This group of 14 graves was a mixture of stone-built 
graves, trench graves, tuff stone sarcophagi and wooden coffins. Around the western part of the templum magnum, the largest cluster, cluster 111 , was found. It consisted of $27 \mathrm{graves}$, with a core of 21 stone-built graves. Furthermore the cluster comprised 4 tuff stone sarcophagi, a wooden caffin and a trench grave. Cluster IV was positioned close to the northern wall of the templum and extended 10 metres in a northerly direction. Among the 18 graves were stone built graves, wooden coffins and trench graves. In each of the clusters 11 , lll and IV, twin graves and graves with precious grave goods were found. Often these graves were siturated in the centre of the clusters.

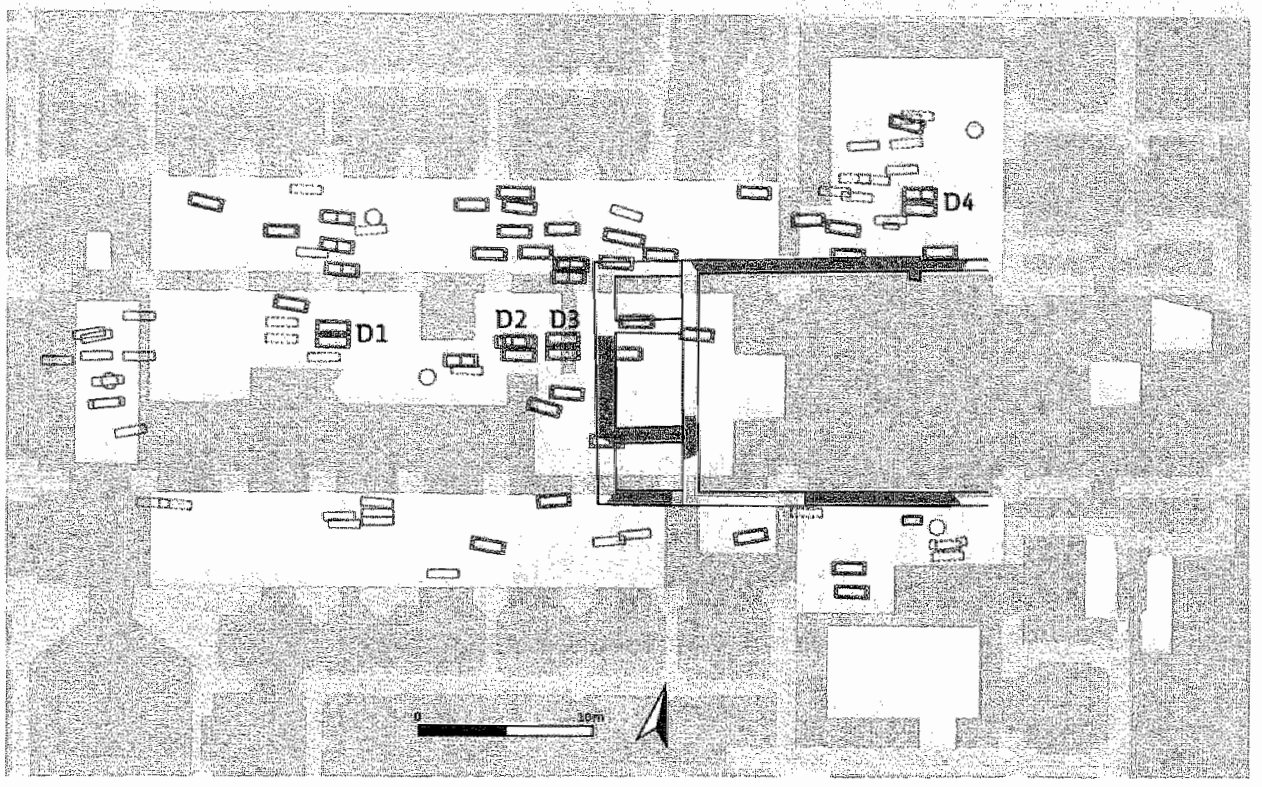

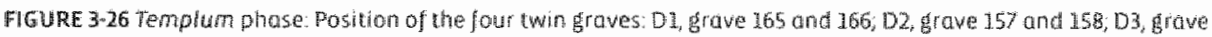
139 and $140, \mathrm{D}$, grovê 17 and $4 \mathrm{I}$.

Twin graves are either stone-built graves of equal size, with one grave constructed against. the other, or they are stone-built graves constructed as one grave containing twa separate spaces for burial. Two twin graves were found in front of the west wall of the templum magnum. (D2 and D3 in Figure $3-26$; grave $139+140$ and grave $157+158$ ). Farther west a third twin grave was found (D1 in Figure 3-26; grave 165+166). The fourth (D4 in Figure 3.26; grave 17+41) was positioned circa four metres north of the church. Of the three twin graves west of the templum two (D2 and D3 in Figure 3-26) were placed in line on an axis from west to east. A third twin grave (D1 in Figure 3.26) was positioned slightly north of the axis of twin graves D2 and D3. Similar graves were also found at other cemeteries from the Merovingian period. ${ }^{2 / 1} M$. Colardelle

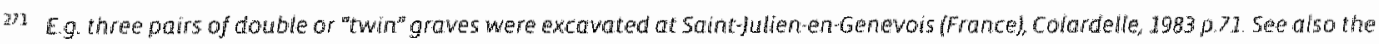
distribution map of tem examples of win graves in Merovingian France on page 37 of the same publication. 
suggests these win graves were graves of members of the same family who were successively buried next to each other. This theory cannot be tested for the twin graves from the Serwaas church site, since only one grave out of the four pairs of graves contained human remains.

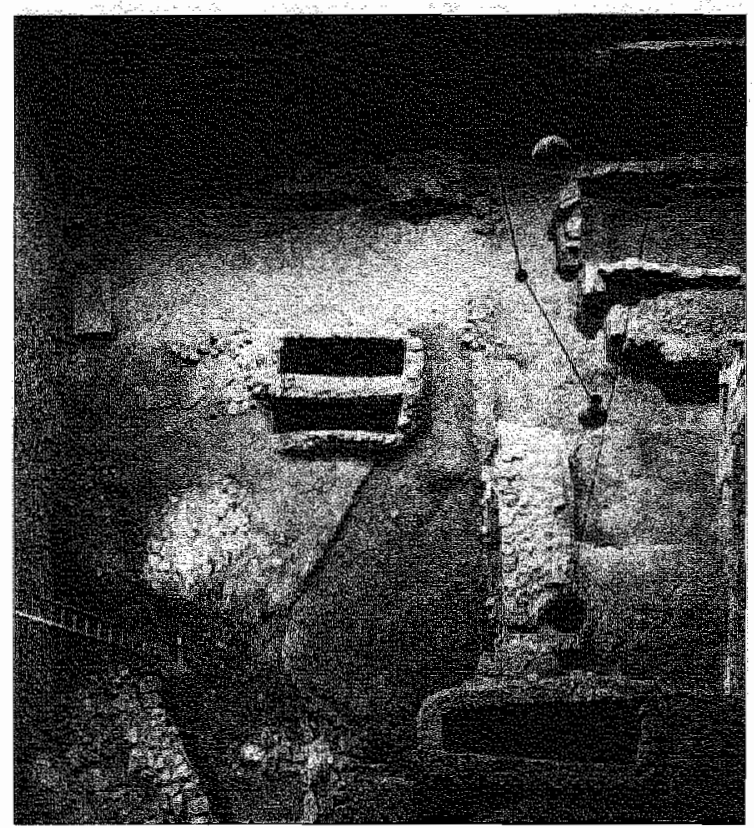

FIGURE 3-27 Twin grave: grave 41 ond 17 see also Figure 326 \& Photograph: City of Manstricht

THE BASILICA PHASE (700-950 AD)

THE CONST PUCTION OF A BASLLCA.

The basilica phase begins with the construction of a new and larger church at the location of the templum phase church. At the same time, or somewhat later, a new bullding was constructed nortli of this church at the Pandhof site. Archaeological findings indicate that the Meravingian church was demolished and replaced by a comparatively spacious church with the ground plan of a basilica. The nave of the new church measured 38 metres in length and the total width of the mave and aisles was 19.70 metres. Measuring the total length of the church was not passible because construction works for the present church had disturbed the area of the choir and possible apse of the church. The location of at least one entrance to the basilica was situated in

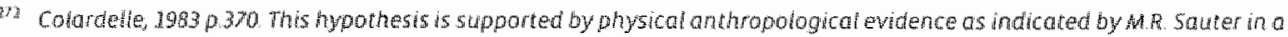

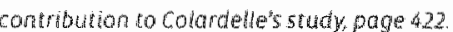


the south wall near the western comer of the church ${ }^{23}$ During the earliest phase this church had an earthen floor and a cancella, a fence or wall that separates the choir from the nave of the church possibly this cancella was decorated with bas reliefs. Fragments of a bas-relief. depicting the "Flight to Egypt" and the "Massacre of the innocents", were recovered below one of the oldest floors of the basitica (see figure 3-29). Comparison with other pre-Romanesque bas. rellefs has led various authors to conclude that this fragment was probably sculpted in the first half of the eight century. ${ }^{274}$ Other evidence for an exceptionally rich decoration of the basilica comes from the rumerous fragments of painted wall-plaster, mosaic stones fincluding gold. leafed mosaic stones) and remains of windows with colloured glass. wh

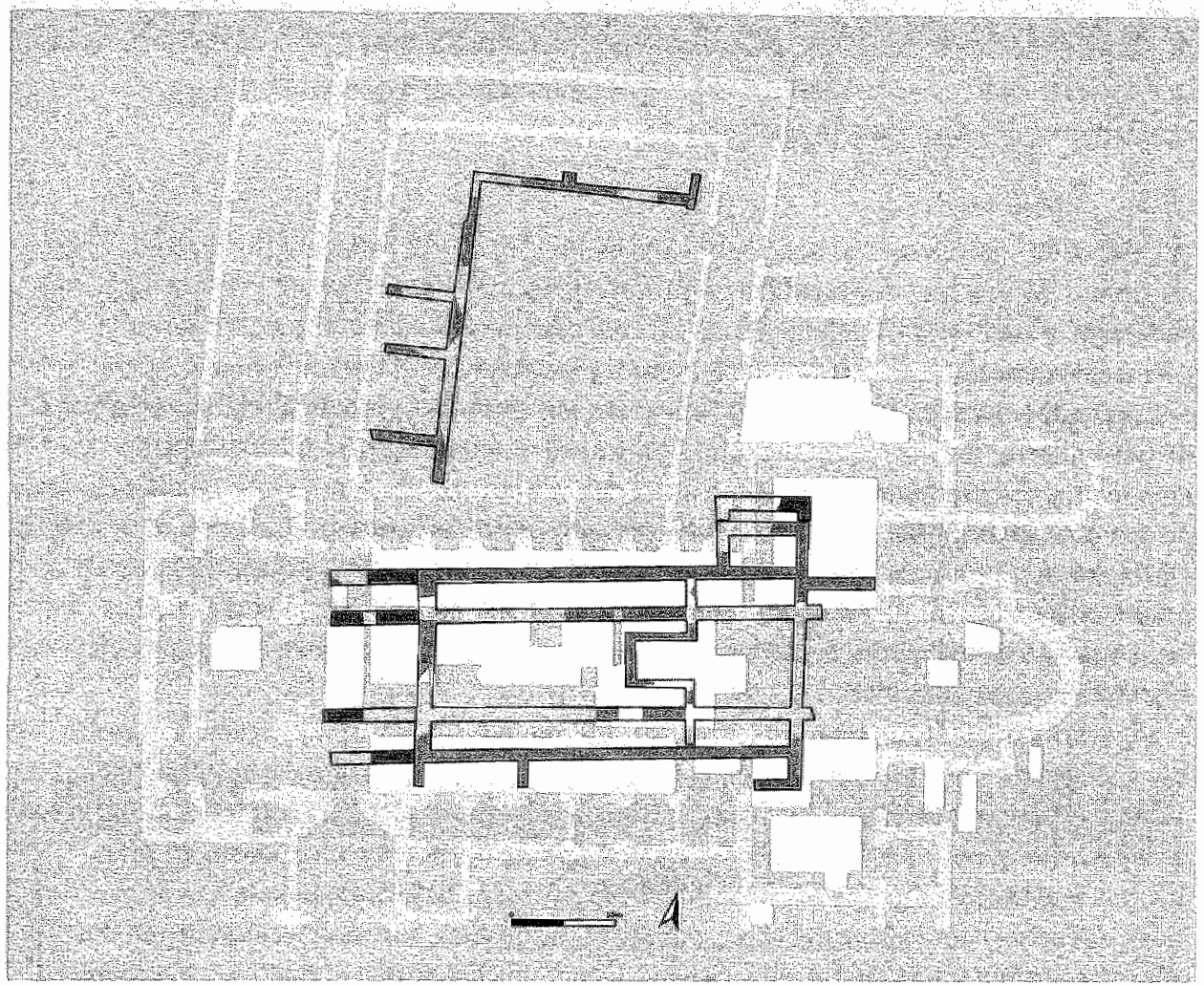

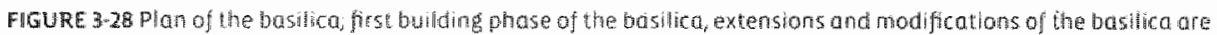
regresented in a daker shade North of the Serwas church she the remains of what seems to have been a monasuc babiding were discovered at the Servons Pandhal site.

23. The present church still has a richly decorated portal, which is richly fursished with polychrome sculpture doting from the ith century

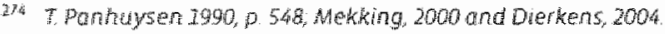

3:5 Ponhuysen 290 


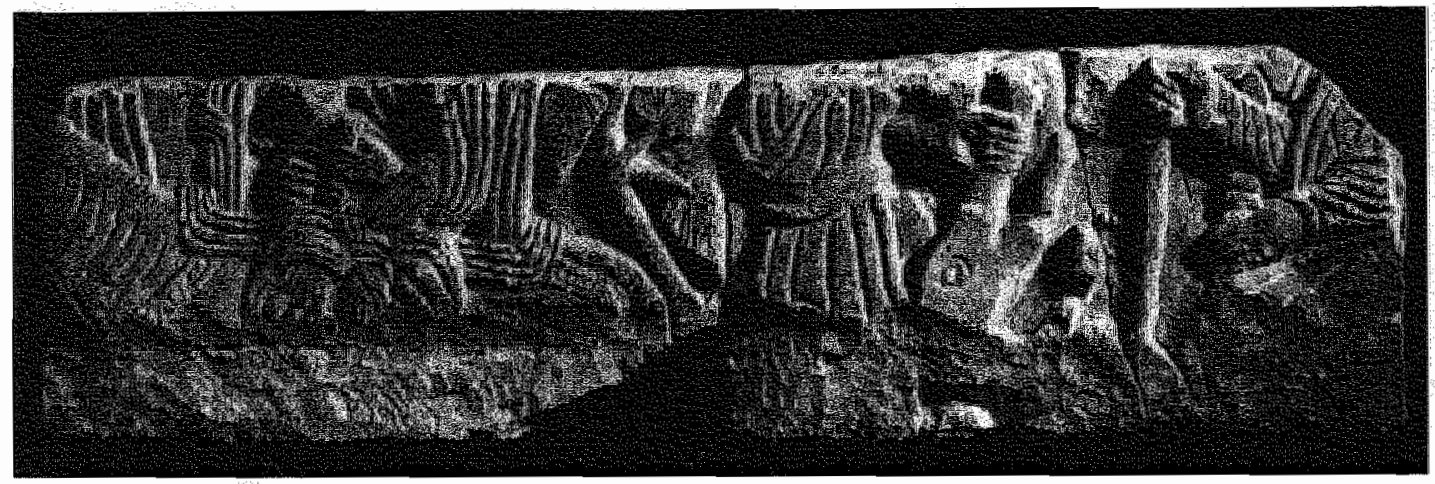

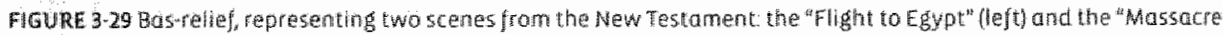
of the lnthocents"s (photograph City of Madstricht)

\section{THE DATE OF THE BASILICA}

The scarce written sources do not mention the building of a large church at the location of the templum magnum. in a preliminary publication presenting an overview of the archaeological campaign of 1981-1989, T. Panhuysen suggests the basilica was built in the eighth century. ${ }^{276}$ Dierkens has recentlly put forward the interesting hypothesis that the construction of the basillca may have been contemporary with a renewal of the cult of Saint Servatius, including a new elevation of the remains of the saint. ${ }^{277}$ Since the available sources do nat explicitly mention the construction of a new church, the dating of the construction of the basilica depends on archaeological findings. Work on the stratigraphy at the Servaas church and Pandhof sites is still in progress. In the near future this may provide a reliable chronology of the building activities. ${ }^{287}$ At present three radiocarbon dates collected from skeletal remains buried in limestone sarcophagi positioned around the cancella present the best indication as to when the basilica may have been built.

in total 5 samples were selected for radiocarbon analys.es. Three of these samples were collected from human skeletal iremains collected from sarcaphagi inside the basilica (F Higure 3-30: B2, B3 and B4). Nineteen trapezoid limestone sarcophagi were buried around the cancella below an old earthen floor, which is considered the first floor of the new basilica. Because of this position and the fact that the sarcophagi were sealed off by a concrete floor it is assumed that these sarcaphagl dated from the earliest phase of the basilica. The sampled human remains were all collected from skeletal remains lying in anatomical position at the time of excavation, suggesting these were primary burials.

\footnotetext{
27s r pornuysen 1990

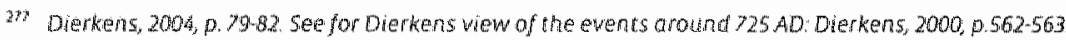

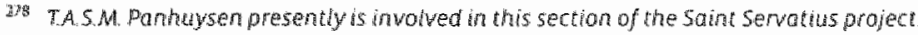




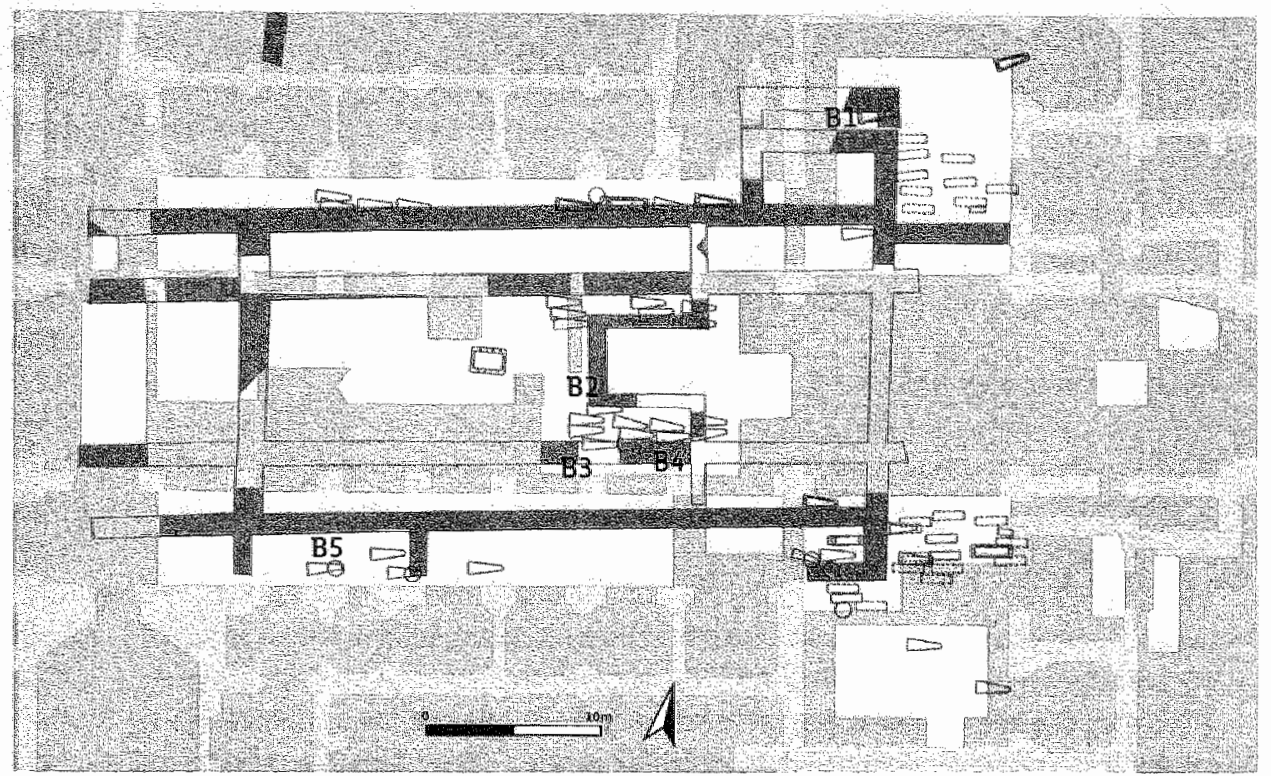

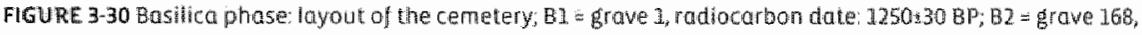

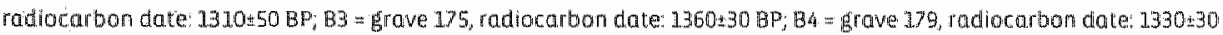
$B P ; B 5=$ grave 187 , radiocarbon date: $1340+30 \mathrm{BP}$

The results of the conventional radiocarbon analyses of samples $B 3$ and $B 4$ were quite consistent, especially the range found for sample B2 analysed by means, of AMS was less specific. Based on the archaeological findings we assume that the sarcophagi around the cancella were deposited within a short period during the last phase of construction of the basilica or shortly thereafter. This was confirmed by the distribution of the callibrated radiocarbon dates which all fall between 1360 and 1310 BP.

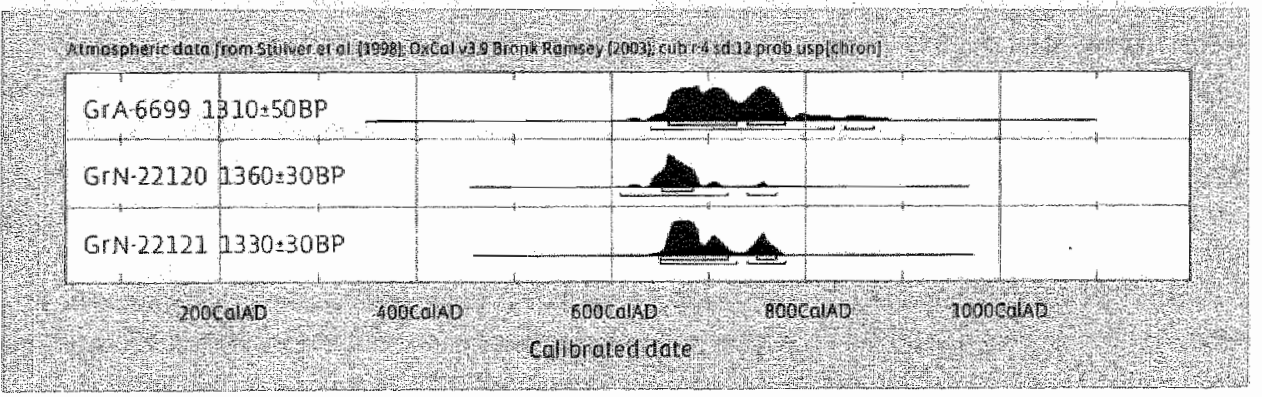

FIGURE 3-31 Probability plots of the calibrated dates of human bone samples coliected from three sorcoghog inside the church the upper 5 ample is sample B2, the midale By and the lower B4. Figure created using OxCal $v .39$ 


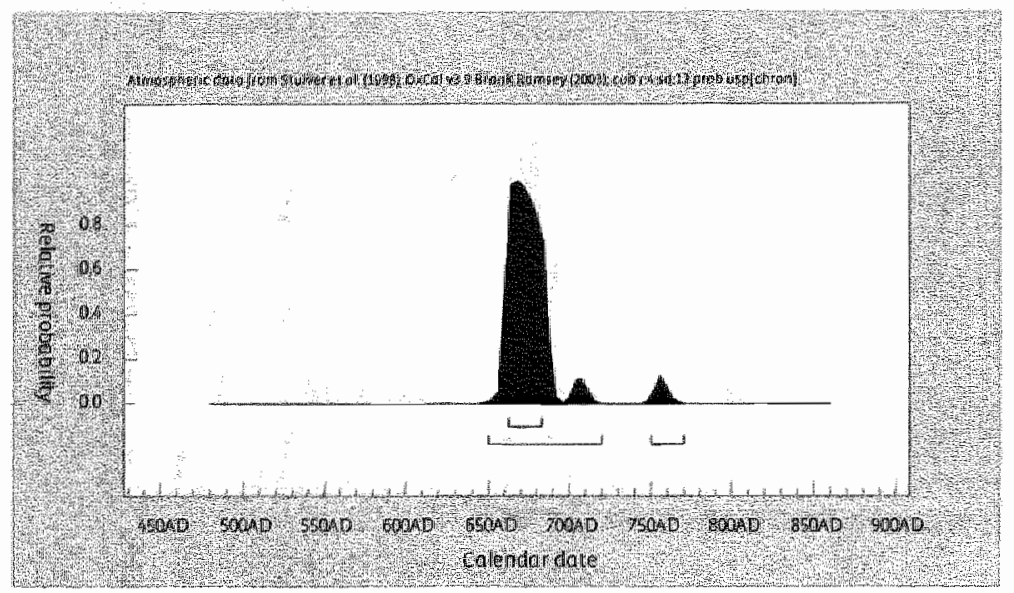

FIGURE 32 Combined results of thee radiocorbon medsurements of samples B2, B3 and $\mathrm{B} 4$.

If the previous assumption is correct the radiacarbon dates may be combined, which results in a smaller interval. The combined data indicate there is a $68 \%$ probability that the individuals interred in these sarcophagi had died between 663 and 683 AD and a $92 \%$ probability that these had died between 650 and $720 \mathrm{AD}$. Of interest in this respect is another burial in a sarcophagus (B5) just outside the entrance of the basilica. The archaeological findings suggest that this grave also belonged to the early phase of the basilica. The radiocarbon date acquired for this grawe $\left(1340 \pm 30\right.$ Cal yr. BP) closely matches the dates found for the sarcophagi around the cancella. ${ }^{279} \mathrm{As}$ discussed above we hove to cansider these data were biased by reservair effects due to the consumption of considerable amounts of freshwater fish. Consequently the radiacarbon dates might be too old, by up to hundred years or more. Given the present evidence this possibility camnot be excluded, but there are no indications this must have been the case. $A$ comparison of the use of trapezoid limestone sarcophagi in the burial ritual in the region may provide an indication whether an early dating is in agreement with the dating of similar sarcophagi at ather sites.

In a study of limestone sarcophagi in the Netherlands and the Rhine and Meuse valley, Lammers assumes that these sarcophagi were produced from the end of the seventh or the beginning of the eighth century to the first half of the eleventh century. ${ }^{28}$ However, there is

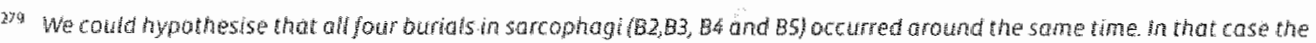
combination of the radiocarbon dates wowld suggest there was a 95 probadity that the individuals buried in these graves died between 65 and 690 AD However the contemporaneous burial of these groves is at present tess evident then of the threen sarcophagi around the cancesta.

2at The foc that fow of the rodiocarbon dates closely correspond, as was experted on archaeological grounds, indicates that if there

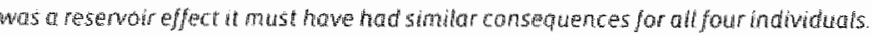

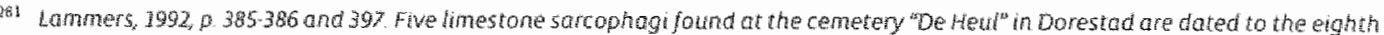

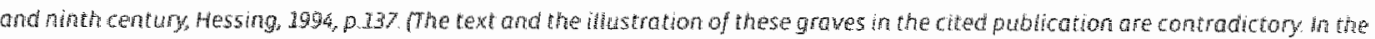


evidence that limestone sarcophagi were used at the beginning of the seventh century. In an article discussing the famous sarcophagus of Chrodoara, found in nearby Amay, Engen dates the lower part between 589 and $634 \mathrm{AD}^{282}$ This is the oldest documented case of the use of a trapezoid limestone sarcophagus in the region of Maastricht. In the Paris basin and the north of France this type of burial was faund in considerable numbers at early medieval cemeteries. In those regions this type of burial was found from the last quarter of the sixth century. ${ }^{28}$ Therefore, it is possible limestone sarcophagi were used in Maastricht from as early as the second half of the seventh century.

All in all the available evidence for the dating of the building of the basilica does not allow for a very precise determination. The combination of the radlocarbon dates suggests the basilica was built at some time between 650 and 720 AD. ${ }^{284}$ It is to be expected that the ongoing analysis of burials, architectural remains and stratigraphical evidence will eventually allaw for the determination of a mare specific date.

During circa three hundred years of use, the basilica underwent several modifications. The position of the cancella was changed at least three times and two red coloured floors of opus signinum replaced the first earthen floor. In the tenth century the western wall was torn down to extend the basilica. More than ten metres were added, maybe to construct a westwork. The augmentum at the northeastern corner of the building was also enlarged. In the late tenth or early eleventh century the basilica was demolished and replaced by a new and grander church. One radiocarban date of humar remains from a stone-bullt tomb that was either associated with the last phase of the basilica or the first phase of the present-day church fits quite well with the expectations concerning the chronology. This burial had a calibrated date ranging from 961 to $1012 \mathrm{AD}(68 \%)$. In $1039 \mathrm{AD}$ the new church was dedicated. The dismantling of the basilica and the construction of the present church may well have taken place by the end of the tenth century. ${ }^{26 s}$

\section{GRAVE TYPES AND CEMETERY LAYOUT}

Seventy-three graves were dated to the same period as the basilica. A third of the giraves was placed within the church, often these graves were found below one of the floors of the baslica. Inside the church, limestone sarcophagi were the main grave-type. In total, 36 trapezoid. limestone sarcophagi were found in and around the basilica. Nineteen of the sarcophagi were positioned in the nave of the basilica around the cancella. Two were placed in the southern augmentum (grave 74 and 77) and two on the inside along the northern wall of the basilica (grave 22 and 106). Thirteen timestone sarcophagi were found outside the church: five along the not thern wall, four around the entrance of the basilica and four mear the southern augmentum.

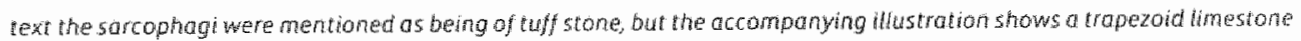

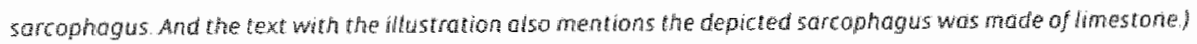

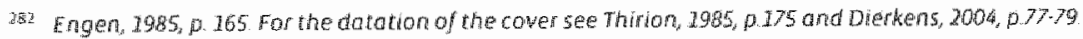

2.: Delohaye, $1985,0.69$

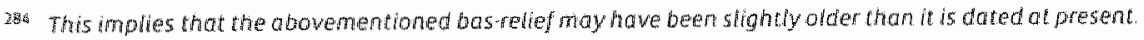

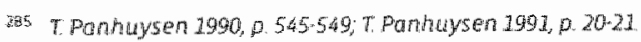


Trapezoid shaped stone-built graves must have belonged to the same category as the sarcophagi. Not only did they look hike sarcophagl, they were also found in the same areas of the cemetery. Two graves of this type (grave 84 and 123) were built against the northern wall. A third one (grave 72) was placed inside the southern wall, near the southern augmentum. Apart from the three trapezoidal stone-built graves, two rectangular specimens were discovered: one against the northern wall (grave 83) and one west of the southern augmentum. Only three coffin graves were found inside the basilica. They were placed above one another in the southern augmentum lgraves 73, 74 and 75). All other wooden coffin graves and trench graves were found either east of the northern augmentum or around its southern counterpart. In the northern group only coffins and trenches were found. Among the graves of the southern clusters were also two sarcophagi and a stone-built grave.

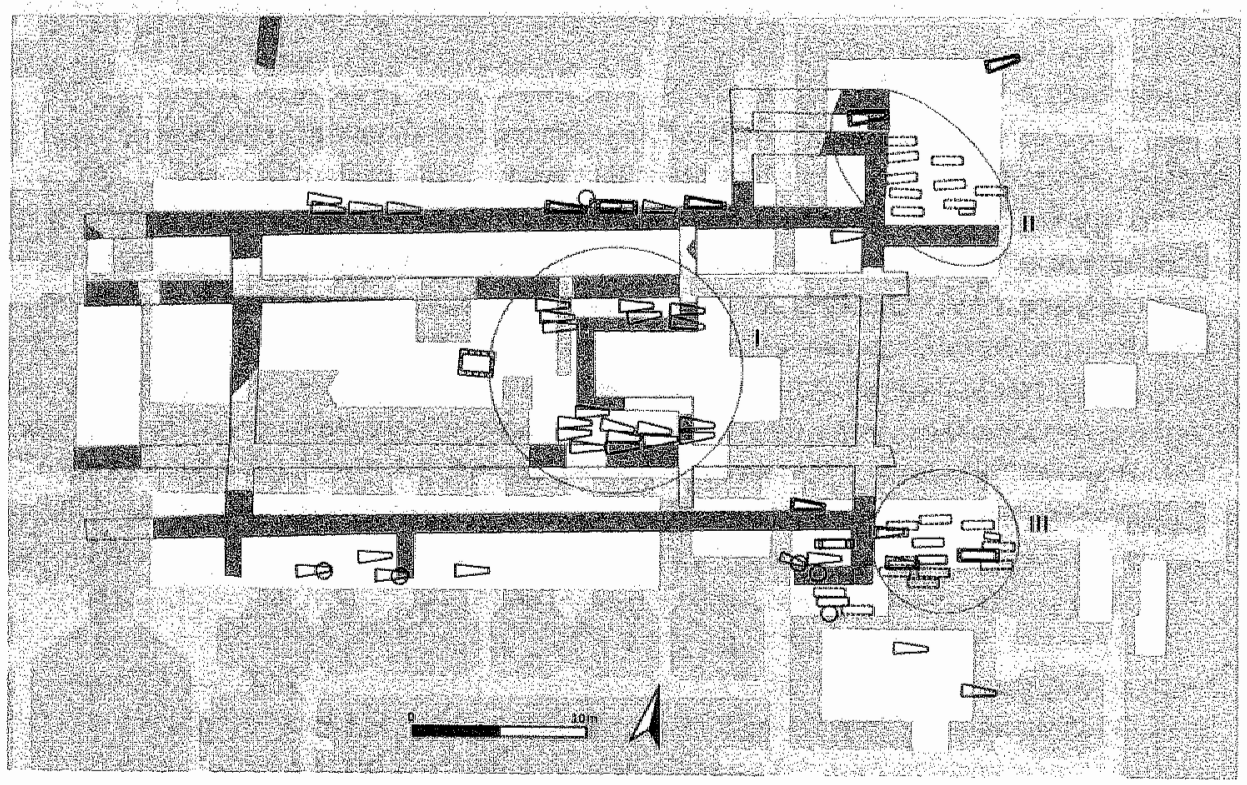

FlGuRE 3.33 Bastica phase: represented are three larder inhumation zones in and around the basilica.

In comparison to the templum phase the plan of the basilica phase cemetery shows a striking change in layout. Instead of clusters of graves of mixed types, typical for the templum phase cemetery, the basilica cemetery was characterised by areas with very little variation in grave type. Warlous zones in and around the basilica seem to have been reserved for specific grave types. Three areas with a specific pattern of burials could be discerned. The first was situated Inside the church around the cancella. It consisted solely of limesitone sarcophagi positioned in the nave of the basilica along the walls of the cancella. A second zone was outside the eastern wall of the northern augmentum, consisting of ten trench graves. At this location the trench graves were placed in orderly rows. South of the church, east of the southern augmentum was a 
zone with a less systematic appearance. Unlike the other zones a wariety of grave types was found at this location; organised in a way that resembled the spatial organisation of the templum phase cemetery. Eleven trench graves, two limestone sarcophagi, two coffin graves and one stone-built grave formed this group of sixteen graves. These graves also were placed in rows parallel to the walls of the basilica, but in a less rigid way. The intercutting of graves suggested this area was used intensively during a large part of the basilica phase. Other smaller groups of graves were formed by eight sarcophagi and stone-built graves sub stilicido along the outside of the northern wall of the basilica. Four limestone sarcophagi positioned in and around the entrance to the basilica formed the last cluster of graves that could be recognised in the excavated section of the basilica phase cemetery.

The boundaries of the basilica phase cemetery are difficult to establish. In general very little of the cemetery area outside of the basilica could be observed during the Servaas church excavations. To the north, the cemetery seems to have extended at least into the cloisters excavated during the Pandhof excavations. The analysis of these graves is in progress and the first results suggest that burial activities in the cloisters continued during the basilica phase. A good indication for this trend is the presence of 7 limestone sarcophagi in this section of the cemetery. ${ }^{285}$ At the Stiftskapel site to the Narth east af the Servaas church site no burials can yet be ascribed to the basilica phose. To the east of the basilica, at the Vrijthof site, the continuous sequence of burials in trench 2 seems to have started during the basilica phase. However, more stratigraphical and chronological evidence is needed to confirm this. South of the basilica there is no information as to whether the cemetery extended in that direction. At the Servaas church site the situation west of the basilica was not systematically excavated. Until now there is no evidence that the small series of graves excavated at the Servaasklooster site continued into the basilica phase. Altogether only a small section of the basilica phase cemetery seems to have been excavated within the trenches of the Servaas church site.

\section{BOSCHSTRAAT SITE}

\section{EXCAVATION HISTORY}

Until the seventies of the twentieth century the area north of the present day market square in the city centre was dominated by industrial activities. Even today factories can still be found in this part of the city. The Boschstraat area, between the Boschstraat and the River Meuse, housed labourers and industries in the nineteenth and twentieth centuries. Prior to the construction of a new residential area circa 6000 square metres of this former industrial quarter were archaeologically investigated. Between 1980 and 1986 twenty-two trenches were excavated. Preliminary results have been published in short reports and articles. ${ }^{287}$

7.6. 5oeters, $1989,0.24$

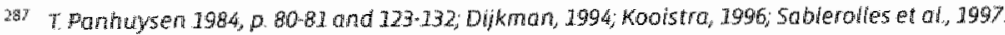




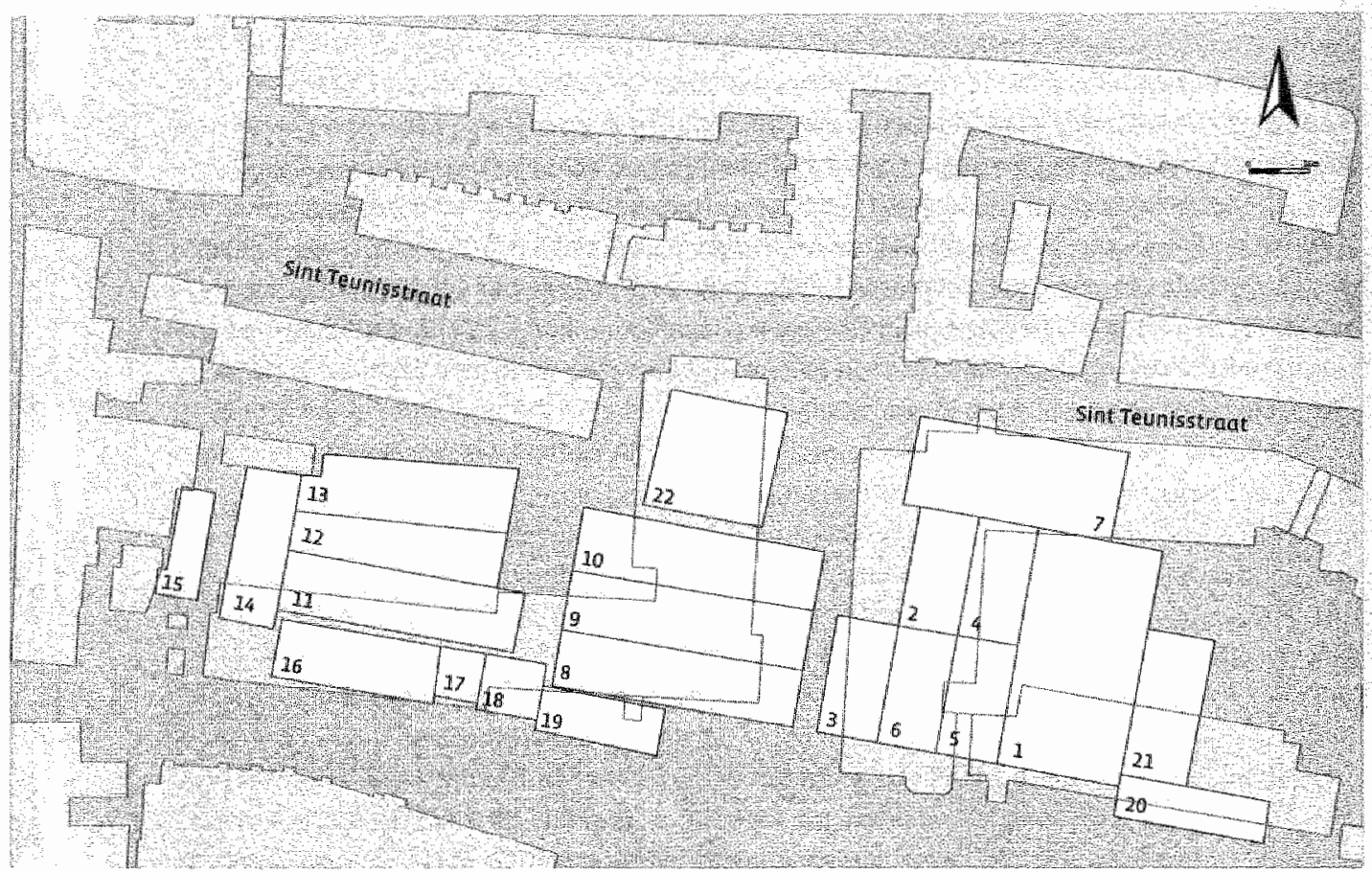

FIGURE 3-94 Boschstroat site: an owerview of the twenty-tho excavotion trenches

TOPOGRAPHY

Due to medieval and post-medieval disturbances it was only possible to determine the appraximate elevation of the early medieval surface level. As far as could be established the late medieval horizon seems to have been in concardance with the twentieth century relief map. With this difference, that in medieval times the elevation of the whole terrain was circa one metre to one and a half metres lower. It reached its lowest level in the southwestern part of the excavated area, around 45.40 metres above NAP. Farther north and east the landscape rose to a level of 46.80 metres above NAP. It was noticed during the archaeol ogical investigation that the terrain gradually sloped upward in a northerly direction. The natural soil is a layer of loamy river sediment on a gravel deposit of the River Meuse. Because of the limited elevation the tertain around the site must have been inhospitable for centuries.

\section{A MEROVINGIAN SETTLEMENT AND GEMETERY}

In the Roman period the Boschstraat area was uncultivated and uninhabited. The first traces of occupation date from the sixth or seventh century ${ }^{288}$ Before that the Roman road to Nijmegen on the left bank of the river was excavated west of the area. Numerous waste pits and wells were found all over the excavated area. The contents of these waste pits indicated that objects 


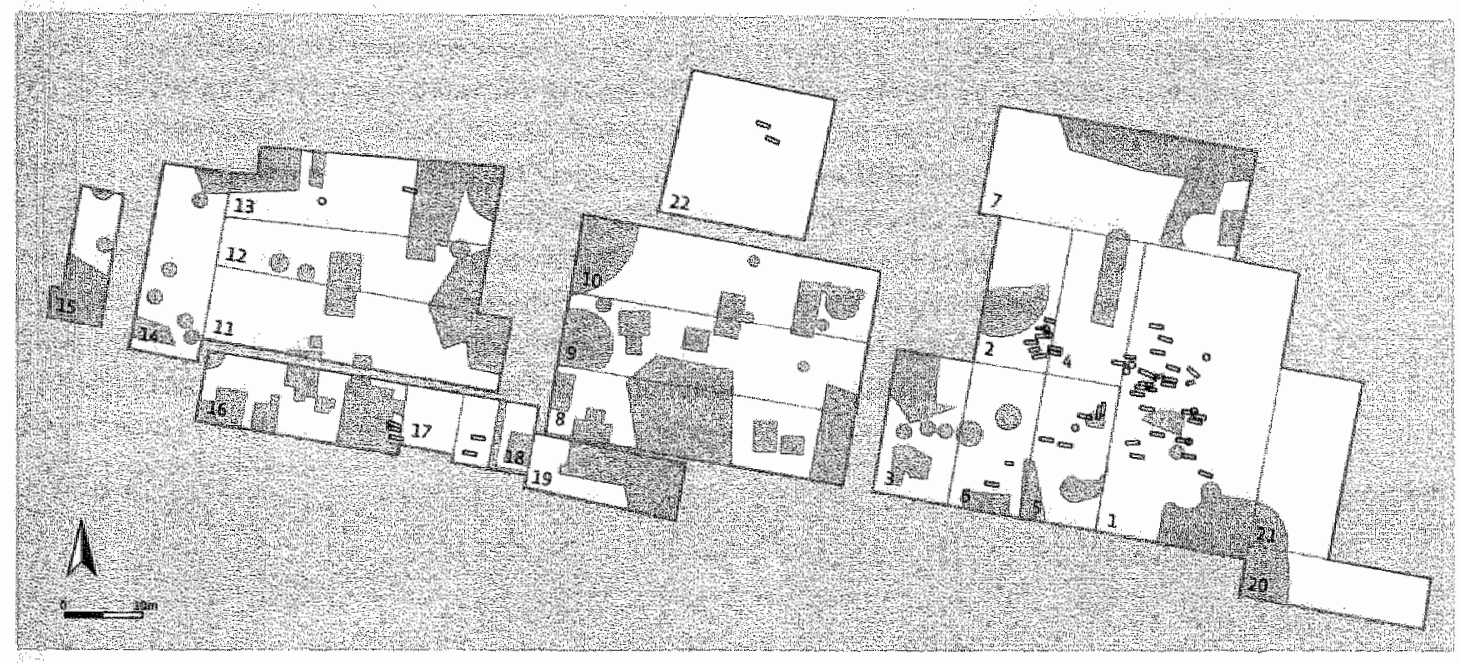

FIGURE 3-35 Boschstrad site on overview of the area where ealy medieval hathumations have been faumd freprasented as nectongular shopesy and those parts of the site that were dishurbed by bater human activities to the level of the infumations frepresented by shaded areas?.

of metal, antler and glass were produced in this area. Furthermore, refuse of food preparation, also found in the pits, suggests the existence of a settlement in close praximity. No house plans could be reconstructed from the excavated postholes. However, the scale and nature of activities suggests houses must have been present. Indicative of the layout of the settiement was a ditch found in the western trenches, running for at least 35 metres from north to south. ${ }^{239}$ A smaller ditch had been dug perpendicular to the main ditch extending 25 metres in western direction. North of this ditch a stretch of deposited gravel was found. These ditches and the gravel deposits are considered demarcations of housing lots or the remains of yards. North-east of the excavated area a concentration of waste pits suggests the presence of a separate hausing arrea north of trench 7 . Whether these areas were occupied contemporaneously, or represent different phases could not be established.

The above-mentioned refuse of various production processes provides an idea of the spread of the various crafts over the terrain, which was published by Dijkman. ${ }^{250}$ Finds associated with iron-working and copper-alloy working were predominantly found in the western excavation trenches: 11,13 and 18 . Remains of glass-working and antlef-working were excavated mostly in eastern trenches: 1,20 and 21 . Only in the centrally situated trench number 22 traces of glass. working and antler-working were found in combination with iron-working. Copper-alloy nails (attested by the find of earthen moulds) were fabricated in the western section of the

25* Trenchnumber $13,12,13$ ond 16 
excavation. Because of its peripheral position the settlement area of the Boschstraat site was expected to have played a role in farming activities and the production of food. Surprisingly, a rough inventory of botanical riacro-remains in 22 soll samples prowided no evidence for activities related to food processing ${ }^{292}$ The finds suggest the excavated areas were predominantly used for the crafting of objects and habitation, not for growing or even processing agricultural crops. Another important feature of the findings at the Boschstraat site are the inhumation grawes, which were found between the various waste pits. Some antedated: the pits others were positioned over older refuse deposits. Based an stratigraphical evidence and analysis of the associated finds the inhumations are considered to date from the seventh and early eighth century. . $^{29}$

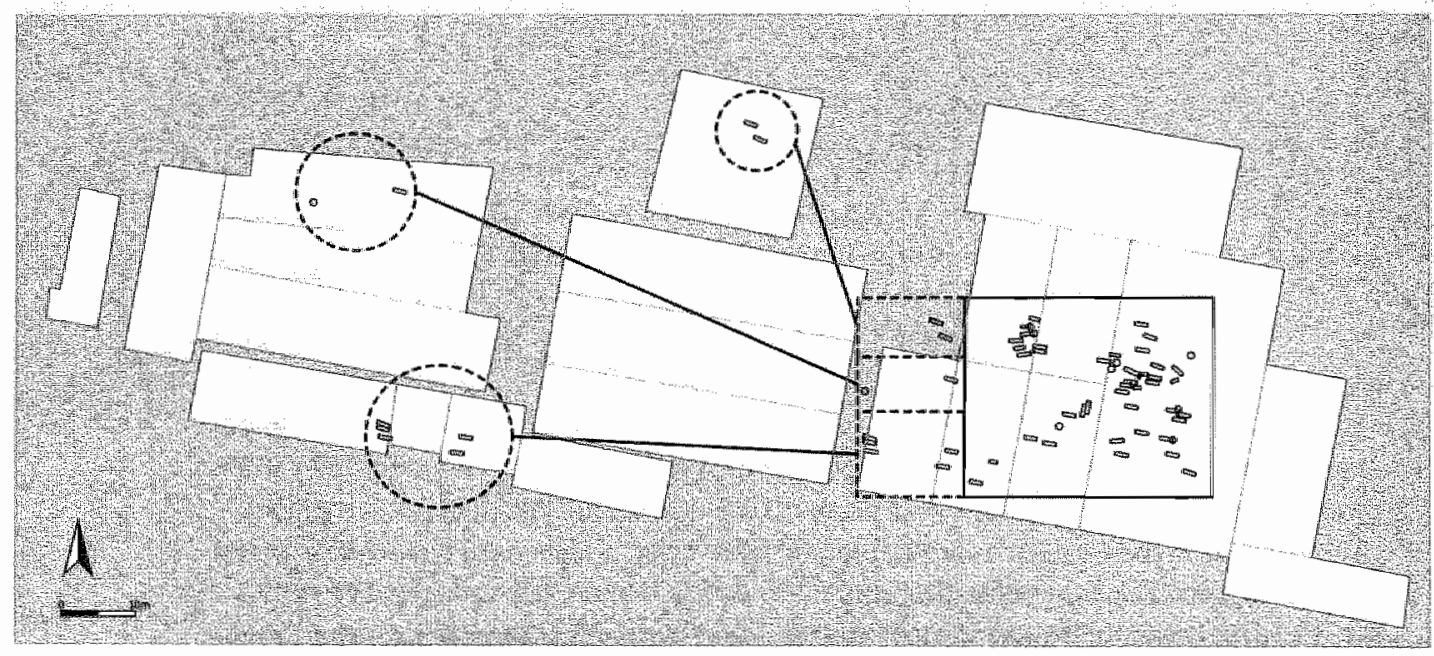

Figuke 3-36 th the following maps of the layout of the in mmations at the Boschstrad site the dispersed inhumation: have been projected in a plon together with the large concentration of graves in the east

This first occupation phase of the terrain was of short duration. It was not just the cemetery which was discontinued in the eight century. The whole area was deserted again. Possibly climatic changes or changes in the water level were a contributing or decisive factor causing the terrain to become unsuitable for habitation. The area was not re-inhabited until the thirteenth century. ${ }^{294}$

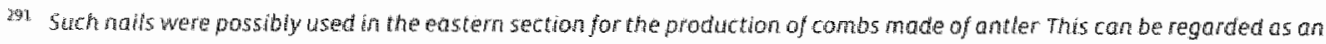
argumen for the contemponane of the two production processes and possibly also for the cowistence of the two habitation areas Dijkman and Enyack, 1998

29 Kooistra, 1996, p281289

293 T. Panhuysem 1966 , p. 134

20 T Panhuyen 1984, p 125 


\section{GRAVE TYPES AND CEMETERY LAYOUT}

At the Boschstraat site 50 giraves could be recognised; six of these contained no skeletal remains at the time of excavation. In addition, skeletal remains were collected from ten contexts. which were not recognisable as formai graves. Because of the archaeological context of these disarticulated human remains it seems plausible that these burials were contemporaneous with the other burials but were disturbed by later activities and processes. Seeing as the majority of graves were trench graves it is not surprising that even minor disturbances would make it difficult to recognise these graves during excavation. At the Boschstraat site 42 trench graves were found. Another six trench graves were lined with stones and therefore designated to a separate category. These trench graves with stones were often found in a central position. Coffin graves were comparatively rare, only two coffin graves were recovered, both of them near to the centre of the easternmost cluster.

"Two patterns can be recognised in the distribution of graves. One group of inhumations was buried together in the abovenmentioned larger concentration of circa 50 graves and disturbed burial contexts, which formed a proper cemetery. A total of 10 inhumations were found to be more dispersed. At three places separate clusters of graves were recovered. In trench 22 a pair of graves was found approximately forty metres north west of the main group of inhumations. Further to the west in trench 13 , about hundred metres from the large concentration of graves, one isolated inhumation and the disarticulated remains of a second individual were collected. A cluster of five graves was discovered in trench 16 and 18 west of the main group of graves. Because of the similarity in grave types and the absence of associated habitation traces of other periods all dispersed inhumations were dated to the same period as the main cluster ${ }^{295}$ Probably the human remains found in trenches 13,16 and 18 were assaciated with the nearby ditches and gravel deposits found in the western excavation trenches. Possibly the dispersed burials were interred close to houses in that area. There is no evidence that the dispersed graves were part of larger clusters. Comparison of the spread of the recovered graves and the distribution of later disturbances of the soil do not suggest that many graves were lost. ${ }^{20}$ This indicates the cemetery and dispersed burials were quite representative of the original number of burials at the Boschstraat site. Moreover, the cemetery in the east was almost completely excawated. Around the cemetery and the dispersed burials contemporary refuse pits were found. This suggests all burials were located close to houses. In the case of the dlispersed burials. this might indicate that the individuals were buried in the yards of the house where they once lived.

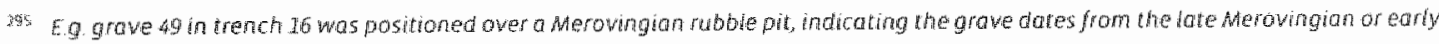
carolingion period.

2 The distroution of burids in the centrat icemetery suggests that more graves might be expected to the east and southeost however

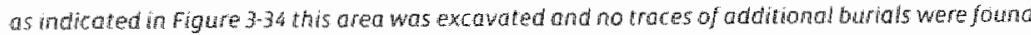

29.
} 


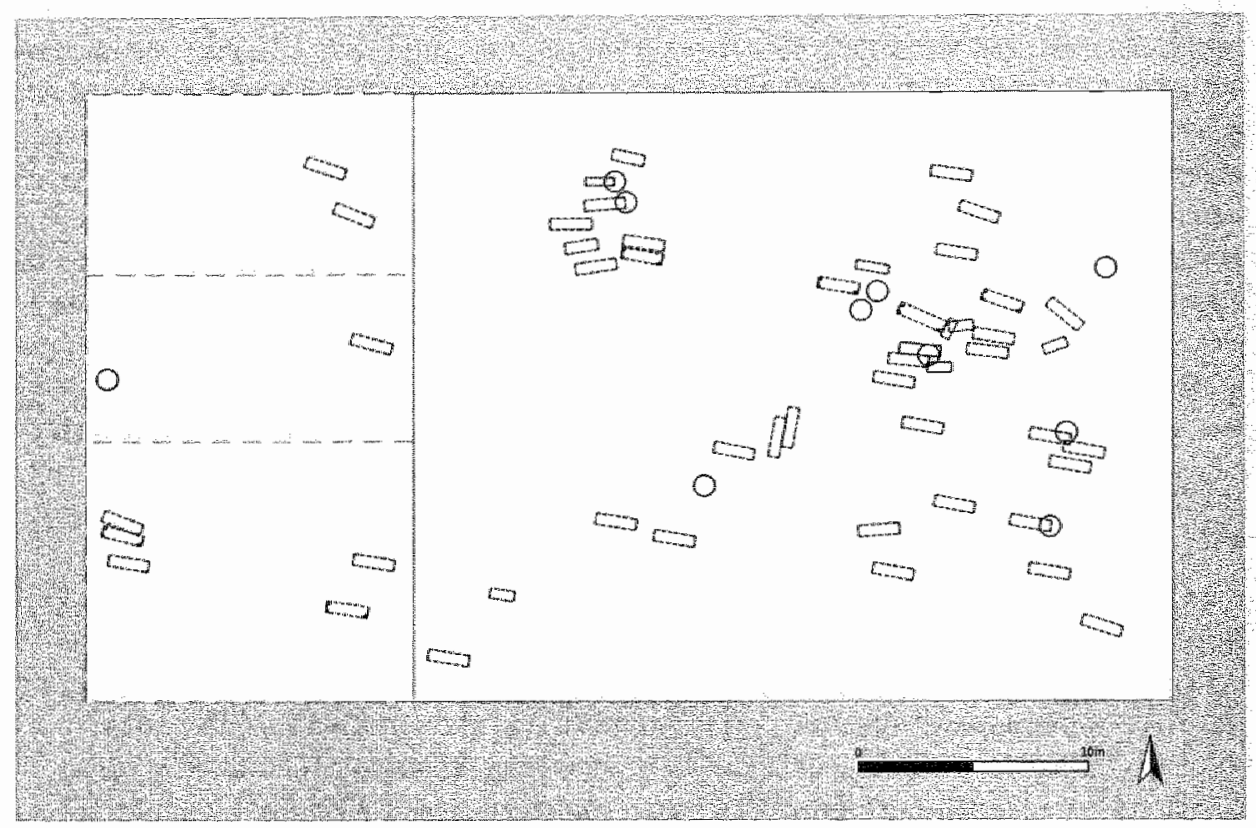

FIGURE 3.37 Distribution of the inhumations ot the Boschstract site.

The main group of inhumations, which was de facto a cemetery, consisted of three subsections. In the northeast the inhumations formed a comparatively large cluster, baptised cluster A. A smaller cluster of eight graves, baptised cluster B, was buried ten metres west of cluster $A$. Between clusters $A$ and $B$ a small ditch was found, oriented north-south. In addition, some post holes were observed. The association between these findings and the graves is unclear. ${ }^{208}$ The separation between cluster $A$ and a third zone of burials just to the south was not well defined. In this southerm zone seventeen inhumation graves were distributed over a stretch of 30 by 15 metres. In general the informal layout of the cemetery and the dispersed inhumations is similar to other burial sites from the seventti and eighth century. ${ }^{29}$

\section{ORIENTATION OF THE INHHUMATION GRAVES AT THE BOSCHSTRAAT SITE}

The graves do not seem to have been oriented along a building or other fixed topographical features. Therefore, it is possible that the orientation of the graves was based on the point at which the sun rises on the horizon around the time of burial, Consequiently the arientation of the graves might reflect seasonal influences on mortality. ${ }^{300}$ For 43 graves the compass

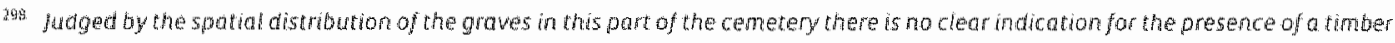
thope or other contemporaneous construction.

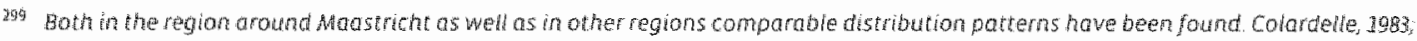

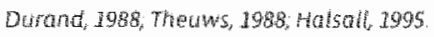

3in Hedls and Green, 1973, fichter and Wolk, 1980 
orientation was determined based on the position of the body or the alignment of the grave. The orientation was expressed in degrees of rotation in relation to the north-south oxis. All 43 graves were roughlly oriented along the east-west axis. Figure 3-38 shows the distribution of the grawes by intervals of 5 degrees. Most graves were categorised in the interval ranging from 77.5 to 82.5 degrees. The orientation of most graves was around the 80.5 degrees, that is 9.5 degrees noith of east-western axis. If we assume that the orientation of the graves was according to the true point of sunrise on the day of burial this would correspond with burial during late autumn, winter or early spring. This is in agreement with the findings of Fichter and volk based on the analysis of two early medieval cemeteries from Southern Germany. ${ }^{30 i}$

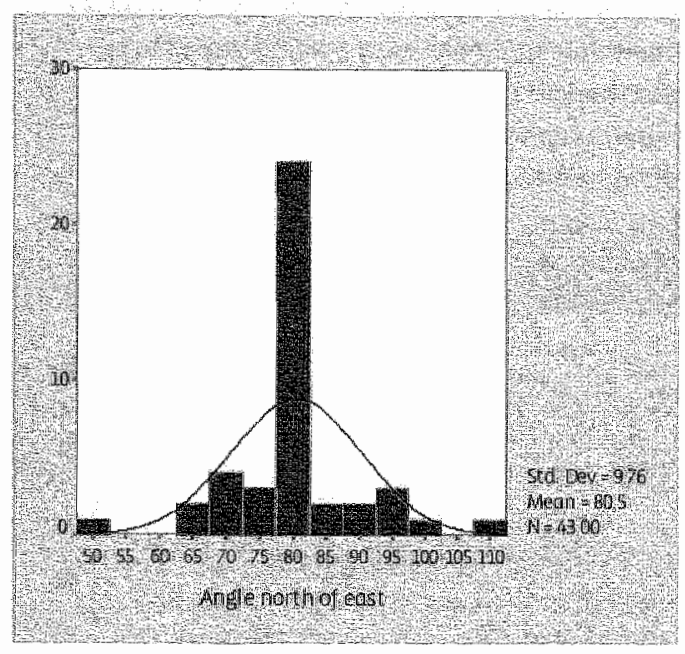

FIGURE 3-38 Orentation of 49 graves at the boschstraat site

Three growes were oriented alang the north-south axis. One of these was of a child buried at the foot end of an adult grave. Two graves ${ }^{302}$ of adults were intentionally buried with an orientation allong the north-south axis. These graves were laying about 20 centimetres lower than most other burials. Traditionally this orientation was interpreted as characteristic of nonChristian burials during the early Merovingian periad. However, Roosens mentions that north south oriented graves can be found in the reglon around the Meuse from the fifth century well into the seventh century. He doesn't consider orientation as a rellable indicator of relligion, ${ }^{303}$ in the Dutch province of Limburg a north-south grawe orientation was rare. Such an exception was the cemetery of Kemperkoul excavated in Sittard not far from Maastricht. This cemetery dated

\footnotetext{
ins Fichter and volk, 1980

3at Grave 22 and 63

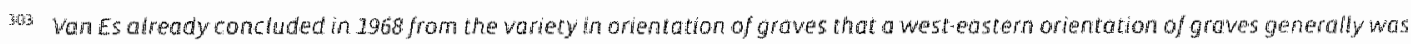

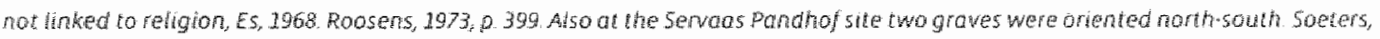
1980,2425
} 
between the sixth and early eighth centuries consisted solely of north-south orientated. burials. How to interpret the two north-south orientated graves is not evident. Were these older graves or were these the first graves of a group settling near Maastricht who soon traded their own habit of north sou th burials for the local custom of west -east burials?

\section{GRAVE GOODS}

Nine graves contained grave goods. All grave goods were found in graves from the main cemetery Mast common were necklaces made of simple glass beads and, incidentally, some amber. Such necklaces were recovered from seven graves. One grave contained a bracelet, composed of the same type of beads as the necklaces. In one of the giraves, in which a necklace was found, a piece of pottery stood at the foot end. Two more pieces of pottery were found together in another grave. The bracelet, necklaces and ceramic objects were relatively simple. Within the central group of graves most grave goods were found in cluster $\mathrm{A}$. There were no indications that graves had been robbed of their waluables. Therefore, we may assume that the

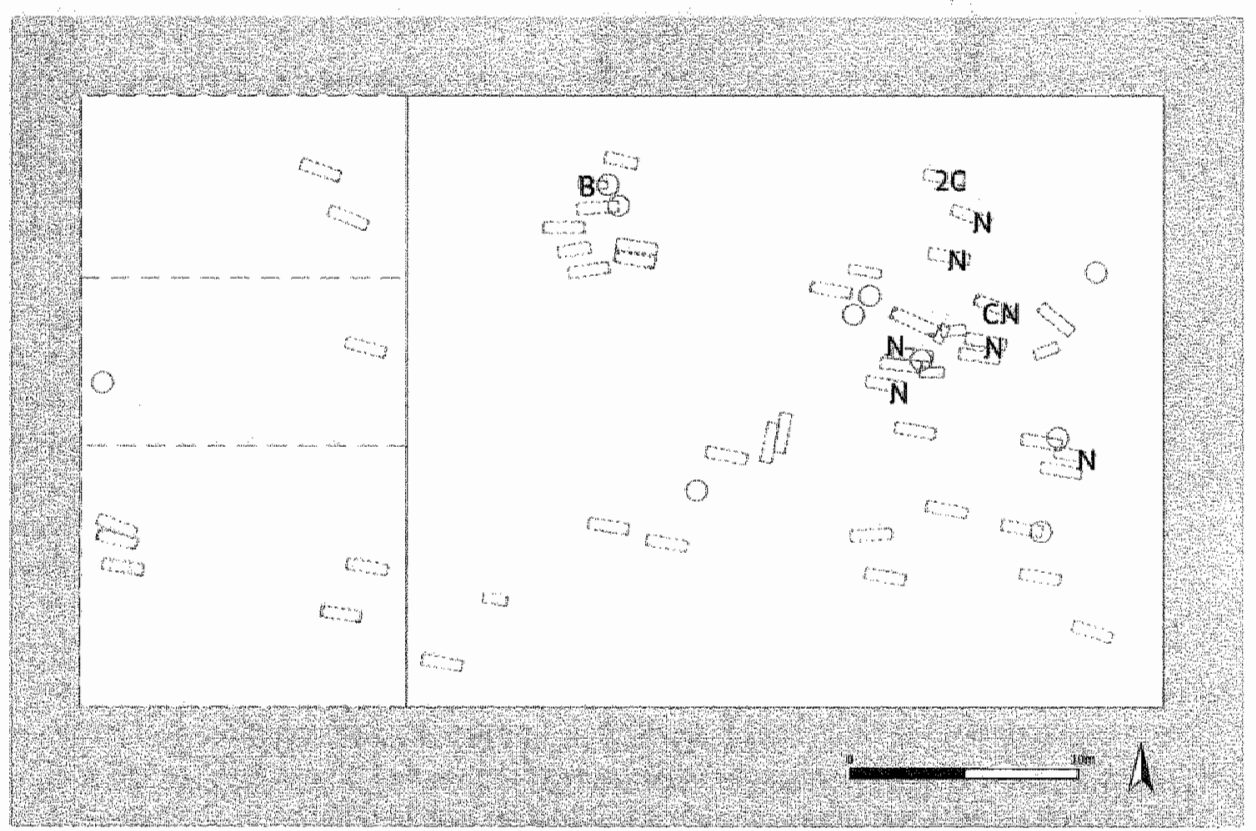

FIGURE 3-39 Distribution of the grave goods aver the cemetery $C=$ ceramic, $A=$ necklace of glass beads, $B=$ bracelet of glass bends.

distribution of grave goods is representative for the actual distribution at the time of burial. Summing up, only about a fifth of the graves contained grave goods. The scarcity of grave goods. may be associated with the dating of the graves to the seventh or early eighth century. During 
this period the custom of furnishing graves with goods seems to have been abandoned in Maastricht. ${ }^{305}$

\section{RESUME BOSCHSTRAAT SITE}

The burial ground excawated at the Boschstraat site dates from the seventh and partially from the early eight century. It coincides with the transition from the Merovinglian to the Carolingian period. The main cemetery (clusters $A, B$ and the southern zone) has been recovered almost completely. Although many graves are positioned clase to others, intercutting of graves was rare. This suggests that the cemetery was in use for a relatively short period and was used by a small population. In contrast with other Merovingian cemeteries the graves at the Boschstraut site were modest. There are no large grave pits and the grave goods are scarce and simple. The incidental ceramic vessel and the necklaces made of gllass beads are plain in comparison to the precious goods found in several contemporary grawes at the Saint Servaas site. The desertion of the cemetery was probably a consequence of the abandonment of the area. As indicated above this abandonment is hitherto unexplained. Possibly it was associated with changes in the local environment rendering the area uninhabitable. otherwise the dissolution of the cemetery may also be associated with a general tendency to discontinue the use of the field cemeteries?. In the eighth century cemeteries not associated with a church were either abandoned or a church was built at the site of the cemetery. 306 .

\section{SKELETAL ARRANGEMENT OF THE BURIALS}

For all burials data were collected regarding the position of the body, limbs and hands in the grave. Sources for these data were excavation drawings, photographs and notes in the excavation reports. Due to the frequent disruption of graves it was not possible to callect data for all burials. Only those graves for which reliable data were available in the documentation were included in Table 3-5. Concerning the position of the crms and hands it was decided to categorise them under "an abdomen" all cases in which one or bath arms were found on the abdomen. None of the individuals was found lying with one or both hands on the thorax. In the cella sample out of twenty skeletons found in a burial context, mineteen skeletons were found in supine position, viz. laid out on their backs. The only exception was a young child buried on its right side. The burial position of the arms, hands and legs during this phase could be inspected in fourteen cases. Five individuals were buried with their arms and hands along their sides and nine individuals with one or two arms and hands on the lower abdomen. In all cases (n=14) the legs were extended. Similar burial positions were observed for the late Roman inhumations at the Pandhof site ${ }^{30}$ During the templum phose there was less variation with respect to the skeletal arrangement. All 34 skeletons found in situ had been buried in supine position. Also in

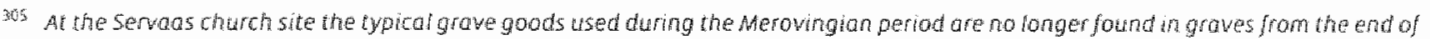
the seventh century.

gok ohler, $1990,0.143$, Chelini, 109, p.484.449

wor soeders, 1989, p 25:26 


m

TABLE 3-5 Arrangement of the body in the grawe, as reconded from skeletal remoins found wi situ

all 29 cases, where the position of the leg's could be inspected, the skeletons were lying with both legs extended. In 15 cases the arrangement of the arms and hands could be determined: 3 individuals were buried with their hands on the abdomen and 12 with their arms allong their sides. All 47 burials found in situ from the basilica phase were buried in a supine position. Twenty-nine individuals were buried with their arms stretched along their body, only three persons were found with their hands on the abdomen. At the Boschstraat site 40 skeletons were found in situ. One skeleton was laying on the right side and another on the left side. All 38 other burials were buried in supine position. Regarding the position of the arms, in a little less than half of the cases the arms were laying straight along the body $(n=14)$. In 15 individuals either one or both arms were bent and positioned on the abdomen. Apart from one of the individuals buried on its side with the legs slightly bent, 31 individuals were found with their legs stretched.

\section{TYPO-CHRONOLOGY OF GRAVE TYPES AT THE SERVAAS CHURCH SITE}

From the late Romain period to the end of the basilica phase the grave types at the Servaas church site changed considerably. These changes seem to be associated with the building phases at the site. The distribution of the six most frequently found grave types indicates that there was very litele continuation in the use of four specific grave types: viz. the tuffstone sarcophagus, the stone-built grave, the limestone sarcophagus and the stone-built tomb.

Trench graves and wooden coffins were found during all three phases. In the cella phase they were the most used grave types and coffins and trenches were found in equal proportions. In the templum phase these grave types still made up a large fraction of the total graves. Together" they accounted for almost half the number of giraves. During this phase trenches and colfins were also found in equal proportions. This is different in the basilica phase. The proportion of wooden caffins appears to have decreased considerably, which was partially compensated by an increase in the number of trench graves. Together both grave types still accounted for 40 per cent of the total number of graves from the basilica phase. In the templum phase new types of graves occur an site. First were the tuff stone sarcophagi dating from the start of the templum

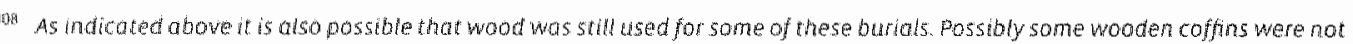
recagnised as wooden cofhns because mo coffin fitings or wood was preserved or because these were constructed withaut he use of metotports 


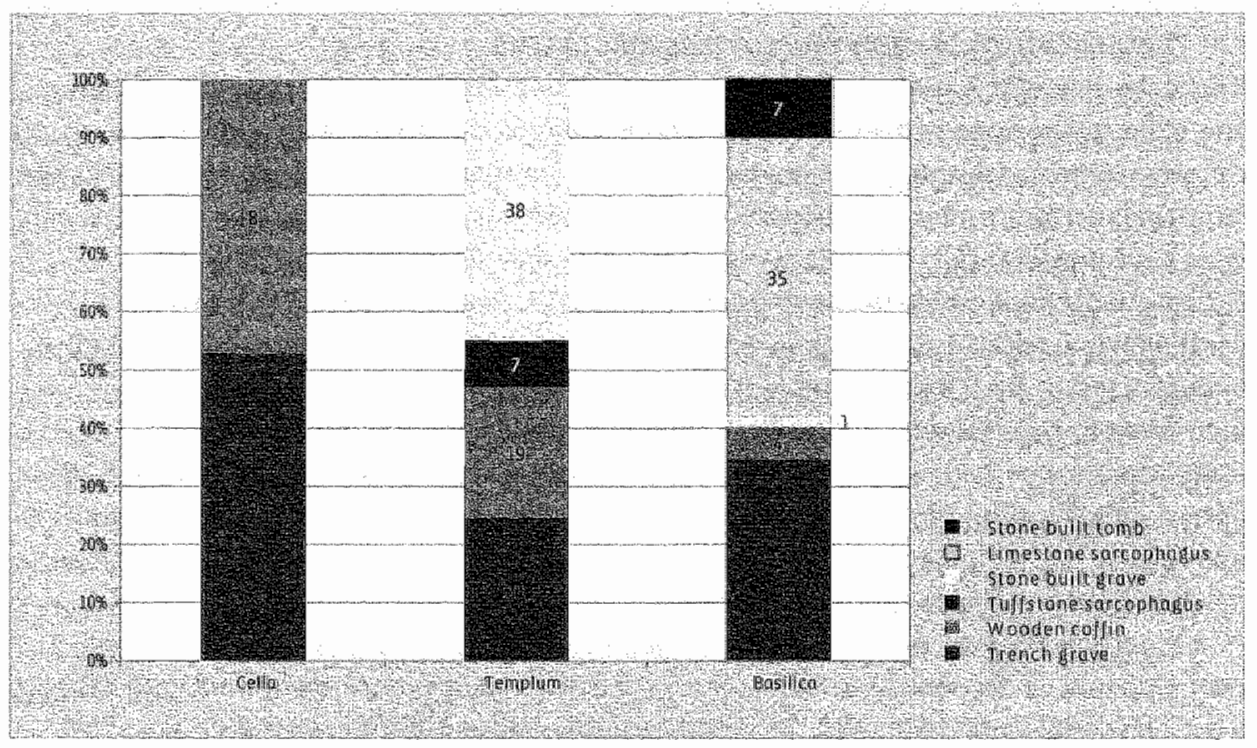

FIGURE 3-40 Distribution of the six mast frequently found grave types lexcawated at the Servads church sitel by period Percentages are calculated per totat of the six grave types per period induded in the counts dre all graves found, alsa groves which no longer contained human remains at the time of excavation.

phase, around the first half of the sixth century. Stone-built graves seem to have been used somewhat later. The findings suggest that when the tuff stone sarcophagil became obsolete the stone-built graves came into use, which in turn were followed-up by limestorie sarcophagl. By the end of the templum phase there were five times more stone-built graves than tuff stone sarcophagi. The stone-built graves allone accounted for 45 per cent of the graves from the templum phase. During the basilica phase the techmique to construct stone-bulith graves continued to be used. However, only one stone-built grave resembled the graves from the templum phase. All other stone-buitt graves were considerably larger and some of these were trapezold in shape. Therefore these graves were categorised as a separate category of stonebuilt tombs. New in the basilica phase were trapezoid limestone sarcophagi, which became the predominant grave type during the first phose of the basilica ${ }^{\text {sog }}$ in fact the number of limestone sarcophagi excavated at the Servaas church site presently represents the largest concentration of this type of graves in the lower Meuse valley. ${ }^{716}$

The distribution of grave types over the three phases demonstrates that wooden coffins and trench graves were used during the whole period. More labour intensive, and therefore most likely more costly grave types, came in to use fram the early templum phase. The various special grave types seem to have been preferred for shorter periods.

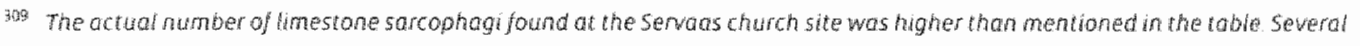
Umestone sorcaphog that were reused in later periods were not inciuded

30 Lammers, 1992 


\section{THE CLASSIFICATION OF INDIVIDUALS BY BURIAL STATUS}

One of the aims of this study is to analyse any assaciations between socid status and health. Therefore, it is necessary to categorize the burials in status categories. Since specific data concerming the social status of the buried individuals are missing, dirchaeologists generally have to use indiret indications. Traditionally warious components of the burial ritual are seen as vallid indicators of social stcitus. For early medieval Westem Europe the feasibility of a classification of burials has been extensively discussed. ${ }^{321}$ From this discussion it may be concluded that burial rituals do not al ways straightforwardly reflect the socio-economic status of the deceased. The interpretation of grave goods, in particular weaponry, to categorise individuals by social status has proven complex and often impossible. What has been established is that there is an association between the grave goods and the sex and age of the deceased. ${ }^{32}$ More and more the burial ritual is seen as an expression of what was considered appropriate by the entourage of the deceased. In a sense the burial ritual was adapted to the needs and possibilities of his or her entourage.

It Is not only the way the social status of the deceased was expressed in the burial ritual which is poonly understood. Due to the scarcity of written sources our view of what determined a person's social status in the early medieval period is obscured. In other words it is not at all evident what early medieval society looked like in a place like Maastricht. The Germanic penal cades specifically acknowledge the existence of three groups in saciety: the free (ingenuus), the half free (letus) and the unfree (semus). Written sources indicate there was an elite in society. However, the legal codes do not mention the existence of mobility as a separate category. They do mention that people of low judicial status could move to influential positions in society. ${ }^{3 x}$ Apart from their judicial status, people often belonged to various sociologilical groups, based on dynamic and varying ordering principles, e.g. family structures, religious or secular hierarchies, work-related groups.

At present, the available archaeological data do not allow us to detect the details of this fine framework of sociah groups and link these to individual burials. The complexity of such a true to life categorisation of individuals is not something, that needs to be achieved for this study. That would lead to minute social units that would be too small to allow for comparisons with significant results hdeally a classification of burialls according to social status should be a reflection of the actual stratification of society and still be simple enough to allow for comparison among the categories. By analogy with the early medieval judicial categories it was decided to distribute the inhumations over three categories. These categories are the low status, intermediate and high status category. However $r_{f i}$ is important to realise these categories are not identical to the three groups in the legislation. They represent burial status which not necessarily reflects the social status of the buried individual.

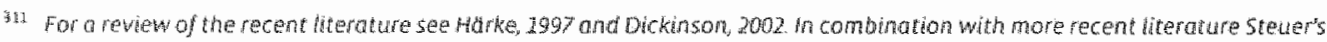
monograph provides on exceftent introduction to the topic steuer, 2982 . Recenty ffros has strassed the importance perishoble grave goods may have mad in the burial ritual Effros, 2002

iil Hoisolt, 1995

313 Staob, 1996; Drew, 1991 
To categorise the graves from the Servaas church site and the Boschstraat site a simple approach was chosen. Criteria for the categorisation of the individuals were the cemetery, the position within the cemetery, the grave type and grave goods. For comparison by status the individuals from the templum and basilica phases and the Boschstraat site were combined to obtain sample sizes that would allow for meaningful statistical anallysis. ". In arder to combine these samples three assumptions have to be made. Firstly we have to assume that the structure of society was more or less comparable during both the templum phase and the basilica phase. Although early medieval society underwent considerable changes between the late Roman period and the high Middle Ages, there are no indications of fundamental rearrangements or transitions, like the emergence of large new social groups. The second prerequisite is that general liwing conditions did not change significantly between 480 and 950 AD. This prerequisite will be tested in chapter eight. The third assumption is that both the templum phase and the basilica phase samples on the one hand, and the Boschstraat site sample on the other hand, were considered to represent complementary sections of early mediewal society in Maastricht. The complementary nature of the early medieval cemeteries of Maastricht will be discussed in chapter seven.

All burials at the Boschstraat cemetery were categorised in the low status category because of the characterisitics of this cemetery. The context of this cemetery as a whole and the materialistic dato of individual graves differed fundamentally from the contemporary burialls at the Servaas church site. ${ }^{335}$ The graves of the Boschstraat site were simple and located in a cemetery that was not associated with a church or the grave of a saint but amidst a settlement of craftsmen. Based on written sources it is difficult to determine the social status of craftsmen. According to Roth the majority of craftsmen were unfree men dependent on secular lords or clerical institutions. ${ }^{316}$ The characteristics of the associated activities on site and the nature of the burials were interpreted as indications that the Boschstraat site served as a cemetery for persons of lower social status.

Because of the assumed presence of the grave of Saint servatius and the consecutive churches built at the site, the templum phase and basilica phase burials were regarded as "ad sanctos" burials of individuals of intermediate or high status. ${ }^{317}$ Within the cemetery a variety of positions, grave types and grave goods was seen. This seemed to allow for a further division of the burials at this site in an intermedlate and a high status category. For this purpose the burials from the templum phase and the basilica phase at the Servaas site were pooled. Various stories of miraculously moving graves for example in the writings of Gregory of Tours indicate

3n The small somple from the cella phase was not included in this comparison as th vepresents the lote Roman period; this would meon

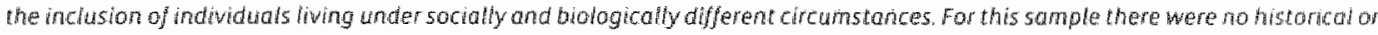
archaeological dato ro determine the social status of the ind widual graves and the burials as a group

ms secondary inhumations were not categorised into status categories because of the uncertainty of their as sociation with the grave type in which they were found.

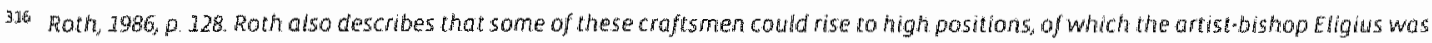
the best example.

31 Effros 7997 , i. 73 
that the position of the grave within the cemetery was considered an important indicator of the status of the inhumed. determined in relation to contemporary buildings and burials. For the beginning of the templum phase the point of reference was the cella memoriae. Later, after the construction of the first stone church, the church became the point of reference. Assessment of the position within the cemetery was reduced to two categories. Burials inside the church or directly adjacent to the church were categorised as of high status. Burials at a distance of a few meters from the church were categorised as intermediate status graves. Grave-types also provide information on the sacial structure of the cemetery by taking into account their monumental aspects and economical value. Grave types were graded based on the amount of labour that was invested into the construction of the grave. Categorised as high status graves were sarcophagi (tuff stone or limestone) and stone-built graves (normal and large). Less valuable grave types comprising burials in trench graves and coffins at the Servaas church site were categorised as intermediate status burials.

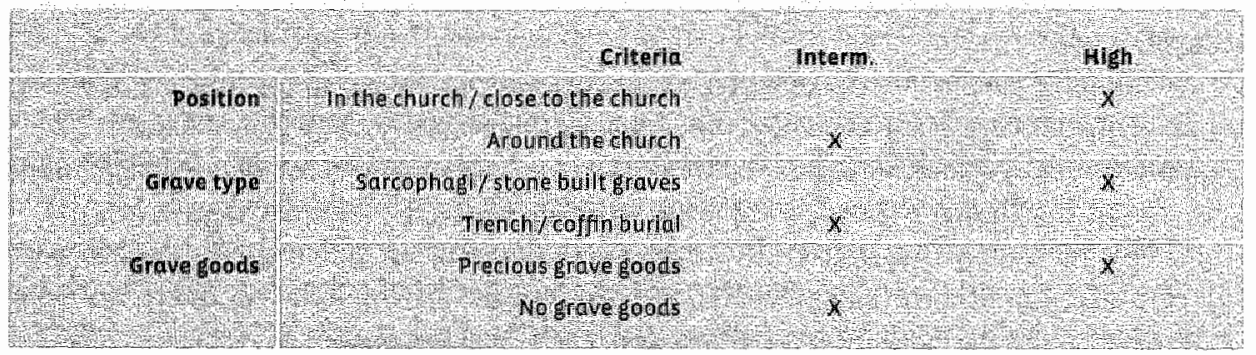

TABLE 3-6 Classification scheme for the terpotum and bositica phase burials ar the Serwoas church site. Not classified were disarticulated remains and secondary butials.

In early medieval cemeteries grave goods are generally used to determine the social status of the individual burials ${ }^{2.29}$ As grave goods were only found in graves from the templum phase and not in basilica phase grawes their value, as an indicator of status, was problematic.

Consequently templum phase graves were judged according to an extra parameter. Another factor complicating the categorisation by grave goods is the loss of grave goods due to either intentional grave robbery or accidental disturbances of the grave during later construction and burial activities. Neverthelless, it was decided to use this parameter because of the presence of precious grave goods in some burials that otherwise would not have been rated as high status burials. And since grave goods were used as a parameter, all graves with grave goods from the Servaas church site were categorised as of high status. Burials with simple grave goods were not graded as of intermediate status since these may have been robbed or disturbed graves. Rich graves were generally fitted out with an assemblage of grave goods ranging from common utensils to precious goods. It is known that in robbed graves thieves would leave behind those 
goods that were of little value. Therefore, it was decided to place all graves with grove goods in situ in the high status category. This decision will probably cause some graves to be placed in the wrong category. Still, the opposite would also be the case if the se graves were categonised in a lower status category, since it is likely that a number af graves with non-precious grave goods represent robbed ar disturbed high status graves.

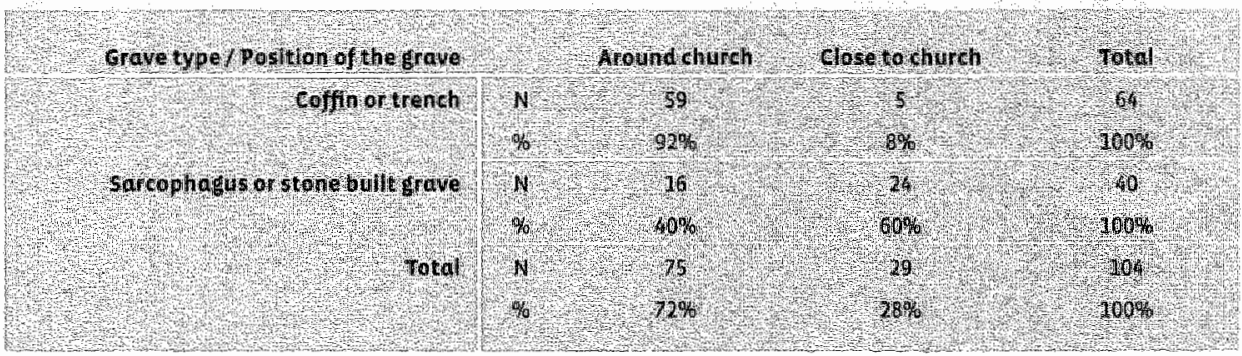

TABLE 3-7 Grave type by position of the grave Grabes, iatso including empty growes, are counted.

All graves were scored as intermediate status burials unless one of the parameters, position, grave type or grave goods, complied with the criteria defined for high status burials. At the Servaus church site 104 graves could be assigned to either of the status categories. In order to determine whether the results for the selected parameters were in agreement with each other the associations between the three parameters were tested. The association between grave goods and either position or grave type was poor. This poor association is not easy to explain. Did the loss of grave goods make this parameter a poor indicator for social status during the templum phase? Alternatively, were other aspects than position and grave type also important indicators of social status? A highly significant association ( $p<0.0001$ ) was found between the position within the cemetery and grave type (Table 3-7). This provides some assurance that the parameters may be used as indicators of status.

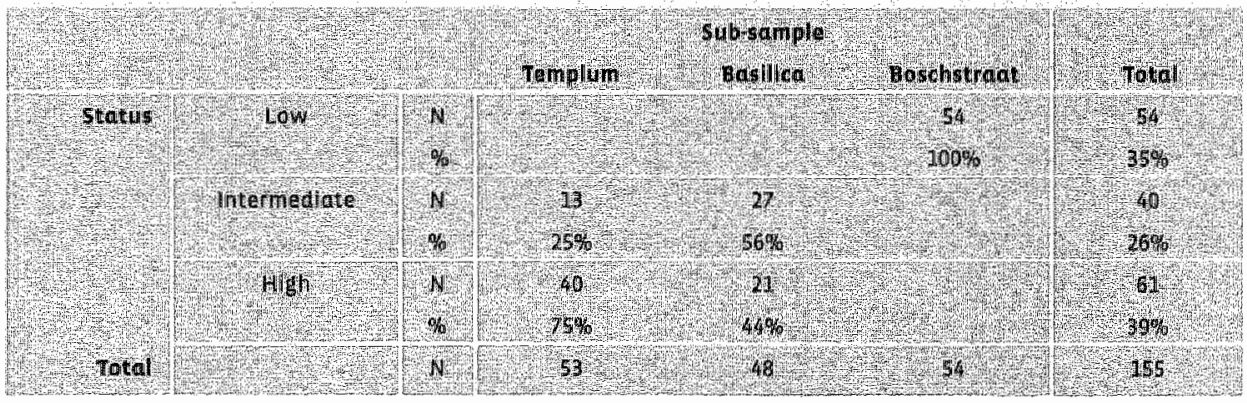

TABLE 3-8 Undwiduals per status coteghy and per site

Ist See steue 1982 an the effect of grove nobbery focus sing on the most precious objects 
In total the skelletal remains of 155 individuals were categorised by status. Not all status categorles were equally represented. It seems that the high percentage of high social status burials in the sample as a whole was mainly the result of the high percentage of burials from this category in the templum phase sample: 


\section{Material survival and recovery of the human skeletal remains}

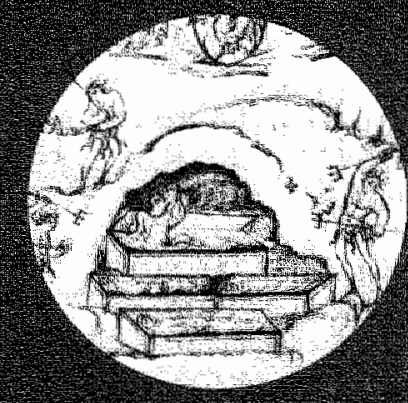


 skeletal remains}

Around 1000 AD emperor otto lll assembled a small group to secretly search and open the grave of Charlemagne in Aachen. To his surprise he found the body of his illustrious and venerated predecessor sitting in his grave as if he had just fallen asleep. According to the account of an eyewitness not only his clothes and personal belongings were well preserved, emperor charles' body also appeared almost immacullate. Only the tip of his nose had fallen victim to decay. Before he closed the grave, otto replaced the missing part of the nose with a golden prosthesis; he cut Charles' nails; collected some hair and extracted one tooth, probably with the intention of keeping them in a reliquary.

Unfortunately the condition of the early medieval human remains excavated in Maastricht never approximated the situation described in this legend. In general only bones were recovered from the graves and even these skeletonised remains were often far from complete. In a paper discussing the problem of incomplete skeletal remains Waldron has argued that variation in the completeness and conservation of recovered skeletons can bicis the results of a study af skeletal materlal. ${ }^{322}$ Therefore, assessment of the completeness and state of preservation of the human remains is a necessary prerequisite for osteo-archaeological studies. ${ }^{3 x 3}$ As will be discussed below an evaluation of the completeness of the skeletall remains may also extend our knowledge of burial customs and the impact of grave types on the preservation of skeletal remainus.

In this chapter, aspects associated with the recovery and preservation of the skelletal remains will be described and discussed. The chapter starts with a description of the recovery procedures on site and preparations for storage and study in the laboratory. The following section addresses matters concerning the completeness of skeletons and bone preservation This section will focus on both the "completeness rate $e^{x}$ of individual skeletons and the "relative survival" of bones and parts of the skeleton at the level of samples and sub-samples. In the following part the completeness rate is used as a parameter to present information on the proportion of the whole skeleton recovered. The relative survival is used to study the selective processes that may have influenced the preservation of varlous parts of the skeleton. Among the three samples from the Servaas site marked differences in completeness and relative survival of the skeletal material were noticed. To determine the differences between the various groups of skeletons mean completeness rates and recowery percentages were calculated. ${ }^{32 / 5}$ After a short.

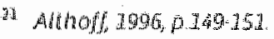

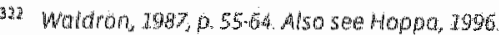

Ma For documentary sources the frvestigation of the material aspects of the source can provide instgh in the context and infortiative watue of the source Likewise the study of the completeress and presenotion of the skeletol remains wan elucidate the informative potential of the sample

At the time of development of the dotobas for this study the at tha was not aware of the method used by waldron to calculate

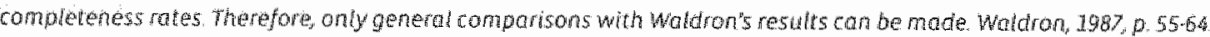


description of the general state of preservation of bone at the two sites this chapter will focus on the factors that influenced the survival of the skeletal material. Finally some of the possible consequences of the variation in relative surviwal on the anthropological and palaeopathological data will be discussed.

\section{RECOVERY PROCEDURES}

Excavation trenches at the Saint Servaas site were completely dug by hand. At the Boschstraat. site, a rescue excavation, a dragline was used to remove a top layer of rubble. Further archaeological techniques applied to detect graves, excavate human bones and record circumstantial information were the same at both sites. ${ }^{325}$ When the outline of a grave or grave-like feature became visible, its contour was recorded on the site plan (scale 1:20). Detalls of graves containing grave goods or skeletal material were often mapped out on additional drawings at a scale of 120. The filling of the grave was carefully removed in situ measurements of the stature of the individual, from the top of the skull to the base of the calcaneus, were taken in the rare cases when all necessary bones were present and in anatomical position. Any finds in the grave were collected after their position was recorded on a drawing of the grave. in about $25 \%$ of the graves a soil sample was taken from the abdominal region. From the sarcophagl and stone-built graves, stone and mortar were sampled respectively.

When necessary, different categories of material collected from the grave were listed under separate numbers: Special items like grave goods also obtained their own number. After the grave and the skeleton had been cleaned, monochrome and colour photographs were made in situ. On an archaeological burial registration form all graves and grave finds were described in a standardised way. Additional information was recarded in the excavation journal. Skeletons found at the Boschstraat site were recovered the same day. Within the Saint Servaas church the climatic conditions were very stable. This allowed the archaealogists to incidentally leave some skeletons in situ for periods up to a fortnight. still, most of the skeletons found at that site were collected within one to three days. Once the bones were lifted, they were dried and packed in plastic bags. At the Boschstraat site skeletal remains were generally recovered on the day they were exposed. For every skeleton the skull, the trunk and the right and left limbs were put in separate bags. The procedures for collection and storage of the bones partially met present day. requirements: ${ }^{375}$ At the time of excavation the research of ancient DNA (aDNA) was still in an early developmental phose and knowledge of the necessary precautions for the analysis of

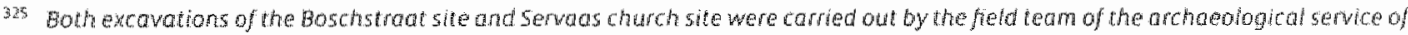

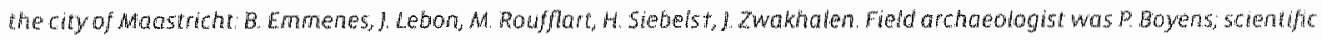
superision T. Panhysen. The author participated for several weeks in the boschstrad site excavation and jor circa 10 wesks in the Senoos church site excavation

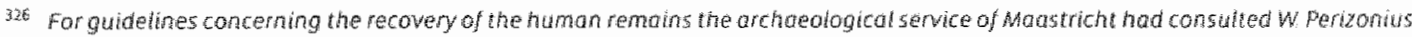
from the institute for Anthropobiology of Utrecht understy Recovery procedures were largely based on his recomimendations. Due to the development of new andyica terhniques (roce elements, stable satopes and ancient onA) ar adaptation of recovery procedures hos become imperative. Examples of recent recommendations for the recovery of human shetetat remaws can be jound 
aDNA was not yet available to the archaeologists. Furthermore, the soill from several graves was not sleved. This probably coused the lass of smaller bones, bone fragments and loose tee th. ${ }^{27}$ Fortunately soil somples were collected frequently providing the necessiary reference samples for future physical and biological analysis.

\section{LABORATORY PROCEDURES}

Since the bones had not been cleaned before storage, lumps of dried loam had to be removed with water. In some cases, skeletons had not been dried sufficiently before storage, which led to the growth of fungl on the bone. All washing activities were done over a fine-mesh sieve ( $2 \times 2$ $\mathrm{mm}$ ) to prevent the loss of small fragments. ${ }^{328}$ Fresh water and soft brushes were used to remove the loam. Drying of the bones took place at room temperature $\left(20^{\circ} \mathrm{C}\right)$. For storage, the bones were packed in plastic bags, which were not sealed but closed in such a way that air could flow in and out of the bag. Many bones were fragmented and had to be reconstructed. Restoration turned out to be time-consuming. Fragments that did not yield valuable physical anthropological or palaeopathological information were not reconstructed. For those fragments that were reconstructed a glue of water-soluble polywinyl acetate was used. Only in exceptional cases were bone fragments treated with chemicals to prevent further deterioration. Fragments of the vertebral collumn and a femur ${ }^{32}$ with pathological changes were preserved by immersion in Archeodermo to forestall further loss of the brittle bone. ${ }^{3: 30}$ Assemblages of disarticulated bones of multiple individuals were carefully ordered into smaller groups replesenting possible individuals. In situ photographs, articulation of joints, symmetry, size and morphological differences, dental occlusion, tooth wear, variation in colour and degree of preservation were used to separate the bones per individual skeleton.

on a schematic drawing of the cranial and post-cranial skeleton, the presence of bones was recorded for each individual. Note was also taken of the presence of hyoid bones and auditory ossicles. Furthermore, on a separate form, record was kept of the completeness of the dentition. Cases in which skeletons showed iron oxide and copper oxide staining, the location of the stains was marked on the stylised drowing. All inventory data were stored in a database.

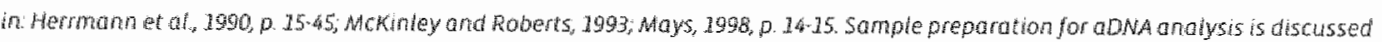
in Hummel and Hermann; 1994 .

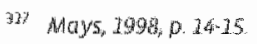

The author was involved in the clearing of all sketetal remains in cooperation wh th. Dassen. This proved adwantageous for the recovery of smalt fragments and specific types of small bones like hyold bones and atuditory ossicles mporoximately za auditory

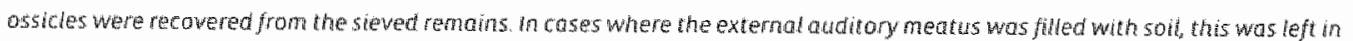
place to be removed at a later stage with dentad instruments. This led to the additonal recover of circa 70 auditory ossicles. 


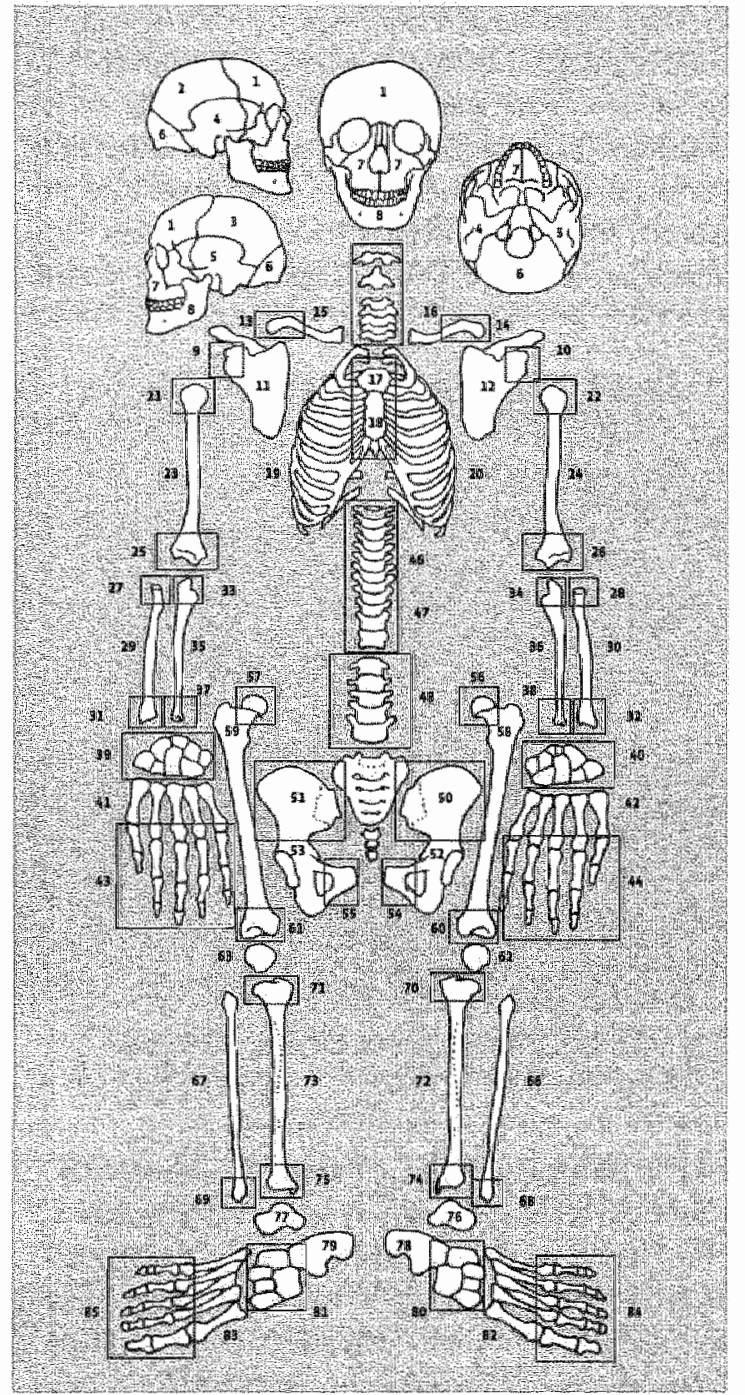

FIGURE 4-1 Example of an inventory drawing: displayirg the 85 sections used to register presence or absence

\section{CALCULATION OF COMPLETENESS RATES AND RECOVERY PERCENTAGES}

Completeness rates were calculated for all individual skeletons based on the inspection of 85 selected elements of the skeleton (Figure 4-1). Not included in the calculation of the completeness rate were the dentition, the auditory ossicles and the bones of the hyold. Cartilage structures that sometimes ossify, like the cricoid and thyroid, were also not included. For the combination of inspected parts of the skeleton the range of the completeness rate could

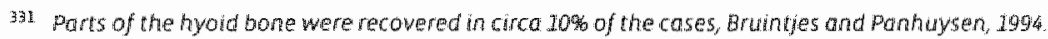


vary from 0 (absent to 1 (complete). These rates were calculated to provide an indication of the research potential of individual skeletons and of groups of skeletons. Included were data on the presence of parts of the skull, the pelvis, the extremities the shoulder girdle, manubrium, sternum and ribs. Larger bones, or bones with large joints were divided in segments, which were separately included in the calculation. ${ }^{33}$ Parts of the skeleton were recarded as "present" in cases in which the part was almost complete on recovery. Functional criteria were applied: enough bone had to be present to ensure that it could be used for a physical anthropological or paldeopathological purpose. ${ }^{\text {3as }}$

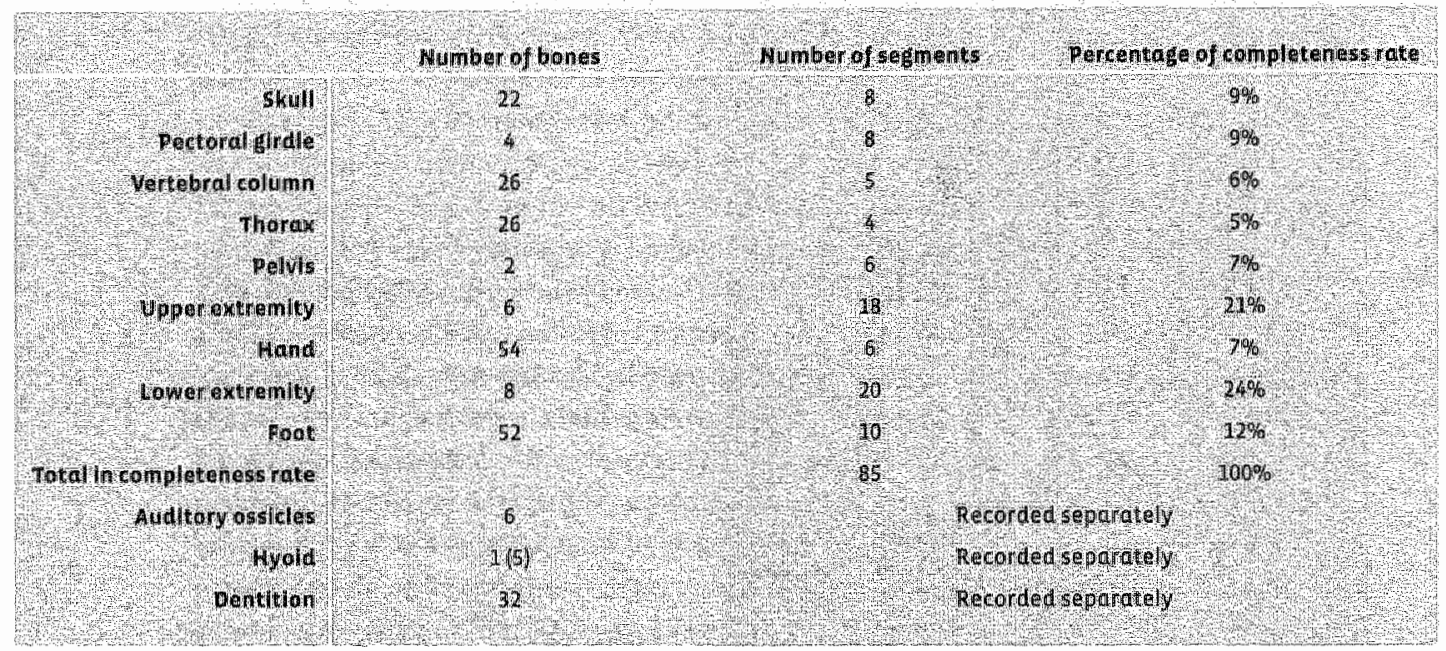

TABLE 4.4 List of bones of the fiuman skeleton and their representation as segments for the calculation of the completeners rate

A different recording strategy was chosen for the smaller bones of the hand and foot and for the vertebrae. The bones of the hand and foot were scored per group of bones, namely the carpal and tarsal bones, the metacapals the metatarsals and the phalanges of the hand and foot. in the initial inventory these bones were recorded individually. However, the small bones of the wrists, hands and feet add up to hundred and four bones in total. Together they constitute about half the number of bones present in the average human skeleton (n=206). If these bones had been included individually in our calculations the (partial) absence of the bones of the wrists, hands and feet would have obscured the other results. By scoring their presence per group of bones the importance of the hands and feet in the formula for the completeness rate is reduced. As a result those parts of the skeleton that often provide basic physical

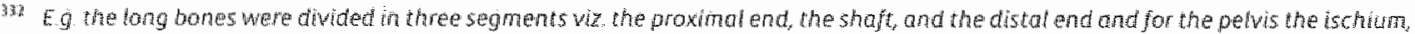
the pubis and the ithum were recorded separacely.

3. a a temporat bone of the skul was scoped present if enough bone remained to score its sex features a distal humerus was scored present if scoring the absence orpesence of degeneravive or otherchanges was possible. 
anthropological and palaeopathological information are of more weight in the calculation of the completeness rate. For the wrists, hands and feet the presence of one bone of each group of bones was sufficient for a score as 'present.".33' The vertebrae were included in a similar way: the vertebral column was divided in five segments. A segment would be scored as present if at least one third of the facet joints and endplates af a segment were avallable for inspection. Completeness rates were calculated for each skeleton by dividing the sum of recovered parts by the total number of expected parts, viz. 85. The thus calculated campleteness rates per individual were also used to compute mean completeness rates per site, per phase and per grave type.

The examined samples showed a cansiderable variation in the frequency with which various parts of the skeleton were recovered. To assess the relative bone survival of a specific bone or segment of the skeleton, recovery percentages were established per sub-sample. This percentage expresses how many of the expected parts were in fact recovered. For all inspected parts of the skeleton the following formula was used to calculate the specific recovery percentage ${ }^{36}$ (in this example the farmula for the right femoral shaft is represented): Recavery percentage femoral shaft $(R)=100 \times \frac{N \text { femoral shafts( } R \text { ) recovered }}{N \text { individuals inspected }}$

Finally to determine the contribution per sub-sample of skeletons to the whole sample proportional percentages (e.g., categorised by period or grave type) were calculated for the 85 parts of the skeleton.

Proportional percentage $=100 \times \frac{\text { Nports recovered per sub }- \text { sample }}{\text { Total } N \text { parts recovered }}$

The recovery percentage and the proportional percentage were calculated for sub-samples based on grave types and building phases. Although these percentages were computed for all parts of the skeleton, the results of a selection of eight skeletal parts will be presented in the text below. This set of eight parts comprised a cross section of the avallable four gross morphological bone types: lang bones; short bones, flat bones and irregular bones. The selection also represents bones consisting of one of the two main types of bone architecture: compact bone and cancellous bone. ${ }^{\text {sy }}$ Furthermore, the set encompasses bones that are easily recognisable during excavations and bones that are more unobtrusive and may be overlooked The eight sellected parts of the skeleton were the frontal bone, the right proximal humerus, the right metacarpals, the sternum, the left ilium, the diaphysis of the left femur, the left talus, the phalanges of the right foot. The eight selected parts of the skeleton used in the table above and

33. Eg. if an os noviculare of the right hand was recowered the corpar bones of the right hord would be recorded as present

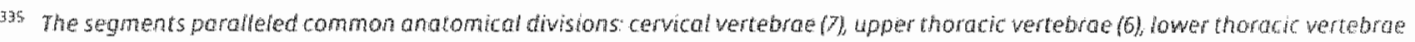

(6) lumbor vertebrae (s) and the sacrum.

3 kecowery percentages for left and right bones or bone sectons were ratculated separatey

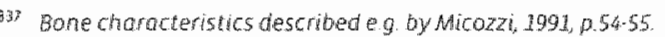


following tables proved to be representative for all inspected parts. Both the right and left side of the skeleton were represented in the selection.

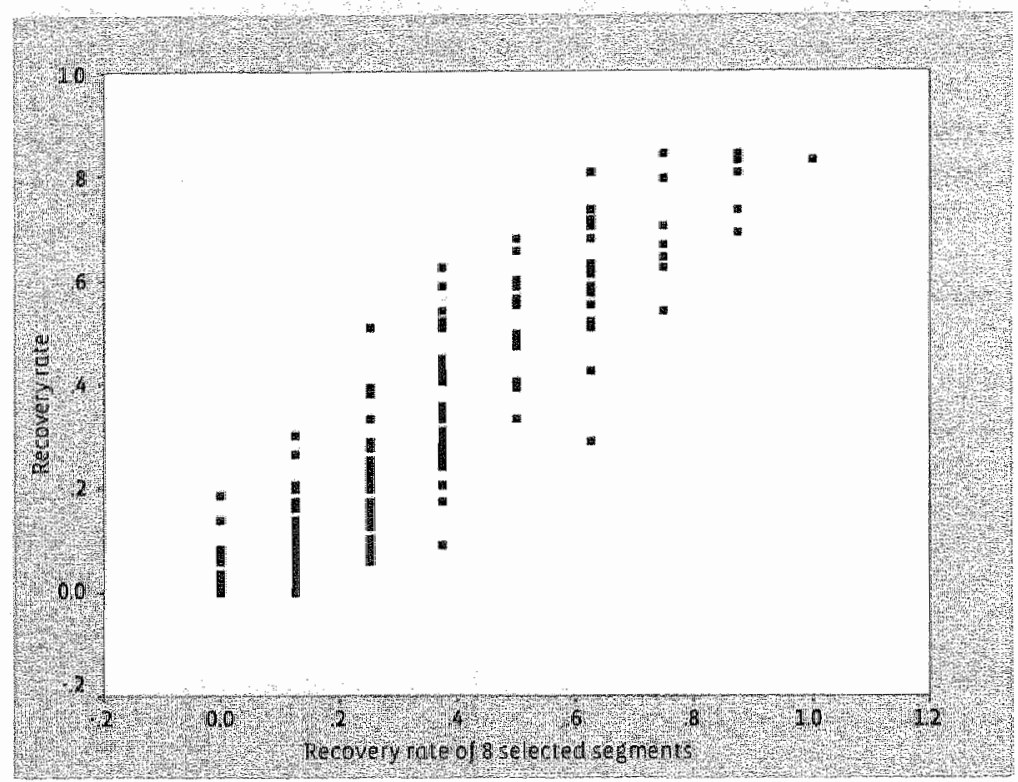

FIGURE 4.2A scatter plot showing the strong correlation between recowery rates bosed on the BS inspected element fon the vertical axis) and the rate based on the selection of segments of the skelecon fion the horizontal axis) (Number of inspected individuals is 2381

Both mean recovery rates callculated on the basis of all 85 parts and the recovery rate calculated from 8 selected parts of the skeleton were similar jor all sub-samples. As shown in Figure 4.2 there was a linear relationship between the two recovery rates Computation of Pearson's correlation for the two rates resulted in a highly significant ( $p<0.001$ ) correlation coefficient of 0.931 . This strong carrelation indicates that in future studies recovery rates can also be calculated based on this selection of eight segments of the skeleton.

\section{NUMBER OF INDIVIDUALS AND COMPLETENESS}

At the Servaas site archaeologists collected the skeletal remains of at least 283 individuals. Of the whole sample 23 indiwiduals could not be dated; 16 individuals were assigned to the period between 950 and $1800 \mathrm{AD}$ and thus fell outsicte the scope of this study. As a result a total of 244 skeletons was considered to date to the period between circa 350 and $950 \mathrm{AD}$. In 60 cases the archaeological evidence did not permit more specific dating. 


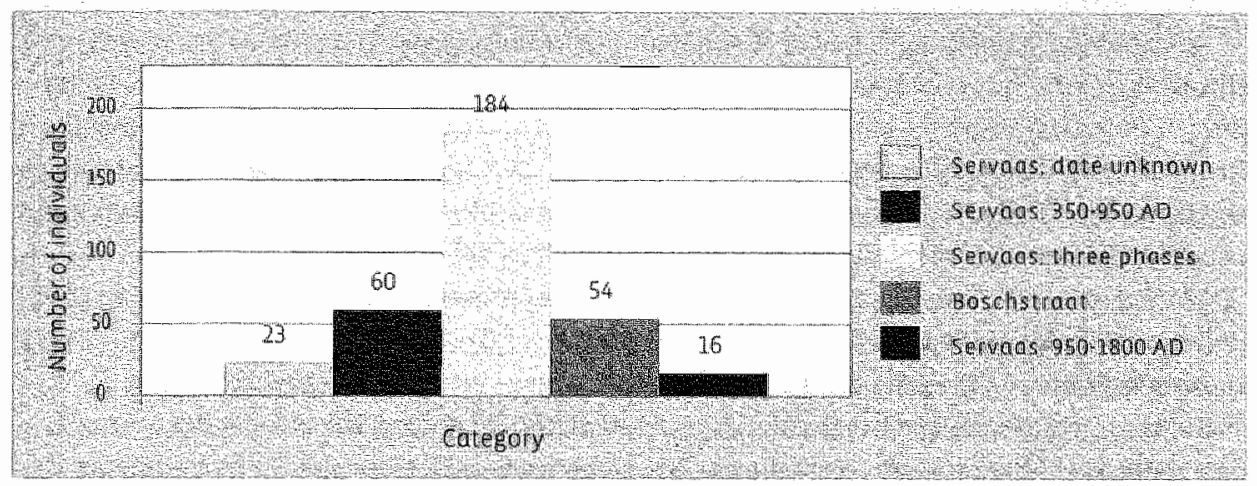

FIGURE 4.3 The bors represent the number of indwiduals from the serwads thurch site and the Boschstraat. The results found for the first the second and the fif th categories $(\mathrm{n}=99)$ were not included in this study.

This study focuses on those 184 inhumations that could be specifically assigned to one of the three building phases before $950 \mathrm{AD}$. At the Boschstraat site 54 skeletons were recovered all dating from the seventh or early eighth century. Therefore, the total number of skeletons analysed within the framework of this study comprised of 238 skeletons. As explained in chapter three the whole sample was divided in four(sub-)samples: viz, the cella sample, the templum sample, the basilica sample and the Boschstraat sample. Below the relevant data concerning the recovery of human skeletal remains will presented per sample.

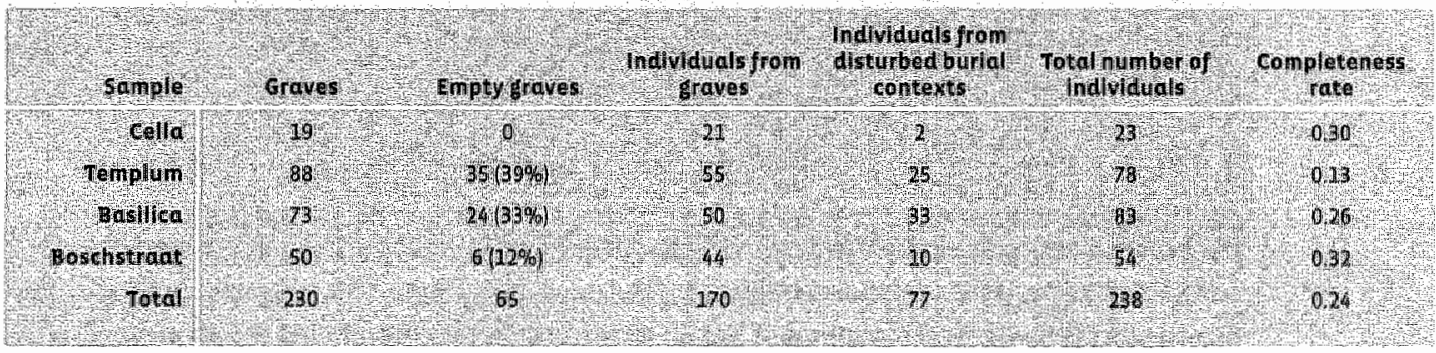

TAMLE 4-2 An overview of data related to the recovery of human skeletal temains from the four samples that were examined for this study.

A total of 23 skeletons was assigned to the celia sample. All 19 graves of this phase contained skeletons. One grave enclosed the articulated skeletons of 3 individuals. Remains of 2 individuals, from disturbed graves, could be added to this collection. Inhumations of the cella phase made up $9.7 \%$ of the sample examined within the framework of this study. Inhumations from the cella sample were the most complete of the three Servaas church site samples, which is evident from a completeness rate of 0.30 . 
The templum sample consisted of 78 skeletons, representing nearly a third of the skeletons in this study (32.8\% of the total sample). Fifty-three of the individuals were found in graves. Thirtyfive $(39.3 \%)$ of the 88 graves of this phase were disturbed and contained no human material. Remains of 25 individuals were collected from elevation layers and disturbed graves. In general the skeletons from the temptum sample were incomplete, resulting in a mean completeness rate of 0.13 More than $80 \%$ of the skelletons had a completeness rate of less than 0.25 .

The basilica sample contained the largest group of skeletons, wiz. the skeletal remains of 83 Individuals (34.9\% of the total sample). About 73 graves were assigned to this phase; $24(32.9 \%$ ) of these were empty. In the remaining 49 graves 50 individuals were found. Fragments of 36 skeletons were collected from elevation layers and disturbed graves. The mean percentage of completeness of the skeletons from the basilica sample was 0.27 . Circa $60 \%$ had a completeness rate of less than 0.25.

At the Boschstraat site 54 skeletons were recowered (22.7\% of the total sample). 5 ix empty graves were recognised (10\%). From 44 graves, skeletons, were callected In addition, skeletal remains of 10 individuals were found in and around the graves. The mean completeness rate was 0.32 and only half of the skeletons were found to have a completeness rate of less than 0.25 .

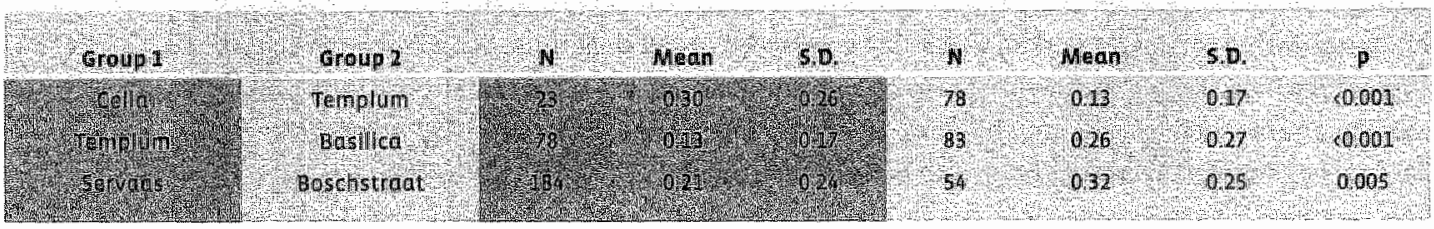

TABLE Gu Comparison of the mean compieteness rates for the four sub-samples and calculated p-values for student's to test

Table $4 \times 3$ shows comparisons of the mean completeness rates for each sub sample. As indicated above the highest mean completeness rate was calculated for the inhumations from the Boschstraat sample, closely followed by the cella sample, the basilica sample ranked third and skeletons from the templum sample were the most incomplete. This suggests that time after deposition of the skeletal remains was not an important factor determining the chances of recovery of human skeletal remains at these sites. Statistical analysis showed that the difference in mean completeness rate between the templum sample and both the cella and basilica sample was significant. In general the skeletal remains recovered from the Boschstraat site were significantly more complete than those collected at the Servaas church site. 


\section{RELATIVE SURVIVAL AND RECOVERY}

\section{Completeness rates per sub-sample}

Table 4-4 shows that the recovery pattern of eight selected parts of the skeleton was not the same for each sample. As might be expected, parts of long bones and other bones with a high proportion of compact bone were recovered more frequently than parts with a high proportion of cancellous bone and small bones. ${ }^{\text {isg }}$ For example, recovery percentages found for the femoral shaft and the frontal bone were generally higher than might be expected based on the mean completeness rate. Low percentages were found for bones like the phalanges or the sternum. However, this pattern of relative survival of bones and segments was not identical for each sample. The templum sample in particular had a pattern of recovery percentages that differed from the other three samples. In comparison with the mean completeness rate, inhumations from the templum sample yielded low recovery percentages for the proximal humerus; the sternum, the illium, the talus and the phalanges of the foot. This pattern of differential survival was reflected in the proportional percentages.

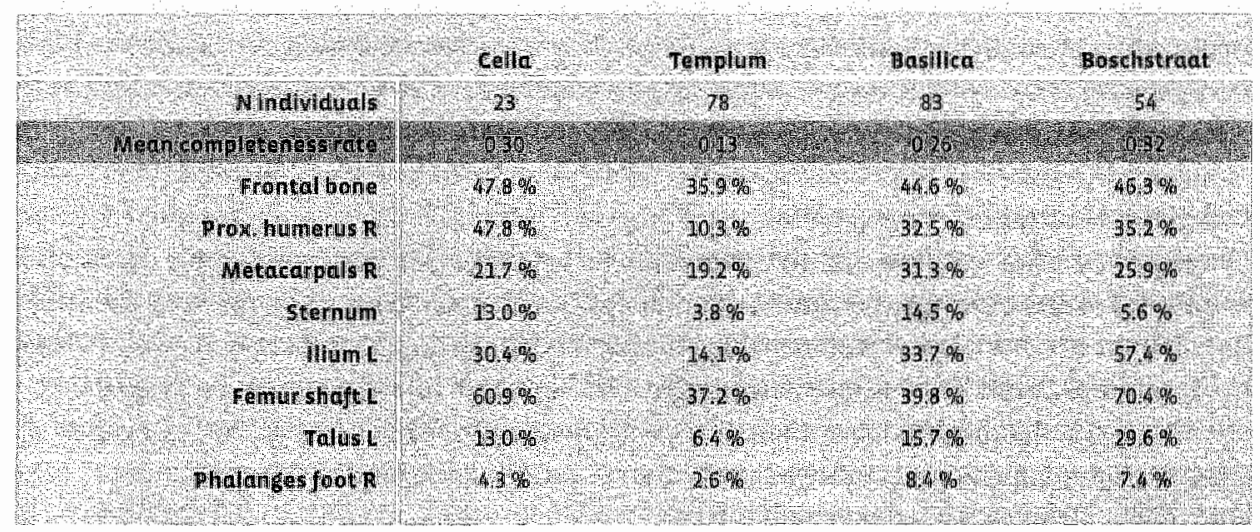

TAELE 4 4 Hean completeness rates calculated jor al 85 parts and recowery percentages ol eight selected parts of the skeleton per stub-somple

Becalise of the variation in recovery percentages it was moticed that bones found in above average quantities in specific samples, caused these samples to be comparatively over represented in the total sample and vice versa. If we look for example at the recovery percentage found for the right proximal humerus in Table 4-4, we see a recovery percentage of $47.8 \%$ for the cella phase and $10.3 \%$ for the templum phase. As a result we can see in Table 4.5 that $16.9 \%$ of the recovered proximal humerl was found in the cella phase, while the templum phase contributed only $12.3 \%$. Thus the cella sample was represented in the total sample by more proximal humeri of the right side than the templum sample, despite the fact that the

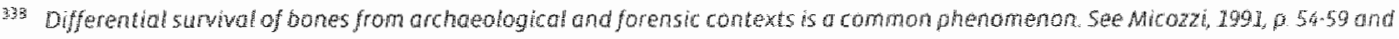
Hoppe, 7996 
latter sample contributed more than three times the number of individuals to the sample as a whole.

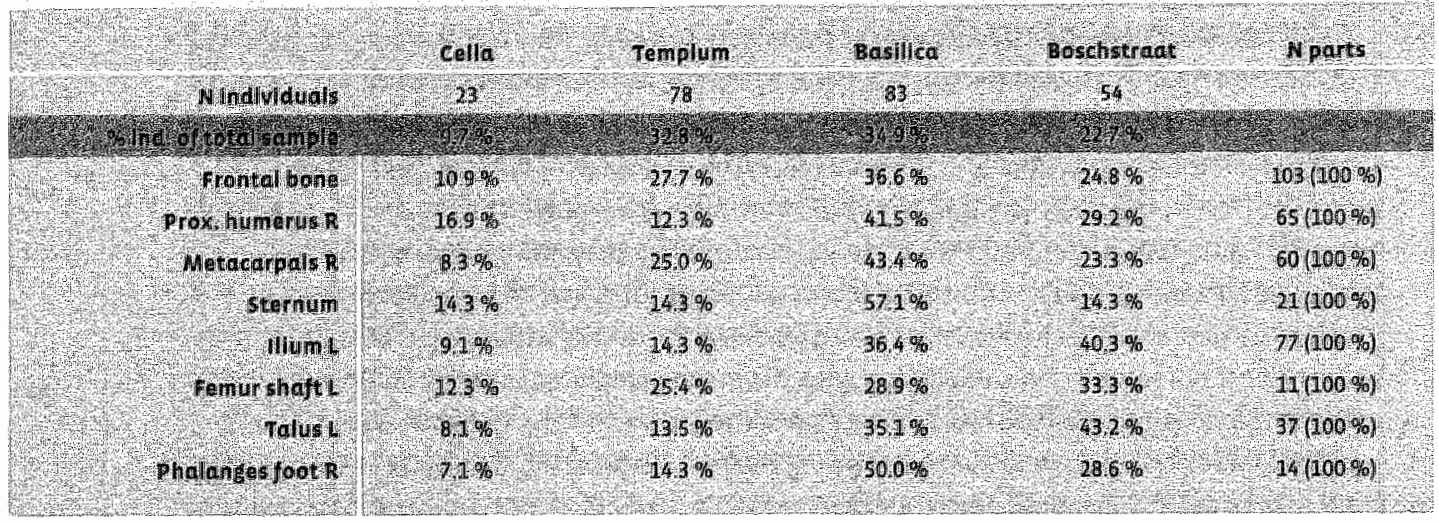

TABLLE S. Proportiond percentage for eight selected parts of the skeleton. In normal distributions the expected proportional percentage for eacil skefetal segment was expected to be equal to the samples percentage of the total sample imaked in reyl, Percentoges manked in botd were more than 25 per cent above the expected percentoge for that sample. Those marked in italic were more than 25 per cent below the expected percentage jor that sample.

\section{Completeness rates per grave type}

Completeness rates calculated for the various grave types also revealed considerable variation. Table 4-6 shows the recovery percentages for the four major girave types at the Servaas and the Boschstraat site. Buriais in trenches yielded the highest mean completeness rate (0.34). A slightly lower rate was found for limestone sarcophagi $(0.28)$. The mean rate of circa 0.24 for stone-buitt graves was not significantly lower than the trench graves and limestone sarcophagi. Only the difference in completeness rate between the trench graves and coffin graves proved to be statistically significant (Student t-test: $p=0.02$ ).

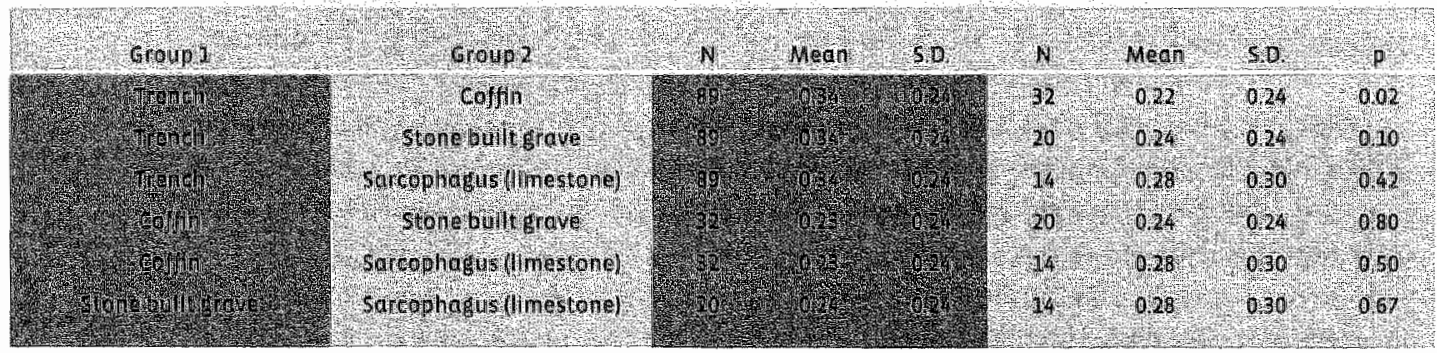

TABLE 4-6 Mean completeness rates for fou molor 


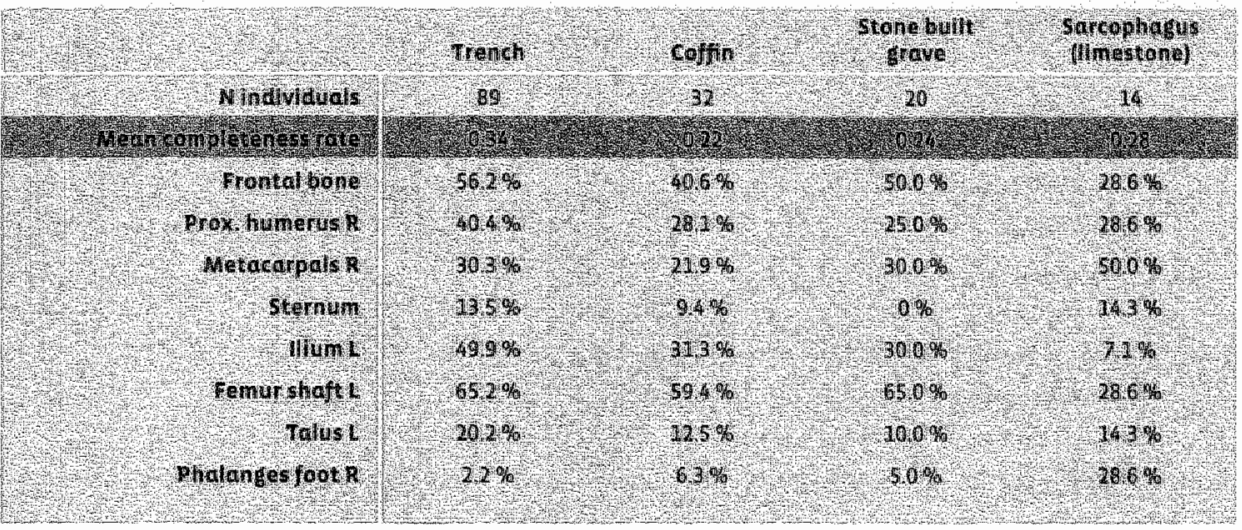

TABLE 47 Mean completeness rate and recovery percenages of eight selected parts of the skeleton for four major grove types

The recovery percentages in Table 4-7 show the variation in relative survival for the set of eight selected parts of the skeleton. In general the recovery pattern was similar to the situation described above: with higher recovery frequencies for larger bones and bone seigments with a large proportion of compact bone. However, between the different grave types some differences in recovery percentages were noticeable. Remains collected from trench graves and limestone sarcophagi in particular shawed considerable variation in recovery percentages. In limestone sarcophagi the percentages found for small bones like metacarpals and phalanges of the foot were higher. Whereas larger but flat bones, tike the frontal bone and ilium, were recovered less frequently from these sarcophagi. Statistical anallysis showed that the low recovery percentages for the left illum and the left femur shaft from limestone sarcophagi were

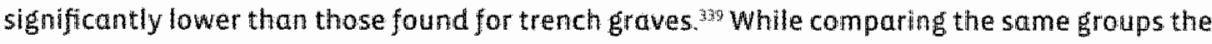
opposite was found for small bones. Although few phalanges could be callected, significantly more phalanges of the right foot were recovered in limestone sarcophidigi. ${ }^{\text {sil }}$

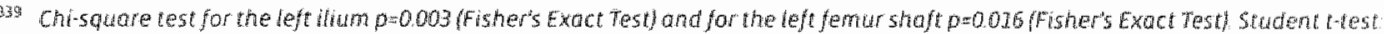
$p=0.06$ for both comparisons of the medn

340 chi-square test for the pholanges of the right foot $p=0003$ (fisher's Exact rest)
} 


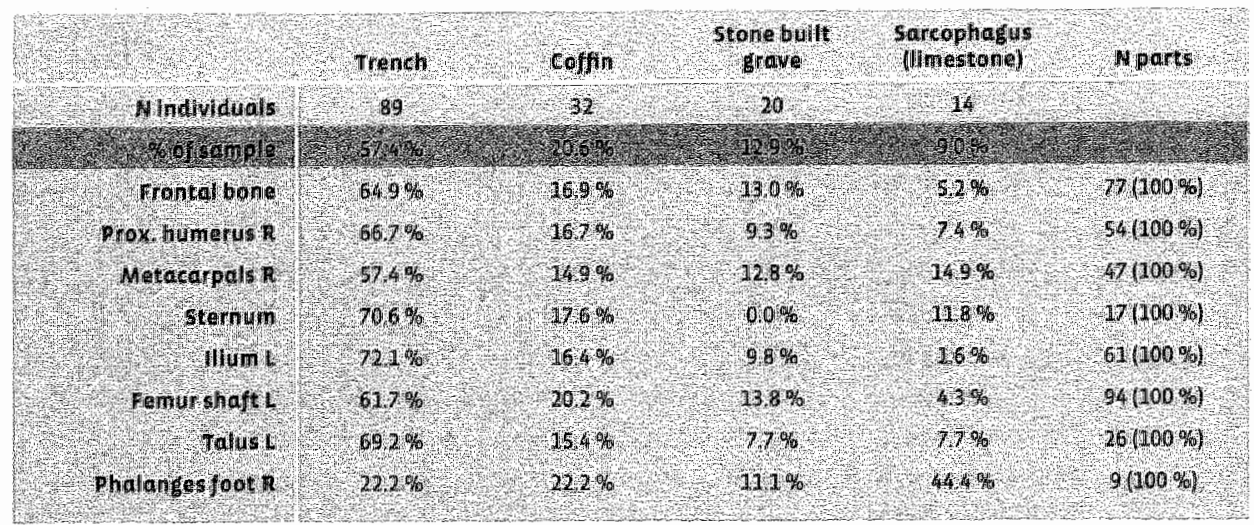

TABte 4-8 Proportiona percentge for eight selected parts of the sketeton calculated for the four majar grave fypes (n-355) for comparison the poportiond percentage of each sample based on numbers of indiwduats is mentioned as wo of samples. Percentages rharked in bold were mare than 25 per cent abowe the expected percentage for that sample Those marked in italic wera more than 2 per cent below the expected percertage for that sample

The variation in survival and recovery influenced the composition of the sample available for study. Table $4-8$ shows that among the remains from the limestone sarcophagi the frontal bone, the ilim and the femoral shaft were under-represented. Clearly aver represented were the metacarpals and the phalanges of the foot. For the trench graves most parts were represented in the sample on a slightly larger scale than might be expected. Bones with a high proportion of cancellous bone, like the sternum, were especially well preserved. In addition, the os ilium was recavered more often from trench graves. Only for the phalanges of the foot did trench graves score mell below average.

\section{PRESERVATION OF BONE TISSUE}

The state of preservation of bone tissue was inspected macroscopically. Generally the preservation of the skeletal remains was good. Indicative of the favourable conditions was the scarcity of erosive changes on the bone surface. When bones were x-rayed or sawn for warious purposes, we often found particles of fine-grained soil had permeated the bone and covered the inner trabecular structure with a thin black layer.

An exception to the general state of preservation was the skeletal material recovered from sarcophagi These bones were generally less well preserved. IIr many cases the cortex of many dense bones like the femora and tibiae had disappeared. Bone with a thin cortex like the iliac part of the pelvis had often disintegrated completely. Several fragments of bones were found to be crackled and were covered by crystals. In these cases the biogenic hydroxy-apatite $\left(\mathrm{Ca}_{3}\left(\mathrm{PO}_{4}\right)_{3} \mathrm{OH}\right)$ of the mineral component of the bone had recrystalised as brushite $\left(\mathrm{CaHPO}_{4} \mathrm{X}\right.$ $2 \mathrm{H}_{3}$ O). Because brushite crystals are larger than hydroxy-apatite their development disrupts the structure of the bone. Being soluble in water, the formation of brushite crystals not only 
contributed to the loss of cortex but also to the desintegration of complete bones. ${ }^{34 i}$ This process accurred predominantly in limestone and tuffstone sarcophagi.

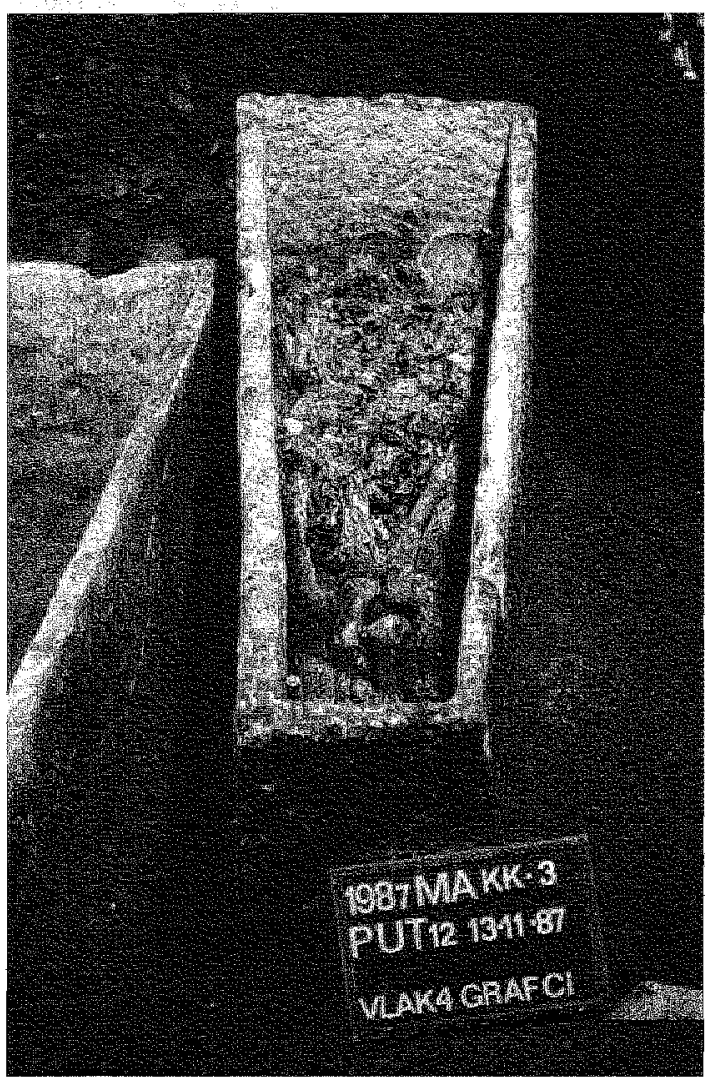

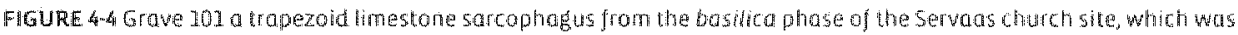

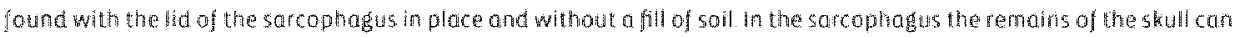
be recognised in the right comer of the head end. Below the skull in the area of the thorax and abdomen few bones were preserved wisible are a few ventebrae the banes of the upper extemities we nat presened. The lower extremilies were preserved, but only in a very fraghte condition (Photagraph Ciry of Maastricht).

Damage of bones due to the activities of scavenging animals was rare at the Servaas church site and absent at the Boschstraat site. At the Servaas church site a few bones displayed signs of possible gnow marks of small rodents. The possibility that rodents had access to graves at this site was evident In one of the stone-built graves the skeletal remains of an adult mouse and five to six non-adult mice were found inside a human skull. ${ }^{34,2}$

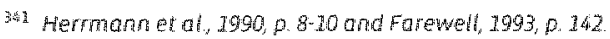

3. Haghund 1997
} 


\section{RELATIVE SURVIVAL AND RECOVERY: RESULTS}

A myriad of physical, chemical, biological and cultural factors is known to affect the preservation and surviwal of human remains. These can be categorised by different principles. From the point of view of the body we can discern intrinsic factors, related to characteristics of the body or skeleton itself, and extrinsic factors, including aspects of the environment and human activities. From a chronological perspective they can be categorised as ante-mortem, peri-mortem, and post depositional. Important determinants are the physical state of the Individual, the post-mortem interval before burial, the grave type, the soil type, the type of bone, the depth of burial, the humidity, human activity at the site of burial and the recovery methods. ${ }^{3 / 3}$ Various studles have shown the importance of the burial location and postdepositional processes. The variation in the completeness rates and recovery percentages found for the Servaas and Boschstraat site suggest that human activities at the cemetery and choice of grave type had a significant impact on the composition of the sample available for study.

It is likely that other taphonomical factors, ranging from intrinsic aspects of the body to perimortem burial ritual, also influenced the composition of the skeletal sample at the twa sites. However, it is difficult to determine the nature and the effect of these factors. Differences in recovery procedures seem to have been no cause for variation, since the same archaeological team excavated all graves in a standardised way. A more plausible option to explain differences in completeness and survival might be the local soil conditions. Although the characteristics of the soill itself did not wary strongly the conditions at the Servaas church site differed considerably from those at the Boschstraat site. At the Servaas church site the burials had been under the roof of the present church for about 950 years, whereas those at the Boschstraat were situated close to the river Meuse and were under a roaf for a shorter period of time or in some cases never at all. How this affected the composition of the samples is difficult to establish. In addition little is known concerning important cultural factors like the interval between death and burial and the clothing or wrapping of the body before deposition in the grave. ${ }^{3 * 5}$ We know even lless of intrinsic biological factors like the physical condition of the inhumed body.

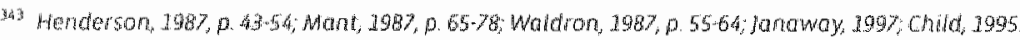

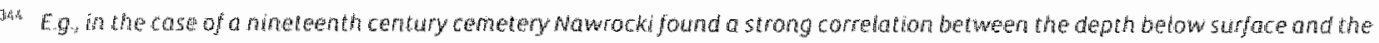

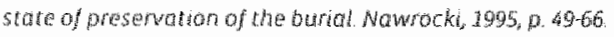

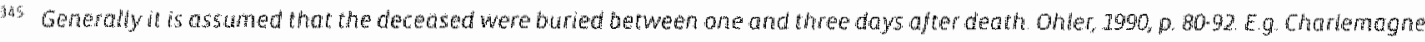
was buried on the day of this deoth. 1911, p.35. Known exceptians to this generat practice were the funerals of ot her kings and

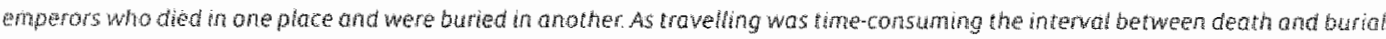

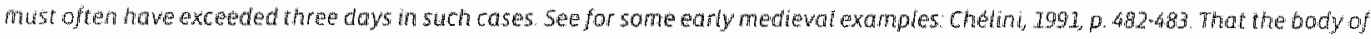
the deceased moy hawe been prepared for its last joumey can be read in the account of the death of emperor chartes the bald in 877 Ab Charles tied in the south of france. As it was his wish to be buried narth of poris in Sarnt Denis, this body had to be transported over a considerabe distance. The Anmales Bertinian descrive the unswecessul atempt to prevent the decoy of chorles body people

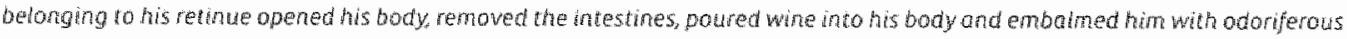
substances. bespite this treatment the body began ta smell. Even ofter they had placed the body in a rarred barrel cowered with

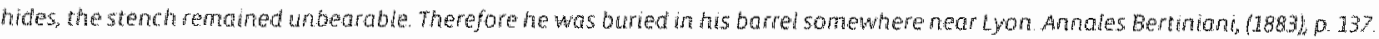


What then remains to be analysed within the scope of this study are two cultural factors: the influence of grave type and the effects of human activity at the site. Judged by the completeness rates and percentages calculated for the major grave types and three phases; both factors have influenced the composition of the sample. Still, it must be kept in mind that a complex of confounding factors determined the quantity and quality of the skeletal material available for examination. The two factors discussed below only provide a part of the explanation

\section{TAPHONOMUC PROPERTIES OF GRAVETYPES}

Here some of the taphonomic properties of the major grave types will be described. This will in part help to explain the differences in recovery percentages found for several grave types and be of use for comparison with other early medieval cemeteries. The completeness rates and recowery percentages indicate that of the four major grave-types, the trench grave yielded the most complete skeletons. in general, bones collected from trench graves were also better preserved. Mean completeness rates for coffin graves; limestone sarcophagi and stone-built graves did not wary much. Although coffin graves and trench graves were found in the same areas and both were found in all phases, a significant difference between the mean completeness rates was noted (see Table 4-6). This indicates that generally the graves without traces of wood or coffin fittings were justifiably labelled as a separate category. At the same time it raises the question as to what caused the difference. The comparatively high completeness rates are thought to be the result of specific characteristics of trench graves. ${ }^{366}$

Mant found that the presence of air and the retention of liquid at the base of a coffin often contributed to increased decomposition of the soft tissue of the body. . $^{37}$ It has been suggested that a rapid rate of decomposition increases the risk of associated bone los.5. ${ }^{348}$ To test if the presence of air and the retention of liquid also affected the chances of survival of skeletal elements at the Servaas church site and the Boschstraat site, the graves were divided in two groups determined by the nature of the grave type. Comparison between graves containing an "open space" or "chamber" at the time of deposition (coffins, llimestone and tuff stone sarcophagi, stone-built graves and stone-bult tombs) and "filled" grave types, lacking such an

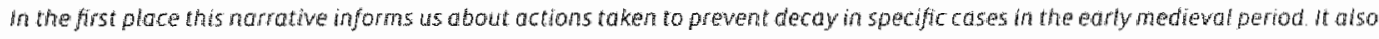
makes us aware that we may encounter traces of such preparations in the sketetal remaims. The opening of the body mey thave caused recognisoble damage to the skeletan, like cut maks on ribs, stemum and pubic symphysis that whe found in listh and

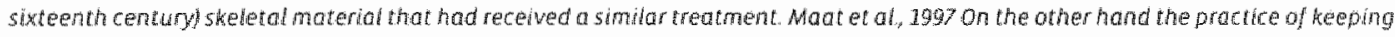
a human body abowe the ground in combination with unsuccessut or temporary corisenotion techniques may possibly have lead to an increased decomposition of the sketetal remains.

3 witrench grawes the proportional percentages for metacarpol bones were in accondance with what might be expected. For phatanges of the foot these percentages were less than that what might be expected Passibly the foot end of trench graves was not always recognised. This may have caused the loss of bones in this area.

3 . Mant, 1987, 0.67-68.

3.4: Gill-king, 2997 , p.104-105 and Child, 1995 
open space, like trench graves. ${ }^{349}$ Below I will use the terms "chamber" and "filled" graves without quotation marks to indicate the two different categories of grave types.

A comparison of chamber and filled graves showed that in Maastricht there was a significant difference in the survival of skeletal parts as expressed in the completeness rate. . $^{\text {sc }}$ In other studies Henderson found a similar correlation between burial in a wooden coffin and poor preservation of the skeleton. ${ }^{15:}$ The underlying reasons for this difference in survival of skeletal parts lay predominantly in two aspects that separate the filled graves fram chamber grave types. In filled burials, like trench graves, the body was directly covered with soil at the time of burial. This had two important consequences. First, the access of air and organisms to the decomposing body was limited, preventing scavenging organisms (e.g. insects and smails ${ }^{35}$ ) and certain fungi from reaching the body. ${ }^{359}$ At the same time the reduced availabillity of oxygen created less beneficial circumstances for some types of bacteria and fungi involved in the decomposition process. ${ }^{354}$ Second, in trench graves the surrounding soll absorbed liquids from the decaying body.

In exhumations of Eraves of World War II, Mant noticed that putrefactive liquefaction accurred mainly in burials in coffins and caused the formation of a semi-fluid mass of about $5 \mathrm{~cm}$ at the base of the coffin. He observed that the retention of water and putrefied tissue was a contributing factor to an increased decomposition of the body.35 At the Servars site. (Figure 4-5) several bones, found in chamber grave types, displayed signs of the presence of liquid levels and a comparatively poorer degree of preservation of bone below the surface lines. This suggests that putrefactive liquefaction not only affected the body but also caused damage to the skeleton. ${ }^{355}$

Among the various chamber grave types, marked differences were found regarding the recovery percentages of various types of bone. E.g a significant difference between coffins and trench graves was found for the number of vertebrae that were collected. The mean number of vertebrae recovered from coffin graves was less than half the mean for trench graves $(p=0.001) .{ }^{357}$ The architecture of this irregular bone, with a thin cartex and a large proportion of cancellous

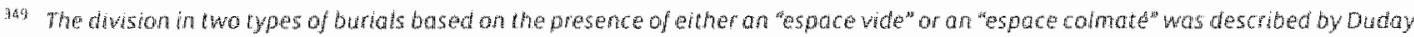
in a study aimed at reconstructing the grave type from the postion of the sketetaremons, Dudoy 1990 in that study oudoy focuses on the interting aspecs of the displacement a bones, the does not discuss possibie conseguences for the state of preservaton

269001

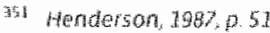

Snat shels were foud in numerous grawes Howewer, these snats were not systendicaly studied the body that are nor cowered by clothes are found to deccy more rapity than sections of the body that are protected by chothes.

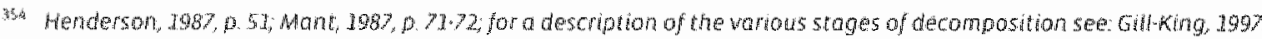

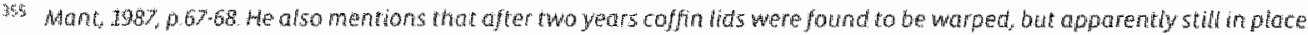
The chonges th the bore suggest there was a retotion be tween the existence of these fluth levels and the recrystaltsation of hydromy. gpatite into brushite. 


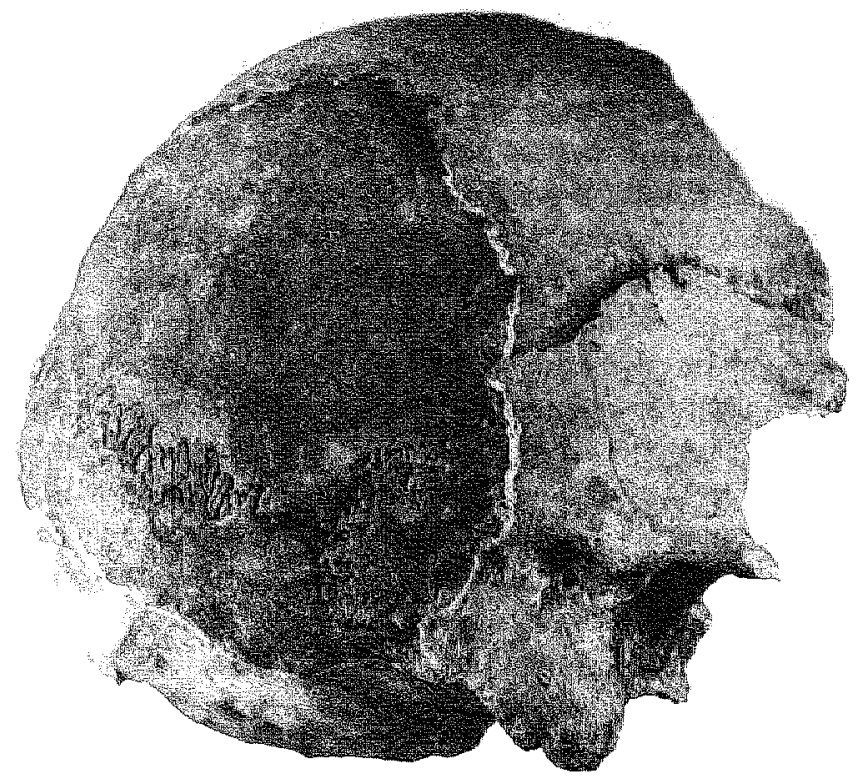

FIGURE 4-5 Right part of the skul of a male buried in a trapezoid limestone sarcophogus ifind 27.09 .02$)$. Changes Indicative of the presence of a fuid level in the burial is a fine line of a concentration of a chatkike substance on the posterior part of the right temporal bone, continuing on the posterior part of the right parteta bone and closing the circle by continuation on the occipta bone. The surface of the bone enclosed by this curcle is darkef than the bone otstide the circle Similar phenomena were recorded in other grawes lphotograph: R. Panhuysent.

bone, probably made this part of the skeleton more prone to decay. The fact that the vertebral column was generally positioned at the bottom of the grave will have resulted in exposure of the wertebrae to the putrefactive liquid. This may have been a contributing factor in the increased decomposition of this part of the skeleton.. ${ }^{350}$

It should be noted that generally the open space in wooden coffins disappeared after several years, when the wood decomposed and the coffin collapsed. From that moment on conservational conditions would gradually become equal to those in trench graves: Therefore, if in humation in coffins had an adverse impact on the preservation of bone, this will have occurred mostly during the first phase after interment. A possible side effect of the collapse of the coffin lid was the chance that large bones, like the skull and pelvis, could break under the sudden pressure of the coffin remains and the soil above the grave. The ensuing fractioning of bones, which was often recorded in the skull and the pelvis, may have contributed to an increased decomposition of bone.

35 Another cantributing factor is the foct that the vertebrae were generaly located below the worax and the obdomen, the region of the body where the decompostion process starts. Gill-king, $1997,097.918$. 
In sarcophagi and stone-built graves the presence of air and the retention of liquid at the bottom of the grave also seems to have enhanced the decomposition of bone. Possibly this: effect was even stronger as the walls and bottom of these grave types would not decompose and could continue to collect liquids from the decomposing body and from the soil above. ${ }^{359}$ This was reflected in the completeness rates, which were generally lower in stone-built graves and especially in limestane sarcophagil some sarcophagi were fitted out with a so-called "seelenloch" a hole in the bottom intended to provide an outlet for liquids from the decaying corpse. once the sarcophag were placed in the ground the outlet would have become obstructed by the loamy soill, reducing the outward flow. The prolonged presence of putrefactive hiquid may have acted as a factor enhancing decompasition in limestone sarcophagi. As can be seen in Table 4-7, flat bones like the frontal bone and ilium, but even sections of compact bone like femoral shafts were recovered in percentages below the mean.

Despite these unfavourable conditions, the mean campleteness rate found for limestone sarcophagi was higher than for wooden coffins and, to a lesser extent, for stone-built graves (Table 4-6). The above average recovery percentages found for the bones of hands and feet seem to have compensated the effect of the above average loss of ather parts of the skeleton. ${ }^{36 .}$ An explanation for this pattern of relative survival might be that it was easier to collect small bones from the well-confined solid bottom of the sarcophagi than from for example trench graves. In other graves these bones were easily overlooked in the dark coloured soil or may have been mistaken for stones or lumps of soil. Recognising them on the solid bottom of the limestone sarcophagi was easier. Besides, many sarcophagi were intact and only filled with a small amount of soil. This also improved the possibilities to recover skeletal material. As mentioned above the bone in limestone sarcophagi was generally poorly preserved.

The completeness rate found for the tuff stone sarcophagi was exceptionally low 0.07 , s.d. 0.03). Two of these sarcophagi were found with the covering lid still in place, a third was partially disturbed. Judging by the scarce skeletal remains collected from the closed graves it seems plausible that the same process which affected the flat bones in the limestone sarcophagi also occurred in the tuff stone sarcophagi. Only, in the tuff stone sarcophagi the decompasition processes seems to have been even more destructive. ${ }^{362}$ The high completeness rates calculated for the three stone-built tombs, containing skeletal remains (mean completeness rate is 0.70, s.d.

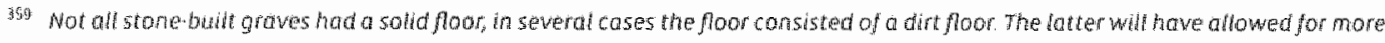
handge ther graves with a solid foras.

To valuate the determination of the sex of the skit and petwis separate percentages of present characteristics were calculated. These percentages give a more detdied wiew of the survival of all parts of the skulland peivis. In comparison to trench graves, a

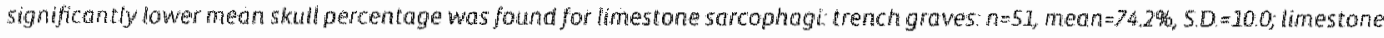

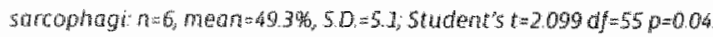

36. Given the foct that bones bing on the bottom of the grave were poorly preserved and were recovered in small numbers the same widu be expected for the shall bones of the hands and feet Nevertheless the proportionat percentages for metacarpals and

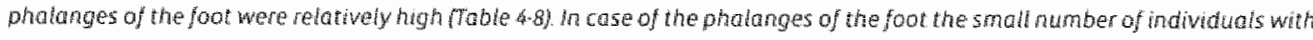
pharanges of the right foot probably exptoins this. For the metacarpats the difference is less marked.

3r? Possibly the themical charateristics of the tuff stone enhanced the decomposition of bone. 
0.05) is in contrast with results for other chamber graves. Regarding the discussion above; it seems unlikely that the grave type was a major contributing factor to this high score. Better explanations are the comparatively undisturbed nature of these graves, which belong to the last phase of burials and the extra care with which these "special" graves were excavated.

For the six trench graves with stones found at the Boschstraat site a high mean completeness rate was found (0.57, S.D. 0.25). In comparison to the common trench graves the difference in completeness rates was significant. ${ }^{363}$ Trenches with stomes were found in the same area as the common trench graves at the Boschstraat site and these graves were not excavated differently from the other graves at this site. Therefore, local soil conditions or recovery procedures cannot account for the marked difference in survival ${ }^{36 a}$ High recovery percentages of almast $70 \%$ were found for the majority of skeletal elements. What caused this difference in completeness rates is presently unknown. ${ }^{365}$

\section{BONE LOSS CAUSED BY HUMAN ACTIVTTY}

That the circumstances at both sites and during the three phases at the Serwans site were not equal can be inferred from the variation in completeness rates, which cannat be explained solely by the taphonomical properties of the grave types. Among the major factors that had an effect on the survival of skeletal remains was the disturbance of the graves by human activities. The effect of two categories of human activity could be examined at both sites: subsequent burials and actions related to habitation and building. Both activities were not selective in a sense that certain skeletal parts were more prone to disappear. As will be indicated belaw, they were selective in a way that graves of specific phases or in certain areas were affected more.

For the cella burials it was found that later inhumations from the cella phase did not disturb the older graves of this phase. Disturbance by graves or buildings of Hater phases was insignificant. Being inhumed at a lower level probably protected the graves of the first phase of the cemetery better against intercutting by later burials. Building activities associated with the construction of the magnum templum were employed in a separate area south of the graves. Because of their position at a lower level, and through coincidence, the cella phase cemetery largely escape destruction by later construction works for the basilica and the present church. The cella phase burials were also protected by the artificial elevation of the site deposited at the time of the bullding of the templum and basilica phase edifices.

Graves from the templum phase suffered more from disturbances by later burial activities. Even intercutting by graves from the same phase had a negative effect on the mean completeness rate. During the templum phase about ten graves disturbed older graves. Building activities accounted for further negative effects. Not only did the demolition of the magnum

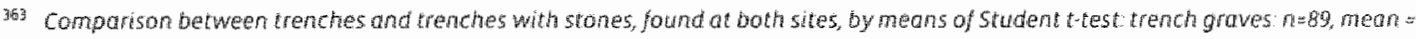

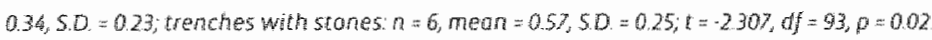

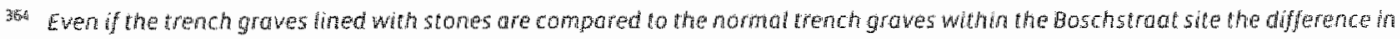

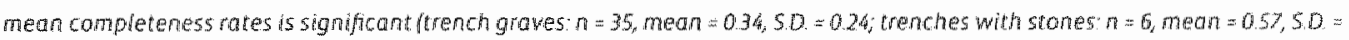
0.25, student $t=2220, p=0.03$ )

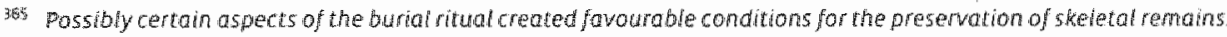


templum and canstruction work for the basilica disrupt the cemetery, it was also damaged due to the replacement of the basilica by the present church. This was reflected in a high number of empty graves and a large amount of disarticulated skeletal material collected from ellevation layers.

In comparison with the templum phase, the conditions for the survival of skelletal material from the basilica phase were generally more favourable. Still, several graves were disturbed during the demolition of the basilica and the construction of the present church. Intercutting by other graves also reduced the amount of bone that was recovered.

At the Boschstraat site the conditions were apparently the besit for the recovery and survival of human skeletal remains. As indicated in Table 4-3 the mean completeness rate calculated for the Boschstraat site was slightly higher than the rate found for the cella phase. Although medieval and past-medieval construction works disturbed large areas of the excavated terrain, the level of the burials was largely unaffected. In addition only few graves intersected older graves, generally causing no disturbance of the skeletal remains.

\section{CONSEQUENCES OF VARIATION IN RELATIVE SURVIVAL AND RECOVERY}

As mentioned at the beginning of this chapter the differentiated loss of skeletal remains may bias the outcome of the physical anthropological and palaeopathological examination. This: could lead to less or less exact demograpinical data or a lack of precision in palaeopathological diagnoses. The lass of complete burials can cause under representation of specific demographic groups, especially non-adults. To apprehend what the possible biases of the Servaas and Boschstraat sample are, the major implications of differentiated loss will be discussed below.

\section{DIFFERENTIAL LOSS OF NON-ADULT SKLLETONS}

it is often assumed that post-depositional processes and recovery procedures may act as a selective mechanism causing the under-representation of non-adult skeletons in archaeological skeletal samples. ${ }^{3}$ The lower percentage of calcified bone in non-adults renders them more vulnerable to decomposition. ${ }^{32}$ In addition the small size and their shape, unfamiliar to the untrained eye, may often have caused these bones to remain unobserved during excavation. For the samples from the Servaas church site and the Boschstraat site the completeness rates calculated for non-adults were significantly lower than for adults ${ }^{\text {. }}$ since less remained of nonadult skeletons, this implies that non-adult skeletal remains were possibly under represented in the sample due to factors relating to differential survival of bone.

One of the causes often suggested for the under representation of non-adult burials is a more superficial position of non-adult graves leading to the complete decomposition of non-adult skeletons. In consequence, burials closer to the surface are often more exposed to the influence

Guyetat. $1997,0.226$

crist at al, $199 \%, 0320.321$ 
of (micro-) fauna and bacteria. ${ }^{369}$ At the Boschstraat cemetery it was possible to test whether non-adult inhumations were buried at a different depth than adult burials. Judged by the mean level of burial the mean depth of non-adult burials was only 5 centimetres above the level of adult burials. This difference was not statistically significant. ${ }^{30}$ At the Servads site this was difficult to test because of the relief in the terrain. Still, also for the Servas site the general impression is that non-adults were buried at the same elevation as adults. At both sites no nonadult graves were found more superficial than adult graves. Therefore, there is no reason to assume that a difference in depth of burial between adults and non-adults was a cause for differential survival favouring adult burials.

As mentioned above the small size and the less calcified state of non adult bones is a factor leading to differential loss of non-adult individuals in the sample. To what extent this factor biased the composition of the Servaas church site and Boschstraat samples can roughly be assessed by looking at the chances of recovery of parts in the adult skeleton with similar characteristics to non-adult bones and the recovery of child graves without skeletal remains. Fragile and small bones, like hyoid bones, auditory ossicles and tooth germs were collected in considerable numbers, both on site and in the laboiratory. The preservation of such bones. indicates that soill and enviranmental conditions generally facilitated the survival of fragile bone. Another indication that non-adult skeletons were not fully decompased on a large scale was evident from the fact that all non-adult graves contained skelletal remains. ${ }^{371}$

Circa $43 \%$ of the non adult skeletal remains were found outside a burial context. Only $26 \%$ of the adult remains were collected without a burial context. The fact that soil from excavation levels was removed by shovel and sieved certainly improved the recovery chances of the bones from adult and non-adult skeletons in layers containing material from disturbed or unrecognised graves. Size and shape of the bones seem to have been important factors in the chances of recovery during this process. The pattern of recovery percentages shows that Jarge and recognisable bones of non-adult individuals were recovered in similar proportions as those of adults. ${ }^{\text {in }}$ However, for most small bones the recovery percentoges for non-adults were extremely low. A possible explanation far the rellatively high percentage af non-adult skeletall remains without a burial context might be that the excavation team was not famillar with the anatomy of the non-adult skeleton and may not have recognised all non-adult burials. ${ }^{{ }^{3{ }_{3}} \text { As }}$

3eg Rodriguez, $1997,0.460$.

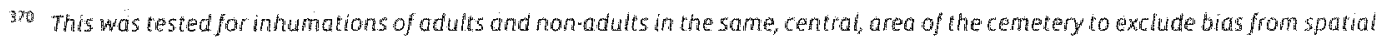

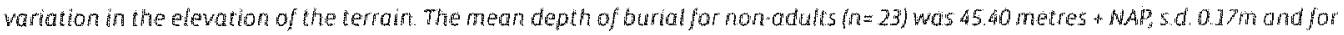

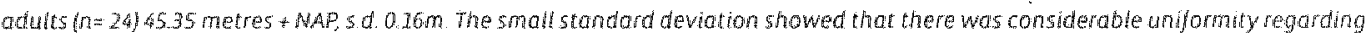
the depth of buriat

gr: As recovered children's growes were found to be adopted to the stoture of the deceased most chid groves were recognisable by the intertar lemgth of the graver

37. The following setection of nan adult bones was recowered in similar proportions the frontal bone, the temporal bone, the moxilla and mandible the scaputa, the dioc part of the pews and to a lesser axtent the shafr of the femur and humerus

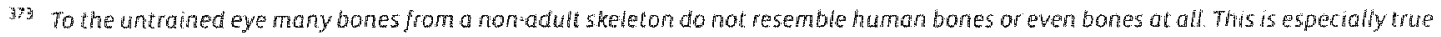
for the remains of chidren between birth and circa he yeors. 
indicated above, sleving the soil seems to have compensated for the loss of non-adult burials. Nevertheless, a considerable number of non-adult graves were documented with great care at both sites and the remains collected. All factors together will probably have rduced the chances of survival and recovery of non-adult bones. However, the absence of empty graves of non-adults suggests that the complete lass of non-adult skeletons was rare.

\section{DIFFERENTIAL LOSS OF SKELETAL ELEMENTS}

Like in other studies large and dense parts of the skeleton were generally recovered in larger numbers than small parts or elements with a high proportion of cancellous bone. ${ }^{3 / 4}$ A correlation was found between certain grave types and the differential loss of skelletal elements. Thearetically the differential loss of bones may hamper the physical anthropological determination of sex, agfe and stature. However, many of the features necessary for these determinations can be recorded from either right or left sections of the skeleton and from different parts of the skeleton. Consequently the collection of basic physical anthropological data is possible for the majority of skeletons.

It is more likely that the differential loss of banes had more impact on the palaeopathological analysis. The diagnosis of pathological conditions in the skeletan is generally more specific if more bones can be inspected. For example, the low recovery percentages of phalanges of the hand and feet hindered the classification of arthropathies ${ }^{375}$ and greatly reduced the possibility to diagnose the presence or absence of $\|$ eprosy. ${ }^{376}$ Because the grave type was an important factor influencing the relative survival pattern, it has to be taken into consideration that in certain cases the distribution of pathology may also be biased by grave type.

\section{CONSEQUENCES FOR FURTHER ANALYSIS}

Normally the number of individuals would form the basis to calculate the proportional size of each sample in relation to the total of skeletons included in this study. Based on the completeness rates, corrected sample percentages can be calculated, expressing the proportion of each sub-sample as a proportion of the total sample. For this purpose, the number of individuals in each sample is multiplied by the completeness rate for that sample. Based on the resulting numbers the corrected sample percentage is calculated. Samples with a low completeness rate, like the templum sample, will thus be represented with a corrected sample percentage that is lower than might be expected based on the number of individuals in each sample.

The skeletal material of the cella phase is characterised by a comparatively high mean completeness rate. This suggests that the bone survival may have partially compensated for the

Whataron, $2987,0.55 \cdot 6$ h

Waldron, $1927,0.63$

(5)

E. leprosy con be recognised by characterstic changes of the phalanges and other bones of the hand and foot.

Espectaly when sub-samples are companed by status (a chassfication partialy based on grave fype this passible effect has to be kept in mind 
small size of this sample. The recovery percentages further imply that differential lass of specific skeletal elements was negligible. As indicated in chapter 3 this sample represents Just a small fraction of the original late Roman cemetery. Campleteness rates and percentages calculatedfor the templum phase predict less favourable conditions for physical anthropological and palaeopathological analysis. This is reflected in the low corrected sample percentage (Figure 4-6). Because of the frequent disturbance of burials and the high number of inhumations in chamber grave types the proportional percentages calculated for smaller skeletal parts were low. The completeness rate calculated for the basilica sample was twice as high as than for the templum sample. Consequently the basilica sample, measured by the corrected sample percentage, was the largest sample in this study. Only the low completeness rate calculated for burials in limestone sarcophagi could have negative consequences for the analysis of who was buried in these sarcophagi. Because of the favourable conditions for bone survival at the Boschstraat site this sample is well represented in the total sample. As is evident from the high corrected sample percentage, the high completeness rate compensated for the smaller size of the Boschstraat somple. The use of trench graves contributed to the high completeness rate at the Boschstraat site.

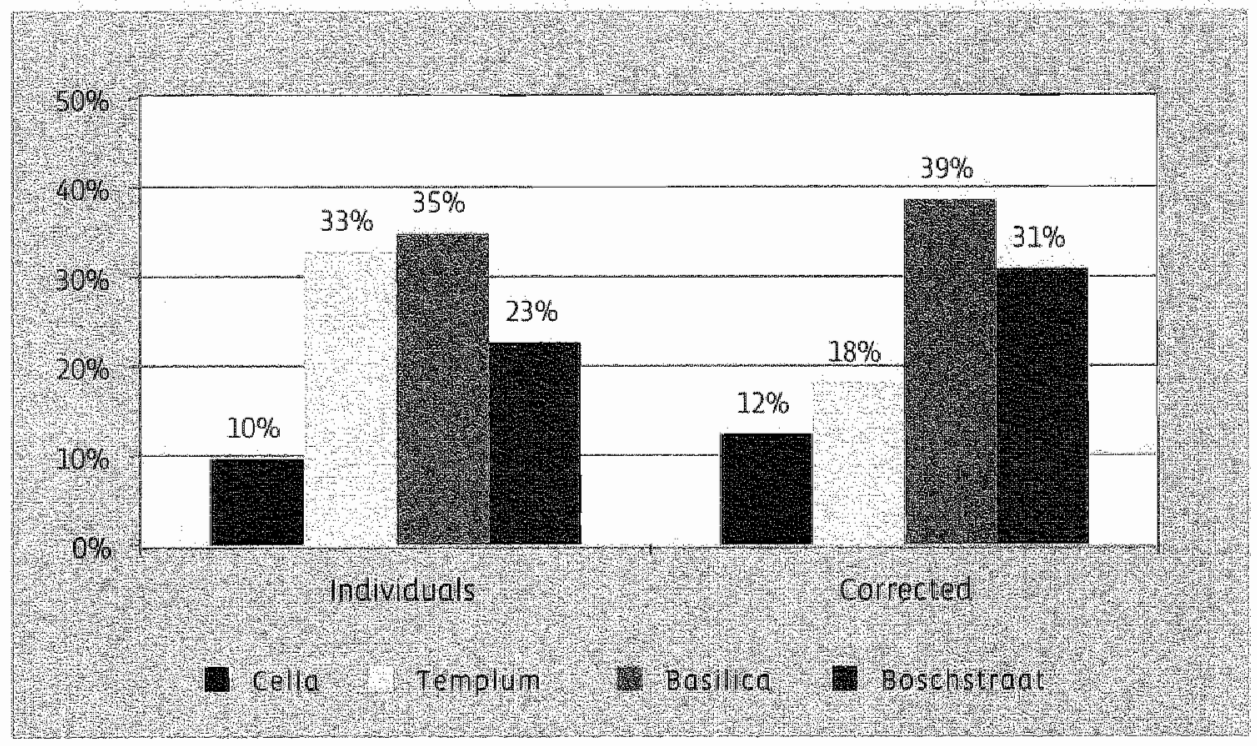

FiGURE 4-6 Sumple percentages based on the number af indwiduals in each sample ond corrected sample percentages based on the number of individuals per sample. 


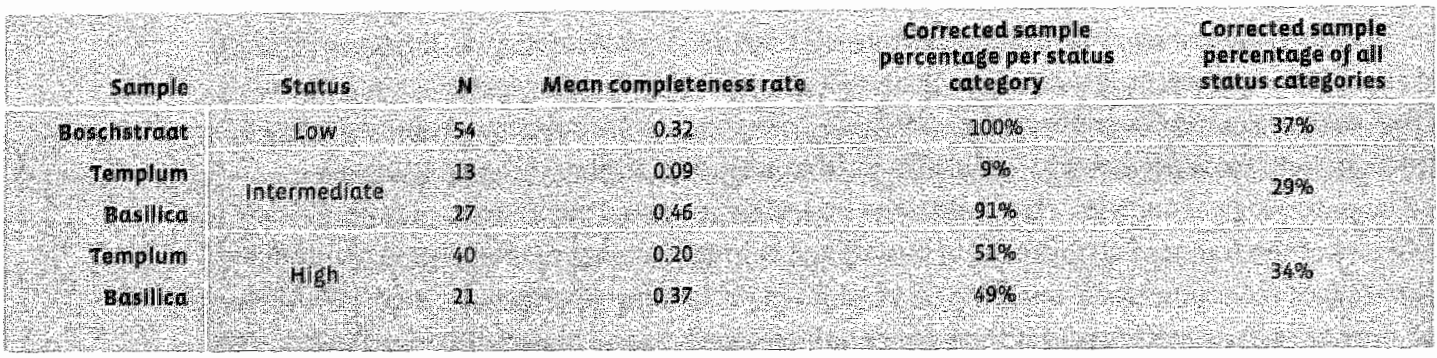

TAPLE 4.9 Summary of the number of sheletons, the mean completeness rates and the corrected sample percentages par sample by status

The statistics for completeness rates and carrected sample percentages can also be used to explore the sample repartition by status (Table 4-9). With respect to their burial status all individuals from the Boschstraat site were categorised as low status, which was represented by relatively well-preserved skeletons. The intermediate status sample was largely composed of burials from the basilica sample (91\%) and only a small proportion from the templum sample $(9 \%)$. To the high status sample the contribution of the templum sample was more in balance with the basilica sample. As can be deduced from the corrected sample percentages in the last column of Table 4.9 the three status categories were more or less equally represented in the total sample available for analysis.

\section{CONCLUSIONS}

The calculation of completeness rates and recovery percentages is a useful toal to analyse the impact of various taphonomical factors on the composition of the samples. A clear difference in completeness rates was found between trench graves and graves consisting of an open space, like in perishable or non-perishable containers, such as a wooden coffin or sarcophagus. This suggests that the presence of air and putrefactive liquid in coffin graves and sarcophagi was a factar that not only enhanced the decompasition of soft tissue but aiso of bone. The analysis of recovery percentages per sample and per grave type has shown that especially small skeletal elements were often under-represented in the total sample. This is expected to limit the posisibilities for detailed palaeopathalogical analysis. For the burials from the templum pluase this effect was stronger, because of the increased disturbance of burials during that phase. With respect to palaeopathological analysis, the available numbers and completeness rates indicate that this study should concentrate on general heat th characteristics and common afflictions. Therefore, this study will focus on general health indicators like life expectancy, stature, Harris lines, caries, maxillary sinusitis and peripheral osteo-arthritis. ${ }^{372}$

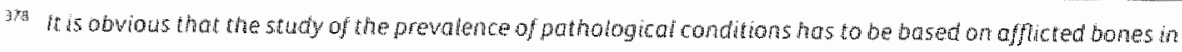
relotion to the number of bones avalable for inspection instead of counts pras number of indwituats 


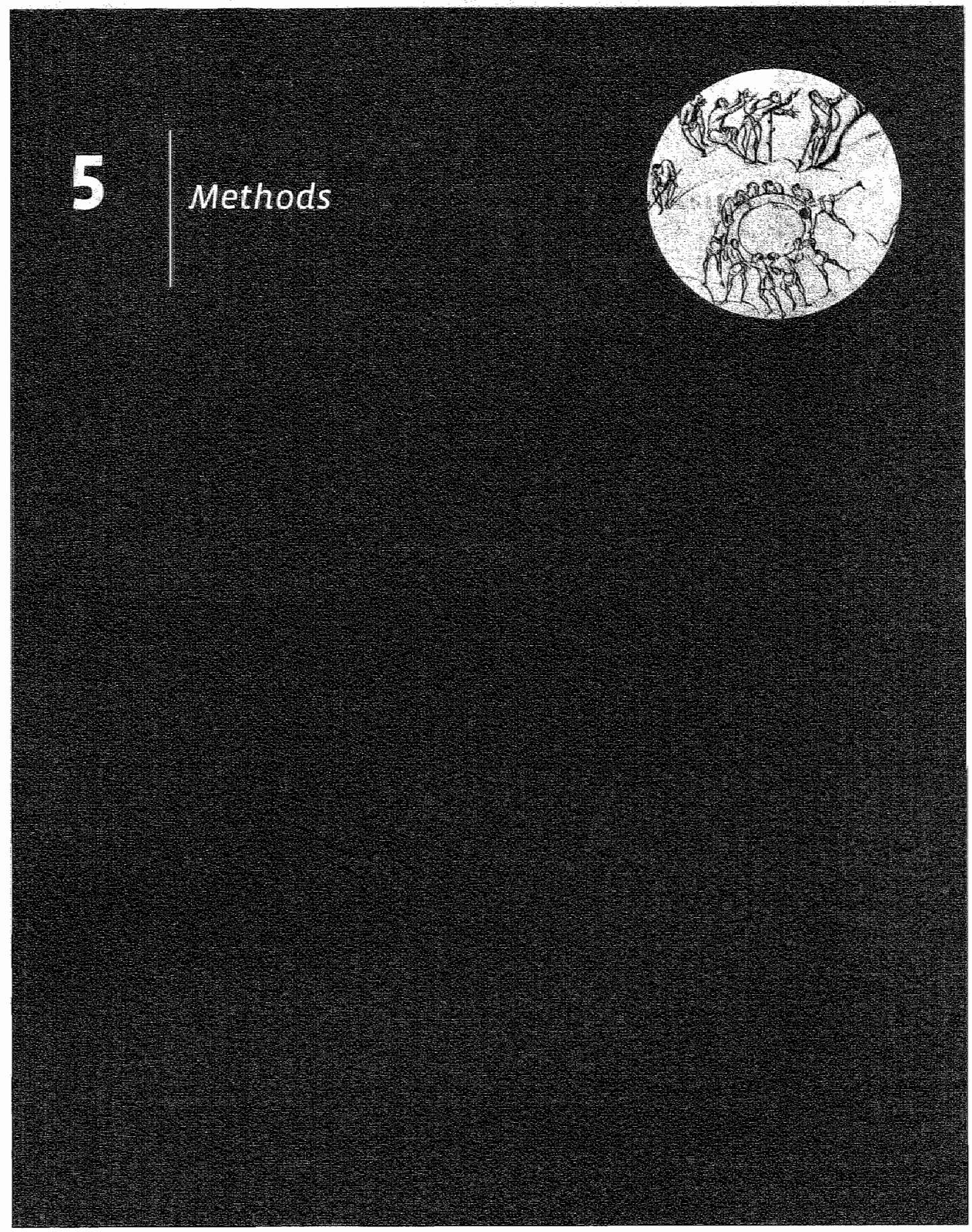




\section{$5 \quad$ Methods}

PHYSICAL ANTHROPOLOGICAL METHODS

A uniform investigation of all skeletal remains was executed. To ascertain that all data were collected in a consistent way, a standard set of forms was used. This was a modified version of the Physical Anthropological Report, developed by Maat for the State Service for Archaeological investigations (R.O.B.).

\section{DETERMINATION OF SEX}

The procedures used to determine sex from bones are non-metrical morphological and metrical morphological methods. develop during puberty, the use of the methods was limited to adolescents and adults only. Either the dentition or epiphyseal union should indicate that an individual had reached adolescence. Methods, developed specifically to determine the sex of younger individuals, were not applied, as many of the available young skeletons were incomplete and the available methods are not adequate in case of fragmented bones "sat

\section{MON-METRICAL MORPHOLOGICAL METHODS}

The non-metrical morphological method recommended by the Workshop of European Anthropologists (WEA) was used to determine the sex of the skeletons. ${ }^{3 * 1}$ Its criteria were developed on European reference materlal. ${ }^{\text {ist }}$ For this method, ten sex features of the pelvis and ffifteen features of the skull have to be examined. All features were scored between -2 and +2 , ranging from hyper-feminine to hyper-masculine. Not all of the features are equally indicative for the degree of sexualisation. To correct for this, all scores are to be multiplied with an appropriate weight factor in order to compute a weighted degree of sexualisation. The latter is. the sum of the scores multiplied by their weight and subsequently divided by the sum of the used weights only, according to the following formula:

$$
\begin{aligned}
& \text { Degree of sexualisation }=\begin{array}{ll}
\Sigma w x \\
\Sigma w
\end{array} \quad \begin{array}{l}
x=\text { the score of the individual features } \\
w=\text { the weight applied to the particular }
\end{array} \\
& \text { features }
\end{aligned}
$$

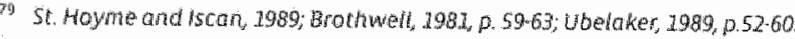

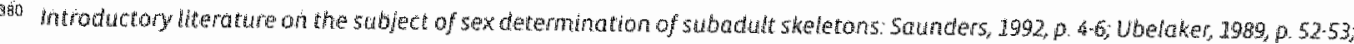
Meterer, 3986

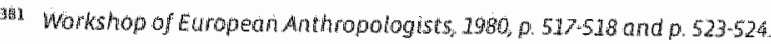

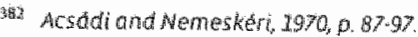

3.t There is one exception the are compose is scored beween $\cdot 2$ and +1 


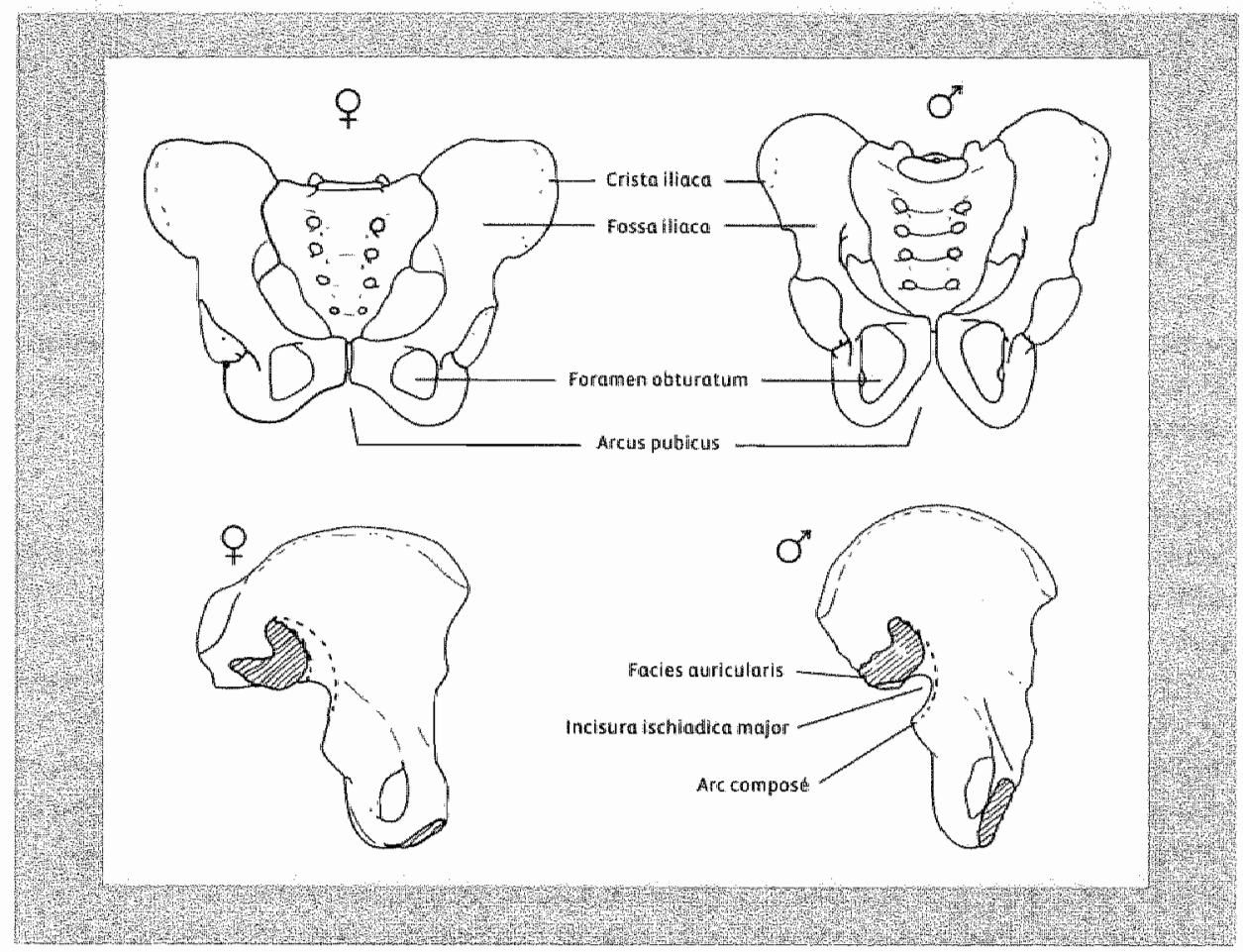

FIGURE 5.1 Sewen of the ten anatomical yeatures of the pel wis that are examined for the nom rmetrical morphological sex devermination

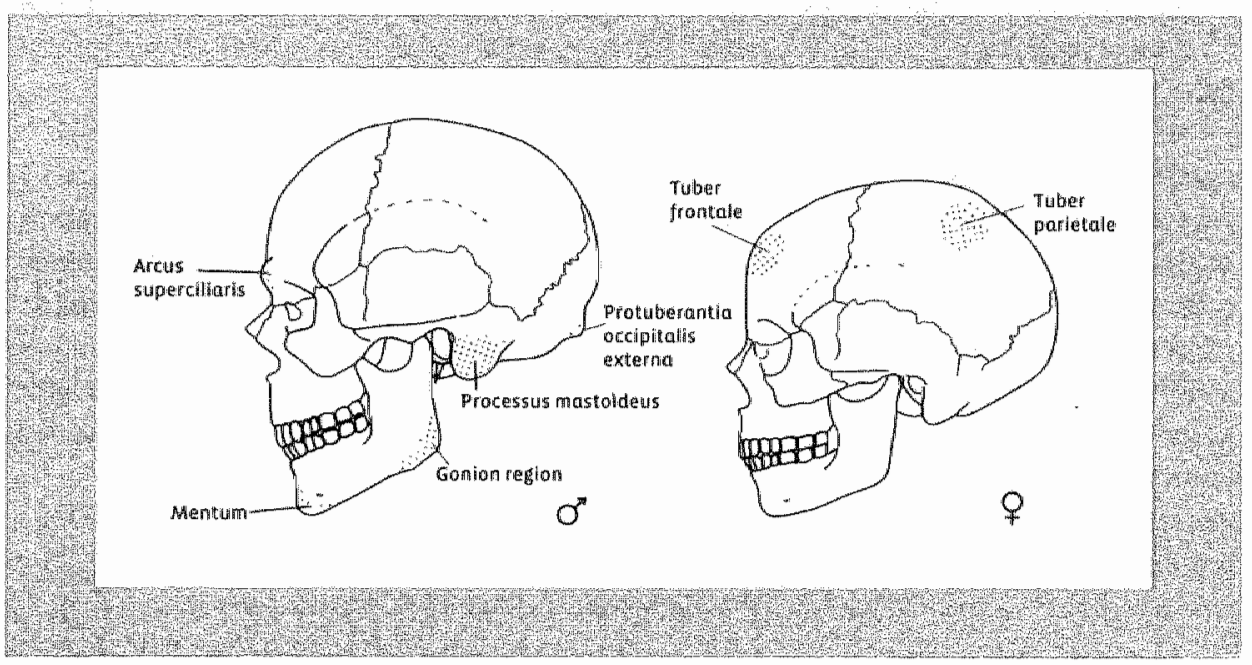

FIGURE 5-2 six out of fifteen andomical features of the shull that are examined for the non-metrical marphological sex determingtion (after Hermann el al. 1990 ). 
This degree of sexualisation was calculated for both the pelvis and the skull. A so-called power of sex diagnosis was computed by dividing the sum of weights of inspected features by the sum of all possible weights (19 in rase of the pelvis and 32 in case of the skull):

Power of sex diagnosis $=\frac{\sum w_{\text {abserved }}}{\sum w_{\text {all }}}$

Between various populations marked differences can be found in e.6. the range of the size of the mastoid process or the shape of the mentum. To take into account possible intra-observer variability, scoring of the skulls and pelves was repeated in a second rally.

\section{Metrical - morphological methods}

Skulls or pelves were not availlable for every individual. To settle the sex of incomplete skeletons and individuals with ambiguous skulls and pelves in respect of sex, an additional metrical-morpholagical method was sought. Because femurs were best represented, measurement of the antero-posterior diameter of the femoral shaft based on MacLaughin and. Biruce's method was chasen. ${ }^{34}$ Their method combines in one measurement two features that display considerable sexual dimorphism: the diameter of the femaral diaphysis proper and the posteriar projection of the linea aspera. With a sliding calliper the maximum antera-posterior femoral shaft diameter (APD) was measured between the inferior margin of the gluteal ridge and the level where the two eminences of the linea aspera diverge. Complete as well as fragmented femora were used. As long as they met the following requirements: the diaphysis had to be intact, femoral growth had completed and pathological changes had to be absent. A sectioning point was calculated from the mean values of individuals sexed by the non-metrical morphological method mentioned above.

\section{ESTIMATION OF AGEAT DEATH}

Individuals up to circa 23 years

Assessment of the biological age at death of young individuals was based on indicators related to growth and maturation of the skeleton. The rapid developmental changes of the skeleton during the first 16 to 18 years allowed for relatively exact age estimates, especially when the results of several methods were combined. All possible indicators were assessed and the resulting age indications were integrated in a conclusive age range. A schematic representation of the applicability of the main four indicators used is given in Table 5-1. In the periad of overlap (around 23 years of age), between the use of indicators based on changes associated with growth and those on adult ageing effects, (ff available) priority was given to the results of the more accurate growth related indicators.

s.a. Maclaughin and Bruce, 7985. 


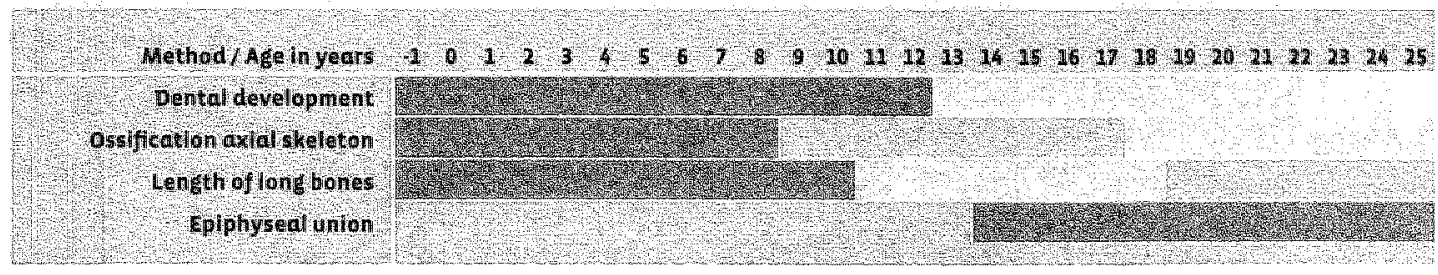

TALLE 5 Agerange of applicability of the main four age indicators for indwiduals up to 25 years. The darkest shoded

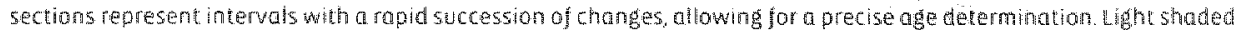
sections represent in erwas aliowing for a tess precke age deremination mermed iate shaded sections represent intervats without change in the age indiratior.

Mast of the children were aged by the state of their dental mineralisation and eruption. In the cases where $x$-rays of the jaws were made these were compared with the diagrams of ubelaker, based on several studies on dental formation and eruption. ${ }^{385}$ For individuals up to 12 years this method produced well-limited age ranges. Ossification of the axial skeleton is suitable to assess the age of indiwiduals up to eight years and between 18 and 25 years. Ossification and fusion of various elements of the axial skeleton were interpreted using a scheme compiled by Maat. ${ }^{365}$ The accuracy of this method improves with the number of features that can be inspected.

If neither the dental development nor the ossification of the axial skeleton could be established, assessment of age by measuring the length of long bones proved to be a valuable method to determine the age of children. Diaphyseal lengths were measured with an osteometric board. To produce the age of the child, the measurements of intact long bones were compared with data from Maresh. ${ }^{39 y}$ Because of the difference in mean adult height of the reference population studied by Maresh and our historical population from Maastricht, all measurements were proportionally compensated. The range ursed from the tables of Maresh was that for girls and boys of the fiftieth percentile.

Age at death for individuals between 14 and 25 years was assessed by evaluating the stage of fusion of epiphyses. The schedule recommended by the Workshop of Europeain Anthropologists was used for this purpose (see figure 5.3): ${ }^{38}$ If the sex of the individual could be settled, the appropriate age ranges were used. In other cases the ranges of both sexes were applied to deduce a more extensive combined range. Seriation of general bone dimensions was used to estimate the age of incomplete remains missing the above mentioned age indicators. This was onlly necessary for a few, very young, childien. Their bones were compared with those of individuals from the same site whose age could be determined.

\footnotetext{
385 Ubelaker, $1989,0.6965$

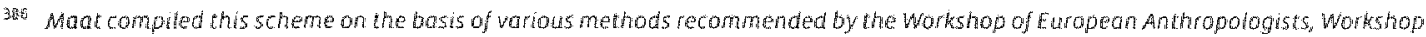
of Europeon Anthropologists, 1980, p. $530-53 \mathrm{y}$

3 ; Moresh, 2955

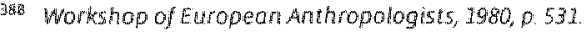




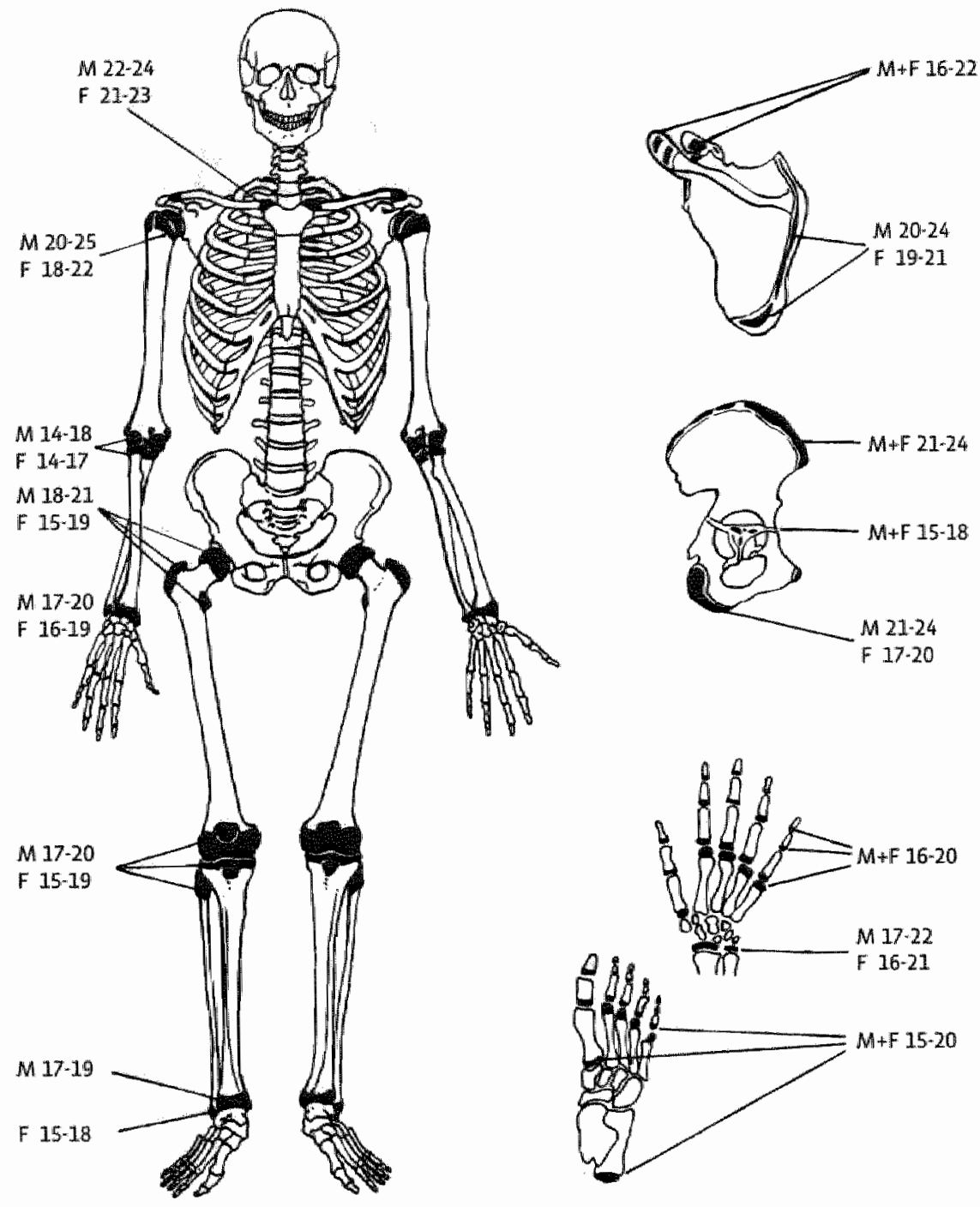

FlGURE s 3 The intervals of epiphyseal union as compiled for the fecommendations for age and sex diagnoses of skeletons by the workshop of European Anthropologists. Age intervals for males are preceded by the leuter "w", those

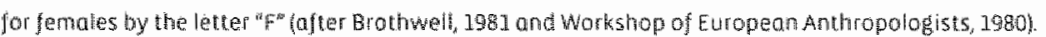




\section{Adult individuals}

The "complex method" developed by Acsodi and Nemeskeri and recommended by the Workshop of European Anthropologists was used to estimate the biological age at death of adult individuals: ${ }^{399}$ It was named "complex" because it combines the estimates of four age indicators. The symphyseal face is regarded by Acsadi and Nemeskéri as the key indicator. Second in importance are the changes within the proximal femur. The other two criteria are age changes in the proximal humerus and closure of the endocranial sutures. This method gains in accuracy through the combination of inspected indicators. All inspected indicators were classified according to their undiwidual ageing phase. The tables developed by sjovold were used to deduce the age or age range from the various age phases of the available indicators. ${ }^{30}$ For individuals with only one age indicator present, the table from Acsádi and Nemeskéri was used. ${ }^{391}$
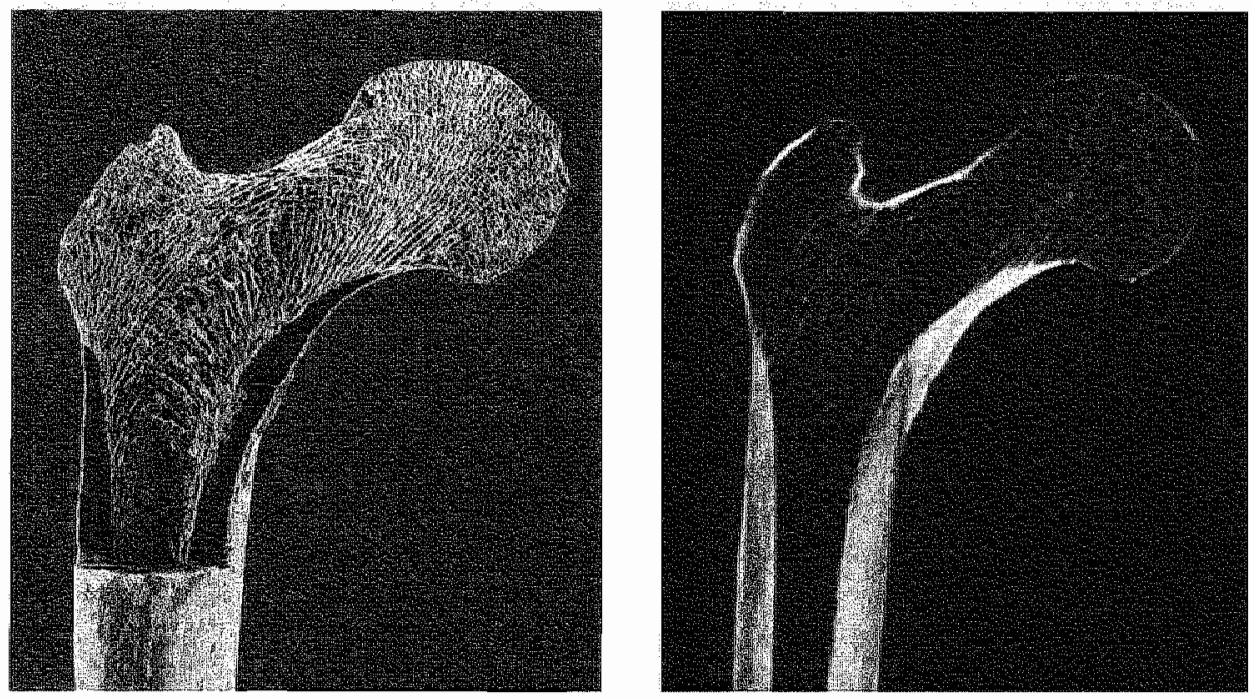

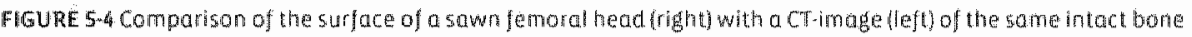
photograph: Ranhuysen, CT-1Thoge P. Hofmon

In most cases the "complex method" could be appllied according to the guidelines of Acsadi and Nemeskeri and the Workshop of European Anthropologists. However, when the proximal femur or humerus was in a bad condition and could not be sawn, Computerised Tomography (CT) was used to make a scan of the same plane as that of the saw surface. Scans were made with a Somaton Plus CT scanner (Siemens). The femur was placed in the gantry in such a postion that the scan plane was perpendicular to the femoral axis through the middle of the head of the femur, collum and the proximal shaft. Empirically a sllice thickness of $2 \mathrm{~mm}$ was chosen. A full

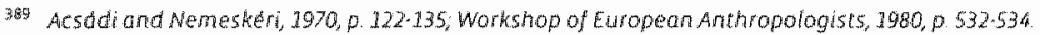

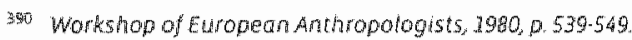

3e. Warkshop of European Anthropologusts, 1900, p 135 
sized hardcopy with a wide window setting was used to assess the trabecular structure. The CT-image proved to be an effective replacement.

Frequently, because of the fragmentary character of the skeletal remains, anly one or two Indicators were available. This would result in age ranges of 15 to 40 years An attempt was made to reduce these ranges to tenyear intervals. Ectocranial suture obliteration and dental attrition were studied to achieve this. Age was estimated from ectocranial suture closure with the help of the schedule of Vallois, as modified by Rösing. ${ }^{399}$ skulls with asymmetrical or atypical suture closure were excluded. Results outside the range deduced by the "complex method" were rejected. The second method used to narrow the results of the "complex method" was seriation based on comparison of dental attrition. Attrition was scored according to the methods of Brothwell and Bouts and Pot. ${ }^{3 \text { sa }}$ For adult individuals whose age could be estimated on the basis of three or four age indicators from the "complex method", the mean attrition rate of the first, second and third malars was calculated, as suggested by Maat and van der Velde ${ }^{395}$ Comparison of the degree of attrition of insufficiently aged individuals with the calculated mean scores per age interval made it possible to assigin these individuals to one of the age intervals.

\section{STATURE ESTIMATION}

For the calculation of living standing height, all long bones of the limbs were measured on an osteometric board. Measurements were taken according to the definitions of Martirn and

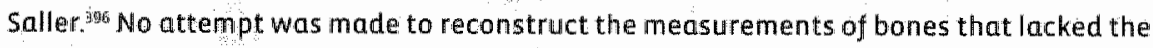
necessary anatomical landmarks. Bones showing traces of fractures or pathological changes which could have had an impact on the length were measured but not used to calculate stature. Stature estimates were computed with the formulas for American Whites as developed by Trotter and Gleser ${ }^{3 y}$ As advised by the authors, the formula with the smallest standard error was chosen in selected cases the estimated stature of individuals over 30 was corrected for the decrease in stature because of ageing effects. In addition to the widely used formulas of Trotter and Gleser we applied the method conceived by Breitinger. ${ }^{3 g g}$ According to Wurm this method produces more reliable estimates for male individuals of north-western Europiean origin. ${ }^{999}$

\section{POPULATION WARIAEHLTV IN NON-METRIC TRATS}

The frequency of a limited number of non-metric traits was assessed. in addition to the long bone lengths, three dimensions of the skull were measured. Maximum cranial length,

wo Hofmanet at ags and Hofman et at. in press.

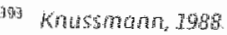

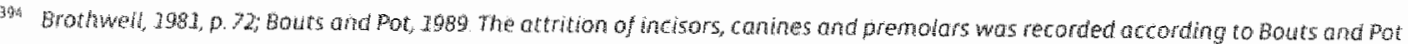
but not used for seriation.

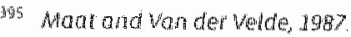

wos Marim and Soder, 1957

no Troter and Geser, 1958

Jys breinger, $199 \%$

395 Wurm, 1985,012 
maximum breadth and basibregmatic height of skuls were measured with a spreading calliper. Only intact crania, not distorted by post-depositional processes, and successfully restored skulls were evaluated. Non-metric variation was scored as present, normal or indeterminable.

Bilateral traits were checked on both sides and scored separately. The skulls were examined for the presence of thirteen traits: metopism, coronal ossicles, sagittal ossicles, lambdoid ossicles, bregmatic bones, Inca bones, ossicles at lambida, assicles at asterion, parietal notchbones, mandibular tori, maxillary tori, palatine tori and double condylar facets. The postcrantal skeleton was inspected for the following nine traits: double atlas facets, posterior bridges of the atlas, lateral bridges of the atlas, sacralisation, lumbarisation, spina bifida, sternal foramina, septal apertures.

\section{PALAEOPATHOLOGY}

Pathological bone changes in general were studied using grass anatomic examination and radiographic analysis. The latter included standard $x$-ray as well as computed tomography. All skeletons were first inspected by the author. A committee of specialists in the field of radiology, orthopaedic surgery, pathological anatomy, anatomy and palaeopathology reviewed all pathological cases. During these sessions, the mast probable diagnosis was settled. 300 pecial attention was paid to the healing of fractures and the presence of pathology in the axial skeleton and the peripheral joints. The paranasal sinus, the mastoid air cells and the auditory ossicles were inspected for traces of infectious disease.

Another indicator for the health status was the prevalence of Harris lines. Harris-lines are transverse lines that are visible on $x$-rays as radiopaque lines in the diaphysis and metaphysis of long bones. X-rays were made of all available intact tibiae, because lines are best assessed in that bone. Lines in the distal tibias were classifjed and their skeletal age of formation calculated as recommended by Maat. Formation rates, representing the number of lines formed per year of bone growth within the overall population were also computed according to Maat.

\section{DENTITION}

The dental remains were recorded with the help of a computer program, developed by Bouts. ard Pot. ${ }^{\text {toz }}$ It facillitates the recording of the presence of teeth, alweolar bone and the degree of attrition, caries, exposed pulp cavities and periapical lesions. On a separate form the presence of enamel hypoplasias, specific pathalogy and anomalies was recorded. The grade of alveolar bone resorption and the formation of calculus were classified according ta Brothwell. ${ }^{\text {its }}$

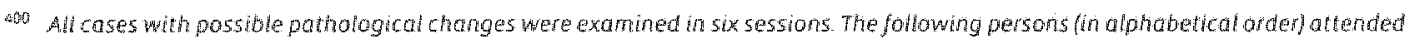

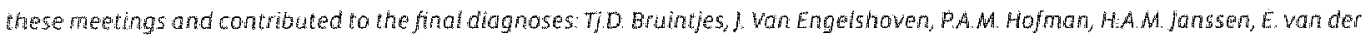

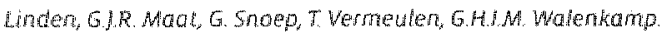

301 Mart, 7984

wot Bouts and pot, 1999

4a: Brothwell, 1981 
DATA RELISTHATONAND STATISTICAL ANALISIS

All relevant information cancerning the archaealogical context and the results from the physical anthropological examination was recorded in a database (MS Access). For analysis of the data a statistical program (5P55) was used. Prevalence of various features and pathologies is generally expressed in percentages: We did not opt for the possibility to calculate them per 10,000 indiwiduals to avoid the suggestion of large sample sizes. For the statistical analysis the following tesits were used, chi-square, chi-square test for trend, Mann-Whitney ranked order, paired t-test. Only the p-value is mentioned in the text or in footnotes. When in cross tabulations the expected number af cases per cell was 5 or less, Fisher's Exact test was used to calculate the probability. Plans showing the distribution of inhumations and various skeletal traits were made with a computer aided design program (AUTOCAD). As a basis for these plans we used a digital map of the city of Maastricht. 


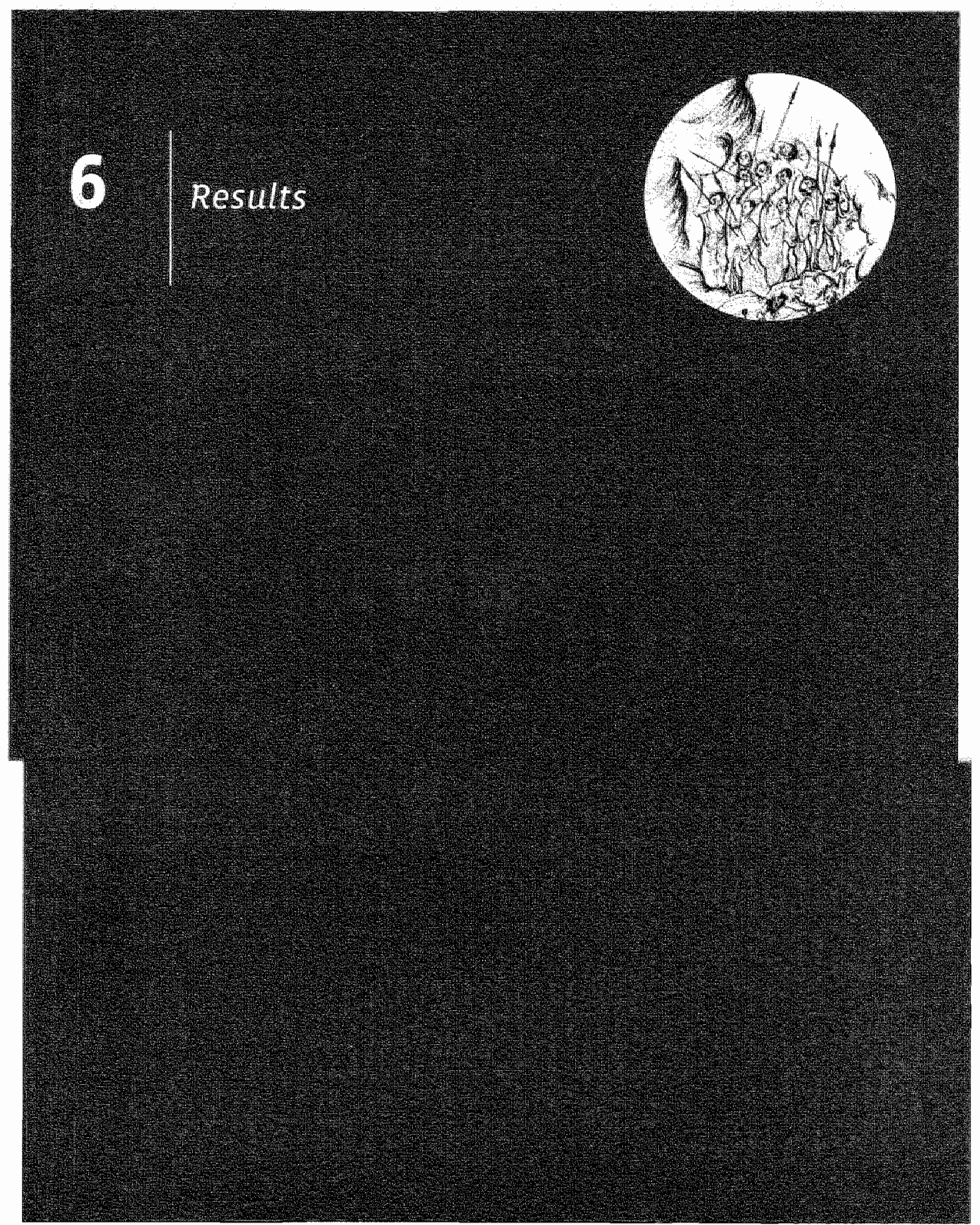




\section{Results}

In general the results from the physical anthropological and palaeapathological examination are presiented per sample or per status category. For the Servaas site the three samples represent the chronological subdivisions described in chapter three. Therefore, they are named: the cella sample, the templum sample and the basilica sample. The data collected from the human skeletal remains of the Baschstraat site are combined in a fourth sample, labelled the Boschstraat sample. As described in chapter 3, 155 inhumations were categorised by status. The low status sample consisted of all Baschstraat site inhumations. Both the samples of intermediate and hilgh status were composed of a mixture of selected burials from the templum and basilica sample.

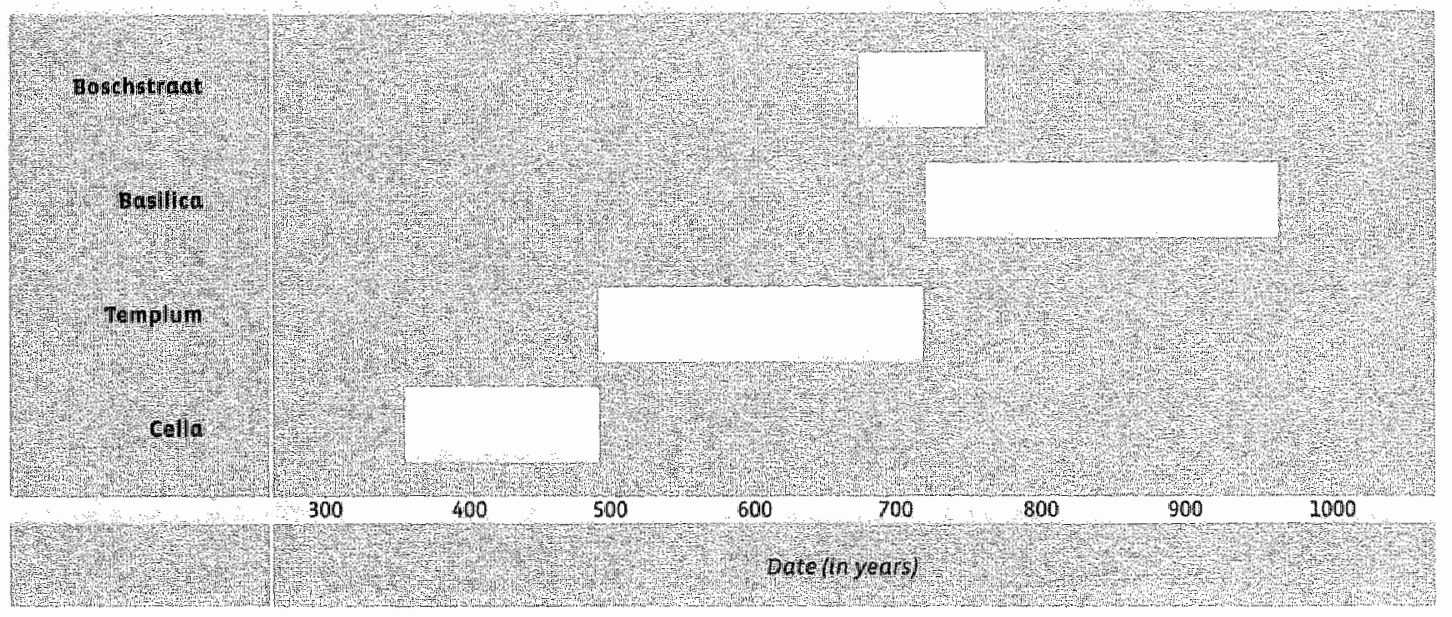

HiguRE 6-1 The four somples examined th this study whth theirrespective chronologed interwats

To investigate the presence of diachronic variation the following pairs, representing subsequent periods, were compared: cella sample - templum sample, templum sample-basilica sample. Being partially contemporary with the later inhumations from the templum sample and the first inhumations from the basilica sample, the data found for the Boschstraat sample were compared with these two samples. The intiumations of the cella sample and the Boschstraat sample were separated by almost 200 years. An even longer period divided the cella sample and the basilica sample. Therefore these samples were not systematically compared. Statistical analysis of possible status-related variation occurred by comparison of the following pairs: low status - intermediate status, intermediate status - high status, low status - high status. 


\section{DEMOGRAPHY}

SEX

The number of individuals in the whole sample population was 238: 184 indwiducts from the Servaas site and 54 individuals from the Boschstrat site. Sexuallisation degrees for the pelvis, the skull or bath could be determined in 122 cases (51\%). Non-metrical morphological methods could be used to attribute sex to 92 pelves (39\%) and 100 skulls (42\%). In 92 cases (39\%) the absence or fragmented state of pelvis, skull and femur or the incomplete development of the inspected features prevented a sex attribution.

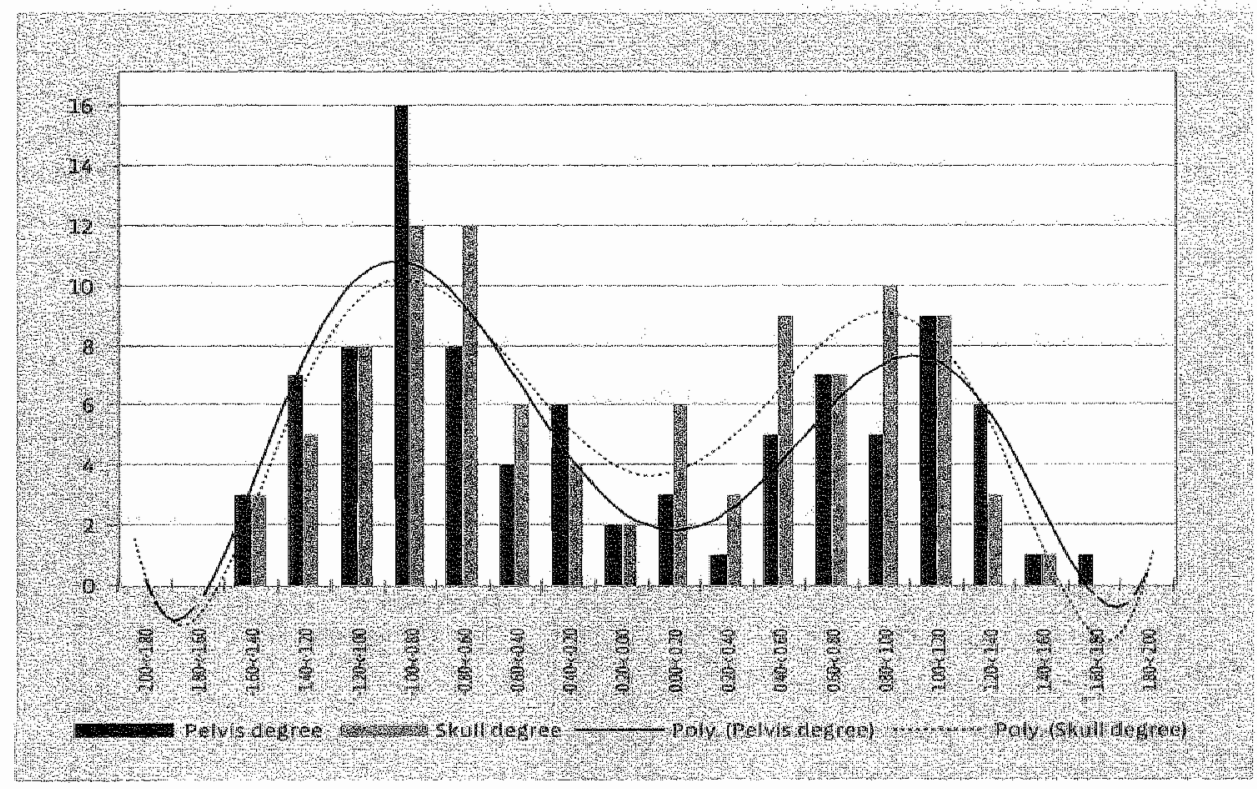

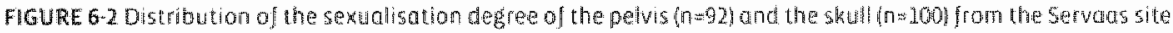
Sexualisation degres below ore considered to ind cote female sex and sexuobsationdegrees above o are indicative for male sex Added is a polynomial line for each feature The height of the calumas represents the number of individudis.

Figure 6-2 displays the distribution of the sexualisation degiree of the pelvis and skull foundi for both sites. As is evident from this graph more pelves and skulls had sexuallisation degrees in the female range. 5till, both polynomial lines reveal a bimadal curve with the lomest point between the two peaks near to zero. This distribution indicates that the nom-metrical morphological method was a reliable tool to assess the sex of this population. In general between 60 to 70 percent of the features, used in the non-metrical morphological method, could be inspected.

this sample was seterted from a sample compising the 5 kelet a remans of 33 individuofs. 


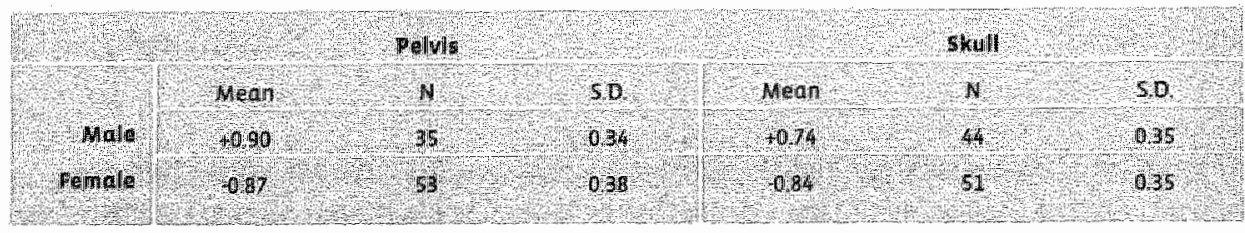

TABLE 6.1 Sexualisation degree colculated for the pelws and shull by means of the non metrical morphotogical method

A total of 53 pelves was categorised as female which had a mean sexualisation degree of -0.87 . The mean calculated for 35 male pelves was +0.90 . For the skulls 51 were female with a mean sexualisation degree of 0.84 . Male sex was attributed to 44 sulls with a mean of +0.74 .

Ambiguous sexualisation degrees (between -0.10 and +0.10$)$ were found in four pelwes $(4.3 \%)$ and 5 skulls $(5 \%)$. Four of these cases with an indefinite result for either the pelwis or the skull could be sexed on the basis of a conclusive sexualisation degree for the other part. For five remaining cases this was not possible. As a result, a total of 117 individuals were sexed by means of the non metricall morphologicall method. Apart from the five individuals of indeterminate sex, there were 68 adult individuals that could not be sexed by means of the non-metric morphological method.

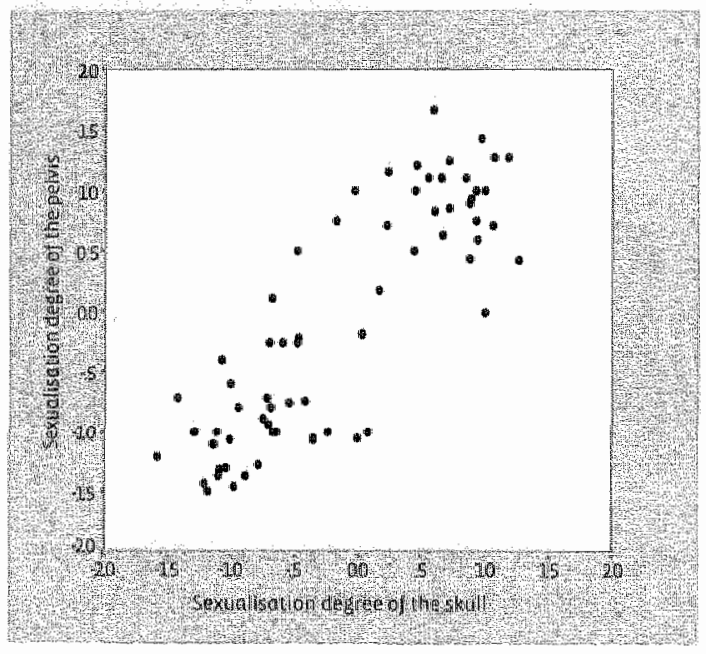

\author{
FIGURE 6-3 scatter pilot of the sexulisation \\ degree of the palvis and the skull of 70 \\ individuals of the senvans and Boschstrad \\ site. The vertical axis represents the \\ sexualisation degree of the pelwis; the \\ sexuahisation degree of the 5 kull is \\ represented on the horizontal axis
}

A scatter plot combining the sexualisation degree of the pelves and the skulls illustrates that in general the results found for the pelves were corroborated by the sexualisation degrees calculated for the skulls. In two out of 70 cases (less than $3 \% d_{,}$from the Servacis and Boschstraat sitey did the sexualisation degree of the skull substantially contradict the assessment of the pelvis. As indicated in the fourth chapter, on methods, it was decided that in case of contradicting results the sex determination on the basis of the peiwis would prevail. 
Classification by the maximum anteriar posterior femoral diameter (APD) was chosen to extend the possibilities to attribute the sex. The APD could be measured in 105 cases. For 69 of these individuals sex had been determined by means of the non-metrical morphological method. Before criteria were defined to assess sex by APD for the remaining 36 individuals, the variation between left and right bones and by sample was investigated. A paired sample test indicated that there was wirtually no difference between the right and left femur APD. Variation between the subsequent phases and sites also prowed statistically insignificant. Based on the values found for 40 females and 29 males an additional sex criterion could be defined.

\begin{tabular}{llll}
\hline & \\
\hline
\end{tabular}

TABLE 6 Statistical date for tha maximum femora anteriorposterior diameter in millimetres of ferwde and male individuals sexed by the non-metrical morphologicat method

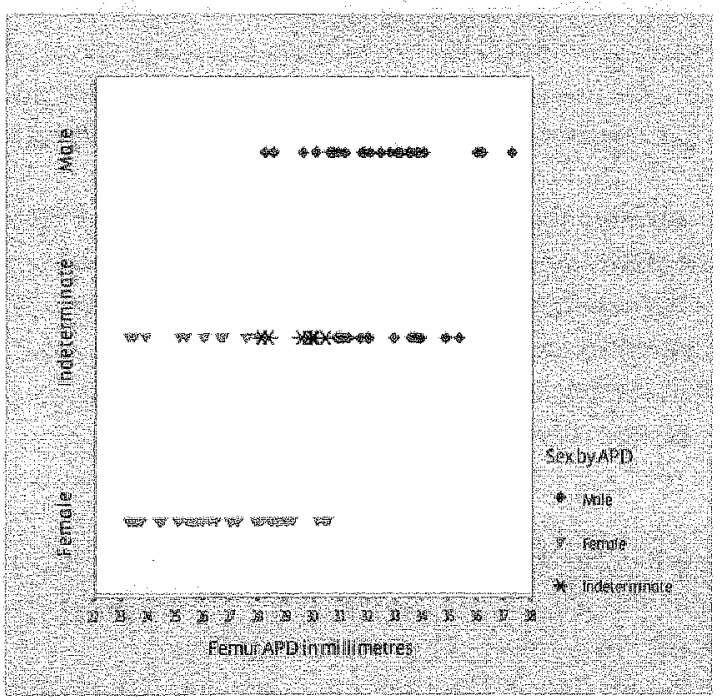

FlGURE 64 Dishribution of maximum femorat anterior pasteriar diameter for male, indeterminale and female ind ividuals (n-205). The vertical position indicates the sex atribution on the basis of the ron metrical mor phological method fra the indeteminate group are 36 iradividuals whose sex could not be determined by means of this merhod the outcome of sex antribution by the size of the APD is visuatised by the markers, on the left in the midd le group are the

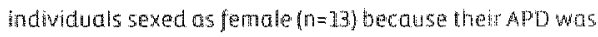

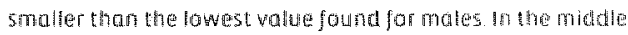

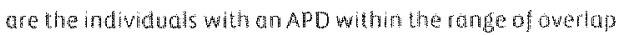
betwer the lowest male ard the hight jemale APD These

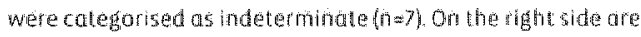

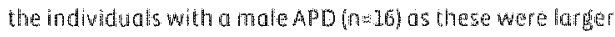
than the hightest walue jourd for females.

A normal symmetric distribution of the values was found for both sexes, whe difference between the mean values for men and women was highly significant. ${ }^{40}$ Between $28.25 \mathrm{~mm}$ and $30.58 \mathrm{~mm}$ the diameters found for men and women showed an overlap. To lower the risk of misclassification it was decided not to attribute sex to 7 individuals with an APD within this

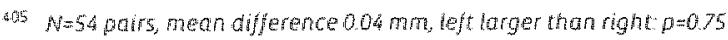

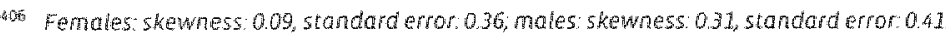

4:D? Fende APD-Male APD p pOOOL
} 
range of overlap. Thirteen individuals of the indeterminate group had an APD of less than 28.25 $\mathrm{mm}$, these were considered female. Sixteen individuals of this group, with an APD greater than 30.58 , were sexed as male.

When the results from the non-metrical morphalagical methad and the metrical marphological sex determinations are combined, sex could be determined in an extra 29 individuals adding up to a total of 146 sexed individuals. Seven individuals were categorised as "indeterminate" because the results of the sex determination by means of the femur APD remained ambiguous.

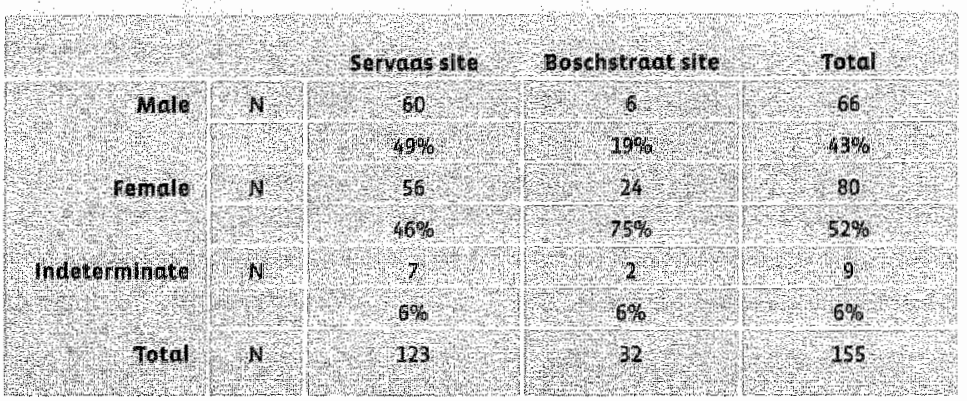

TABLE 6.3 Number of sexed and unsexed individuals from the Servas site and the Boschstraat site after sex determination by ryeans of the non-metrical marphological methad and the anceriar posterior diameter of the femer

In nine individualls neither the non-metrical morphological method nor the anterior-posterior diameter of the femur provided a conclusive indication of the sex. Therefore, these remained categorised as of indeterminate sex. Thirty-two adults were recovered in conditions that did not allow for determination of sex and were thus categorised as "unsexed". The impact of the completeness of the skeleton on the feasibillity to determine sex is evident. All but one of the unsexed adults were skelletons with recovery rates of less than 0.20 .

\section{SEXKATIO}

Table 6.4 displays the sex distribution for the four samples. For the whole study a majority of females was found. Marked differences in the distribution over the sexes were visible among various samples of the Servaas site and for the Boschstraat site. None of the samples approximated an equal distribution of males and females. The cella sample and basilica sample had a slight majority of male burials. Both the templum sample and the Boschstraat sample show that female burials predominated. At the Boschstraat site, the number of female burials largely exceeded the male burials.

Calculation of Pearson's chi-square learned that the differences between the consecutive phases at the Servaas site were not statistically significant. ${ }^{458}$ However, the mutual differences

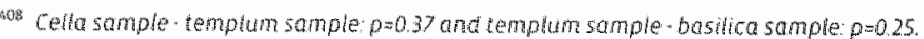


in sex distribution between both the templum sample and the Boschstraat sample and the basilica sample and the Boschstraat sample were significant. ${ }^{\text {abs }}$

\begin{tabular}{|lllll}
\hline & \\
\hline
\end{tabular}

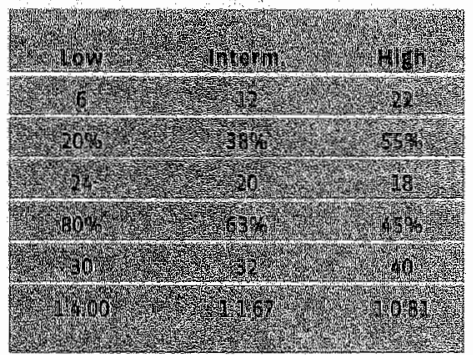

TABEE E. Sex distribution by sample and status

Analysis of the distribution of sex by status yielded a significant result for one comparison. The percentage of females in the sample of low status was markedly higher than in the sample of high status. Like the sample of low status, the sample of intermediate status consisted mastly of women. Variation between these two samples was less evident and not significant."18 Comparison between the intermediate and high status samples showed a majority of female individuals in the intermediate sample and a majority of males in the high status sample. Still, the variation in the distribution of sex between these two groups did not differ significantly.in

AGE

The results of the estimation of age at death are generally presented separately for two age categories, viz. non-adults (individuals under the age of circa 20 years) and adults. Not only are different methods used for age estimation of the two categories, separation of the data is also necessary for further physical anthropological and palaeopathological analysis. Determination whether an individual was non-adult or adult was possible for all individuals included in our sample.
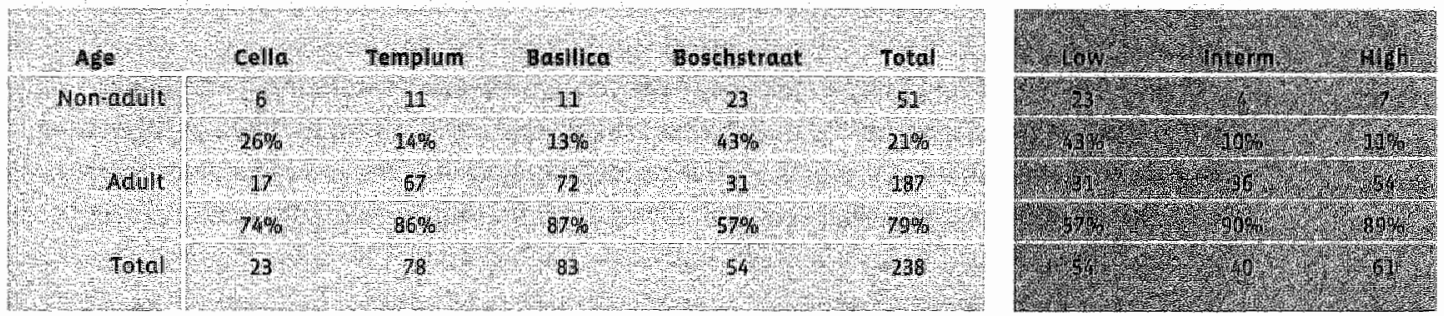

TARLE 6.5 Distribution of non adutt and adult individuals by sample

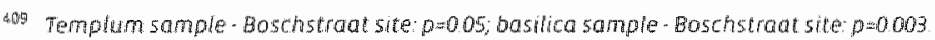

4. Low status - high status: $p=0.004$

41 Low status - intermediate status: $p=0.17$

internediate stotus - high status: $p=0,16$
} 
Circa $21 \%$ af all individuds were scored as non-adults. In this respect both excavation sittes differed considerably. At the Servaas site 28 individuals (15\%) out of 184 were non adults. The proportion of non-adults found at the Boschstraat site was more than twice as high: $23(43 \%)$ out of 54 . Also within the Servaas site sample the percentage of non-adults varied among the three samples. The templum sample and the basilica sample had similar proportions of non-aduits. However, the percentage of non-adults in the cella sample was approximately the double of the percentage found for the templum and the basilica sample.

When the samples defined by status are compared it is evident from the preceding table that the low status sample (from the Boschstraat site) has a comparatively high proportion of nonadult individuals. For the intermediate and high status samples relatively low percentages, viz. $10 \%$ and $11 \%$ respectively, of non-aduits were found. The chi-square calculated for the distribution of non-adults over the status categories indicated that the variation deviated significantly from expected normal distributions. ${ }^{5,2}$

\section{Non-adults}

of the whole sample 51 individuals were categorised as non-adults. Ossification of the axial skeleton was the ageing method that could be used most, viz. in $70 \%$ of these cases. In addition, dentah development contributed to the age assessment of $54 \%$ of the non adult individuals.

Furthermore, lengths of the long bones and epiphysed fusion were employed in $42 \%$ and $18 \%$ of the cases respectively. ${ }^{445}$ Thus it was possible to assign 50 non-adults to ten-year age intervals. ${ }^{416}$
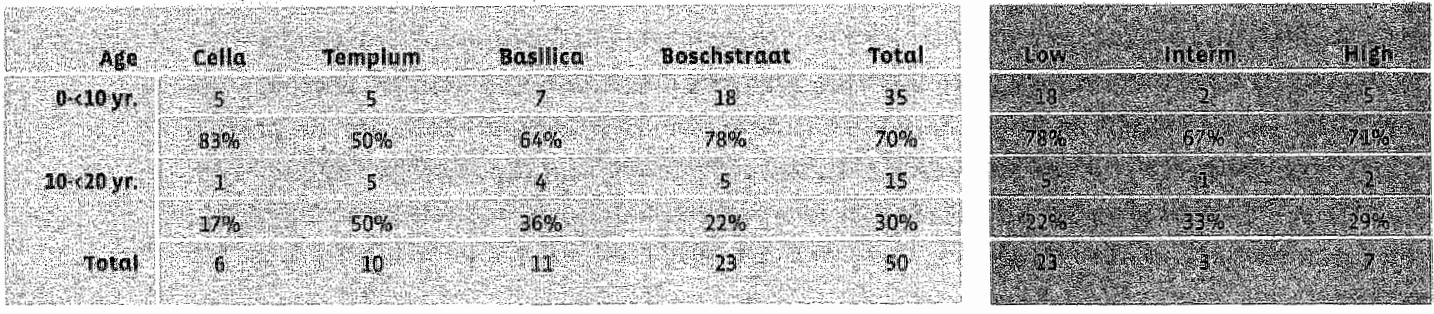

TABLE G Gon-duth mortatily by sample and status.

Childiren who had died between birth and ten years made up the majority of non-adult burials (70\%). In comparison with the templum sample and basilica sample, an even higher percentage of the non-adults from the Boschstraat sample died in the youngest age category. However, the difference between these samples was statistically not significant. al? Further

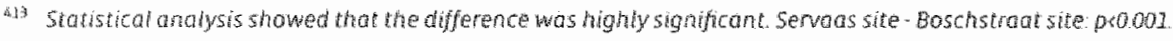

as For poble 6.5. pe0001.

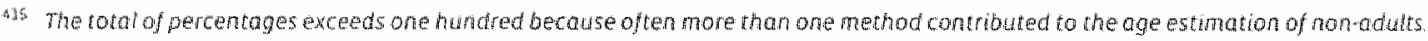

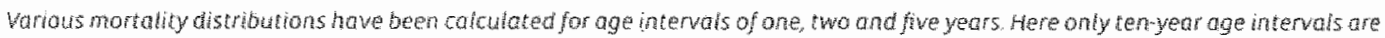
presented onder distributions will be presenced in the discussion

Wy Templum sample - Bosichsthat she pro.22; basilica sample - Boschstrant site pwo 43
} 
Tnvestigation of martality ${ }^{238}$ of 46 non-adults who could be categorised in 5 year age intervals showed that $50 \%$ of all non adult individuals died during the first five years.

Analysis of non-adult mortality by status was possible for only 33 individuals. Mast of them belonged to the low status category. Despite their small number the mortality pattern of the indiwiduals from the intermediate and high status samples was similar to that of the low status sample.

\section{Adults}

Use of the "complex method" enabled the assessment of age at death for 121 adult individuals. Not all of the four age indicators could be inspected in equal proportions. Most used was endocranial suture obliteration, viz. in $68 \%$ of the cases. Inspection of the femoral head was possible in $67 \%$ of the individuals. The humeral head could be examined in $47 \%$ of the whole sample and the pubic symphysis in $9 \%$. Often only one or two out of four age indicators were available for inspection (in $61 \%$ of the cases). Estimation of age at death is more precise when three or four features can be inspected. The remains of 41 individuals allowed for estimation within an age range of 5 ar 6 years. For another 80 individuals use of the "complex method" resulted in age ranges of twenty years and more. Seriation on the basis of the ectocranial suture obliteration and dental attrition contributed to a reduction of the age range for 53 of these individuals. Ultimately a totall of 94 adults could be assigned to tenyear age intervals (sex could not be assessed for two of these individuals).

\section{Age distribution in intervals}

Male and female individuals were not equally distributed over the various age categories.

Female mortality was slightly higher in the intervals between 20 to 30 and 30 to 40 years.

However, the differences were minor and statistically not significant. In order to create samples of larger size the sample was divided in 20-year age intervals (see tables 6.7 and 6.8).

When arfanged by 20-year age intervals, eight more sexed individuals and an additional five unsexed individuals could be included in the analysis. Table 6.8 shows that in 20-year age intervals female martality is higher than male mortality for the interval between 20 to 40 years. However, the variation in mortality is not statistically significant. Therefore, males and females were combined in further tables presenting mortality in 20-year age intervals.

When analysed per periad, significant differences in age distribution were not found. Still, two distribution patterns could be recognised. Both in the cella sample and the basilica sample the highest number of deaths ranged within the 40 to 60 years interval. In the templum and Boschstraat sample most adult individuals died between 20 and 40 years. For the whole sample, mortality in the 20 to 40 years and 40 to 60 years intervals is simillar. Furthermore, ages of 60 years or over were comparatively rare. In this respect, it is noteworthy to see that in the Baschstraat sample three individuals reached an age of 60 ar more.

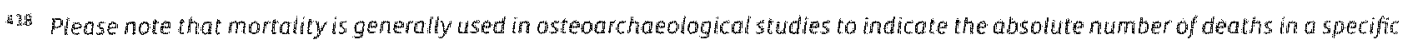
age interwat. Thus the term is used in a diferent meanng than be demographical publications dealing with tiving populations 


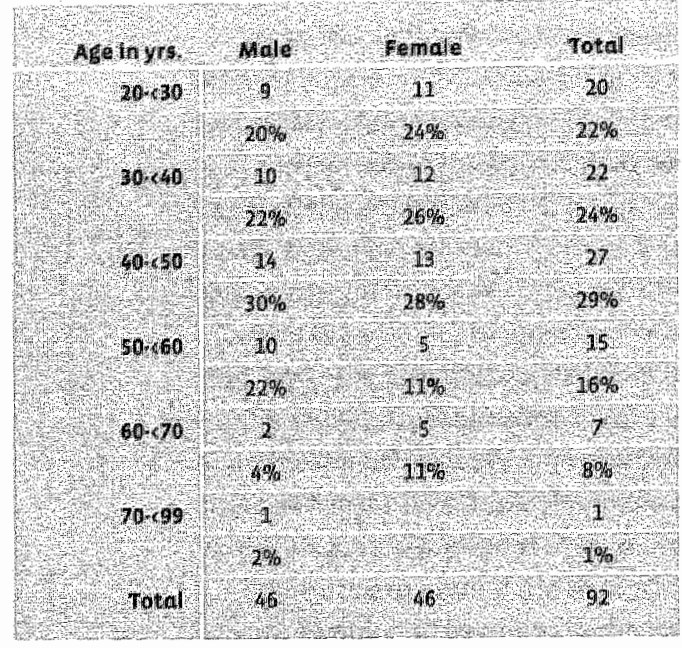

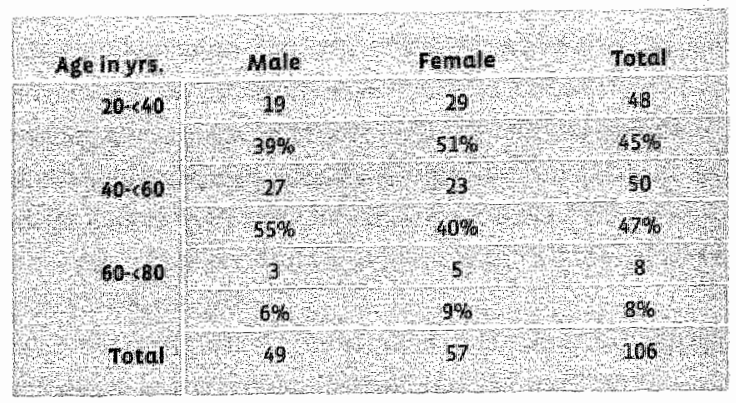

TABLE 6.7 Distribution of agse of death in 20 -year age interwats by sex

TABHE 6.8. Age distribution in 10-year age intervats for adw th by sex
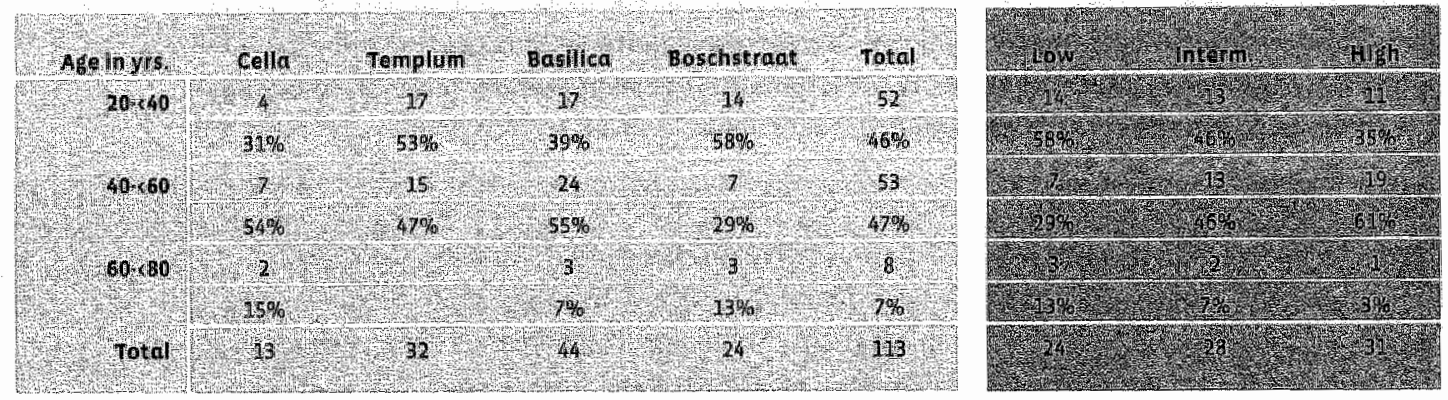

TABLE 6.9 Distributhon of age al death for adults by sample and stakes

Age at death could be determined for 83 adults who could be categorised by status. In Table 6.9 the distribution shows that the highest mortality tended to shift from the 20 to 40 years interval, in the low status category, to the 40 to 60 years interval in the high status category. in the group of intermediate status, deaths are equally distributed over the two intervals. For the mere six individuals whose deaths ranged in the age interval of 60 to 80 years the opposite was found. Only when calculated separately for the age categories between 20 to 40 and 40 to 60 years could the trend be substantiated by statistical analysis. ${ }^{\text {it }}$ When all three age-categories were analysed the reverse trend in the 60 to 80 years category counterbalanced the shift in mortality.

at When a chisture is tested for tremd for the two age categories of 20 to 40 and 40 to 60 years and the three status categories, the ourcome indicates significance $p=0.04$ 


\section{Meanage at death}

Adult mortality in different samples was also compared by calculation of the mean age at death Mean age at death was first calculated from the ages of indwiduals whose age could be assessed on the basis of 3 or 4 age indicators of the "complex method". This allowed calculating the mean age at death for a total of 41 individuals.

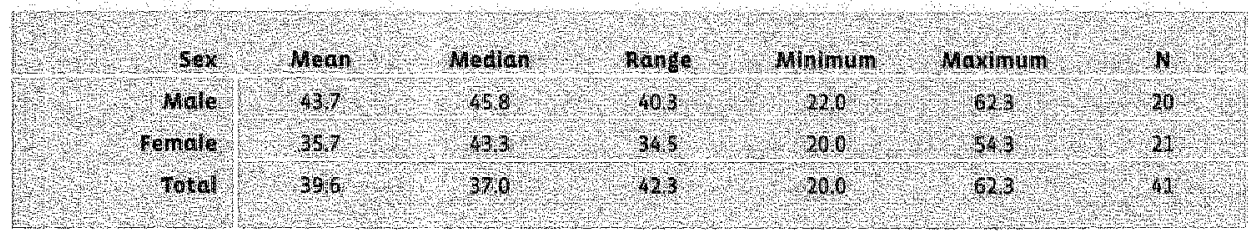

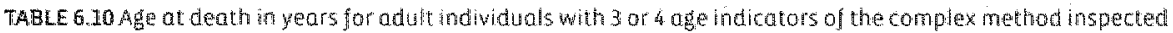

The mean age at death for males was circa 8 years higher than the female mean age at death Statistical analysis indicated this difference was significant. ${ }^{\text {ial }}$ Consequently, it was decided to calculate separate means for men and women. The mean age at death was al so calculated on the basis of the mid-values of ten-year age intervals. In this way mean ages at death could be calculated for 92 adult individuals. ${ }^{422}$

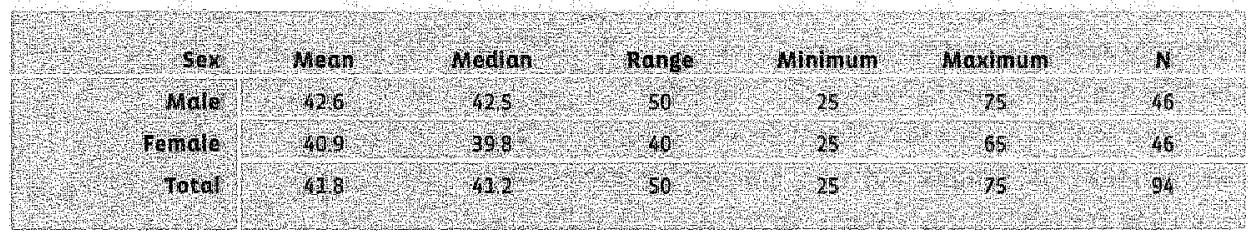

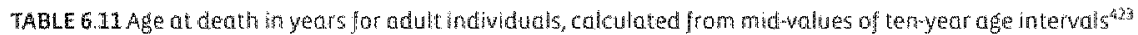

Male mean age at death was 1.1 years lower when calculated on the basis of mid-values of ten-year age intervals. Calculation of female mean age at death by the same method resulted in a considerably higher age. Therefore, the difference between male and femaie mean age at death was reduced to little more than one and a half years. This difference was mot statistically significant. However, because of the significant difference between male and female mean age at death described in Table 6.10, it was decided to calculate the mean age alt death not anly for the whole sample but also separately for males and females

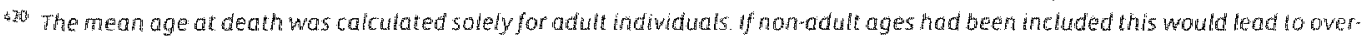

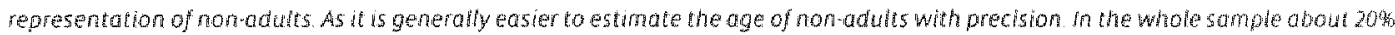

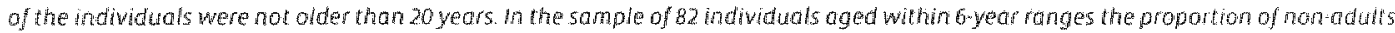
was $50 \%$ Not only wath this result in underestimation of the mean age at death, it abo created the risk that the nean age of death was biased by wariations in the proportinn of mandades in the samples

42: Mate-Jemale Mann-Whiney p=002 (Student-test: $p=002$ )

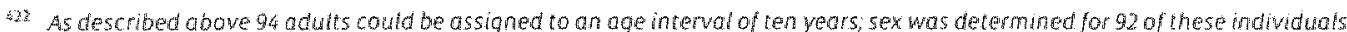

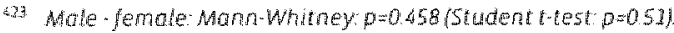




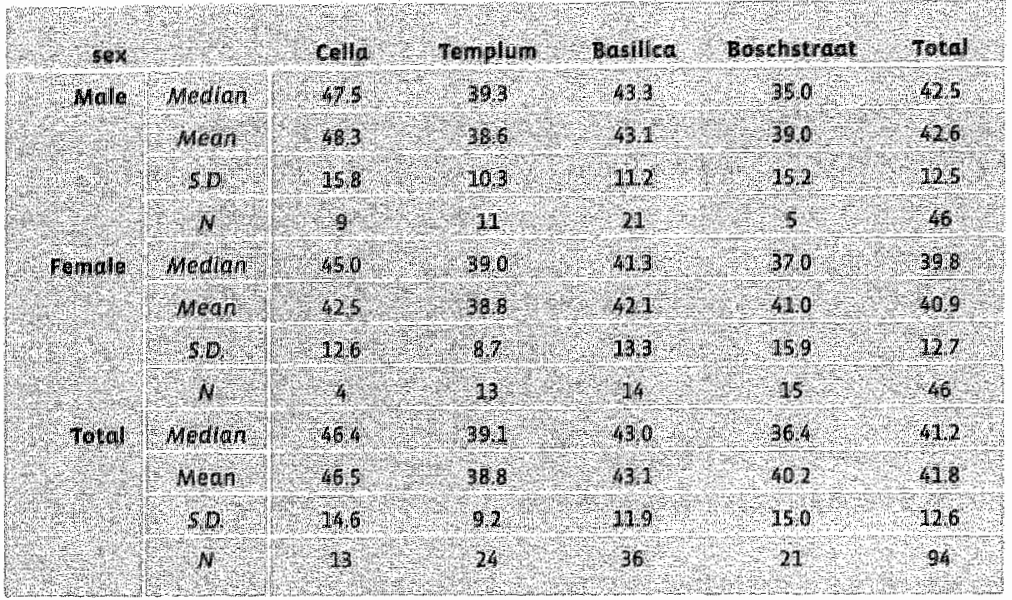

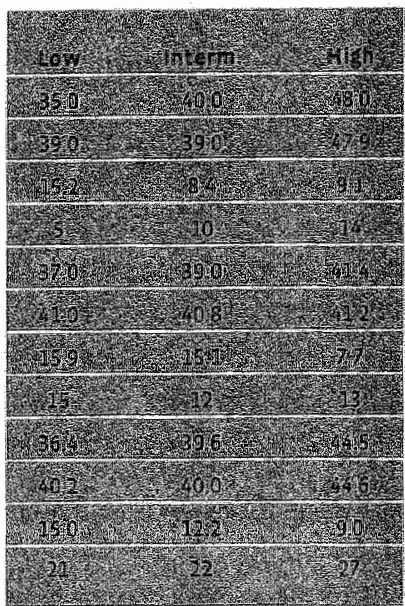

TALLE 6.12 Age at death in years of aduts by somple and status, calculated from mid-watues of ten year age interwals

Variation among the mean ages at death calculated for males in the four samples was considerable, viz. a range of almost 10 years. Still, the calculated differences between the samples were not significant. The men from the templum sample and the Boschstraat sample generally died at a younger age then those of the basilica and cella sample. In comparison with the other samples, the high mean age at death for the cella sample is remarkable. However, given the wide varlation in this sample, expressed in the standard deviation, the differences between the cella sample and other samples could not be labelled as statistically significant. Mean age at death of the females varied little; the differences among the four samples did not exceed more than five years; the differences proved to be insignificant. The lowest mean age at deeth was calculated for the female burials from the templum sample. In mone of the four samples in table 6.12 was the variation between female and male mortality statistically significant. For the cella sample a large discrepancy was found between female and male mean age at death, with a higher age for men. Between the mean age at death of men and women from the templum sample the difference was marginal. For the basilica sample meon age at death of males exceeded female mean age at death by circa one year. The opposite was found for the Boschstraat sample where female mean age at death surpassed male mean age at death by two years. ${ }^{49}$

Mean ages at death were equal for the malie individuals of low and intermediate status. However, mean age at death of males of high status was more than eight years higher. Statistical analysis indicated the difference between males of intermediate status and high status was significant. The variation of female mean age at death among all three status-

s. Wale and farmate ages at death were combined and tested for wariation in the rean age ar death between the following samples:

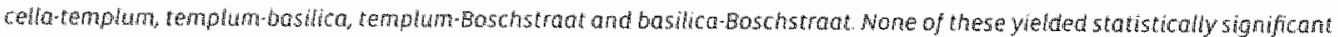
differences

i2s Intermediate status male - Figh statis moles Mann whitrey $p=00$ : 
categories was judged insignificant. Comparison between the male and female mean age at death for the high status category also indicates that age at death for males in the high status category was relatively high. Female mean age at death for this category was circa six years. lower and when statistically tested the difference missed significance with a small margin. ${ }^{\text {sin }}$

\section{POPULATION VARIABHLITY}

\section{CRANIAL MEASUREMENTS}

Cranial measurements are recorded to define the shape of the skull and be able to distinguish variation between populations. Because few crania were recovered intact and few damaged skulls could be sufficiently restored, the number of measurable skulls was limited. Three skull dimenisions could be reconded in about a fourth to a sixth of the adult individuals: the maximum cranial length, the maximum cranial breadth and the basi-bregmatic height.

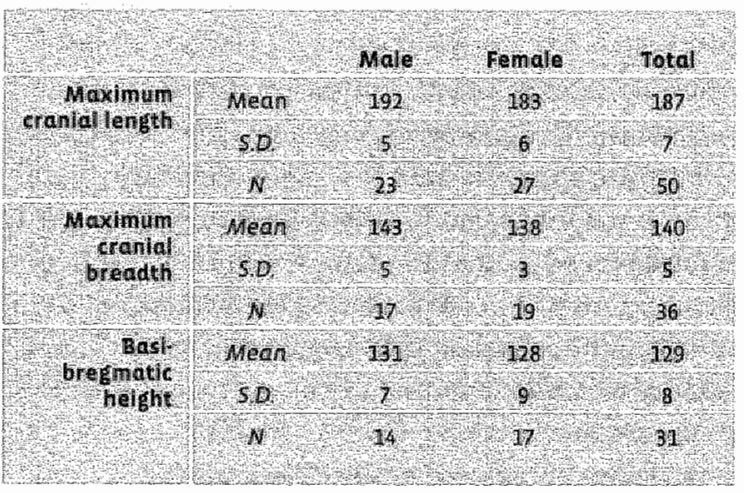

TABLE 6.13. Skull measurements in millimetres by sex

All three measurements were tested for sexual dimorphism. Generally male skulls were larger than female skulls: With respect to the maximum cranial length and the maximum cranial breadth the observed differences between males and females were statistically significant. ${ }^{\text {az }}$ Variation for basibregmatic height appeared nat to be strongly associated with sex. When the mean values for these dimensions were compared by period and status no statistically significant differences between the samples were observed. (Analysis of the maximum cranial length and maximum breadth was carried out separately for male and female individuals.) Biased an these measurements three cranial indices were computed: the horizontal cranial index (length-breadth), cranial height-length index and the cranial height-breadth index. No

\footnotetext{
Bs High status mate - figh status female Marn-Whitney p*0.06.

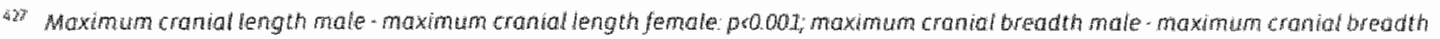

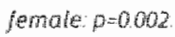


significant sexual dimorphism was discerned for any of the three indices. Therefore these data were not further analysed by sex.

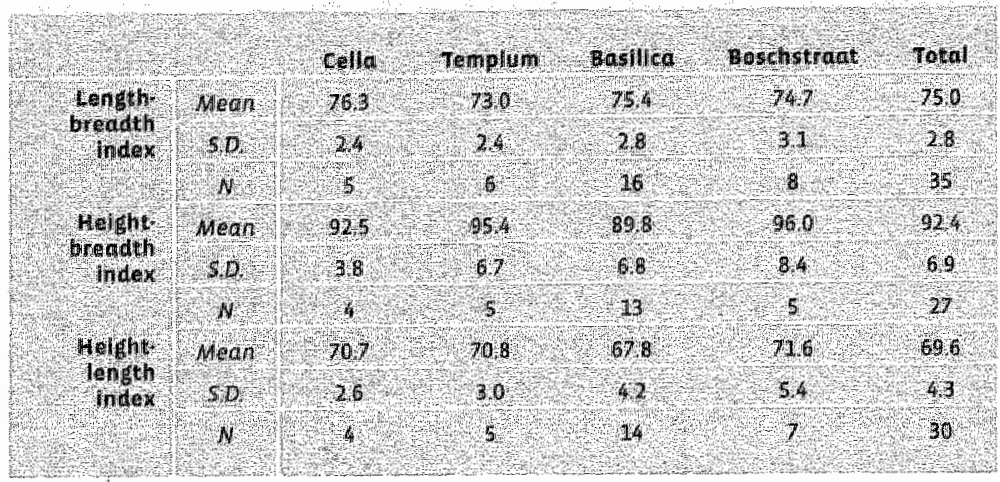

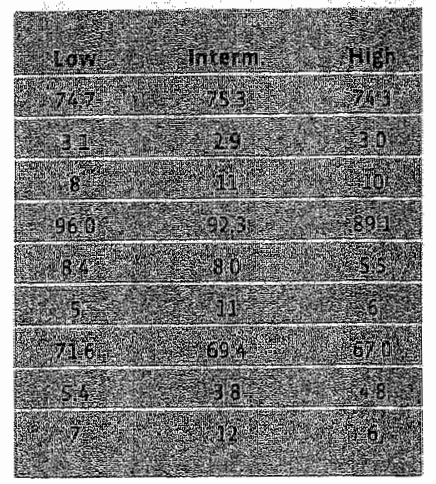

TABLE 6.14 Cratialindices by somple arad states

Only one of the comparisons of the indices by sample showed a difference that was statistically significant ( $p<0.05$ ), wiz. between the horizontal cranial (length-breadth) index in the cella sample and the templum sample. ${ }^{478}$ judged by the mean horizontal cranial index the individuals of the templum sample would be described as clearly dolichocranic le.g. long. headed, cranial index $>74.9$. Whereas the mean found for the cella sample was 3.4 higher than the mean of the templum sample, which characterises the cella sample as mesocranic (e.g a cranial index between 75 and 79.91. Like the skulls from the templum sample, the mean calculated for the skulls of the Boschistraat site matched with the dolichocranic range. Those of the basilica sample were on the average mesocranic.

The differences between the various samples by status were marginal. None of the comparisons of the means of the three indices indicated that the differences between the status categories were statistically significant. Besides the calculated means of these indices, the cranial length-bieadth index was also studied at the level of individual cases. The distribution of brachycranic, mesocranic and dolichacranic skulls was inspected by sample and by status category.

Except for one brachycranic skull from the basilica sample, all other skulls were either dolichocranic or mesocranic. Among the skulis from the basilica sample and the Boschstraat sample the mumber of dolichocranic and mesocranic skulls was almost in balance. Deviating distribution patterns were found for the cella sample and the templum sample. The majority of the cella sample skulls were found to be mesocranic, whereas the templum sample skulls were mastly dolichocranic. This large proportion of dolichocranic skulls in the templum sample may be considered to deviate significantly from the distribution found in the rest of the population.

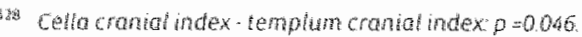

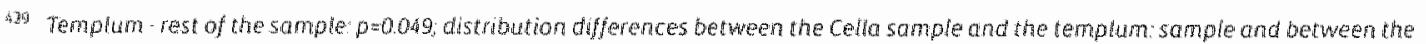
cello somple and the rest of the sample were mot signficant Respectively proos and p=0.19. 


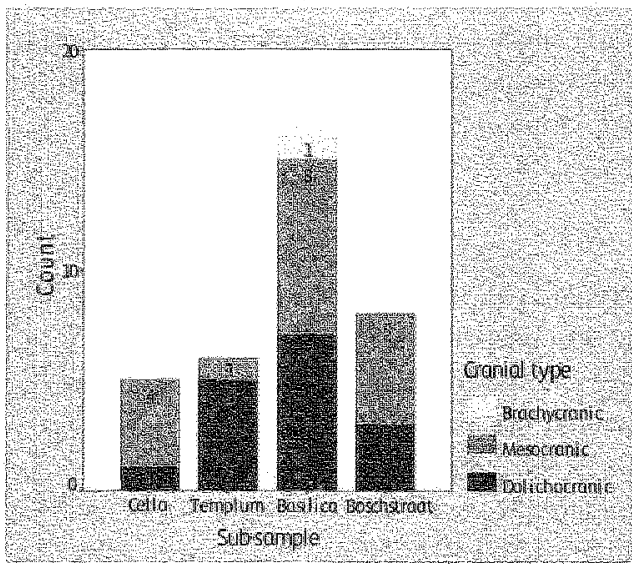

FIGURE 65 Distribution of the crantal typers by sample

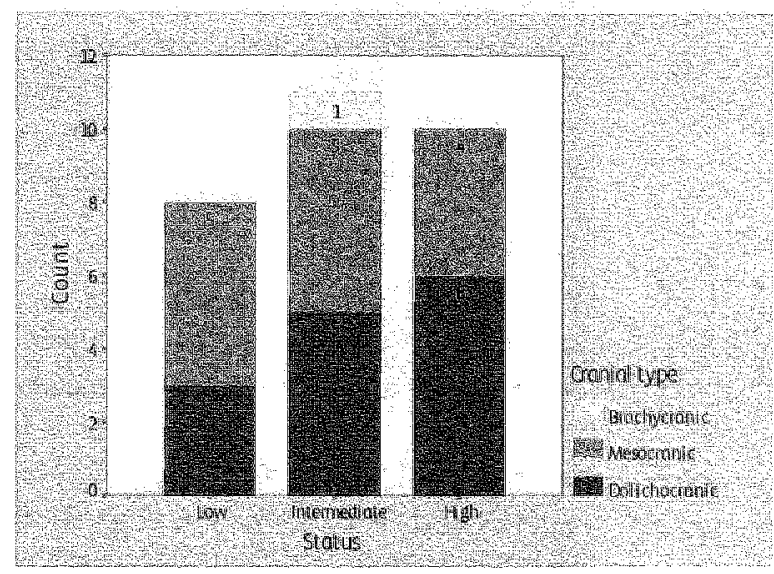

FIGURE 6-6. OAstribution of the cranial types by status

The distribution of eranial types over the various status categories showed that the proportion of dolichocranic sikulls increased with status. in the low status category $37.5 \%$ of the sklulls were dolichocranic, in the intermediate category $45 \%$ of the skulls and in the high status categary $60 \%$ of the skulls were dolichocranic. However, statistical analysis indicated this trend was not statistically significant.

\section{POST CRANIAL MEASUREMENTS}

Many llong bones were either damaged or could not be recovered altogether. Therefore, the number of bones that could be measured was low in 151 aduits, for whom sex could be determined, the femur, the humerus and the tibio were the most measured bones. in 43,38 and 28 percent of the cases measurement of the respective long bone length was possible.

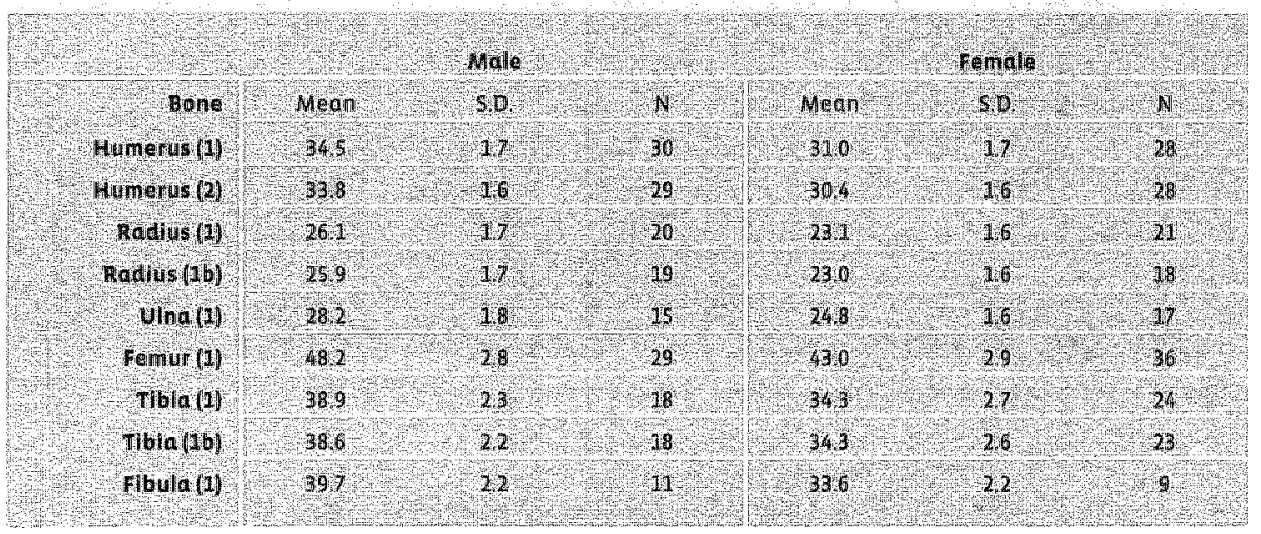

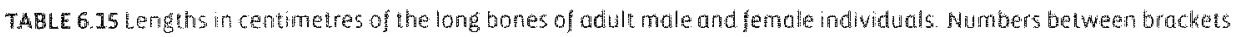
behind the numss of the bones refer to the numeravon of measurements as defined in Martin and 5 alfer 1957 
Sextol dimarphism in the long bone lengths was considerable and statistically significant for all nine dimensions listed in Table 6.15. Therejore, female and male long bone lengths were further andysed independently. As measurements within one type of bone display a strong correlation, the mean of only one measurement per bone is presented below.

\section{Lengths byphase or site}

Comparison of the four samples showed that variation in the lang bone lengths of the upper extremities of the males was marginal. In general the bones from the basilica sample were larger than the bones from the cella and templum samples. Those of the Boschstraat sample were the shortest male individuals. However, the difference between the means of the various samples was never significant. The same was true for the measurements of the lower extremities. In general the mean lengths calculated for the lower extremities of the four samples show the same pattern as was observed for the upper extremities. Again the greatest mean lengths were found for the individuais from the basilica somple.

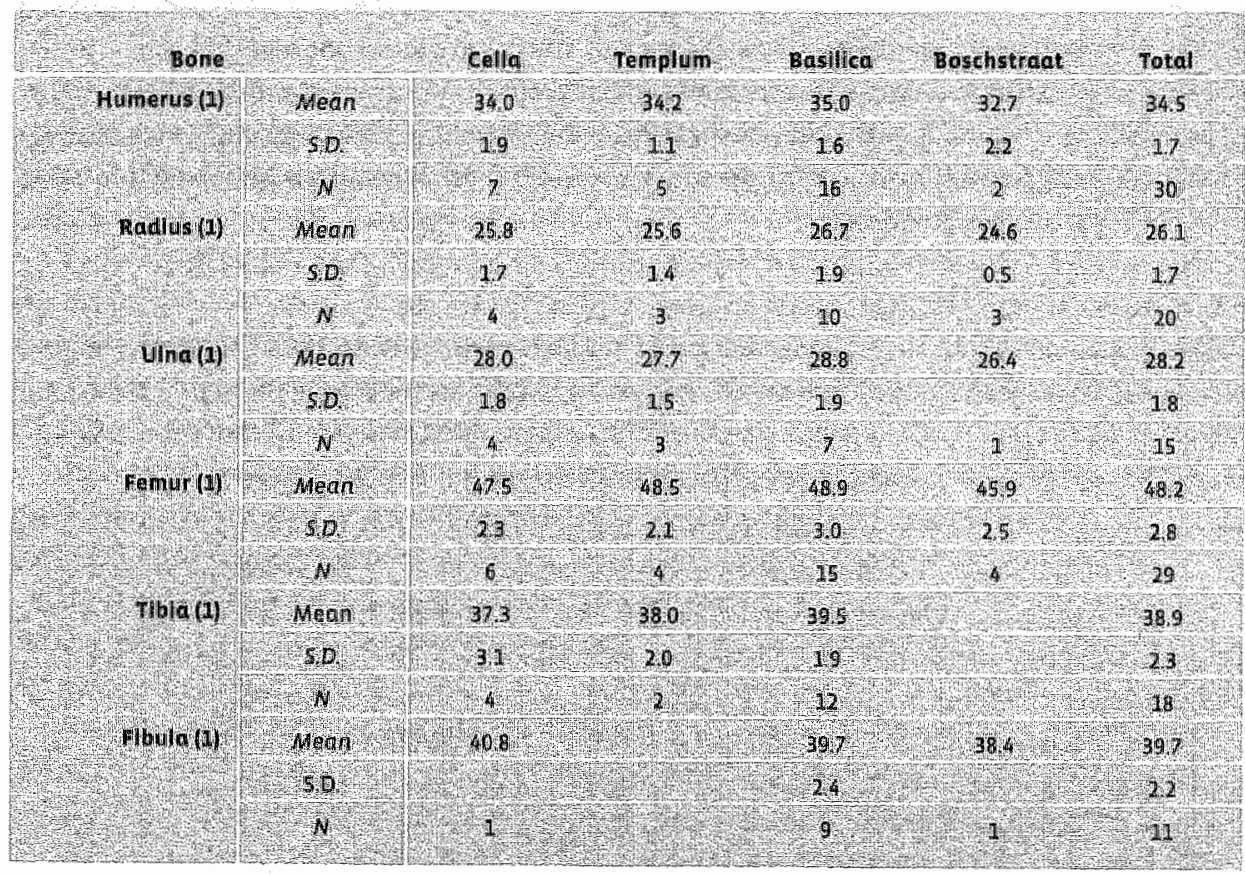

TABLE 6.36 Length in centimetres of the long bones of adtutumales by sample 


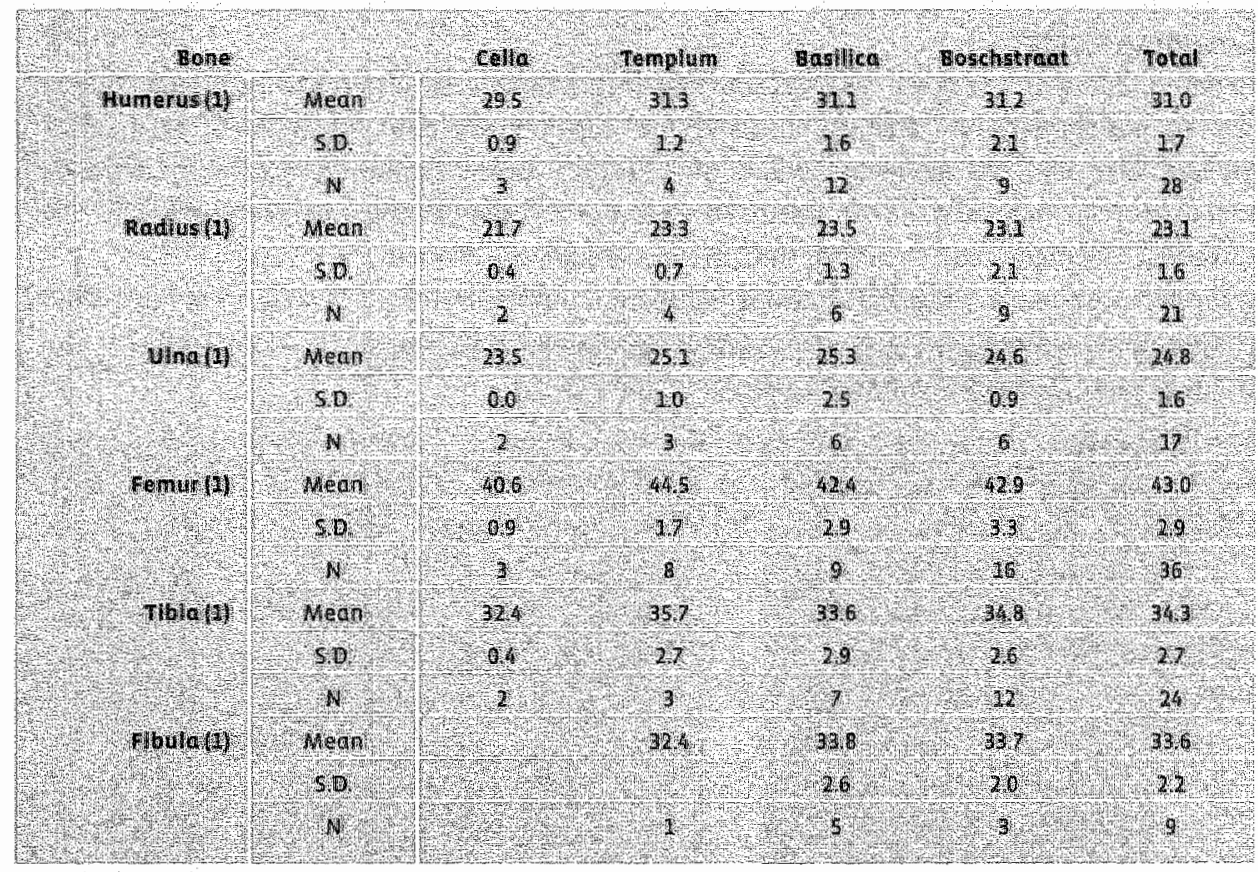

TABLE 6.17 Lengths tr centimetres of the long bones of adult jemales by sample

Among the females the variation in long bone length of the samples was atsolmited. All mean dimensions of the long bones of the cella sample females were smaller than those of females of the other samples. With regard to the upper extremities for the radius lengths, the difference between the means of two samples was statistically significant. Despite the small number of bones that could be measured, the mean maximum length of the radius for cella sample females proved to be substantially shorter than for templum sample females. ${ }^{\text {in }}$ For the lower extremities, the wariation in long bone lengths among the female individuals of the templum sample, the basilica sample and the Boschstraat sample were statistically insignificant. The mean lengths of the femur and tibia calculated for the templum sample and the Boschstraat sample were higher than the means found for the basilica sample. All means calcullated for the cella sample were shorter than the other three samples. In comparison with the mean femur length of the cella sample females, the mean found for the templum sample females was significantly higher. ${ }^{\text {an? }}$

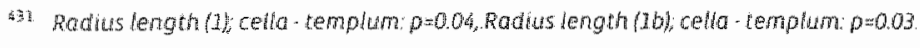

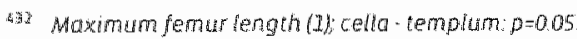




\section{Lengths by status}

In male individuals the mean lengths for higher status categories all surpass the means found for samples of low or intermediate status. For the upper extremities comparison of the means yielded no statistically significant results. Still, as table Table 6.18 shows there was a consistent increase of the mean length with status. For the lower extremities the same trend could be observed. The means calculated for the high status sample exceeded the means for the intermediate sample. These in turn were higher than the means for the low status sample. When the variance was analysed by means of linear regression analysis it appeared that only in case of the femur this trend wos statistically significant.

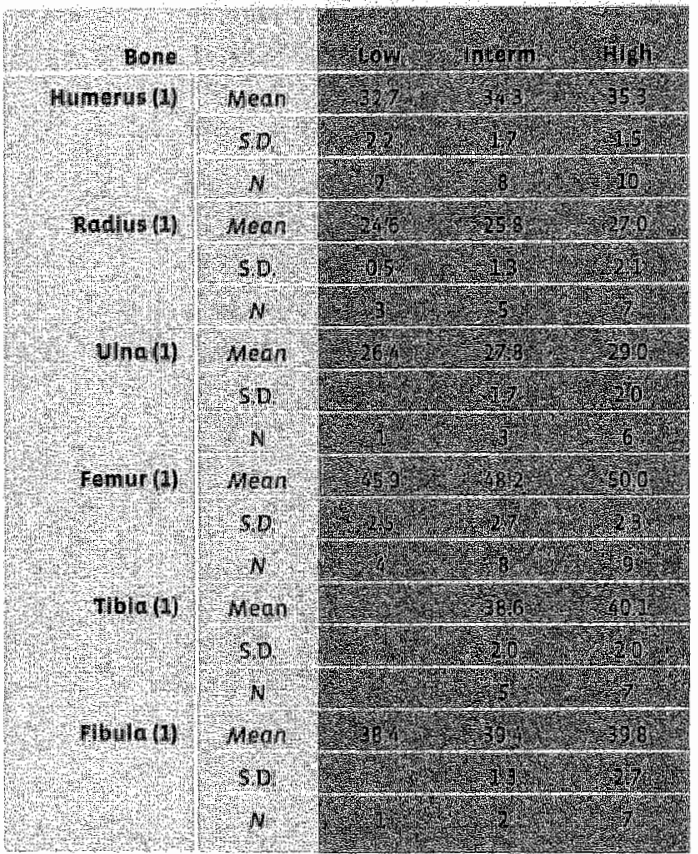

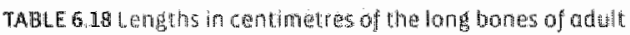
males by status

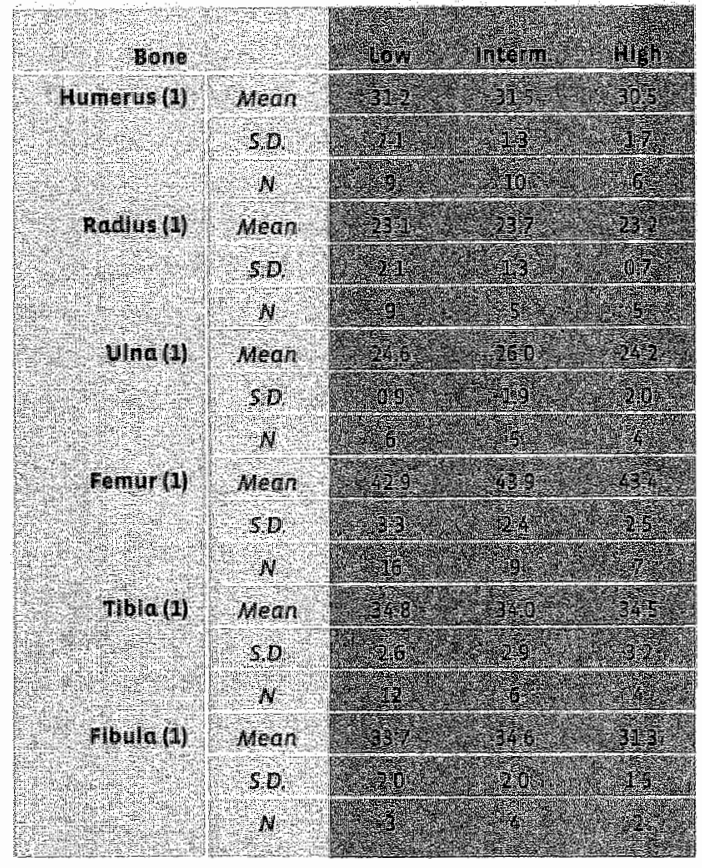

TABLE 6.19 Length in centimetres of the long bones of adult females by status

Comparison of mean long bone lengths of females showed that the means of the three status categories did not vary much. With respect to the upper extremities of female individuals: the highest means were all found for the category of intermediate status. However, the difference between the mean lengths was marginal. The mean long bone lengths in the lower extremities were distributed in what appeared to be a more random way. Unlike the situation found for the upper extremities, for the lower extremities none of the mean lengths measured for the three status categorles was consistently larger than the other.

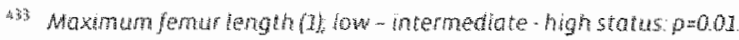




\section{Asymmetry}

For those individuals with both the left and right bones present the difference in length between the sides was analysed for each type of long bone using a paired sample t-test. Asymmetry in the lower extremities was insubstantial and although the left bones were often langer mone of the sides appeared to prevall consistently over the other. Therefore, only the results found for the upper extremities are presented below. When tested to which extent asymmetry carrelated with period or site and status category, variation was found to be insignificant.

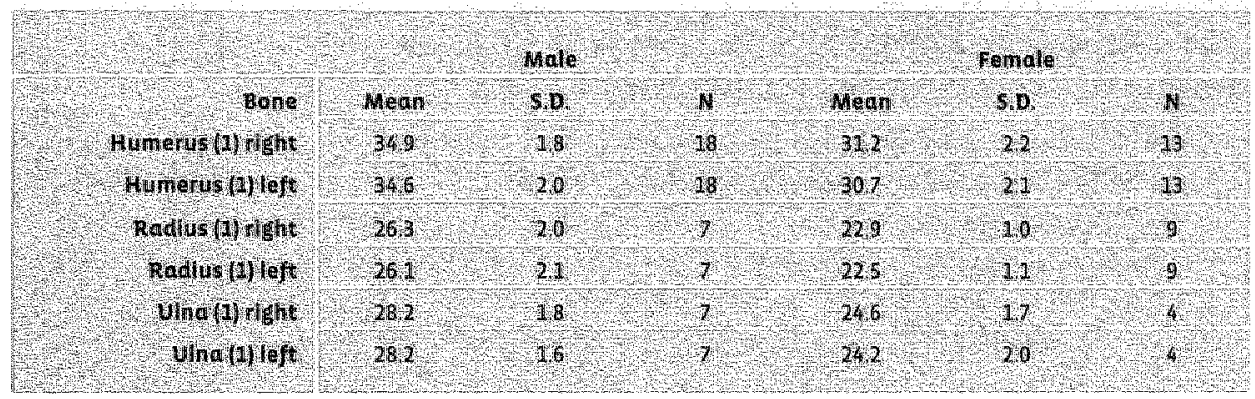

TABLE 6.20 comparison of mean lengths in centimetres of the right and left humerus, radius and wha ir male and

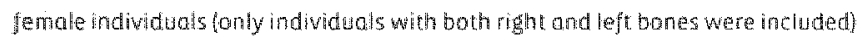

In the male sample (table 6.20) the mean lengths for the right humerus and radius were higher than the means for the left side. Only in the humerus proved this size difference to be statistically significant. ${ }^{434}$ The mean difference between right and left bones was larger in the female sample. In general they also had longer bones on the right side (Table 6.20). 5tatistical analysis indicated that in the female sample the difference was significant both for the bumerus and the radius,

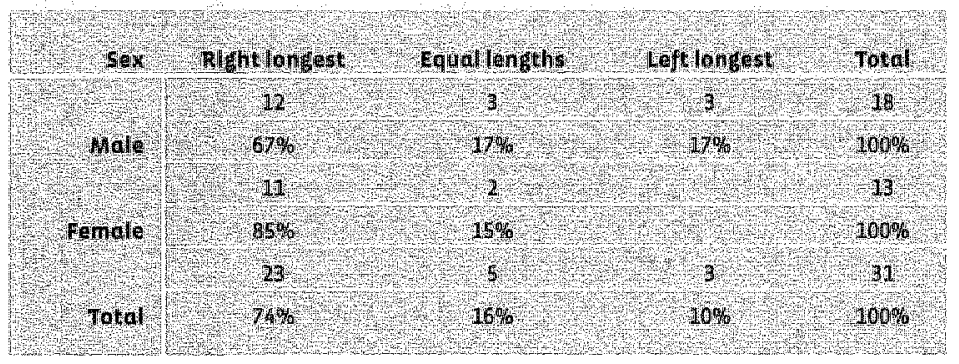

TABLE 6.21 Asymmery in the humerus for mates and jemales

In case of the humerus the asymmetry was further analysed per individual. When categorised by asymmetry it is evident that three out of thirty-one individuals (10\%) had longer

ay: Maximum humerus length (1) Wilcoxon signed ranktest $a=002$

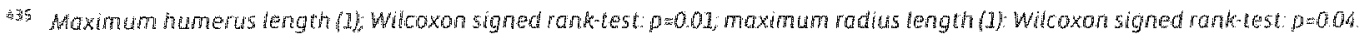


bones on the left side. All three of these individuals were males. Almost equal lengths of the humeri were found in 16 per cent of the sample. A clear majority of nearly 75 per cent of the inspected individuals had a longer right humerus. The wariation between males and femalles in this distribution was not statistically significant.

\section{STATURE ESTIMATION}

The lengths of the long banes of 43 males and 53 females could be used to calculate estimates of stature for 96 individuals. A large difference in mean stature was found between male and female individuals (see table 6.22). This was statistically significant, consequently further analysis of stature occurred separately for males and femalles.

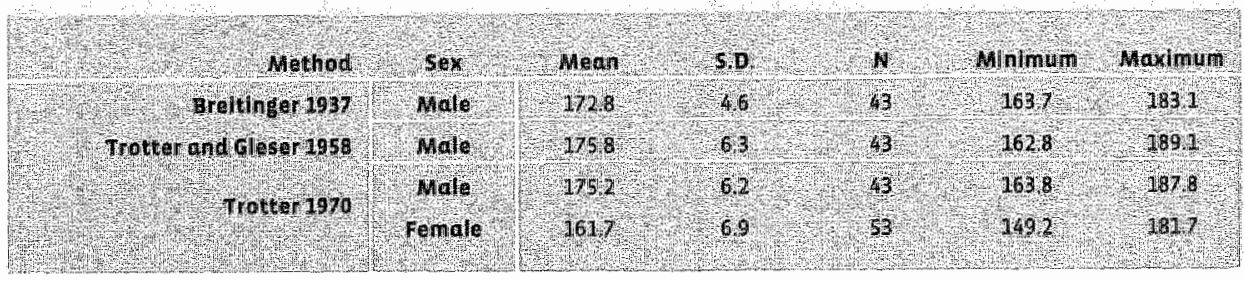

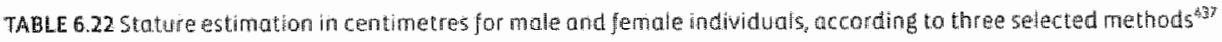

The range for male stature extended to circa 25 centimetres, female stature to circa 32 centimetres. single extreme walues are largely responsible for the width of these ranges. ${ }^{435}$ Comparison of female stature estimated according to Trotter 1970 and male stature estimated according to Breitinger 1937 indicated that the difference between malle and female mean stature was circa 11 centimetres.

When analysed by sample, wariation in the stature of male individuals was moderate. However, the first three samples (representing subsequent chronological periods) displayed an increase of mean stature with time. Still, when statistically tested this increase did not prove to be significant. Significant differences among the male samples existed between the malles from the Boschstraat silte and bath the templum sample and the basilica sample. Among the female individuals no trend of increasing stature with time was obserwable. The mean stature

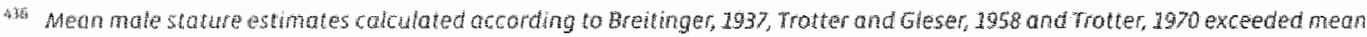

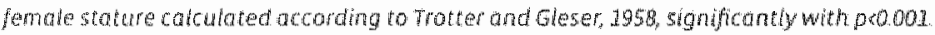

w3 Inchaded this table is the mean staturestimated on the basis of the formulas for white mates and white females as published by

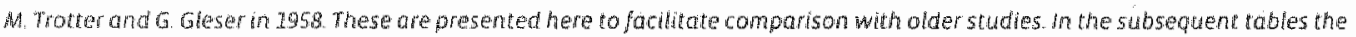

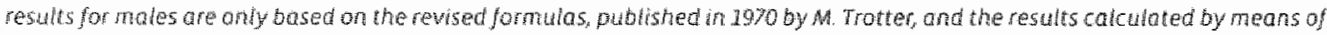

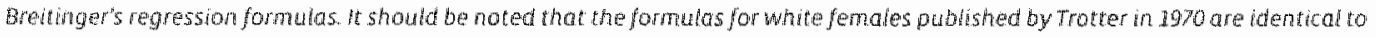
the formulas puth shed by Troter ard Gleser in 1958

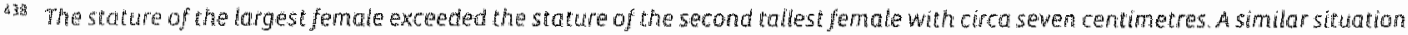
was found for the minnum statwe for mates whete the shorrest male was seven centimetres shorter than the second shortest wate.

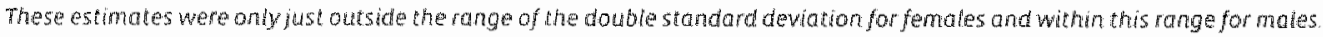

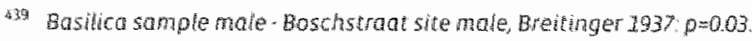




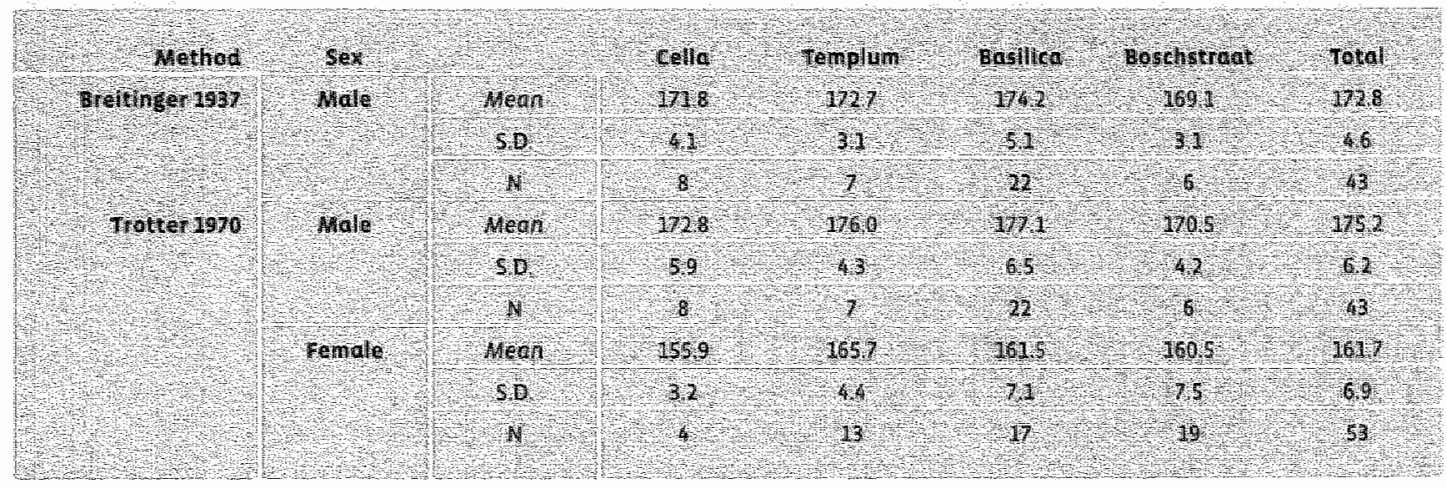

TABLE 623 Stature estimacion in centimetres for male and fermale individuals by sample

calculated for females from the templum sample clearly surpassed the other samples. When mean female stature for the templum sample was compared with mean stature calculated for the cella sample and the Boschstraat sample the differences proved to be statistically significant. ${ }^{400}$

Another aspect is the variation in sexual dimorphism reflected in the mean difference in stature between the sexes. The difference in stature between males and females for the sample as a whole was circa 11 centimetres. Both for the cella sample and the basilica sample a greater difference was found viz. 15.9 and 12.7 centimetres respectively. Between the males and females of the templum sample and the Boschstraat sample the dimorphism in stature was less prominent. For the templum sample the difference in stature between the sexes was only 7.0 centimetres and for the Boschstraat site 8.6 centimetres.

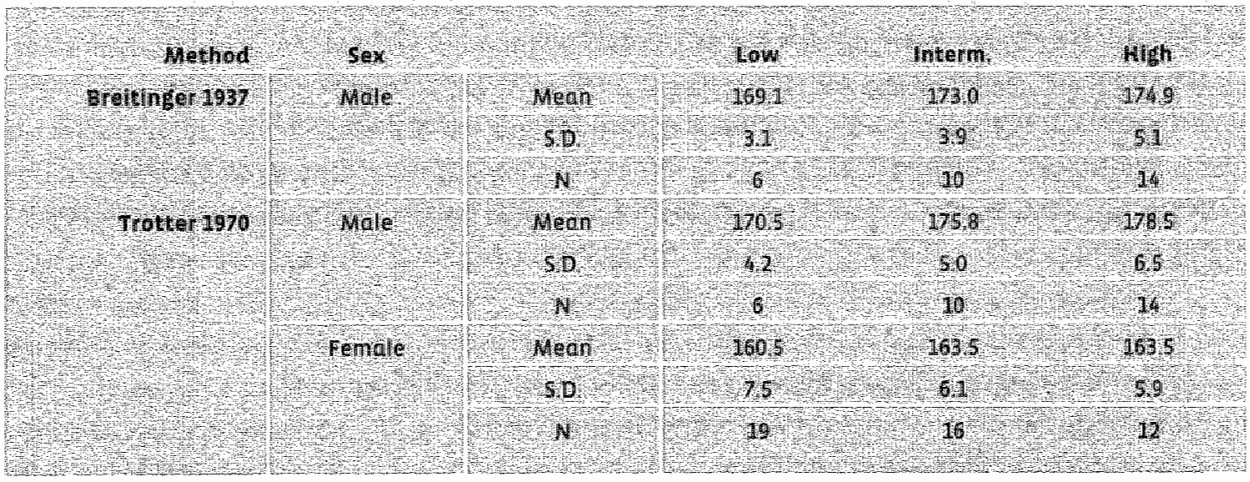

TABLE 6.24 Sitature estimation in centmetres for male and femole individuals by status.

Table 6.24 sthows different trends in stature by status for males and females. In male individuals mean stature for each category is higher when status is higher. Analysis by means of

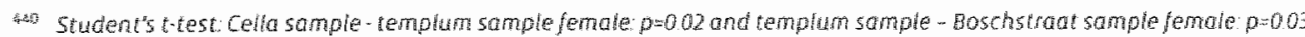


linear regression indicated this trend in males was statistically significant. ${ }^{43}$ For fenales a larger stature was found for individuals of intermediate status when compared with individuals of low status. However, mean stature calculated for both the intermediate and thigh status categories was equal. ${ }^{4 / 2}$ These deviating trends also dictated the sexual dimorphism in stature. The difference between mean male and female stature imcreased with status. in the low status category the difference was $8.6 \mathrm{~cm}$; in the intermediate and high status category it was 9.5 and 11.4 centimetres respectively.

\section{MON-METRICAL YARIATION}

Six non metric traits, listed in the table on the next page, could be inspected in sufficient numbers to allow for comparison between various samples. In general no strong correlation was found between observed non-metrical variation and sex. An exception is the prevalence of a septal aperture of the left humerus (foramen olecrani). Significantly more females were found with this trait than malles. ${ }^{43}$ Metopism was also found mostly among women. Still, statistical andysis of the distribution of this trait did not indicate there was a significant correlation between metopism and sex.4. The results are not displayed separately by sex would lead to toa small sample sizes. In case of the prevalence of septal apertures it has ta be kept in mind that the proportion of males and females in the samples may bias the percentages presented in the tables.

Variation in the prevalence of nom-metric traits among the samples was statistically not significant. Also no evident chronological trends were observable. However, several traits showed considerable variation in their prevalence per sample. For example, both lambdoid ossicles and septal apertures were found more often in the cella sample than in any other sample. The individuals from the Boschstraat had the highest percentage of metopism and assicles at lambda. In the templum and basilica samples the prevalence of mast traits was more or less equal to the prevalence in the sample as a whole.

When the non-metric traits were analysed by status category it could be abserved that there was no relation between specific traits and status. The only exceptions were lambdoid ossicles. The prevalence of lambdoid assicles was higher in the intermediate status category than in the high status category. This difference in prevalemce between the two categories was statistically significant:

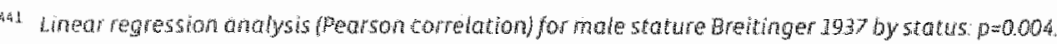

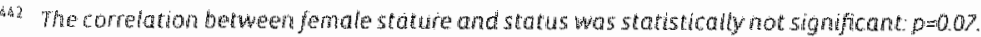

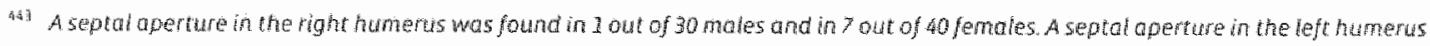

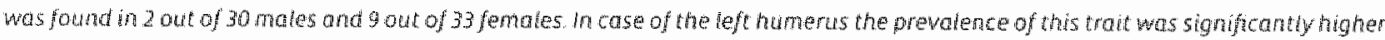
in fermates thar in mores femole - mate $p=0046$.

atio Male - femala $p=007$

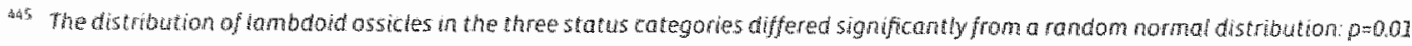
Statistical andyss also indicited that the difference in distibution between the internediate status and high status was significant $p=0.03$ 


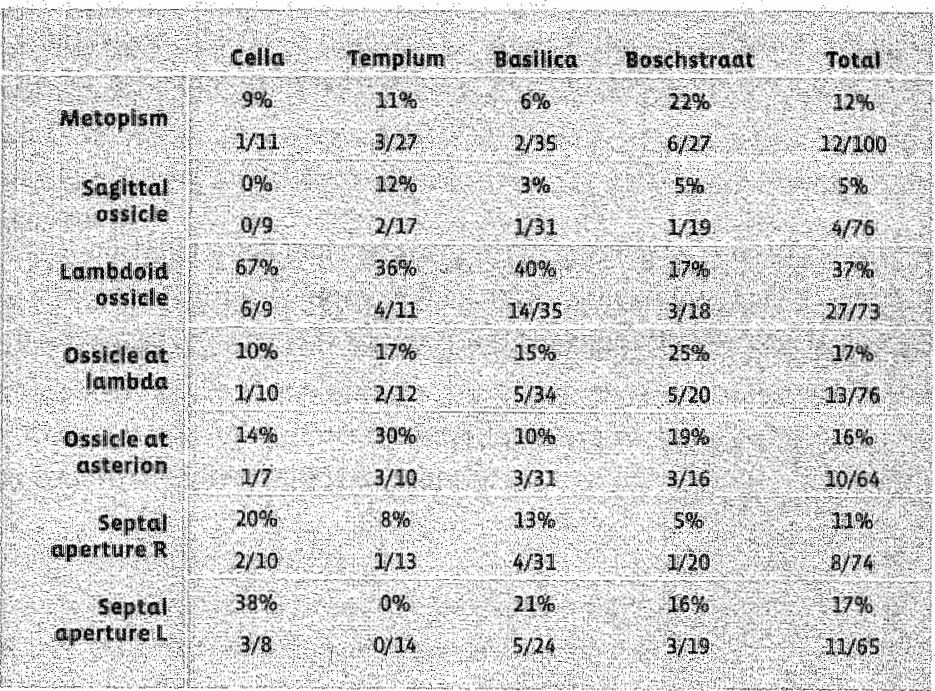

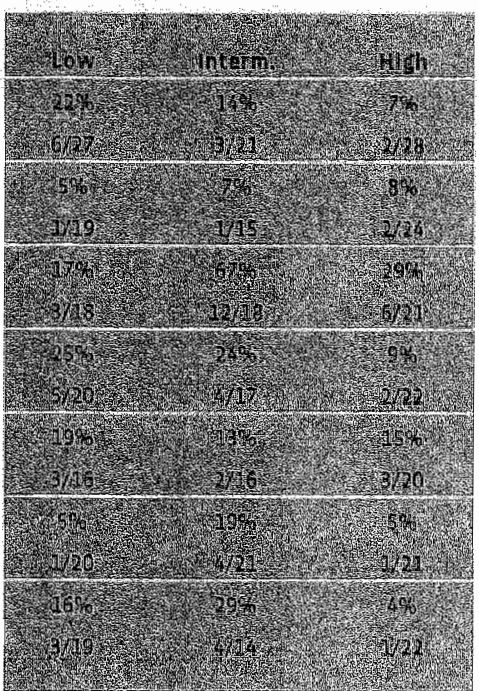

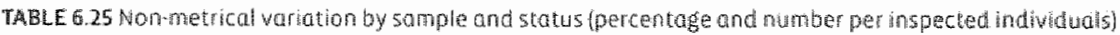

\section{HEALTH}

\section{STRESS MARKERS}

\section{Harris lines.}

The tibiae of 48 adult individuals were complete enough to be inspected for the presence of Harris lines. ${ }^{546}$ Of these 48 individuals 21 were of malle sex, 24 femalle and 3 were of indeterminate sex. Beside type I, II and III lines, remnants of Harris lines were visible on the $x$-rays. Postdepositional bone loss had damaged 60 lines. Due to the bone loss the length of the limes did not extend half way into the medullary cavity. Therefore these lines did not comply fully with the criteria defined by Maat for type I, 11 and 111 lines. ${ }^{4 k 7}$ With respect to their density these incomplete lines were less obtrusive than moderate or strong lines and were considered to represent damaged type l lines. Therefore, these incomplete lines have been included in the counts and calculations as type llines. Because only complete tibiae were $x$-rayed, it was possible to calculate the age of formation for all lines. The results related to the presence of Harris lines will be presented in three forms: counts and percentages of individuals with and without Harris lines, the mean number of lines per indivilual and the mean formation rate of Harris lines per sample or status category. Statistical anallysis indicated that the prevalence of Marris lines in adult individuals was not associated with sex. Also no association with age was

\footnotetext{
Wh Definitions and method's are described in chapter 5

4.t? Mat, 1984

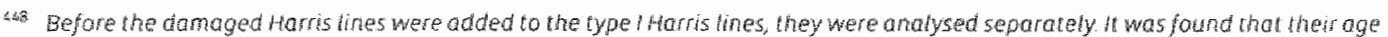
distribution and prewtence was wery similar to bpel lines.
} 
found. When the 20 to 40 and the 40 to 60 years intervals were compared, the results indicated that no significant difference in the prevalence of Harris lines existed between these age categories.

\section{Presence of Harris lines}

Judged by the presence of type f to lll lines, 81 per cent of the inspected individuals had one or more Harris lines. Statistical analysis of contingency tables for the presence of the three types of Harris lines showed that only the correlation between the presence of type II and type IIIl limes was statistically significant. as

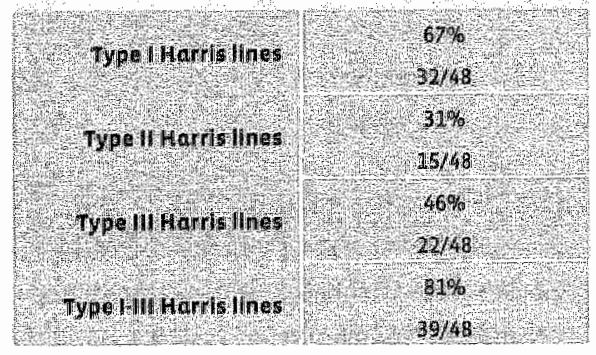

TABLE 6.26 Various types of Marris Ines in ha odult indiwiduats

With respect to type I lines, inspection of the mean number of lines, the formation rate of lines and the age of formation provided no indication of any correlation of these types of lines with sex, chronological sample or status. Ther efore, the data related to lype I lines were not presented separately in the tables below. They are included in the calculations for all line types.
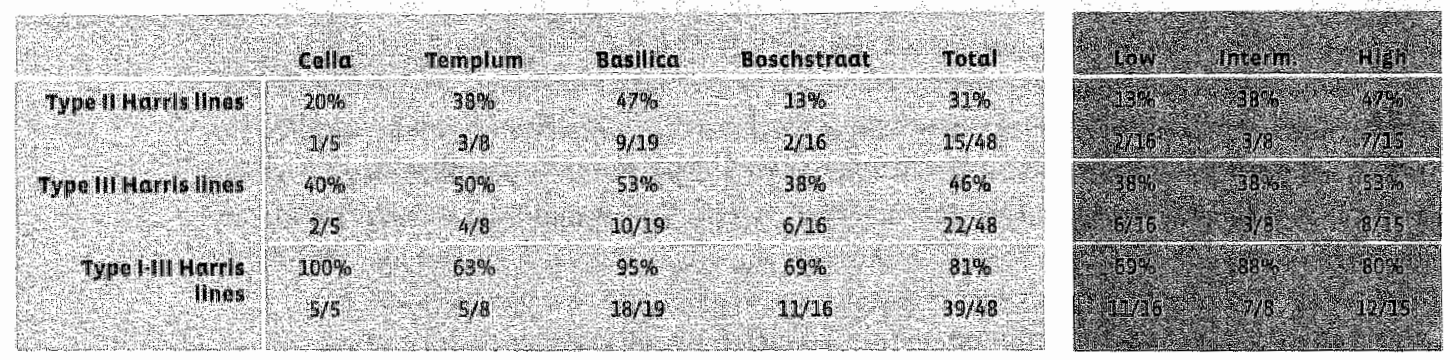

TABLE 6.27 Harris lines in adult individuals by sample and stohus

Table 6.27 shows that the number of individuals with type Ill and type lil lines increased from the cella phase to the basilica phase. Hawever, analysis did not provide support that this trend

was Both the mean number of lines and the mean formation rates were more or fess egtal there was also no trend indicating that less

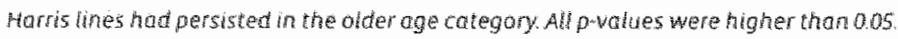

tho The ll lines - type thr kines 0 ool. 
was statistically significant. ${ }^{5.5}$ Judged by the prevalence of individuals with type I to III lines the basilica sample appears to be the most affected sample. The comparatively low prevalence of individuals with type 11 lines in the Boschstraat sample is remarkable. When the basillica and Boschstraat samples were compared the number of individuals with type ll lines was signiffcantly higher in the basilica sample. ${ }^{452}$ For type lll lines the variation between the samples was limited.

Status-related variation in the percentage of individuals with Harris lines could be examined in 39 individuals. Generally the highest percentage of indiwiduals with Harris lines was found for the high status category. Comparatively, low percentages were found for the low status categary. For type II lines and type I to III lines the trend indicated that the number of indiwiduals with Harris lines increased with status. In case of type II Harris lines this trend proved to be statistically significant. ${ }^{453}$

\section{Mean number of Harris lines}

In totall 144 type I to $1 / 1$ Harris lines were counted. The mean number of lines per individual was tested for possible influences of sex and age at death. No significant correlation between these factors was found. ${ }^{\text {st }}$ Variation in the mean number of thes was also examined for a possible correlation with samples or status. No significant variation in the results was observed. Further comparisons were made on the basis of formation rates.

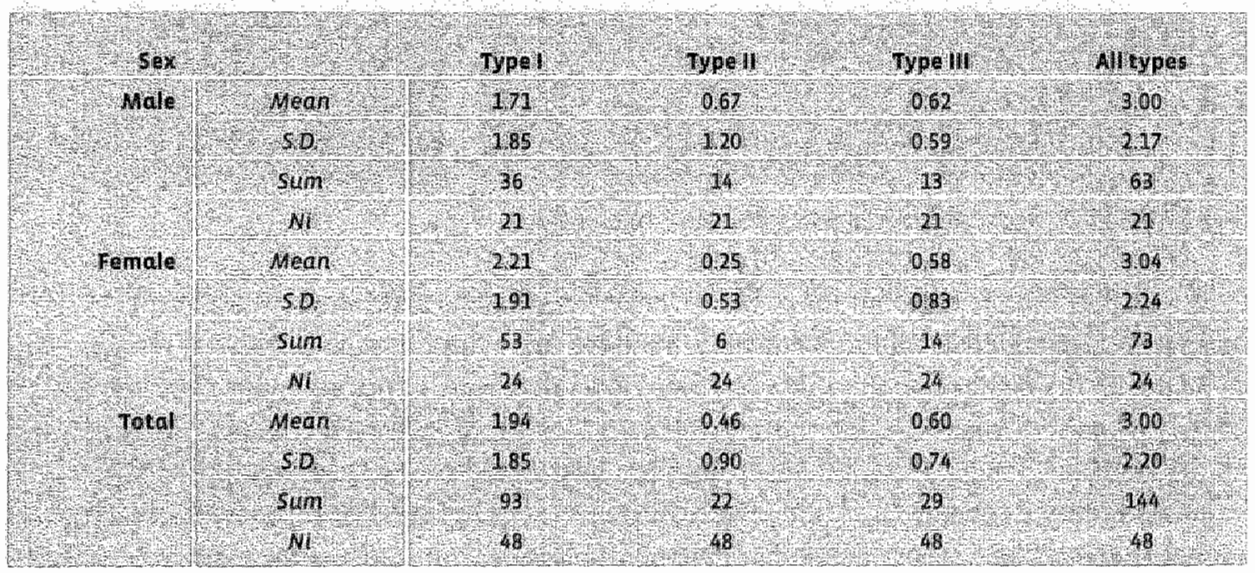

THALE 6.28 Mean number of Harris lires per indiwdud, in the botlom section of the table, "total", rumbers ore higher" because of the incluston of unsexed individuals

45. When tested whth chisquare far trend for the celda, templum and basilica sample the lowest p walue was found for the distribution of indrutduats with type il lines: $p=027$

452 Basilica sample- Boschstroot site: pw004.

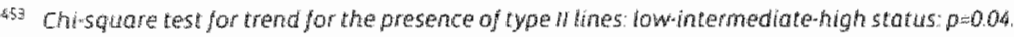

wh The lagest relative difference was observed for the mean number of type hid hris lines per individual for females the mean number of this type of lines was less thon half the mean for moles. 
Formation rates of Harris lines per year of individual growth

When compared by sample the formation rates did not wary much. For all counts the cella sample and the templum sample display similar rates. The formation rates found for the basilica and the Boschstraat samples were generally higher. The rate calculated for the Boschstraat sample was considerably lower than the rate of the basilica sample only for typell lines. There was a tendency for the formation rates of type ll lines separately, and for all lines together (type $1, i l$ and $\mid 11)$, to increas diachronically from the cella phase to the basilica phase. However, this trend was statistically not significant. With respect to the variation in formation rates by status, minor differences between the categories were also observed. Apart from the rates for type il ines all formation rates were more or less equal for the three status categories. The formation rate for type ll lines was found to increase with status. Statistically the correlation between the mean formation rates of type II Harris lines and sitatus was significant.

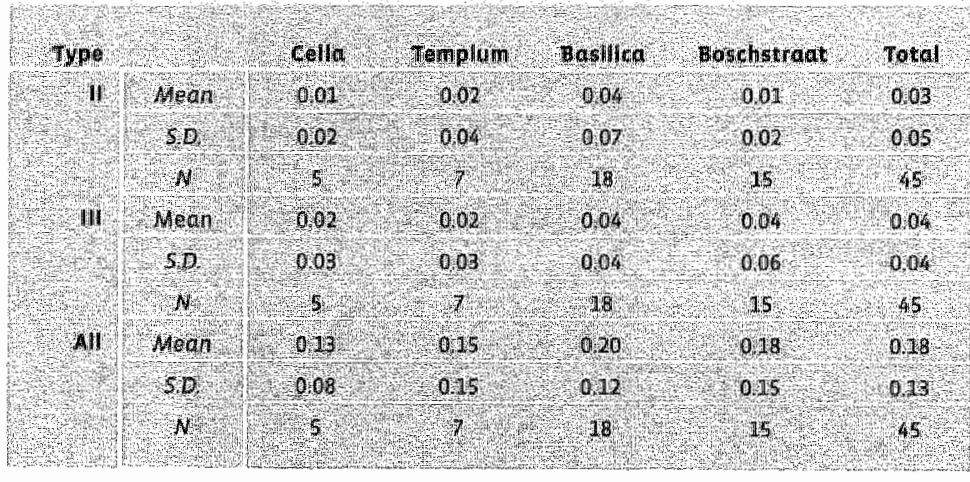

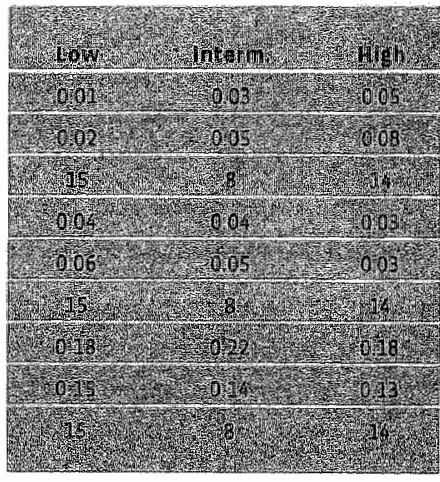

TABLE 629 formation rote of Harris lines by sample and status

Analysis of the age of formation of Harris lines was based on a database in which all 1.44 Harris lines were filed as separate entities. Therefore the results in table 6.30 do not represent Individuals. The numbers in this table represent individual Harris lines categorised by 1 -year age intervals based on their age of formation. Harris lines were found in 39 individuals: 18 males (63 Harris lines), 19 females (73 Harris lines) and 2 unsexed individualls (8 Harris lines). The table shows that there was a difference in predilection of the age of formation of Harris lines between male and female individuals. In females the majority of lines formed from the eighth up to and including the twelf fth year. In males the periad of increased Harris line formation ranged from the tenth up to and including the fifteenth year ish For both sexes the main period of formation of type III Harris lines seems to have been from birth to the fourth year. The formation of type I and II Harris was found to occur later in the growth perlod, viz. from the sixth up to and including the fifteenth year of age.

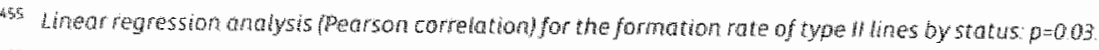

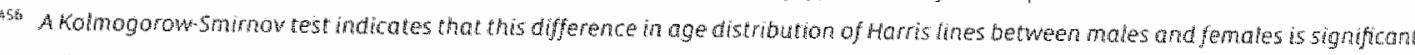
$p=0,0$
} 


\begin{tabular}{|c|c|c|c|c|c|c|c|c|c|c|c|c|c|c|c|c|c|c|}
\hline & & & & & & & Aye & rom & tio & 114 & 48 & trats & & & & & & \\
\hline $74 \mathrm{PS}$ & sex & 1 & 2 & 3 & 4 & 5 & 6 & 17 & 8 & 9 & 10 & $\mathrm{an}$ & 12 & 48 & 14 & 43 & 16 & Trokal \\
\hline & Male & 3 & म & & & 3 & 4 & 3 & 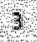 & 2 & 3) & 4 & 2 & 3 & s. & 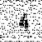 & 1 & 36 \\
\hline & Jemale & ] & $\mathrm{X}$ & & 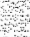 & 1 & ? & 2 & 8 & 9 & 8 & 7 & 8 & 4 & 1 & & & 57 \\
\hline II & Hale & & & & & 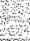 & & 1 & 12 & 3 & 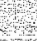 & 1 & 3 & 3 & 2 & & & 16 \\
\hline & Prmale & es & 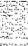 & 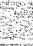 & & 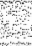 & & & 1 & 1 & 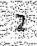 & 2 & & & 4 & & & 6 \\
\hline H) & Male. & 8 & 3 & 4 & 1 & 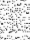 & & 1 & & 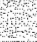 & & 4 & 2 & & 1 & & & 13 \\
\hline & temole & 1 & 3 & 2 & 1 & 1 & & 2 & 1 & 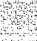 & & & 3 & 1 & & & & 44 \\
\hline total & Mare & 1 & 3 & 4 & 1 & 4 & I & 1 & 5 & 3 & ut & 4 & 5 & 8 & 7 & 6 & M & 163 \\
\hline & Female & 2 & 3 & 2 & 1 & 2 & 3 & 4 & 10 & 10 & 10 & 12 & 9 & 4 & 4 & & & 13 \\
\hline & Total & 6 & 6 & 7 & 9 & 2 & 4 & 1 & 15 & 13 & 19 & 36 & 16 & 44 & 18 & & 9 & 14 \\
\hline
\end{tabular}

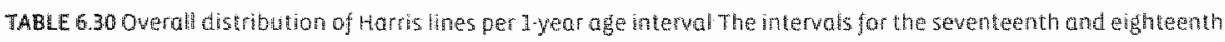
year huve not been inchded in the table os nolimes seem to have formed during those intervals.

\section{Horris lines and stature}

To investigate a possible correlation between the occurrence of Harris lines and adult stature scatter plots were made, depicting stature and the total number of Harris lines for each indiwidual.

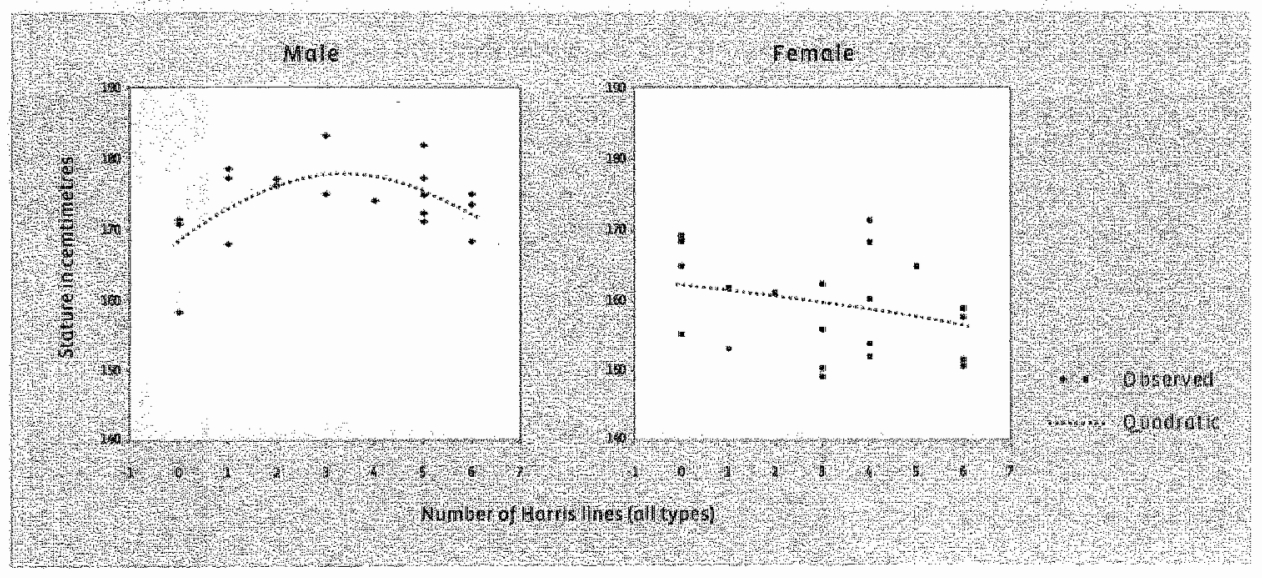

FIOURE -7 The lefr chart displays the correlation between stature and the number of Harris lines for mole individuots.

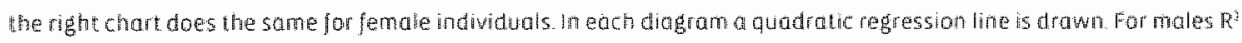
is 0.498 and for females $0.165^{457}$

Figure 6-7 illustrates that with respect to the correlation between the number of Harris lines and stature per individual, the trend in females deviates from the trend in males. In malles, Harris lines show a positive correlation with stature up to indiwiduals with three Harris lines.

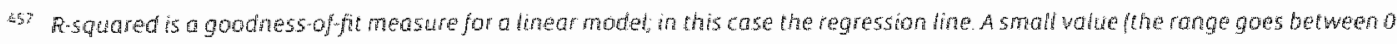
and y indicates that the model line does not fit the dota well. 
More than three lines were assaciated with slightly under awerage stature. Female individuals with a higher number of Harris lines tended to be shorter. This dimorphism was also found when stature was compared between individuals having formation rates of Harris lines lower than the mean and individuals with higher formation rates. The mean stature of females with low formation rates of Harris lines was found to exced the mean stature calculated for females with higher formation rates. For male stature the opposite was true. Males with an above average formation rate of Harris lines were in general slightly taller. ${ }^{458}$

\section{Enamel hypoplasia}

A total of 90 adult individuals were inspected for the presence of enamel hypoplasia. Enamel hypoplasia is a condition representing a period of deficient enamel formation during growth. It is visible as a decrease of the enamel thickness on the crown surface. Most cases of enamel hypoplasia were of the linear type, viz. horizontal grooves around the circumference of the crown. ${ }^{\text {t59 }}$ Two individuals had more serious additional pit-type defects. Plane-type defects, characterised by malformation or complete absence of enamel af large sections of the crown surface, did not accur. In 27 ( 30 per cent) of the inspected individuals the hypoplastic defects were of a mild to moderate nature. They were difficult to detect macroscopically as the defect was only superficial. Furthermore six individuals ( 7 per cent) had defects that were more marked, wiz. easily detectable lines. ${ }^{460}$ None of the individuals had severe lines with missing enamel. Na correlation was found between enamel hypoplasia and sex or age.
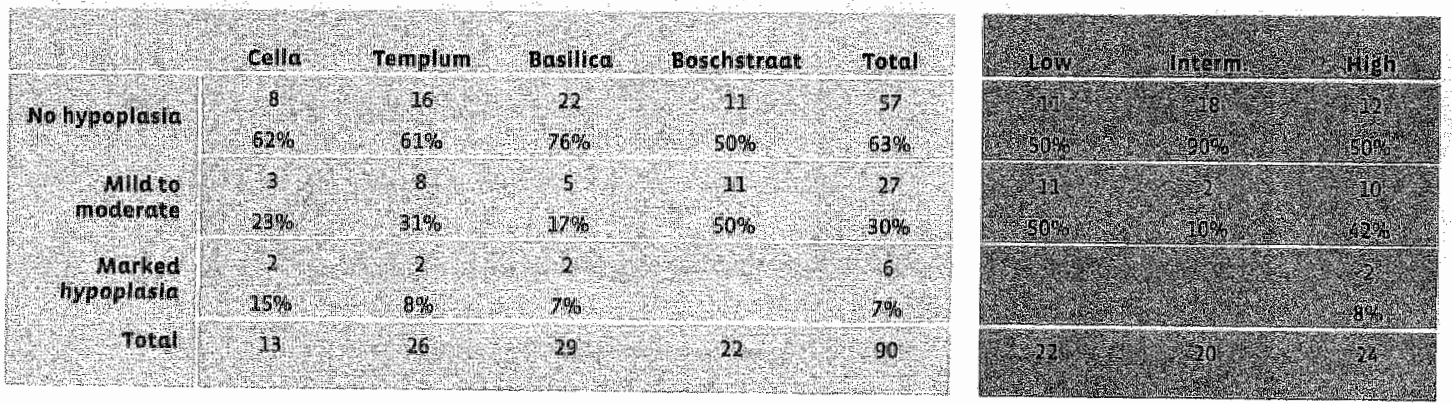

TABLE 6.31 Ename hypoptasia in adult ind widuats by sample and status

Table 6.31 shows the occurrence of individuals with enamel hypoplasia in the four samples. Compared to the other samples the individuals of the basilica sample were less affected. For the individuals of the Boschstraat sample the opposite was found. In that sample the percentage of

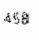

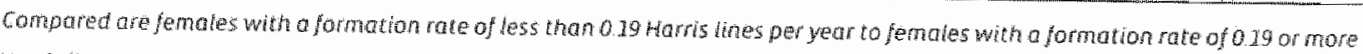

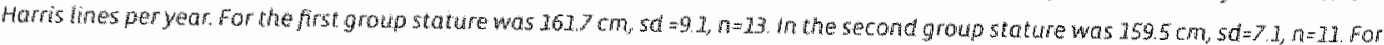

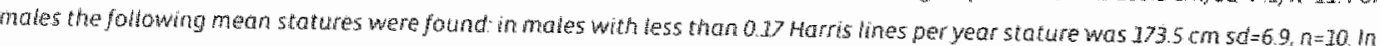

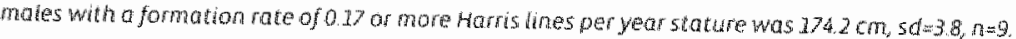

fist Hen, 1996

450

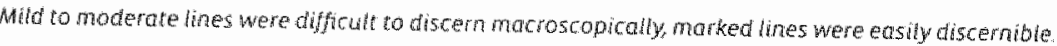


individuals with enamel hypoplasio was 13 per cent higher than the mean. Still, this variation was not found to be statistically significant.

Among the three status categories statistically significant variation was found for the distribution of individuals with enamel hypoplasia. In table 6.31 the lowest percentage of individuals with enamel hypoplasia was found for persons of intermediate status. Both in the low and the high status categaries significantly more individuals were found to have enamel hypoplasia. ${ }^{463}$ When the presence of enamel hypoplasia was tested for correlation with the presence of Harris lines no statistically significant results were obtained.

\section{Cribra orbitalia}

The orbital roofs of 102 individuals (nom-adults included) were inspected for the presence of cribra orbitalia. Scored as cribra orbitalia were all orbits with multiple pits in the interior. superior surface of the orbit. In the Maastricht sample na cases with expansive new bone formation in the orbits were found. Comparison of the prevalence of cribra orbitalia among the non-adults and the adults showed that the percentage of non adults with this condition was only slightly higher. Amang the non-adults 18 per cent (4/22) had cribra orbitalia, among the adults 14 per cent (11/80). ${ }^{462}$ In Table 6.32 only the data on adult individuals are presented. ${ }^{463}$ No correlation between sex and cribra onbital a was found in the sample as a whole, allowing the combination of results for males, females and unsexed individuals in the tables.

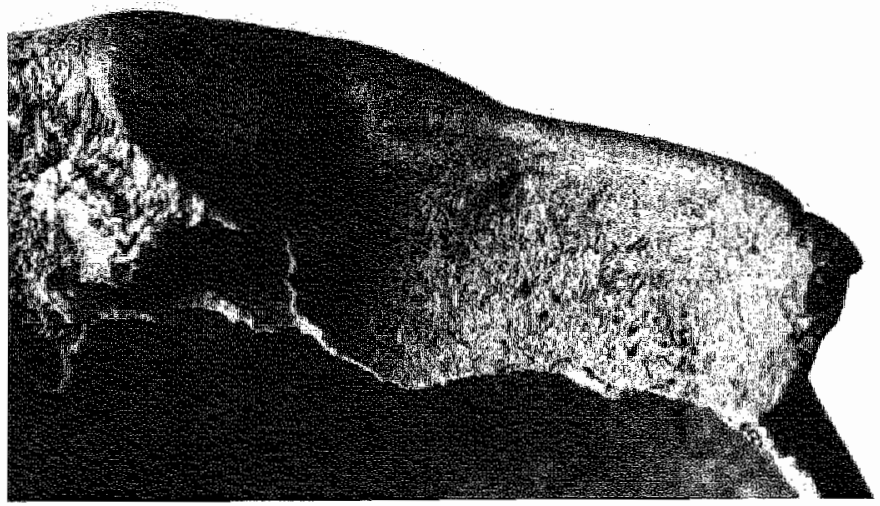

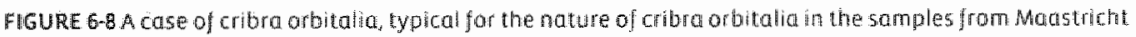
(photograph R. Painhuysent.

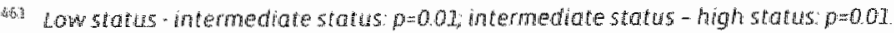

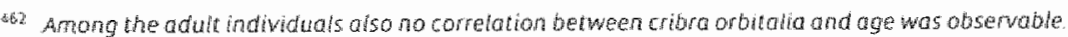

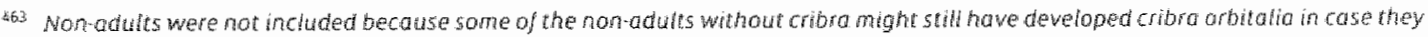
nod hed longer. Whereas the prevalence among aduls represents in theory the total rumber of oses deweloped owing the

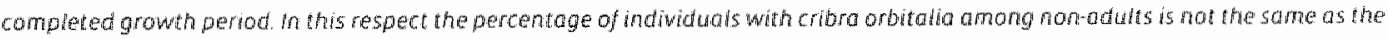
percentage catculated for adults

sas Moles 16 percent $16 / 97)$ and fameles 13 percent $(5 / 40)$. 

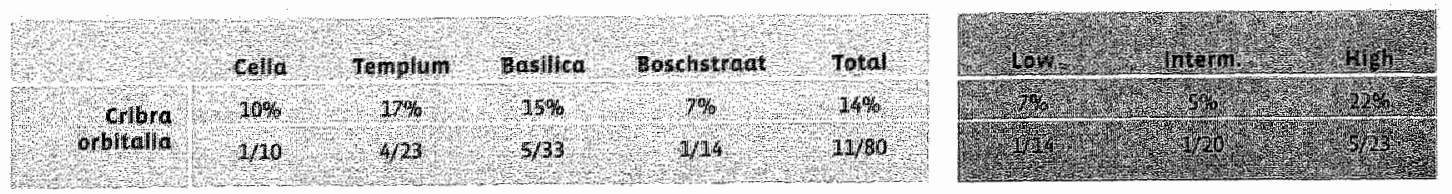

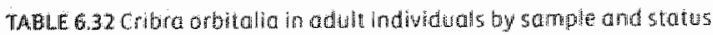

Table 6.32 illustrates that the percentage of individuals with cribra orbitalla ranged from 17 to 15 per cent for the templum and basilica samples. For the preceding cella sample and the contemporaneous Boschstraat sample lower percentages were calculated. In contrast with the distribution of individuals with cribra orbitalia by sample the distribution by status category was characterised by langer differences among the groups. When categorised by status, the cases of cribra orbitalia occurred mostly in the high status category and less in the intermediate status category. Still, calculation of Pearson's chi-square for the intermediate and high status category indicated this deviating distribution pattern was not statistically significant. ${ }^{\text {s.5 }}$

\section{PATHOLOGY}

The description of pathological conditions is limited to types of pathology found in frequencies that allowed for comparison between the samples. An exception was made for those cases in which the specific type of pathology could yield valuable information on the hed th situation.

\section{TFAUMAA}

\section{Fractures}

All bones were inspected macroscopically for the presence of fractures. The diagnosis of healed fractures was primarily based on the presence of a change of contour of the bone and deviation of the axis of long bones. Both bones with evident healed fractures and bones for which the presence of a well-healed fracture was suspected were $x$-rayed. Broken bones displaying no sigins of callus formation were also examined to ascertain whether the breakage of the biones had occurred during life or after deposition of the body. No bones were found to display perimortem, unhealed fractures. On the basis of the brittle appearance of the edges of the fracture and the direction of the fracture lines all fractures that might possibly be peri-mortem fractures were identified as post-mortem fractures. This diagnosis was further supported by the fact that most unhealed fractures showed a distinctive bright colour of the surface of the fracture las opposed to the darker colloured surface of the periosteal surfoce). Therefore, it could be ascertained that many of these past-mortem fractures were the result from damage during the recovery or post-excavation treatment of the skeletal remains. 


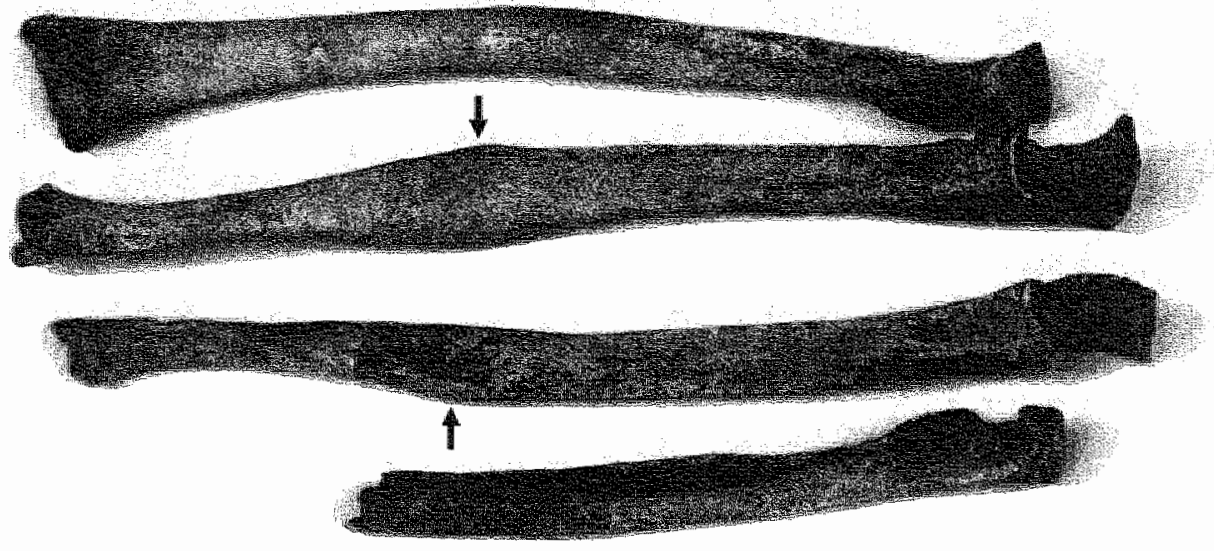

FIGURE 6-9 Healed fracture of both the right and left ulna ${ }^{\text {a.to }}$ (photograph. Fanthusen)

A total of 24 individuals had contracted fractures during life (circa $10 \%$ of all individuals). Six of these individuals had two fractures. In total the number of healed fractures was 30 . One of the individuals was younger than 20 years; all others were older ${ }^{567}$ Male individuals had more fractures than females, viz. 13 males (circa $20 \%$ of the males) and 8 females (circa $10 \%$ of the females). The percentage of individuals with fractures in the 20 to 40 years interval and the 40 to 60 years interval was more or less the same, wiz. 14 and 15 per cent respectively. For the 60 to 80 years interval the percentage of individuals with fractures was much higher, viz. 38 per cent. However, the total number of individuals in this last age interval comprised only eight persons. and the variation in prevalence among the age categories was statisticaliy not significant. In the case of healed fractures of long bones the type of fracture was determined in co-operation with consulted specialists. Most fractures were either oblique or transwerse fractures (11 and 10 cases respectively). Two cases were diagnosed as spiral fractures. Distribution of the fractures with respect to the side of the body was almost equal, viz. 13 on the right side and 11 on the left side.

45. Individual rumber $13-106$ a jemale aged between 3 and 40 years from the boschstrat site

sh Servos site 50902 , bostico sample, sex unknown, age between 25 and 20 years frocture of the weft wha 


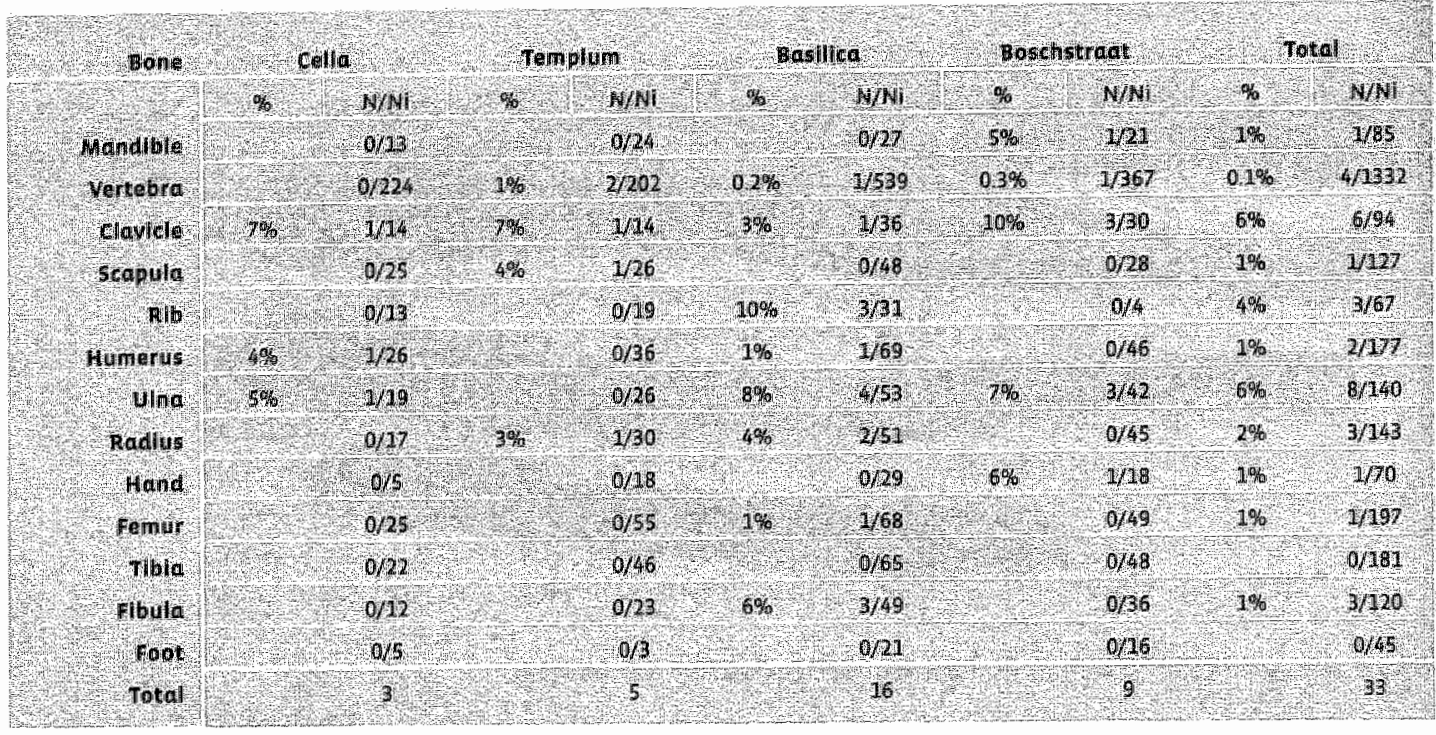

TABCE 6.33 Frequencies of healed frat tures by sample Bones of the hand and foot are included in the table as ar assemblage of bones. Represented are fractured oones on parts of the sketerom as a percentage of the total number of that bone or part of the skeleton inspected in adutt indw duals. In all cases right and left bones were found in simiar quantives. "figh" is the number of healed fractures and "Wi" is the number of bones or parts of the skeleton thot could bé inspected.

The distribution of the fractures within the skeleton was analysed on the basis of all 33 fractures found in adult individuals. With 14 fractures ( 48 per cent) the bones of the upper extremities were most often affected. Second carne the shoulder girdle with seven fractures (24 per cent). Both the lower extremities and the trunk were involved four times (14 per cent each). One fracture was found to have affected the skull ( 3 per cent). When the distribution per type of bone is considered, most fractures occurred in the long bones, viz. 17 fractures. Three individuals: had fractured ribs and another three had a fracture of the vertebral arch. The other fractures were contracted in the spinal process of a thoracic vertebra, the glenoid cavity of a scapula, a mandibular condyle and the os capitate of the right hand. No statistically significant carrelation was found between the type of bone that was fractured and the sample or status category. 5 till, fractures of the ribs as well as fractures in the lower extremities were found exclusively in individuals from the basilica sample. With a total of seven, these fractures made up almost half the total number of fractures found in the basilica sample. Fractures of the lower extremities and ribs were found almost exclusively among male individuals: six out of seven fractures were seen in five male individuals and one in an unsexed individual.

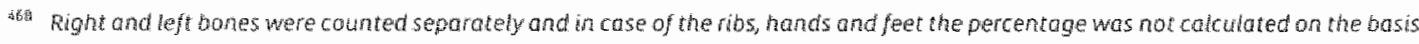
of thdidual bones but on ases in which ribs or bones of the hand ond feet couth be inspected. 


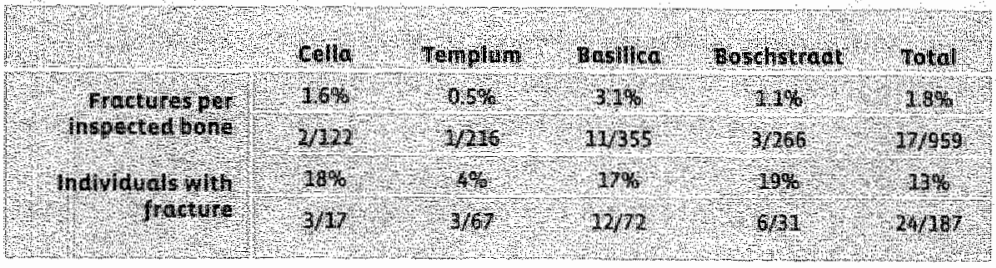

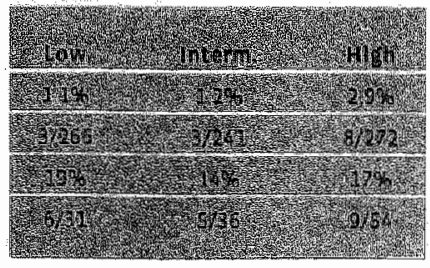

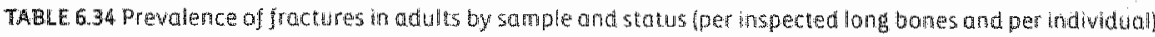

The percentage of individuals with one or more fractures in the templum sample was significantly lower than in the basilica and Boschstraat samples. ${ }^{\text {sis: }}$ As indicated above, there was a marked variation in recovery rates between the samples. In order to chrcumvent possible bias due to the variation in recovery rates, the frequency of fractures in the long bones was calculated as a percentage of the number of inspected long bones. Distribution of the fractures per inspected long bone also displayed a statisticaliy significant difference between the templum and the basilica samples, but not between the templum and the Boschstraat samples or between the basilica and the Boschstraat samples. ${ }^{50}$

Comparison of the prevalence of fractures per individual and the prevalence calculated per inspected long bone presented no indication for a correlation with status. As stated above, there was a specific pattern of fracture distribution in the basilica sample. Fractures in the lower extremities and ribs only occurred in this sample. With regard ta status this pattern was less consistent.

\section{Fracture healing and secondary osteoarthrits}

Fracture healing was investigated by inspecting the alignment of the fragments of each fractured bone for angulation, rotation and dislocation (ad latus and ad axis). Complete consolidation had occurred in all fractures. In $5 \mathrm{x}$ cases (21 per cent of the adult individuals with fractures) the fracture had healed almost completely in anatomical position. Less optimal healing was found for 22 fractures ( 76 per cent). In these cases marginal angulation, displacement, ratation or a combination of these was found. The outcome of the assessment of the quallty of healing after consultation with specialists was that in case of these fractures permanent functional impairment was unlikely. Only one individual had a fracture of the femur that at first sight seemed to be poorly healed. In this case the fracture had caused some permanent functional impairment. Nevertheless, given the difficulties associated with this type of fracture it had healed reasonably well. ${ }^{4 \prime 2}$ Another factor that was taken into account for an assessment of the healing of the fractures was the presence of secondary osteoarthritis. secondary osteaarthritis was defined as the occurrence of osteoarthritis at joints that are biomechanically related to the fractured bone. In five individuals with fractures osteoarthritic changes were diagnosed as secondary to the fracture. None of these cases of secondary

\footnotetext{
4ss Templum - basilica $p=0.047$ (Fisher's Exact test) remplum - Boschstraat: $p=0.03$ (Fisher's Exact test)

4.0 Templum - basilica $p=004$ (Fishers Exact test)

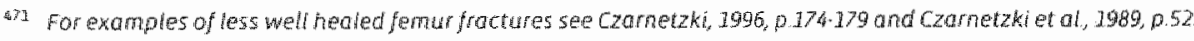


osteoarthritis occurred in the group with fractures with near to optimal fracture healing. secondary osteoarthritis was found four times in individuals with less optimal fracture healing and the fifth individual was the person with the poorly healed fracture of the femur. All fractures were consolidated and displayed remodelling of the permanent callus. This suggests all fractures had occurred well before the time of death. Estimates of the moment of fracture varied. between one and five years before the time of death.
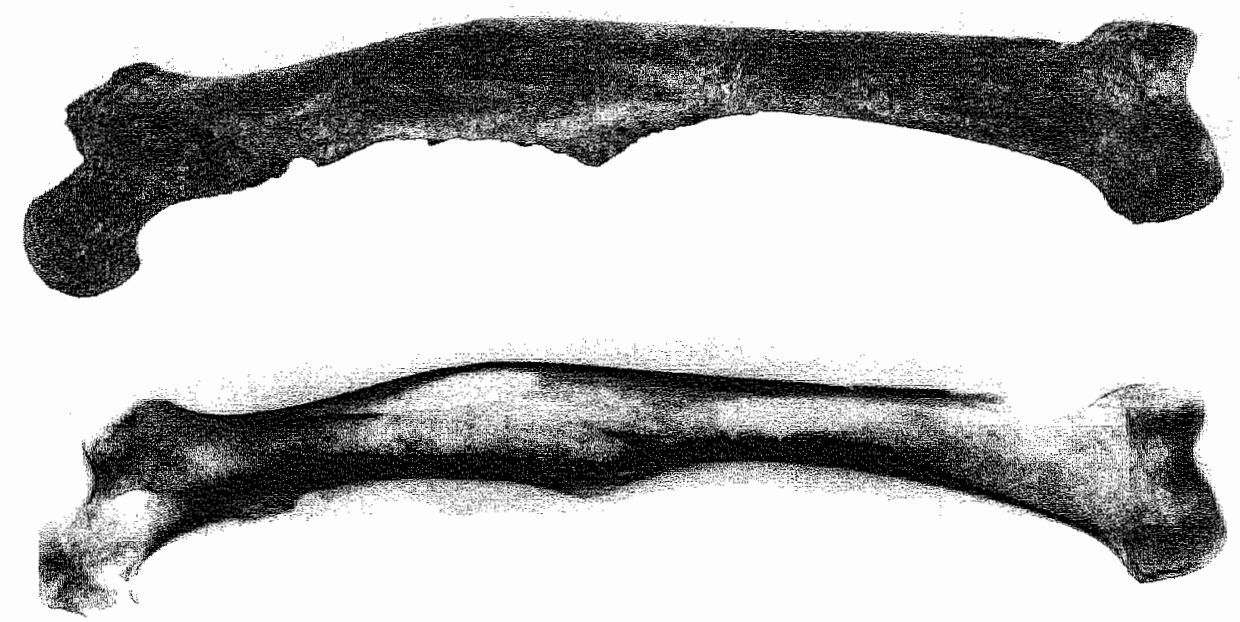

FIGURE 6.10 Diaphysea frarure of the femur, with angulation of the diaphysis, exoratation and shortenng ${ }^{2}$ tphotographi Panhusen).

Spondylolysis

Spondylolysis is a separation mostly occurring at the site of the pars interiarticularis of the neural arch of the vertebra. As a result the dorsal part of the vertebral arch, consisting of the laminae, spinous process and inferlor process, is separated from the rest of the vertebra. The aetiology of spondylolysis was a matter of debate. Traditionally it was considered a congenital abnormality. Recent studies show that spondylolysis is the result of a stress fracture that has not (completely) healed.

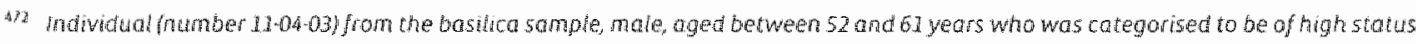

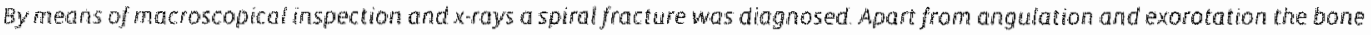
hor heated reasonably well with a shortering of the bone of circo 25 millimetres (in comporison to the right femur).

Aufdeheide and Radriguez-Martin, 1998, p. 63.64 


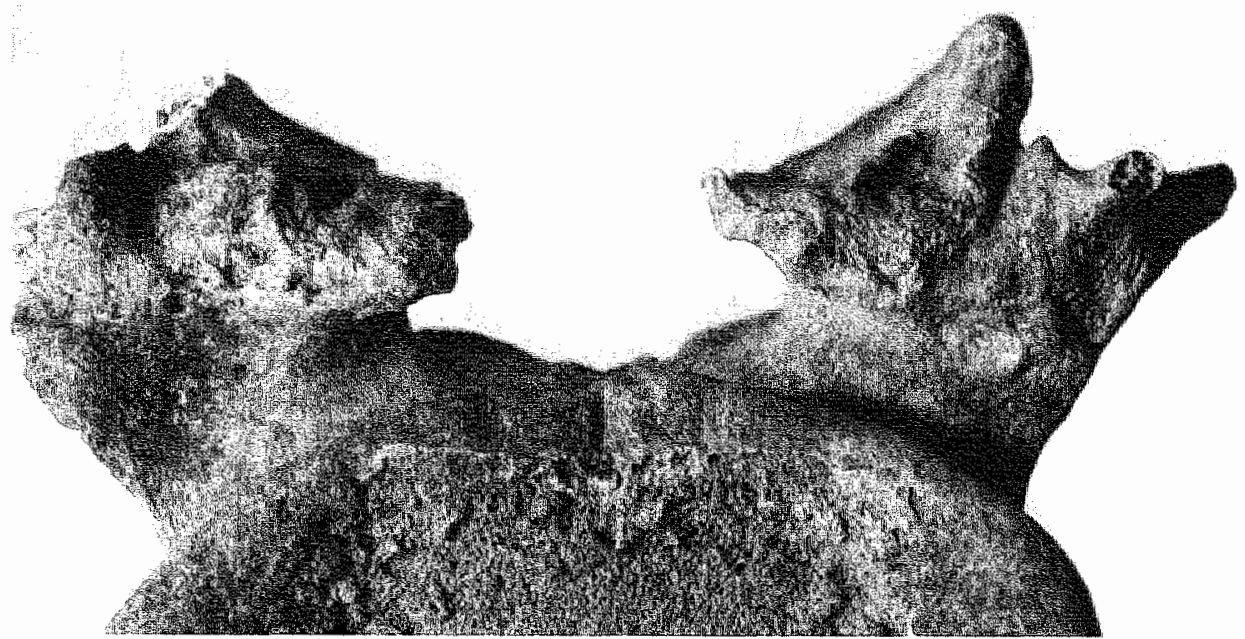

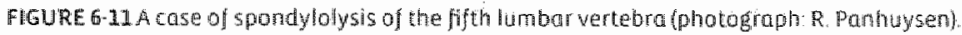

In 71 individuals one or more lu mbar vertebrae could be inspected. Three individuals were found with spondylolysis ( 4 per cent). All three cases of spondylolysis concerned the fifth Humbar vertebra. individual 05.08.08 was a case in which spondylolysis was found in the fifth lumbar vertebrae in combination with partial fusion of the fifth lumbar vertebra to the upper part of the sacrum (hemisacralisation).

\begin{tabular}{llll}
\hline & \\
\hline
\end{tabular}

TABLE 635 Andividuals with spondylolysis

Injuries by sharp bladed and pointed objects

Nine individuals were found to be injured either by cuts of sharp bladed objects or by pointed abjects. Traumatic changes caused by a sharp bladed object were found in six individuals. In five of the se cases the skull was the part of the body that was injured. 


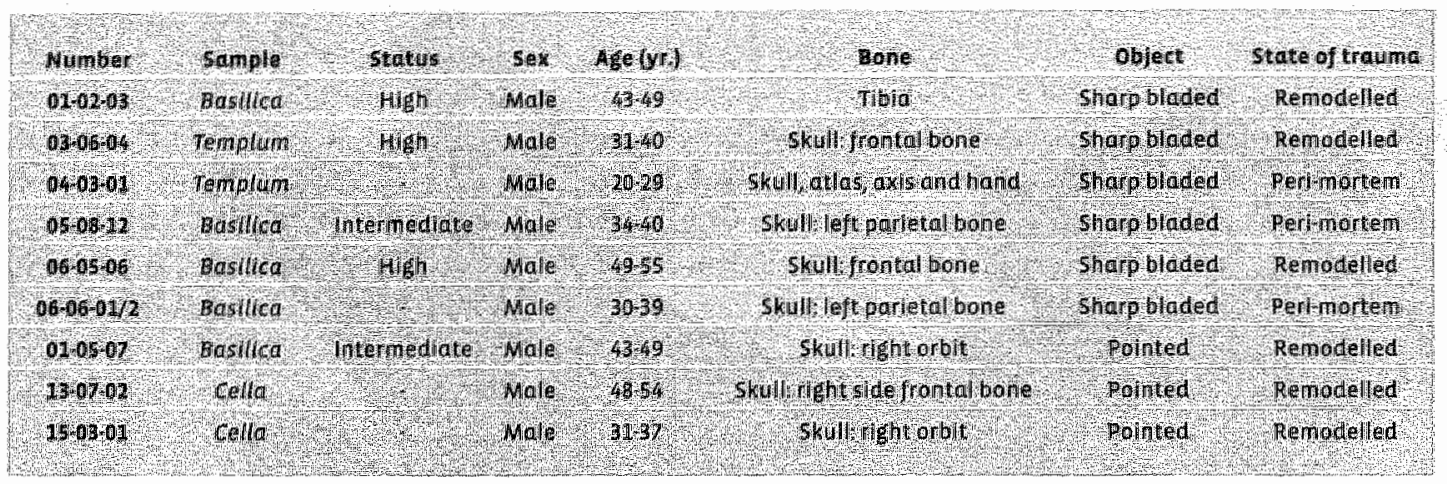

TABLE 6,36 Indiwduds wh injurles caused by sharp bladed and pointed objects

Apart from one individual all skulis displayed signs of only one cut. In one of these five cases not just the skull was injured but cuts were also observed on the atlas, axis and carpal bones. on the skull of this individual traces of at least seven cuts with a sharp bladed object could be observed. The sixth case was an individual with an oblique cut-mark on the tibia. in three of the individuals with sharp bladed injuries signs of healing could be recognised. In the other three cases no indications for healing were found. Because of the typical fracture pattern surrounding the cut bone and the uniform collour of both the edges of the cuts and the periositeal surface it was possible to classify the latter traumata as a result of peri-mortem incidents.

Traumatic changes caused by sharp pointed abjects were abserved in three individuals. Each of these injuries was found on the right side of the frontal bone, in or around the arbits. In all three cases same form of bone reaction had taken place around these traumata. This suggests that some time had passed between the mament these individuals had been injured and their death.

All injuries by sharp bladed or pointed objects were found in male individuals; only adult Indiwiduals were affected. Two injuries had occurred in the cella sample (both by pointed objects), two in the templum sample (both by sharp bladed objects) and five in the basllica sample (one by a pointed abject and four by sharp bladed objects). No traces of such injuries were found among the indiwiduals from the Boschstrat. When distributed by status category two traumata where found in the intermediate categary and three traumata in the high status category. A combination of fractures and injuries caused by sharp bladed or pointed objects was found in two individuals. One individual had a healed fracture of the right humerus and an injury on the skull, caused by a pointed object. ${ }^{24}$ The other individual combined a healed fracture of the left clavicle with cuts of the skull. ${ }^{\text {. }}$.

\footnotetext{
47. Individual $130 \% 02$

wh individud 060506
} 


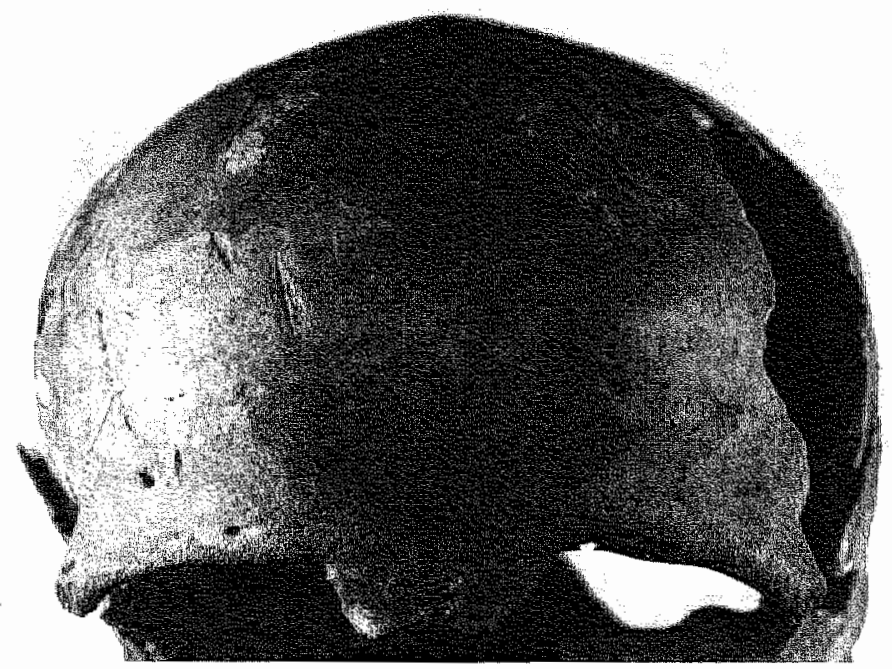

FIGURE 6-12 Frontal bone af a male who died between 31 to 40 yars. Left of centre a lorighdinal deprasion is wisible. representing a heded trauma from a sharp biaded object. To the left of this troma post mor tem damage of the skull is

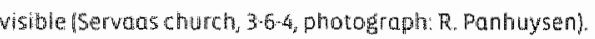

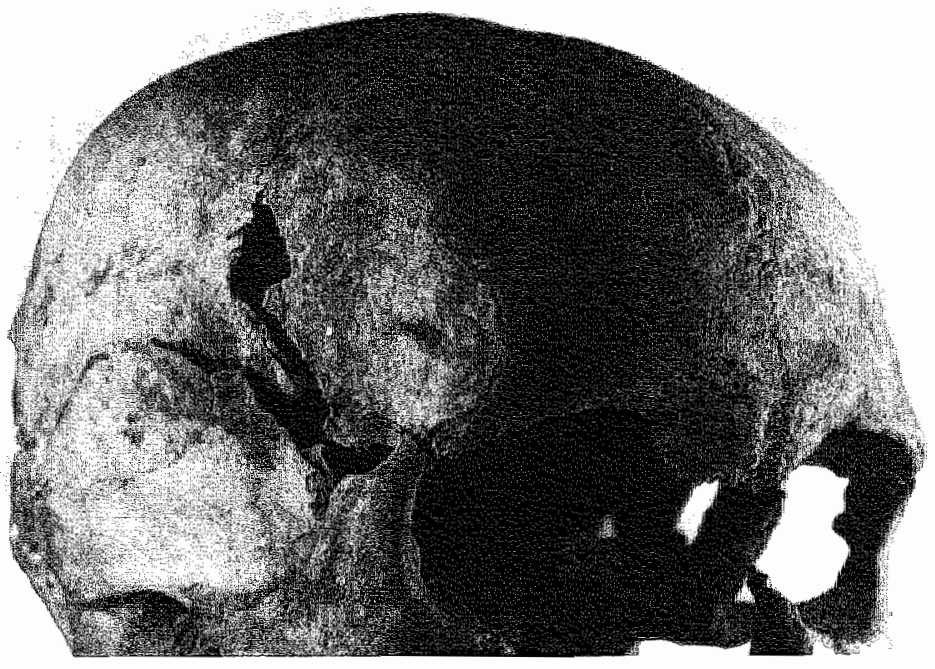

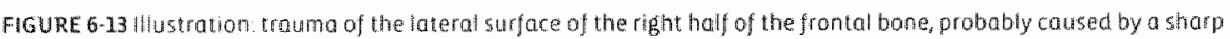
pointed object: 1-5.7photogroph: Pontruysen) 


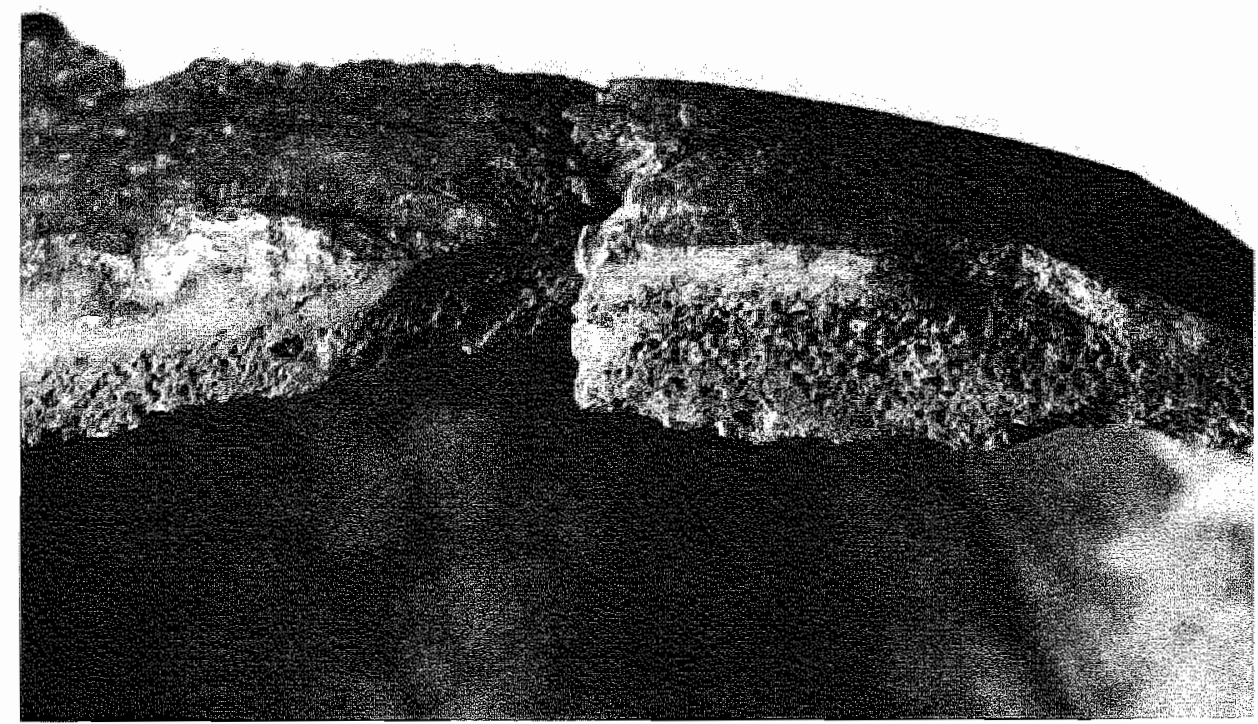

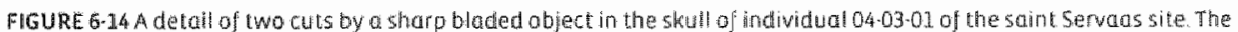
first cut is visible in the middle of the photograph (19, the second cut (2) intersets at an angle with the first cut

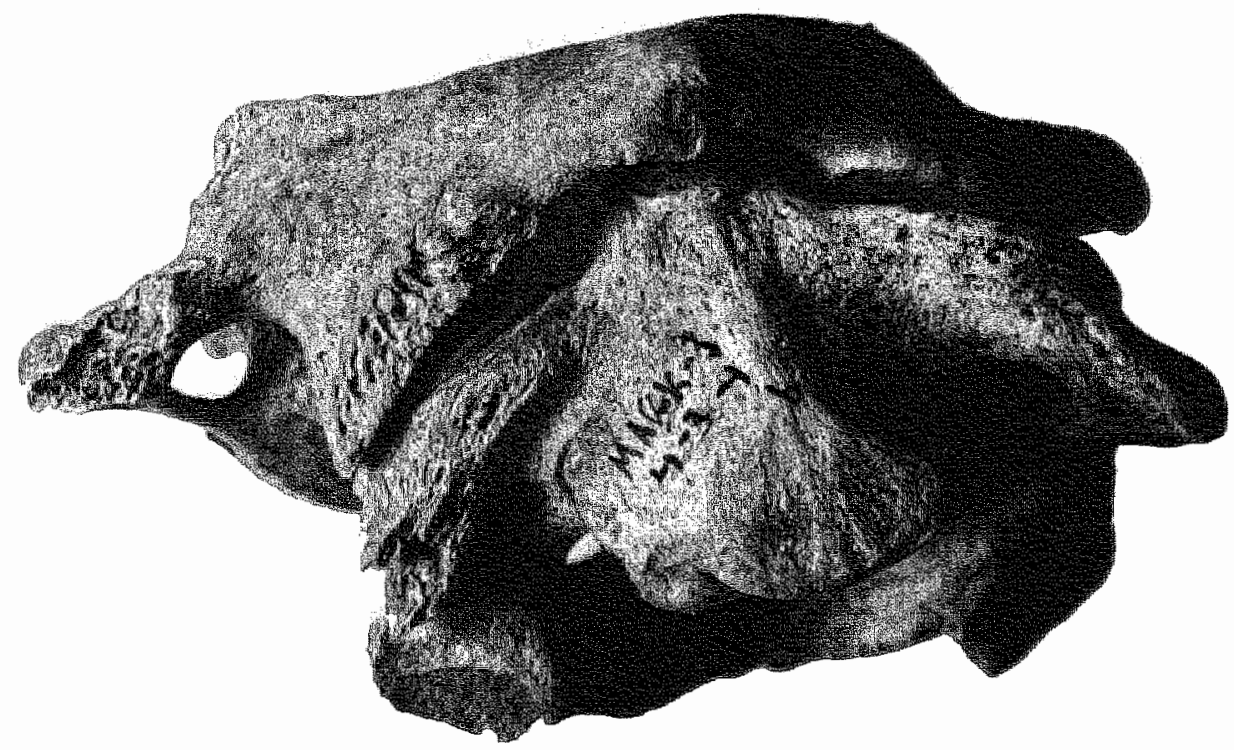

FGURE 6.15 Another detail of trauma due to injury with sharp bladad object in indwidual of 03 -0l of the sant serwaes site 1 Servars church site, $4-3-1$, woth photogrophs R. Panhuysent 


\section{osteochondritis dissecans}

In palaeopathology osteochondritis dissecans is a condition in which the bone below the cartilaginous surface of a joint is damaged. The most likely cause for this damage is a constitutional vascular anomaly combined with some form of trauma. Two cases of asteochondritis dissecans were found. In both cases the knee joint was affected. When counted as a percentage of the total number of knee joints inspected the prevalence of as teochondritis dissecans was ane per cent. One of the individuals was female between 40 to 60 years of age from the basilica sample. The other individual, from the Boschstraat sample, was an adult malle

\section{ARTHROPATHES}

Arthropathies are diseases affecting the joints. The following arthiropathies were examined systematically in this study: osteogrthrosis or osteoarthritis, degenerative disc disease and seronegative spondylarthropathies. Arthropathies in the peripheral joints were scored as percentages fram the total number of that joint that could be inspected. For the study of arthropathies in the vertebral column the spine was divided in five segments the cervical vertebrae $(n=7)$, the upper thoracic vertebrae $(n=6)$, the lower tharacic vertebrae $(n=6)$ the lumbar vertebrae $(n=5)$ and the sacrum $(n=1)$. Only those cervical, thoracic and lumbar vertebrae were included for which the joint surfaces and endplates of two or more vertebrae were present in a segment. The presence of one segment was sufficlient for an individual to be counted in the tables.

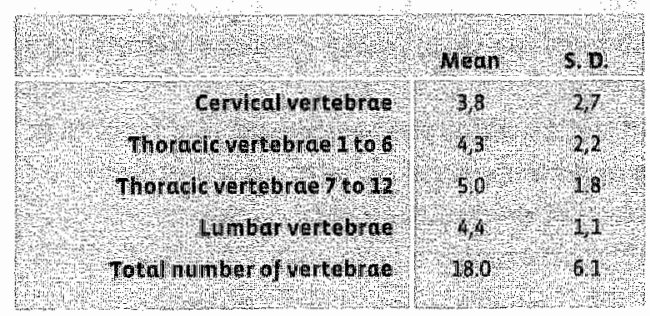

TABLE 6.37 Mean number af recovered vertebrae in 74 adult indivd uats with wertebrat

In 74 adult individuals the vertebral coiumn could be inspected. In most cases two or more of the segments of the vertebral column and a substantial number of vertebrae could be examined. The sacrum was available for inspection in 58 of the 74 adult individuals. Below the results are mot presented per segment of the vertebral column but per individual. In cases where there was considerable variation in the distribution of pathological changes in the vertebral columin this will be mentioned in the text.

\section{Osteoarthritis}

Osteoarthrosis or asteoarthritis $(O A)$ includes pathological changes of both peripheral and vertebral synovial joints. The presence of arthrosis was scored in accordance with the criteria 
published by Rogers and Waldron in 1995 in line with practice in (palaeo-) pathological literature these degenerative changes are further referred to as "osteoarthritis" (DA). Changes in the peripheral synowial joints are indicated as peripheral asteoarthritis (POA), similar changes in the synovial facet joints of the vertebral column are labelled as vertebral osteoarthritis (VOA). Scored as cases of osteoarthritis, were joints displaying either eburnation ar a combination of at least two of the following types of changes: marginal asteophytes, pitting on the joint surface and subchondral cysts. ${ }^{\text {an }}$ Excluded from the analysis of the prevalence of osteoarthritis were five cases in which asteoarthritis was considered to be secondary to a fracture and four individuals affected by a seronegative spondyllarthropathy. The data on temporomandibular joint steoarthrits will be presented in a separate paragraph.

Ostecarthritis of the peripheraljoints

Seven individuals (6 per cent of all examined individuals) were diagnosed with peripheral osteoarthritis, in four individuals multiple joints were involved. Eleven peripheral joints displayed asteoarthritic changes. Males were more often affected than females: five males (10 per cent of all males) as opposed to two females ( 3 per cent of all females). Six individuals with peripheral osteoarthritis could be categorised in an age at death interval. For all six the estimated age at death varied between 40 and 60 years. The small number of individuals. produced little variation in the distribution of individuals with peripheral osteoarthritis over the four samples: two in the cella sample, three in the templum sample, one in the basilica sample and one in the Boschstraat sample. Four individuals with peripheral osteoarthritis could be categorised by status: one each in the low and intermediate status category and two in the high status category

With regard to the distribution of osteoarthritic joints within the body it was noted that both the upper and lower extremities were involved in almost equal percentages. Six joints of the upper extremities and five joints of the lower extremities had asteaarthritic changes.

osteoarthritis in the lower extremities was most frequent in the knee joint; viz. three individuals had four joints affected.

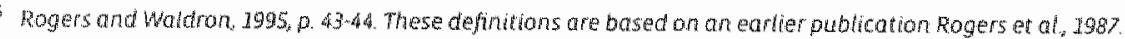

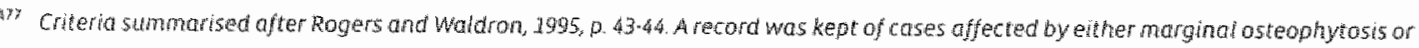
subchandral cysts. Anabyis of these data suggested uniform aistribution of these changes over the various samples and stotus categorizs 


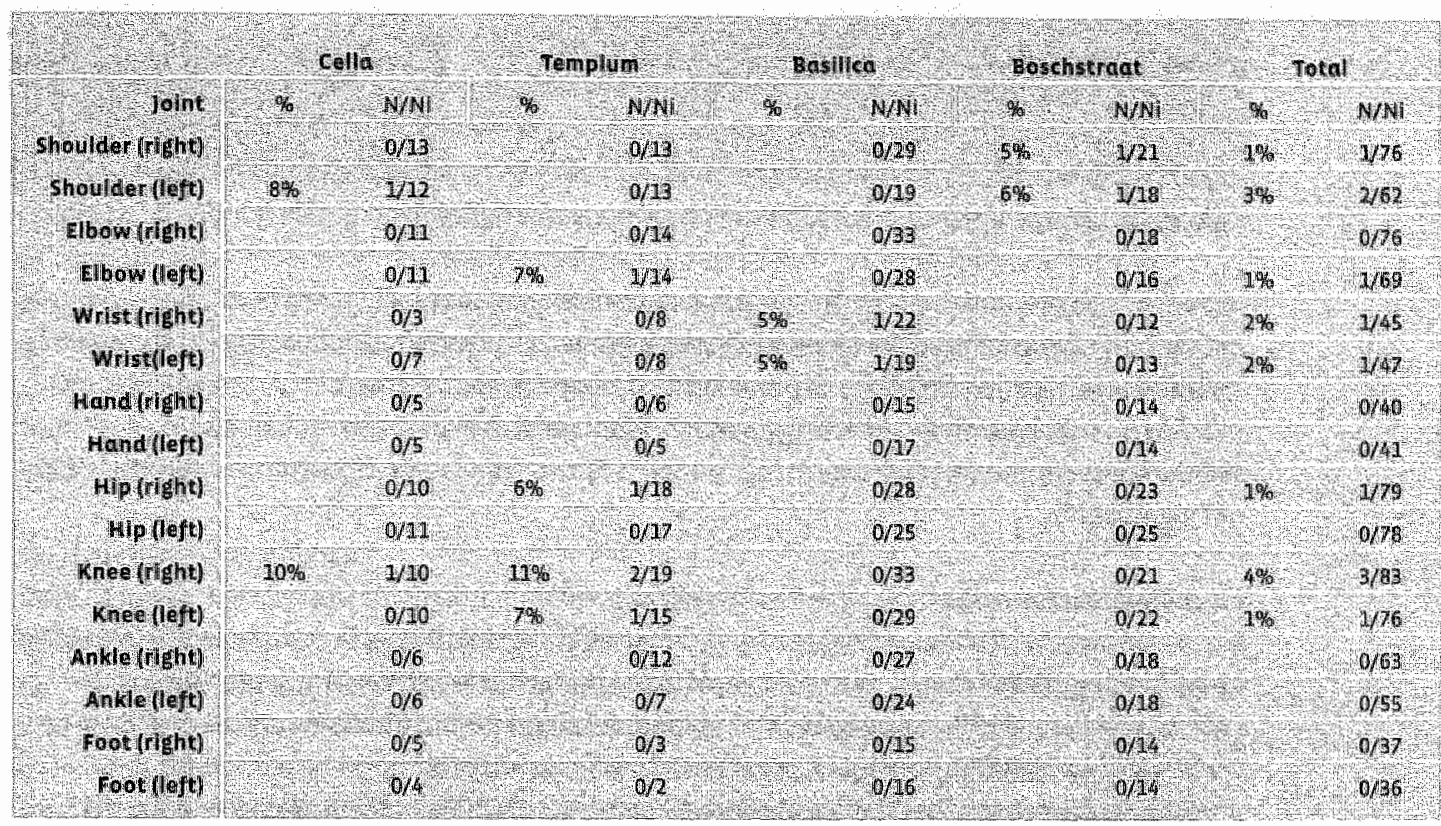

TABLE 6.38 Distribution of peripheral osteoarthrits by somple in adult indiwiduls, Presented are the numbers of loints with and without asteoarthritis. "N" is the number of joints displaying signs of osteonrthritis and "Niw is the number of joints that could be inspected.

\section{Temporomandibular joint osteoarthritis}

In 99 adult individuals the temporomandibular joint could be inspected for the presence of asteoarthritis. Seven females ( 14 per cent) had osteoarthritis of the temporomandibular joint. only ane male was affected by this condition (2 per cent). This asymmetric distribution over the sexes was close to statistical significance ${ }^{6 / 8}$ Relatively speaking most cases of temporomandibular joint osteoarthritis were reconded in the age categorles of 60 years and older. The increase of temporomandibular joint osteoarthritis from 5 per cent in the age group fram 20 to 40 years to 37.5 per cent in the age group of 60 years ar more represented a trend that was statistically significant. ${ }^{399}$ In one case osteoarthritis of the temporomandibular joint appeared to have been secondary to a fracture of the neck of the mandibular condyle. No association existed with arthritic changes in the other peripheral ar vertebral joints. Generally high rates of dental attrition were foumd in combination with temporomandibular joint osteoarthritis.

4x. Males-Females: p=0.06 (Fisheris Enatiest).

4.79. For the three twenty year intervals between 20 and 80 years af age the following percentoges were found 5 per cent (no 40 ) 7 per cant

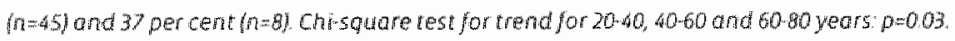



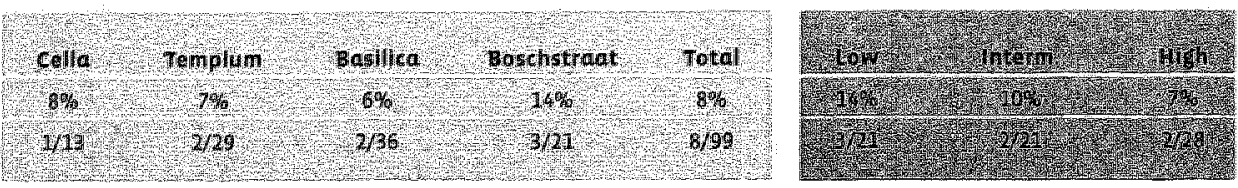

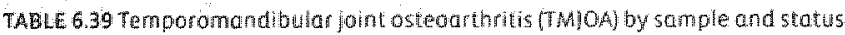

Among the various samples the variation in firequency of temporomandibular joint osteoarthritis was limited. The frequency was highest in the Baschstraat sample. In the cella, templum and bastlica samples the prevalence of temporamandibular joint osteoarthritis was more or less equal.with increased status there was a decrease in the prevalence of temporomandibular joint osteaarthritis. Analysis of this trend indicated that it was statistically not significant.

\section{Vertebral osteoarthritis}

The presence of vertebral osteoarthritis was recorded systematically for two synowial joints: the apophyseal facet joints and costavertebral joints. As indicated above, the same diagnostic criterla were applied that were used for the peripheral joints. In 74 individuals the presence of werttebral osteoarthritis could be inspected. No significant difference was found for the prevalence of vertebral osteoarthritis between male and female indiwiduals. Within the consecutive twenty-year age categories a marked rise in the prevalence of wertebral osteoarthritis was recorded. Between the cohort of 20 to 40 years and 40 to 60 years the prevalence increased from 6 per cent to 25 percent. ${ }^{6 / 1}$ Due to the small number of individuals in the age category of 60 years or older it was not possible to determine if this trend continued. The majority of changes diagnosed as vertebral osteoarthritis was found in the apophyseal facet joints.
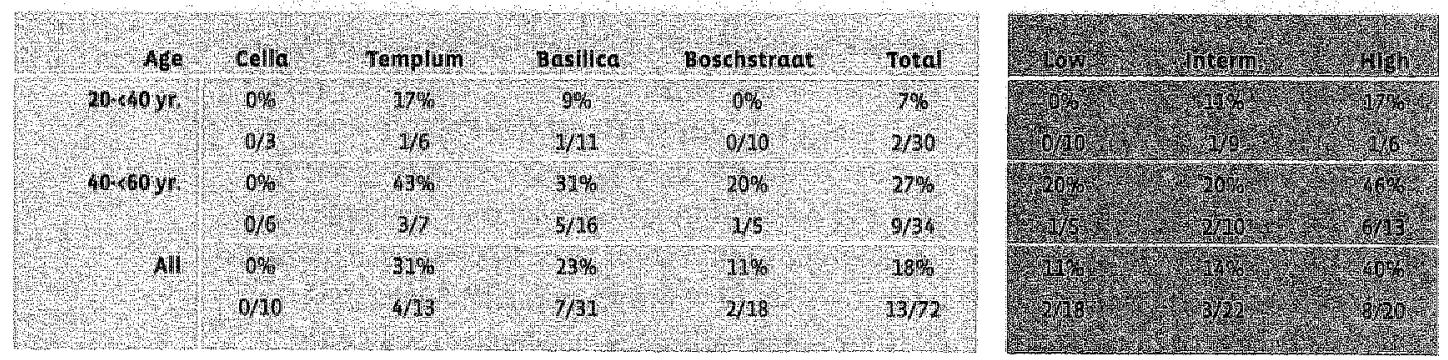

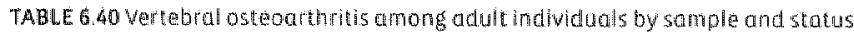

In the cella sample none of the individuals was found to have suffered from vertebral asteoarthritis. In the templum and basilica samples the prevalence of vertebral asteoarthritis was similar. Among the adults of the Boschstraat site the percentage was lower. Overall the

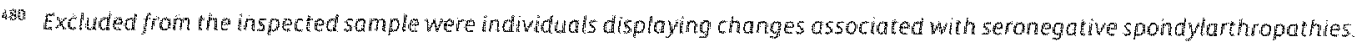

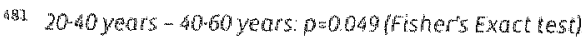


varlation in prevalence of vertebral osteoarthritis was not significant: neither among the consecutive samples at the Servaas site nor between the templum and Boschstraat sample.

In comparison to the low and intermediate status categories the high status category was characterised by a higher prevalence of vertebral osteoarthritis. This increase in the prevalence of vertebral osteoarthritis with status was statistically significant ${ }^{\text {sax }}$ Looking at the distribution of osteoarthritic changes within the segments of the vertebral column it was evident that predominantly the cervical and lumbar vertebrae were affected. When checked for distribution patterns with significant differences in prevalence per segment of the vertebral column one significant result was found. The lumbar vertebrae of individuals from the high status category were more often affected by vertebral osteoarthritis than were those of the low and intermediate status categories. ${ }^{\text {is }}$

\section{Degenerative disc disease}

Degenerative disc disease (DDD) is a term used to describe changes in the discovertebral joint that are considered to be caused by degeneration. Two types of pathological changes in the spine are thought to be indicative of degenerative disc disease: asteophytes along the margin of the vertebral endplate, and Schmorl's nodes in the central part of the endplate. Both vertebral osteophytes and Schmorl's nodes ore considered to be the result of displacement of material from the intervertebral disc. ${ }^{484}$ Various types of osteophytes may be formed on or close to the margin of the vertebral body, Vertebral osteophytes that are limited to the marg in of the discovertebral junction and do not extend on the anterior surface of the vertebral body were recorded as signs of degenerative disc disease. ${ }^{\text {s. }}$ Scored as Schmorl's nodes were blunt indentations in the surface of the superior or inferior vertebral endplates.

in 74 adult individuals the presence of degenerative disc disease could be examined $77 \mathrm{per}$ cent of the cases displayed signs of degenerative disc disease. More males ( 81 per cent, $n=32$ ) than females (74 per cent, $n=42$ ) were affected. The difference was not statistically significant. An increase in the incidence of degenerative disc disease with age was found. Among the individuals between twenty to forty years circa 67 per cent displayed signs. For the category of individuals between forty and sixty years an increase of 19 per cent to a total of 86 per cent was found
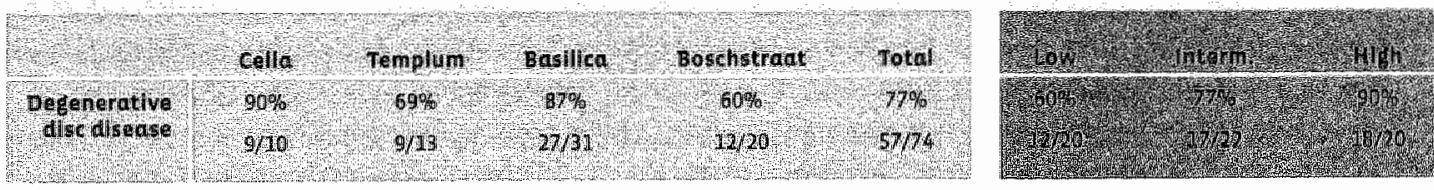

TABLE 6.41 Degeneratwe disc disease among adult indiwinuals by sample and status.

Ga. Chisquare test for trend $n=0.03$

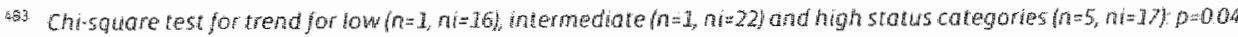

isa. Resnich 19960.256

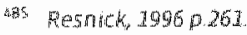

486 years - 40.60 years $p=008$ (Fisher's Exact test). 
The results indicate that in the templum and Boschstraat samples the prevalence of degenerative disc disease was lower than in the preceding cella sample and the later basilica sample. Analysis of the data, comparing the combined largely Meravingian samples of the templum phase and the Boschstraat with the basilica sample from the Caralingian period, indicated that the difference between the two periods was statistically significant. ${ }^{43}$

Comparison of the prevalence of degenerative disc disease in the three status categories indicated that the percentage of affected individuals increased with status. This trend was statistically significant. At the level of the lower thoracic wertebrae this trend was most manifest. Among the individuals with a lower thoracic spine available for inspection the percentages of individuals with degenerative disc disease were 42 per cent, 60 per cent and 100 per cent for the low, intermediate and high status categories respectively.

Distribution of the prevalence of degenerative disc disease in the segments of the vertebral column revealed minor differences between males and females. In the samples from Maastricht the prevalence of degenerative disc disease in the cervical and upper thoracic vertebrae was higher in females than in males. In the upper thoracic vertebrae this asymmetric distribution over the sexes was statistically significant. ${ }^{490}$ At the level of the lower thoracic wertebrae the prevalence of degenerative disc disease was similar for both sexes. For the lumbar vertebrae the percentages for degenerative disc disease were higher in males then in females. It was also noted that the increase in degenerative disc disease with age was not of equal proportion in all five segments of the spine. ${ }^{6 * 1}$ The prevalence of degenerative disc disease at the different levels of the spine was not equal for all samples. The templam sample in particullar was characterised by a relatively high prevalence of degenerative disc disease in the upper tharacic vertebrae. Despite the small number of individualls, analysis comparing the templum and basilica sample indicated that the variation in distribution was statistically significant. ${ }^{32}$ At the levell of the lower thoracic vertebrae the prevalence of degenerative disc disease was considerably higher in the templum sample and significantlly lower in the Boschstraat sample. ${ }^{\text {a9x }}$

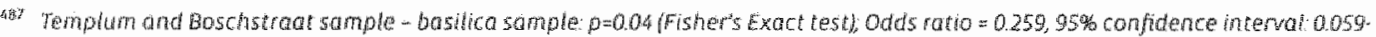
1069

Ch-square test for trend for low, intermediate and high status categones: $p=0.03$.

Distribution low status (8/29), intermediate status (12/20), high stotus (17/1)) Chisquare test for trend for low, intermediate and high stalus categories: poodi. There was a discrepancy between the prevalence of 100 percent boo in the high status category for the lower thoracic vertebre and o prevalence of 86 per cent when calculated per individual when the percentage is calculated per ind fividual, six more indiwiduals are included for which the lower thoracic vertebrae were not or inconpletely recowered.

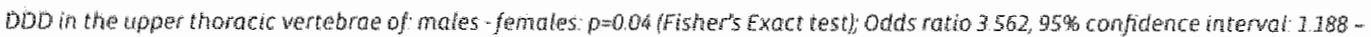
10678

Whit When the prevatence of Dov in the three wenty years age intervats was analysed per segment of the vertetral column the cross tabutations for the cervicat vertebrat and the fumbar vertebrae yielded stakisticaly significant results. For the increase of DoD in

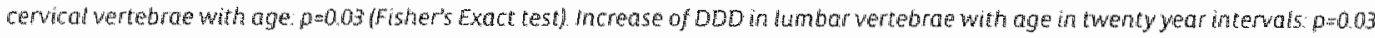
FFisher's Exact test?.

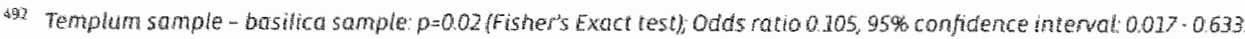




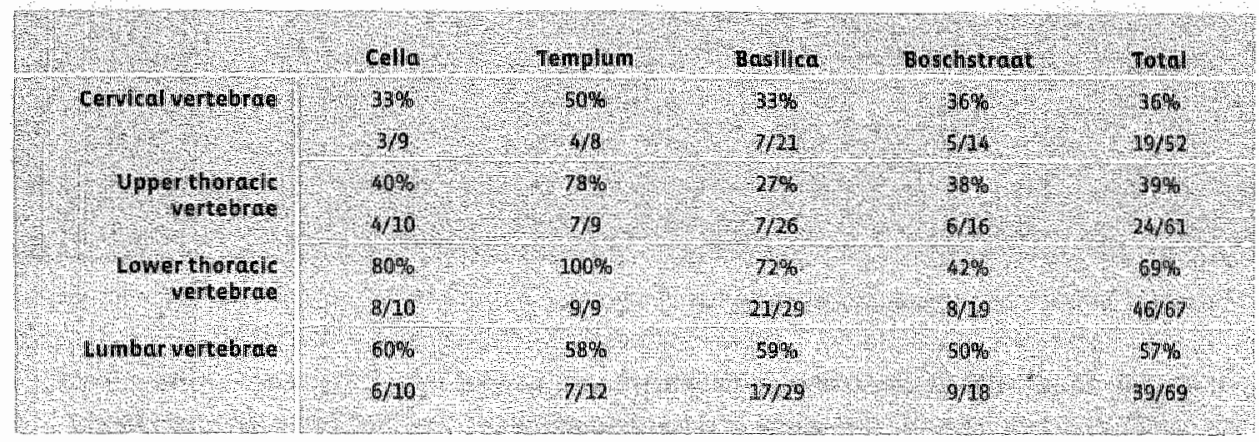

TABLE 6.42 Distribution of degeneratve disc disease in the segments of the vertebrat column in adult individuals by sample

\section{Seronegative spondylarthropathies}

In four cases a combination of pathological changes was found which were thought to be indicative of seronegative spandylarthropathy. The term seronegative spondylarthropathy is used to describe a group of diseases that may affect the joints in ways similar to theumatoid arthritis but differs from the latter because of the absence of theumatoid factor in the blood. The three major seronegative spondylarthropathies are ankylosing spondylitis, psoriatic arthritis and Reiter's syndrome. In palaeopathology the diagnosis is generally based on specific changes in the joint and the characteristic distribution of these changes over the various joints. Clinically four conditions are considered relevant for the diagmosis of seronegative spondylarthropathy: spondylitis, sacroilitis, enthesopathies and asymmetric synovitis. ${ }^{\text {ags }}$ The first three can also be used for the diagnosis of seronegative spondylarthropathy in palaeopathological studies. Spondylitis is an inflammation of one or more of the vertebrae. In palaeopathological specimens seronegative spondylitis can be recognised through the presence of syndesmophytes, since the erosions are difficult to distinguish from past-mortem changes. Syndesmaphytes are bony outgrowths extending vertically from the edge of ane wertebral body to the next. The presence of sacroilitis is apparent from marked erosion of the sacro-iliac joint or intra-articular bony ankylosis of the same joint. Enthesopathies are hypo- or hyperplastic bone transformations occurring at the site of insertion of muscle tendons and ligaments. In seronegative spandylarthropathies the enthesopathies are hyperplastic.

In all four cases of seranegative spondylarthropathy we found ossification of ligaments and erosion of the sacroiliac joint, with or without intra-articular bony ankylosis. All individuals had syndesmophytes sometimes in combination with signs of "calcification" of the intervertebral disc. Enthesopathies were also found in all four individuals. 


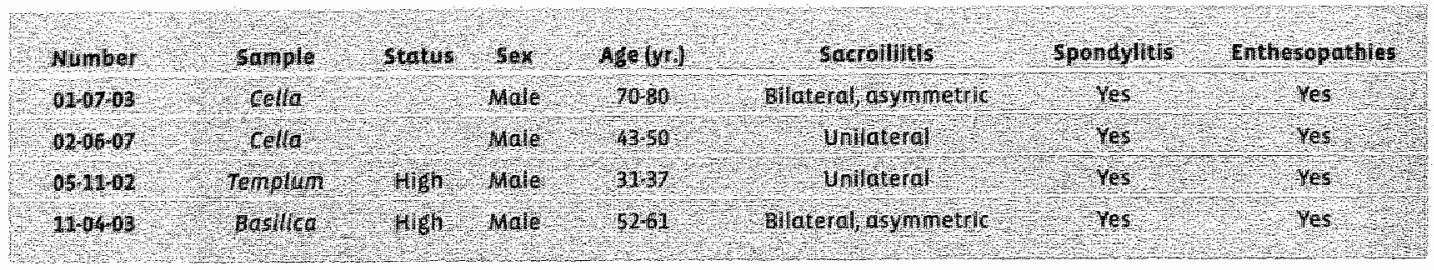

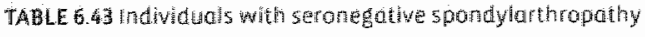

All individuals with seronegative spondylarthropathy were males. Twa cases were found in the small cella sample. In the templum and basilica samples there was one individual with seronegative spondylarthropathy in each sample of the Servaas site, none in the Boschstraat sample. In the case of number 11-04-03 the skeleton was sufficiently complete and the nature of the bone changes and their distribution was sufficiently distinct to allow for a more detailed diagnosis. The bilateral asymmetric sacroilitis, in combination with limited joint changes in the hands and feet in contrast to the serious changes in the large joints and widespread syndesmophytes with para-vertebral ossification best fit with a diagnosis of reactive arthritis also known as Reiter's syndrome. ${ }^{.95}$

\section{DHFFUSE IDHOPATHIC SKELETAL HYPEROSTOSIS}

Diffuse idiopathic Skeletal Hyperostosis. (DISH) is a skeletal disorder characterised by the ossification of ligaments, muscular attachments and cartilage. ${ }^{\text {9.5 }}$ The ossification is most marked allong the vertebral column. Especially on the right anterollateral aspect of the thoracic spine laminated assification of the anterior langitudinal ligament progressively appears with age. This may occur at various consecutive vertebral bodles and often continues across the intervertebral disc resulting in flowing anterior ossification (FAO). Apart from the aforementioned changes in the vertebral column, ossification of entheses at extra spinal sites like the crista iliaca and the insertion of the Achilles tendon are also considered characteristic for DISH. ${ }^{\text {ais }}$

The palaeopathological diagnosis of DISH is generally based on the clinical description of DISH. ${ }^{\text {कas }}$ However, when these criteria are strictly applied to incomplete skeletons a large number of individuals with changes associated with DISH would not be included in the analysis. Since a statistically significant carrellation was found between flowing anterior assification in the spine and ossification of extra-spinal entheses, the presence of the combination of these conditions was scored as DISH and analysed in separate tables. ${ }^{99}$

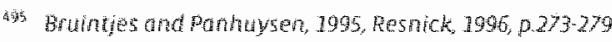

Als Also kpown as forrestiers diseose.

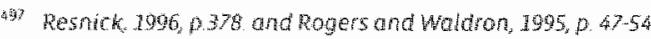

4 gig Rogers and Waldron, 1995,051

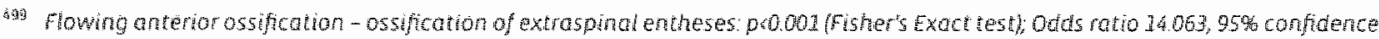
intervat $4.297-47.115$ 


\begin{tabular}{llll}
2 \\
\hline
\end{tabular}

TABLE 6.44 individuals whith DISH, FAO indicates which vertebrae are affected by flowing anteriar osstication (c) centical, $T=$ thoracic, the number indicate the number of the vertebral

When the classic strict criteria for DISH were applied, i.e. ankylosis of 4 consecutive thoracic wertebrae and extra spinal enthesopathies, DISH was diagnosed in 1 out of 74 cases (1 per cent). In individual 01-02-03 the ossification of the anterior ligament led to fusion of vertebrae with the characteristic "candle-wax" appearance. Three other cases were still included in the table because of flowing anterior assifications, which did not fuse completely but were in cllose contact.

When the count of cases of DISH was based on the presence of flowing anterior ossification in at least two vertebrae in combination with ossification of entheses at extra-spiral sites then 15 out of 74 individuals were diagnosed with DISH (20 per cent). Significantly more males than females had $\mathrm{DISH}$, viz. 31 per cent of the males $(\mathrm{n}=32)$ in comparison to 12 pier cent of the females $(n=42) .004$ The prevalence of DISH increased with age. Between 20 to 40 years 10 per cent $(n=30)$ had $\mathrm{DISH}_{3}$ between 40 to 60 years: 26 per cent $(n=35)$ and in the category of 60 years or more: 50 per cent $(n=6)$. Analysis indicated this trend was statistically significant..$^{501}$

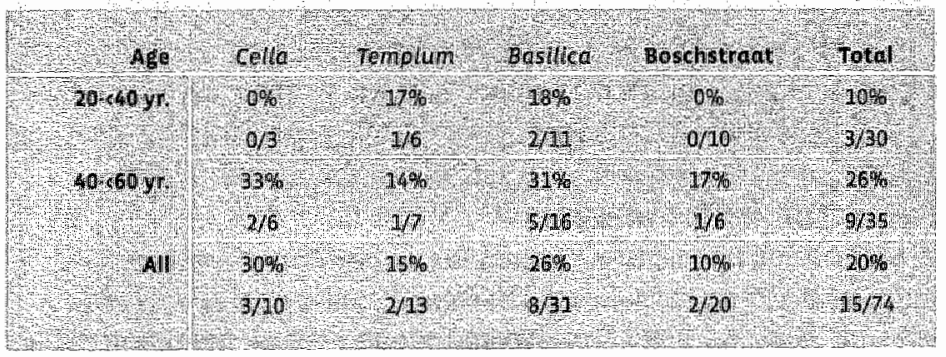

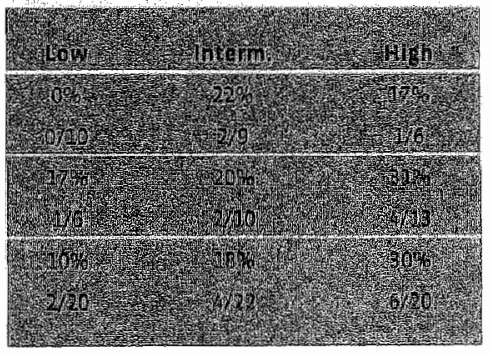

TABHE 6.45 Cases of DISH in adutt individuals by sample and status

The prevalence of DISH was highest in the cella and basilica samples. In the templum sample the prevalence was lower. Therefore, there was no unidirectional diachronic trend among the three sampies representing consecutive phases at the Servaas site. Overall the variation in prevalence of DISH was statistically nat significant. With respect to the distribution of $\mathrm{DISH}$

5hat Mates - femdes $p=0.048$ (Fisher's Exact test) odds ratio $0.297,95 \%$ confidence intervat $0090-0983$

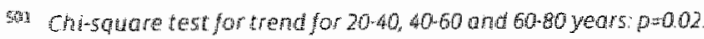


over the three status categories the data indicate that the prevalence increased with status. However, this trend was not statistically significant. ${ }^{502}$

\section{INFECTIOUS DISEASE}

Although infectious diseases generally affect soft tissue, chronic infectious diseases may lead to skelletal lesions. Skeletal lesions caused by infectious disease were found in long bones, in the maxillary and mastoid sinus and around the tip of the roots of dental elements. Infectious disease associated with the dentition will be analysed separately in the section on dentition. This section presents the data related to periostitis, osteomyelitis, chronic maxillary sinusitis, mastoiditis and pleuritis,

\section{Periostitis and osteomyelit is}

In palaeopathology the term periostitis is used to indicate that new bone has been formed by the periosteum. In such cases the inner layer of the periosteum forms woven bone on the surface of the cortex in reaction to various types of insults of which infection is by far the main cause. In palaeopathology this bone can either be woven bone, thought to represent fresh bone formation, ar sclerotic, suggesting the periosteal llesion has stabilised. Two impartant causes for periostitis are haematogenous infection and trauma. ${ }^{\text {s.d }}$ In this study the data on periostitis are based on inspection of adult individuals with at least two of the long bones of the lower extremities present: Periostitis was considered present when either fine-pitted bone well distinguishable from the underlying cortical bone ar a thickened surface of remadelled bone fixed to the underlying cortex were found.

The long bones of 94 individuals were inspected. In 19 individuals periosteal new bone formation was found (20 per cent). Periostitis was most frequent in the tibia, fibula and fernur (in order of declining frequency); usually at the level of the diaphysis. Significantly more males had periostitis than females. ${ }^{505}$ Among 42 males 13 (31 per cent) were diagnosed with periostitis. Among 48 females 5 cases (10 per cent) of periostitis were found. No significant association was found between the prevalience of periostitis and age.

Between the templum, basilica and Boschstraat samples the variation in prevalence of periostitis is small, ranging, between 17 and 26 per cent. The three samples from consecutive phases at the Servaas site (cella, templum, and basilica) indicated that the percentage of cases of periostitis increased with time. However, analysis using Chi-square test for trend demonstrates that this was not statistically significant.

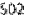

5.:1: : However, as the detiology of this endocrand new bone formation is still controversial these data will be presented in a separate section below

50.9

05 Ortener $2003_{n}, 208$

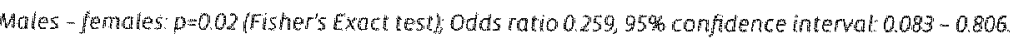



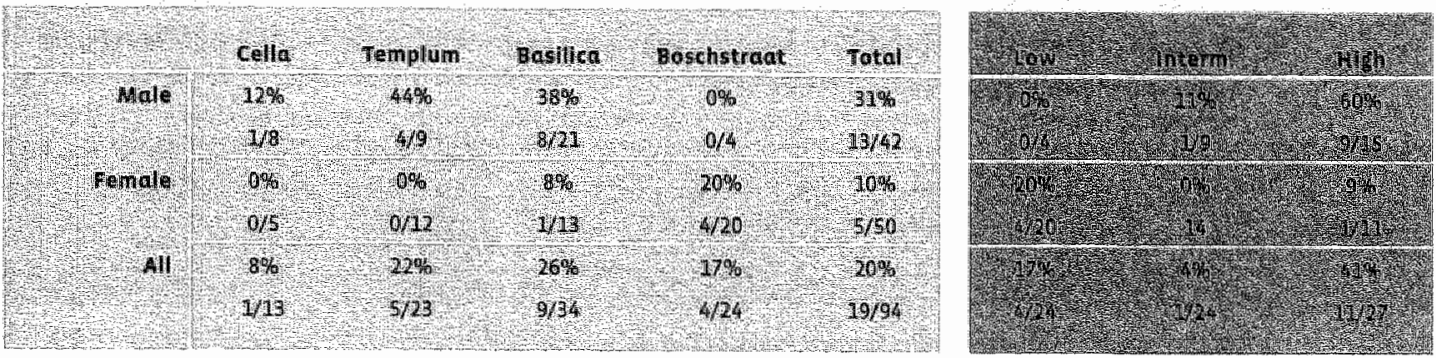

TAELE 6.46 Adult individuals with periostitis by samplas and satatus

Among the three status categories there was a strong variation in the prevalence of periostitis. In the category af intermediate status a low percentage of cases of periostitis was found, whereas the high status category contained a comparatively high number of cases. There was no unidirectional trend indicating an increase or decrease associated with status. A Chisquare test of the data presented in Table 6.46 indicated that the distribution as a whole varied significantly from expected distributions. ${ }^{306}$

In three of the individuals with periostitis the infection was part of an osteomyelitis. Osteomyelitis is an infection of the entire bone, including the endosteal surface inside the bone. In all three individuals osteomyelitis had affected one of the long bones of the lower extremities. In one of these cases the osteamyelitis was most likely secondary to a fracture of the femur. All cases were found in the basilica sample. Two individualls with osteamyelitis could be categorised as being of high status.

\begin{tabular}{|c|c|c|c|c|c|c|}
\hline Mombar & Sumple & strituls & sex & Ale $(y)$ & Infectious chsease & Aone \\
\hline 0.00504 & Basitica & Hgan & mentale & $317 \%$ & Dstoon y ellas & $7 \operatorname{lu}_{9} 1 \mathrm{a}$ \\
\hline 0606 014L & Bastica & & Nale & 10\% & 7) Comyelts & Fbula \\
\hline 11,0403 & Basulara & $4 \mathrm{~g} / \mathrm{H}$ & Male & 5464 & (1) crompentis & rentur \\
\hline
\end{tabular}

TARL 6.47 Cases of osteomyelitis

\section{Chronic maxillary sinusitis and mastoiditis}

During chronic infection of the maxillary sinus irritation of the periosteum induces new bone formation, which can be recognised as spicules of bone or a bone plaque. Causes for chronic maxillary sinusitis are infections of the nasal cavity, periapical dental abscess or extraction of (pre.) molars, allergy and septum deviation. In 64 individuals one or both maxillary sinuses were inspected macroscopically, if necessary an endoscope was used. In 29 individuals (45. per cent) signs of chronic maxillary sinusitis were present. Chronic maxiliary shinusitis was found in 40 per cent of the malles and 50 per cent of the females. Comparison of the prevallence in the arge

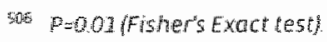


category of 20 to 40 years and 40 to 60 years shows a significant increase with progressing age from respectively 31 per cent to 59 per cent.
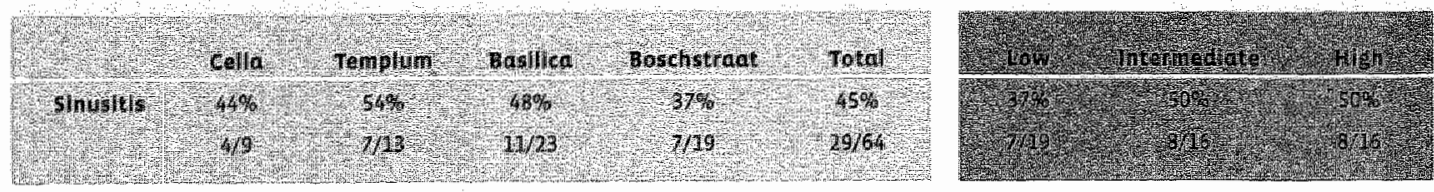

TABLE 6.48 Adult individuals whth chronic moxillary simusitis by somple and status

There was hittle variation in the prevalence of chronic maxillary sinusitis in the four samples. Both the highest percentage and the lowest percentage were recorded in the templum and the Baschstraat sample respectively.

Distribution of the cases of chronic maxillary sinusitis over the three status categories indicated that the prevalence was lowest in the low status category and was equally high in the intermediate and high status category. The difference in prevalence among these categories was not statistically significant.

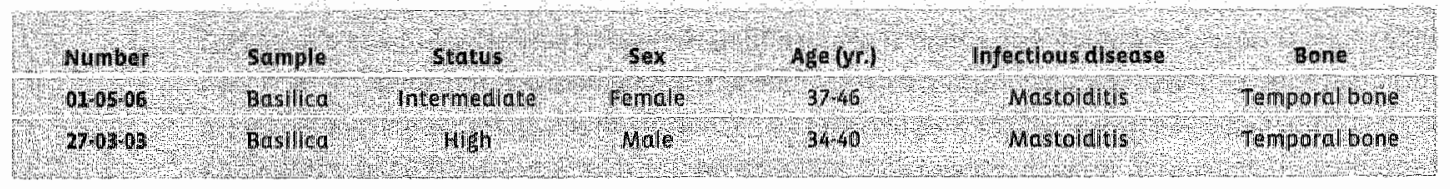

TABLE 6.49 Cases of mastolditis

Mastoiditis is an infection inside the mastoid process, which can be recognised by the presence of a fistula ariginating in an abscess in the mastoid cellulae and opening on the exterior surface of the mastold process. Two cases of mastoiditis were found one male and one femalle, both from the basilica sample.

\section{Pleuritis}

One individual was diagnosed with changes due to pleuritis. In this individual the interior surface of three ribs had been affected by periosteal new bone formation. This was interpreted as the result of an infection of the pleura.

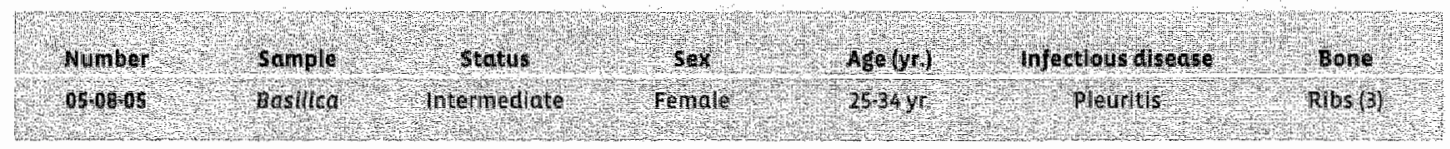

TABLE 6.50 Case of pleuritis 
Endocranial new bone formation

In some individuals it was abserved that periosteal bone had formed on the interior surface of the skull. The palaeopathogical interpretation of this endocranial new bane formation (ENBF) is under debate. According to one hypothesis the new bone formation is the result of meningitis, another hypothesis suggests the bane formation may be caused by a subdural ar an epidural haematoma. This condition was only found in non-adult individuals. The interior surface of the skull of 26 non-adult individuals was inspected. Five undividuals ( 19 per cent) had new bone formation on the interior surface of the skull.

\begin{tabular}{|c|c|c|c|c|c|c|}
\hline Number & Sample & status & Age (y) & Bones involved & vilsitu buston & tyole \\
\hline onodig2 & (cello & & 24 & Hortol, par neral & Symnefrical & 10 \\
\hline 041004 & $\operatorname{sos} 16 \mathrm{co}$ & thendme & 12 & Hrontallemporol & 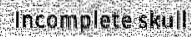 & 40 \\
\hline $0403109 / 4$ & Bosctiotoat & boy & 03 & Temporal & Symoruerical & No \\
\hline 02070071 & Bosthitiadt & Low & 12 & fronthl hemporal & Hecomploto Kull & No \\
\hline $0204.007 / 2$ & Boschistrat & Kow & 1218 & 4 Tempord & Hepmplotpossul & $\sqrt{10}$ \\
\hline
\end{tabular}

TABLE 6.52 Cases of endocranial new bone formatiom

With respect to the age of the individuals 4 out of 5 were four years or younger. The distribution over the samples was highly variable. One af the inspected non-adults of the cella sample had endocranial new bone formation. From the consecutive templum phase none of the 5 inspected individuals showed signs of endocranial new bone formation. In the basilica sample endocranial new bone formation was found in 1 of the 5 inspected individuals. For the Boschstraat sample the score was 3 individuals with endocranial new bone formation out of 14 individuals (21 per cent).

\section{NEOPLASA: OSTEOMA}

A neoplasm is defined as a mass of abnormal tissue that grows by cellular proliferation more rapidly than normal and continues to grow after the stimuli that initiated the new growth cease. ${ }^{503}$ Only one type of neoplasm was found in the population, viz, osteamata. Osteomata are benign, bone-forming lesions that are generally found on the outer surface of the neuracranium, but they can also form on the facial bones of the skull or in the postcranial skeleton. ${ }^{5 x^{2}}$ Twelve individuals had one or more osteomata (6 per cent of the adult individuals). Ostemata were mare common in males than in females, 12 per cent versus 5 per cent respectively. ${ }^{\text {s.10 }}$ The prevalence of osteomato was not associated with the age of the individuals. All asteomata were equally distributed over the four samples and there was no evident association with status.

\footnotetext{
sied Stedan, $1990,0.1030$

the Aufderheide and Rodriguez-Martin, $1998, p 375$

so statistically this difference in prevalence was mat significont.
} 
CONGENTAL ANOWHALIES SPINA BIFIDA OCCULTA

Spina bifida occulta is a limited defect occurring in the spinal column characterised by the (partiall) absence of the vertebral arch. The adjective 'occulta' is used for cases in which this defect has nat resulted in exposure of the spinal cord or its membranes. In the examined population there were 7 adult cases of spind bifida occulta; one in the atlas of a female from the basilica sample (11-04-04) and six in the sacrum. The latter were all cases of partial spina bifida occulta. In these cases the neural arch of the second, third and fourth sacral vertebrawere incomplete.

of the six cases with spina bifida occulta four were females and two males. The small number of individuals results in a distribution over the samples that is largely influenced by chance.

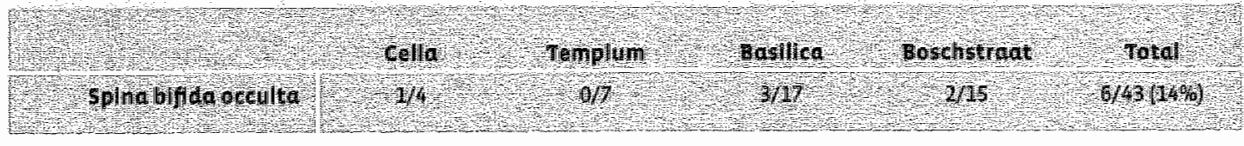

TABLE 6.52 Adule ind widuals with partial spina bifida occulta in the sacrum

\section{ENTHESOPATHES: CORTICAL DEFECTS}

An enthesopathy is a hypo- or hyperplastic bone transformation occurring at the site of insertion of muscle tendons and ligaments into bones or joint capsules. Apart from the bone forming enthesopathies associated with DISH two types of enthesopathies were found in relatively large numbers. Mast common were cortical defects at the site of insertion of the costaclavicu ar ligament on the clavicle. Also on the crest of the greater tubercle on the humerus, the insertion site for the pectoralis major muscle, similap cortical defects were found. Cortical defects are changes in the surface of the cortex ranging from marked porosity to deep oval or oblong pits. Clinical studies indicate that cortical defects are caused by repeated pulling stress at the site of insertion. ${ }^{511}$ In palaeopathology enthesopathies like cortical defects are known as biomechanical musculo-skeletal stress markers. The cortical defects at the site of insertion of the costoclavicular ligament are also named rhomboid fossae.

All cases were found in adult individuals. Therefore, the prevalence of cortical defects is calculated in ratio to the adult part of the sample. in 58 individuals the medial half of one or both clavicles was available for inspection, the proximal part of one or both the humeral shafts could be inspected in 98 individuals. Both clavicles and humeri could be examined in 58 individuals. About 34 per cent of the inspected individuals had a cortical defect on the clavicle. The humerus was avallable for inspection in a larger number; the prevalence of cortical defects was lower, viz. 10 per cent, When both clavicles and humeri were available for inspection $(n=58)$ the prevalence of cortical defects was also 10 per cent. The presence of a cortical defect on the humerus was strongly assaciated with the presence of cortical defects on the clavicle. In the 58 individuals where both clavicles and humeri could be examined, all six cases of cortical defects. on the humerus were found in individuals who al so had cortical defects on the clavicle. ${ }^{512}$

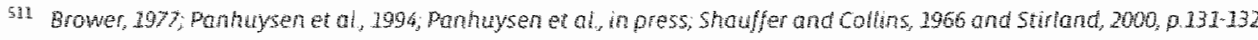


Cartical defects, independent of the bone affected, were found significantly more often in imales than in females. ${ }^{\text {si3 }}$ There was no association between age and the prevalence of cortical defects.

\begin{tabular}{|c|c|c|c|c|c|}
\hline & Colla & Tenollum & Basilea & Boschstrait & nola \\
\hline celourde & 3) & 45 & $38 \%$ & $23 \%$ & 348 \\
\hline & 319 & 51 & $8 \longdiv { 2 1 }$ & 411 & $20 / 58$ \\
\hline Humerus & 74 & 180 & 119 & 48 & 108 \\
\hline & $1 / 15$ & 42 & 4,7 & $1 / 24$ & $40 / 98$ \\
\hline Clavicle ond & 118 & $18 \%$ & 96 & $46 \%$ & $10 \%$ \\
\hline & 18 & 211 & 221 & 1177 & $6 / 58$ \\
\hline
\end{tabular}

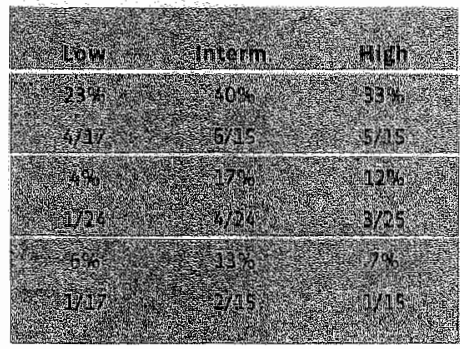

TABLE 6.53 Number of adults with contical defects by sample and stotus

The distribution of cases of cortical defects over the samples did not vary significantly. The highest prevalence was found for the sample from the templum phase, the lowest for the Boschstraat. In general the percentage of cortical defects in the clavicle was threat times as high as the percentage of cortical defects in the humerus. When the distribution of cortical defects was analysed by status no significant variation was recorded. The intermediate status category scored the highest prevalence of cortical defects.

\section{HYPEROSTOSIS FRONTALIS INTERNA}

Hyperostosis frontalis interna is abmormal deposition of bone on the inner aspect of the frontal bone and in some cases on the parietal bone. $t \mathrm{t}$ is found almost exclusively in females, of whom most are 30 years or older. ${ }^{5 i A}$ A hormonal disorder is mostly proposed to be the cause of hyperostosis frontalis. 515

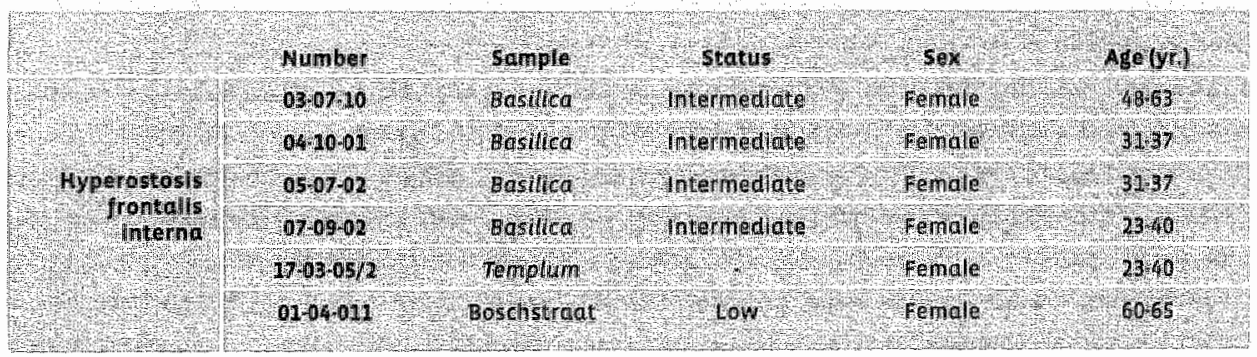

TABLE 6.54hdividuals with hyperostosis frontolis intema

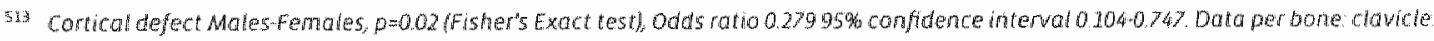

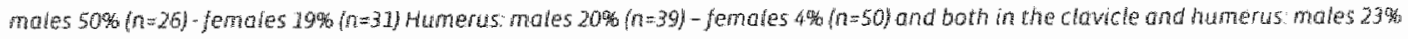
$(n=26)-$ famales $0 \%(n)=31)$

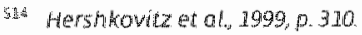

515 5technan, $1990, p 73 \%$, Aufderheide and Rodriguez-Martin, $1999,0.419$
} 
Out of 79 skulis that were inspected 6 (8 per cent) had hyperostosis frontalis interna. All six individuals were females, which means that 15 per cent of the females $(n=40)$ had hyperostosis frontalis interna. Two thirds of all cases came from the basilica sample.

\section{DENTITION}

The dentition could be inspected in 99 adult individuals and 18 non-adult individuals. Because the non-adult sample is composed of indiwiduals with different degrees of dental development the description and analysis of dental data will focus on the adult individuals with 28 or more erupted permanent teeth. Recorded were the total number of erupted elements, the total number of inspected positions in the jaw, postmortem loss of elements, ante-mortem loss of elements and elements with caries. Furthermore the degree of attrition was scored and the presence of calculus, alveolar atrophy, periapical abscesses and fistulas was documented. ${ }^{\text {sh }}$

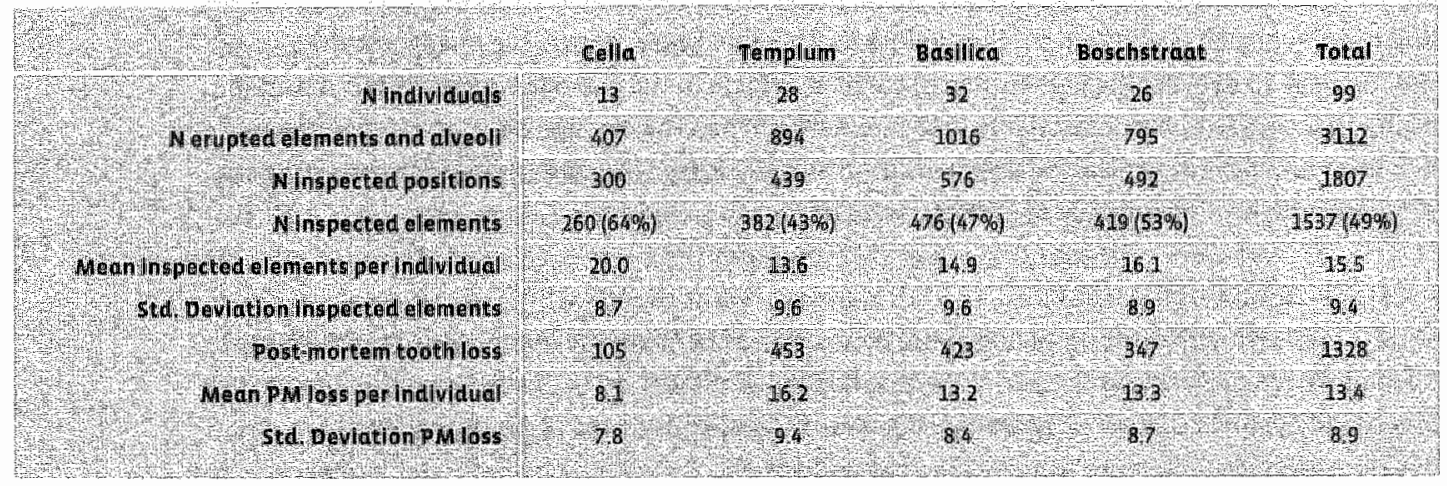

TABLE 6.55 Number of inspected elements, inspected positions and postmontem tooth loss in individuals with 28 or more permonent teeth

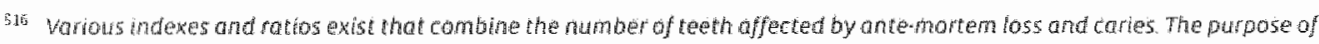

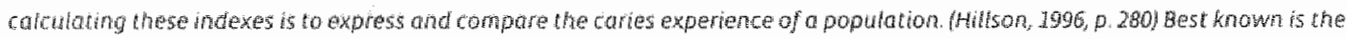

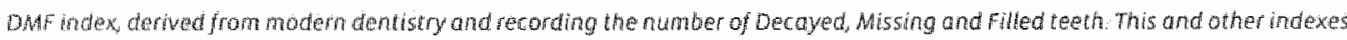

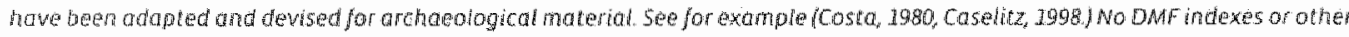

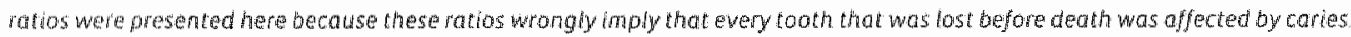

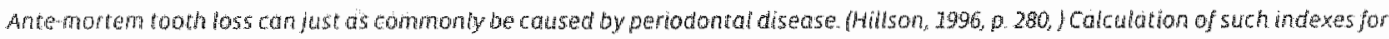

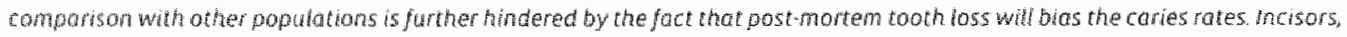
canmes and premolars are low mote of ten than we molors, whereas molars are moneofen affected by caries. Thus samples with

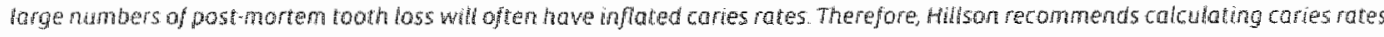
and DMF indexes or ratios per type of tooth (Hilson, 1996 , Hillson, $200 \mathrm{x}$, As this is hitherto not common practice in osteoarchaeotogy this would reduce the chances of finding comparable data in osteodrchoeotogicat sudies of contemporaeneous papulations.

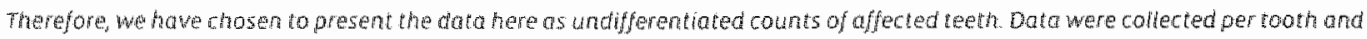

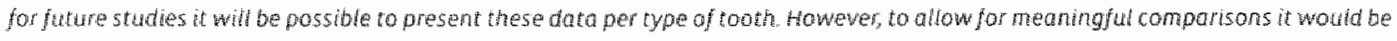
necessory to increase the number of knperted teeth 
Table 6.55 lists the number of elements available for inspection in each sample. Apartfrom the number of erupted elements and ante-mortem tooth loss (see below) this number was largiely determined by the rate of post-mortem tooth loss. The mean post-mortem toath loss in the templum sample was twice as high as in the cella sample. Post-mortem tooth foss in the basilica and the Boschstraat samples ranged between the values found for the cella and templum samples.

INSPECTED DENTITIONS

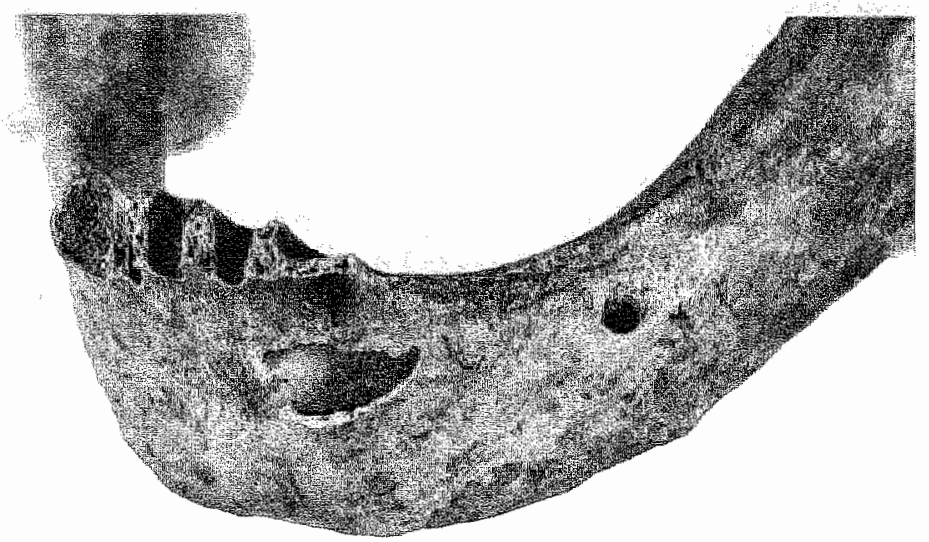

FIGURE 6-16 Detaled wew of the left antrior part of the mandible Becatse of post-depositional bone loss part of the crown and root of an impocted canine are vis bble [see arrowl. All molars and premolars were absent due to ante-

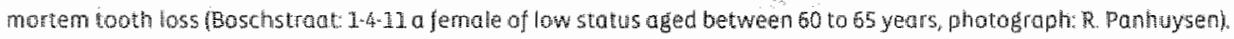

In humans the regular number of erupted elements in the permanent dentition is 32 . This number may be increased due to the formation of supernumerary teeth or it can be reduced as a result of agenesis or impaction of dental elements. Supemumerary elements, extra teeth, were not found in the examined samples. Agenesis and impaction were both present in the population, Congenitally absent teeth are teeth that have not formed at all (agenesis). The third molars are the teeth that are most frequently missing because of agenesis. ${ }^{53 .}$ An impacted tooth is a tooth that has remained inside the jaw. Third molars and upper canines are generally the most commonly impacted teeth. ${ }^{518}$ with respect to the eruption of the third molars it is difficult to distinguish between agenesis and impaction. In case a dental element had nat erupted it was generally scored as congenitally absent. Only in case part of the element was visible in the jaw either macroscopically or on radiographs, it was scared as a case of impaction.519

517 Hifis an, $7996,0.112$

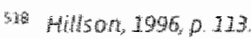

5: Radiogrophs of the cientition were only made in exceptiona? casts 


1
3

TABLE 6.56 The numbar of erupted etements in adut individuals by somple

Impaction was found in one individual from the Boschstraat sample. In this case a mandibular canthe had remained inside the jaw. in 13 individuals the absence of third molars was scored as a case of congenitally absent teeth. The thind molars of both the upper and lower jaw were absent in one individual. Nine individuals were found with missing bath third molars in either the upper or lower jaw. In addition, three individuals missed only one of the third molars. Most individuals, however, had 32 erupted elements, viz 86 per cent.

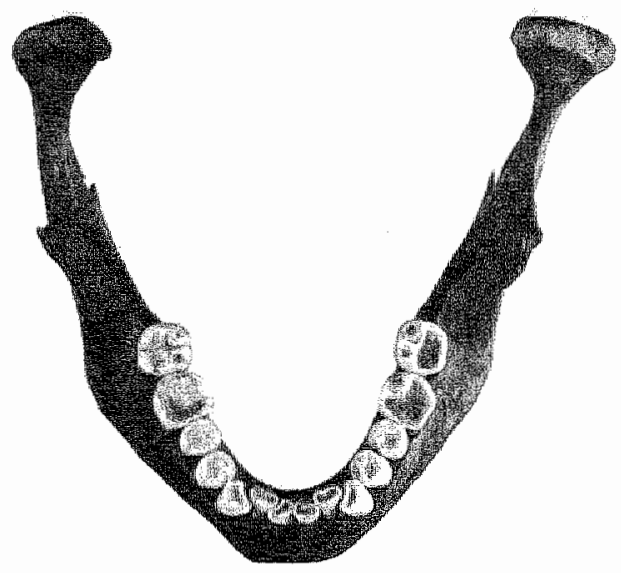

FIGURE 6.17 Mandibulid seen from abowe. The left and right third molars are absent both the first and second molars show an adwanced rate of attrition of the occlusal surface Due to the abrasion of the enamel lwhite in the

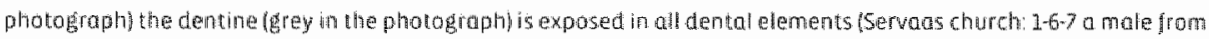
the cella sample aged be tween 50 to 59 years. fphotograph. Panhusent.

\section{ATTRITION}

To determine the rate of attrition or tooth-wear the molars of all 99 individuals with 28 or more erupted elements of the permanent dentition were inspected. However, in order to be included in the data set the dentition of an individual had to be unaffected by ante-mortem tooth loss or other pathological conditions that might affect the rate of attrition. Application of these criteria 
resulted in a reduction of the number of individuals avail able for inspection to 50 . The average rate of attrition of the first molars could be recorded in 40 individuals, of the second malars this was possible for 41 individuals and the third molars could be inspected in 30 individuals. In all three types of molars the rate of attrition was slightly higher in males than in females. However. this difference was not statistically significant.
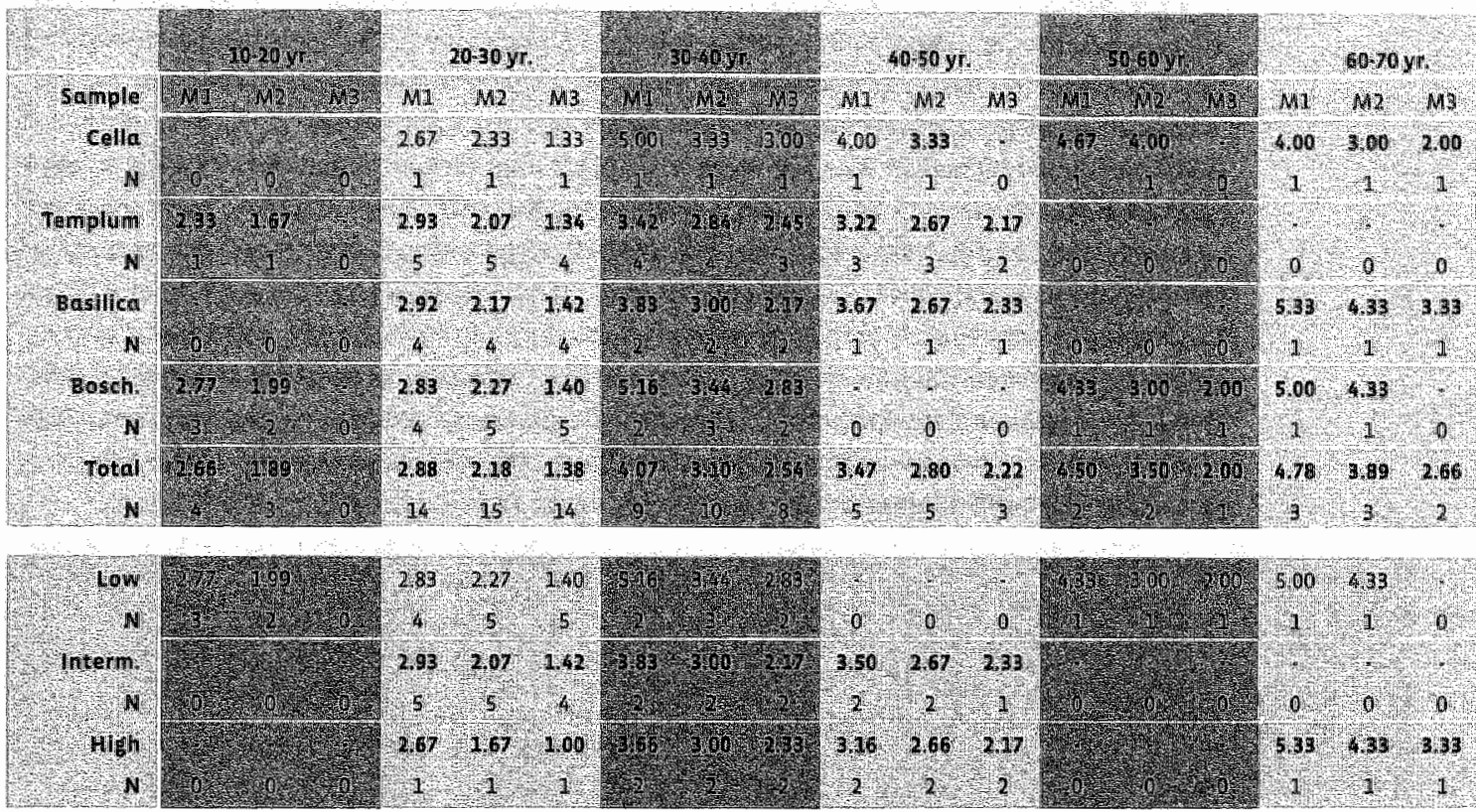

TABLE 6.57 mean attrinon rate of the first second and thid molar by sample and status caiggory for tenyearage intervals Not all

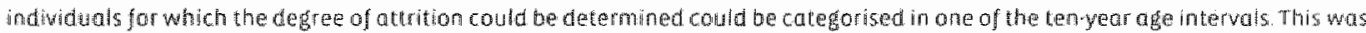

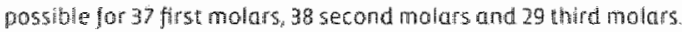

With advancing age the degree of attrition increased. This correlation between age and degree of attrition proved to be statistically significant for all three types of molars. ${ }^{520}$ still, the general increase of the attrition rate with age was not constant. As can be seen in Table 6.57 the attrition rate scored for individuals in the 30 to 40 years age interval was higher than in the following ten-year age interval. The variation in the degree of attrition among the four samples was generally limited. The small number of individuals hindered comparison of the degree of attrition, among the three status categories. Also in this comparison the 30 to 40 years age interval was characterised by higher attrition rates than for the following ten-year age interval.

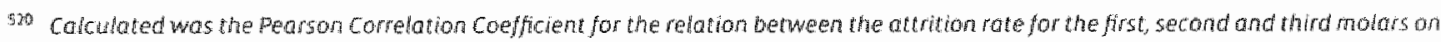
one site and the age as repiesented by the ten year age intervals on the other side for first molars the parson Corralation

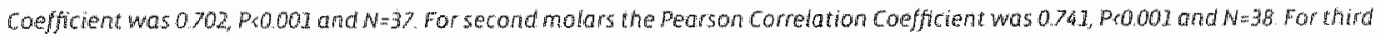
malars the Pearson Correfotion Coelficient was $0.559, \quad P=0.002$ and $N=29$ 
CARIES

Dental caries is the destruction of enamel, with or without the involvement af dentine and cement due to the acid production by bacteria present in dental plaque. Caries can be recognised as cavities in the crown or on the surface of the root. or more erupted elements of the permanent dentition two individuals lacked all teeth due to ante-mortem and post-mortem tooth loss, leawing 97 individuals for inspection of the presence of cartous lesions. In 56 individuals ( $58 \%$ ) caries was found. Out of 1537 dental elements that could be inspected $166(11 \%)$ were affected by caries. In general the carious lesions were found to be occlusal caries, wiz in the pits and fissures of the crowns of the teeth. A considerable number of elements had carious lesions on the approximal surface of the crown. Caries on the root Just below the cement-enamel junction, the neck, was rare. ${ }^{52 a}$ Females were relatively more often affected by caries than males; viz. $42 \%$ and $37 \%$ respectively. ${ }^{523}$ There was an evident but not statistically significant increase in the number of indiwiduals with caries with advancing. age. Among the individuals in the age category between 20 to 40 about $52 \%$ had at least one element with carles ( $n=40$ ), in the category from 40 to 60 years this percentage increased to $71 \%$ $(n=41)^{5 j *}$ The following tables on caries data presented as a percentage express the proportion of carlous teeth as a percentage of the number of inspected ellements. In addition the percentages of individualls with caries are listed.

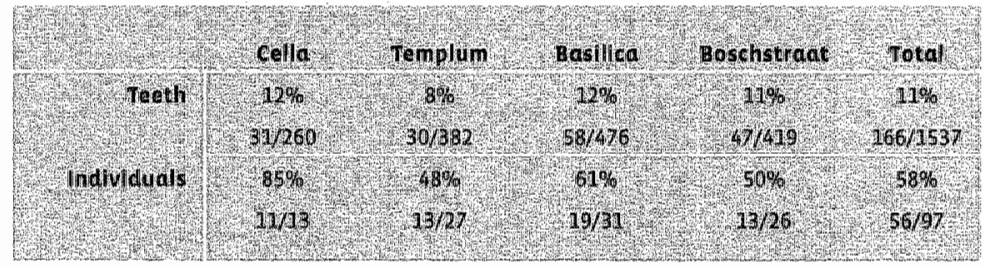

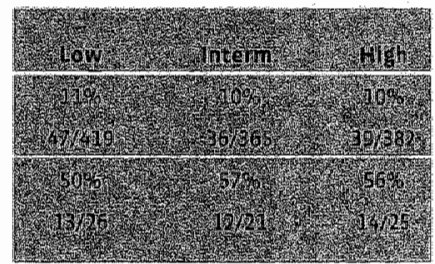

TABLE 6.58 Caries by sample and status. First the data are presented concurning the number of elements with carious

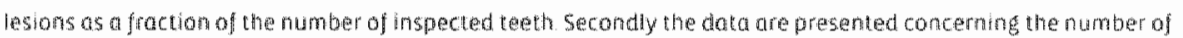
individuals with carbous teath as a fraction of the ramber of indiuduats

The variation in the prevalence of carious elements in the four samples was moderate. A relatively low proportion of carious elements (8 per cent) was found for the templum sample. In the other three samples the percentages of carious elements were higher (11 to 12 per cent). statistical andlysis of the prevalence of cariaus elements in these samples indicated that only the difference between the templum sample and the basilica sample was significant. ${ }^{525}$ The data for the three status categories indicated there was little variation in the prevalence of cariaus

sn wilson, $2996,20.269$

52 It was recorded which dements were affected by cares. However these dato are now presented here becouse a breakdown of the information into teeth categates and type of taries would lead to wery smat sanpies.

hx Mars-females $p=0.6$ (Fishers Exact test)

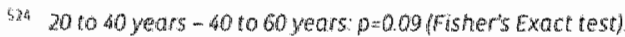

sas Percentage of carious elements: templum ws basilica $p=0$ as (Fisher's Exact test) 
lesions. The percentage of affected elements was marginally higher in the low status category, whereas the proportion of individuals with caries was slightly lower than in the intermediate and high status groups.

\section{ANTE-MORTEM TOOTH LOSS}

Ante-mortem tooth loss is the loss of permanent dental elements during life. Teeth may be lost during life either passively because of pathological conditions or through extraction. Advanced caries or attrition followed by secondary eruption and periodontal disease may cause the lass of teeth during life. Ante-mortem tooth loss was determined by inspecting the alveoli or tooth sockets. The criteria for scoring ante-mortem tooth loss were, besides the absence of a dental element, clearly remadelled margins of the tooth socket or complete disappearance of the tooth socket due to advanced remodelling of the jaw. Without traces of remodelling of the tooth socket it was assumed that the tooth had been lost due to post-depositional factors. Antemortem tooth loss was found in 49 individuals ( $49 \%$ ) out of a total of 99 individuals. A total of 255 teeth $(14 \%)$ out of 1807 inspected tooth positions were found to have been lost during life. Both males and females were affected in equal propartions. ${ }^{526}$ A strong and statistically significant association existed between the age of individuals and the prevalence of ante-mortem tooth loss. ${ }^{527}$ of the 40 individuals who died between 20 to 40 years 10 individuals $(25 \%)$ had antemortem tooth loss. In comparison to the 20 to 40 year age interval ante-mortem tooth loss tripled to $31(76 \%$ ) among the $4 \mathrm{I}$ individuals who died between 40 to 60 years. Therefore, the data on ante-mortem tooth lass are presented separately for the two age categorles of 20 to 40 years and 40 to 50 years. In addition to the data on the proportion of teeth lost, the data on individuals with ante-mortem tooth loss are also presented to facilitate comparison of the data with other sites.

For the age category between 20 to 40 years the differences in ante-mortem tooth loss were minimal. An exception was the comparatively high value for the sample from the cella phase (12 percent as opposed to 5 percent in the other three samples). A different distribution was found for the 40 to 60 year category. This age category showed an increase in ante-mortem tooth loss from the cella sample to the basilica sample. Statistical analysis of these rising percentages in the three subsequent samples from the Servas site indicated that this diachronic increase was statistically signuficant. ${ }^{528}$ with circa 19 per cent ante-mortem tooth loss, the individuals from the Boschstraat had an equal percentage of ante-mortem tooth loss as the individuals from the cella sample. The prevalence of ante-mortem tooth loss in the three status categories could be analysed in 74 indiwiduals with 1379 observable alveoli, tooth positions. Both in the age category between 20 to 40 years and for the sample as a whole the highest rate of ante-mortem tooth loss

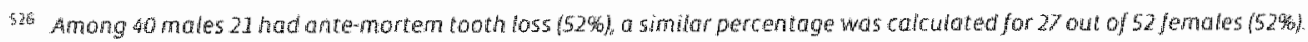

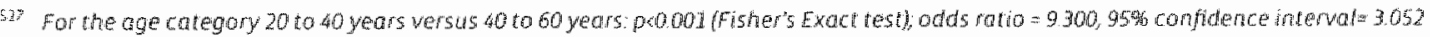
29.432 .

5.2 Chrougre test for trend cello-templum-basilica $p=0.04$
} 


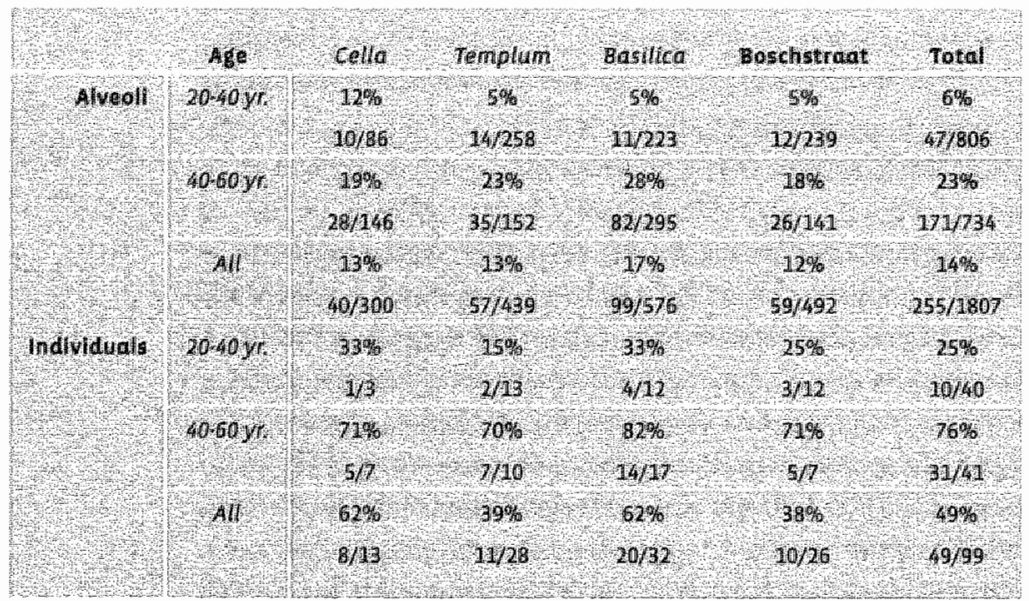

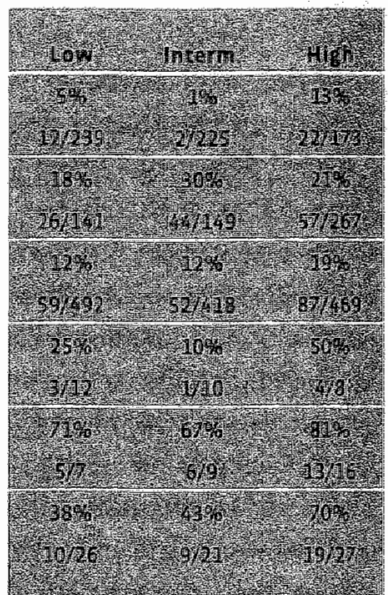

TABLE 6.59 Ante-mortem tooth loss by samphe and by status, percentages represent the number of alveofit with evident signs of antemontem tooth loss as a percentage of the total number of alweoli that coutd be insperted.

was found for the high status category. ${ }^{529}$ In the 40 to 60 years interval the differences between the status categories were not statistically significant and displayed no trend to increase of decrease with status.

\begin{abstract}
ABSCESSES
Periapical abscesses are alveolar abscesses located around the apex of the tooth root. They are the result of bone resorption caused by periapical periodontitis from micro organisms. All 99 Individuals with a completely erupted permanent dentition were inspected macroscopically for the presence of periapical abscerses. When possible teeth were removed from the jaw in order to inspect the socket. The tooth sockets were not examined radiographically. Therefore, not all periapical abscesses will have been detected. The presence of a cavity with (partially) remodelled bone around the root of a tooth was considered diagnostic evidence for periapical abscesses. In 45 individuals ( 45 per cent) periapical abscesses were found. A total of 12017 per cent) abscesses was recognised while inspecting 1807 alweoli. Males and females were evenly affected. A strong inciease in the prevalence of periapical abscesses with advancing age at death was found.$^{530}$ As a consequence the data are presented separately for the 20 to 40 and 40 to 60 year age categories and for all individuals with almost completely erupted permanent dentitions.
\end{abstract}

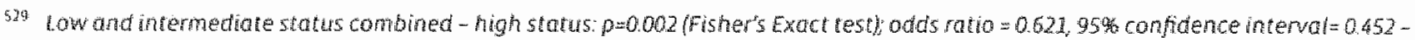
0.853 .

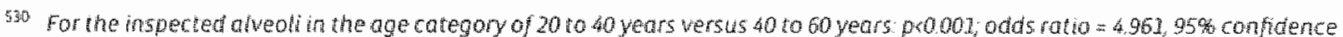
interval $=297-8395$ 


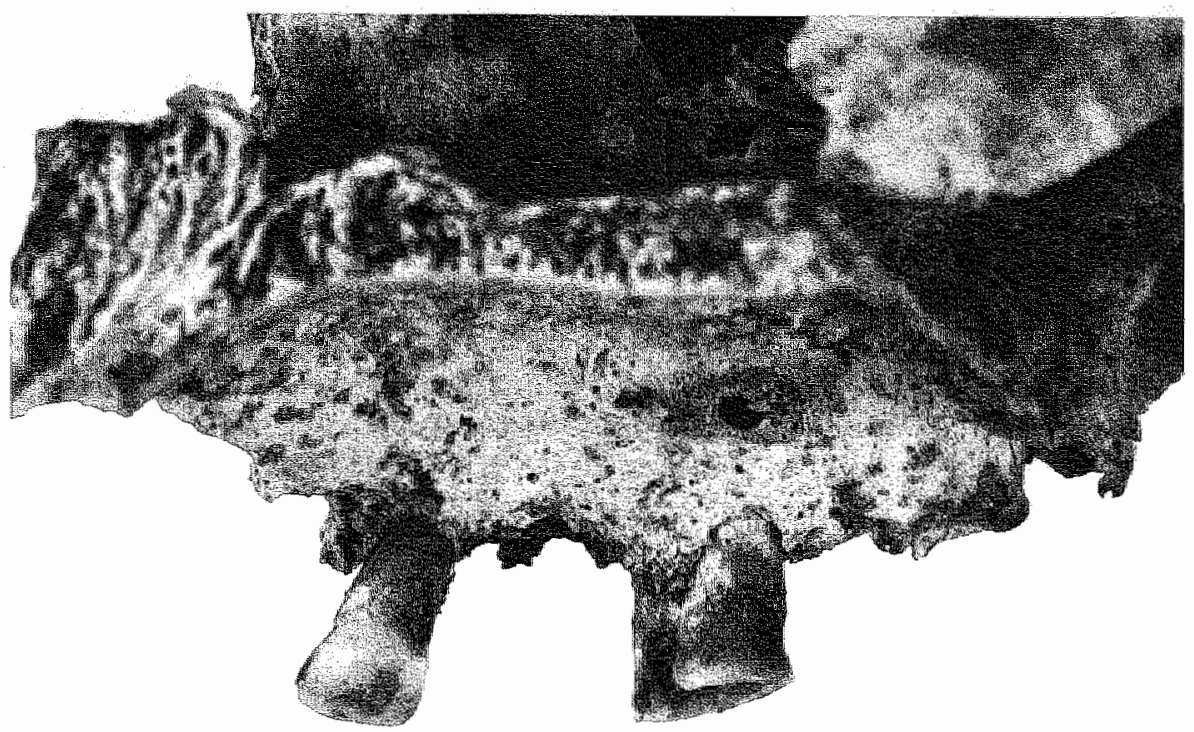

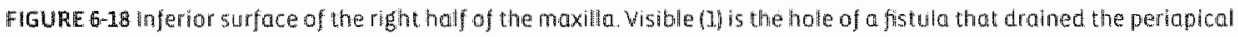
abscess at the root of the first malar (solid arrowl As so note (2) the carious lasion on the interproximal surgace of the

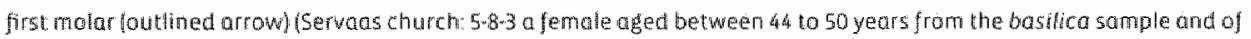
thigh status, photodraph: R Panhusen

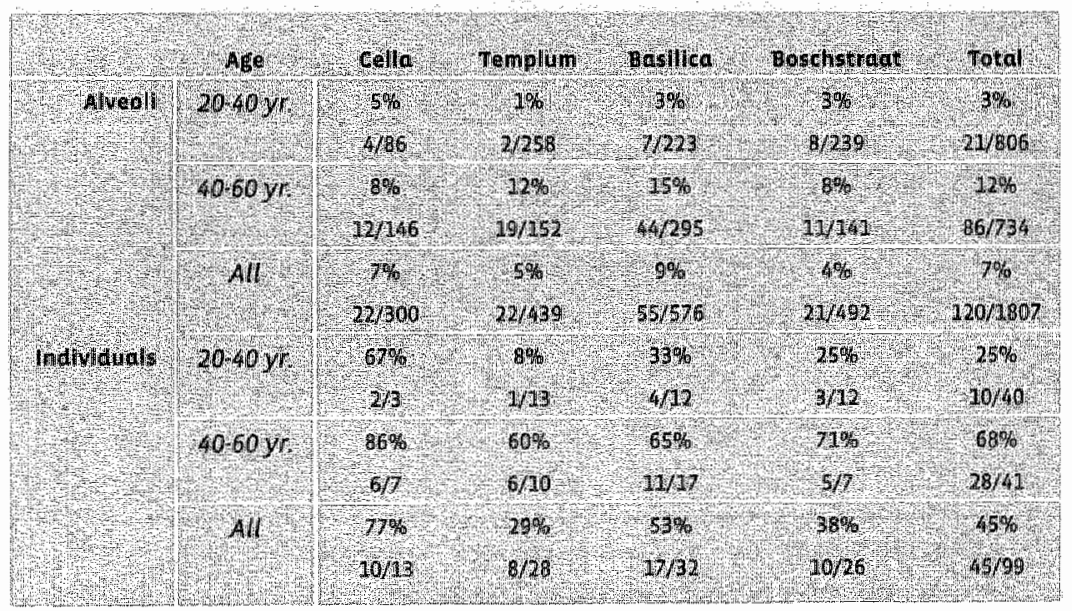

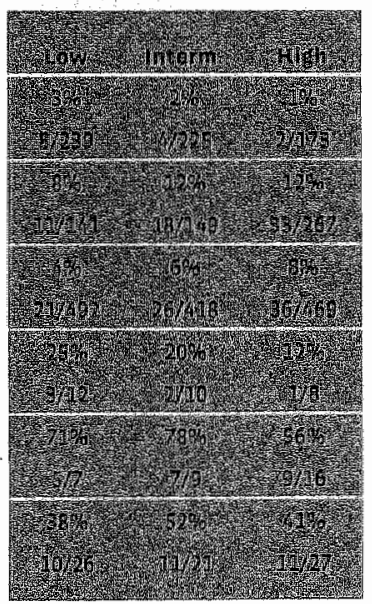

TABLE 6.60 peridpical abscesses by somple and by status 
In the 40 to 60 years age interval the prevalence of periapical abscesses was found to increase diachronically. It rose from about 8 per cent in the cella sample to 12 per cent in the templum sample and in the last period, wiz the basilica phase, abscesses were present in 15 per cent of the inspected tooth-sockets. This trend was statistically significant. ${ }^{\text {sal }}$ When the presence of abscesses in individuals of all age categories was compared a similar trend was not present. Looking at the number of individuals (not alveoli) with periapical abscesses no evident trends could be recognised. However comparison of the high number of individuals with abscesses in the cella sample with the low number in the templum sample indicated that the difference between these samples was statistically significant: ${ }^{32}$ This high number of individuals with abscesses in the cella sample contrasts with the trend of the increase of affected alveoli over time. The increase of the number of abscesses in the inspected alveoll from the low to the high status categories indicated that the prevalence of periapical abscesses was assaciated with

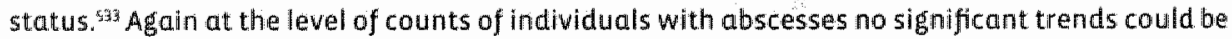
recognised.

\section{CALCULUS}

Dental calculus is mineralised plaque and exists in two types, viz. supra-gingival and subgingival calculus. Supra.gingival calculus is found as a deposit in the shape of a band on the enamel of the cervical crown. Sub-gingival calculus is formed on the root of the tooth. Only the presence of supra-gingival calculus was recorded systematically in this study. With advancing age there was a relative increase in the number of individuals with calculus. However, statistical analysis indicated this trend was not significant. Calculus distribution over males and females showed that significantly more males than females had calculus. ${ }^{536}$ Therefore, data concerning males and females are presented in separate rows in Table 6.61.
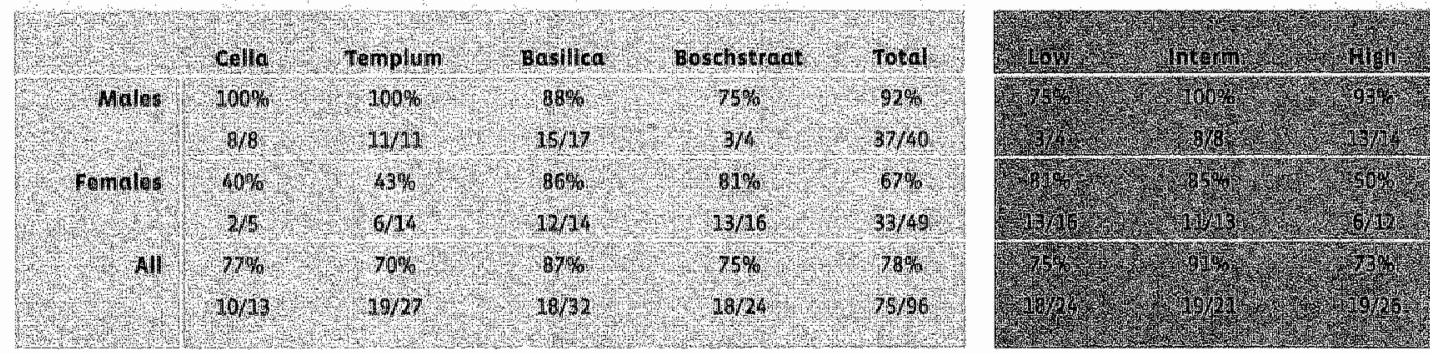

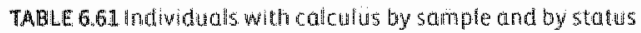

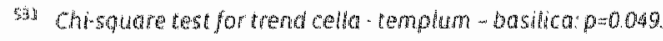

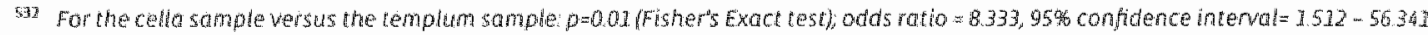

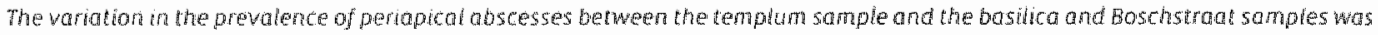
not significant whith valdes of oor and o 57 respectivety

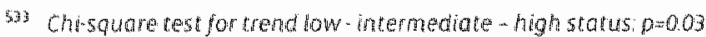

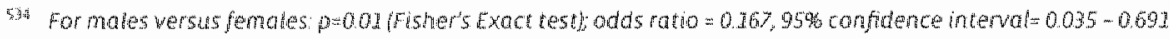


Regarding the prevalence of supra-gingival calculus among the combined male and female samples there is little variation between the four samples or the three status categories. The largest variation in the prevalence of calculus was found for females in the various samples. In the cella and templum samples the prevalence of calculus was comparatively low, whereas it was approximately wice as high among the females of the basilica and Boschstraat samples. The difference in prevalence between the templum and basilica females was found to be statistically significant. Although the prevalence of calculus was evidently lower among females of high status, the difference was not statistically significant. Considerable fluctuations in the difference in prevalence of calculus between males and females were found in the four samples and three status categaries. In the cella and templum samples calculus was much less common in femalles than in males. Almost equal percentages in males and females were found for the basilica and Boschstraat samples. Comparison of the sexes in the three status categories showed marginal differences in the groups of low and intermediate status. In the high status category almost all males had calculus, whereas half of the females were affected. This association of calculus by sex in the high status category is statistically significant. ${ }^{3.6}$

\section{ALVEOLARATROPHY}

Alvealar atrophy is the retraction of the supportive tissues of the teeth. In osteo-archaealagical studies this is recorded by describing the recession of the alveolar bone. The occurrence of alveolar atrophy was found to be associated with age. In the 20 to 40 year category circa 60 per cent of the individuals had evident atrophy. This increased to 90 per cent in the 40 to 60 years category. This correlation with age is statistically significant. ${ }^{5 *}$

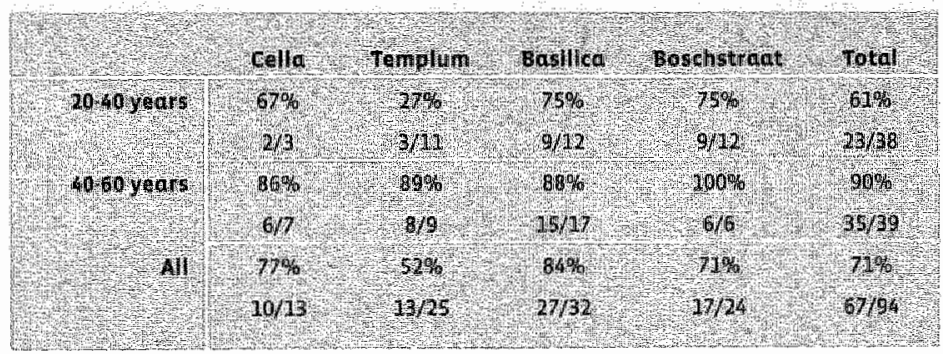

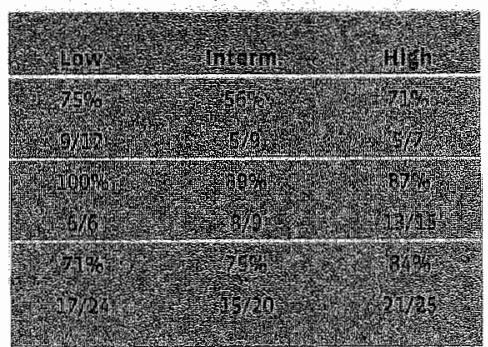

TABLE 6.62 indwiduals wh olveolar chophy by sample and status

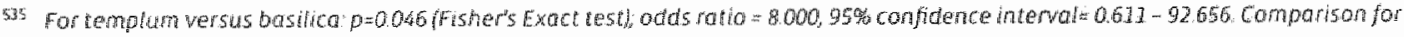

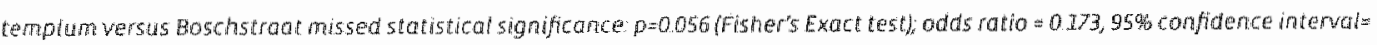
$0.023-1219$

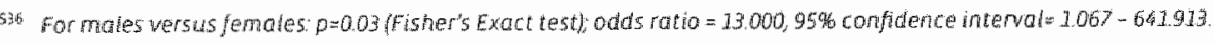

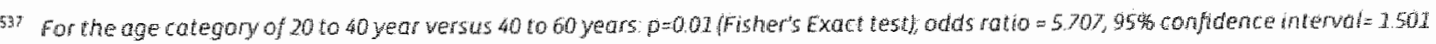
$-23.534$
} 
In general the various samples showed little variation in the prevalence of alveolar atrophy. An exception was the low prevalence in the 20 to 40 year age category in the templum sample. The difference with the higher prevalence in both the basilica and Boschstraat samples proved to be statistically significarit, ${ }^{\text {52. }}$ Among the status categories there was little variation in the prevalence of alveolar atrophy.

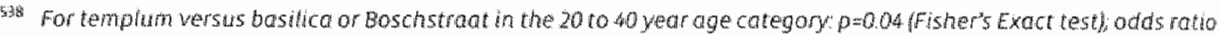
$=0.125,95$ confidence intervat $=0.013-1061$ 
Discussion

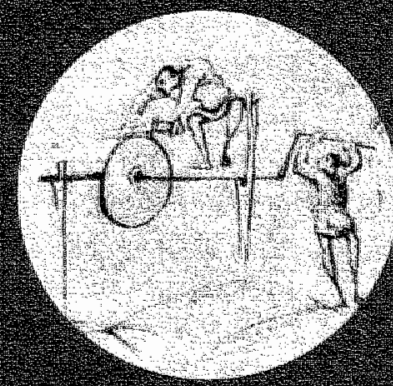




\section{Discussion}

\section{INTRODUCTION}

It is the aim of this study to use human skeletal remains from two sites as a source of information concerming the living conditions in early medleval Maastricht. In addition, this. study seeks to contribute to the interpretation of the archaeological findings relating for example to the layout of the cemetery of each chronological phase and to diachronic changes at the cemeteries. With these goals in mind the following analysis of the callected data is divided into an introduction, a review of the parameters used in this study and a main section discussing the results in their chronological and topographical context. ${ }^{539}$

The extent to which historical events can be described largely depends on the available sources. With respect to the description of living conditions in the late Roman and early medieval period, the information depends mainly on the quality and quantity of human remains. Thus the reliability of the available information will be determined by the presence of an adequate number of individuals and whether statistical methods can validate the trends encountered in the material. It is worth reiterating that asteo-archaeology is generally confronted with limitations in its scientific approach. Osteo-archaeological knowledge is largely acquired fram unilateral observations in uncontrolled circumstances. Unlike physical anthropological and medical studies of living individuals, which can rely on experimental studies under controlled circumstances, osteo-archaeological studies have to rely on observations and attempts to interpret these observations in their context.

\section{GENERAL CHARACTERISTICS OF PHYSICAL ANTHROPOLOGICAL AND PALAEOPATHOLOGICAL DATA}

Before we cain discuss the results of the physical anthropological and palaeopatholagicall examination it is mecessary to review the parameters that are used to obtain an image of the living conditions in late Roman and early medieval Maastricht. It is not the purpose of this study to extensively evaluate all methods applied in collecting data, as this would require a series of separate studies. The review is aimed at providing a concise description of methodological aspects that have an impact on the validity of the results and the way the data may be interpreted. 


\section{SEX}

Ht us generally recognized that the methods for the determination of sex in adult individuals based on the inspection of the pelvis ard skull generate reliable results. ${ }^{5 * 1}$ As Acsadi and Nemesker have indicated in the description of their method, it is necessary to test whether the method can be applied correctly in the sample under study..$^{502}$ An indication that this non. metrical morphological method was appropriate to determine sex for the Maastricht population is evident from figure 6.2 in the previous chapter. The anterior-postevior femoral diameter was used as an additional indicator of sex. This metrical morphological indicator was applied only in cases with unambiguous values, in order to reduce the chance of incorrect determinations. With respect to a possible bias in the determination of sex in cemetery samples, Walker has indicated that in some cases females may be underrepresented in excavated samples. ${ }^{547}$ One of the reasons for female underrepresentation is the more gracile nature of female bones, which increases the susceptibility to age-related bone loss in females. This may have a negative effect on the preservation of female skeletal remains. In our samples the recavery rate of male skeletal remains was indeed slightiy higher than in females. However, the difference in survival of male and female bones was not statistically significant. . $^{\text {sh }}$ Therefore, it is unlikely that this effect had a noteworthy impact on the representation of females in the examined samples. Another source of bias in sexing skeletal remains mentioned by walker is the ongoing development of male cranial features in young males up to the age of 30 years. In theory this trend could lead to the erroneous attribution of female sex to young males. Walker further signalled a tendency to develop more "male" cranial features in females of 45 years and older. ${ }^{\text {;as }}$ Since the determination of sex was primarily based on the sexualisation degree of the pelvis it is unlikely that these age related changes in the cranium have significantly biased our results. Furthermore, the limited effect of this age related masculinisation of elderly females is evident from the high correlation between sex determinations for pelves and skuls (see the scatter plot in figure 6.3).

Data on the distribution of the sexes can provide waluable information on the composition of the cemetery population. ${ }^{\text {sat }}$ Generally the number of males and females is expected to be in balance in a population. overrepresentation of either males or females in a cemetery sample can be the result of an existing imbalance in the composition of the living population. However, it can alsa be a consequence of gender based selective mechanisms in the burial customs. For example an overrepresentation of male burials might be an indication of the foundation of a monastic ar canonical community or it could be a result of a tendency to bury males and females at different cemeteries. The determination of sex will also be used to plat the distribution of the sexes in plans of the cemetery. This will help to determine whether there

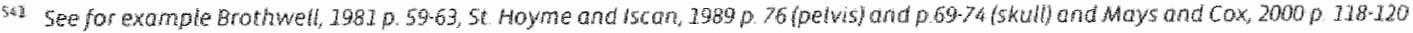

52. Acsodiand Kemesicéri, 1970, p.91-97.

5sat Wutker at, 1988 and Walker, 2995 , 035

sha The meare recovery rate for males $(n=66)$ was 0.34 and for females $(n=98)$ o 33

whs Walkar, 1995,03640 and Weis, 1972

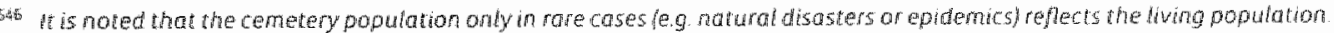


were concentrations of burials of either males or females or whether they were buried in the same areas. Another line of research is the analysis of the possible association between grave goods and sex. In recent years, especially since the study of Halsall, 3 , this topic has become a facus of study.

\section{AGE AT DEATH}

The avaliable methods for estimation of age at death for non-adults are considered quite reliable. Estimation of age at death of adult skeletal remains is not undisputed. For both age categories it should be recalled here that all methods lead to estimates of the biological age, based on an assessment of various ageing processes in the skeleton. It is known that there is considerable wariation in the progress of these ageing processes. Therefore, on the individual level there may be a discrepancy between the estimated biological age and the actual calendar age. Within larger samples of skeletons the effect of individual discrepancies between biologicall age and the calendar age are generally considered to be levelled out, namely the number of individuals with a blological age younger than their callendar age is expected to equal the number of individuals with a biological age older than their calendar age. However, any bias intraduced by the method of age determination will not be reduced by an increase of the sample size. To the contrary, the incorporation of the tendency to either underage or owerage in a method will affect the whole sample. Furthermore, it is recalled here that it is not possible to reconstruct precise life tables based on osteo-archaeological data, since the mortality distributions and graphic representations all illustrate the number of deaths in certain age intervals, not the number of living individuals in that age category. Because of the nature of the examined samples it was decided not to include mortality tables in this chapter but to use bar charts for the illustration of mortality patterns.

\section{AGE OF NOWADULTS}

From a methodological point of view estimation of age at death for mon adults is fairly accurate. In individuals up to 20 years the ongoing development of multiple skeletal and dental elements and the rapid growth of long bones generally allows for precise and reliable age estimations. On the basis of these results it is possible to acquire a detailed picture of mortality among the nonadult population. However, comparison of these data with other studies is often hindered by the

He Hall 1995

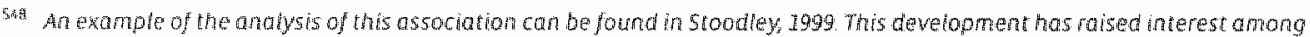

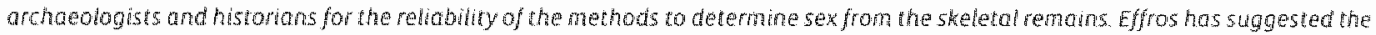

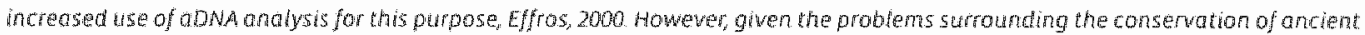
DNA, the risk af Contamination with modern DNA and the costs of DNA analys is it is not to be expected that aDNA analysis will be

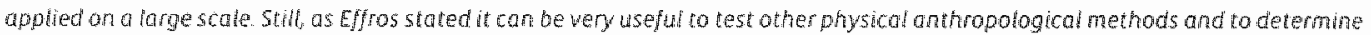
the sex of non adtul indiduals. Far the time being morphotogical sex determination will be the most frequanty opplied methat providing relioble resutio. 
large voriety of age categories used in the literatupe. And it has to be taken into account that attribution to these age categories is determined by asteological and dental age characteristics or the desire to create age categories of an equal number of years for statistical purposes. often these age intervais do not correlate with the biological and pathological developments that affect the morbidity and mortality risks in the individual. For example an approach categorising children in ten-year age intervals will group children between birth and two years with a high mortality risk with children from 5 to 10 years who generally have a lower mortality risk. Furthermore, it should be noted that the socio-cultural classification of individuals in age categories seldom correspands with the categories used in physical anthropology. 553 it is evident that ostealogical criteria, like the fusion of the epiphyses of the clavicle, did rot determine when an individual was culturally considered an adult. Written sources indicate that in early medieval Europe the cultural transition from childhood to adulthood took place quite early in life, around 12 to 14 years. ${ }^{552}$ That is well before girow th has campleted.

With respect to non-adult mortality methodological aspects pose no obstacle to the use and interpretation of the physical anthropological data. Still, other factors may hinder the use of these data. The proportion of non-adult individuals in the excavated population may be reduced due to a higher susceptibility to decomposition processes of the bones of younger children. ${ }^{553} \mid \mathrm{n}$ addition, the number of non-adults in a cemetery may also be increased or decreased as a consequence of specific burial customs. ${ }^{5 \% 4}$ When it can be ruled out that the recovery of nonadult skeletal remains is seriously affected by differential preservation or preferential burial the data can be used to calculate nom-adult mortality. This is considered to be a reflection of general strain on the population and to be determined by the living conditions as well as the demographic developments and the pathological laad. It is not just the proportion of non adults versus aduits in a population which is of interest, but also the distribution of non-adult mortality during the first two decades of life may yield information on generall living conditions. For example a high mortality in the first two years after birth is considered to be indicative of poor living conditions, often in combination with population growth. ${ }^{55}$

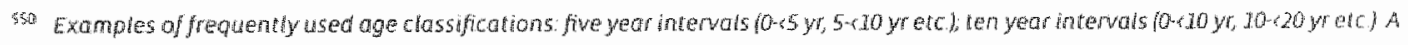

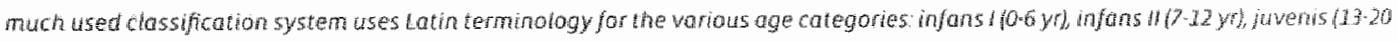

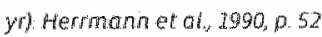

5,1 Lhrke, $2004,17.18$

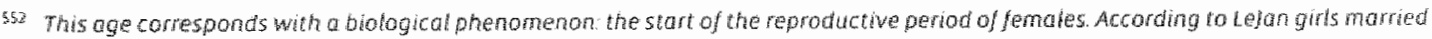

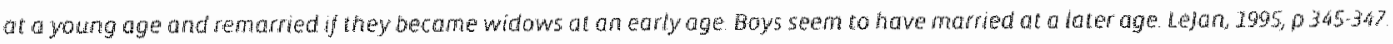

s5. Guyetob. 1997 .

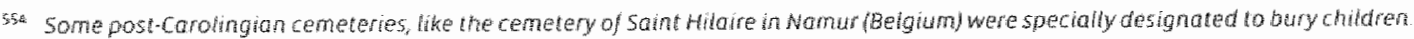

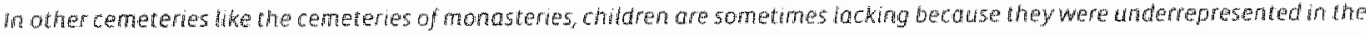
community

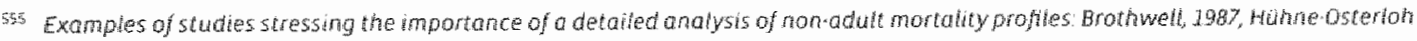
and Grupe, 1989, Wolleson, 1991 and Zink, 1999 


\section{AGE OF ADULTS}

Estimation of age at death for adults is generally considered less precise and known to be less rellable than for non-adults. ${ }^{55}$ Age assessment of adult individuals is hampered by interindividual variation and is often considered to be problematic in older individuals. ${ }^{52}$ For this study estimation of age at death was done by means of the "complex method". When necessary this method was used in combination with ectocranial suture obliteration and molar attrition. Like all methods to estimate age at death the "complex method" is certainly not without flaws. Molleson and Cox described that for the individuals with a known age at death in the Spitalfields population (London, UK) the "complex method" tended to overestimate age at death for individuals younger than 40 years and underestimate age for individuals of 70 years or more. ${ }^{5 a t s e n}$ studied a population of 151 adult individuals of known age from Alkmaar (NL) and found similar trends. However $r_{s}$ in the Alkmaar study the age estimates based on the "complex method" were found to be more in agreement with the actual ages at death than in the spitalfields study. ${ }^{559}$ This difference between the two studies may partially be explained by the way the "complex method" was applied. In the Spitalfields study the proximal humerus and femur were not sawn for inspection of the trabecular structure; in the Alkmaar study these bones were sawn according to the instructions by Acsadi and Nerneskeri. ${ }^{560}$ Despite the afforementioned disadvantages of the method, the "complex method" was chosien as the basis for the estimation of age at death for adults in our population because it is a method using. multiple indicators that may limit the effect of bias encountered in single indicator methods. Furthermore, it was developed on the basis of a European population, reducing the chance of bias due to inter-population differences. The widespread use of the method in Europe and the Netherlands was also a factor in the selection of this method as the basis for ageing in this study, since this would allow the data to be compared with other studies.

The estimates of the age at death for adults were used to calculate mean ages at death Generally, mean variation in mean ages at death of different populations is difficult to interpret, since the mean age at death does not take into account the distribution of mortality over the consecutive age intervals. Furthermore, comparison of the mean age at death from different populations may be biased by the use of different methods, or when the same method is used, they may be influenced by inter abserver variation. In this study comparison of the mean ages at death among the samples is feasible because the same investigator collected all age estimations, using a fixed set of methods. To ascertain whether the general distribution of mortallty is comparable the overall distribution of mortality in the compared samples will be examined. Mean ages at death will be used to determine whether there were diachronic changes in the age at death and whether there was a correlation between age at death and

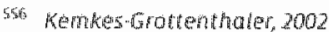

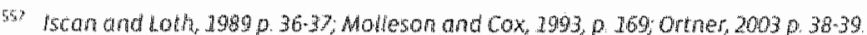

5eta Mollason and Cox 1993, D. 69

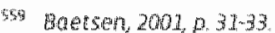

sta Molleson Grad Cox, 1993, fD. 169

s6. Maat, 198 ? 
status. The distribution of mortality will also be studied by means of bar charts representing the mortality profiles. In principle the distribution of mortality ower ten-year age intervals may provide mare detailed information on the risk of dying at certain ages. However it must be kept in mind that this is not only a function of the risks of dying in the consecutive ten-year age intervals, but possibly was also determined by selective mechanisms in the burial customs.

\section{STATURE}

Comparison of standing living height between warious samples was done by calculating stature estimates from standardised measurements of lang bones. For this purpose long bones were measured to the nearest millimetre. ${ }^{5.62}$ From these measurements stature was calculated separately for males and females. The regression formulas used to calculate stature are devised from series of long bone measurements from individuals of known stature and sex. The result, a mean stature in centimetres for males and females, is appealing since it allows us to visualise the average standing height of males and females in a population. More importantly it facilitates comparison with archaeological, histarical and modern data on stature. However, the existence and use of different regression formula also introduces some distortion in the data on stature. ${ }^{53}$ For example for the skeletal remains from Maastricht the formulas from Trotter ${ }^{56}$ and from Trotter and Gleser: ${ }^{56 t}$ yield structurally higher statures than the formulas developed by Breitinger ${ }^{\text {stit }}$. These differences are largelly the result of differences in praportions of the bones in the upper and lower extremities, spine and skull in the populations for which various authors developed their regression formulas. The use of different regression formulas also hinders comparison of the results presented in older studies applying other methods and regression formulas, e.g. the formu las developed by Pearson and Olivier. ${ }^{56 x}$ Therefore, in this study it was decided to present both the calculated stature and the mean lengths of the long bones for adult males and females.

Adult stature is dependent on genetic factors and various aspects of living conditions, like the quality and quantity of nutrition, physical stress and disease load. Therefore, stature is considered a valuable indicator for the general living conditions and socio-economic situation. Because multiple factors can have an effect on growth, stature is a non-speciffic indicator of general living conditions. In order to study the impact of socio-economic factors we have to determine whether the ethnic composition of the population was more or less stable during the periad under study. With respect to the cella phase in Maastricht and the transition to the

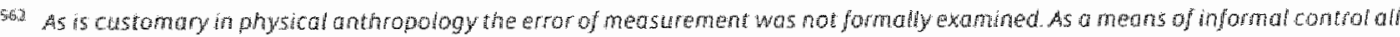
measuremerts of simgle bones were repeoted.

5h Troter 1970

s.s. Frotter and Gleser. 1958 . 
templum phase it is hitherto unknown whether the ethnic background of the population changed. As mentioned in chapter two there are indications for a "Germanization" of local culture in the Merovingian period, roughly coinciding with the templum phase. The historical and archaeological sources do not indicate whether this "Germanization" process was accompanied by the influx of considerable mumbers of individuals who differed genetically from the Gallo-Roman population. For the templum phase and the basilica phase we have no reason to assume large changes in the genetic composition of the population. Therefore, the analysis of differences in lang bone growth and stature may provide information on possible differences in living conditions for the templum and basilica phase.

socio-economic factors are assumed to influence adult stature by means of staltus-related differences in access to quantitatively and qualitatively sufficient nutrition and other elements of living conditions. ${ }^{309}$ In several studies Wurm has shown studies that high status was associated with above average stature. ${ }^{5 \% 0}$ Changes in stature may also provide information on general changes in living conditions. An increase in stature over time within a more or less stable population may be interpreted as an indication for improvements in living conditions. Male and female stature is affected differently by changes in the living conditions. Therefore, attention is also paid to changes in the dimorphism in stature. ${ }^{57}$

\section{METRIC AND NON-METRIC VARIATION}

It was mentioned before that because of the often-fragmentary nature and incompleteness of the skeletal remains only the presence of a select number of non-metric skeletal traits was sicored. For the same reason no more than three measurements of the cranilum were taken ${ }^{5 \% 2}$ Although nor-metric traits have been studied since the nineteenth century the interpretation of the data on non-metric ar epigenetic variation of skeletal traits is mot at all straightforward. As the presence of most traits depends on multiple genes their occurrence is explained by means of a threshold model, developed by Falconer. ${ }^{573}$ According to this model the development of a trait depends on whether the gene laad in an individual surpasses a threshold. A polygenetic distribution is considered to have an additive positive or negative effect on the development of a trait. Internal and external environmental factors may also contribute to the development of non-metric traits. Factors like parity, maternal age, sex and nutrition may either push an individual over the threshold or prevent the development of a trait. The occurrence of some of

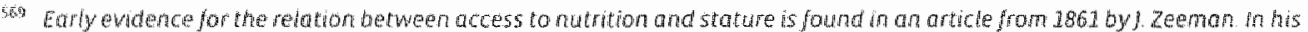
publication zeman describes that fuctuations in the price of rye were ossocianed with fluctuations in the percentrges of andersized

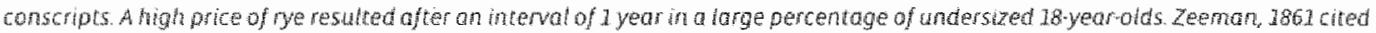

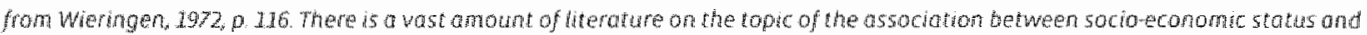
stature Introductions to this topic ore wieringen, 1972 and Floud et al, 1990

5\% Wurm, 1985

5). Valenzueta 193

52 Hartin and soller. 2957

"3.3 Haser and De Stefono, $3989,250,3$. 
these traits may also be influenced by the age of the individual, as several traits are thought to appear or disappear with advancing age. Some non-metric traits are also considered indicators of ontogenic stress or poor health conditions during pregnancy. ${ }^{574}$

In this study one non-metric trait, viz. lambdoid ossicles, displayed considerable variation between the separate phases in the sample. The spatial distribution of individuals with lambdoid ossicles in the cemetery is studied to establish whether this trait was evenly distributed or whether it was found to be concentrated in clusters of individuals. A clustered distribution might indicate that the individuals buried in these clusters were genetically related. ${ }^{57}$ However, since the development of this type of non-metric trait depends of genetic and enviranmental factors it is difficult to determine to what extent its occurrence is the result of genetic relationships. ${ }^{5 \%}$ Still, this topic deserves some attention, as family relations may have been an important factor in the selection of the burial location. With respect to metric variation in the sample, few data could be collected and analysis of these data did not indicate that metric variation was clearly associated with period or status. Therefore, metric data will not be discussed below.

\section{THE EFFECT OF STRESS AND DISEASE}

Osseous changes, like Harris lines and cribra orbitalia, and dentall changes, like enamel hypoplasia, may all be induced by various farms of systemic stress. Both physical stress, e.g. disease, nutritional deficiencies, heavy labour and intoxication are possible causes. Therefore the data an stress indicators are combined in the analysis to provide insight in the presence of stress.

However, the presence of stress-related changes in the skeleton cannot be used as an unequivocal sign of poor health. Markers of physical stress in the skeleton can be seen both as a negative phenomenon, viz. evidence for the exposure to stress, and as a positive phenomenon, namely the ability to react to pathalogical conditions. In recent years osteo-archaeologists have realised that there is no straightforward relation between the presence of stress indicators or signs of disease and poor living conditions. In many cases the skeletal reaction may be interpreted as proof that the individual temporarily survived or overcame the strain on its health. The ability to survive and overcome diseose and stress will of ten have been attributed to good health. Individuals with less resistance to stress and disease may have died before the sikeletton could react. This notion that the presence of asseous changes due to stress and disease may in certain samples be associated with good health is named the "osteological paradox".

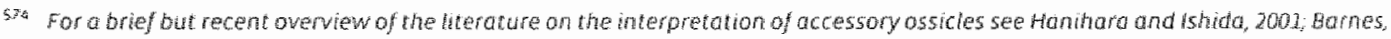
1994 provides examples for the interpretation of non metrir variation in the axid skeleton as developmental defects

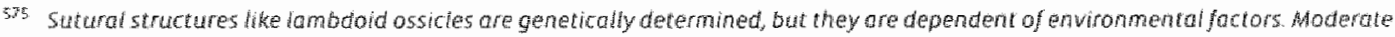

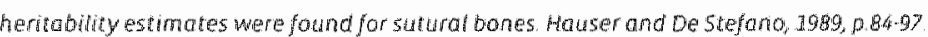

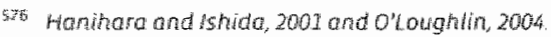

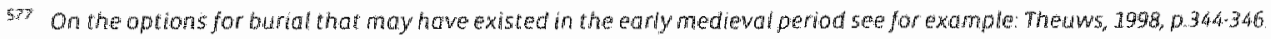

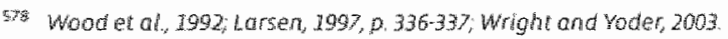


The study of various health indicators in relation to each other and in the context of the historical and archaealogical data on liwing conditions will contribute to reaching valid interpretations. For example an increase in the prevalence of Harris lines and enamel hypoplasia in combination with a temporary decrease in mean age at death might together be interpreted as indicatars of a deterioration of living conditions.

\section{HARRIS LINES, ENAMEL HYPOPLASIA AND CRIBRA ORBITALIA.}

As described in chapter 5 a Harris line or growth arrest line is a small layer of bone formed during a period of delayed bone growth. In adult individuals they can be seen in the marrow cavity as a thin layer of trabecular bone. On radiographs of the long bones of nonraduits and adults Harris lines are visible as transwerse radio-opaque lines indicating the presence of increased bone density. ${ }^{5 / 9}$ There is little doubt that Harris lines are associated with periods of delayed or arrested growth. However, because such growth insul ts can be caused by a variety of conditions, Harris lines are considered to be a non-specific stress indicator. Possible causes of Browth insults that might possibly lead to the formation of Harris lines are: quantitative or qualitative deficiencies in nutrition, exposure to toxic substances, disease, and physical strain. In present day clinical practice Harris lines are also encountered in individuals who did not experience natable physical stress ${ }^{580}$

Due to limited access to $x$-ray facilities examination of Harris lines is not a standard procedure in osteoarchaeological studies, which reduces the availability of comparable data. The possibility to compare data of different studies is further reduced due to the fact that there is considerable variation in the methods used to study harris lines. The applied methods vary in the selection of bones for examination and the definition of Harris lines.

Enamel hypopllasia is also considered to be an indicator of physical stress interfering with proper growth of dental enamel. ${ }^{\text {san }}$ Like Harris lines it is a non-specific indicator. The recording of these defects in the enamel surface was done by macroscopic inspection. As most enamel defects were in the shape of horizontal lines and not very marked the classification of hypoplasia was rather straightforwardy recorded as present or absent. ${ }^{\mathrm{s}}$. Unfortunately not all osteoarchaeological studies include results for this stress indicator in the data set. This limits the possibility of comparing data with contemporaneous or otherwise interesting populations.

Cribra orbitalia are more specific as an indicator of physical stress. These osseous changes of the roof of the eye orbits are associated with iron deficiency ancemia. Although this considerably limits the range of causes for this phenomenon, a large variety of conditions, like dietary insufficiencies, low birth weight, chronic diarrhoea, parasitic infection and genetic diseases, may cause this condition ${ }^{583}$ Although cribra orbitalia are often categorised according

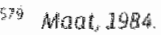

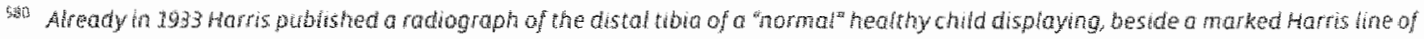

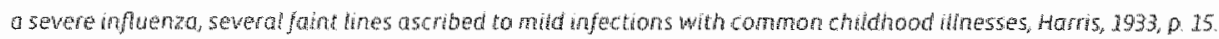

skinner and Goodmon, 1992, 160-162, Lukacs, $1989,0.267$.

is In additon the age of formation was recorded.

sis $\operatorname{larsen}, 3997,290,30$ 
to different descriptive systems, many studies present data on the prevalence of cribra arbitalia. This has lead to a situation where data for comparisons on a population level are available.

\section{PATHOLOGY}

As indicated in the chapter on methods a panel of medical specialists and physical anthropologists reviewed all pathological cases. Pseudopathology ${ }^{534}$, normal wariants and mild degenerative changes were either excluded beforehand or during sessions of the paleopathology panel. The panel assisted in diagnosing the disease and the assessment of the impact of various pathologies on the life of the affected individual. With respect to peripheral asteoarthritis and degenerative changes in the spine the application of the criteria developed by Rogers and Waldron ${ }^{555}$ in combination with the clinical experience of the panel members lead to the use of conservative standards for the scoring of these conditions. Various pathological conditions can prowide information on the health conditions in Maastricht. Fractures can inform us about occupational risks and medical treatment, arthropathies and musculo-skeletal stress markers may inform us about physical activities. ${ }^{586}$ The frequency of sharp bladed injuries is an indicator of the amount of violence. In some instances signs of healing may shed some light on the availability of medical care. The prevalence of a candition like DISH is often interpreted as a sign of an affluent diet. ${ }^{58}$ other more specifically diet-related information can be obtained from the study of carious lesions, peri-apical abscesses, ante-mortem tooth loss and calculus.

\section{CONSIDERATIONS REGARDING THE REPRESENTATIVENESS OF THE SKELETAL REMAINS} The assumption that skeletal remains collected at an archaealogical site represent the whole population of a settlement during a specific time frame is generally to be refuted. ${ }^{\text {shg }} \mathrm{A}$ basic inventory of the composition of the examined sample in relation to the living population may provide insight into the informative value of the data. Such an assessment should take in to account three major factors that determine the composition of the sample under study: the biological filter, the cultural fillter and the effect of post-depositional processes. Generally these factors cause a reduction or blas of the information that is contained in the human remalns. The

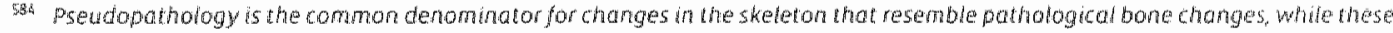

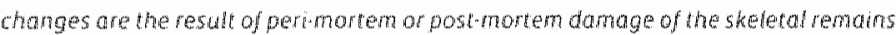

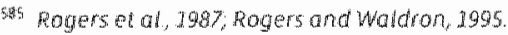

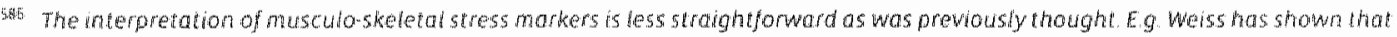
the manifestaton forcurrence and sizel of musculosketatal stress markers is dargety dependent of age of the ind widuals in stead of physical activities; Weis5, 200 t

54: Waldron, 1985, Rogers and Waldron, 2007 and Weinfeld et al, 1998.

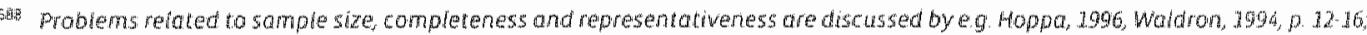
Sounders and Merring. 2995, Buchet and Lorren, 1975
} 
biolagical filter consists of enviranmental conditions and subsistence strategies which determine the demographical composition, heal th status and mortality pattern of the original population. The cultural filter is defined by burial customs determining who was buried at a cemetery and whether the place of burial was selected on social and demographic grounds. The possibility of selective butial on the basis of demographic or social characteristics will be discussed below in the sections on sex and age distribution. In chapter four the fimiting effect of some post-depositional processes was described. It is recalled here that the cemetery at the Servaas site was not completely excavated and that the inhumations from the templum phase in particular had suffered from the intense building and burial activities. The cemetery at the Boschstraat site was almost completely excavated and at that site few graves had been disturbed by later human interference.

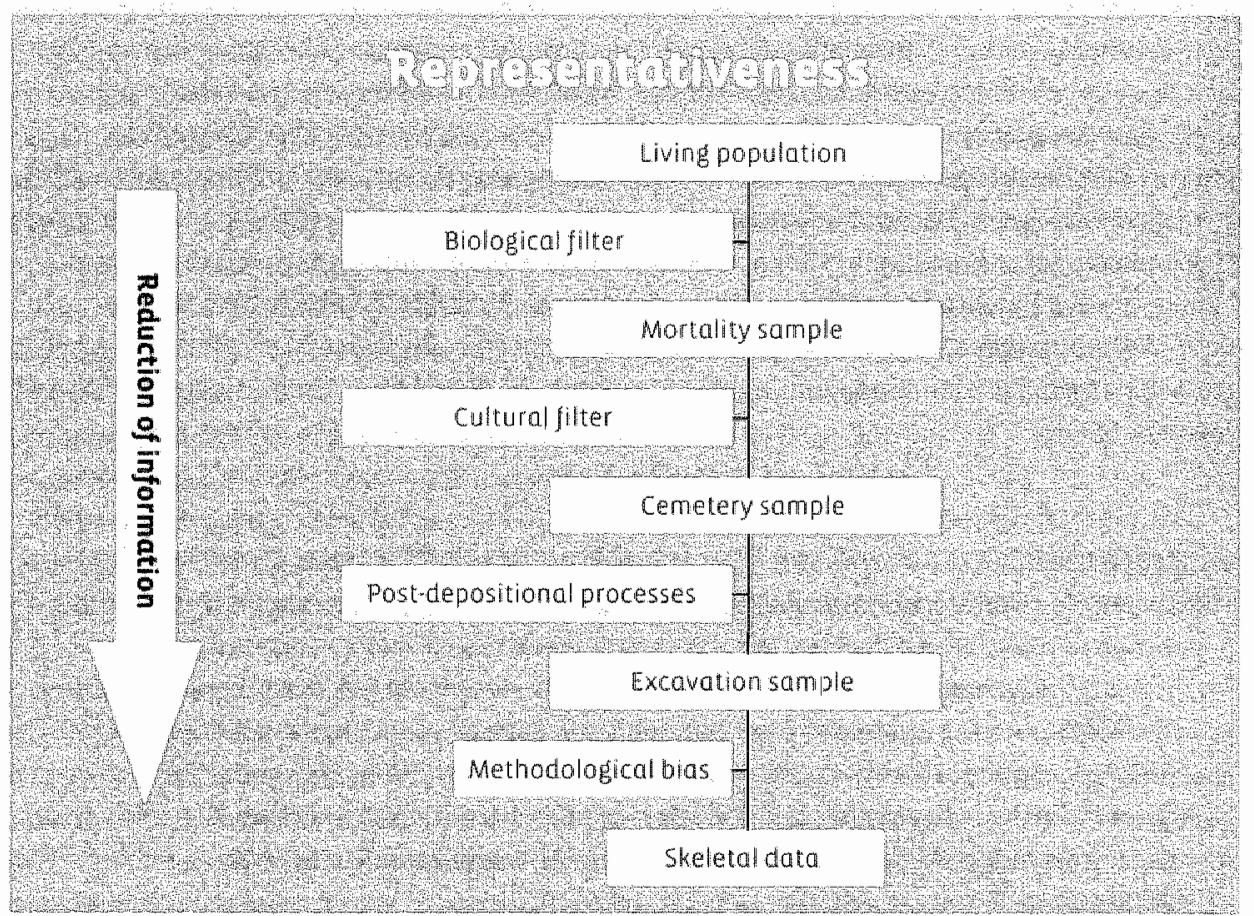

FIGURE T-1 A law chat representing the reduction and bis of infomation colledted from fouman skeletal renains. (after, Hoppa. $3996, p .52)$

THE COMPOSITION OF THE ORIGINAL POPULATHON

Little is known about the provenance of the population interred at the early medieval cemeteries of Maastricht. In general people buried at a cemetery are expected to have lived in the nearest settlement or in surrounding settlements. For the cemeteries of Maastricht such peripheral settlements may have been situated in the valley of the River Meuse up to a distance of several 
kilometres from Maastricht. In the case of the cemetery of the Sint Servads complex it seems plausible that the assumed presence of the grave of Servatius also attracted the burial of persons from further away. ${ }^{5.59}$ Early medieval histories describe the transport of deceased kings and bishops over large distances to be buried at important locations. ${ }^{\text {sat }}$ on a local or regional scale this practice may have been followed and resulted in the burial of non-local people at the Servaas cemetery. For the cemetery at the Boschstraat site we have no information on whether people from neighbouring settlements also used this cemetery. The close association between the graves and the traces of habitation and occupation at the same site suggest it was mainly used to bury people who lived in the vicinity of the burial area.

At present there are no reliable data concerning the size of the population and the demagraphic development of Maastricht in the first millennitum AD. As stated in chapter two the expansion of the habitation area and an increase in the number of settlements in the Meuse valley suggest that the population in the region expanded from the seventh century on. Nevertheless, we are ill informed regarding the population growth and density and the size of the total habitation area of Mastricht. An important factor in the demographic analysis of the inhumed populations is the possibility of migration to and from Maastiricht. The influx of migrants or the departure of inhabitants may have altered the demographic make-up of the population considerably. Five developments in the region may have instigated the migration of individuals and groups to Mastricht. For the late Roman period it is assumed that there was a shift in secular and religious authority possibly associated with a migration of people from Tongeren to Maastricht. At the same time there was a decline in the population of the rural settlements. This trend may have been tied in with the concentration of people in and around defendable places like Maastricht. The following seizure of authority by Frankish nobility most likely also led to migration. Because of its functions as a centrall place it is possible that members of the Frankish nobility and their retinue settled in or around Maastricht. The religious community, which formed around the grave of Saint Servatius, may also have attracted some immigrants. Furthermore a passage in the miraculae by Einhard mentions that Maastricht had "many inhabitants, mostly merchants" . 59 This informs us of the temporary or permanent influx of merchants. Little is known about the emigration of inhabitants from Maastricht. The general impression is that the surrounding countryside was repopulated and that hew lands were cultivated from the Carolingian period on. ${ }^{592}$ It is possible that similar developments led to migration from Maastricht: In general we may assume that during the 600 year focus of this study the population of Maastricht was not stable nor isolated.

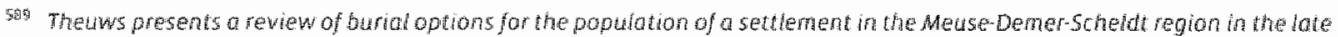
Merowingion period theuws, 1998

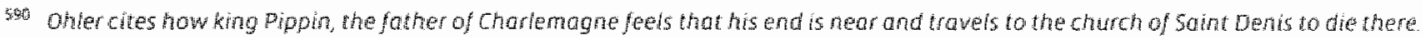
onter 1990,53 . See also on owerwew of the transferal or bodies to their ploce of burial in the eighth ard nhth centuries published by Chaterint, 7992, p. 483

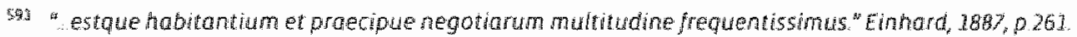

sts For an overwiew of the development of new settements in the Meuse-Demer-Scheld region see Thewws, 1998 
Since we cannot make reliable estimates of the population size of Maastricht and settlements nearby, it is not possible to determine what proportion of the original population was examined for this study. It is evident that the sample of 238 individuals only represents a fraction of the total number of indiwiduals that lived in Maastricht during the late Roman and early medleval period: As indicated above the skeletons examined for this study came from two cemeteries out of a constellation of at least ten early medieval cemeteries in and around Maastricht. Additional cemeteries from this period may still lay hidden in the subsoill. The examined samples in this study seem to represent sections of the Servaas cemetery and a mare or less complete cemetery from the Boschstraat.

\section{THE CELLA PHASE}

The cella sample consists of skeletol remains of 23 individuals found in 20 graves from the Servaas church site. The graves of this phase were attributed to the late Roman period ( 350 and $480 \mathrm{AD}$. Only a small section of the total late Roman cemetery fell within the boundaries of the Servaas church excavation. The centre of the late Roman cemetery lay to the north, closer to the Roman road. Burials from what is expected to be the centre of the cemetery were excavated at the Servacis Pandhof site, just north of the Servaas church site. Two features characterise the cella phase cemetery. Firstly there is an area with small clusters of graves in the northernmost. excavation trenches. A. second important feature is a rectangular building found south of the late Roman graves. As indicated in chapter three this rectangular building is cansidered to have been a cella memoriae, a burial chapel. No graves from the late Roman period were identified further south of this structure. It is not clear what the absence of late Roman graves in this area implies. The structure stood possibly at the border of the cemetery, since most of the excavation trenches reached the lowest elevation associated with late Roman activities. Therefore, it seems plausible that late Roman burials did not extend further to the south and that the area excavated within the Servoas church site fepresented the southern fringe of the late Raman cemetery. ${ }^{5.3}$

Because of its position at the margin of the cernetery the cella sub-sample may not be representative for the late Roman cemetery as a whole. The chances are that the sample has been biased with respect to sex, age and status of the individuals. Still, these skeletons are the largest series of human remains from late Roman Maastricht that have been examined so far. In anticipation of further research of the Servaas Pandhof burials this sample is the best saurce of information concerning living conditions in late Roman Macstricht.

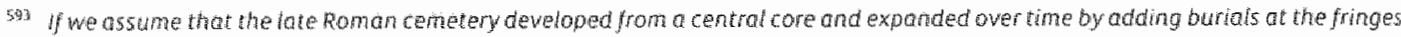
then is is possible that the buriats included in this study date from the last part of this phase. 


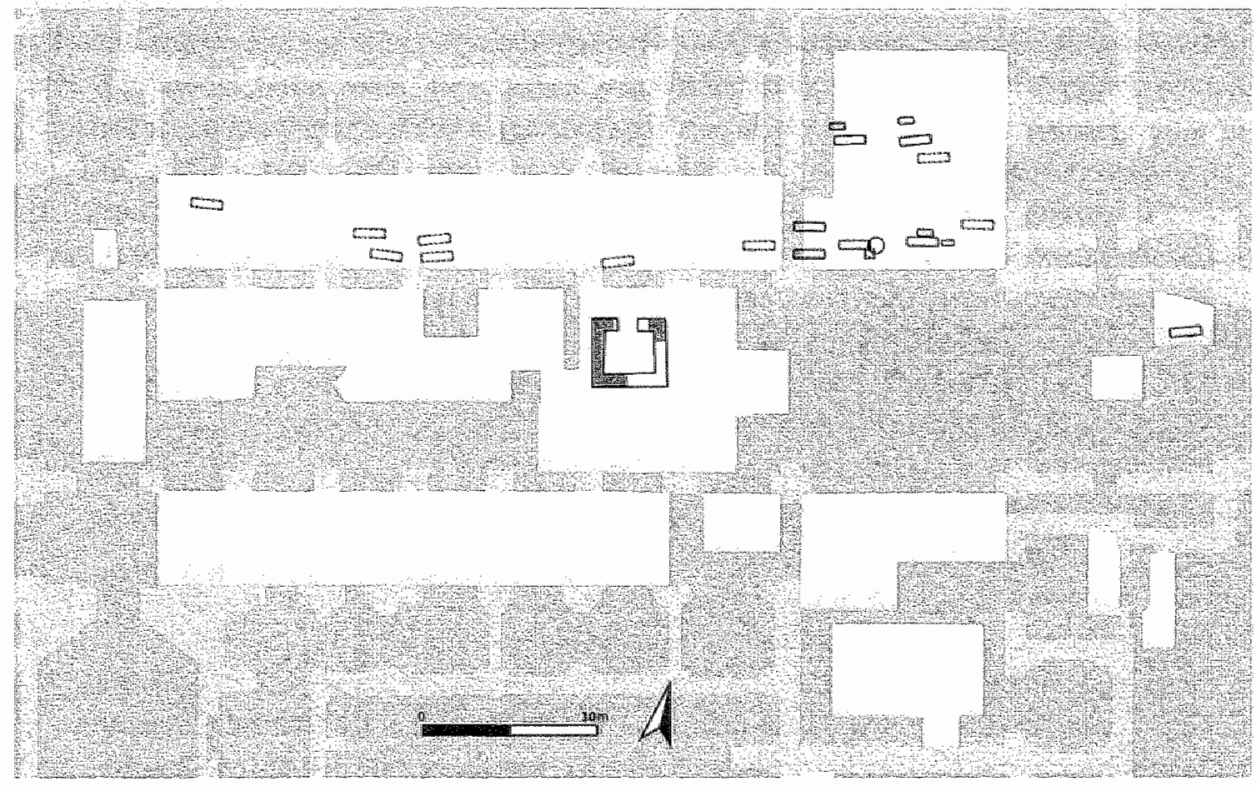

FIGURE 7-2 Plan of the cella phase cemetery.

\section{REFERENCE DATA}

No recent published physical anthropological and palaeopathological studies from late Roman cemeteries in the region were available. Therefore, one Dutch study of an older Roman cemetery and studies of more distant late Roman cemeteries were used for comparison: Valkenburg. $\left(\text { NL }^{594} \text {, Poundbury (UK) }{ }^{595} \text {, Cirencester (UK) }{ }^{596} \text {, Saint-Martin-de-Fontenay (F) }\right)^{597}$, and Linz (AU) addition to these studies of skeletal remains demographic data callected from gravestones

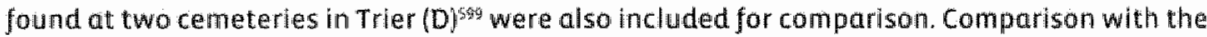
data presented in this study was generally anly possible for demographic data. Data relating to the palaeopathological condition were often treated in a casuistic and not in an epidemiological way or were recorded in ways that barred comparison with the cella data. Only the physical anthropological examination of the Valkenburg remains largely resembled the approach used in this study. The inhumation graves at this site dated from the second half of the first century to the beginning of the third century. These graves were considered to be the graves of a local population living and working near a Roman castellum. H. Lonnée studied the remains of 47 juvenile and adult individuals from this site in a way simllar to this study, which

\footnotetext{
39 Lonnde and wat, 1998

5ys Fondelt, 1993

Howhin et al, 1982

39 Pilet, 1994

sog Witsche Schrota and Tescher Nicolo, 1991

539 Gauther, 2975.
} 
allows for comparison of some of the palaeopathological data. Molleson examined six late Roman cemeteries of Poundbury, Southwest England. These combined cemeteries date from the fourth and early fifth century and were positioned between a hill fort and the Roman town of Durnovaria. Over 1400 inhumation graves were collected from these cemeteries. ${ }^{601}$ The Bath gate cemetery excavated in Cirencester, South England, dated from the fourth and fifth centuries. About 405 individuals were recovered and studied by Calvin Wells. The cemetery appears to be a late Roman city cemetery used by all age categories and both sexes. The cemetery of SaintMartin de Fontenay was used from the Iron Age to the end of the seventh century; 38 inhumations were dated to the late Roman period. This cemetery was situated in the northwest of France and studied under the direction of Pilet. It does not seem to be associated with a Roman urban centre but is situated in a more rural setting. The cemetery of Linz-Tiefer Graben in Austria was associated with a late Roman urban centre. Wiltschke-Schrotta and TeschlerNicola studied 39 individuals from this cemetery. Because of the high frequencies of pathological changes in the skeleton the authors suggest that the cemetery was used to bury Individuals from some sort of hospital ${ }^{\text {sea }}$ Data collected from the texts on late Roman gravestones from two cemeteries, St. Matthias and st. Paulinuls, also represent a population buried in an urban context. Trier is located circa 170 killometres from Maastricht in Germany close to the border with Luxemburg. The texts on the gravestones only prowide comparative data on the sex and age distribution in the cemetery.605

\section{PHYSICAL ANTHROPOLOGY AND PALAEOPATHOLOGY}

The skeletal remains from the cella sample were relatively well preserved and with respect to the completeness of the material this sample scored the highest recovery rate $(0.31)$ of the three samples excavated at the Servaas church site. This had a positive effect on the collection of physical anthropological and palaeopathological data. ${ }^{604}$

In comparison to some other late Roman samples the cella sample comprised a large proportion of non adult burials, viz. 26 per cent. The cemeteries of Cirencester ${ }_{x}$ st. Martin de Fontenay and Linz all have lower percentages of non-adults. Possible explanations for this. phenomenon may vary per cemetery. Only at Poundbury and in the gravestones from Trier percentages of non-adults were higher than in the cella sample A high mortality around birth and in the first few years is of ten considered to be a sign that non-adult mortality in a cemetery population represents the actual mortality in society. ${ }^{\text {nt }}$ of the six non-adult individuals in the

6 Lon Lem and Mad; 1998

607 Farwell and Molleson, 1993

(ti) Mchirr etal, 1982.

603 Plitel, 1909.

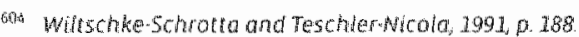

6o: Gaurhier, 1975

G6 As a consequence the relotwely small sample contributed comparatively many data to the analysis. E. in the total sample the percentage of left proximat femon avalable for inspection of the cetla sample was equal to the percentoge for the templum sample 
cella sample five died before reaching the age of five. ${ }^{\text {6ns }}$ For the Roman Empire Parkin estimates that infant and child martality was circa 300 per 1000 liwe births. ${ }^{609}$ However, since figures on fertility are lacking it is difficult to use this estimate to calculate a percentage of non-adult mortality in Roman cemeteries ${ }^{20}$ in general the proportion of non-adult burials and the fact that most of these children in the cella sample died before the age of five comply with general motions concerning infant and child mortality in the late Roman period.

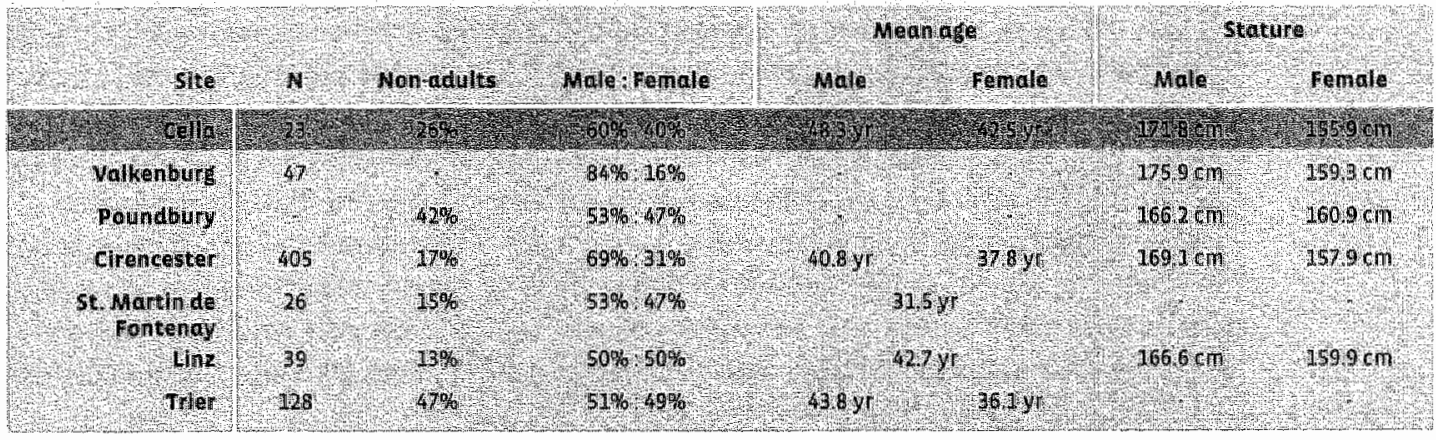

TABLE 7-1 Demographic data for the cella sampie and six other late Roman cemeteries (N represents the number of indwetuals included in the study, not all characteristic like age and sex coula be detemined jor all indivicuas.)

The demographic composition of the cella sample shows a minor imbalance with respect to the distribution of the sexes. Males slightly outnumbered females in the cella sample. For Raman period cemeteries such uneven distributions are often interpreted as the result of military presence. Because of the small sample size no conclusions can be drawn from the slight. overrepresentation of males in the cella sample. Apart from Valkenburs and Cirencester the other cemeteries all appeared to be used by a balanced number of males and females. The marked overrepresentation of males in the valkenburg population is perhaps caused by the burial of locally recruited male labourers. ${ }^{\text {th }}$ In most sites males and females were buried in the same areas of the cemetery.

Mean age at death calculated for the adult individuals ( $\geqslant 20$ year) of the cella sample was 48.3 years for males and 42.5 years for females. The difference between males and females with respect to their mean age at death was remarkable but not statistically significant. in comparison to the data published for Cirencester and Trier mean age at death for cella sample

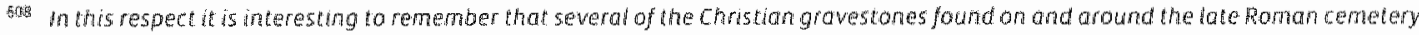
refer to deceased children. Boppert, 1986 .

6ag Parkin, $1992,0.9293$

53: For Roman Goul coulon mentians wo chido mortofity percentages: 25 per cent for a second century cemetery and 10 per cent for a Late Roman Cemebrery as an example for differences within the Roman period, Cowlon, 1994 , p.139. 340 .

6) Hates 9 (60\%) and Jemales $6(40 \%$

f12 connée and Mact, 1998, p. 14
} 
males and females was high. This suggests that the living conditions of the population buried at the cella phase cemetery were relatively favourable.

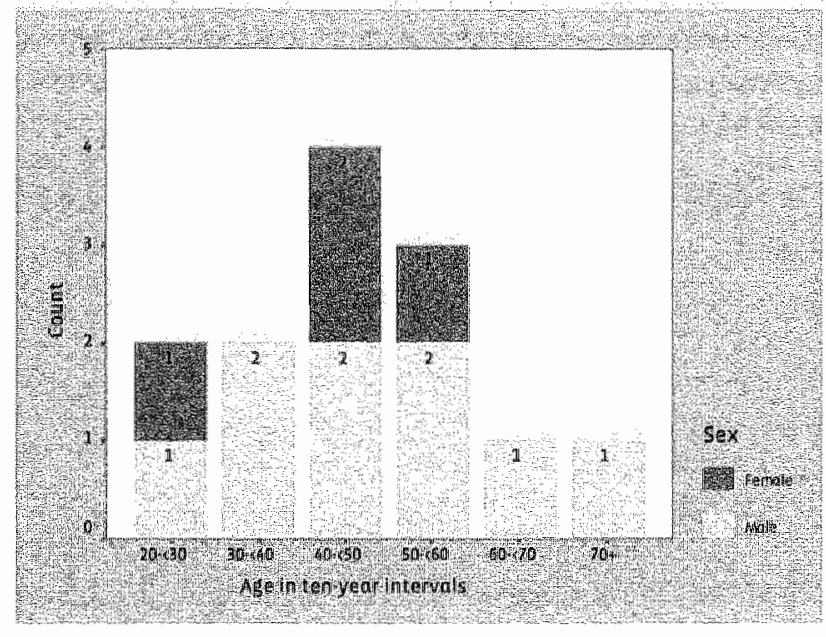

FGURE 7-3 Distribution of mortalty among aduit individuals of the cella sample (n=13)

These relatively favourable living conditions also seem to have been reflected in the stature of males which was high in comparison to other late Roman cemeteries. Only at the valkenburg site was a higher stature noted. However, it should be mentioned that stature for the Vakenburg sample was calculated on the basis of the regression formulas of Trotter and Gleser published in 1958. These are known to yield higher stature values than the formulas of Breitinger used for the cella sample. ${ }^{\text {ta }}$ The data regarding the mean femur length from the Valkenburg site and the cella sample are not conclusive, but these seem to confirm that the males from the Valkenburg site were most likely taller than the males from the cella site (Valkenburg: 50.4 centimetres, $n=3$; cella: 47.5 centimetres $n=6$ ). Male stature in the cella sample further exceeds the means calculated for Poundbury, Cirencester and Linz. Oddly enough there was a large difference between male and female stature in the cella sample. As a result female stature in the cella sample was considerably lower than in the reference cemeteries. Regarding stature a significant difference between males and females is normall. In the case of the cella sample the dimorphism exceeded expectations. ${ }^{16 n}$ Generally males are circa 10 to 11 centimetres taller than females. ${ }^{65}$ In late Roman Maastricht the difference in stature was 15.9 centimetres. In the cella

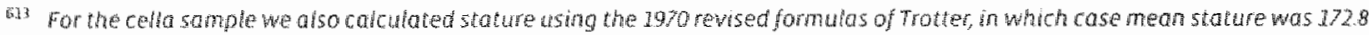
centimetre 5 . These jormulas also generaly produce lower vatues for stature than the Trater and Gleser fornulas of 1958

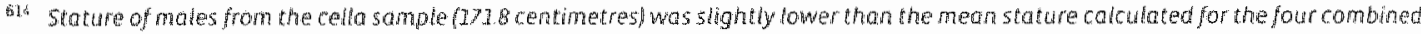
samples The mean stature of females (2559 centmetres) however, was a most 6 centmetres below the mean calculated for the Whole female poputation

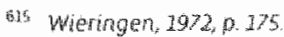


sample male stature was 110 per cent of femalle stature. This value exceeds the percentages found for male stature in modern populations (circa 107 per cent). The late Roman populations from Poundbury, Cirencester and Linz do not show similarly large differences between male and female stature (Poundbury 103\%, Cirencester 107\% and Linz 104\%) Possible ethnic differences between males and females were a factor contributing to the dimorphism in the cella sample. ${ }^{816}$ Consequently, as an indicator of socio-economic circumstances the dimorphism in the cella sample produces a mixed signal. Male stature suggests that living conditions were relatively favourable, whereas female stature indicates less favourable conditions. However, the small sample size provides no assurance that this effect was not the result of chance. Therefore, it was decided to refrain from further interpretation of this phenomenon until it is either refuted or confirmed by the ongoing examination of late Roman burials from the Pandhof site. ${ }^{517^{*}}$

Cranial non-metric data could be compared to the data acquired from the Valkenburg and Cirencester populations. Out of eleven skulls one displayed a metopic suture (circa 9 per cent). which was comparable to the prevalence calculated for Valkenburg and cirencester (14 and 8 per cent respectively). Lambdoid ossicles were common in the cella sample (67 per cent) and the Cirencester population (62 per cent) and less common in the Valkenburs, population (40 per cent).

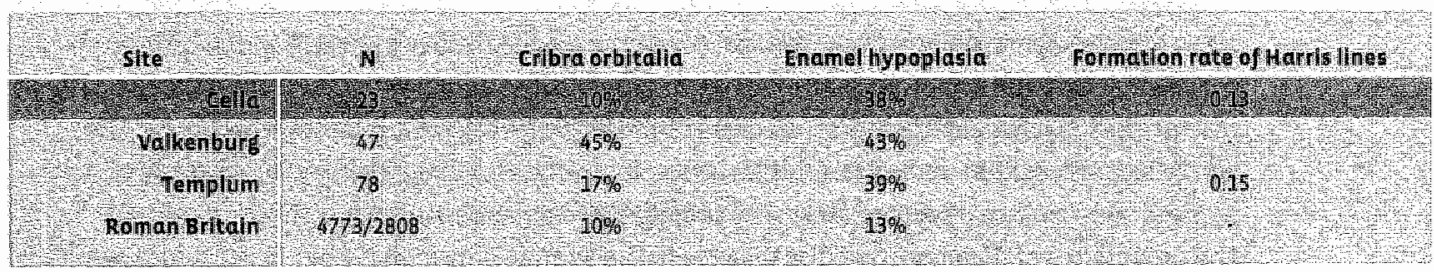

TABLE 7-2 Prevalence of cribra orbitalin and enamel hypophasia and the formation rate of Harris lines in the celta sample two reference populations and in Romano Britist data.

The prevalence of cribra orbitalia suggests the cella sample and the Valkenburg population differed in general health conditions. Cribua orbitalia were found four times more often in the Valkenburg population than in the cella sample. The prevalence rate calcullated for the cella sample corresponded with the crude prevalence calculated for 4773 individuals from 29 British sites dated between 43 and $410 \mathrm{AD}$. Valkenburg population is in contrast with the relatively high stature calculated for this population. Enamel hypoplasia was also mare common in the valkenburg population but this difference was not very marked. The pooled data of 2808 individuals from 25 British sites from the Roman period showed a much lower prevalence of enamel hypoplasia, viz. $13 \%$. The

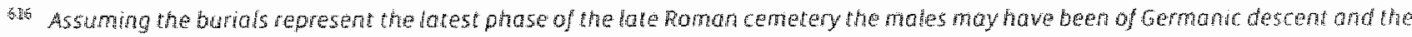
Jemales of Gallo Roman descent

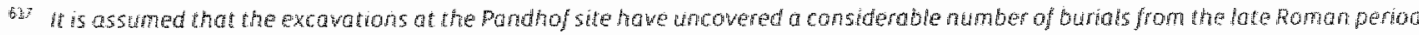
At the the of wring the results of this excovation are anolysed and the human remans are sudied with the framework of the saine servatius propect

Ge Roberts and Com, 2003, p 14014.1. 
formation rate of Harris lines could only be compared to other samples within the framework of this study. A formation rate of 0.13 Harris lines recarded for the cella sample represents the lowest formation rate of the samples included in this study. However, the difference with the templum samples was indistinct.

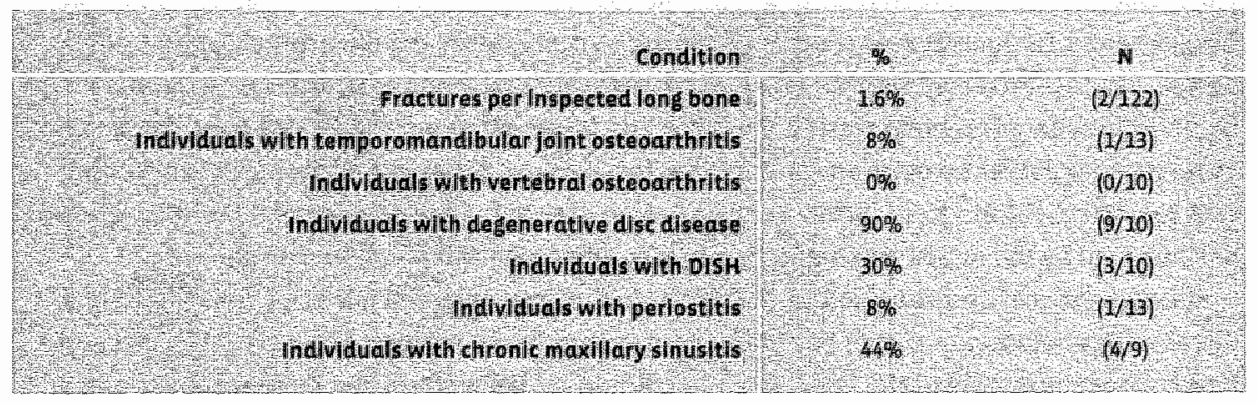

TABLE 7-3. Selected polaeopathological results for adult indiwiduals in the cella sample

In general the parameters presenting information on the health of the cella sample show no signs of extreme pathological conditions. Given the small number of (adult) individuals in the sample it is difficult to compare the results to percentages calculated from larger samples. Two fractures in 122 inspected long bones correspond with the mean number of fractures in the whole sample examined. Further trauma were single injuries found in two skulls caused by a pointed object. Trauma due to sharp bladed objects was not encountered in the cella sample. The prevalence of degenerative disc disease in the sample was high (90 per cent), which makes it a common condition among adult individuals. Surprisingly, the high mean age at death and the high prevalence of degenerative disc disease was nat accompanied by a high prevalence of vertebrall osteoarthritis. To the contrary none of the inspected indiwiduals had changes caused by wertebral osteoarthritis. The prevalence of DISH $(30 \%)$ was the highest of the four samples in this study. The selected reference samples provide few data for the prevalence of DISH. In Roman Britain DISH was relatively rare: viz. 23 cases ( $0.4 \%$ of the total burlals). ${ }^{619}$ A relatively small number of individuals of the cella sample showed signs of periostitis (8\%). Chronic maxillary sinusitis was present in almost half the number of adult individuals, a prevalence that talled with the mean found for the whole sample.

Why Roberts and Cox, 2003, p. 138 . 


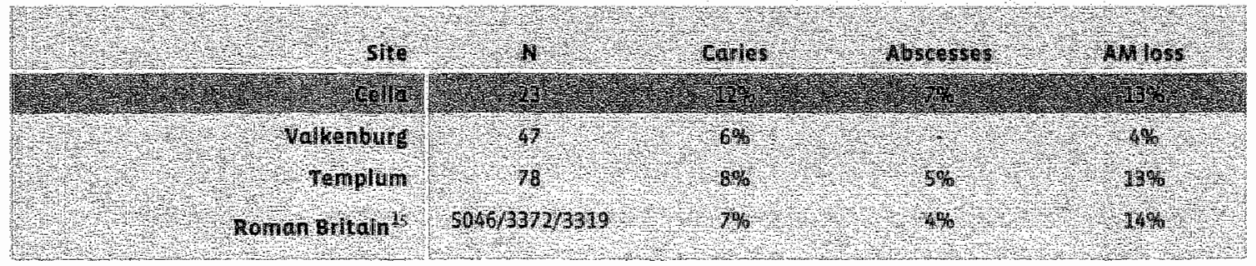

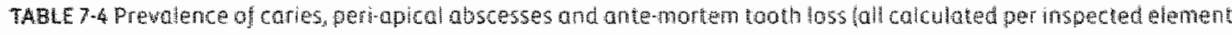
ar postion in the bastica sample and reference populations

The prevalence of caries, periapical abscesses and ante-mortem tooth loss corresponded with the mean found for the examined population as a whole. In comparison with data from Roman Britain the percentages for caries and abscesses were relatively high. The frequencles in the cella sample were also high in comparison with the Valkenburg population. Most likely this was the result of differences in diet. The cella population may have consumed mare sticky carbohydrates. Furthermare, a peculiar dimorphism in the distribution of calculus in males and females was found. All inspected males $(n=8)$ had calculus, whereas 40 per cent of the females $(n=5)$ had formed calculus deposits in their dentition. A simillar trend was visible in the pooled data of 21 Roman cemeteries from Britain presented by Roberts and Cox. Although fewer individuals had dental calcults ( $27 \%)$, calculus was found 1.7 times more often in males than in females. ${ }^{620}$ A difference between calculus in males and females was further found in the templum sample. In the basilica and Boschstraat samples there was no such difference. This disparity suggests there may have been a difference in diet and dental hygiene between males and females.

\section{AMALYSIS OF THE OSTEOLOGICAL DATA IN CONTEXT}

Graves of males and females were almost evenly distributed over the cemetery (see jigure 7-4). Two groups of grawes were arranged in ways that merit some attention. First, four graves lying northwest of the remains of the cella memoriae were roughly arranged in pairs. In both pairs the burial to the south contained the skeletal remains of a female and next to this an the north side a male burial. This arrangement of graves (Figure 7-4) suggests a relation existed between the male and female individual burlals. A second group with a remarkable arrangement was lying more to the east and consisted of two burials of females that were each accompanied by associated child graves. It is tempting to speculate about the possible relation between these burialsin Possibly the children burled close to the two females may have been their offspring. This would infer the presence of a genetic relation that could be examined by means of anclent DNAanalysis. In a preliminary study of ancient DNA from skeletal remains excavated at the site it has hitherto proven difficult to extract ancient DNA of sufficient quality and quantity to examine a possible relation between the female and the children. ${ }^{\text {tis }}$

620 Roberis and cox 2003, p. 131-132. In total 255 males and 150 females hod dental calculus

an Gijn, 1956 


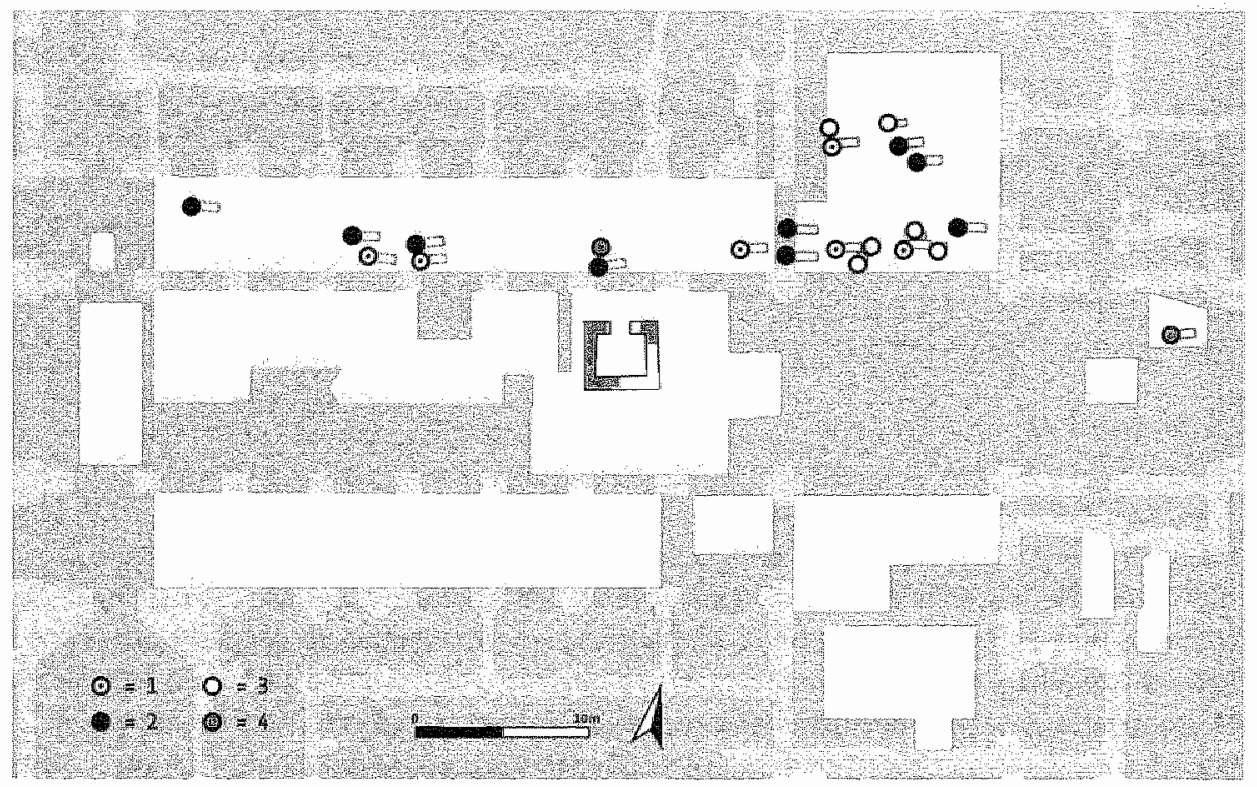

FlGURE 7.4 Plan of the distribution of Durials of males and females at the cello phase cemerery. The large numbers to

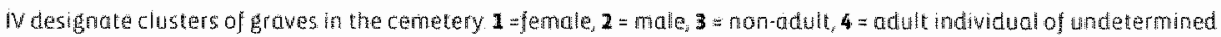
$\operatorname{sex}$.

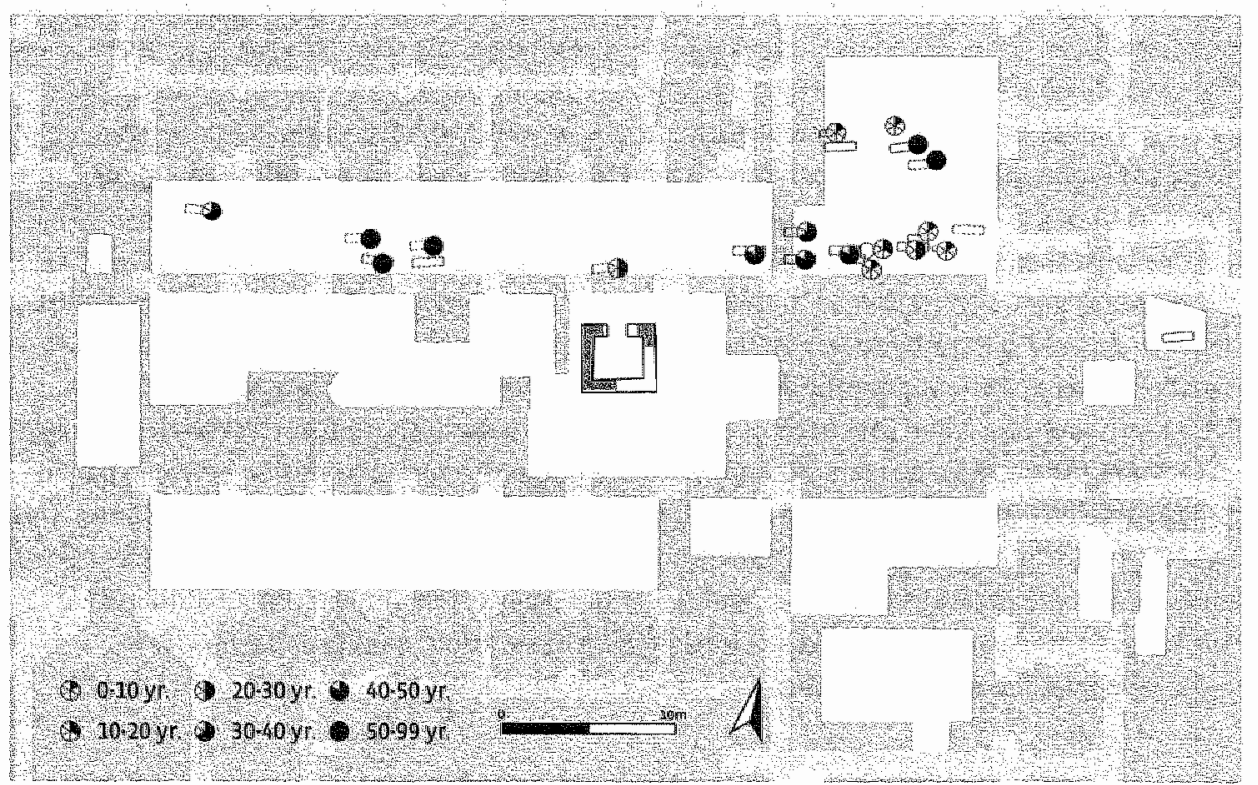

FIGUEE 7.5 Plan of the distribution of individuats by age at the cella phase cemetery. 
The distribution of the individuais by age category shows that all individuals under the age of ten years were found in the eastern part of the cemetery. If we dichotomise this and compare the eastern concentration of burials with the more dispersed burials in the west na statistically significant difference between the two sections was found. ${ }^{\text {wa. }}$ With respect to the adult individuals no apparent age-related distribution pattern was recognized. The paired male and female graves in the northwest and the female graves accompanied by child graves seem to indicate that family relationships in part determined the position where an individual was buried at the cemetery.

\section{concluston:}

As was discussed in chapter three the histarical sources and the gravestones assaciated with the late Roman cemetery along the road to Tongeren all imply the cemetery was used to bury Christion inhabitants of Maastricht and surroundings. The small section of this cemetery examined within the framework of this study indicates that all demographical categories were present in the cella sample. Non-adults, males and females of all age categories were found in small heterogeneous clusters of burials. The combination of sexes and age categories in these clusters suggests they possibly consisted of burials of related individuals, belonging to one or more families. The considerable proportion of non adult individuals in the sample might imply that infants and young children were not underrepresented in this section of the centetery. other remarkable demographic characteristics of the sample are the relatively high mean age at death calculated for male individuals, the above average sexual dimorphism in stature and the difference in prevalence of dental calculus between males and females. The combined evidence suggests living conditions may have been different for the sexes. Mean age at death and stature both suggest that the conditions were more favourable for males. The inspection for warious pathological conditions provides no indication for the presence of extreme physical or pathological stress during this phase. Harris lines, enamel hypoplasia and cribra orbitalia were present but the prevalence of these conditions never exceeded the mean values calculated for the combined samples. Ninety per cent of all individuals had degenerative disc disease. This relatively high prevalence may in part be influenced by the relatively high age at death. As will be discussed below the relatively high prevalence of DISH is mat considered as an indicator of poor living conditions. To the contrary the prevalence of $\mathrm{D} / \mathrm{SH}$ in the cella sample may probably be interpreted as a sign that at least some individuals in the sample had consumed an affluent diet. ${ }^{623}$

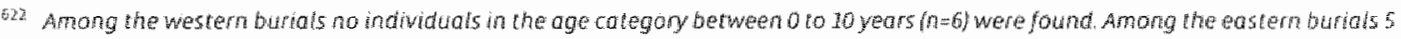

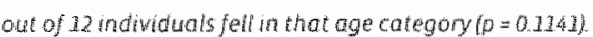

s.2 Woldon, 7985 , Rogers and Woitron, 2001 


\section{THE TEMPLUM PHASE}

After the cella phase the site of the present-day servas church became a desirable place of burial for the Merovingian elite. A clear indication for this development is the use of impressive tuff stone sarcophagi and precious grave goods found in several graves. The presence of graves that were less costly and contained no grave goods or only simple objects suggests that individuals of somewhat lower status were also buried at this cemetery, albeit generally at a larger distance from the church. Early on in the templum phase there was no stone church at the site and mast burlals were located in the same area as the burials from the cella phase. Only after the construction of a stone-built church was the cemetery area extended towards the south and the west. This wos accomponied by a shift in grave types. The tuff stone sarcophagi are all associated with the early templum phase. During the later templum phase composite stone coffins replaced the tuff stone sarcophagi. Generally, the graves seem to be distributed in small clusters, with vacant zones in between. There seems to be no formal organisation of the grawes in rows, although in some areas the distribution of the graves appears to reflect the presence of paths or other constructions that provided orlentation points for the alignment of graves.

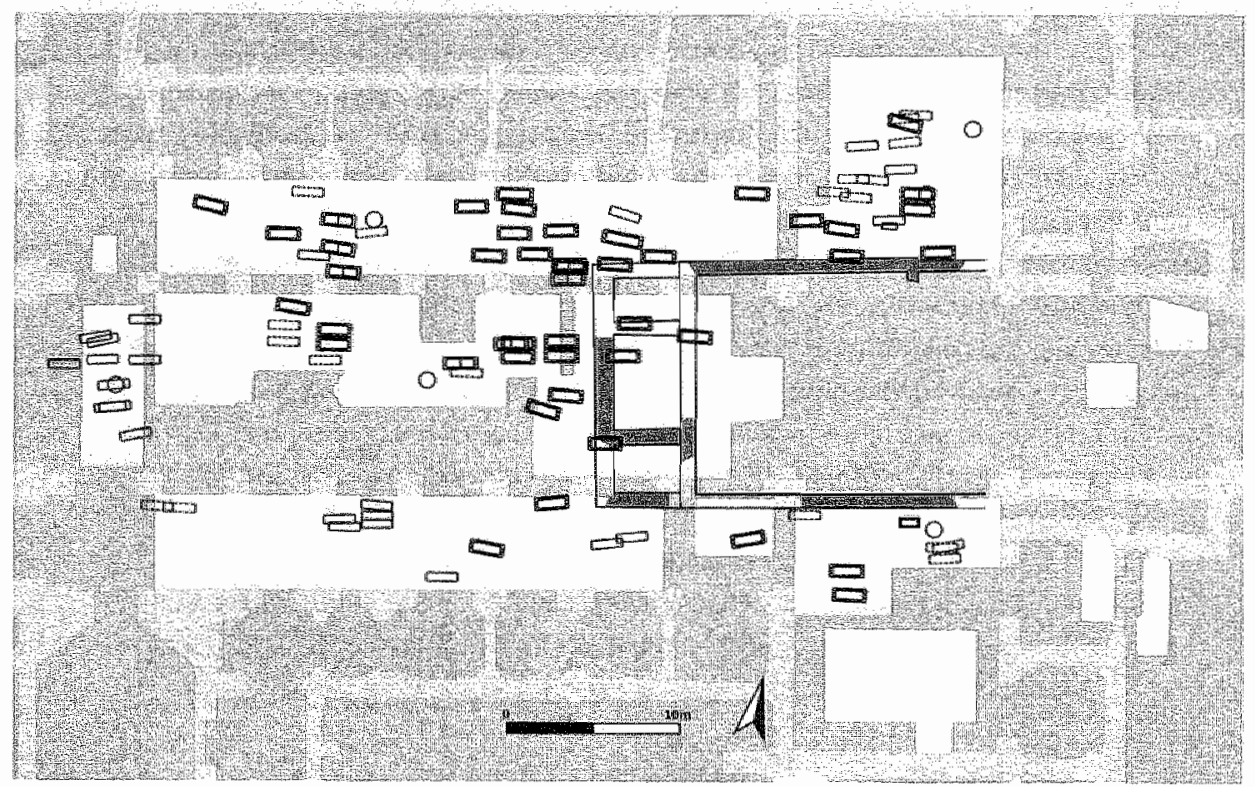

FIGURE 7 -6 Plan of the burials associated with the templum phase.

Based on the present knowledge of the chronological developments the templum phase roughly spans a period of 220 years between 480 and circa 650 to $700 \mathrm{AD} .^{626}$ Circa 88 graves were associated with this phase. The skeletal remains of 78 individuals were available for study. Only 
a section of the original cemetery of this phase was included within the boundaries of the excavation trenches inside the Servaas church. Within the excavated part of the cemetery a considerable proportion of graves had been lost due to builling and burial activities.

Unfortunately the subsoil of the church building from the templum-phase itself could not be studied because it was largely disturbed as a consequence of the construction of crypts for later church buildings. Therefore, the sample from the templum phase represents a selection of the persons buried around the church. As discussed in chapter three this selection most likely consisted of persons of high and intermediate status.

\section{REFERENCE DATA}

Despite the large number of Merowingian cemeteries been excavated, there are relatively few published studies on the physical anthropology and palaeopathology of comparable populations in the region. Additional reference data were obtained from studies of cemeteries located as far away from Maastricht as Normandy. Besides comparison with data from the Boschstraat site which may have been partially contemporaneous with the templum phase, four other cemeteries were selected: Rosmeer (B), Tournai (B), St. Martin de Fontenay (F) and Saffig (D). The Merovingian cemetery of Rosmeer was situated circa 10 kilametres west from Maastricht and was excavated by $H$. Roossens. The cemetery was situated in a rural setting and comprised 118 graves; several graves were fitted out with costly grave goods. The graves in the cemetery date from the second half of the sixth century to the end of the seventh century. ${ }^{625} \mathrm{P}$. Janssens studied the human skeletal remains from those 48 graves. The distribution of the sexes and the age structure were calculated from the published data collected by P. Janssens. ${ }^{625}$ Mean age at death was calculated as a mean of the midvalues of ten-year age intervals. Roosens presented information regarding the stature of males and females buried in Rosmeer. ${ }^{627} \mathrm{~A}$ second cemetery included here for comparison was the Merovingian cemetery of the Saint Brice quarter in Tournal, circa 205 kilometres west of Maastricht. This cemetery was situated around the site that is thought to be the burial place of king Childeric (who died circa 481 AD). Tournal was a late Roman urban centre. In the sixth century it was probably not large in size but a place of some significance given the frequent wisits of the Merovinglan aristocracy. ${ }^{629}$ The 91 graves excavated to the north of this grave represent only a part of the original population of this cemetery. Here too some graves were fitted out with preclous grave goods. The presence of King Childeric"s grave, probably positioned at the centre of this cemetery, suggests that the st. Brice cemetery was a cemetery far individuals of high status. The mean values and percentages for saint Brice were calculated by the author based on the data published in a catalogue by A.

\footnotetext{
6.25 Rovsenset al, 1976, p.42.2 and Roosens, 1989

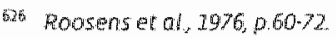

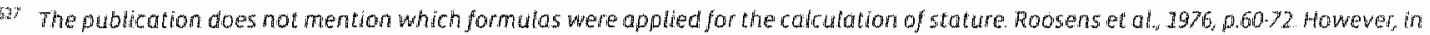
wher publications dansens stated that he generaby used the formutas of Dupertus and Hadden; Dupertus and Hodden, 2952

W2. Pycke, 1990
} 
DHulst. Further west, in the French Calvados region, a third cemetery was situated at a distance of circa 570 kilometres. This cemetery, mainly of Merovingian date, from Saint-Martin. de-Fontenay in Normandy was excavated and studied under the direction of Pilet. Its setting was more rural in nature than the cemeteries of Saint Brice and the Saint Servaas. Both elaborate grave types and preciaus grave goods were found as well as more plain variants. The fourth cemetery was situated near Saffig in the Mayen-Koblenz district, 170 kilometres southeast of Maastricht. This cemetery, also in a rural setting, was in use from the first half of the sixth century to the end of the seventh century. During that period the associated settlement probably almost tripled in size from circa $35 / 40$ to at least 110 inhabitants. Generally the skeletal remains were poorly preserved; as a consequence onlly a few physical anthropological data were available and published by W. Melzer. ${ }^{\text {wa }}$

\section{PHYSICAL ANTHROPOLOGY AND PALAEOPATHOLOGY}

The various activities that disturbed the graves of the templum phase had a negative effect on the recovery rate of the skeletal remains of the templum sample. Thirty-five of the 88 graves were empty. The skeletal remains of a total of 78 individuals were recovered from the remaining 53 graves and from well-dated contexts. As a consequence of the disruption of many graves the sample had a recovery rate of 0.13 . This indicates that in most of the burials from the templam sample a large proportion of bones was missing.

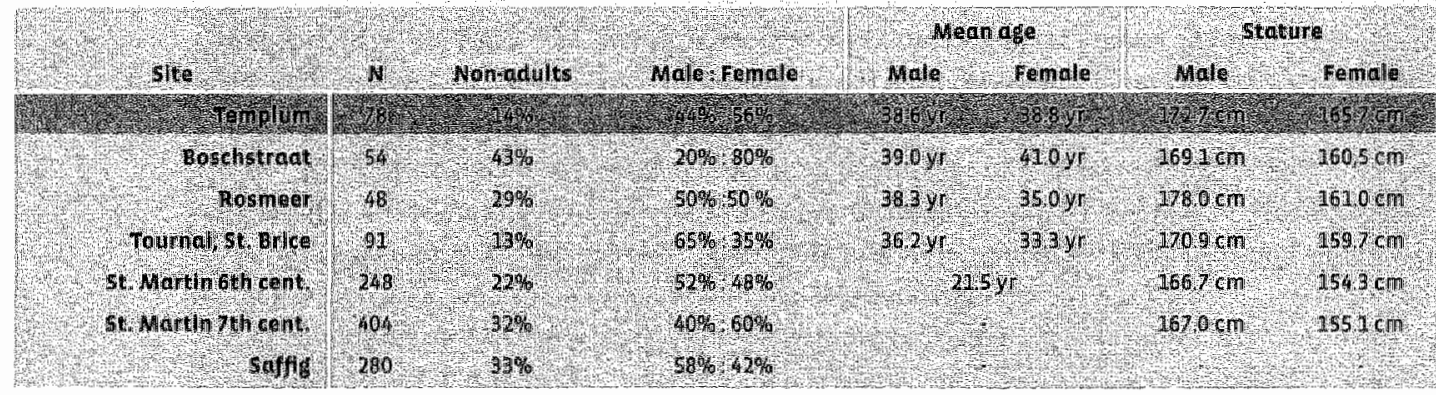

TABBilE 7.5 Demographic data Jor the templum sample the Boschstrat somple and four Merowngian cemeteries

In comparison to the Boschstraat sample and the cemeteries af Rosmeer, 5t. Martin-deFontenciy and Saffig the proportion of non-adults in the templum sample was low. Only at the other high status cemetery from an urban context, St. Brice, a similar percentage of non-adults was found. It is unlikely that this low proportion represents the actual mortality among non-

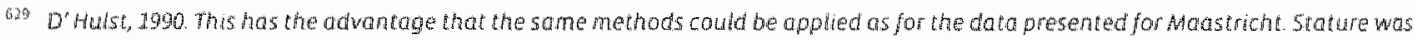

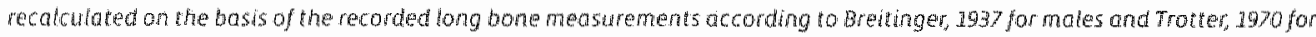
jomales

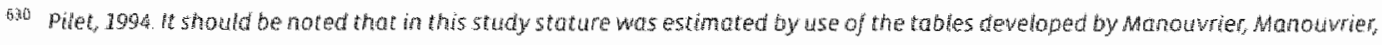
1893

6) Melrer 793 
adults Apparently specific characteristics of the templum phase and St. Brice cemeteries had an impact on the demographic composition of the cemetery population. We can only speculate about the alternative burial location for non-adult individuals, missing at the templum phase cemetery. However, it is striking to see that the percentage of non-adult burials was relatively high at the Boschstraat cemetery. Within the templum sample females were marginally more numerous than males. However, the under representation of males is too small to assume that during the templum phase females structurally outnumbered the males. We have to take into account that large sections of the cemetery have been disturbed completely and other previously excavated skeletal remains from this cemetery can only be studied when the previous excavations of 1953-54 and 1969-70 have been analysed. At most reference cemeteries small imbalances in the number of males and females were recorded. The only exception among the reference populations is the Boschstraat sample. At that site females clearly outnumbered the males.

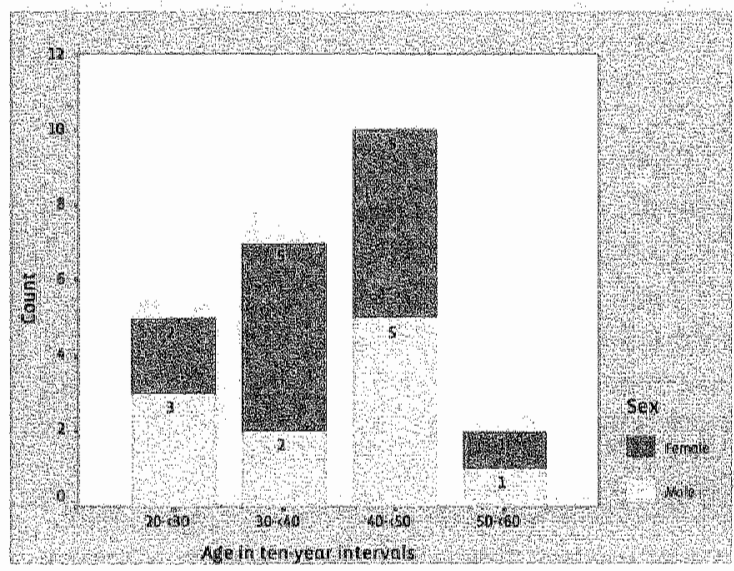

FIGURE $7 \rightarrow$ Distribution of moptalty among adut indwiduals from the templum sample in 24 ?

There was little difference in the mean age at death between templum phase males and females. This tendency was also found at the Boschstrant cemetery. In the reference cemeteries the difference between male and female mean age at death was larger. At Rosmeer and St. Brice the mean age at death of femalles was roughily three years below male mean age at death. Unfortunately no comparable data were available for 5 t. Martin-de-Fontenay and Saffig. For the cemetery of Saffig the graphical data also suggest that female mortality was higher before the age of circa 30 years, whereas male mortality was much higher around the age of forty. In comparison to Rosmeer mean age at death was slightly higher in the templum sub-sample. A larger difference, ranging from about two years in males to more than five years in females, existed between the templum sub-sample and 5t. Brice.

With respect to the distribution of mortality among adults it was found that mortality steadily increased from the 20 to 30 years age interval to a peak in the 40 to 50 years age interval, 
leaving only a few survivors whose death occurred in the 50 to 60 years interval. This age distribution deviates from what is generally seen in historical populations. In such populations the martality curve seldom displays such a marked difference in mortality between the last two tenyear age intervals. Usiullly a more gradual decrease in mortality is seen, representing a slowly declining number of survivors. ${ }^{632}$ This mortality distribution could partially be the result af rondom effects occurring in small sample sizes. Still, it is not likely that this can completelly explain the mortality curve.

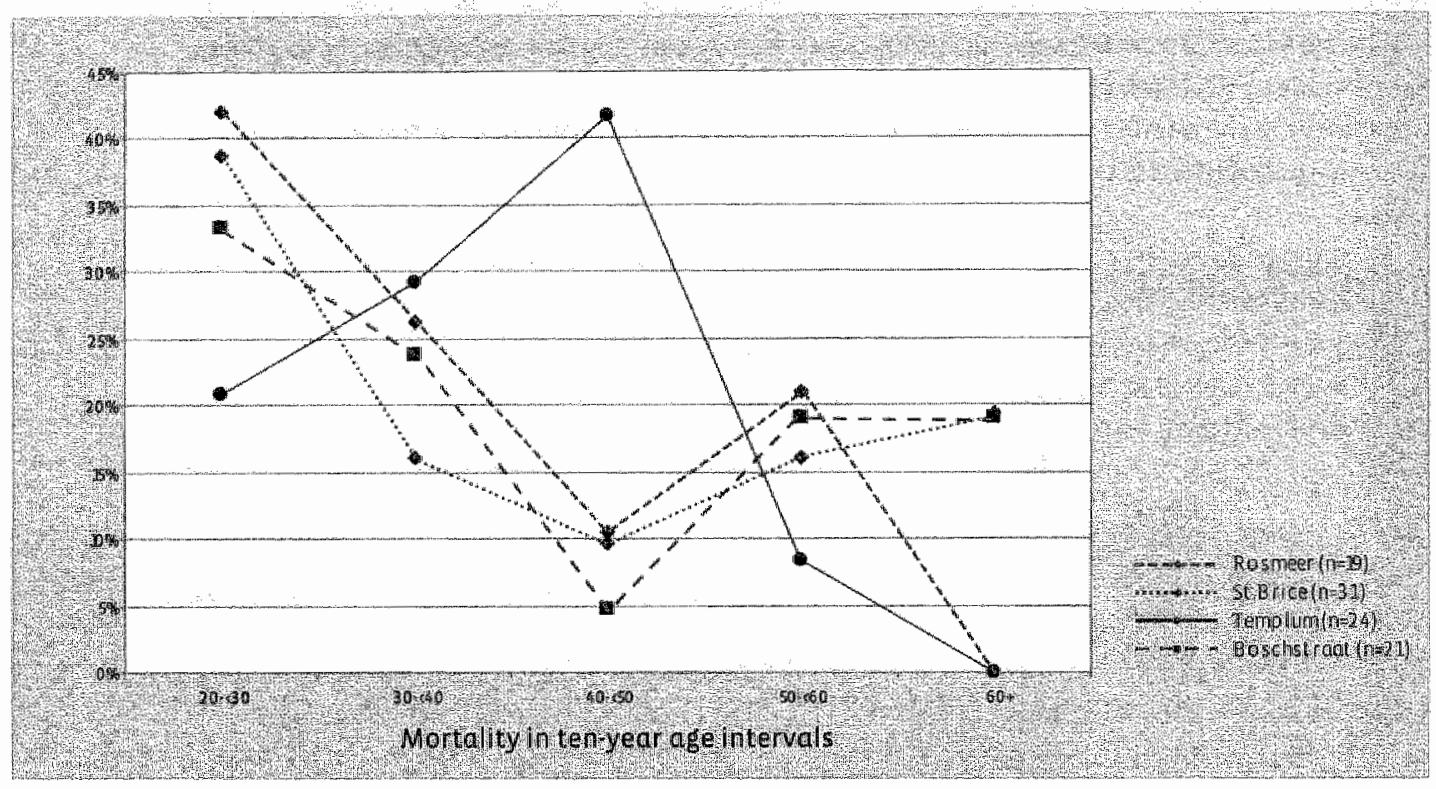

FIGURE 7-Adult mortality in ten year a

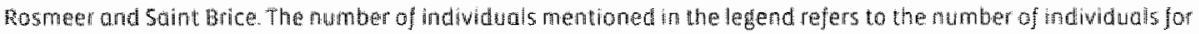

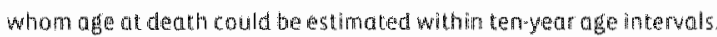

Comparison of the templum mortality distribution with three of the reference populations in Figure 7.8 illustrates that in the templum sample martality for the 40 to 50 years age interval was considerably higher than in the reference populations. Also in these reference populations small sample size might limit the representativeness of the results. Still the difference is considerable and it seems to represent two different trends.

In order to hypothesize on the biological and cultural formation processes of the Servaas cemetery during the templum phase we assume that this mortality distribution is representative for the actual age distribution of individuals buried in this section of the cemetery. Factors which might explain this age distribution were an increased mortality risk for 
this age categary ${ }^{633}$, an uneven distribution of age categories within the Servaas cemetery or prefierential burial. On the basis of the present data it is assumed that cultural factors determining the distribution of burials amang and within cemeteries had a large impact on the age and sex distribution in various sections of the cemetery.

A possible explanation might be that local living conditions were such that the mortally risk was higher for the 40 to 50 years age interval and that only few individuals survived to later intervals. However, there are no indications that disease, occupational hazards or violence put both males and females in this age category under more straln than other age categries. ${ }^{6.4}$

Two factors seem to have had an impact on the age and sex distribution in the sample. These were the custom to bury individuals of high status in separate sections in and around a church, and the practice of preferential burial of individuals in the Servaas cemetery from elsewhere. Since the examined section of the cemetery was situated close to the cussumed grave of saint Servatius, this area would have been considered a prestigious location for burial. Generally such ad sanctos burial locations were reserved for high status secular and clerical individuals. ${ }^{65}$ Possibly high status individuals buried at this cemetery may have been older because it took individuals time to acquire a social position that was associated with an ad sanctos burial. At present it is not possible to determine whether these high status individuals were living locally or whether they came from places in the region. ${ }^{\text {.3. }}$ Only two sections of this large Merovingian cemetery have been excavated and only one of the uncovered samples of skeletal remains has hitherto been examined. Therefore, it is difficult to determine whether the atypical representation of older individuals is a consequence of an unewen spatial distribution of these age categories within the Saint Servatius cemetery or whether this was the result of preferential burial. Preferential burial is defined here as the practice of burying a deceased person at a different cemetery than the cemetery where the majority of the individuals of his or her local community is buried. In that case the high number of burials in the 40 to 50 years category may partially have been caused by preferential burial of individuals who had acquired sufficient status to be buried near Saint Servatius.

The notion that the individuals buried in this section of the cemetery were of high status seems to be supported by the data on the stature of these individuals. The mean male stature of 172.7 centimetres was only exceeded by the stature colculated for the males buried at the cemetery of Rosmeer. According to the data males at Rosmeer were more than 5 centimetres.

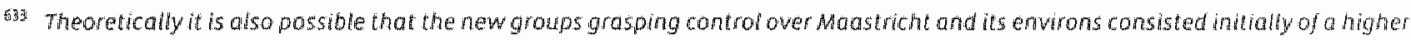

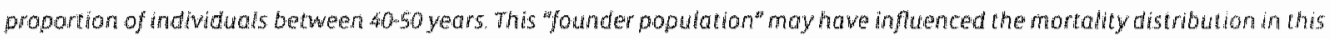
section of the Serwas cemetery

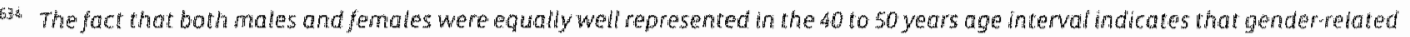
occupathona hazards were an untkely explanation for this phenomenon th that case the differentatiar in mate and femate: activites would mast likely have lead to sexud dimorohism in occupation raloted pathologies and mortatity.

6as see for example Treffort, 7996, p. 147 and Hassenpflug for an andysis of areas in and around a church that were a focus jor high status burdis Hassenplug, 1999,0227228

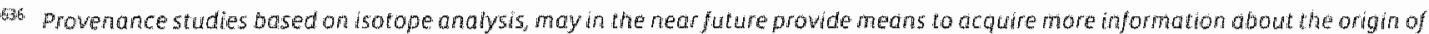
separate indwidwals in the cemetery. 
taller. This larger stature at Rosmeer might partially be a consequence of the application of different regression formulas for the calculation of stature.6:3 However, the difference is large enough to assume that the males at Rosmeer were relatively tall for the Merowingian period. other reference cemeteries indicate that male stature was generally below the mean calculated for the templum sample. Mean stature of the females from the templum sampie was at least more than 4 centimetres above the mean calculated for females in all reference cemeteries. This suggests that the females from the templum sample grew relatively tall and most lived in mare favourable living conditions. In contrast to the situation in the cella sample, within the templum sample the difference between mean male and female stature was relatively small, viz: 7 centimetres. (Male stature was circa 104 per cent of female stature.) Overall, the stature of males and females in the templum sample seems to indicate that living conditions were relatively good during that phase. This corroborates the data concerning mortality in the templum sample, which also suggested that in this respect the inhabitants of Maastricht fared reasonably well.

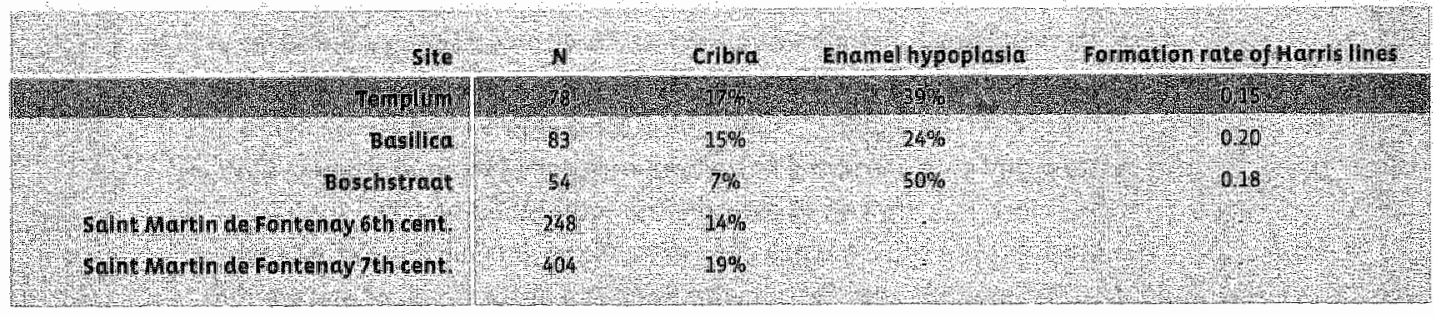

TABLE 76 Prevalence of cribra orbitalia and enantel hypephas a and the forma kian rata of Haris lines in the templum sample and reference populations

With respect to cribra orbitalia the prevalence in the templum sample was 17 per cent, comparable values were found for the two phases at the Saint-Martin-de-Fontenay cemetery. At two other Merovingian cemeteries from Normandy, Saint Martin and le Martray, both in the community of Giberville, the prevalence of cribra orbitalia was 14 and 31 per cent respectively. 38 Considerable variation is faund in the prevalence of cribra orbitalia. Although the presence of this alteration of the roof of the orbits is generally considered an indication for iron-deficiency anaemia, often in association with inadequacies in nutrition and a variety of health problems, dissimilarities in prevalence are difficult to interpret. prevalence of cribra orbitalia in the Merovingian period might be the consumption of different diets or the prevalence of infectious disease and the occurrence of chronic diarthoea. No significant differences in the prevalence were found between males and females. The

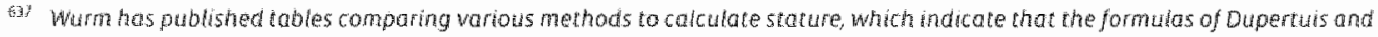

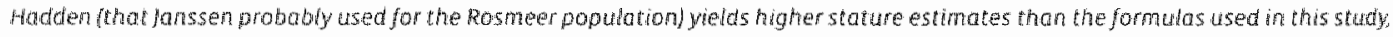
Whitrm and Leimeister, 1986

what pilet et al, $1990,0.5758$ and p 75 .

axis taren, $1907,20.40$ 
prevalence of enamel hypoplasia was similar to the prevalence in the cella sample. In the basilica sample fewer indiwiduals showed signs of enamel hypoplasia. This would suggest that in this respect living conditions in the templum phase were less favourable. However, enamel hypoplasia is not a very specific indicator of stress which makes hit difficult to explain this high prevalence in combination with other health indicators that suggest the living conditions were relatively good. For Harris lines, the differences between the samples were too small to draw any conclusions on differences in living conditions.

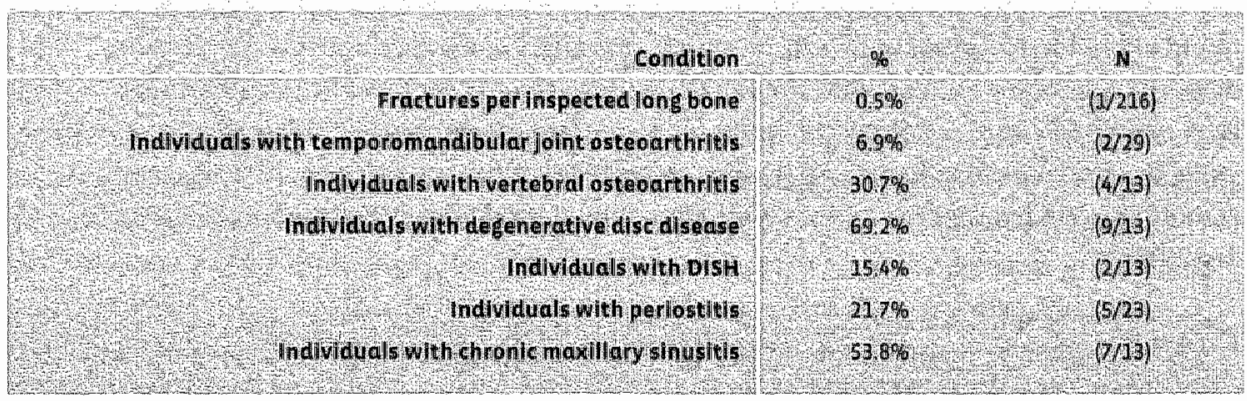

TABLE 7-7 Selected palaeopathological results for the temphm somple

Most parameters providing information relating to the pathological conditions in the templum sample give reason to believe that the population was not exposed to a high level of pathological strain or excessive occupational hazards. In comparison to the preceding cella phase cemetery an increase in the prevalence of three conditions was noted: vertebral osteoarthritis (VOA), periostitis and chronic maxillary sinusitis. When compared with the subsequent basilica phase cemetery no significant changes in the pathology were recorded. only one fracture was found in the templum sample. The prevalence of DISH in the templum sample was lower than the cella and the basilica sample.

one uncommon form of pathology was found in the templum phase population. Two male individuals had injuries of the skull caused by sharp bladed objects. Both individuals were buried close to each other a few meters north of the northern wall. Similar injuries were not found in the cella sample or at the Boschstraat cemetery. Also at the cemetery of Saint-Martinde-Fontenay none of the individuals had injuries caused by sharp bladed abjects ${ }^{\text {iat }}$ one male individual from a contemporaneous cemetery in Borgharen had a comparable injury of the skull. ${ }^{\text {b. }}$ And in the basilica sample four males had sharp bladed injuries. In the early medieval period injuries caused by a sharp bladed object are generally the result af a blow with a sword or axe. in Maastricht the characteristics of the cutting injuries indicate that these were the result of wounds inflicted by a sword. ${ }^{\text {hn? }}$ ?hese injuries provide evidence on the presence of

250 Plet 1994 .

6hi Rentuysen, 2000 and Renthusen, 2002

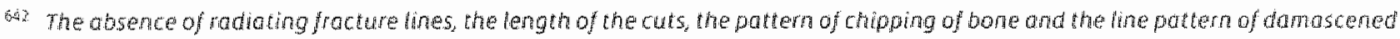

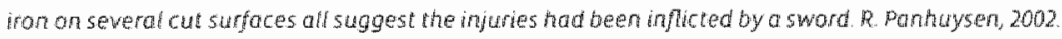


violence in saciety. In this respect one of the two individuals is especially of interest. The skeletal remains of this male with an age between 20 to 29 years showed the individual had suffered at least seven blows with a sword. . Not $^{* 3}$ Nonly was the skull hacked to pieces, cuts on the atlas and axis indicated that the individual was also wounded at the throat to the extent that the skull was almost severed from the rest of the body. Injuries to the bones of the wrist suggest that the victim tried to protect himself during the attack. Both the blows to the skull and the cut to the throat were independently lethal. The combination of cut wounds implies that after this individual was killed the body was further mutilated. Cases with multiple injuries were also found in the Towton study of fifteenth century casualties of a battle between two armies ${ }^{655}$ it is difficult to determine under what circumstances the skeleton received the series of blows to the skull and hands. Because of the similarity of the pattern of injuries with the cases in the Towton study it seems plausible that these injuries were inflicted during armed combat. However, it cannot be excluded that the injuries were the result af local violence or the consequences of an execution.

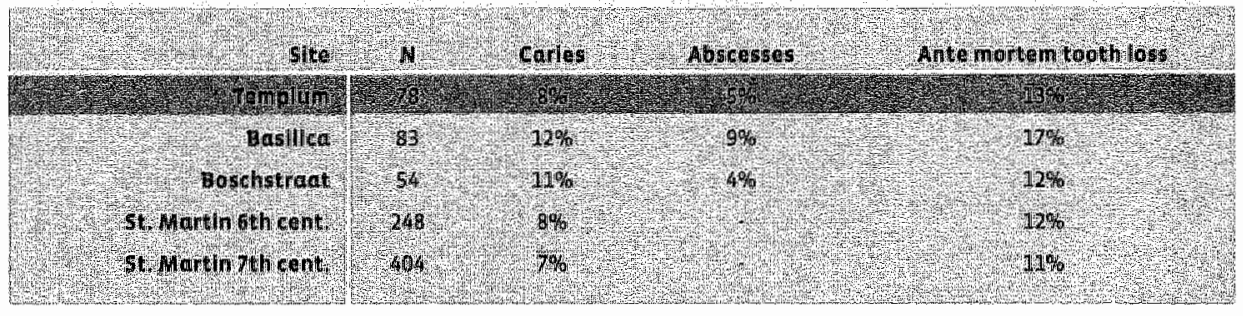

TABLE 7-8 prevalence of caries, abscesses and ante mortem tooth loss in the templum somple and reference populations

The percentage of teeth affected by caries was comparable to the percentages found at Saint-Martin-de-Fontenay. For the basilica and the Boschstraat sample the carles percentage was considerably higher. Frequencies of caries are for a large part determined by diet, especially the consumption of easily fermentable carbohydrates and the consumption of food high in sugar content. The difference in the frequency of caries between the templum sample and the basilica and Boschstraat sample suggests a general change in the diet may have occurred. The individuals from the last two samples possibly consumed more carbohydrates and sugars. Sugars in various forms had been available at least from the Roman period; honey especially

6. Unfortunaty the skeletal remains were not found in a primary buriat the bones were found in the fill of a stone built grave.

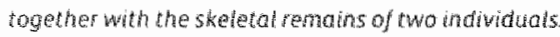

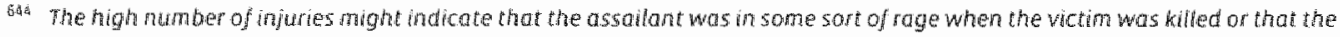
opponent intended to prevent identification of the victim.

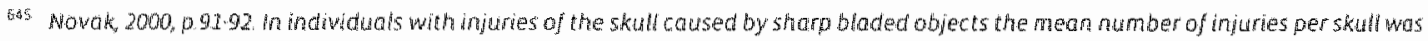
2.7. An a sample of 28 crania with injuries 9 crania had received 4 or mare blows by a sharp bladed abyect

Lerstent $2997,0.6566$ 
seems to have been a common foodstuff. ${ }^{67}$ The number of peril-apical abscesses and antemortem tooth loss in the templum sample was similar to that in the Boschstraat sample. Also at Saint Martin-de-Fontenay similar percentages of ante-mortem tooth loss were noted. The general impression is that oral health in the templum sample was better than in the basilica sample. Like in the cella sample calculus was mare common in males (100 per cent, $n=11)$ than in females ( 43 per cent, $n=14$ ). The most plausible explanation would be that this was the consequence of a difference in diet or oral hygiene between males and females. However, other aspects of dental heal th do not show such marked differences between males and females.

\section{SPATIAL DISTRIBUTION}

On the basis of the physical anthropological information two out of four clusters in the templum cemetery (described in chapter 3 , see figure 7-9 on the next page) comprised only female skeletal remains, viz. in cluster I and cluster $11{ }^{2 * 3}$ The other clusters contained burials of both sexes. ${ }^{\text {tias }}$ Both clusters 1 and 2 were lying west of the western wall of the templum. Because two clusters could be recognised, with a space of circa 7 metres in between, the two are described as separate entities. Still, these clusters may together have formed one zone reserved for the burial of females.

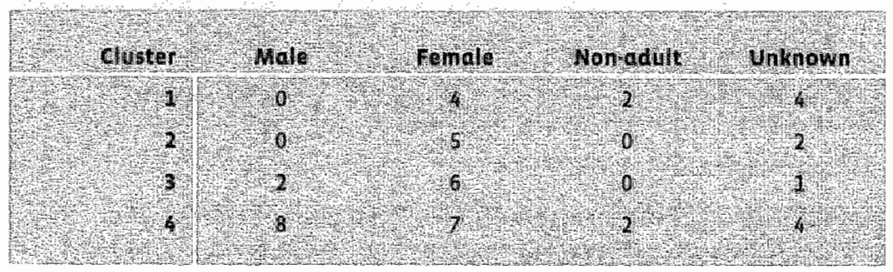

TABLE 7-9 The distribution of the number of male, female, non-adut individuals in the 4 clusters; the last column mentions the number of remains adut individuols for which sex could not be determined.

Cluster I was found circa 25 metres to the west of the western wall of the templum. This cluster consisted of at least 9 graves, wiz. coffins and trench graves. We are in the dark concerning the confines of this cluster as it was delimited on three sides by the boundaries of the excavation trench. Only the eastern limit, consisting of a void space, could be established in the neighbouring excavation trench. Among the skeletal remains found in this cluster were two non-adults and four females. Cluster II was lying at a shorter distance from the church.

S47 Hagen, 1995, p. 150-159, Toussaint-Samat, 1994, a. 15.97.

sut As a cautionary note it shoutd be mentioned here that skeletal remains were not found in alt graves in these zanes And not all

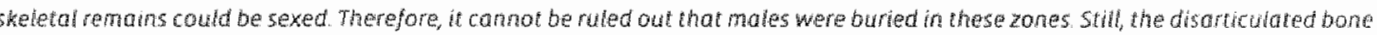
in these zones also seems bindicate that femates were mostly buried here

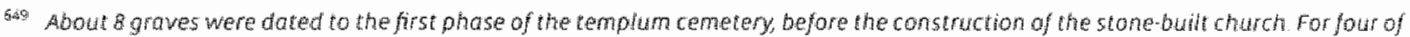
these groves sex could be deternined and these were all of female sex fa those graves that were contemporamy with the stone buit church males and femeles occur in roughly equal proportions. The four female growes were distributed ower dusters two and three In theory this may hove biased the sex distribution in these clusters 


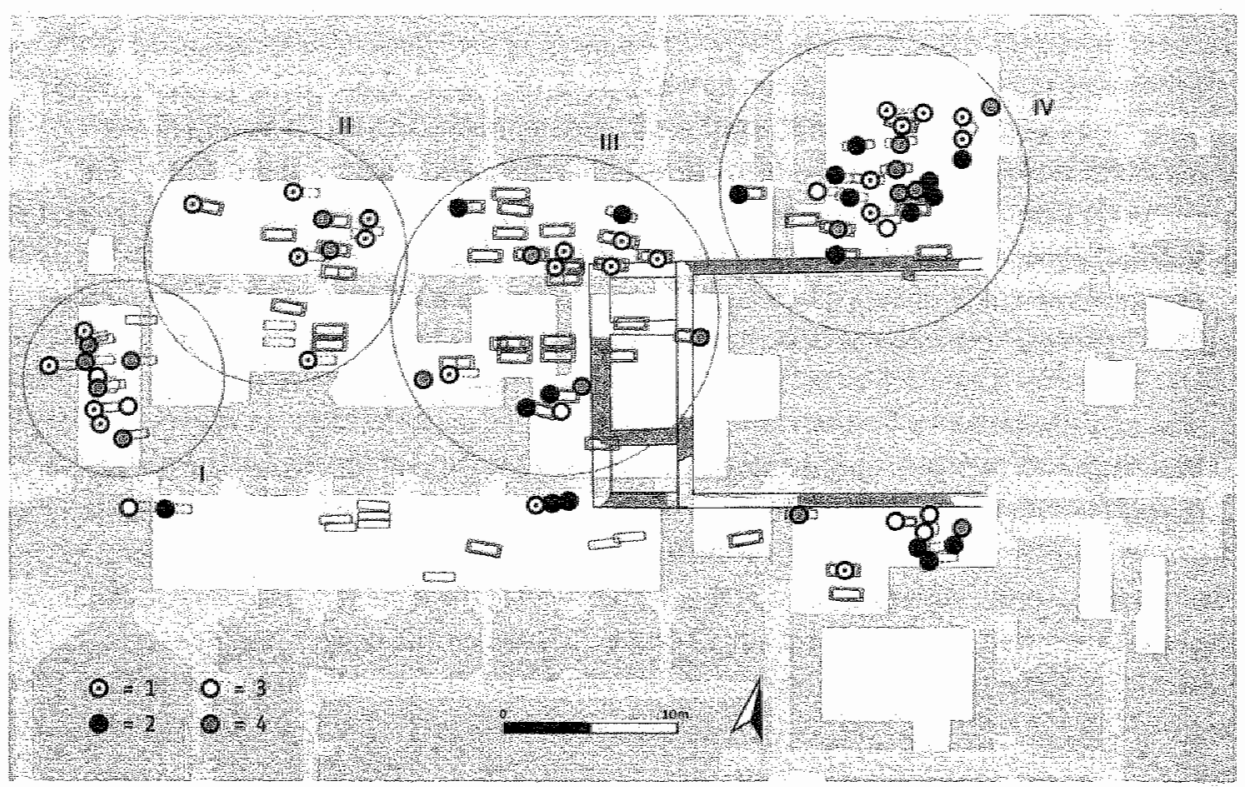

FIGURE 7wa Plan of the distribution of burials of maltes and females at the templum phase cemetery. The large numbers

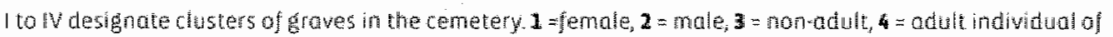
undetermined sex

It comprised about 14 graves lying at circa 15 metres from the western wall of the templum in the direction west-northwest. This cluster of tuff stone sarcophagi, stone-built tombs, trench graves and wooden coffins extended over a length of at least ten metres from north to south. In the east and west the limits of the cluster were recognisable as space void of inhumations. Our view of the northern and southern limits is obscured by the boundaries of the excavation trenches. These graves contained the skeletal remains of 6 females and 2 individuals for whom sex could not be determined.

Clusters III and IV consisted both of male and female burials. Still, the majority of graves in the third cluster contained female burials. Due to the construction of a crypt for the Romamesque church no information could be collected for possible inhumations in the interior of the church building from templum phase. Therefore, it is not possible to determine whether people were buried inside the church during the templum phase. Likewise we cannot test whether this space was more reserved for male burials as is generally assumed ${ }^{65}$ one grave, viz grave 137, appears to have been positioned inside the stone-built church of the templum phase. The skeletal remains found in this grave did not allow for the determination of sex. In this case

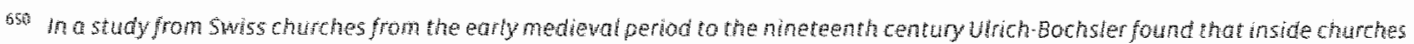

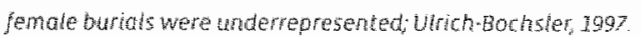


grave goods (including a sword and a small sifver cross found at the bottom of the grave) indicate the primary burial in this grave was a male. ${ }^{651}$

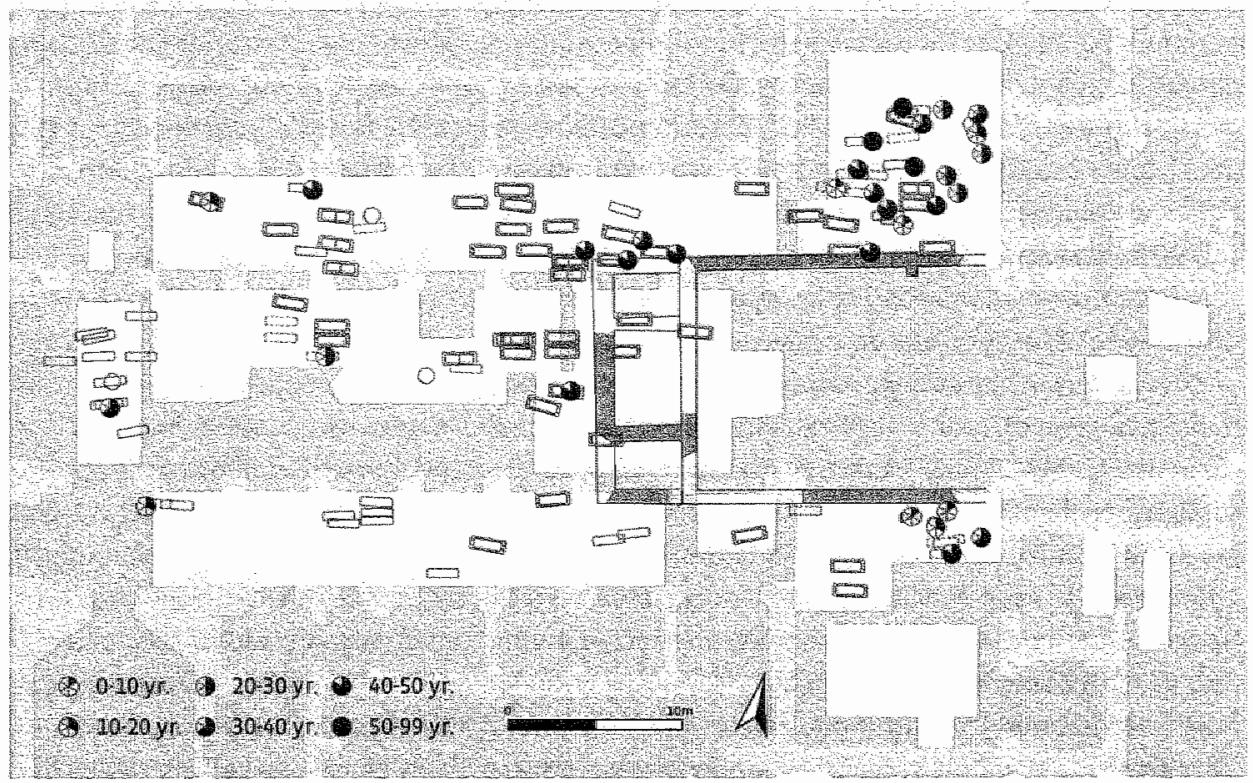

FIGLRE 7-10 Plan of the distribution of indiyiduals by age at the templum phase cemetary

As stated earlier the poor state of conservation serlously hampered the possibilities to estimate age at death for many burials of the templam sample. This is reflected in the map above, showing few individuals that could be assigned to ten-year age intervals. Most individuals for whom more specific information could be collected were concentrated in the eastern excavation trenches. In that area the templum phase graves were probably better

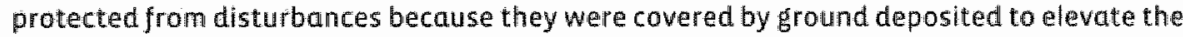
terrain. No definite concentrations of specific age categorles could be recogmised, Only a few younger individuals were found dispersed over the cemetery. In general the spatial distribution of graves seems to have altered only slightly from the situation in the cella phase of the cemetery. One divergent aspect in the cemetery was the absence of pairs of containing the remains of juxtaposed males and females. Still, the presence of both sexes and various age categories in most clusters of burials suggests that these clusters were not composed of members of specific social groups like monks or canons. More likely the individuals buried in

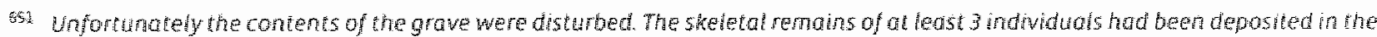
grave this suggests that groves in the aned were dismanted during construction works. Humon remains found in these graves where

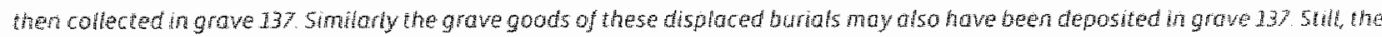
nature of the grave goods indicates that the graves in this setion of the cemerery were most likeb al mate individuals. 
these clusters were members of separate families. At this stage it is difficult to hypothesize about the two clusters in which only female burials were found. An explanation might be that these females belonged to some form of a religious congregation. or possibly the cemetery became a burial place for the women of one or more intermediate to high status families. A glimpse of possible kinship relations could be abtained by examining the distribution of nonmetric variation. Most of the conditions like lambdoid ossicles were found predominantly in the area north of the church. Cortical defects, a musculaskeletal stress marker, and individuals with cribra orbitalia also were found mostly in that area. This would suggest that the group buried in this area had a shared genetic background and similar living conditions. Still, this is also the section of the cemetery with the best-preserved remains and it cannot be excluded that the distribution of these conditions is the product of a disparity in the availability of data.

Several speclial grave types were used for burials during the templum phase. The most remarkable graves used at the beginning of the templum phase were seven tuff stone sarcophagi. Only three of these contained human skeletal remains. In two of these cases sex could nat be determined. The third case was the grave of the "rich lady" . For this richly furnished grave the physical anthropological data confirmed the determination of sex deduced from the grave goods; her age at death fell in the range between 20 to 40 years. As mentioned in chapter three another special type of grave was constructed during a later stage of the templum phase. Four composite stone coffins were built in pairs as "twin graves". Similar grawes were also faund in other cemeteries fram the Merovingian period. ${ }^{553} \mathrm{M}$. Colardelle suggests these twin graves were graves of members of the same family who were successiwely buried next to each other. ${ }^{55 h}$ Unfortunately at the Servaus church site no skeletal remains in situ were recovered from these giraves. Therefore, the physical anthropological data cannot contribute to the interpretation of this special grave type.

Recent studies have pointed to the existence of an association between sex and age of the deceased and the grave goads a person received at the time of burilal. ${ }^{655}$ This association could also be studied in the templum phase cemetery. However, at the time of study several grave goods were still under examination and no complete overview was available. Due to the effect of post-depositional disturbances on the graves and the loss of grave goods this only allows for some general observations. At the templum cemetery grave goods were more frequent in the graves of older individuals. Most objects were found in graves from individuals between 40 to 50 years. It is recalled here that this was the age category that seemed to be overrepresented in

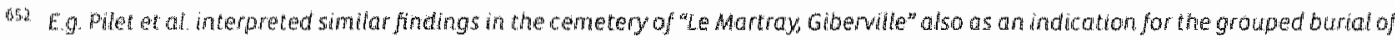
individuds who were related, being members of a fomily pilet et al, 1990,05 . Also Treffort has described tho a grouped burial of members of a family had a long history, treffort, 7996 , $170-172$

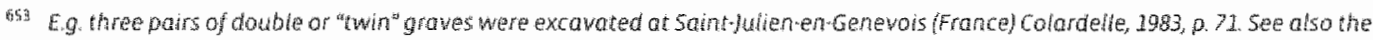
thistribution map of tan examples of twin graves in Merovingian france an poge 374 of the same publication.

5s. Colardele, 1983, p. 370. This hypothesis is supported by physical an thropological evidence as irdicated by MR. Sauter in a contribution to Colondelfe's study, p. 422

ass g Hatsohl 1995 , pussim. 
this section of the cemetery. Another age category associated with many grave goods was between 10 to 20 yeass. The majority of grave goods was found in the graves of females.

\section{CONCLUSION}

The transition from the cella phase to the templam phase appears at first to hawe been a process of gradual change. Before the construction of the stone-built church a few individuals were buried in the area that was already used during the cella phase. The placement of seven tuff stone sarcophagi in this in tial phase marks the moment that this zone became burial area for individuals of a high status. Only later in the phase, towards the end of the sixth century, the burial area expanded, probably after the construction af a church. With the construction of a church at this lacation this section of the cemetery was no longer positioned at the periphery; it became the central area. This shift in focus of the cemetery also caused an increase in the number of inhumations in the area. Further associated with this shift was a change in the demographical composition of the population buried at this section of the cemetery. Nonadult individuals were underrepresented and females were slightly overrepresented Indicators like the prevalence of lambdoid ossicles, cribra orbitalia and cortical defects, suggest that the individuals buried north of the church were possibly genetically related and may have lived under similar conditions.

In comparison with various contemporaneous populations, the demographical parameters suggest that during the templum phase living conditions in Maastricht were generally above average for those individuals buried in the examined section of the Servacs cemetery. Mean age at death, and male and female stature were relatively high. Health conditions were difficult to compare. However, the palaeopathological examination provided no evidence for a poor state of health. Two individuals with injuries to the skull caused by blows with a sword provide an indication for the probable involvement of inhabitants of Merovingian Maastricthit in armed canflict.

\section{THE BASILICA PHASE}

The construction of a large basilica, at same time between 670 and $750 \mathrm{AD}$, must have resulted in a dramatic change in the external appearance of the religious complex. Echoes of these changes are recognisable in the layout of the cemetery. After the construction of the basilica the arrangement of the graves was more orderly in most areas of the cemetery, e.g. in the area in the corner formed by the north wall of the choir and east of the northern extension. Furthermore an increase in the burial density was noted south of the church. This is remarkable since there appears to be enough space to bury north of the church. Burial in the north was possibly restricted, or new develapments south of the church may have made that area more attractive as a place of burial. However, in the area south of the church the layout of the graves appeared to be less orderly. In contrast to the imprecise east-west orientation of the graves in the previous phases the basilica phase graves closely followed the orlentation of the church. Inside the church a large concentration of limestone sarcophagi was found arranged around the cancella. 
Most of the nave and aisles were not used for burial purposes. In the eastern part of the church six grawes were placed against the interior wall of the basilica and in the onnexes and extensions. More limestone sarcophagi were buried outside along the walls of the church.

Together with those positioned inside the church around the cancella, a considerable number of limestone sarcophagi were found. The recurrent use of this costly type of grave indicated that also during the basilica phase individuals of above-average status were frequently buried at the heart of the Servaas cemetery.

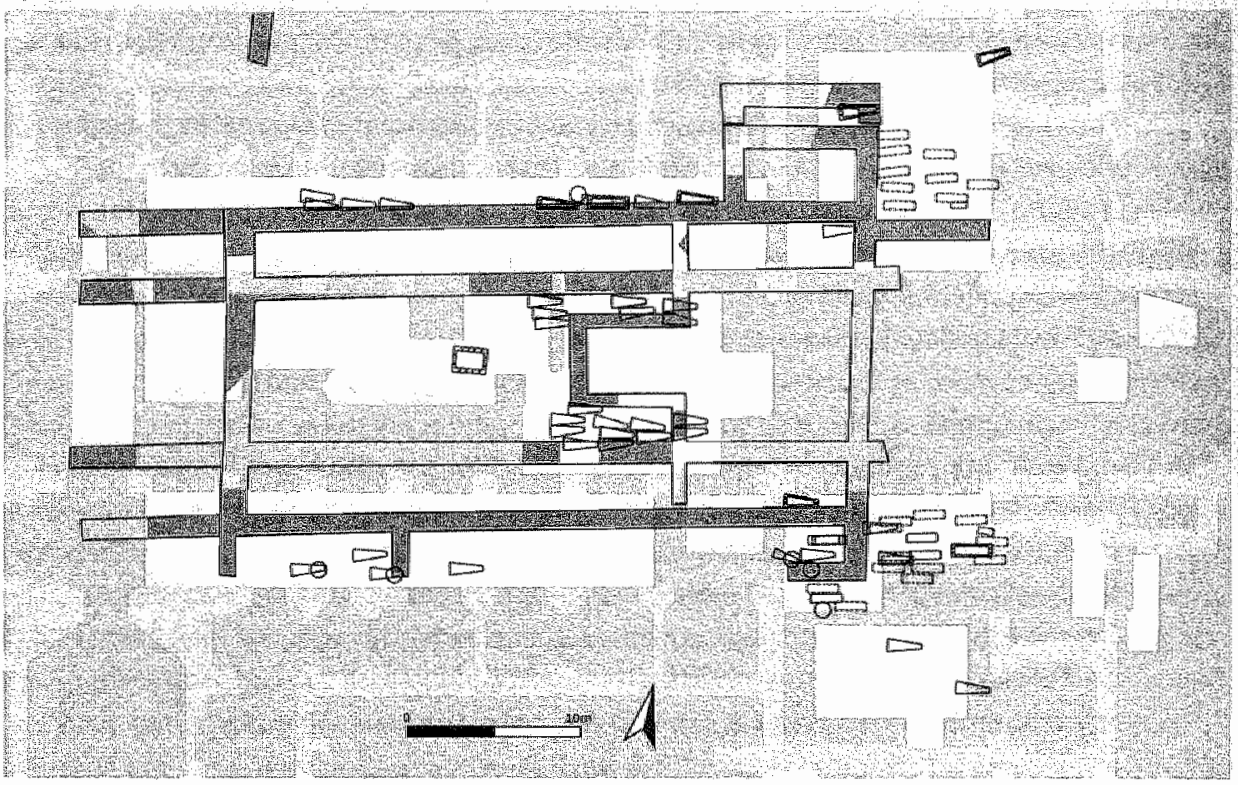

FIGURE 7-11 Plan of the buthing and burids assoctated wh the bastico phase

Consisting of 83 individuals, the sample from the basilica phase was slightly larger than the templum phase sample. Included in the sample were all buriats that could be associated with the basilica, dating between circa 670 and $950 \mathrm{AD}$. After the ninth century little burial activity was noted in the area. Only a small section of the original cemetery was represented in our sample as only the area inside the church and a small strip around the outside walls of the basilica fell within the perimeter of the excavation trenches. This selection of graves is considered to represent burials of individuals of intermediate to high status because of the nearness to the assumed location of the grave of Saint Servatius and the frequent use of limestone sarcophagl. The margins of this cemetery have hitherto mot been determined. In four other excavations near the present church, sections of the same cemetery were found. A large section of the cemetery was excavated at the Pandhof site, inside the courtyard adjacent to the Saint Serwas church. Close to the eastern end of this church a considerable number of graves were excavated in trench two of the Vrijthof excavation. The early medieval graves found at the 


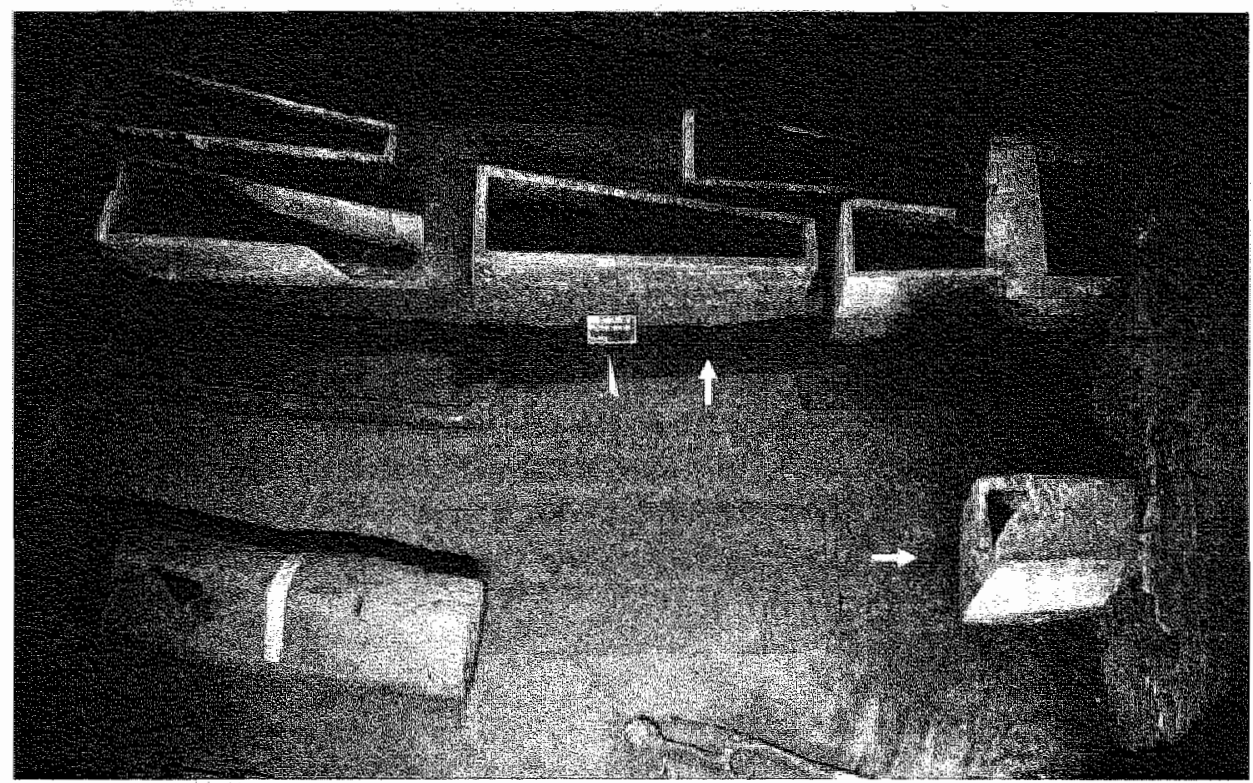

FIGURE 7-12 the top half of the photograph shows the limestone sarcophagh os they were positoned agdinst he outer woll of this boslica (see upward arrow, on the right süde, inside the bosilica (see orrow pointing right) is on sarcophagus with of fid still in phoce.

lower levels of the Stiftskapel site were also a part of the cemetery, although for this location we have no indication whether it was used for burial during the basilica phase. Finally the graves excavated at the Servaaskloaster site prabably also belonged to the same cemetery spreading out around the Servaas church. It seems plausible that the area from the saint Servaas church site to the Roman road was continuously used as a burial ground from the late Roman period up to the nineteenth century. However, after the ninth century the number of burials inside the present church decreases drastically. Between the tenth and the nineteenth century only a few provosts and members of the aristocracy were buried inside the saint Servatius church.

\section{REFEREMCE POPULATIONS}

Recently published physical anthropological reference data from Carolingian cemeteries from the region of Mastricht are scarce. Seven reference populations were selected. Two regional cemetery samples, from Namur (Belgium) and Susteren (The Netherlands), were used as reference populations despite the fact that the chronology of these cemeteries extended 50 to 200 years after the end date of the basilica sample. The cemetery from the Chapelle Saint Hillaire site in Namur (Belgium) comprised of burials from the Carolingian periad and the subsequent early ottonian period. ${ }^{\text {ses }}$ This sample consisted of 22 adult burials recovered in and around an 
early medieval chapel dedicoted to Saint Hilaire. s.5. $^{3}$ Because of the burial inside and close to a thurch we assume that these individuals were of intermediate to high status. The cemetery excavated at the Saivator Square in Susteren also consisted at least partially of burials of intermediate to high status. ${ }^{\text {tsa }} 5$. Bcetsen studied a total of circa 43 burials from this excavation A third sample used for comparison was excavated at Rijnsburg, in the west of the Netherlands near the coast. These burials were positioned in a late Carolingian cemetery which preceded the construction of a Romanesque church. G. Maat examined a totall of 16 individuals, dating between circo 875 and $1133 \mathrm{AD}$. In addition, data from geographically distant sites ranging from Haithabu (Germany) in the north to San Vincenzo al Volturno (Italy) in the south were used for comparison. The cemetery from Haithabu contained burials from the ninth century and belonged to a large settlement focused on trade and manufacture. ${ }^{\text {s.n }} \mathrm{U}$. Schaeffer studied the skeletal remains of 100 individuals from this site. V. Higgins examined the human remains of 276 individuals from a cemetery excavated at the site of the monastery of San vincenzo al Volturno. ${ }^{62}$ These skeletal remains were recovered from various burial areas around the monastery. Although as a whole the callected samples consisted of burials from the late Roman period to the end of the Carolingian period, most of the graves dated from the eighth and ninth centuries. High status burialls, burials of in termediate status and lower status individuals from the local population living in the vicinity of the monastery were represented in the sample. In addition, a cemetery from France and one from switzerland were used as a reference population, viz Villiers-le-Sec (France) ${ }^{653}$ and Satigny-Geneve (Switzerland). The cemetery of Villiers-le-Sec was a small village cemetery north of Saint Denis, France, from which 48 individuals were recovered and examined by G. Auboire. ${ }^{\text {Gat }}$ Villiers-le-Sec was a village that was part of the property of the monastery of Saint Denis. Because of its association with a small settlement with agricultural functions it is assumed that predaminantly individuals of low to intermediate status used this cemetery. Simon and Leemans studied the cemetery excavated in Satigny-Genève. ${ }^{655}$ This population represents 103 Carolingian burials from a larger cemetery in use from the sixth to the thirteenth centuries. The cemetery was associated with a church and priory in a rural setting not far from Geneva. Generally the publications of the above mentioned

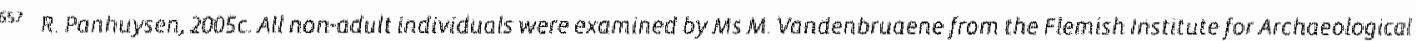

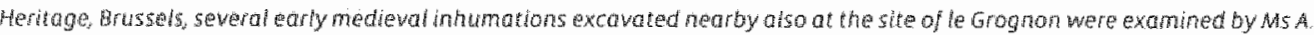

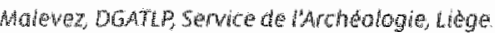

Baetsen, 1998

65\% Corduluke at al. 1998

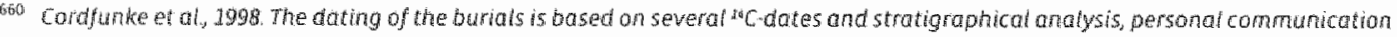
by MFP Dinstro who is preparing a cloctoral thesis on the Rinsburg site

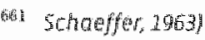

G. Used for comparison in our tables were the dora kindly provided by Ms V Higgins. Recently the results of the osteonchaeological examination of these skeletal remains were publishent Highins, 2002)

6his Discance from Mastricht circa $400 \mathrm{~km}$

G6is Auboire, 1988

Gits Simonand teemans 9991 
populations provided general demographic data. Specific health related data are often lacking or unsuitable for comparison due to the variation in methodology.

\section{PHYSICALANTHROPOLOGY AND PALAEOPATHOLOGY}

Although some graves were damaged in the eleventh century during the construction of the present church, the skeletal remains in the basilica sample were considerably more complete (recovery rate: 0.27 ) than those of the templum sample (recovery rate: 0.13 ). As a result more infarmation could be gained from this sample. Generally the preservation of the skeletal remains was good, however the in humations deposited in limestone sarcophagi were poorly preserved. Many of these remains showed signs of the presence of levels of putrefactive fluid in the graves. Those parts of the skeleton that were exposed to these fluids were often poorly preserved, ranging from loss of cortical bane to complete dissolution of bone tissue.

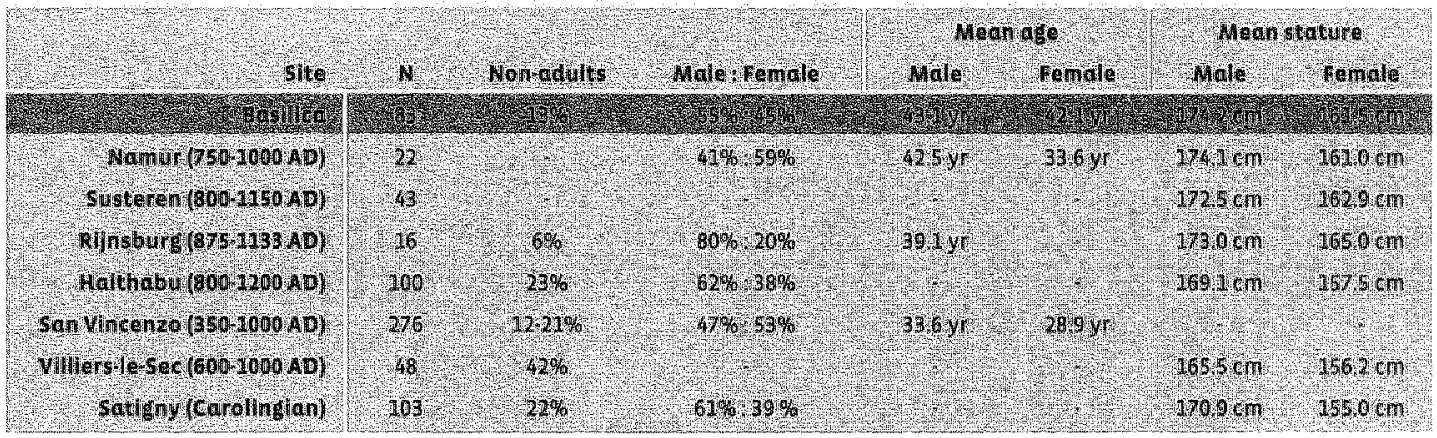

TABLE 7 -10 Demographic data for the bastica sample and five reference cemeteries.

The law percentage of non-adult burials in the basilica sample suggests that this age category was underrepresented in the sample. This is corroborated by the distribution of nonadult mortality in five-year age intervals which shows a relatively low number of deaths in the first five years of life (4/11), and a relatively high number of deaths between 15 to 20 years $(4 / 11)$ an interval that is normally characterised by low mortality. This suggests that selection by a.ge was a factor determining whether individuals were buried in the examined part of the basilica cemetery. Similar distributions of non-adult mortality were found in other cemeteries. At the site of San Vincenzo al Volturno, Higgins found low to moderate percentages of non-adult burials for the Caralingian period ranging from 12 to 21 per cent for different burial areas. This phenomenon was explained by the fact that in general moderate to high status burial areas were examined. At the sites in Haithabu and Satigny non-adult mortality was slightly above 20 per cent. However, a considerably higher percentage was found for the rural cemetery of villiers-le-Sec, where over 40 per cent of the individualis died before reaching adulthood.

In the basilica sample and the cemeteries of Namur and San Vincenzo the number of males and females was approximately in balance. At Haithabu the males outnumbered the females, which might be a result of the (temporary) influx of male traders and craftsmen in this 
settlement, serving as a port of trade. Both in the cemeteries of Satigny and Rijnsburg more males were buried. For Satigny this was considered the result of the presence of a community of manks at the priory. The same was possibly true for the Rijnisburg burials.

Litte variation in mean age at death was found between males and females of the basilica sample, viz. 43.1 and 42.1 year respectively. In comparison to other Caralingian cemeteries and populations fram ather periods a difference of ane year is small since in many historical populations mean age at death for females was about five to ten years lower. Generally, the mean age at death calculated for males and females of the baslica sample was relatively high in comparison to contemporary samples. The males from Namur almost reached the same mean age at death ( 42.5 years), but there the females seem to have died earlier ( 33.6 years). Both the males and females of san vincenzo generally died at a younger age, resulting in lower mean ages at death.

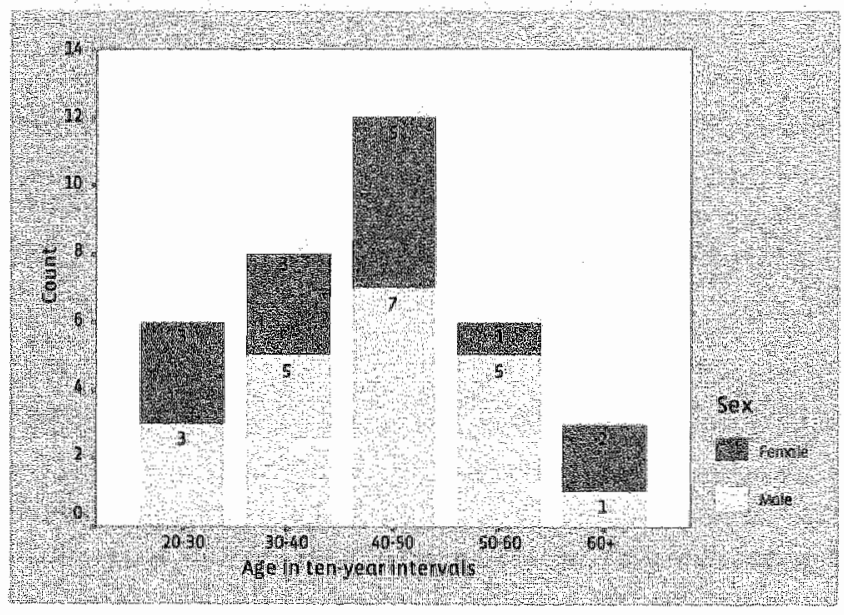

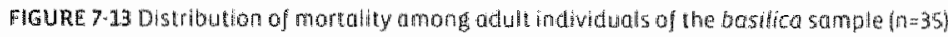

Unlike the templum sample, the distribution of adult mortality in the basilica sample was in agreement with mortality distributions commonly found for adult individuals in pre-industrial populations (compare Figiture 7-7 and Figure 7-13). This was noticeable in the higher proportion of mortality in the 50 to 60 and 60 to 70 year age intervals. Again the highest number of deaths was found for the 40 to 50 year age interval. Up to and including the 40 to 50 years interval females were almost equally represented. The two last intervals showed fluctuations in the representation of the sexes. This may just as well reflect actual changes in the proportions of male and female mortality or be a consequence of the small number of individuals.

stature of both males and females was relatively high. The stature of males from the basilica sample was not exceeded in any of the reference populations. Both males and females in Namur were generally as tall as those of Maastricht. The males in the Susteren population were less. than 2 centimetres shorter. At the sites of Satigny and Haithabu mean male stature was 
respectively circa 3 and 4 centimetres lower and the difference with malles from the village population of Villiers-le-Sec was more than 8 centimetres. For females, the same ranking according to mean stature was found among the reference populations, with the exception of the females of Susteren, whose mean stature exceeded the mean calculated for the basinca sample by 1.4 centimetres and the females of Satigny who generally were sharter than the females in all ather reference populations. The two populations that were geographically nearest to Maastricht, viz. Namur and Susteren, have mean statures for males and females that were much closer to the basilica sample than the other reference populations. For the basilica sample male stature was circa 108 per cent of female stature, which is marginally larger than the difference generally found between males and females.

With respect to other heal th related characteristics few data could be collected from the reference studies. Therefore, the data from the templum and Boschstraat samples were included in the comparison of the prevalence of cribra arbitalia, ename hypoplasia and Harris lines.

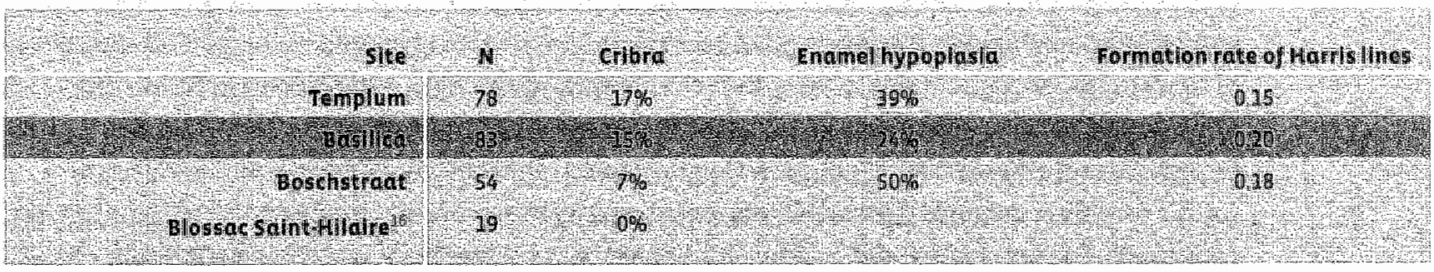

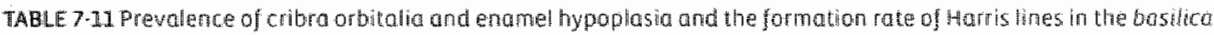
sample and reference populations

The prevalence of cribra orbitalia was only slightly lower than in the templum sample and twice as high as in the Boschstraat sample. In Blossac Saint-Hilaire a Carolingian cemetery in Poitiers (F) none of the inspected skulls $(n=19)$ had cribra orbitalia. It should be noted here that the cases of cribra orbitalia from the basifica sample were generally individuals with rather superficial changes of the orbita. None of these cases had proliferative new bane formation in the orbits or evident sigins of poratic hyperostosis of the skull. With respect to the health conditions related to the formation of cribra oibitalla the situation for the basilica sample appears to have been similar to the situation for the individuals of the templum sample. Almost a quarter (24 per cent) of the individuals from the basilica sample showed signs of linear enamel hypoplasia. The formation rate of Harris lines does not show much variation between the samples from Maastricht. Therefore, no additional information on physical childhood stress can be deduced from these data. Given the relatively maderate nature of these cases of hypoplasia and their low prevalence in combination with the relatively high mean stature, it seems unlikely that individuats from the sample experienced substantial physical stress during childhood.

At first sight some of the palaeopathological parameters presented below might suggest that the individuals of the basilica sample were on average not living under favourable health conditions. However, for several of these parameters longevity resulted in an increased risk of 
acquiring these pathological conditions, rendering it less likely that they were the result of poor living circumstances.

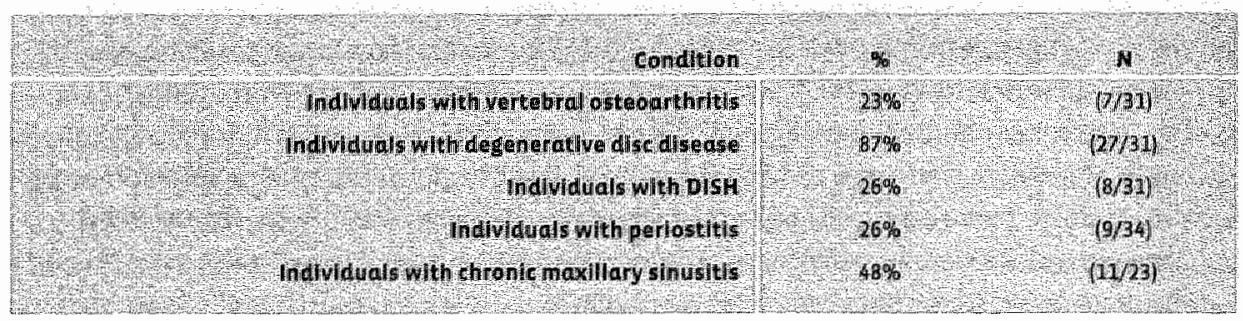

TABLE $7 \times 12$ Seleced palaeopathological results for the basilica sample

An example of the possible impact of increased longevity is the prevalence of vertebral osteoarthritis (VOA) and degenerative disc disease (DDD), which was relatively high. Both conditions are known to increase with age. This trend was also observed in the pooled samples of this study. Consequently it is likely that the comparatively high mean age at death in the basilica sample was an important cause of the elevated percentages of degenerative disc pathology in the spine. ${ }^{665}$. The high prevalence of $\mathrm{DASH}$, almost twice the prevalence calculated for the templum sample, can partially be explained by the increased langevity. ${ }^{66}$. A factor further contributing to this high prevalence of DISH could be a change in general living conditions, in particular the diet. As indicated above DISH is often associated with an affluent diet and the lifestyle of high status members of religious communities. ${ }^{568}$ ]anissen found changes associated with DISH in practically all the skeletal remains of eleventh to sixteenth century canons buried in the "Stiftskapel" $(n=17)$. ${ }^{6,3}$ The association of DISH with the lifestyle of high status members of religious communities is of particular interest in the basilice sample. It is expected that a proportion of the basilica burials were either canons or monks. The increased prevalence of DISH may therefore be associated with the burial of members of a religious community or individuals with a similar life style. Rouche and Pearson have pointed out that people in the Carolingian perhod may have theoretically had access to sufficient quantities of food, as suggested by warious written sources. Whether quantitatively and qualitatively sufficient diets were awailable to all social groups remains debatable ${ }^{* 0}$ Rouche indicates various early medieval, membeirs of monastic communities may have received abundant diets ${ }^{673}$

Gibi in iager samples this assumption can be tested bycalculating the prevatence per age category, unfortunately in this study sanple sizes were too snotil.

in a lorge stuty of two hospital populations weingeld and coworkers found a strong correlation between age and prevalence of DrSk Weinfeld et al. $199 \%$ 
With respect to parameters that provide an indication of the exposure to infectious diseases it is noted that both chronic maxillary sinusitis and reactive new bone formation on the long bones of the lower extremities were found in a relatively high percentage of the inspected individuals: The prevalence of chronic maxillary sinusitis was slightly lower than the prevalence in the templum sample. in the skeletal remains inspected for this study and in another sample from Mastricht the prevalence of chronic maxillary sinusitis was found to increase with advancing age, largely due to the increase of dental pathology in older individuals. ${ }^{62}$ So the relatively high prevalence of chronic maxillary sinusitis in the basilica scample might also be a consequence of the high proportion of individuals dying at a more advanced age. Another cause for chronic maxillary sinusitis may be rhinogenous sinusitis, which is thought to be strongly influenced by living conditions. ${ }^{673}$ Since little is known about living conditions, especially housing conditions, it is not possible to interpret this aspect of the prevalence of chronic maxillary sinusitis.

At present there is no satisfactory explanation for the relatiwely high prevalence of reactive periosteal new bone formation (in palaeopathology this is diagnosed as periostitis) in the long bones of the lower extremities (26\%). Thi5 was about 5 per cent more than in the templum sample. Some of these cases of reactive new bone formation were possibly infections secondary to orall pathollogy. However, in the four combined samples periosteal new bone formation was not found to increase with advancing age. This suggests that it is unlikely that the age composition of the basilica sample can explain the relatively high prevalence of periosteal new bone formation.

Bone changes due to trauma were found in considerable numbers in the basilica sample. Two types of trauma may provide clues concerning the living conditions of the individuals from the basilica sample, viz. healed fractures and intentional injuries caused by sharp bladed objects. of all inspected long, bones 3.1 per cent displayed changes caused by fractures and the ensuing healing process. This is the highest prevalence of fractures per inspected number of bones in all four samples in this study. As was stated in chapter 6 the increase of fractures from the templum to the basilica phase was statistically significant. Since fractures were more common in males than in females, part of this increase may be explained as a result of the higher proportion of male burials in the excavated section of the cemetery. In comparison to a study by Judd focussing on trauma from medieval and later medieval populations from Britain, the percentage of bones with fractures in the basilica sample is higher than the percentage found for a leper hospital cemetery from chichester (2.6 per cent). This is surprising, since the percentage of fractured long bones found for this hospital population was already considerably higher than the percentages calcullated for three medieval cemeteries that were used for comparison in the same study. ${ }^{676}$ Therefore, we may conclude that the lifestylle of the individuals from the basilica sample was associated with an increased risk of fractures.

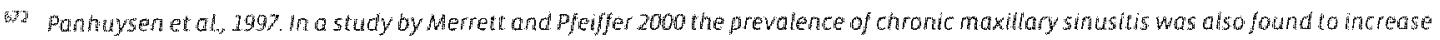
with advaning age, herret and Pfeiffes, 2000, p. 310-31t

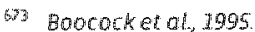

$60 \%$ fuded and Roberts, $1998,0.51$.
} 
The distribution of the fractures in the body may shed some light on what caused the fractures. Fractures of the upper extremities were the predominant type of fracture and their distribution was similar to the distribution in the other three samples. It is recalled here that only four healed fractures were found in the bones of the lawer extremities of the four samples in this study. All four of these were individuals from the basilica sample. The fractures of the lower extremities (one in the femur and three in the fibula) may be particularly indicative of a shift in lifestyle or occupational risks. Such fractures are often caused by a fall from a height and may have been the result of equestrian accidents or construction work and other activities on scaffolds. ${ }^{625}$ Apart from the fractured femur the other fractures in the upper and lower extremities had healed well, with no indication for seriaus functional complications. Although there is no unequivocal evidence for the presence of medical care it seems likely that fracture treatment included the use of splints and adequate rest. Regarding the femur fracture the consolidation of the bone suggests traction was applied..$^{676}$ The study of complications in fracture healing, like secondary asteoarthritis, suggests that most fractures were treated successfully. ${ }^{\text {gr }}$ secondary os teoarthritis was found in association with circa 27 per cent of the healed long bone fractures. In general, the treatment of fractures seems to have been effective in preventing functional impairment and other complications.

Also of interest in determining the hazards to which the population was exposed was the analysis of injuries caused by shorp bladed abjects. As discussed above these injuries were considered to be inflicted by weapons, most likely swords. Four cases of sharp bladed injuries were noted in the skeletal remains from the basilica sample. All cases were adult male individuals. In three individuals the head was injured and in one individual the tibia. Two of the injuries were (partially) healed and two showed no sign of healing and were consequently considered peri-mortem injuries. About 21 male skulls were recovered with 50 per cent or more of the skull intact. Sharp bladed injuries were found in 3 (14 per cent) of these skulls. In all skulls the left side was affected. ${ }^{63}$ Sharp bladed injuries were dacumented in other Caralinglan and. mediewal cemetery populations like Haithabu, Arras and a collection of cemeteries from Baden Wärttemberg. With respect to the quantification and distribution of the injuries inflicted by

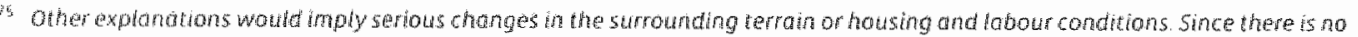

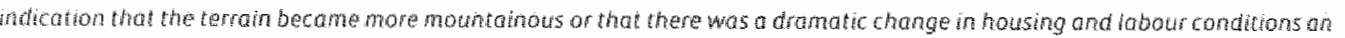

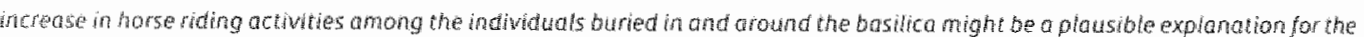
thanging phevolence and distribution of fractures.

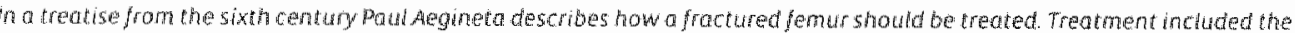

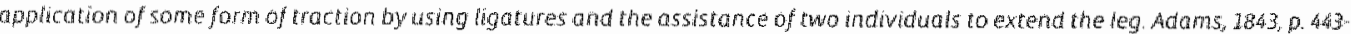
西自的

this Sircisis, 190

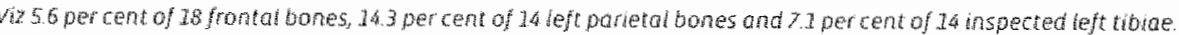

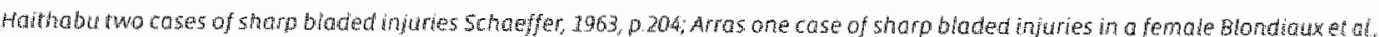

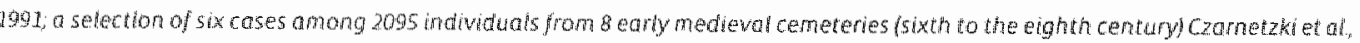

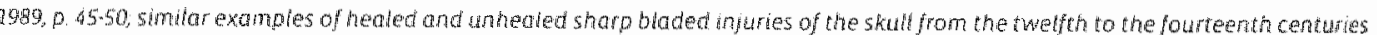
arementionte in crametzki, 1996, o. $298-195$ 
sharp bladed objects we may compare our data with similar results from a survey by Weber and Czarnetzki. These authors found that circa 10 per cent of 304 early medieval skulls displayed signs of either sharp or blunt force trauma. They also noted that these traumas were predominantly found in males. Another similarity to the trauma pattem in our study is that most traumas involved the left half of the frontal bone or the ieft parietal bones. Generally it is. argued that in case of combat with swords righthanded assallants in a frontal attack will inflict most damage to the left side of their opponent.

The spatial distribution of individuals with sharp bladed injuries within the basllica phase cemetery was nat random. One individual with a healed injury of the tibia was found north af the northern transept in a monumental grave. All three individuats with sharp bladed injurles to the skull were found in burials south of the choir of the basitica. in fact they were found within a stretch of 6 by 1 metres, parallel to the axis of the church ${ }^{\text {ail }}$ This concentration of sharp bladed injuries in burials is peculiar and will be discussed below. Overall, way conclude that both the prevalence of fractures and the distribution of sharp bladed injuries in this sample indicated that males buried around the basilica in particuar had a lifestyle that exposed them to considerable risks of breaking bones or getting injured in armed conflict.

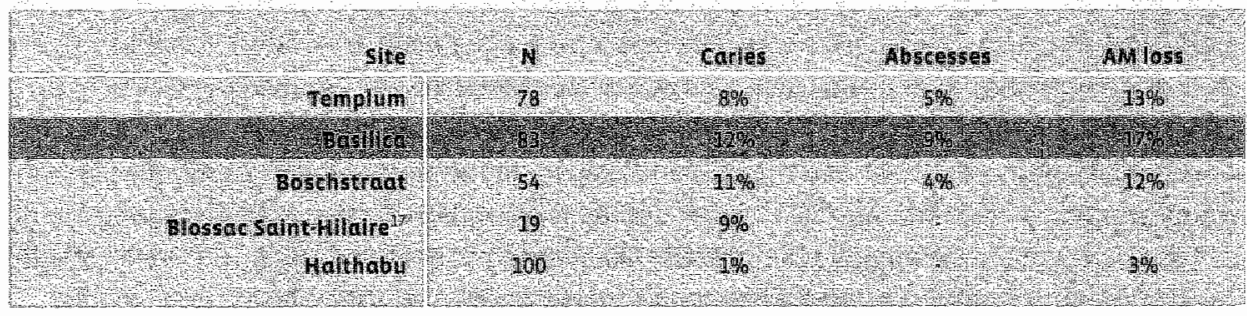

TAELE 7-13 Prevalence of caries, peri-opical abscesses and ante-mortem tooth loss fall calculated per inspected rement or position in the basilica sample and reference populations

A considerable number of dental elements from the basilica sample were affected by carles. With a prevalence of 12 per cent this was considerably higher than in the templum sample (8 per cent) and slightly higher than in the Boschstraat population (11 per cent). The prevalence of ante-mortem tooth loss (17 per cent) was higher than in any of the three ather samples piresented in this study. Both caries and ante-mortem tooth loss are known to increase with increased consumption of carbohydrates (especially sugars) ${ }^{632}$, advancing age and the consumption of more refined foodstuffs. It is possible that the increased longevity of the indiwiduals of the basilica sample may partially explain the higher prevalence of caries and ante-mortem tooth loss. From the eight century on sugar may have been available in Western Europe, however, it is not likely sugar became abtainable in large quantities before the eleventh

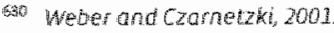

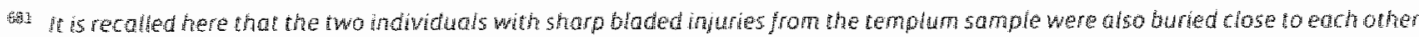

Hitson, 1996,278
} 
century and it long remained an expensive product. Therefore, it is more likely that an increased consumption of other sugars may have contributed to the increased caries prevalence. In comparison to the Boschistraat sample, which had a similar percentage of carious elements, the basilica sample had a higher prevalence of dental abscesses and ante-mortem tooth loss. This might be an indication that the two samples differed in the consumption of abrasiwe foodstuffs ${ }^{\text {as }}$ The basilica sample individuals might have consumed mare refined foadstuffs. This may have allowed for the occurrence of more caries lesions on the occlusall surface of the dentition, leading to more peri-apical abscesses and ante-mortem tooth loss. ${ }^{635}$ in that case a change in diet was responsible for the relatively high rates of caries and antemortem tooth loss. With respect to the formation of calculus no difference between males ( 88 per cent) and femalies (86 per cent) was noted (in contrast to the situation in the cella and templum samples).

\section{SPATIAL DISTRIBUTION}

Outside the basilica all burial areas were used for both male and female burials. No systematic pattern could be recognised in the positioning of male and female burials. The burials outside the church were generally a mix of male, female and non-adult burials. This indicates that these areas were not exclusively used to bury individuals from a clerical community. It is possible that the area around the basilica was used as an ad sanctos burial ground by some famllies of high social status. Non adult burials were not evenly distributed outside the church: most non-adults were buried south of the choir and the southern annexe. In this part of the cemetery the graves were placed close together. The difference in spatial organisation between the northern graves and the southern graves suggests that the se areas were used for burials of two different groups. The fragmentary condition of the skeletal remains recovered from inside the basilica did not allow for the determination of sex in the majority of cases. Therefore, the absence of female burials inside the nave of the church cannot simply be regarded as evidence that females were not buried inside the church. Only one grave inside the church containing female skeletal remains was found in an annexe south of the eastern corner of the southern aisle. This female burial was found in the only grave that was positioned on the same spot as two previous graves. ${ }^{636}$ No evidence for the presence of a permanent demarcation of the grave was found. The fact that the consecutive burials caused marked disturbance of the previous burials indicates the three individuals were not buried at the same time. Stlll, the relatively precise superpasition of the graves suggests that the burials were placed intentionally at the same spot and that some form of grave marker must have been present. We can only guess the reason why these

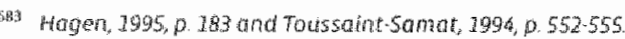

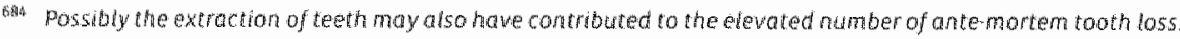

6itis

Maot and wan der Velde, 1987

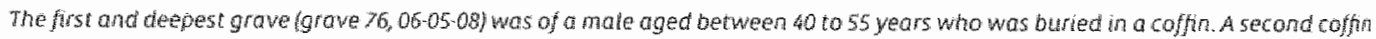

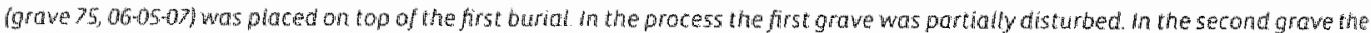
renains of a child between 6 and 7 years were found At the siame spot the third grave forave 23 , o6 os oul was postioned, disturbing the difl's grave betow the top grave was a trench grawe, contoining the remains of a femate aged between 31 and 37 years. 


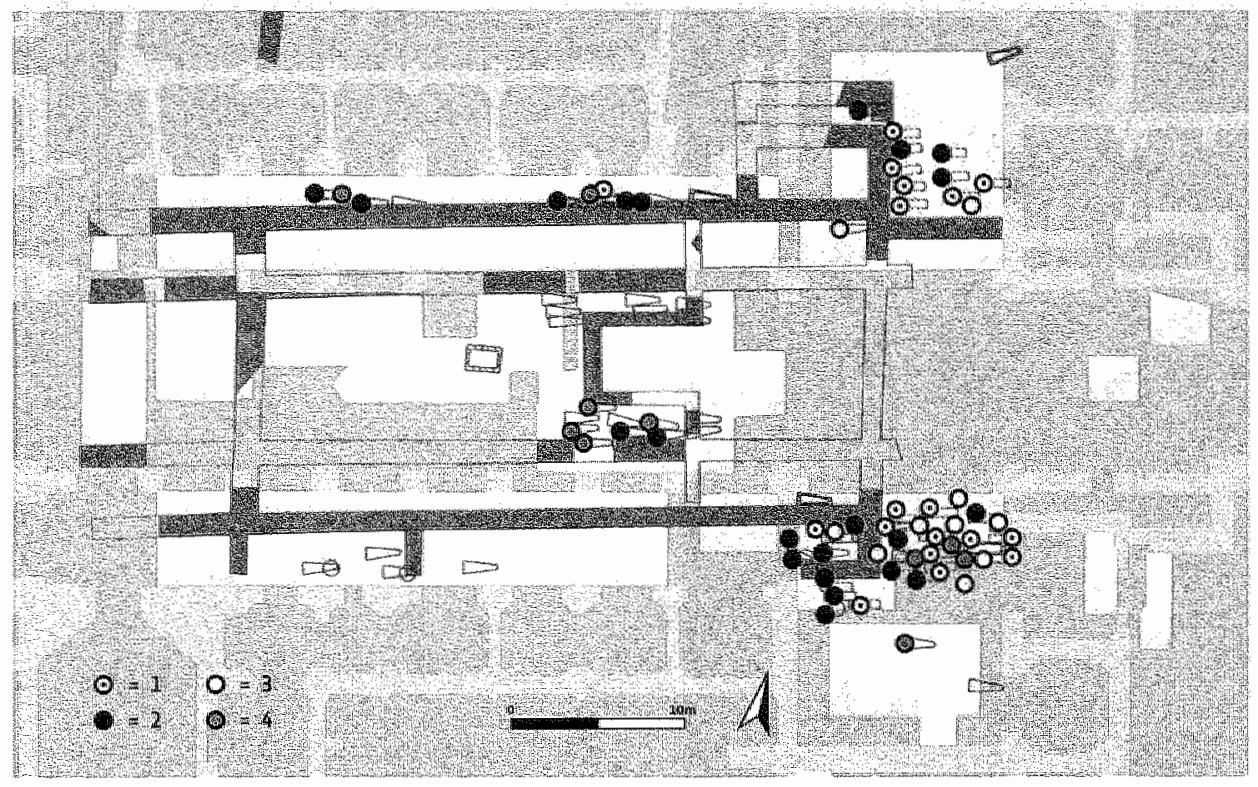

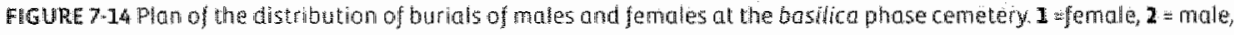
$3=$ nora-od bot, $4=$ adtult individual of undetarmined sex.

three individuals were buried in the same spot. Possibly they were members of the same family. The annexe may in that case have been a small funerary chapel for a family.

With respect to the distribution of the sexes by grave type there was no evidence of primary burials of females in sarcophagi. A total of 35 limestone sarcophagi were excavated within the confinements of the Servatius church excavation. Only 14 of these contained human remains. In 6 of these the human remains were not lying in situ. Most likely these remains represented secondary depositions.

In 8 sarcophagl a primary burial was found: 7 were males and ane was an individual of unknown sex, aged between 6 to 10 years. This might implicate that limestone sarcophagi were predominantly or even exclusively used for the interment of males. Regarding similar sarcophagi found in Liege in the middle and to the south of the Saint Lambert church; otten assumes that these were used to bury clerics. ${ }^{67}$ However, due to the absence of primary inhumations in the other 27 sarcophag i it remains unknown whether the use of these sarcophagi in Maastricht was reserved for the burial of clerics. 


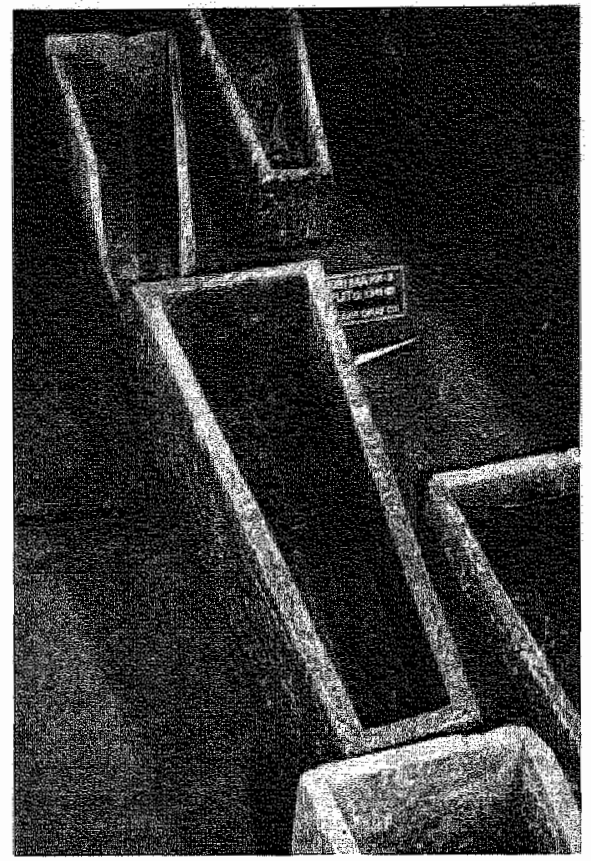

Figure 7-15 Surcophagi positioned in the centre of the bosifica.

Analysis of the distribution pattern of individuals by age indicated that burials of adult individuals were dispersed evenly over the excavated section of the cemetery and not clustered by age. As mentioned above, non-adults were found mostly outside the basilica in the south. eastern part of the excavated area and to a lesser extent in the north-eastern part. Very young chilldren were clearly underrepresented in the excavated section. The absence of normal proportions of children dying between birth and up to 5 years will be discussed in more detail below. The underrepresentation of this age cotegory and the low proportion of non-adult burials between 5 to 20 years in this sample both imply that burial in this section of the cemetery was predominantly reserved for adult individuals.

The clustered distribution of individuals with lambdoid ossicles in the various sections of the cemetery sugges ts that genetic relations may have determined the place of burial within the cemetery Other factors are known to have an effect on the formation of lambdoid ossicles, and the interpretation of this epigenetic trait as an indicator is not without discussion. Still, the distribution of individuals with and without this trait might provide an opening to determine genetic relations within the cemetery: In the future this may possibly be tested by means of ancient DNA amalysis. 5 knulls could only be inspected in individuals burled outside the church or in the southern annexe. Therefore the analysis of the spatial distribution of this epigenetic trait is llimited to these parts of the cemetery. Overall the basilica sample comprised a relatively large number of individuals with lambdoid assicles (viz. 14 out of 35,40 per cent).

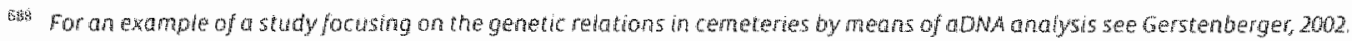




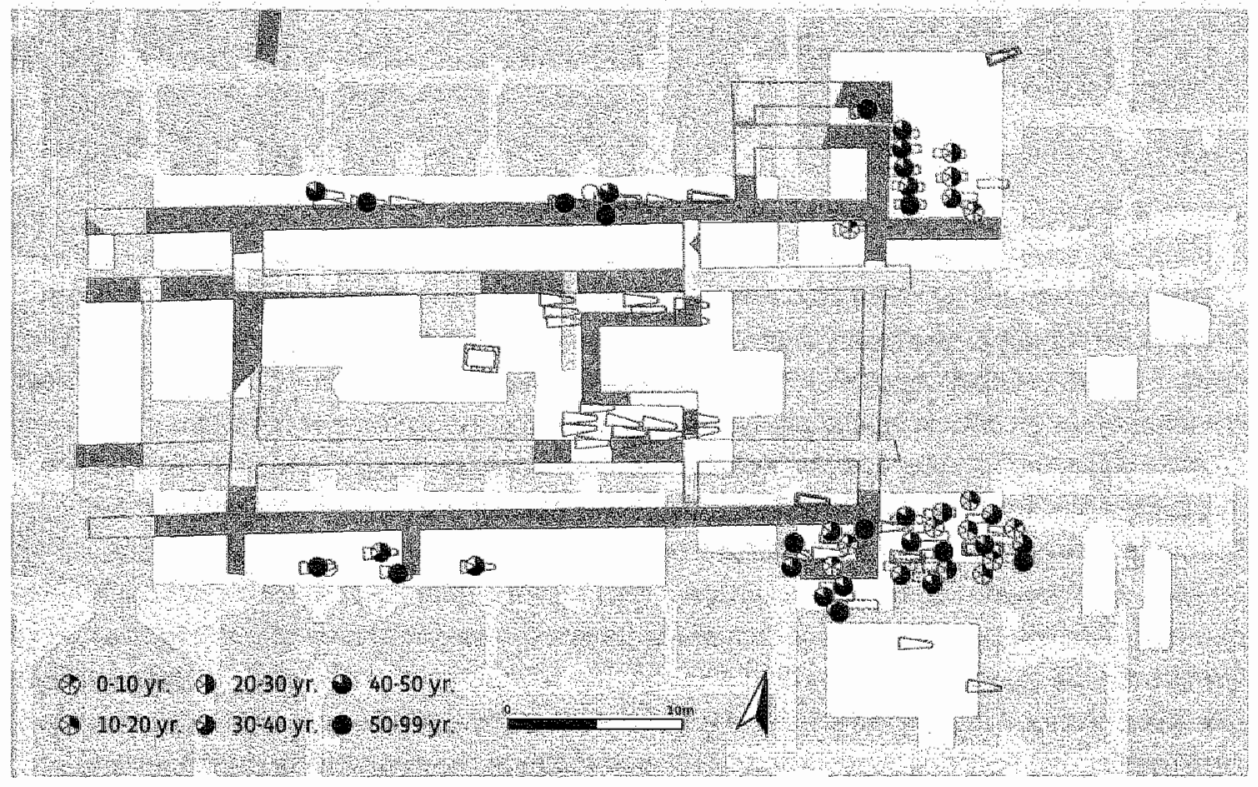

Figure 7-16 Pifan of the distribution of indiwiduals by age at the basilica phase cemetery.

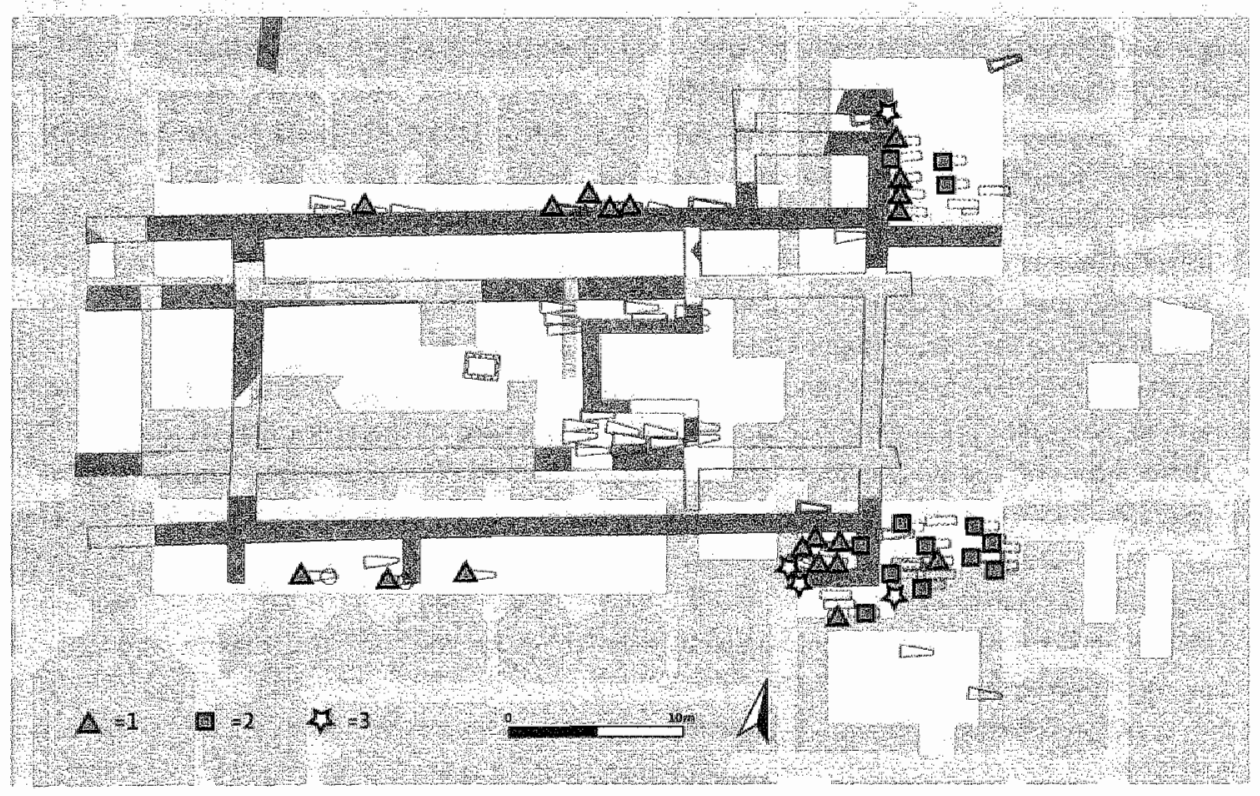

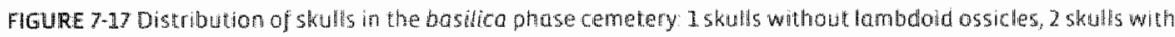

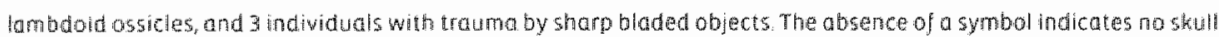
ramaing were found 


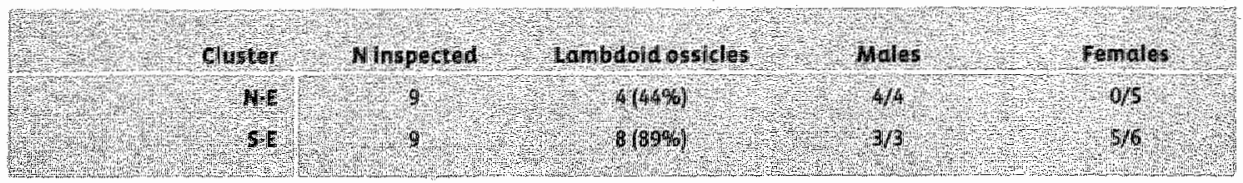

TABLE 7-14 Distribution of lambdoid ossicles in the wo noin etusters

All individuals with lambdoid ossicles were either buried in the northeast cluster ( 4 out of 9 , 44 per cent) or the southeast $c$ luster ( 8 out of 9,89 per cent) or the southern annexe ( 1 out of 4 in situ burials, 25 per cent). No lambdoid assicles were found in any of the individuals buried along the walls of the basilica ( 8 individuals with skulls). In the northeast cluster there was a clear division between the males and females regarding the presence of lambdoid ossicles. All four male skuls had one or more lambdoid ossicles, while none of the five female skulls had any lambdoid ossicles. 1 in the southeast cluster almost all males and females had lambdoid ossicles, only one female skull had none. Since the presence of lambdoid assicles is thought to be determined both by genetic and environmental factor $s^{5 \%}$ "it seems plausible to interpret the specific distribution of this trait as an indication that relatives, possibly members of the same family, were buried together in private areas of the cemetery. In this respect it is of interest to note that lamboid ossicles were present in all males of both the northeast and the southeast clusters. It is templing to cansider that the males were genetically related and were members of one or twa families exerting hereditary rights to be buried in close proximity to Saint servatius. Whether there was a genetic relation between the two clusters cannot be determined on the basis of the present evidence. The difference in the layout of these two clusters of graves, one organised in formal rows, the other in partially intersecting graves, suggests that at least two different groups used these separate areas of burial. ${ }^{\text {.9x }}$ In this context it is also noted that the individuals with trouma caused by sharp bladed objects were also found exclusively among the burials in clusters with individuals with lambdoid assicles. Three individuals with such traurna were buried close to each other in the sou theast cluster and the southern annexe.

Burlal clase to the choir inside a church was often reserved for secular and clerical individuals of thigh standing ${ }^{62}$ It is as sumed that burial outside the church, near the main altar and choir, was still a prestigious burial lacation for laypersons. ${ }^{693}$ Therefore, the combined results concerning spatial distribution by sex, age, presence of lambdoid ossicles and sharp. bladed trauma support the hypothesis that the areas north and south of the eastern choir were

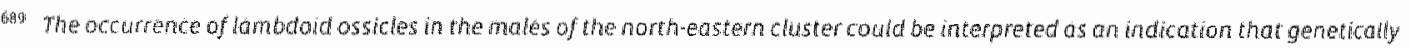

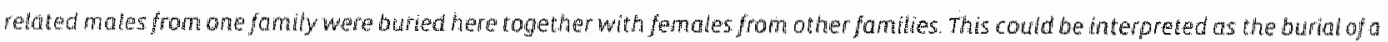
mate the of descendarts with spouses who came from other famblies

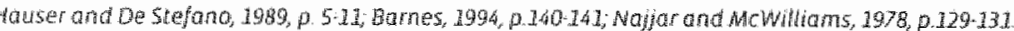

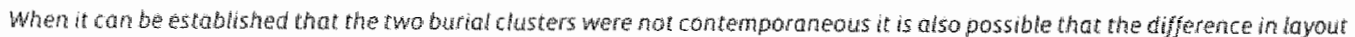
Was the resute of changing wews cancerning the spatiat organisation of groves. Hawewer, at presen there is no indication that the burats in the clusters were not contemporaneous

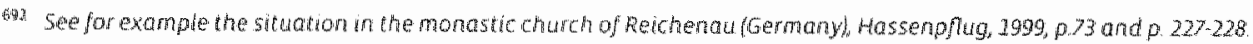

G9: Aries 197\%, Chelin, 1991 and Effros, 1904 
predominantly used as a burial ground for adult members of two or more familles of above average socio-economic status. The traumas by sharp bladed objects found in some of the males buried in these sections of the cemetery suggest that these families or groups may have been involved in armed conflict.

\section{COMCLUSIOW}

The construction of a new church building in the basilica phase was accompanied by a change in the layout of the cemetery. At the time of the construction of the basilica and shortly thereafter there was a short phase where a group of 18 limestone sarcophagi was buried inside the church around the cancella. These changes tied in with changes in the demographic composition of the population buried in this section of the cemetery. After the templum phase, during which females slightly autnumbered males, the basilica phase cemetery is characterised by a reversal of this situation. Males outnumbered the femalles by 10 per cent. Mean age at death slightly increased both for males and femalles with circa 4 to 3 years respectively. As a. result mean age at death was slightly lower for females. With respect to stature, a more significant dichotomous development was noted. Mean male stature slightly increased to 174.2 centimetres, whereas the mean female stature decreased 4 centimetres to 161.5 centimetres. It is not clear whether this change in average stature is associated with changes in the living conditions of males and females respectively or the selection of females from another ethnic or socio-economic background. Another possibility might be that the proportion of femalles of high status in this area of the cemetery decreased due to burial ell sewhere at the Servaas cemetery or in other cemeteries. Other general health indicators do not indicate that living conditions declined during the basilica phase. The prevalence of some pathological conditions probably increased due to the overall rise in longevity. In part this may also explain the relatively high prevalence of DISH. However, it seems likely that this was associated with improving living conditions, especial ly regarding the diet of these individuals. The increase in the number of teeth affected by caries could be considered a development in support of the notion that diet changed. Although part of the caries increase was a consequence of the thigher mean age at death. The higher prevalence in caries and especially peri-apical abscesses will have contributed to the relatively high prevalence of chronic maxillary simusitis. Whether fractures were olso a sigh of increased longevity is difficult to determine. The relative high number of fractures and injuries by sharp bladed abjects sugrests that males especially had a lifestyle that may have exposed them to a higher risk of contracting traumas then females. The distribution of sharp bladed trauma within the basilica phase cemetery indicates that certain groups of males within society were evidently at risk from being wounded or killed in armed conflict since dill cases of sharp bladed trauma were found in groups of individuals with lambdoid ossicles buried in prestigiour areas of the cemetery. It is possible that several of the males with cuts were

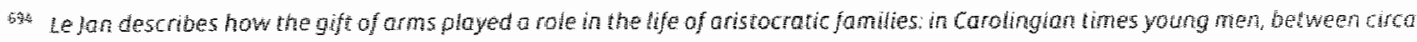

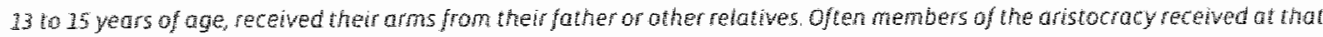

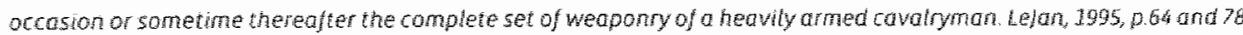


genetically related. These butials we possibly associated with the ruling families in the region who were involved in armed conflict against internal and external adversaries. ${ }^{\text {ess }}$

\section{THE BOSCHSTRAAT CEMETERY}

The Boschstraat area appears to have been inhabited for a relatively short period of time during the seventh and the early elghth centuries. As described in chapter three the Boschstraat sample consists of two types of inhumations found at this site: inhumations concentrated in a cemetery and burlals dispersed over the excavated area in three clusters of two to five graves. The largest group of 45 inhumations was concentrated at the site of a small cemetery. Since very

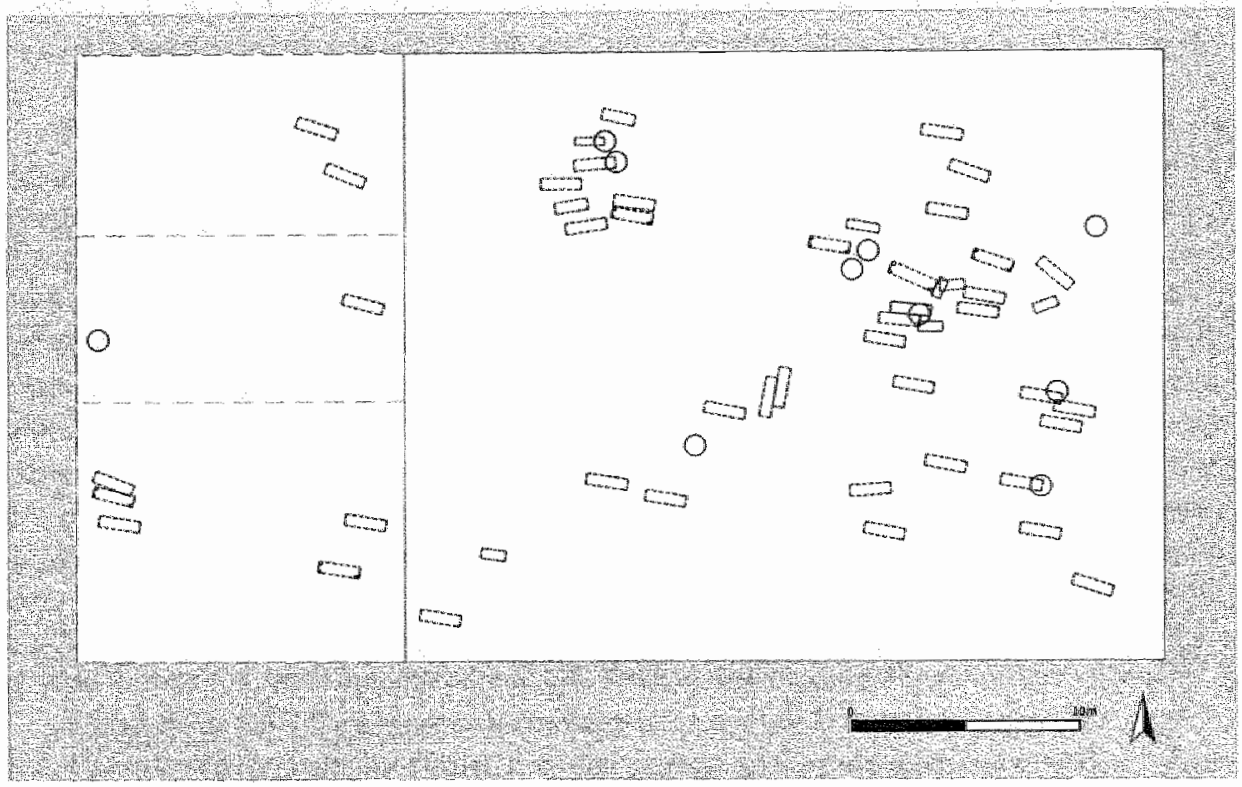

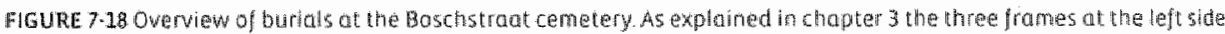
of the flyure represent buriat clisters fownd dispersed in the excavated area. The right section of the figure represents the camerary.

Wittle of this section of the site was lost due to latter disturbances, this cemetery was excavated and recovered almost completely. The three dispersed clusters of graves consisted of 9 burials. Possibly there were more small clusters of inhumations in the areas that were not recovered. These separate clusters of burials were presumably graves positioned in the yards of houses. Unfortunately no house plans and only wague indications of yards could be recognised at the time of excavation. As a result little is known concerning the exact relations between the burials and the buildings and yords. All 54 individuals at this site were buried in trench graves. Six of 
these trench graves had a few stones at the head and/or foot end. Only in three graves were plain grave goods found in the graves. Because of the distribution of the graves among the remains of a settlement and areas used for the manufacture of various objects, we assume that the cemetery was used to bury the dead of the surrounding settlement. At the same time the simple grave types in combination with the manufacturing activities in the settlement were reasons to assume that the individuals buried at the Boschstraat site were of low status.

\section{REFERENCE POPULATIONS}

Since the burials and other archaeological features were dated to the end of the seventh and the early eighth centuries, the physical anthropological and palaeopathological results are compared with both the templum and basilica phase sample. Further comparisons were made with three populations used in the section on the templum sample that were also mainly dated to the seventh century: Rosmeer, a selection of the Saint Martin de Fontenay cemetery and the Saffig cemetery. None of the reference samples used for comparison with the basilica sample were used since these samples often consisted of a majority of ninth or tenth century burials.

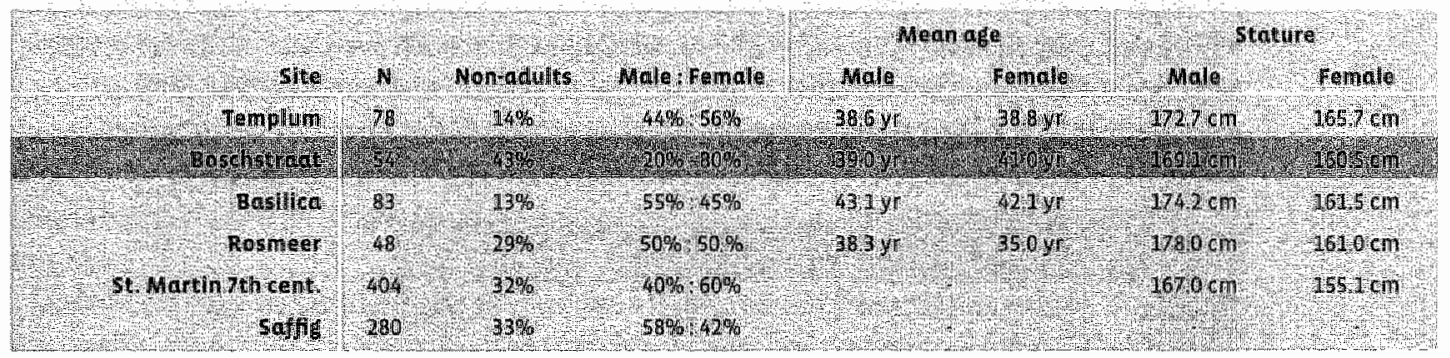

TABLE 7-15 Demagraphic datn for the Boschstrad somple and five reference populations

\section{PHYSICAL ANTHROPOLOGY AND PALAEOPATHOLOGY}

in total 50 graves were excavated at the Boschstraat site. In six af these no human remains were present. The remaining 44 graves yielded the skeletal remains of 44 individuals. The remains of 10 individuals were additionallycollected near these graves. The latter were recovered as articulated skeletal remains, lacking a recognisable burial context, close to the other burials. Because of the undisturbed nature of the cemetery and the burial in trench graves the mean recovery rate was relatively high: 0.32 . This is the highest recovery rate calculated for the four samples in this study.

The Boschstraat cemetery was characterised by two phenomena: in comparison to the templum and basilica samples there was a relatively high percentage of burials in the non-adult category and an exceptionally high propartion of female burials. In particular, the high proportion of female burials is an indicator that the Boschstraat cemetery is different from ather early medieval cemeteries. Because of this it will be difficult to analyse the demographical and pathological data from the Boschstraat cemetery. Below, the proportion of non-adult burials will be reviewed first, and secondly the unequal distribution of males and femalles will be discussed. 
The burials of non adults at the Boschstraat cemetery were partially clustered within the central cemetery. As this cemetery was more or less completely excavated, the concentration of children will not have biased the end-results. No further special cemeteries for children were found at this site. In addition, no child butials were recorded in the three dispersed clusters of burials. Non-adults were buried in the same type of graves. In contrast to what is sometimes expected ${ }^{6}$, non-adults were also buried at the same depth as adults. Therefore, it is unlikely that factors like grave type and depth of burial had a negative effect on the possibility to recover skeletal remains of nom-adults. This seems to be supported by the fact that larger bones like the frontal bone of the skull, the os ileum or the femoral shaft were recovered in more or less the same percentages in non-adults and adults. Overall there are no indications that the proportion of non-adult burials was considerably biased due to factors rellated to the excaviation strategy, burial ritual ar differential decay. Nevertheless, it cannot be determined whether the number of non-adult burials reflects the actual number of deaths of non-adults in the settlement associated with the cemetery. If we neglect the uneven proportions of males and females in the cemetery the percentage of individuals dying before the age of 20 was 43 per cent. This is circa 10 per cent higher than the non-adult proportion in the reference samples from Rosmeer, Saint Martin de Fontenay and Saffig. Although non-adult mortality at the Boschstraat is within the margins found or expected for other early medieval cemeteries it is rellatively high for a population that is further characterised by a high mean age at death and an average mean stature. ${ }^{69} \%$

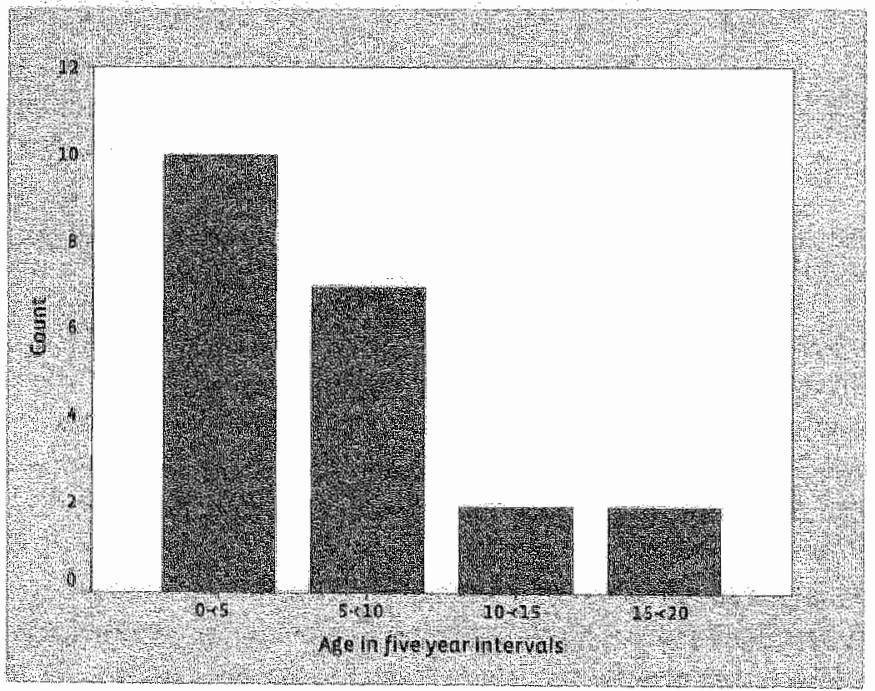

FIGURE 7 - 19 The distribution of non adult individuals from the Boschstraat by five-year age intervals in $=21$ )

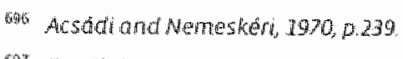

6. E. Zink, 1999 
Looking at the data presented bellow the relatively high number of non-adult burials was not the result of poor health conditions of the Boschstraat population. The distribution of non adult deaths shows that the majority of children died between birth and five years of age. However, only two to three of these children died during the first year after birth. Generally the highest mortality is expected in the first year of life. Various authors consider this as an indication that individuals dying around birth and during the first year of life are missing from the sample and often they propose to correct for this deficit. ${ }^{598}$ However, Brothwell has reasoned that much of the mortality variation may still reflect demographic fact. ${ }^{699}$ He sugigsts that changes in the occurrence of specific diseases and fluctuations in environmental stress were the principal causes of differences in child death group composition. ${ }^{200}$ In addition Molleson has argued that demographic trends like slow population growth and small family size may also have contributed to low mortality rates for children between birth and two years. ${ }^{\text {ing }}$ Recently Kölbl indicated that infant mortality in early medieval cemeteries was for a large part determined by fertility. She has elaborated on the notion that for a high number of infants in a cemetery population, one not only assumes a high rate of infant mortality but also a high number of births. According to palaeodemographical literature, the observed fertility was low in early medieval Europe because the early medievall population in Western Europe was growing at a slow rate. ${ }^{20}$ A possible factor contributing to this low fertility rate was discussed by Riddle, who presented evidence that some forms of birth control applied in the late Roman and medieval periad may have been effective. ${ }^{76 a}$ For the Maastricht population there are no reasons to assume that the growth rate was higher than in contemporary places and that likewise the birth rate was low.

From a palaeopathological point of view there is no evidence that children born in Maastricht were relatively more exposed to physical stress and a high disease load. The skeletal remains of non-adults and adults from the Boschstraat show no signs of elevated pathalogical strain during the growth period. ${ }^{\text {ar }}$ A study of the age at weaning of individuals excavated at the Pandhof site suggests that weaning in early medieval Maastricht occurred at two to four years of age. ${ }^{\text {pog }}$ Late weaning is considered to result in a lower death rate during the first year of life. ${ }^{\text {, }}$. These weaning practices possibly contributed to the survival of a higher proportion of infanits and so to a low infant mortality rate.

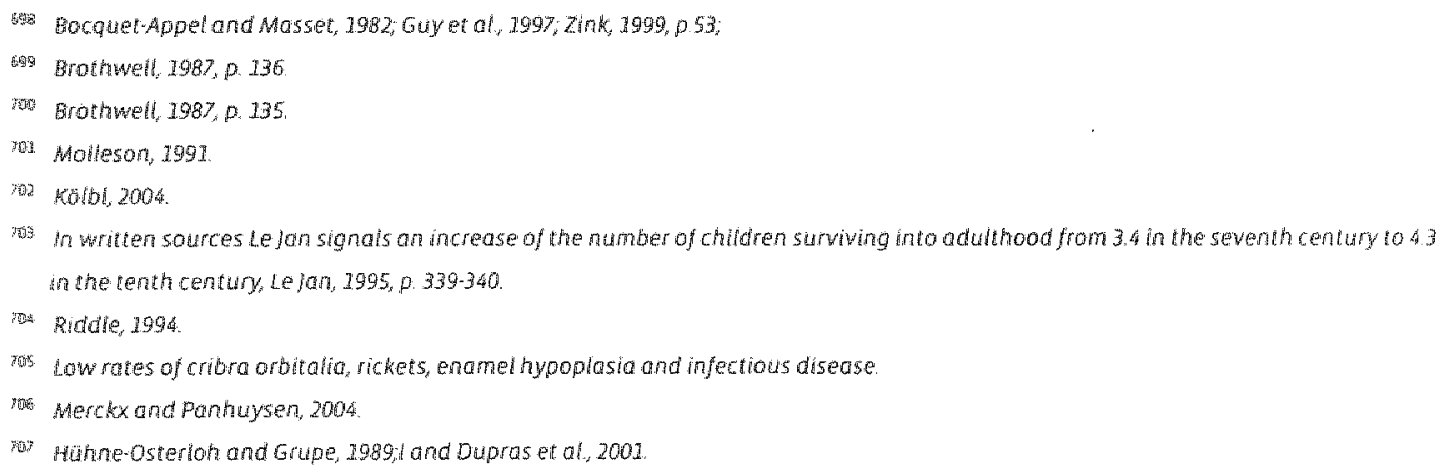


It must be acknowledged that it cannot be ruled out that some burials of very young childran (between birth to 1 year of age) were not preserved or not recovered. However, becouse of the archaeological circumstances and the demographical and pathological conditions we may assume that the excavated number of non-edults at the Boschstraat was largely representative for the number of non-adult burials at this cemetery. Whether the proportion of non-adult burials at the cemetery was representative for the proportion of non-adult deaths in comparison to adult deaths is less evident. Comparison with non adult mortality figures from other sites is: hampiered by the uncertainty about the representation of adults in the cemetery. For an evaluation of non-adult mortality in relation to the situation at other sites we first have to examine the representativeness of adult burials in the cemetery.

The nature of adult mortality can be studied by looking at the male female ratio. As is visible in Table 7-15 the sexes were not in balance in this cemetery. This is in contrast with other rural early medievall cemeteries. In an extensive study of funerary customs in the northern part of the French Alps, colardelle found that the number of males and females was generally in balance (mostly at rural icemeteries) or that males outnumbered females (mostly when a church was present) ${ }^{709}$ There seem to be three plausible explanations for the fact that female burials outnumbered male burials (6 males and 24 females). This could be the result of an actual overrepresentation of females in the living population. Other explanations would be: $a$ predilection for burying females from other settlements at the Boschstraat cemetery, or iargescale" burial of males from the Boschstraat settlement in another cemetery. We could formulate these explanations as: female overrepresentation at the site, funerary immigration of females and funerary emigration of males. Combinations of these processes may have occurred too. The available evidence suggests that the funerary emigration of males provides the best explanation for the male-female ratio.

Regarding the nature of the site there was no indication that structurally more women than men inhabited the settlement. Apart from monastic sites there are few communities with a similar preponderance of female burials. Given the context of the cemetery it is unlikely that the Boschstraat settlement was associated with a numnery. The various remains of the manufacture of bone, metall and glass objects sugigest that activities associated with males occurred at the site. There is no reason to assume these males did not live in this settlement. Concerning the possibility of preferential burial of females at the Boschstraat cemetery there is no independent. evidence for such a trend. It is unlikely that a low status cemetery like the one at the Boschstraat site would be selected for preferential burial of females from elsewhere. It is also implausible that the high number of females in the cemetery was solely the res ult af preferential burial of females from other settlements at the Boschstraat cemetery. In that case the expected number of males would have been larger than the number of nom-adults. In my view a considerable number of males from this community were not buried at the Boschstraat:

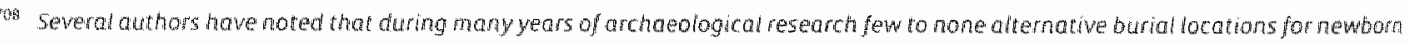
infonts have been recovered, kolbt, 2004 .

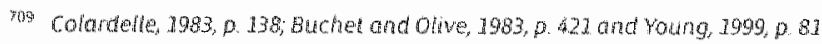


cemetery. Since none of the examined early medieval burial sites in Maastricht was characterised by overrepresentation of males it is unknown where these males were buried. ${ }^{\text {ro }}$

Whatever the causes of the skewed sex ratio and its effect on the proportion of non-aduit burlals the fact remains that the composition of the Bosichstraat cemetery population differed considerably from all reference populations. It is possible this also affected the mean age at death and mortality profilles. Despite the 5 mall sample size, male mean age at death was four years lower in comparison to the basilica sample, but in comparison to the templum sample and the Rosmeer cemetery the difference was negligible. Female mean age at death was relatively high and showed more variation among the reference populations, viz. the females from the Boschistraat sample lived on average about one year less than the females from the basilica sample (table 7-16). They lived about two years longer than the females from the templum sample and six years longer than the females buried at Rosmeer. The difference with Rosmeer is surprising since several of the giraves at this site contained more prestigious grave goads than wiere found at the Boschstraat cemetery. ${ }^{13}$

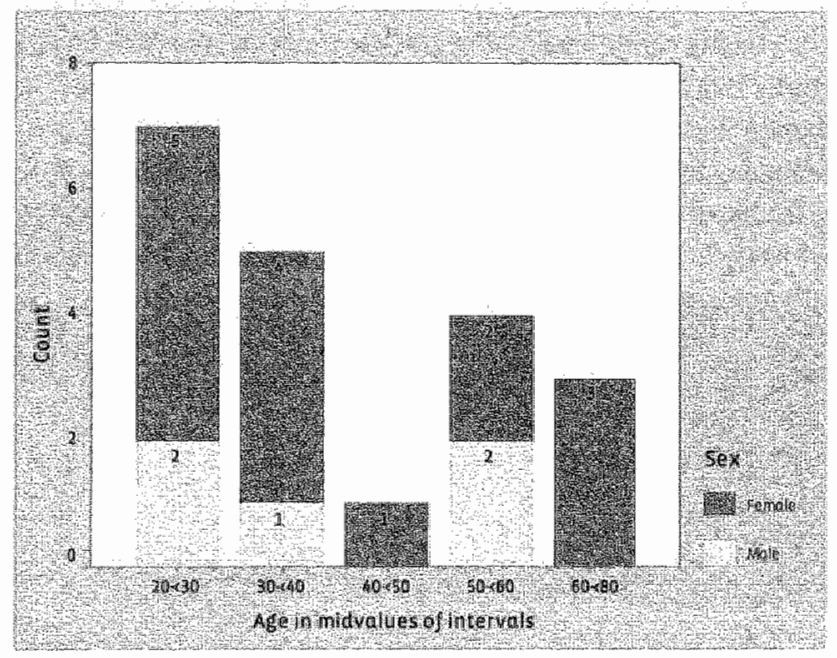

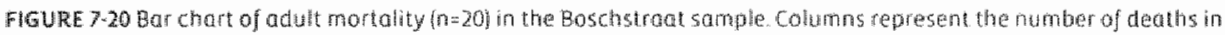
the waspective ten-year oge intervals.

The mortality profile of the Boschstraat sample differs in two ospects from common mortality profiles. Firstly there was a high mortality in the age interval between 20 to 30 years and secondly there was the low mortality in the 40 to 50 years age interval. Small sample size will have contributed to the peculiarities of this mortality profle and the fallowing suggestions

na Two possible explanations for burial in other cemeteries might be preferential burial at ather cemeteries in the vicinity for feasons in the social and cutural domain and migration of males bother sites At present there are no dowa walabte which support or refut either of these explanations.

ris posensed, 1976 
should be considered as hypothetical. Burial customs may have determined the compostition of the cemetery population. Unlike the situation in the Boschstraat sample, elsewhere mortality is often low in the 20 to 30 year age-interval. Explanations for the large number of deaths in this category include preferential burial at this cemetery for individuals dying in this age interval or preferential burial elsewhere of individuals dying in all other intervals, and especially in the 40 to 50 year age interval.

Mean stature of the five males from the Boschstraat sample was considerably lower than in the templum and basilica samples. ${ }^{32}$ This suggests that the males from the Boschstraat sample had less favou rable living conditions during growth than the males fram the templum and basilica sample. Males from Saint-Martin de Fontenay were slightly less tall; thase from Rosmeer were almost 10 centimetres taller. ${ }^{\prime 13}$ Mean female stature for the Boschstraat the basilica and Rosmeer samples all ranged with in one centimetre. Females at Saint Martin de Fontenay were on average 5 centimetres shorter; those of the templum sample were 5 centimetres taller than the females from the Boschstraat. Mean stature for females from the Boschstraat, the basilica sample and Rosmeer does not indicate that among these samples there were considerable differences in living conditions during growth. However, the females of the templum sample were significantly larger, which suggests that the females buried at the Boschstraat cemetery were raised under less privileged conditions than those of the templum sample. The rank order for mean female stature among the reference populations differs from the rank order for mean age at death. Stature is an indicator of living conditions during growth, whereas mean age at death is more likely to be determined by circumstances during the whole life span. Therefore, the variation in rank orders by mean stature and mean age at death may have been the result of shifts in living conditions from youth to adulthood. Given the short period of use of the settlement and its cemetery it should be taken into consideration that "demographic founder effects" had an impact on the composition and the characteristics of the population. When the population settled at the Boschstraat site it possibly consisted of a number of adult females who lived under less favourable conditions during youth but enjoyed better living conditions during their adult live. As a result their age at death would have been higher, but their stature would have been lower. ${ }^{\text {,19 }}$

HEALTH

When we compare the results for cribra orbitalia with the results for stature in the Boschstraat sample and three reference samples, these health indicators do not indicate that one single trend might explain the variation between the parameters. The prevalence for cribra orbitalia in the Boschstrat sample was lawer than in the templum and the basilica samples. 


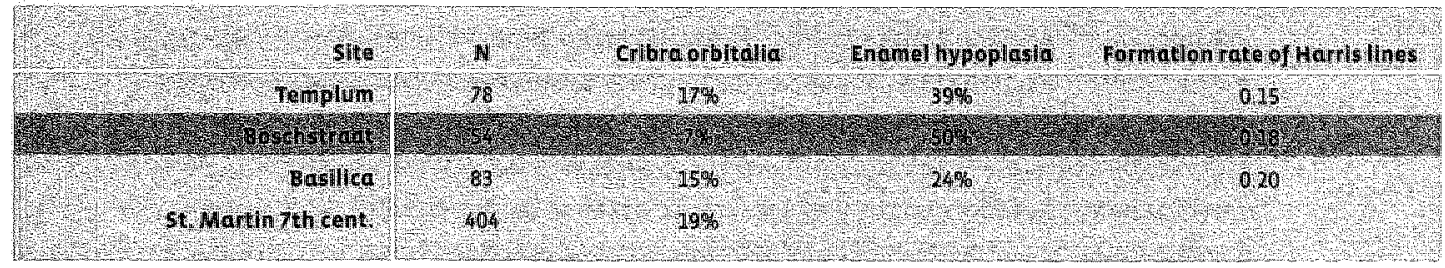

TABLE 7-17 Prevalence of cribra orbitalio and enamel hypoplasia and the formation rate of Harrim limes in the Boschstract sample and reference populations

This suggests that with respect to conditions associated with anaemia the living conditions during growth were more favourable for the Boschstraat population than for the templum and basilica samples. However, this might not have been the case for all aspects of health during growth, as seems to be evident from the higher mean adult stature of the females in the templum and basilica samples. If we take two other parameters into account the general image of health during growth does not become clearer. Slightly more individuals at the Boschstraat

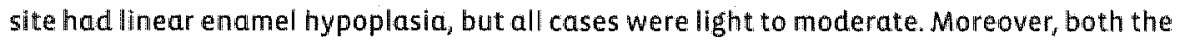
percentage of individuals with Harris lines and the formation rates of Harris lines were lower than in the basilica sample and slightly higher than in the templum sample. In the cemetery of Saint-Martin de Fontenay the general health situation appears to have been less favourable. Not anly did relatively more individuals at this cemetery have cribra orbitalia, they also had a lower mean stature for males and females.

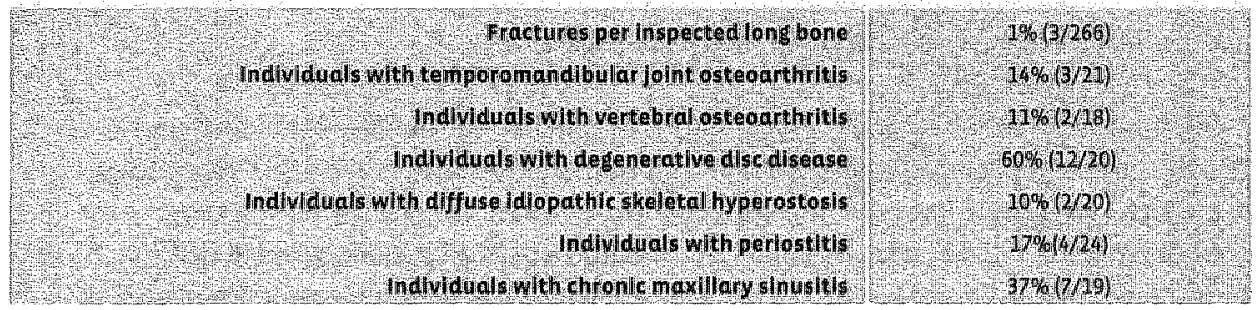

TABLE 7-1B Sellected palaeopathological resutts for the Boschstraat sample

As in the templum sample, fractures were an uncommon finding at the Boschstraat site. There were no fractures in the lower extremities. All three fractures of the long bones were found in the ulna. Six other fractures were found in the hand, the mandible, a vertebra and three fractures in the clavicle. Overall the frequency and the distribution of the fractures were more similar to the templum sample than to the basilica sample. Injuries due to cuts with sharp bladed objects or injuries from piercing objects were not found in this cemetery. Of interest might be the relotively high prewalence of temporo-mandibular joint osteoarthritis (TMJOA). In comparison to the templum and basilica samples this condition was found wice as often in the Boschstrant population. The sample size is too small to draw any definite conclusions, but it is tempting to consider the nature of the diet as a possible factor contributing to this prevalence. The 
prevalence of wertebrat asteourthritis (VOA) and degenerative disc disease (DDD) was low in comparison to the templum and basilica samples. For vertebral osteoarthritis this was also the case when the prevalence was compared per age category. This renders it unlikely that the prevalence of vertebral osteoarthritis was low because of a lower mean age at death. At present we have no explanation for the low prevalence of these two conditions. Apparently some aspects of the activities and diet of the Boschstraat populations had a mitigating effect. Also for DISH the Boschstraat population was characterised by a relatively low prevalence. For a population which we assume was of low status this was not surprising since DISH is generally associated with the lifestyle and diet of individuals of high social status. The prevalence of periostitis (17 per cent) was just below the prevalence found for the templum sample. An explanation for the variation in prevalence between the samples is presently lacking. Chronic maxillary sinusitis was found to be less common (37 per cent) than in the templum and the basilica samples. For a great part this will have been a consequence of the relatively low frequencies found for peri-apicall abscesses and ante-mortem tooth loss. ${ }^{\text {ys }}$

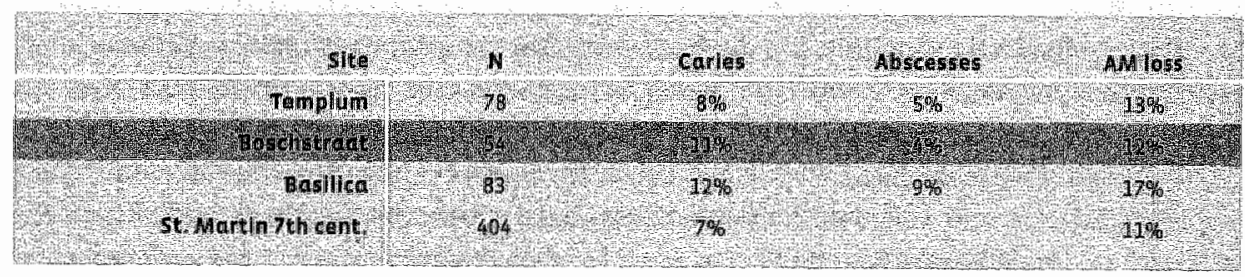

TABLE 7-I9 Prevalence of caries, peri-apical abscesses and antemontem lowth loss (all calculated per inspected element or position) in the mostistraat sample and reference populations.

As discussed abowe the caries percentage in the Baschstraat sample was almost as high as that of the basilica sample, whereas the percentage of antermortem tooth loss was relatively low which was more in line with the results for the templum sample. The results suggest the diet consumed by the Boschstraat site population created a risk of developing caries and may have been similar to the diet of the basilica sample. This would still leave the lower prevalence of peri-apical abscesses and ante-mortem tooth loss unexplained. Usually a highther caries rate also results in a higher rate of ante-mortem tooth loss. "The fact that fewer carious teeth seemed to have caused periapical abscesses in the Boschstraat population may have been related to the consumption of more abrasive foodstuffs. The consumption of less refined food possibly caused more attrition on the occlusal surface of the dentition and prevented the development of carious lesions on this surface. ${ }^{21}$ Fewer carious lesions in the acclusal surface probably lead to

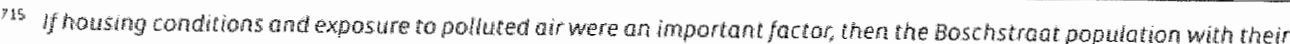
manufoctung activites wound have been axpacted to have an above average prevolence of chronic maxul ary sinusitis.

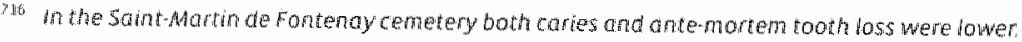

3. For a description of this process see Mad ond wan der valde, 1987.
} 
fewer peri-apical abscesses and less ante-mortem tooth loss. ${ }^{\text {. }}$. As a result of the lower rate of infections of the jow fewer infections of the maxilla occured and therefore, fewer cases of adontogenic chronic maxillary sinusitis. The caries prevalence was not the only characteristic of the dentition shared by the Boschstraat population and the basitica sample. Also the prevalence of calculus in both populations was simillar. And unlike the cella and the templum samples the prevalence of calculus in males and females was in balance in the Bioschstraat population as well as in the basilica sample."

\section{SPATHAL DISTRIBUTION}

The spatial distribution of males and females in the cemetery shows that the few males buried at this cemetery were fairly evenly distributed. Two were found in the dispersed clusters, four others were lying in the cemetery. One of the male skeletons was positioned in a trench lined with some stones. This burial was surrounded by at least six graves of nom-adult individuals.

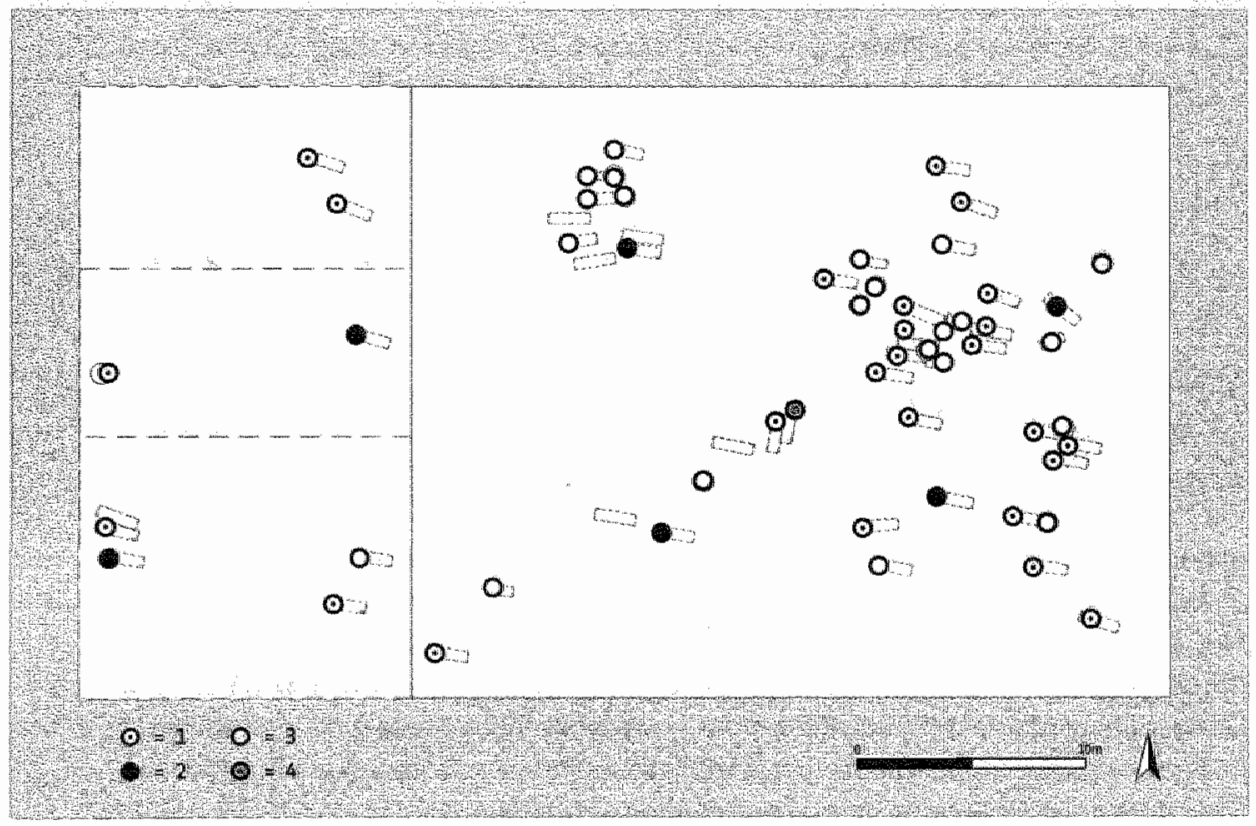

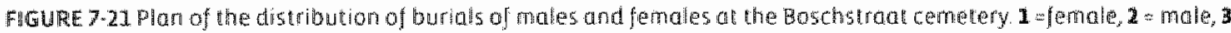
= non-adtut $=$ aduth individual of undetermined sex

The The dribution of carious lesions is expected to be differen beween the boschstal sample and the basitica sample the data on

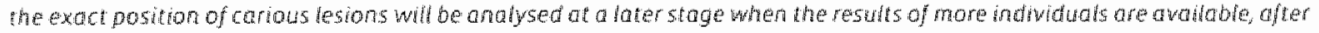
cancusion of the study of the Pandhof and vijthof samples.

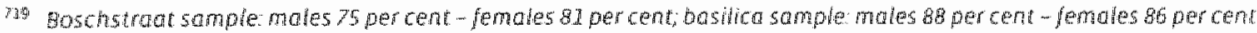


These graves were surrounded by a vacant zone of circa 7 metres and seemed to form a separate. cluster north west of the nucleus of the small cemetery. More non-adult graves were found in the rest of the cemetery. In four instances young children were buried at the foot end of an adult female. It is tempting to assume there was a genetic relation between the adult females and the non-adult burled in or near their grave. In the future this might be examined by means of aDNA analysis.

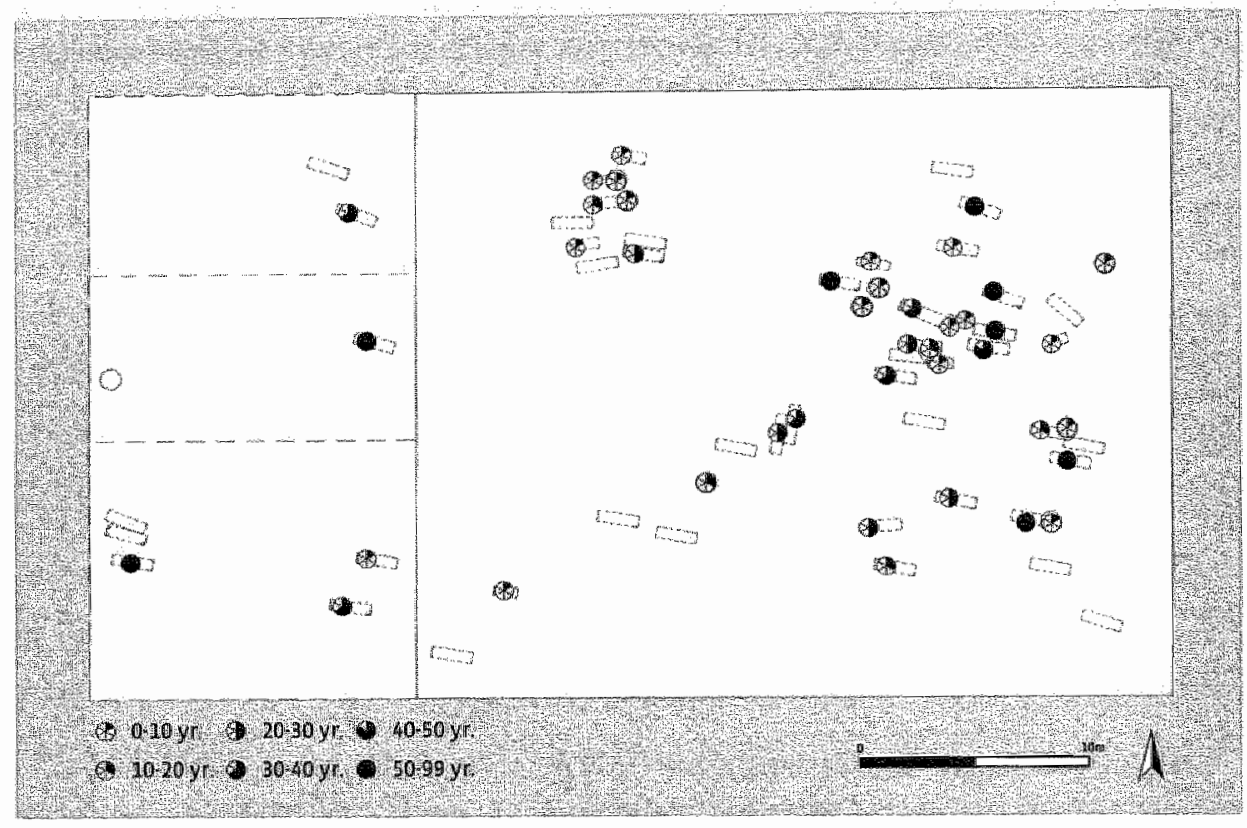

FIGURE 7-22 Plan of the distribution of indiwiduals by oge all the Bosthstrat cemetery.

The spatial distribution by age shows that in the dispersed burial clusters both young children and adults up to old age were represented. In the cemetery it is apparent that the small cluster of non-adults surrounding the grave of a young adult male consisted only of children under the age of ten years. In the rest of the cemetery no concentrations of specific age groups were recognised. The two north-south arientated graves contained the in situ remains of a female and an individual of indeterminate sex. The spatial distribution by sex and age provides no clues aiding in the explanation of their unusual orientation. These graves, together with an empty grave and some disarticulated remains; appear to be surrounded by a vacant area. This area was possibly empty because of the presence of a structure on top of the grave. In that case we could think of some sort of founder grave covered by an earthen mound, which was not uncommon in rural cemeteries. 


\section{concuston}

The most striking characteristic of the Boschstraat sample is the overrepresentation of females in the sample which may have been the result of preferential burial of a considerable number of males at ane of more other cemeteries. Both the dispersed clusters of burials and the central cemetery show no evident differences regarding distribution by sex and age. In many general health aspects the Boschstraat cemetery population resembled the skeletons from the basilica sample. However, with respect to important health parameters like mean adult age at death and stature the Boschstraat population scored slightly lower.

\section{PREFERENTIAL BURIAL AND FUNERARY MIGRATION}

In the following section of this chapter some of the results and findings that transcend the discussion of separate phases or samples will be reviewed. As indicated above, in some instances the demographical data from the samples seem to represent a selection of the living population. abviously it was not expected that the cemetery population was a direct reflection of the complete living population of early medieval Maastricht. For example Waldron and Hoppa have stressed the fact that cemetery populations consist of the non-survivors of alliving population. Several factors, varying from burial customs to procedures of excavation land treatment) of skeletal remains, are known to reduce the possibilities of gaining knowledge about the living population. ${ }^{20}$ In addition we know from contemporary written sources that preferential burial may have resulted in the burial of individuals in cemeteries at some distance from the place where they lived and died. As referred to above, this was not unusual for royal burials and has been considered a possibility for ather high status burials as well. ${ }^{321}$ An example of this practice related to Maastricht is the burial of bishop Lambertus of Maastricht. After Lambertus was murdered in Liège, an event that is thought to have taken place around $700 \mathrm{AD}$, Lambertus was buried in Maastricht. And later his successor transferred his remains to Liège. sometimes testaments from the Carolingian nobility provided detailed instructions concerning the place of burial. Treffort mentions an example of far reaching provisions to assure that they would be buried at a preferred location. In 876 AD count Heccard from Autun indicated in his will that he wanted to be buried at the monastery of Fleury-sur-Loire. The count even prowided for the possibility that his body could not be transferred to the monastery. In his will he requests that in that case his bones should be transferred to the monastery "when the right time had come ${ }^{\text {in }}$. The custom to bury selected persons at specific burial sites was thought to oceur on a small scale at sites like important churches and monasteries. In addition, various elite families built and owned private churches or were inwolved in the administration and funding, of monasteries. As a consequence, members of the elite were often buried in or near these churches or monasteries. ${ }^{33}$ Written sources provide no evidence that individuals of law social

\footnotetext{
Fg. Waldron, 1996. p.1.21; Hoppa, 1996 passim.

rat chelini, $1991,0.489$

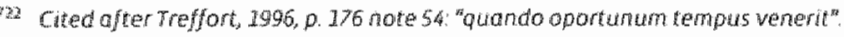

n2 Seevarious passages in Treffort, 1996 and Hassenpfug. 1999
} 
status were buried at other burial sites than the local cemetery Various normative sources like the resolutions from church councils and instructions for parish priests indicate that people should be buried at the cemetery of their parish. In the same texts it was decreed that onlly members of the clergy and some very privileged persons could be buried inside a church other areas outside the church were also reserved for high status burials. These were locations like the atrium, the portico or along the walls of the church (sub stilicido). ${ }^{30}$

Hitherto, few mediteval cemeteries from one conurbation have been studied and published in a way that allows conclusions on the selection of burial sites by the deceased or their next of kin. Both in Lund (Sweden) and York (Great Britain) physical anthropological and palaeopathological data from several medieval cemeteries were collected. For medieval Lund (990-1536 AD) Arcini found that in the examined cemeteries the age and sex distribution did not vary between the cemeteries. ${ }^{725}$ in medieval York the mortality profiles and sex ratios of the examined medieval cemeteries did nat imply that large groups of individuals were buried at cemeteries outside their parish, or in the case of monks and Jews, at cemeteries other than those associated with their communities. ${ }^{726}$ In York variation in burial location for groups by social status appeared to have occurred predominantly within the cemetery. In at least one cemetery in York it was possible to discern areas that were used by groups differing in social status.

Based on early medieval written sources it was expected that burial preferences of high social status groups would have played a role in the layout and composition of the Servaas and the Boschstraat cemeteries. This was especially true for the Servaas cemetery, since this cemetery was situated at the spot where the local population and religious institutions assumed Saint Servatius was buried. At least since the sixth century the veneration of this saint brought about the construction of a church and this site become the focus for an increasing number of ad sanctos burials, generally a privilege for individuals of high social status. The use of expensive tuff stone sarcophagi, limestone sarcophagi and precious grave-goods in some graves are considered reflections of the high social status of the burials. In our samples the demographical data of the templum and basilica phase cemeteries and the Boschstraat cemetery differed from the data cited for various reference cemeteries. ${ }^{28}$ Differences were

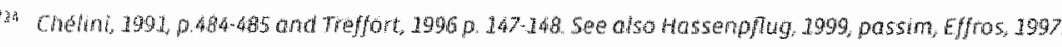

Anstiri, 2909

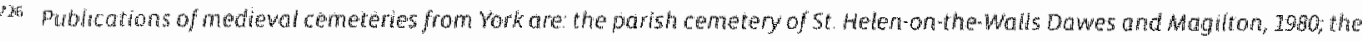

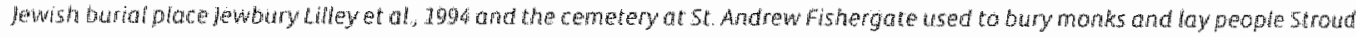

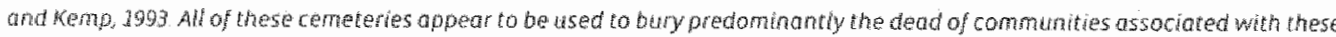

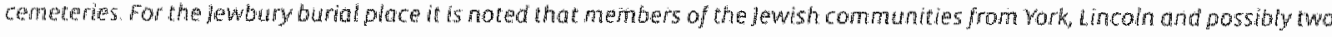
oher places were buried at this cemetery in the thiteenth century.

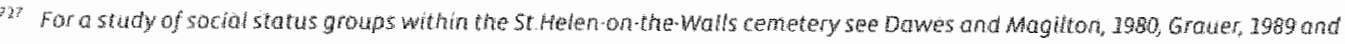
recently sulvon, 200 :

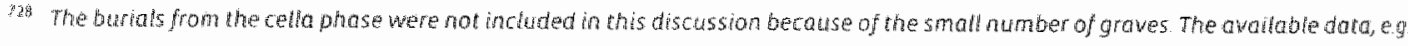
the burial of mates and fanates in pairs of graves, were not suggest we of prefarentid buridof either mates or females or of

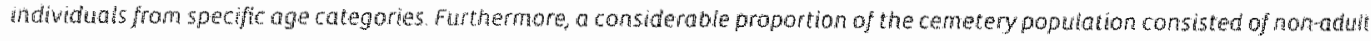

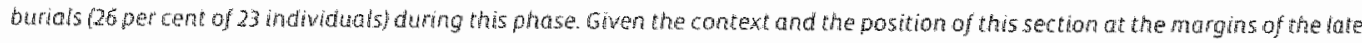


observed for three demographical parameters: the male female ratio, the percentage of nonadults in the cemetery and the general mortality distribution. Furthermore, the clustering of individuals by sex and the non-random distribution of certain trauma at the Servaas church site suggest burial preferences may have had an impact on the structure of the cemetery.

\section{THE SERVAAS CHURCH SITE}

During the templum phase (circa $480-700 \mathrm{AD}$ ) the area covered by the excavation trenches became the centre of the cemetery. For this phase the demographical data differ from what might be expected if a cross-section of the population had been buried in this part of the cemetery. Slightly more females than males (25 females and 20 males) and relatively few nonadults (14 per cent of 78 individuals) were buried here. The low proportion of graves of children under the age of two years in particular suggests that the non-adult age category was underrepresented in the sample and that the area around the church was predominantly reserved for adult burials. ${ }^{p_{29}}$ The preliminary results of the physical anthropological examination of the skeletal remains from another section of the Servaas cemetery (viz. the Pandhof site) indicate that in this section allarger proportion of non-adults was buried. ${ }^{3 i}$ This might compensate the low proportion of non-adult burials in the centre of the cemetery. In that case preferential burial within the cemetery also affected the demographical composition of samples from different areas within the cemetery. Another aspect of the mortallty distribution in the templum sample was the slight under-representation of individuals dying at an older age (50 years and mare). This could be an indication that, like very young individuals, older individuals did not receive high status burlials as often as individuals between 30 to 50 years. ${ }^{132}$ A comparable phenomenon was recognised in the distribution of grave-goods in contemporary cemeteries from the region of Metz. Halsall found that in that region individuals of 50 years or more received fewer and less prestiglous grave-goods. ${ }^{32}$ In this view it might be notewarthy that during the templum phase slightly more females than males were buried in prominent locations, in expensive grave types. and wilth precious grave-goods. However, the numerical difference between male and female burials was small and we do not know the male-female ratio in other sections of the Servaas

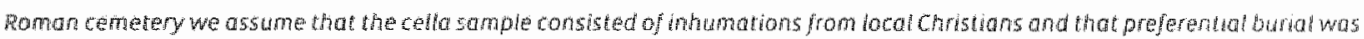
vot huntrest in this cemetery.

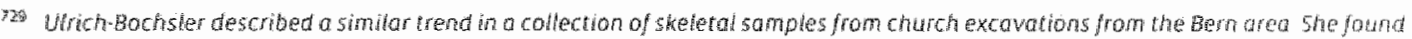

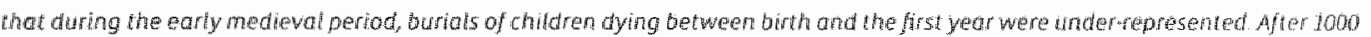

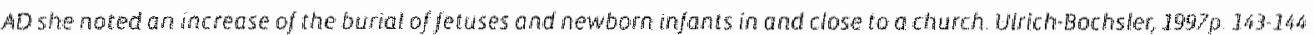

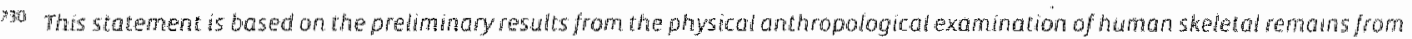

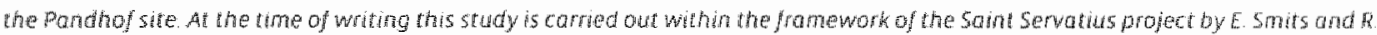

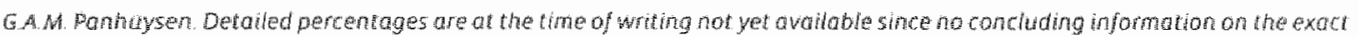

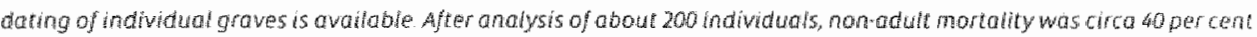

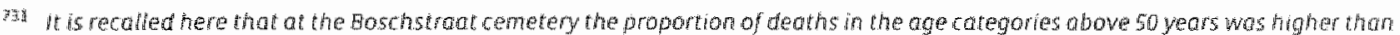
mignt be expected.

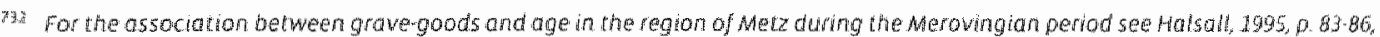
possimand 254 
cemetery or inside the church. For preferential burial in different areas within the Servaas cemetery there was unambiguous evidence: the under-representation of non-adults in the area close to the church in combination with the higher proportion of non-adult burials in the area covered by the Pandhof site and the presence of two concentrations of female burials in the templum phase cemetery. As described abowe the area close to the church is known to be a high status burial location. The age and sex distribution in this section of the cemetery indicate that age and sex of the deceased were important criteria whether an individual would be buried at this location.

During the basilica phase (circa 700-950 AD) the cemetery was also characterised by an underrepresentation of non-adults (13 per cent of $B 3$ individuals). As indicated for the templum phase this may have been compensated by burial of non-adults in other sections of the Servatius cemetery. The distribution of adult mortality did not indicate that specific age categories were under-represented. Unlike the situation in the templum phase, males slightly outrumbered females during the bosilica phase ( 31 males and 25 females). Perhaps this was the result of the inclusion in the sample of burials from inside the church. Burial in the church was even more esteemed than burial close to the church, since the right to be buried inside the church was reserved for clerics and select laymen. ${ }^{23}$ Corroborating evidence for the high status of burials in and outside the church was the frequent use of special grave types. At least 35 limestone sarcophagi and 7 stone-built tombs were utilized at the Servaas church site during the basilica phase. The available data suggest that females were rarelly buried in limestone sarcophagi or inside the church. Evidence for the occurrence of preferential burial in the basilica phase cemetery thus consisted of the under-representation of non-adults in the area around the church and the possible absence of female burials inside the church.

In conclusion, preferential burial within the Servaas church site samples was not documented in the cella phase. However, the archaeological and demagraphical data indicate that in the templum and basilica phase samples preferential burial seems to have been an important factor. What could not be established is whether there was an actual influx af burials from individuals outside the lacal community and to what extent this may have affected the demographical composition of the cemetery. As mentianed befare, written sources indicate that monasteries and important ecclesiastical centres were appealing sites to be buried. Therefore, it seems plausible that the serwas cemetery also attracted high status burials from members of the elite living in the Meuse Valley or possibly even further away. Detailed genetic and provenance studies using ancient DNA and stable isotope analysis may in the future provide more information on this matter.

\section{THE EOSCHSTRAAT STTE}

With respect to the sex ratio, the Baschstraat cemetery differed considerably from what was expected. Since this cemetery is thought to have been associated with a community of low status craftsmen and their families it was presumed that the proportion of males and femalles in the cemetery would be in balance. Instead, males were considerably under-represented in the 
sample: in comparison to a balanced representation about 75 per cent of the males (circa n=18) were missing from this cemetery. Not one of the reference populations in chapter 7 or any of the six rural and urban cemeteries from Normandy and Poitiers (fourth to tenth centuries) displayed similar disparate sex ratios. ${ }^{73}$ As discussed above it is assumed that the missing males were systematically buried at another cemetery in Manstricht or its surroundings. At the Boschstraat cemetery the proportion of males buried at another cemetery exceeded the scale of preferential burial on an individual basis and resembled a type of funerary migration. Other explanations for the absence of a proportion of male burials could be that this was the result of selective migration of males during life, a disproportionate susceptibility to epidemic disease of females or the death elsewhere of male combatants in armed conflict. All three alternative explanations cannot be disqualified categorically, but there are reasons to consuder some as less probable. Least plausible is the hypothesis that the cemetery represents the victims of an epidemic disease. The layout of the Boschstraat cemetery does not suggest that it was created in a single short episode. In case of an epidemic disease, we might expect more collective burials and contemporameous graves sharing the same orientation. In addition, epidemics are rarely so selective that they cause such marked differences in male and female mortality. ${ }^{735}$ The traces of actiwities associated with the manufacture of glass, metal and antler objects in the Boschstraat settlement argue against the long-term absence of males due to migration. Written sources indicate that most of the activities related to early medieval craftsmanship seem to have been carried out by males. ${ }^{736}$ The activities related to crafts in the Boschstraat silte area may therefore be seen as an indication of the presence of males in the community living at this site. Death in armed conflict or during occupational activities away from the settlement might be a plausible explanation for male under-representation on a small scale. However, so many males are missing from the cemetery that this becomes a less probable explanation, especially given the fact that armed conflict was mostly between individuals of intermediate and high social status. ${ }^{717}$ What then caused this funerary migration is unknown; neither do we know precisely what the alternative locations for burial were. As indicated in chapter three the existence of a considerable number of early medieval cemeteries in Maastricht is known through historical records, isolated finds and excavations. Until now none of the excavated cemeteries indicate owerrepresentation of adult males. The data fram the Boschstraat cemetery suggest that burlal outside the local cemetery was not only a privilege for a small number of individuals of above average status. Apparently this practice may also have been part of the burial ritual in individuals of lower status.

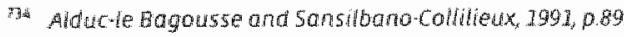

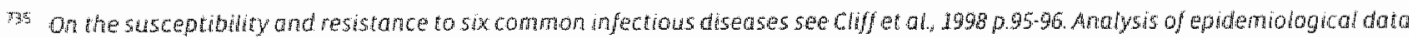
on these diseases show no differance in susceptbitity and resistance between mates and ferrales

36 This is not explictity stated in contemporary sources, however those accounts mentioning names ar gender of craf tsmen indicate these were males See Roth, 1986 possim.

*37. For to bear a sword and to partake in armed conflict a person generally had to be a frea mare and have sufficient means ta have weopons, armour and harses te fon, 2000, 282.
} 


\section{COMPLEMENTARY CEMETERIES IN MARASTRCHT}

As described above the cemetery population of the Boschstraat site showed differences in the demographical composition that suggest that this cemetery did not include all deaths in the population and did not represent a cross section of mortality in the local population. on the basis of the present indications for preferential burial and funerary migration a system of complementary cemeteries in early medieval Maastricht and surroundings may have existed. The distribution of grave-goods could be taken as a lead, how to interpret this burial practice. Grave-goods are na longer exclusively seen as personal belongings of an individual. The interpretation of grave-goods has become more complex. It is recognised that they can be the expression of a variety of burial customs and in addition may be statements of the relatives of the deceased. Although the grave type and the location of the grave are less often interpreted. within the same contextual framework, these aspects too are a reflection of burial customs and statements of the deceased. In an article on settlement patterns and burial practices Theuws has argued that the relatives of a deceased had in some cases a range of options for the lacation of the burial. ${ }^{723}$ Possible burial places in rural settlements during the late Merovingian period were: isolated graves or small clusters in the farmyard, rural cemeteries without a church, cemeteries originating around early churches in the region or important cult centres outside the region.

For the groups living in and around Maastricht similar aptions for burial existed. At the Boschstraat site we see both small clusters of burials in the yard and burial at a settlement cemetery. Cemeteries like those of nearby Rosmeer and Borgharen may also have belonged to a system of complementary cemeteries in and around Maastricht. The cemeteries of Rosmeer and Borgharen may have been associated with an estate or one or more rural settlements. The main Vijthof cemetery is more difficult to categorise since this cemetery partially resembles a cemetery like those frequently found in rural contexts. In case of the Vrijthof cemetery, the vicinity of the Sint Servaas church and its surrounding Servatius cemetery may have affected its use. ${ }^{2 t 3}$ The cemetery at the Lage Kanaaldijk may have been an example of a cemetery which evolved into a cemetery with a church, and may well have been in the possession of a local aristocratic family. This could explain the large number of otherwise rare limestone sarcophagi at this cemetery. As indicated above, the Servatius cemetery became an ad sanctas cemetery, at least from the sixth century when the first stone-built church was canstructed. since that time it probably attracted both burials from the local community as well as from high status individuals from the region of Maastricht or further away. This study has provided data that suggest that these cemeteries may have functioned in a system of complementary cemeteries. The most manifest effect that could be recognised in the demagraphy of these cemeteries was the under-representation of male graves in the Boschstraat cemetery. The under-representation

P. Panhuysen, 1999

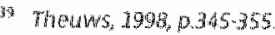

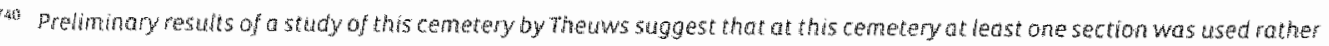

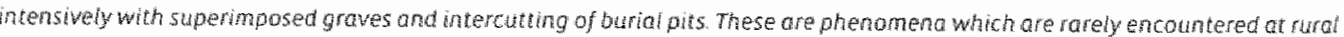
cencteries. 
of individuals of 50 years and older in the templum and basilica samples and the underrepresentation of individuals of 40 to 50 years at the cemeteries of Rosmeer and the Boschstraat were possibly also a result of burial preferences. This might reflect a trend to reserve high status burials for individuals who died between circa 15 and 50 years. The presence of a constellation of complementary cemeteries would provide the most plausible explanation for the skewed demographic profiles found at the Boschstraat cemetery and the age distribution at the Servaas church cemetery, the Bosichustraat cemetery and Rosmeer. Most cemeteries were used to bury a papulation living nearby. Some individuals or sometimes groups of individuals were buried at another cemetery. We do not know exactly what criteria were used to select the place of burials for these individuals. What we do know is that these criteria included or were associated with age and sex of the deceased. In addition status will have been a factor determining the burial place. Analysis of data collected in the ongoing Saint servatius project will allow us to test this hypothesis and provide more insight in what factors determined the selection of the burial location. ${ }^{741}$ In conclusion it is evident that burial customs in the early medieval period lead to the concentration of individuals within and among cemeteries according to social conventions. Judged by the demographic profiles of the cemeteries and the clusters within these cemeteries, sex and age were important in the determination of an individual's position in society; at least at the time of burial. The impact of these decisions are not always as manifest as the significant absence of males in the Boschstraat cemetery. Nevertheless, it is essential to consider the possible impact of such a process on the composition of early medieval cemetery samples. Finally we may conclude that the populations examined in this study were not representative of a cross-section of the local population. The samples examined for this study represent various groups in early medieval society. Some of these groups we can identify as representatives of the elite. Others, like the clustered female burials at the templum phase cemetery, cannot be identified. Nevertheless the data collected in this study are prosopographical observations.

\section{DIACHRONIC CHANGES IN LIFE CONDITIONS AT THE SERVATIUS CEMETERY IN MAASTRICHT}

The human remains from the Sint Servaas church site were attributed to three consecutive phases. This provides the opportunity to analyse the asteo-archaeological data for the presence of diachronic trends at one and the same site. The data from the Boschstraat sample were not included in the diachronic analysis because these data are from the time of the transition from

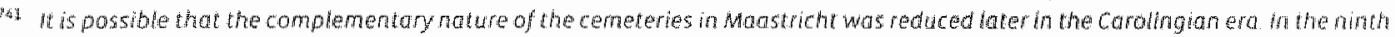

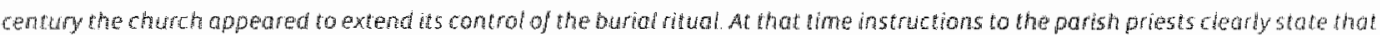

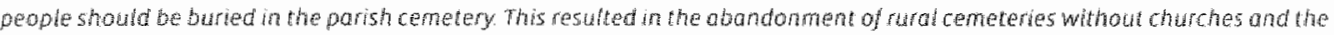

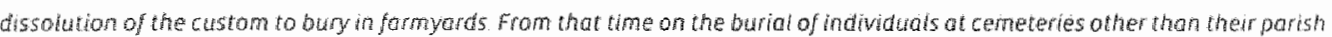

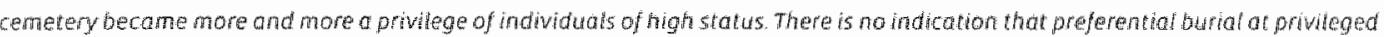
oreas within cemeteries was reduced at the some time the fact that the buriat of loypersons inside the church was authorsed in

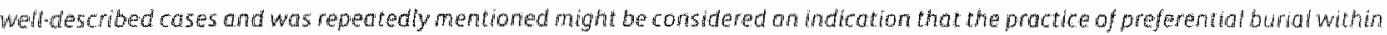
cemeteries may even hove increased. 
the templum to the basilica phase. For this site mo specific information concerning the dating was available per grave, which makes it impossible to fit the Boschstraat burials in either the templum or basilica samples. Being from another type of cemetery could make it more difficuit to interpret the results. For the remaining three samples it should be noted that relatively small data sets were available. Therefore, the results of the diachronic comparison of these data are preliminary conclusions. As discussed above the demographical composition of the templum and basilica samples is probably biased by the use of the cemetery by groups of intermediate and high status and this may have had an impact on other osteo-archaeological results.

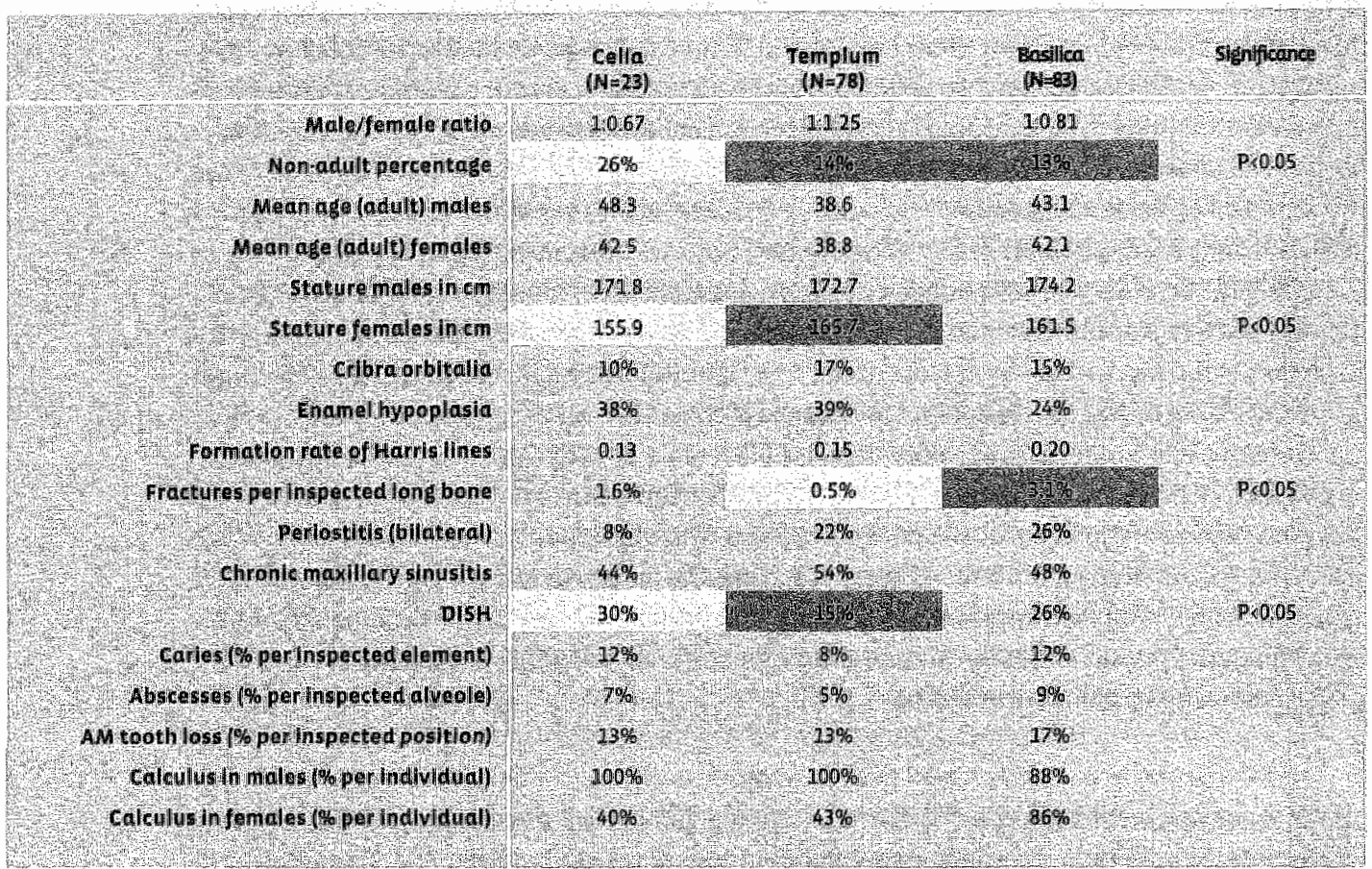

TABLE 70 An owerview of selacted data awailable for andysis of possible diachonic trends All data are presented in detail in chapter six. The number of ind ividuals mentioned for each phase represents the total number of hadividuais in each somple it is reminded here that means and percentages in the table could generally be colculated for smaller nuthers of individus from these sampies. Comparisons yielding statistically significant results are represented by Inht and dakt grey shading in sone cases two phases were compared in others a comparisan was madebetwan onie phase on one side andi the combined results of two phases on the other side.

Probably the early medieval cemetery does not provide an overview of the life conditions of a cross-section of the population of Maastricht. it is expected to represent the life conditions of individuals of specific groups of intermediate and high status. The samples were compared for a selection of parameters listed in the table below. These parameters were expected to provide 
information on the general health condition during growth (stature, cribra orbitalia, enamel hypoplasia and Harris lines), the prevalence of long bone fractures, DISH (diffuse idiopathic skeletal hyperostosis) and infectious disease (periostitis and chronic maxillary sinusitis) and dental health and diet (caries, peri-apical abscesses, ante mortem tooth-loss and call culus). changes in these parameters are described for the transition between the cella and templum phase and between the templum and basilica phase.

\section{THE CELLA-TEMPLUM TRAMSITION}

The transition from the cella phase to the templum phase was dated to the secand half of the fifth century AD. The transition between these phases is considered to represent possible changes in life conditions between the late Roman and the Merovingian period. ${ }^{\text {ia }}$ Based on asteological data documenting a parallel situation in ltaly, the transition from the late Roman to the early medieval period was expected to show a marked decline in general life conditions. ${ }^{343}$ When the various parameters of the three phases in the Servatius cemetery were compared no uniform trend of an evident deterioration of life conditions in the templum phase was naticeable. The decrease in mean age at death for males and females did fit with expectations. However, this decrease was not statistically significant and not supported by simillar trends in other parameters. A reliable indicator of life conditions that contradicts the results for mean age at death is adult stature. Both male and female stature showed an increase. The remarkable increase in female stature from the cella phase to the templum phase was statistically significant. Several indicators of general health during growth display no marked changes. For the prevalence of cribra orbitalia a moderate increase was noted. This might suggest that anaemia, presumably caused by poor nutritional conditions or chronic infections, may have been more prevalent in Merovingian Maastricht than before. Is this in contradiction with the increase in stature? An explanation might be that a high prevalence of individuals with cribra orbitalia indicates that a larger number of individuals overcame anomia during child hood and survived into adulthood. With respect to the occurrence of fractures the templum phase population seems to have had a lower risk to fracture any of the long bones of the upper extremities. ${ }^{7}{ }^{4}$ Most likely this was the result of a difference in the daily activities of these individuals. It is tempting to interpret the lower prevalence of fractures as an indication that, being individuals of intermediate and high status, the templum phase sample population was less involved in manual labour. Another striking difference between the cella phase and the templum phase was the high prevalence of DISH in the cella phase sample. As discussed in the previous chapter DISH is often associated with an affluent diet. A decline in the prevalence of DISH might thus be an indication for a more restrained diet during the templum phase. This would be in accordance with the decrease in caries and peri-apical abscesses. Ante-mortem

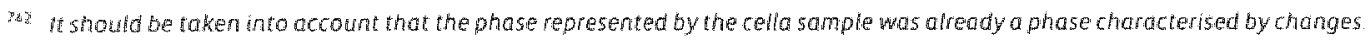

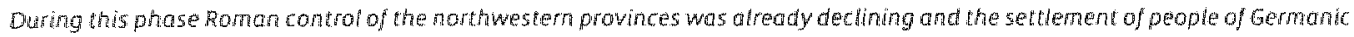
ethnicity was in pragress

Mas. Manzi et at, 1999

7u Fractures of the lower extramities were only found in the somptefrom the basilica phase. 
tooth lass did not decline but stayed at the same level. Also the imballanced distribution of calculus, with male prevalence more than twice the female prevalence, remained unchanged. Together the change in caries rates and prevalence of peri-apical abscesses suggest there was a difference in diet between the cella and templum phase cemetery populations. This is not reflected in the archaeobotanical evidence, which indicates that in Maastricht many staple crops remained the same from the Roman period throughout the first Millennium AD. The onlly major change seems to have been the introduction of rye. However, spelt wheat remained an important crop..$^{\text {ing }}$ Instructions for the managing of royall domains indicate that orchards also remained in use after the Roman perlod. ${ }^{3 ;}$. Early medieval law cades contain a detailed description of fines for the theft of beehives, indicating the importance of beekeeping in early medieval times. ${ }^{\text {* }} \mathrm{B}$ "We may therefore assume that honey was avallable as a sweetener and thus was a contributing factor in the development of caries. Altogether the situatian concerning the staple crops and the continuity in the availability of several other components of the diet was stable. Therefore "it is not likely that the decrease in caries was caused by changes in the absolute presence or absence of cariogemic components in the diet. Most likely the effect of the diet on caries and related abscesses was a consequence of changes in food processing, the proportion of cariogenic components or of cultural factors.

Overall, the transition from the late Roman period to the Merovingian period shows no uniform effect on the parameters listed in Table 7-20. In a large British study comparing data from a series of Roman and early medieval populations $C h$. Roberts and $M$. Cax also found contradictory trends for various health parameters. After the Roman era the British data also show an increase in mean adult stature ${ }^{* 4}$ Claims for a sharp decline in life conditions in Maastricht after the late Roman period seem to be refuted by the data presented in this study. In fact the increasing stature suggests that the Merovingian population of Maastricht experienced better life conditions than the late Roman population.

It should be noted that least two factors may have influenced the outcome of the comparison of the cella and the templum phase samples. The first factor was the general status of the group buried at the section of the cemetery during each phase. As indicated in the first section of this chapter the templum sample most likely consisted of a large number of high status burials. it is discussed below that these groups may have enjoyed better circumstances during growth and adult life than individuals with a lower status. Therefore, the studied templum sample may not be representative for the whole population in Merovingian Maastricht, on the ather hand we also do not know what the social position of the individuals in the cella sample was. In fact the relatively high prevalence of DISH in this sample might be an indication for a relatively high position in socilety. A high prevalence of DISH suggests constant access to an affluent diet whichy is often a privilege of high status individuals. Another factor that might partially have biased the

Borels arid oijmon, 2000

stople chops are crops of aereds that form the principal components in the cinet.

Bakeis and Dikmom, 2000

SEE G Drew, 1991, 0.7273 and $0.21 \%-214$

Robers and Cok 2003, 36*2.20 and 390 
differences between the cella and templam was a possible change in the genetic constitution of the population, due to the presumed arrival of an elite of Frankish origin. An indication for possible changes in the genetic composition of the templum sample may have been the abrupt and statistically significant change of the mean horizontal cranial index, which shifted from mesacranial to dolichacranial ( $p<0.05$ ). Whether cramiometric data are good indicators of genetic affiliation is a matter of discussion. ${ }^{35}$ Given the political and social changes in Maastricht it is plausible that there was an influx of high status individuals of a different genetic background. However, it is not known when the Gallo-Roman population changed by the arrival of groups of Germanic origin. The available data do not tell ws whether this already started in the third or fourth century, at the time of the arrival of the first wave of troops and farmers of Germanic origin, or in the fifth century when Germanic culture became dominant. ${ }^{74}$

THHE TEMPLUM-BASLLICA TRANSITION

The templum and basilica phases are dated between the secand half of the fifth and the end of the tenth centuries. Based on the carbon 14 datallisted in chapter three we assume that the transition from the templum to the basilica phase took place between the last quarter of the seventh and the first quarter of the eighth centuries. Regarding the transition from the templum to the basilica phase we studied general differences between the Merovingian and Carolingian period Written sources provide little indication that life conditions changed from the Merowingian to the Carolingian period. Given the above-mentioned stabillty in the food situation, with possible beneficial influences due to climate changes and improvement of agricultural techniques, it was assumed that the various parameters for the health situation would show little change, and possibly even some improvement in health. Because the site was used predominantly for the burial of individuals of intermediate and high status in both phases no status-related health changes were expected. These expectations were largely corroborated by the osteo-archaeological data. Mean age at death of males and females increased slightly. Male stature increased while female stature decreased. This contradictory development of stature may partially have been a result of the sample selection. In the basilica phase the propartion of high status burials of males with a high stature increased. One of the general thealth indicators, enamel hypoplasia, showed a decrease in prevalence from the templum to the basilica phase. Fractures were more frequently found in the basilica phase. Fractures of the lower extremities were recorded only for this sample. The basilica sample showed a higher prevalence of DISH. Like all of the mentioned changes this increase was statistically not significant. But similar to the high prevalence of DISH in the cella sample this was accompanied by a higher prevalence of carious teeth and peri-apicall abscesses. The percentage of ante-

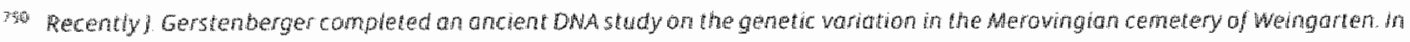

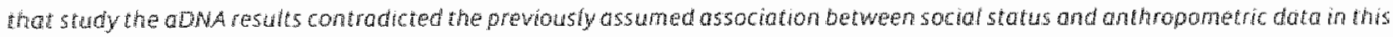
cametery Owerall Gerstenberger found hat he Merowngian population was rather homogenic and genetic relotions between ind wituals showed no association with social status Gerstenberger. 2002

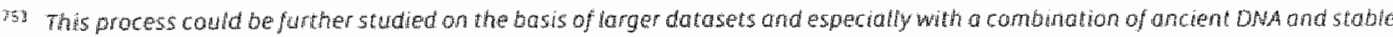
isotopes ancilyses. 
mortem tooth loss was also higher than in the preceding phase. Together these data suggest the individuals in the basilica sample cansumed a diet with negative impact on dental health, which may have been more affuent than in the templum phase. The sharp increase in calculus among females ( $\rho 40.05)$ may also be a result of changes in diet ${ }^{752}$

Often it is implicitly assumed that in contrast to the Roman period no proficient health care was available in the early medieval period and that the available medical care was inadequate. This is in contrast with the histonical sources like penal codes that make provisions for the reimbursement of the costs of medical care in case individuals were wounded in the context of domestic violence for example. The institution of leper houses and other care for the sick was: taken up by the ecclesiastical institutions at least from the sixth century on and is for example reflected in the plan of Saint Gall, a design for an ideal monastery. This plan reserved space for medicinal herb gardens and an infirmary. At present the only way to study the effects of medical care in early medieval Maastricht is via the study of fracture healing. As mentioned above most fractures from the templum and basilica sample had healed without serious complications in some cases the healed condition of a complicated fracture suggested that the persons that treated the fracture must have had experience in this field. ${ }^{\text {ths }}$

Regarding the general diachronic trend no decline in heal th conditions was found for the transition from the cella phase to the templum phase in the Sint Servaas church samples. The increase in adult stature sugBests certain aspects of life conditions may even have improved. However, this may also be a consequence of the burial of thigh status females in the sampled area. Comparison of the templum phase sample and the basilica phase sample also did not reveal any large changes.

\section{STATUS RELATED DIFFERENCES IN HEALTH}

Analysis of the relation between social status and life conditions is generally awkward. Several prablems have to be solved and various premises have to be fulfilled. ${ }^{\text {rss }}$ often parameters like Beneral stress indicators and degenerative changes lead to ambiguous interpretations. Knowledge of social status and its possible effects in past societies is frequently incomplete. Despite these obstacles an attempt was made to study the association between burial status and life conditions in early medieval Maastricht. This was considered important since the early

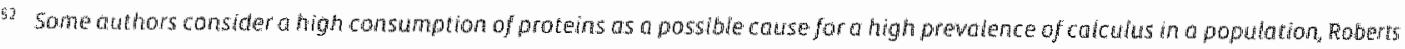
anto $\cos , 2003$

this brew 1999

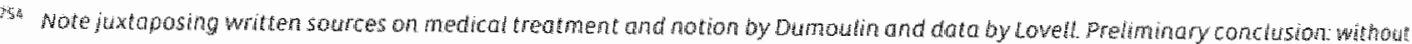
(optmal) medical treatment many factures may still hea without serious complications. However, in case of napor fractures of the Huinterts, fenur and tibia healing without complications is of ten dependent of medical treatment

75s Tomention a few one needs wowdedge of the social stratfication during the period under examingtion. The nature of this stratification should be such that it had an weft on asteo-archaeological parameters. Offerant social categories need to be recognts oble by specific elements in the buriat ritual Examples of swates focussing on stotus reloted variation heath conditions are Powell, 1980; Grauer, 1989 , Robbet al, 2001 
medieval period is a formative period for the social structure in Western Europe. ${ }^{756}$ After the Roman period a new social organisation seems to develop with new authorities like the church and an emerging aristocracy claiming a leading role in saciety. Analysis of the impact of status on life conditions could provide insight in the nature of $50 \mathrm{chial}$ stratification between the fifth and the tenth centuries. ${ }^{757}$ This study is based on 155 selected individuals for whom burial status could be determined from their archaeological context. As indicated in chapter three burial status was defined by the cemetery, position within the cemetery, grave type and grave goods. It is worth reiterating here that burial status is not a straightforward reflection of the social status of the buried individual. The low status category $(m=54)$ was represented by the burials from the Boschstraat cemetery, and was considered to belong to a population of possibly unfree craftsmen and their families. Both the intermediate status ( $n=40$ ) and high status ( $n=61$ ) categories consisted of burials at the Sint Servaas church cemetery. Like for the diachronic comparison all ostea-archaeological parameters included in this study were analysed for changes associated with buriall status (see chapter 6). Table 7-21, on the next page, shows an overview of the results, which will be discussed below.

The male-female ratios in the three status categories were a reflection of the buriall customs at the two cemeteries. This also implies that low status males were only marginally represented in the comparison, which has an impact on the results for the low status category. At present there is no way to compensate for these effects or to estimate this bias. When the data for the low and intermediate status males were grouped their mean age at death was significantly lower than of the males in the high status category. For females no significant differences in mean age at death were found. The difference in mean age at death between males and females in the high status category was considerable. In the context of this cemetery this mighth be an indication that a considerable proportion of malle burials consisted of male individuals leading a sheltered life, like monks or canons. ${ }^{758}$ Regarding adult stature the males of intermediate status resembled more the males of high status. Surprisingly the prevalence rates for cribra or bitalia were lower for low and intermediate status individuals than for high status individuals. In reference to the osteological paradox this could be interpreted as an indication for better chances of overcoming anaemic conditions during growth for individuals in the high

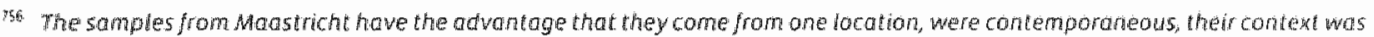

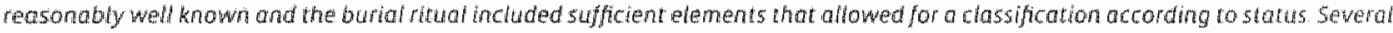

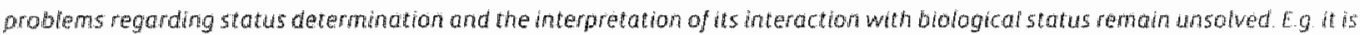
fot clew whether status disployed in burial contex wos exacty the same as the status of an individuat And during the tater

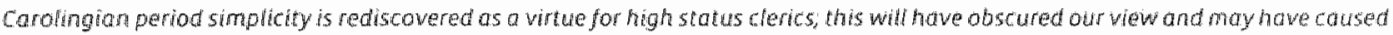
us to place such burials in the wrong status calegory

Sg. Were the fife conditions of high status individuols better and did this restit in an above average stature and hean age at death? or did the easy access of free famers of intermediate status to agricuturat products allow them to achiewe the same biological starus as high social status indwiduals?

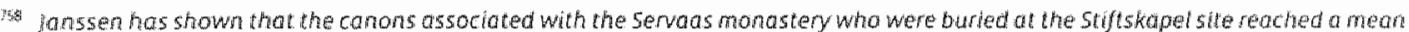
age at deat h of circa 56 years, acquired a mean stature of 7 th centimetre and all alsplayed signs of bish. This suggests that thiz

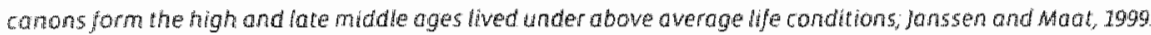


status sample. The prevalence of enamel hypoplasia was distributed quite erraticly; il was high in both the low and high status categiaries and significantly lower in the intermediate status cotegory.

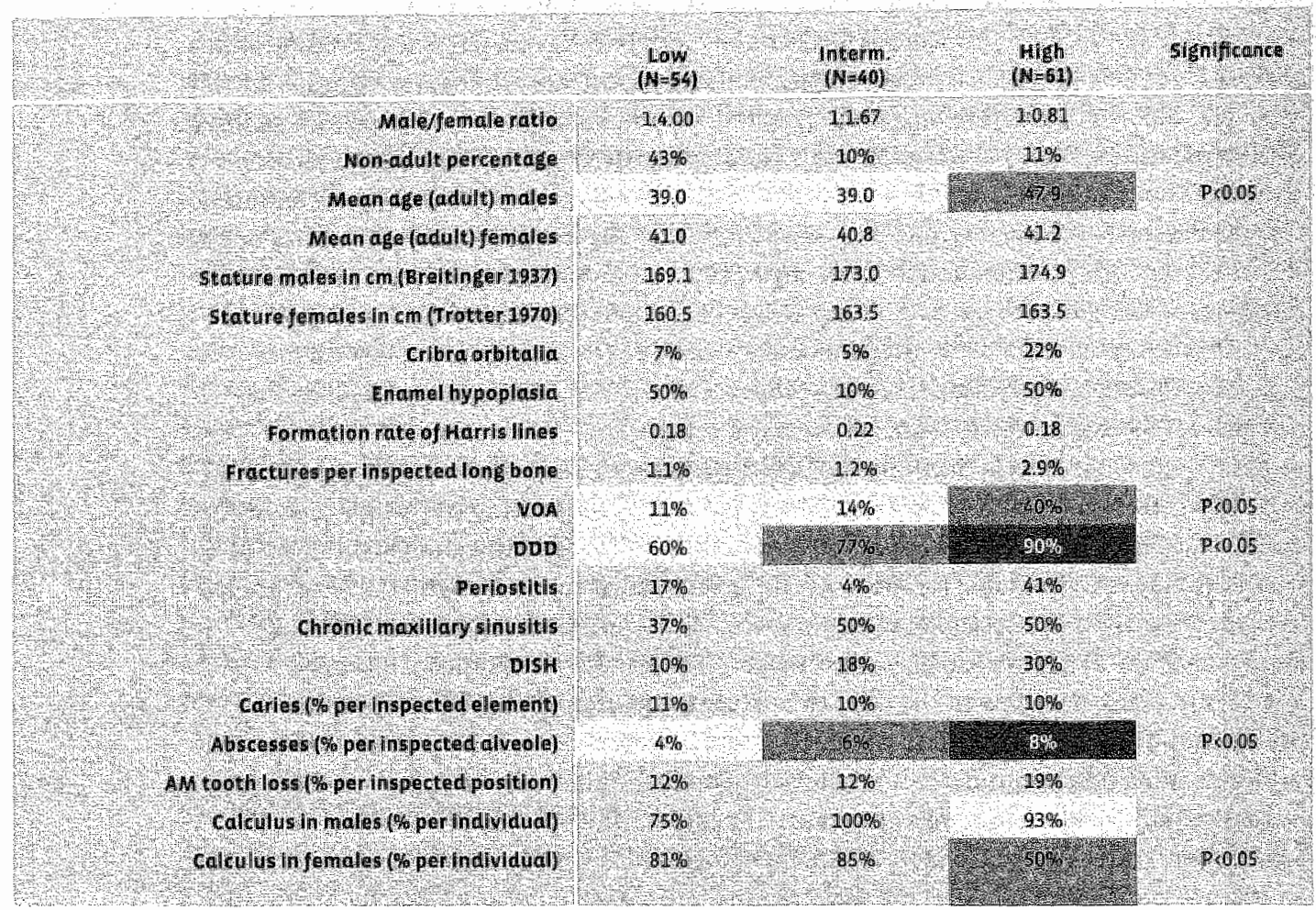

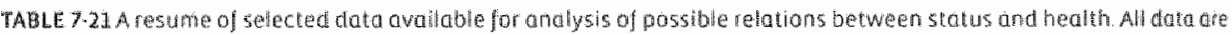
presented in atal in chapter sx. The number of individuals mentioned for each phase represents the total number of

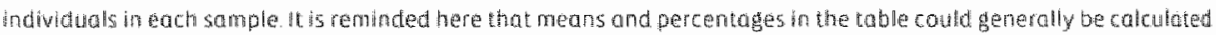
for smaller humbers of indviduals from hese scmples comparsons yielding statistically sign ficont results are represented by ligh dnd darker grey shading in some coses two phases were compored hothers a componsom was

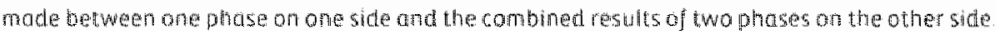

The prevalence of long bone fractures and their distribution within the skeleton indicated that the low and intermediate status groups were both characterised by a lower prevalence of fractures than the high status group. This suggests that the high status individuals were involved in activities associated with an increased risk of fractures. With respect to further parameters related to adult health and occupational activities it was noteworthy that vertebral osteoarthritis (VOA) was found significantly more often in individuals of high status than in individuals of low or intermediate status. This was most marked for the lumbar vertebrae. ln 
part both the elevated number of long bone fractures and the prevalence of vertebral asteoarthritis may have been a consequence of the increased longevity of malles in this category, but it may also have been linked to occupational activities or horse riding. For degenerative disc disease (DDD) the increase with status was found to be statistically significant. This trend was most manifest in the lower thoracic vertebrae. This may also have been associated with occupational activities or the constitution of the individuals in each category. The data on DISH show a clear increase with status, however this trend was not statistically significant.

The equal distribution of caries in the three status categories would suggest that access to cariogenic foodstuffs was not linked to status. Oddly enough the prevalence of peri-apical abscesses increased with status. ${ }^{760}$ This trend was statistically significant $(p=0.0263)$. For antemortem tooth loss the low and intermediate status categories scored an equal prevalence rate, whille high status individuals had lost more teeth prior to death. The higher prevalence of antemortem tooth loss may have been a result of the higher pirevalence of peri-apical abscesses and was possibly linked to the increased longevity recorded for the males in this category. The difference between males and females in mean age at death in the high status category was not the only health-related difference between the sexes. High status males had significantly mare dental calculus than females $(p=0.026)$. The prevalence of calculus was considerably lower than among females of low or intermediate status.

The interpretation of the differences between the three status categories is quite complex and open to debate. Several of the examined parameters for health show no consistent differences between the status categories. Simllar results were found in other studies focussing on the relation between burial status and health conditions. ${ }^{75}$ Because of the skewed propartion of adults at the Boschstraat cemetery the association between nom-adult mortality and status can only be studied for the intermediate and high status categories. In this respect it is ewident that non-adults were underrepresented in these groups. Several parameters displayed little disparity between the three status categories: female mean age at death, the formation rate of Harris lines and the prevalence of caries. Overall there seems to be some similarity between the low and intermediate status categories, especially for cribra orbitalia, fractures of the long bones and vertebral osteoarthritis. For female stature, chronic maxillary sinusitis and calculus in males the intermediate category was more similar to the high status group. The high status category was characterised by a high prevalence in cribra arbitalia, fractures, degenerative disc disease, DISH and periastitis. For dental abscesses and degenerative disc disease a trend was recorded that indicated that the increase in prevalence

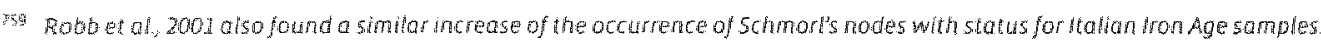

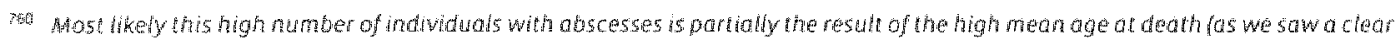
increase of abscesses with agel found for the cella sample and the contras is increosed by the incomplet enes of many of the

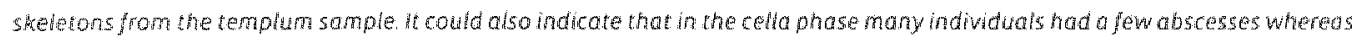
later fow individuals had many abscesses.

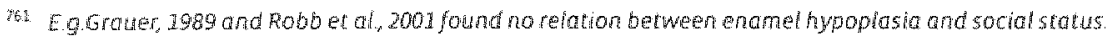


with status was statistically significant. The most plausible explanation would be that this was a result of the increased longevity in the high status sample.

The above mentioned significant associations between status and the selected parameters indicate that there was a correlation between status and health conditions. The males in the high status sample in particular may have had a special position in society. High status males not only seem to have been taller and reached an older age but they also had a higher risk of fractures As a group the high status individuals also had more vertebral osteoarthritis, degenerative disc disease, DISH and peri-apical abscesses. of these the higher risk of fractures, vertebral osteoarthritis and degenerative disc disease may have been assaciated with occupational or equestrian activities. High status fenales were in key parameters (mean age at death and stature) more similar to females of intermediate status. This suggests that females did not benefit from the advantages or did nat suffer from the disadvantages of a higher status categrory for hitherto unknown cultural or biollogical reasons.

Returning to the general similarity between the health status of low and intermediate status categories as opposed to the high status category might help in interpreting who was buried at the cemeteries of Maastricht. The similarity between the two status categaries might be an indication that these consisted largely of a local population. If so this local population had the option of burying at settlement cemeteries like the Boschstraat cemetery or if their status permitted at the Servatius cemetery. In line with what written sources suggest, the high social status group was then probably buried at the prestigious areas of the Servatius cemetery, a space they probably had to share with regional aristocracy. As a result the high status category of the Servaas church site would consist of a heterogeneous group of local and regional individuals. This pheriomenon might provide an explanation for the differences in cemetery layout that can be recognised during the basilica phase. In the Carolingian period the group of high status burials may in part have been associated with the monastery or chapter of canons that was linked to Saint Servatius. 


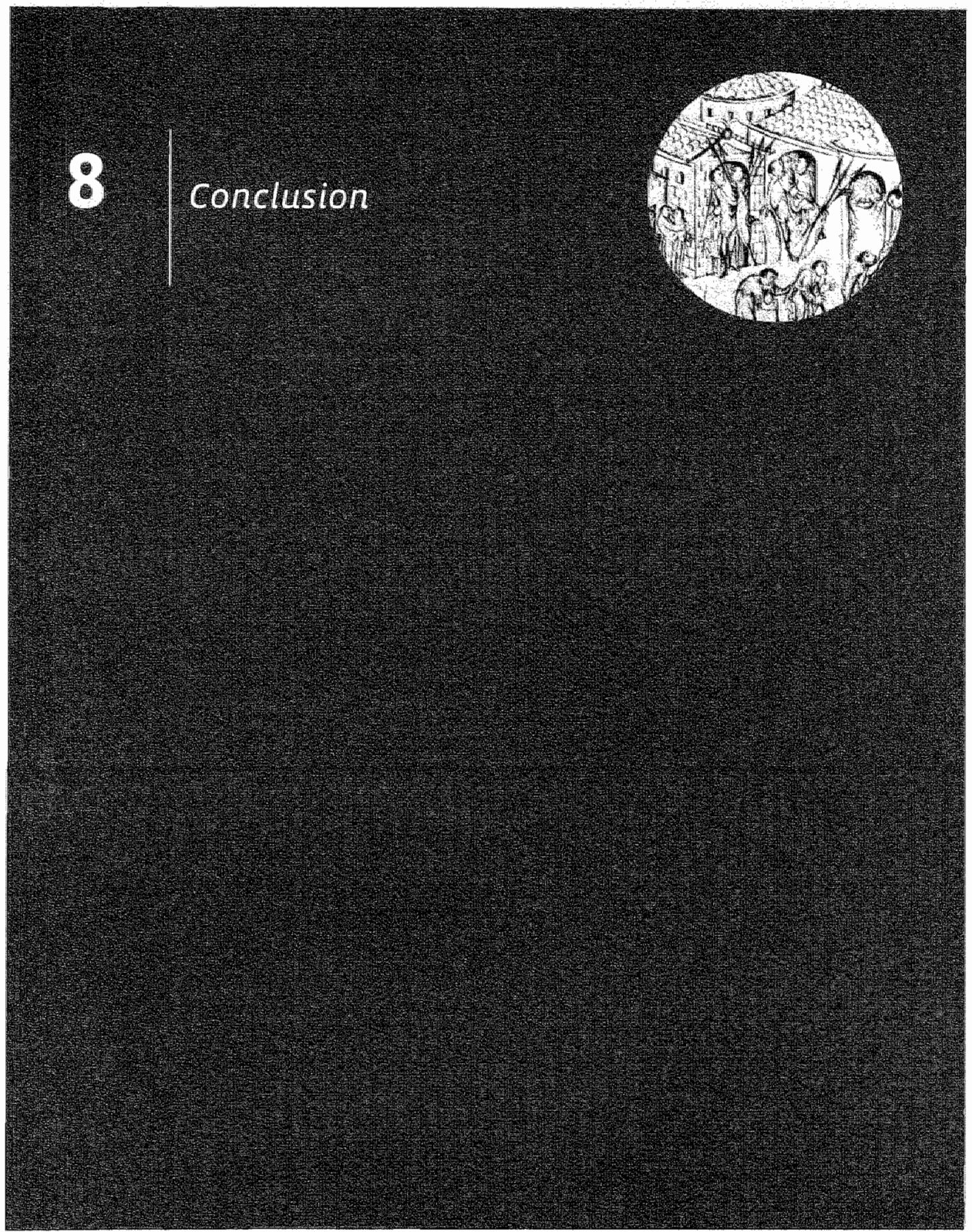




\section{Conclusion}

This study presents the results of a physical anthropological and palaeopathological analysis of the skeletal remains of 238 individual excavated at the Servaas church and Boschstraat sites from Maastricht. The cemetery excavated at the Servads church site represents a section of the large Serwas cemetery; the Boschstriat site contained, among others, a cemetery of circa 40 graves and several dispersed graves. The Servaas cemetery was in use from the late Roman period to the nimeteen th century. Most of the graves at this cemetery date from the early medieval period. At the Baschstraat site all graves were early medieval. During the late Roman and early medieval period Maastricht became an important central place in the Meuse valley. Reviewing the data listed and discussed in the previous chapters, the question arises what do the warious asteoarchaeological data add to our knowledge of early medieval Maastricht? The study of the skeletal remains has provided insight in the demography and health of the individuals buried at the two cemeteries. This study has further shown that the analysis of these data within their historical and archoeological context may provide information on local historical developments. Analysis of sex, age and stature of the human remains, in association with the distribution of their graves, showed that at the Servaas church site diachromic changes in the layout of the cemetery and variation in grave type were associated with changes in the use of the cemetery. Archaeological finds indicate that during the late Roman and early medieval period the servaas cemetery was used by a variety of graups in society. Since historical and archaeological sources provide little information on the composition of these groups, our knowledge of the burial practice in Maastricht is limited. Physical anthropological and palaeopathological dato may provide some clues about the composition of these groups. In general the Servaas church site was the section of the Servaas cemetery, positioned in and around the consecutive churches, that was used to bury indiwiduals of intermediate and high social status. The Boschstraat cemetery was found amidst remnants of a late seventh to early $8^{\text {th }}$ century settlement that was invalved in the production of objects of metal, antler and glass. Given the main activities employed at the site and the simple graves the population of the cemetery was probably of low social status.

At the Servalas church site all burials could be categorised in one of three consecutive phases: the cella phase, the templum phase and the basilica phase. During the cella phase (circa 350-480 AD) the burials at the late Roman cemetery seem to represent graves of males, females and children in small clusters, who were possibly family members. We assume that these individuals were inhabitants of Mastricht of intermediate social status. The individuals buried during the templum phase (circa 480-700 AD) showed more diversity in grawe type and distribution patterns in the cemetery. The weal th represented by the prestigious grave types and precious grave goods. are considered indicative for the burial of high status individuals, probably members of the emerging Frankish aristocracy. As is evident from the use of tuff stone sarcophagi in the middle of the sixth century, the site attracted high status burials even before a stone-built church was constructed. Possibly, this may have encouraged bishop Monulphus to construct a church, the 
magnum templum, at this site. Around or at least shortly after the construction of this church the cemetery developed into an ad sanctos burial place: in the cemetery, separate areas and clusters were recognised. One cluster consisted of female burials and another of a combination of females and non-adults. Other areas were composed of a mixture of male and female burials. Non-adults were underepresented in the templum phase sample. The first results of the physical anthropological examination of burials from another section of the Servaas cemetery suggest non-adult burials may have been concentrated in a less prestigious area of the cemetery.

The basilica phase cemetery (circa 700-950 AD) was characterised by an expansion of the buildings of the church and monastery. This coincided with changes in the layout of the cemetery that suggest that the organisation of the cemetery changed. In some areas burials seem to be placed in a well-ordered manner, other areas of the cemetery show a continuation of the seemingly unordered juxtaposition and superposition of graves. Possibly this was a reflection of the increasing control over the burial ritual by churches and monasteries. A series of graves from the basilica phase was located inside the church, in particular a group of limestone sarcophagi in the centre of the church. Many of these sarcophagi contained no, or poorly preserved skeletall remains. Therefore, the information collected from these graves was fragmentary. All graves inside the church, for which sex could be determined, indicated that males were buried there. Evidence that females were buried inside the main sections of the church was lacking. It is tempting to consider the concentration of limestone sarcophagi at a central place inside the church as evidence for the presence of a community of monks or canons. This implies that such a community existed at the time of construction of the basilica. The area around the church seems to have been used to bury both males and females and a small number of non-adults. Because of their position close to the church, and the assumed location of the grave of Saint Servatius, these graves most likely were also used to bury individuals of high social status.

The Boschstraat cemetery (circa end seventh early eighth century) differed in many aspects from the Servaas cemetery. Its position in relation to the inhabited areas of Maastricht was more peripheral and clasely associated with a separate settlement. Regarding the demographical composition of the cemetery population this site was most unusual. Females largely outnumbered males in this cemetery, which is thought to be the result of burial of males at another cemetery in the area. This odd male-female ratio in the Boschstrat cemetery is the main argument far the assumption that the cemeteries in and around Maastricht formed a constellation of complementary cemeteries. In this constellation various burial places provided a resting place for individuals and groups, which suited their social status, limeage, membership of a group or other characteristics.

Regarding diachronic changes in health from the late Roman period to the end of the Carolingian period, the data collected for Maastricht indicate that changes occurred. From the late Roman period to the Merovingian period there was no deterioration of living conditions. This fits the notion that the transition from the Roman period to the Merovingian period was a gradual process, characterised by continuity in many aspects of daily life. Male stature, generally considered a good indicator of socio-economic circumstances, even increased during 
the whole periad. The differences in health between the templum phase and the basilica phase were small. For males, living conditions seemed to have improved, whereas a decrease in female stature suggested that their situation may hove deteriorated. A comparison between a selection of early medieval cemeteries suggested that the population of Maastrïcht on average may have enjoyed better health conditions than in other areas of the Frankish territories.

Based on the location of the grave, the grave type and the presence of grave goods, all early medieval individuals were categorised in status categories. Three status categories were defined: low social status, intermediate social status and high social status. Normally sacial stratification is associated with noticeable differences in health between groups in society. Comparison of the health canditions of the individuals in these status categories on average showed minor differences in health. Since negative and positive health indicators were not uniformly distributed over the three status categories, the differences were difficult to interpret. Differences between individuals of low and intermediate status were generally insignificant. only for high status males noticeable beneficial effects on health could be observed. It seems plausible that the overall low population density and the beneficial circumstances concerning the food supply in Maastricht reduced the effect of sicial stratification on health.

As we have seen in the previous chapter, warious groups in society used the Boschstraat cemetery and the servaas cemetery as a burial place. Since only a small section of the cemeteries of early medieval Mastricht has been examined we can only abtain a vague notion of these. groups. As a result, these first prosopographical observations are incomplete. However, physital anthropological and palaeopathological data have allowed us to discern clusters of female burials in the templum phase cemetery and to notice the absence of male burials at the Boschistraat. Because of these data, we could look for evidence for the presence of complementary cemeteries. Without the osteoarchaeological data, we would be ignorant of the relatively favorable living conditions in early medieval Maastricht. Ongoing studies of more sections of the Servaas cemetery and other early medieval cemeteries in Maastricht will in the near future provide additional physical anthropological and palaeopathological data from which we can learn more about the various groups in early medieval Maastricht. The cambination of traditional physical anthropological data and aDNA and isotope analysis may even allow us to study the relations between individuals and groups buried in different locations in Maastricht. 


\section{Bblography}

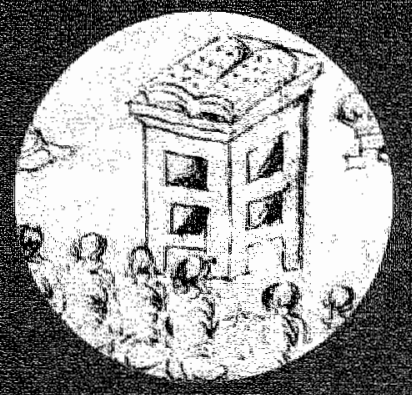




\section{Bibliography}

(1883) Arnales bertiniani, In Morumento

Germaniae histarica, Scriptores in usum scholarum separatim editi, vol. $5(E d$. Waitz, G. Hannower.

(1891) Annales Fuldenses, in Monumenta Germaniae Ristorica, scriptores in usum scholarum, vol. 7

(Ed, Kurze, Fl) Hannover.

(1913) Vita Landiberti episcopi Tralectensis vetustissima, Ir Manumenta Germaniae historica, Scriptores revun merovingicarum, Vol. 6 (Ed. Krusch, B.) Hamnover-Leilpzis p. 353-334.

(1936) Gesta sanctorum patrum Fontanellensis caenobil, (Eds.. Lohier, F. and Laporte, ].) Rouetr Paris.

(1980) Annales Bertiniani, In Quellen zur karolingischen Reichsgeschichte, vol. 2 (Ed. Rau, R.) Darmstadt, p. 11-287.

Acsadi, G. and Nemeskeri, J. (1970) History of human iffespan and mortality, Akrademiai Kiado. Budapent.

Adams, F. (Ed) (1843) The seven books of Paulus Aegineta, London.

Alken, M. ). (2000) Radiacarboin dating tn Archaeological method and theory: An enrychopedia (Ed. Elis, L.) Garland Publishing, New York, p. 505.509.

Alducle Dagousse, A. (199.4) Naturation ossemse majorite lé gale: lla place des adolescientes ery paleodnt hropologie in La fanme pendant le moyen age et l'poque maderne, Vol. 17 (Ed. Buthet, L. CNRS Editions, paris, p. 3i-39.

Alduc-le Bagousse, And sansilbano-Collileux, $M$. (1991) Milieu urbain, milheurat: le mande des wivants et des morts au haut moyen age en Poitou et basse Normandie. Apports de lanthropalogle In Ville et campagne en Europe accidentale Me - XJle sibcled, Vol. 14 (Ed. Buchet, L.) CNRS Editions, Paris, p. 83-101.
Aithoff, G. (1996) Oto Wh. Wissenschaftiche Bucheselilschaft, Darmstadt.

Arcini, C. (1999) Health and disease in early Lund. osteo pathologic studies of 3,305 individuats buried in the cemetery ared of Lund $990-1536$ Lund, p. 207.

Aries, P. (1977) L'homme devant la mort, Editions diu Seuil, Paris

Atsma, H. (1993) Les monastères urbains du nord de la Gaule In La christianisation des pays entre Loire et Rhin (Ne-Vile siectel, Vol, 2 (Ed. Ruche, P) Les éditions du cerf, Paris, p. 163-187.

Auboire, G. (1988) La population de Villers.le-Sec, Whe-Xe sueclet: Etude anithropologique in Un village au temps de Charlemagne (Eds. Cuisenier, 1. and Guadoginin, R.y Étitions de la Reunion des musées nat onaux, Parïs, p. 180.123.

Aufderheide, A. C and Rodrigurz-Martin, C. (1998) The Cambridge encyclopedia of human paleopathology, Cambridge University Press, Cambridge.

Bach, A. (1986) Germanen-Slaven-Deutsche: Anthropologische Bearbeitung des frohmittelalterlichen Graberfeld won Rohnstedt. Kreis Sondershausen, weimar.

Baetsen, S. (1998) Het meriselikk skeletmateriad won het salvatorplein te Susteren. Amersfoort

Baetsen, S. (2001) Graven in de Grote Kerk: het fysisch antropologisch onderzogk van de gravern in de st. Laurenskerk wan Alknaar, Gemeente Alkmaar, Alkmoar.

Bakels, C. C. (1996) The pollen diagram Voerendad.7 In Borderland farming: Possibilities and limitations of farming in the Roman period and carly middle ages between the Rhine and Meuse(Ed. Kooistra, L. I.) Van Gorcum, Assen, $139-146$. 


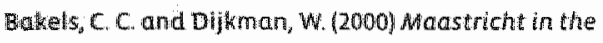
first maldenium AD the archaeobotanical evidence, Archaeology Section of the Mharitipality of Mastirieht.

Burnes, E (1994) Developmental defects of the axial skeleton in poleopathology, University Press of colorado, Colorada.

Bass, W. H. (1987) Human osteology: A laboratory and field manuel of the human skeleton, columbia.

Bouchhenls, 6 . and won Prittwitz u. Gaffron, $\mathrm{H} . \mathrm{H}$ (Eds.) (1992) Spurensicherung archäologische Denkinalpflege in der Euregio Maras-Rhein, Veriag Philpp won Zabern, Mainz am Rheir.

Bayliss, A., Shepherd Popescu, E., Beqvan Athfielld, N. Bronk Ramsey, C, Cook, G. T. and Locker, A. (2004) The potential significance of dietary offsets for the interpretation of radiocorbon dates: an archueologically significant example from mediewal Nomich, Journal of Archaeological Sickence, 31, p. 563-575.

Bay-Schuller, R. (1975) Die anthropologische Berabeitung des menschichen skelettmaterials des frükischen Friedhofes am Bernerring in Basel in Das fränkische Gräberfeld von BasedBernerring, Val. I (Ed. Martin, M.) Archäolagischer Verlag in Basel, Basel, p. $317-368$.

Bentike, P. (1985) Polaeopathology of Danish sketetons, Copenhagen.

Bierbrauer, W. (1996) Tromanen imfränkischen Siedelgebiet In Die Franken - Wegbereiter Europas, Vol 1 (Eds. Wieczorek, A, Perin, P. won Welck, Kand Menghin, Wh Philipp von Zabern, Mainz, p. $110-120$.

Bullard, M. 1994) Les ligines de Harris en osteonarcheologie: evalution dun stigmate Evenenentiel au cours de la croissance et du weillissement squelettique implications en paleorépidémiologie in La femme pendant le moyen dge et l'epoque moderne, Vol. 17 (Ed. Buchet, L.) CWRS Editions, Paris, p. 135.155.
Wloemers, 1. H. F. (1973a) Archeologitche kroniel wan Limbure over de jaren 1969-1970, publications de la Societe Historique Archeologinue dans le Limbourg, 107-108, 7.79.

Blomers, ). H. F (1973b) Twenty five years of RoB research in Roman Limbutgerithen van de Rijksdlenst voor het Oudneldkundig Bodemonderzoek, $23, p .237$ 258.

Bilak, D. P. [1979) De Franken in Nederland, Fibula. val Dishoock, Haarlem.

Blondhaux, J., Jacques, A. and Bayard, D. (1991) Dix neuf squelettes dans lhabtat in Wilte et campagne en Europe occidentale the - Xhle siecle) Vol. 14 (Ed. Euchet, L) CNRS Editions, Paris, p. 1124 .

Bocquet-Appel, ).P. and Masset, C. (1982) Farewell to paleodemography, Jounal of Human Evolution, 11, p. 321333 .

Bacquet Appel, ].P. and Masset, C (2985) Matters of moment journal of Human Evolution, 14, p. $107-112$.

Boddington, A. (1987) Choos, disturbance and decay in an Anglo-Saxon cemetery in Death, decay and reconstruction: Approaches to archaeology and forensic science (Eds, Boddington, $A_{.,}$Garland, A. N. and Janaway, R. C. Manchester Univershty Press, Manchester, P. 27-42.

Boeren, P. C. (1972) Jocundus. Blographe de saint Servais, Den Haage

Boeren, P. C. (1993) Les évéques de Tongres. Maestricht in Lo christianisation des pays entre Loire et Rhin (Vve-Vive sidecled, Vol. 2 (Ed. Riche, p.) Les editions du cerf, paris, p. 25-36.

Bohme H. W. (1996) Söldmer und Sledler im spatcantiken Nordgallien In Dien Fräken . Wegberaiter Europas, Vol. 1 (Eds. Wheczarek, A., Perin, P. von Welck, K. and Menghin, W. Philipp Won Zobern, Mainz, p. 91-101.

Boissavit-Camus, B., Galiní, H, Lotans, E., Prigent, D and Zadora-Rio, E. (1996) Chrono-typologie des tombes en Anjou-Poitou-Touraine In Archealogie 
du cimetiere chretilen FERACF/La Simare,

Tours, p. $25 \% \cdot 269$.

Boocock, P. Roberts, C. A, and Manchester, K. (1995)

Maxillary sinusits in mediewal chichester

England American jounat of Phystcal

Anthropotogy, $98,0,483-495$.

Boppert, W. (1986) Die frohchistlichen

Grabinschriften aus der Servatiusikirche in

Mastricht in sint servatius bisschop wan

Tongeren Madrticht. Het wrogste Christendom

in het warstand, Vol 28 lEd. de Difn, G.) Borgloon,

p. 64.96

Borghuis, N., wan Hees, $R_{2}$ wan Hellenberg Hubar, Mekiking, A., the Poel, P., Misser, I and Zeegers, G (1979) Budragen tot de bouwgesche denis wan de Sint Servaaskerk te Madstritht: Deell, De Oostpartif, Publlations de lo Sociéte Historique et Archeologique dons le Limbourg, 115. p.6.266.

Boswe $f_{1}$ ] [1988) The kindness of strangers: The abandonment of childrun in Western Europe from late antiquity to the renais sance, Pantheon Books, New York.

Bouts, W. H. M. and Pot, T. [1989/ Computerized neconding and analysis of excavated human dental remains In Burial archaeology: Current research, methods and developments, vol. 211 IEds Roberts, C, Lee, F, and Rintiff, I.J, p. 11312\%

Beitinger, (2937) Zu Berechnung der Köperhbue aus den langen Gliadmaßenknochen, Anthropologischen Anzelger, 14, p. 24,9-274.

Btennecke, H. C. (1986) Servatius von Tongern. En gallscher Bischof un arianischen streit in Sint Servatius, bisschop wan Tongeren-Mastricht. Het vroegste Christendom in het Moasland Wol. 28, Ed de Diju, Gi.) Borgloon, p. 27\%32.

Breuler, H. (1969) Die Maras ais Schiffahrtsweg, Franz steiner Verlag, Whesbaden.

Bridger, C. and Siegramid, F. (1987) Die Xantener stiftsimmuntat Grabungsgeschichte und Uberlegungen zur Siediungstopogrophie in Beiträge zu Archäologie des Rheinlandes, vol
Sondendruck Dr. Fudlolf Habett GmbH, Sont, p. $63-133$.

Brimblecombe, P. (1988) Climate conditions and populotion development in the middle ages In Dhe Bevolkerungsentwicklang des ewopdischen Mittelalters: Das wirtschaftgeographisthe und kulturelle Unifeld, Wol. 39 heft 2 (Eds. Hermanm B. and Sprondel, R.j Verlag Karl Alber, Munchan; p. $141-148$.

Brothwell, D. R. (1981) Digging up bones, Britush Museum (Natural Historyl, Landon.

Brothwell, D. R. (1987) The problem of the interpretation af child mantality in earlier poputations, Anthropol Port, 4-5, p. 135 143.

Brover, A. C. (1977) Cortical "defect" of the humerus at the insertion of the pectoralis major. American Journal of Roentgenalogy, $128,0.677 .578$.

Bruintjes, T. D. and Panhuysen, R. G. A. M. (1994) Hyoid bones in two early medievall populations from Naastricht (The Netherlands) Homo, 45 (Supplement), p. 26.

Brutintjes, T. D. and Panhusen, R. G.A. A. (1995) The paleopathological diagnosis of seronegative spondytarthropathies In Proceedings of the Wth European meeting of the Paleopathology Association, Barcelona 1st - 4th september, 1992 (Eds. Eatista, R., Campillo, D. and Carreras, T.) Museu darquelogia de Catalumya Barcelond. p. 73.77 .

Brulet, R. (1990) La Gaule septentrionale au BasEmpire: Occupation du sol ev défense du territoire dans larriere-pays du limes aux I we t. Ve sidecles, theinischen Lamidesmusew Tirer, Trilet:

Brulet R. (1995) Das spatromische Verteidigungsystem zWischen Mosel wad Nordseeküste ln Die rönische Reichsgrenze zwischen Mosel und Nordseekuste IEds. Bechert. T. and Willems, W. J. H.) Kanrad Theiss Verlag, 5tutitgart, p. 102-119.

Buchet, L. (Ed.) (1989) Homme et milleu, Paris. 
Duchet, L. (Ed) (1992) Wille et campagne en Europe occidentale (Vexhe siècle), Paris.

gurichet: L. (Ed.) (1994) La femme pendlant le moyert dge et lépoque moderne, CNRS Editions, Paris.

gychet, L. (1996) Die Landnahme der Franken in Gallien aus der Sicht der Anthropologen in Die Finaken - Wegbereiter EuropasVerlag Phillipp von Zabern, Mainz, $p .662 .667$.

guchet, L. and Lorren, C. (1975) Dans quelle mesure la necropole du hout moyen age offre-t-elle une image fidele de la sociétế des wivants? in La mort au moyen age, Vol callection recherches et documents XXV Strasbourg, p. 2748 .

瞅数et, L. and Olive, C. (1983) Anthropologie: B. Interprétations prowisoires in Sépulture et traditions funéraires du Ve au XIII e siècle ap. $1 . C$. dans les campagnes des Alpes Frarçaises du nord IEd. Collardelle, M. Société Alpine de documentation de recherche en archéologie historique; Grenoble, p. 420-433.

Buikstra, I. E. and Ubelaker, D. H. (Eds.) (1994) Standards for data collection from human skeletal nemains, Arkansas Archeological Surwey Fayetteville.

Bullough, V. and Campbell, C. (1980) Female longevity and dilet in the middle ages, speculum, 55 . p. 317.325 .

Camon. A995 Material cullute and burial representativeness In Grave reflectians: portritying the past through cemetery studies (Eds. Saunders, S. R. and Herring, A.) Canadian Sicholars Press; Toronto, p. 3-17.

Carli-Thiele; P. (1996) Spuren won Mangelerkrankungen an steinzetlichen krnderskelette, Erich Goltze, Göttingen. Coselitz, P. (1998) Caries-Anclent plague of kumankind in Dental Anthtopology, fundamentols, himits and prospects (Eds. Alt, K. W. Rosting, F. W. and Teschler.Nicola, M.j.j Springer Verlag wienna, p. 203-226.
Chanier, C. (1994) Les enfonts meroving iens d'ErpsKwerps: probleme de croissance, Acto Archaeologica Lovdniensia, 33; p. 91-99.

Chelini, ). (199:) L'aube du mayen tge: Naisance de la chrettenté occidentale, Editions Picard, Paris

Child A. M. (1995) Towards and Understanding of the Microbial Decomposition of Archatological Bone in the Burial Evwtronment, Joutual of Archaeological Science, 22, p. 165.174.

Cliff, A, Haggett, P, and Small man Raynor, M. (1998) Deciphering gtabal epidemics. Anatytical appraaches to the disease records of world cities, 1888-1912, Cambridge University Press, cambridge.

Cohen, M. N. (1989) Heath and the rise of civilization, Yalle Uniwersity Press, New Hawen.

Colardelle, M. (1983) Sepulture ef traditions funeraires du we au xul e siecle ap. J.C. dans les campagnes des Alpes Françatses du nord, Société Alpine de documentation et de recherche en archeologile historique, Gremoble.

Colardelle, M., dArchimbawd, D. and Raynaul, C. (Eds.) (1996a) Typo chronologie des sêpultures du Bas-Emplre a la fin du Moyen-Age dans le Sud-Est de la Gaule, FERACF / La Simarre, Tours.

Colardelle, M.x Demians d'Archimbaud, G. and Raynaud, C. (1996) Typonthromolagie dies sepultures du Bas- Empire a la fin du Moyen-Age dans le Situd Est de lo Gatulle In Archeologie du

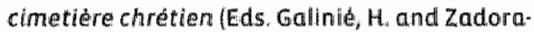
RIO, E. FERACF / LA SIMARRE, TOHIS, p. 271-303

Comas, 1. (1960) Manual of physical anthropology, Charles $C$ Thomas, Sprimgfield.

Cordfunke, E. H. P. Borg, K. W. d. and Maat, G. D. R. (1998) De skeletten uit thet grafmonument te Ryjnsburig: een thermieuwd onderzoek, Bulletir van de Konimklijke Wederlandse Oudherdkundige Bond, 97, 1-14.

Costa, R. L. (1980) Incidence of caries and abscesses in archeological Esikimo skeletal samples from 
Point Hope and Kodiak Island, Alaska, American journal of Physical Anthropology, 52, p. 501.514.

Coulon. G. 1994) Lenfant en Gaule Romaine, Editions Errance, Parts.

Cousin, M. (2002) Archeologle des carrieres souterraines de Doutela-Fontaine, Association Féglonde potr la Diffusion de Hrcheologie en Pays de Lotre, Angers.

Crist.,T. A. J, Washburn, A., Park, H, Hood, I and Hickey, M. A. (1997) Cranial displacement as a Laphonomic process in potential child abuse cases In Forensic taphonomy; the postmortem fate of human remains (kds. Haglund, W. D. and Sorg, M. H. CRC Press, Boca Raton, p. 319.336.

Czametzki, A. (Ed.)(1996) Stumme Zeugen ihrer Leider. Krankheit und Behandlung wor der medizinischen Revolution, Attempto, Tübingen.

Czarnetziki, A, Uhlig, C. and Wolf, R. (1989) Wenschen des Frihen Mittelalters: im Spiegel der Anthropologie und Medizin, Wortembergisches Landesmuseum Stuttgart, stutetgart.

D'Hulst, A. (1990) Inventaire anthropologique un Les foulles du quartier Saint-Brice a Tournai: L'environnement funéraire de la sépulture de Childéric vol. I, Wol. LXXII (Ed. Brulet, R.) Departement d'archeologie et d'histoire de l'art. Louvalinda Neuve, p. 106.121

Dostugue 1. and Gervals, V. (1992) Paleopathologie du squalette humain, Paris.

Dawes, 1. D. and Magilton 3 . R. (2980) The cemetery of Sil Helerion-the-Walls Aldwark, Council for Brithly Archaeology, York.

De Boe, G. (19\%0) Een Meroving isch grafveld te Borsbeek (Antwerpen), Nationale dienst vooi opgravingen, Brussel.

De Boe; G, De Bite, M. and Wan Impe, L. (1992) Neerharen-Rekem: Die komplexe Besiedlumgsgeschichte einer vor denkesbagkern geretteten Fundstatte in Spurensicherung. archdologische Denkmalpflege in der Euregio

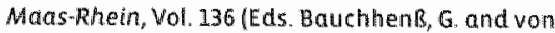

Prittwitz Gaffron, H-H. Werlag Philipp wom Zabern, Mainz am thein, p. 477-496

De Eoone, W. I. (1969) De Franken In Limburgs verleden Masiticht, p. 173-176.

De Grooth, M. E.T. (1987) Villa rusticat het boerenbedriff in het Rign/Marasgebied Am Longs de WEG EdS. Stuart, P. and de Grooth, M. E.T) Thermenmuseum Heenten, Heerlen, p. 81-8.

De lo Haye, $\mathbb{R}$. (1985a) De bisschoppen van Mastricht, stichting Historische Reeks. Waastricht, Maastricht.

De la Haye, R. (1985b) Willem Heck en zijn schatgraverij in de Sint-Servads, De Sint Sinuad, 22. P. 173-175.

De la Haye, $R$ (1988) Humbertus historie herscheven (II), De Sint Servaas, 41/42, p. 327-328.

De la Haye, R. (1994) In welke eeww leefde sint Servaas? De Macs gow tijechrift voor Limburgse geschiedenis en oudheidkunde, 113 , p. 5.28 .

De la Haye, R. (2002) 3. Liege in province ecclésiastique de Cologne (Germania Secunda) Voll XII (Eds. Gauthier, M., Beaujard, B. and Prewot, F.) De Boccard, Paris, p. 117-124.

De Moreau, E (1940) Histoire de l"Église en Belgique, L'Édition Universelle, Brussels.

Deeters, ]. [19701 Servatiusstift und Stadt Manstrich: Untersuchungen zu Entstehung wnd verfassung. Ludwig Rohrscheid Verlag, Bonn.

Delahay' 6.R. (1985) Les sancophages de plerre In Collections Merowingiennes, Voh. II (Ed. Pếin, p.) Les musees de la ville de Paris, Paris, $\rho$. $689-699$

Demougeot, E. (1979a) La formation de l'Europe et fors invasions barbares: ll 1 De lavërement de Diocletien (284) a l"occupation germanique de l'Empire romain d'Occident (debut du We siecte) Aubiter, paris:

Demaugeot, E. 1979 bl La formation de l'Europe et les invasions barbares: 11,2 De lavenement are Diocletien (284) \& loccupation germanique de 
Pemplre romain doccident (debut du ve stecte) Aubier, Parts.

Deppeyrot, G. (1994) Richesse et société chez les Merovingiens, carolingiens, editions Errance, Poris.

Dickinson, T. M. (2002) What:'s new in early mediewal burial archaedogy?, Early Medieval Europe, 11, p. 71787 .

Dierkens, A. (2000) Refrexions sur l'histoire religieuse de Mastricht d'époque mérovinglenne, In Lewargelisation des régions entre Meuse et Maselle et la fondation de liabbaye d"Echternach Ne-lKe suécle), Vol. CXVu (Ed. Polfer, M.) Centre Universitaire de Luxembourg, p. 542:567.

Dierkens, A. (2004) La sculpture sur pierre du trés haut moyen age dans l'ancien diocése de Tongres-Maastricht-Liege in Bruc ealles well: Archaeological essays concerning the peoples of north-west Europe in the first millenium $A D$, Vol. 15 (fed. Lodewilickx, M.) Leuven Uniwersity Press, Leuven, P. $73-86$.

Dierkens, $A_{\text {a }}$ and Margue, M. (2004) Memoria ou damnatio memoriae? Limage de Gislebert duc die Lotharingie (+ 939) In Retour aux sources: textes, efudes et documents d'histoire médievale offerts a Michel Parisse Picard, Parilis, p. 869-890.

Difkman, W. (1989) Een vindplacts uit de ljzertijd te Magsticht Randwyck, Rijksdienst woor het Ond dheidkundig Bodemonderzoelk, Amensfoort.

Dijkman, W. (19920) Funde aus Maastricht in spurensicherung: archäologische Denkmalpflege in der Euregio Mars-Rhein, Vol. 136 (Eds.

Eauch hen $B_{\beta} G$ and vor Prittwitz U. Gaffron, H. H. Neirlag Philipp won Zabetn, Mainz am Rhein, p. $367-378$.

Dijkrnan, W (1992b) La diffusion de la terre siglibe deconé a la molette dans la vallée Mosame five. We silecles Ir Actes du cangrés de Tournai, 28-31 mai 1992 (Ed. Rivet, L.) Société Française d'Étude de la Ceramique Artique en Gaule, p. 291-296.
Dijkman, W. (1993) La terne sigllke decorê a lo molet a motijs chrétiens dans la stratigraphe macstrichtoise (Pays-Bas] et dans le nord ouest de l'Europe, Gallia: Fouilles et Manuments Archeologiques en France Métropolitaine; 49 (1992), p. 129-172.

Dijkman, W. (1994) Maas-Tricht, lieu de defense et centre religieux in Archeologie des villes dans le Nord Ouest de l'Europe (Whe - Xllfe sléted Actes du Ve Congres International d'Archeologie Médiévale (Douar, 1991), Vol. 11 (Eds. Demolon, P., Galinie, Hand verhaeghe, $F$. SociétéArchéologique de Doudi, Doudi, p. 3539.

Dijkman, W. (1995) Een urmenveld in Mastricht. Withuisweld, Archeologie in Limburg, 66, p. 49-55.

Dijkman, W. (1997) Crematieresten in MarastrichtRandwyck Archeologie in Limburg, 74, 0. 77. Dijkman, W. (2003) The Merovingian cemetery of Borgharen (Maastricht) and an early Frark named BOBO in Essays on the Early Franks, Vol. 1 (Eas. Taclyke, E, Looijenga, ]. H., Harsema, O. H. and Reinders, H. R.) Barkhuis, Groningen, p. $212-230$.

Dijkman, W. and Ervynck, A. (1998) Antler, bone, horn, ivory and teeth: The use of animal skeletal materials in Roman and early medieval Maastricht, Arehaeology Section ${ }_{i}$ Municipality of Maastricht, Maastricht.

Dijkman, W. and Hulst, R. A. (2000) Het urnenveld van Muastricht Vroendael, Archeologie in Limburg. 84, p. $19 \cdot 26$.

Dijkstra, M. F. P. and Flamman, J. P. (2004) Onderweg naar gisteren. Archeologisch onderzoek naar zooo jaar wegopbouw langs de noordzijde wan het Vrifthof te Maastricht, Amsterdam, p. 113.

Dougados, MA., Van der ilinden, $S_{\text {, }}$ Juthlin, R, Huitgeldt, B., Amor, B, Calin, A, Cats, A., Dijkmans, B, ollwier, 1., Pasero, G., Veys, E and Zeidier, H. (1991) The European Spondylarthropathy Study Group preliminary criteria for the classification of 
sparidylarthropathy, Arthitis and Rheumatism. 34, p. $1218-1227$.

Drew, K. Fil1991 the laws of the Salian Franks, in Universly of Pennsywania Press: Middle Ages Seriesphiladelphia, $p .256$

Duby, G. (1979) The early growth of the European economy: Warriors ond peasants from the seventh to the twelf th century, Corneli University Press, New York.

Duday, H. (1990) Observations osteologiques et décomposition don cadarre sepulture colmatếe ou en espace wide (1). Revue Archeologique du Centre de la France, 29, p. 193-196.

Duday, H. and Masset, C. (Eds.) (1987) Anthropologie physique et archeologie: Methode d'écude des sefpultures, paris.

Dudo (1865) De moribus et actis primorum Normanniae Ducum, (Ed. Lair , J) Caer.

Dupertuis, C. W. and Hadden, J. A. (1951) on the reconstruction of stature from long bones, Aurerican lournal of Physical Anthropology, 9 , p. 15.53.

Dupras, T. L. Schwarcz, H. P. and Fairgrieve, 5. I. (2001) Infant feeding and weaning practices in Roman Egypt, American Journal of Physical Anthropology, 215, p. 2042212 .

Durand, M. (1988). Archélogle du cimetiere mediéval au sud-ast de l'Oise. Relations avec lhabitat et wolution des rites et pratiques funeraires du Vtane atu xhene siecle.

Effros, B. (1994) Fram grave goods to Christian epitaphs: Evolucion in burial tradtion and the expression of social status in Merovingian society, in History Los Angeles, p. 492.

Effros, 1 (1997) Beyond cemetery walls: early medieval funerory topography and Christian salvation, Early Medieval Europe, 6, p. 1-23.

Effros, . (2000) skeletal sex and gender in Merowingian mortuary archmeolody, Antiquity, $74,0.632 .639$
Finhord (2887) Transiatio et miracula ss. Marceltini es Petri, in Monumenta Germaniae Historico scriptores, Vol. 15 (Ed, Haitz, G) Hannower; p. 23826.4 .

Einfard (1911) Vita Karali, In Alonumento Germaniate historica, scriptores rerum Germanicarum, wol: 25 Ed. Halder-Eger, O. Hannover, p. I-4.1.

Engen, L. (1985) Les sarcophages méravingients duns la vallé de la Meuse, in La civilisation mérowingienne dans le bassin mosane, Woll 22 (Eds. Willems, , and Otte, M.) Amay Liege, p. 161170 .

Es, W. A. W. (1968) Grafritueet en kerstening, Fibula van Dishoeck, Bussum.

Evig, E. (1980) Frohes Mitelater, podagogischer Verlag Schwamn, Düsseldor].

Ewig, E. (1993) Die Merowinger und das Frankenreich, W. Kohlhammer, Stuttgart.

Forwell, D. E. and Molleson, T. 1. (1993) Excavations at poundbury 1966-1980: Wolume fin the cemeteries, Dorchester.

Fichtenau, H. (1984) Lebensordnungen des 10 . Jahrhunderts: Studien über Denkart und Existenz in einstigen Karalingerreich, Anton Hiersemann, Stutigart.

Fichter, G and Valk, P. (1980) The easterm arientation of Merovingian grawes and the seasonal distribution of motbidity and mortality lusing the Sasbork-Behans and Bchoffingen-Bigdten cemereries as examplesw journal of Human Evolution, 9, p. 49-59.

Finke, L, Dehmel, U. Klinkhardt, K. and Nöther, 5 . (1997) Epigenetische Merkmale bei Bevolkerungsgruppen des fruhen Mittelatiers aus dem Atittelelbe-5aale-Gebiet, in Medieval Europe, Vol. 2 (Death and Burial in Medieval Europel (Eds. De Boe, G. and Vertaeghe, F.) Bruggite. 85-91.

Fiorato, V., Boylston, A, and Knüsel, C. (Eds.) (2000) Blood red roses: The archaeology of a mass growe 
from the battle of Towton AD 1461, Oxbow Books, Oxford.

Flad, R., Wachter; K. W. and Gregory, A. (1990)

Height, health and history: mutritional status in the United Kingdom, $1750-1980$, Cambridge

Unversity Press, Cambridge.

Folcuin [1841] Gesta abbatum Lablensium, in Monumenta Germaniae historice, 5 criptores, Vol.

4(Ed. Pertz, G. H.) Hannover, p. 5.4\%74.

Fossier, R. (1991) La société médiévale, Armand Colin, Paris.

Frère, H. (1977) Le denier carolingien, spécialement en Belgique, Institut superieur d'ar theolagie et dhistoire de lart, Louwain-la-neuse.

Fried, 1. (1995) The Frankish kingdoms: 817.911: the East and Middle kingidoms In The New Cambridge Medieval History, vol. Il c. 700 -c. 900 (Ed) Mckitterick, R.) Cambridge Uniwersity Press, Cambridge, p. 142-158.

Galinëe, H. and Zadara-Rio, E. (Eds.) (1996) Archeologie du cimetiere chretien, FERACF/La Simarre, Tours.

Gallien, V. (1994) La femme: temoin de l"évolution du cimetiere de la basilique a saint-Dents, durant le haut moyen age in La femme pendant le moyen age et l'epoque moderne, Vol. 17 (Ed. Buchet, L.) CNRS Editions; Paris, p. 69.86.

Gathier, N. (1975) Recuell des inscriptions Chretiennes de la Gauhe, Porris.

Geidhusser, B. Guckenthan, 5. and Heudorfer, R. 11996) Hebverletzumgen und Trepanationen in 5 tumme Zeugen threr Letden Krankheit und Behandlung wor der medizhischent RevolutionfEed. Czannetzki, A.l Attempto, Tubingen, p. 183205 .

Gerstenberger, J. (2002) Analyse alter DNA zur Ermittung won Heiratsmustern in einen fruhmittelatterlichen Bevolkerung, in Mathematics and ScienceGätingen, p. 201. Gintr, M. v. (1994) Ancient DNA, Maastricht.
Gllking, H. (1997) Chemical and ultrastructural ospects of decomposition in Forerisic taphonomy: the postmortem fate of human remains (Eds. Haglund, W. D. and sorg, M. H.) CRC Press, Boca Ratoh, p. 93-108,

Glazema ${ }_{\star}$ P. and Ypey I. (1956) Meroving is the ambachtskunst, Wereldvenster, Madstricht.

Goetz, H.W. (1995) Social and military institutions \#n The New Cambridge Med heval History, Voll $11 \mathrm{c}$ 700-C. 900 (Ed. Mckitterick, R.) Cambridge University Press, Combridge, po. 451-480.

Goossens, W. (1920) Een Frankische grafwandst in de St. Servadskerk te Mastricht, Oudheidkundige Mededelingen van het Rifksmuseum voor Oudheden te Leíden, 1, p. 64-65.

Goossens, W. (1927) Wondst van een Romeins brandigraf te Marastritht, Oudheidkundige Mededelingen van het Rijksmuseum voor Oudheden te Leiden, 8, p. 55-59.

Graver, A. L. (1989) Health, disedse and status in medieval York, in Anthropology, p. 313.

Graver, A. L. (Ed.) (1995) Bodies of evidence: Reconstructing history through skeletal analysis, New York.

Gregory of Tours (1885) Liber in glaria confessorum, In Monumenta Germanice historlca, Scriptores rerum Merowingicaram, Wo. 1,2 (Ed. Krusthi, B.) Hannover, p. 744820 .

Gregory of Tours (1951) Historiarum llbri decem, ln Monumenta Germaniae thistorica, Scriptores rerum Merovingicarum, Wo:. 1, 2 (Eds Krusch, B. and Levison, W. Hamnaver, p. 537.

Gregory of Tours (1986) Historiarum Vibri decem, Im Ausgewahlte quellen zur deutschen Geschichte des Mittelatters, Vol. 2 (Ed. Buchner, R.? Darmstadt, p. 1-381.

Grierson, P, and Blackburn, M. (1991) Medieval European coinage: t the edrly midd ages (sith 10th centuries d Cambridge Umiversity Prests, Cambridge. 
Grmetk M. D. (1989) Diseases in the arcient Greek world, The johns Hopkins Unimersity Press, Daltimare.

Grollew Raoux, ]-L, Crubézy, E., Rougé, D., Brugne, 1. F, and Saunders, S. R. (1997) Harris lines: a study of age-associated bias in coumting and intierpretation, American Journal of Physical Anthropology, 103, p. 208.217.

Guigon, P. (1994) Les sitpulures du hat movert-age en Bretagne, Rennes.

Guy, $\mathrm{H}_{2,}$ Masset, $\mathrm{C}$ and Baud, $\mathrm{C}$ (1997) Infant taphonamy international Jaumal of osteodrchaeology, 7, p. 221-229.

Hagen, A. (1995) A second handbook of Angto-Saxon food 3 drink: production and distribution, AngloSaxon Books.

Haglund, W. D. (1997) Rodents and human remains in Forensic taphortamy: the postmortem fate of human remains (Eds. Haglund, W. D. and Song M. H.) CRC Press, Boca Raton, p. $405 \cdot 414$.

Halsall, (5. (1995) Settement and sacial organization. The Merovingian region of Metz, Cambridge University Press, Cambridge.

Halsall, G. (1998) Social hidentities and social relationships in early Merowingian Gaul in Franks and Alamanni in the Merovingtan period: an ethographic perspettive, Vol. 3 (Ed. Wood, If the Boydell Press, San Marino, p. 141-165.

Hanthare, T. and ishida, H, (2001) Frequency warlations of alscrete cranial tralts in major human populations. I. Supernumerary ossicle wariations, yournal of Aratony, 198, p. 689-706.

Hardenberg, H. (1962) De Macstrichtse Wraenhof In Miscellamea Trajectensia: Biflragen tat de geschiedenis wan Mastibcht, Vol 4 Limburgs Geschied en Oudheldkundigg Genootschap. Marstrictit, p. 29.53

Hatke, H. (1997) The nature of burial data In Burial e Society: The chromological and social analys is of archaeological burial data (Eds. )enser, C. K and
Hoilund Nielsen, Ka Aamus University Press; Aarhus, p. $19-28$

Harris, H. A. (1933) Bone growth in heath and disease, oxford uniwersicy Press, London.

Horris, M, and Ross, E. (1987) Death, sexand fertinty, Columbia University Press, New" York. Hartmann, I. L. H. (1986) De reconstructie van een. middeleeuws landschap:

Nederzertingsgeschiedenis en instelligen won. de heerlükheden Eijsiden en Bpeust bij Macastricht (10e-19e eeuw), Wan Gorcium, Asisen.

HassenpfuE E. (1999) Das Lalenbegrobnis in der Kurche. Historischarchdologische Studien zh Alemonnien im fruhen Mittelatter, Verlag Narie Leilorf, Rahden.

Hauser, $G$ and De stefano, G. F. (1989) Epigenetic variants of the human skull, $E$. Schweizerbart'sche verlagsbuchlondlung Stuttgart.

Henderson, (1987) Foctors determining the state of preservation of human remains In Death, decay and reconstruction: Approaches to archatology and forensic science (Eds. Boddington, $A_{*}$ Garland, A N A and Jamaway, R. C.) Markesester University Press, Manchester, p. 43-54.

Henrion, Fand Hunot, J. $\psi_{0}$ (1996) Archeologie et technologie du cercuell et du coffroge de bois th Archeologia du cimetiere chrétien, Wol II (E.ds. Galinia, $H$ and Zadora-Rio, EJ FERACF/LO Simarre, Tours, p. 197-204.

Herlithy, D. (1987) Outline of population developments in the middle ages in Determinanten der Bevölkerungsentwicklung im Mittelalter (Eds. Herrmann, B and Sprandel, R. VCH Veriagisgesellschaft, Weinheim, p. 14-23.

Herrmanm, B. (2987) Anthropologische Zugange zu Bewökerung und Bewalkerungsentwicklung hrs Mittellaiter in Determinanten der Bevölkerungsentwicklung im Mittelaiter (Eds. Hermonn, B and Sprandel, R.) Weíntheim. p. 55.73 
Hemment, Grupe, G., Hummel, 5., Piepenbrink, $H$. and Schutkowski, H. (1990) Prahistorische Anthropologie Leitfaden der Feld-und Labormethoden, Berlin.

Hermann, B. and Sprendet, R. (Eds) (1987)

Determinanten der Bevölkerungsentwicklung im Wittelatter, Weinheim.

Hermann, Bi and Sprandel, R. (Eds.) (1988) Die

Bewolkerungsentwicklung des europdischen

Mittelaiters: Das wirtschaftgeographische und

kuturelle Umfeld, verlag Karl Alber, Freiburg. Hershkowitz, I, Greenwald, C., Rothschild, B. M.

Latimer, B, Dutour, O, Jellema, L. M. and Wish

Baratz 5 . 14999$\}$ Hyperostosis frontalis interna: an anthropalogical perspective, American

Journat of Physical Anthropology, 109, p. 303-325. Hessing W. A.M. (1994) Tien eeuwen grofrituleel (Eds. Es, W. A. W. and Hessing, W. A. M.) Rijksdienst voor het oudheidlikundig Bodemonderzoek, Romeinen, Friezen en Franken in het hart van Nederland, p. $130-137$.

Heymans, H. (1978) De topografie van de Merawingische grafvelden in Belgisch-Limburgen Madstricht, Acto Archoeologica Lovaniensia, 17, p. 66-134.

Higfins, W. (1989) A model for assessing health patterns from sikeletal remains in Burial archaealogy: Current research, methods and developments, Vol: 211 (Eds. Roberts, $C$. A, Lee, $F$. (ind Bintlaffi, 1.) Oxford, p. 175/204.

Higeins: W. (2002) The people of San Vincenzo in late Antiquity and the early middle ages in San Vincenzo al Volturno 3: The finds from the 1980 B6 excawations (Eds. Mitchell, J, and Hanssen, L. L.) Centro Italliano di studi sull'alto medioewon spolleto p. $425 * 437$.

Hilson, S (1996) Dental anthropology, Cambridge uniwersity press, cambridge.

Hilson, 5. 2001) Recording dental carles, International journal of Osteoarchaeology, 11 , a. 249289
Howitschka, E. (1986) Vom Frankenteich zur Formierung der europdischan statem tund Wölkergemeinschaft 840-1046. Ein studienbuch zur Zeit der späten Karolinger, der attonen und der fruhen salier in der Geschichte Mitteleuropas, Wissensehaf thiche Buchgesellschaft, Darmstadt.

Hofman, P. A. M., Panhuysen, R. G. A. M, and Mart, G. ]. R. (1995) Use of computed tomography in age determination in Proceedings of the IXth European meeting of the Poleopathology Association: Barcelona 1st-4h September, 1992 (Eds. Batista, $\mathbb{R}_{,}$Campillo, D. and Carreras, T.) Museu d'Arquelogia de Catalunya, Barcelona, p. 157-161.

Hofman, P. A. M., Panhuysen, R. G. A. M. and Maat, G. J. R (in press) Assessment of the trabecullar structure of the proximal fermur: A comparison of two techniques In Proceedings of the Xuth European meeting of the Paleopathology Association "Gottingen 1994 Gottingen.

Holck, P. (1986) Cremated bones, Anatomical Institute, University of Osla, Oslo.

Hoppa, R. D. (1996) Representatiweness and bias in cemetery samples: implications for palaeodemagraphic reconstructions of past populations, In Department of Anthropology. Hihne-Osterloh, G. and Grupe, G. (1989) Causes of infant montatity in the Middle Ages revealed by chemical and palaeo pathologicall andyses of skeletal remains, ze itsefirif fur horphologische Anthropologie, $77,0.247 .258$.

Hulst, R. A. (1995) Verslog opgraving Lage Kanacldip, Mastrieht.

Hulst, $\mathbb{R}$ A and Dijkman, W. (1997) Nicastricht/AmbyHewkel strat; een archealogische Axlocatie, Archeologie in Limburg, 74, p. $61-70$.

Hulst, R.A. and Dijkiman, W. (2001) Rapport AAO Pasestraat, Bargharen, gemeente Maastricht, Malastrilchit. 
Hummel, s. and Hermann, B. (1994) General aspects of somple preparation In Anctent DNA: recovery and analysis of genetic material from paleontological, archaeological, museum. medical and forensic spectmens (Eds. Hermonn, B. and Hummel, s.) springeruellag New York, New York, p. 54 6 6.8.

Iscan, M. Y. and Kennedy, K. A. R. (Eds.) 1989) Reconstruction of life from the skeleton, Wiley ard Liss, Naw York.

Iscan ${ }_{\text {f }}$. Y. and Loth, S. R. (1989) Osteological manifestations of age in the adult in Reconstruction of the from the skeleton (Eds. Iscan, M. Y. and Kenmedy, K.A. R.I Willey and Liss, New York

Isican, M. Y, Loth, 5 R and Wright, R. K. (1984) Age estimation from the ribs by phase analysis: White males, lownal of Forensic Sciences, $29, \mathrm{p}$. $1094-1104$

iscan, W. Y, Loth, S R. and Wright, R. K. (1985) Age estimation from the rib by phase analysis: White females, Journal of Forensic Sciences, 30, p. $853 \times 863$.

lames, E, (1991) The Franks, Basill Blackwell, oxford. Janaway, R. C. (1997) the decay of buried human iremains and their associated materials in Studies in Grime: An introduction to forensic archaeology (Eds. Hunter, I. Roberts, C. A. and Martin, A.) Rowtledge, London, p. 58-85.

Jonsten, H. A. M. and Mad, G. I. R. (1999) Canons buried in the "Stiftskapel" of the saint servatas basolica at Masitricht A.D. 1070-1521. A paleopethological study, Barge's Anthropologica, Leiden.

Janssiens, P.(1963) Examen anthropologhique des squelettes matrovinglens diarion in Sipultures merovingtennes au "Vieux cimetiere" d"Arton, Vol. ga (Eds. Roosens, Ht. and Alenus-Lecert, I) Alon, p. 175-186.

Jamssens, P. (1967) Examen an thrapologique des ossements du cimetière Mérowingien de
Hollogne-aux-pierres in Tombes Mérovinglente: a Hollogne aux-pherres, Vol. 101 IEds. Alents Lecerf, I and Dradon, M. B Brussels, 9. 91-129: Janssens, P. (1970) Het anthiropologisch onderzok in Grafwondsten uit de Romeinse en Merowingische tijd te Tongeren, Vol. 116 lEds. Roosens, 4 and Mertens, 1.) Brussels, p. 29-42.

Jocundus (1856) Transiatio et miracula s. Servati Traiectensis, In Monumenta Germanta historica, Sicriptores, Vol. 12 (Ed. Köpke, R.) Hannover, p. 85-126.

judd, $M$. A. and Roberts, C. A. (1998) Fracture paterns at the Medieval Leper Hospital in chichester, American journal of Physical Anthropology 105 p. 4355.

Kalf, J. (1916) Opgravingen in de St. Serwaskerk te Maastricht, Bulletin van den Nederlandschen oudheidkundige Bond , p. 17.44.

Kemkes-Grottenthaler, A. (2002) Aging through the ages: historical perspectives an age indicator methads in Paleodemography: age distributions from skeletal samples; Vol. 31 lEds. Hoppa, R. D. and Vaupel, J. W.) Cambridge University Press, Cambridge, p. $48 \cdot 72$.

Knussmann. R. (Ed.) (1988) Anthropologie: Handbuct der Vergleichende Biologie des Menschen, Stuttgart.

Koch, U. (1996) statten der Totenruhe - Grabformen und Bestattwngssitten der Franken lon Dhe Franken. Wegbereiter Europasverlag Philipp non Zabern, Mainz, p. 723-737.

Kolbl, 5. (2004) Das Kinderdefizit im fruhen Mitcelalter - Realitalt ader Hypothese? In Geowissenschaftlichen fokultat Tubirgen, p. 204.

Kooistro, L. I. (1996) Borderland forming Passibilities and limitations of farming in the Roman periad and early middle ages between the Rhine and Meuse, Van Gorcum, Asser.

Krogman, W. M. and Iscan, M. Y. (1986) The humar skeletan in forensic medicine, Charles C Thomas, springfield. 
kroos, R. (1985) Der 5chrein des Hedigen Servatius in Maastricht, zentralinstitut fur kunstgeschichte in Monchen.

Kunter, M. and Wittwer-Backofen, U. (1996) Die Franken - Anthropologische

Bewolkierungs Siedlungsgebiet In Die Franken - Wegbereiter Europas (Eds. Wierzorek, A. Périn, $P_{n}$, won Welck, K. and Menghiun, W.) Vertag Philipp von Zaberm, Mainz, p. 653-661.

Lammers, 5. (1992) Medieval Chirstian interments in stone: monolithic limestone sarcophagi, Berichten van de Rijksadienst woor het Oudheidkundig Bodemonderzaek, 39 (1989), p. $377-434$

Lanting, 1. N. and wan der Plicht, ]. (1996) Wat hebben Floris $V$, skelet 5 wifterbant 52 en visotters gemeem?, Palaeohistoria, 37/38, p. 491-519.

Larsen, C. S. (1997) Bioarchaeology: interpreting behovior from the human skeleton, Cambridge University Press, Cambridge.

Le Jan, R. (1995) Famille et pouvoir dans le mande Franc (Whe-Xe siéclel, Publications de la Sorbonne, Paris.

Le Jan, R. (1996) Austrasien - Versw chi einer Begriffsdefinition Im Die Franken - Wegbereiter Europas, Vol. 1 IEds. Wheczorek, A., Perin, P., won Welck, K. and Menghin, W.) Verlag Philipp von Zabern, Mainz, p. 222-226.

Le Jan, R. (2000) Frankisth giwing of arms and ritwals of power: Continuty and change in the Caralingian period in Rituals of power, Vol a tEds. Thew ws, F. C. W. J. and Nelson, J. L.) Brill, Leiden, p. $281-309$

Lebect, 5. (1990) Les origines frangues Ve.IXe sidecle, Editions du Seuil, Paris.

Leupen. P. H. D. (1997) Het gelijk van Slint-Servans en Onze-Lieve-Vrouwe. De Maastrichtse kapitteds in de Vroege Middeleeuwem In De kerk en de Nederlanden: Archieven, instellingen, samenleving (Eds, Erkelens-Buttinger, E. S. C.,
Henderikx, P. A, seeuwenberg, H. L. P., Leupen, P. H. D., Maarschalkelweerd, P. and Verkerk, C.L. Verloren, Hiversum, p. 29-42

Levison, W. (1948) Dos Testament des Dicikons Adalgisel-Grimo vom Jahre 634 Im Aus rheinischer und frankischer Frihzeit (Ed. Levison, W.) Düsseldorf, p. 118-138.

Lilley, I, M, stroud, G, Brothwell, D. R, and Williamson, M. H. (1994) The Jewish burial ground at Jewbury, Council for British Archaeology, Vork. Livi Barci, M. (1990) Population and nutrition: an essay on European demographic history, Cambridge Uniwersity Press, cambridge.

Livi-Bace: M. (1993) A concise histony of world population, Bhackwell, Cambridge.

Lohier, F, and Laporte, J. (Eds.) (1936) Gesta sanctorum potrum fontanellens is coenabil, Rouen-Paris.

Lohike, B. (2004) Kinder in der Merowingerzeit: Gräber von Maddchen und Jungen in der Alemannia, Leidorf, Rahden/ Westfaler.

Lonnée, H., A. (1990) Pathologie van menseli)ke botresten uit de Romeinse tijid afkonstig wit de inhumatiegraven van het grafveld op het Marktveld te Valkenburg (2.H.) In Graven bij Valkenburg W: het archeologisch onderzoek in 1987 en 1988 (Eds. Bult, E. I. and Hallewas, D. P.) Ebution, Delft, 17. 217.229:

Lonne, $H_{1}$, a and Mat, G. ). R. (1998) Inhumations in a Roman cemetery at Valkenbufg-Mark tweld (Zuid Holland) in the Netherlands in Barges Anthropologica vol. 3 Leiden p. 5.4 .

Lorans, E. (2000) Le monde des morts de lantiquité tardive al'époque moderne (IVe-XIXe S.) In Archéologie funéraíre (Eds. Crubezy, Ex, Lordns, E, Masset, C.,perrinn, F. and Tranoy, L.) Editions Errance, Paris, p. 155-197.

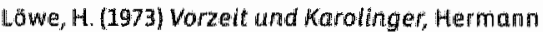
Böhlaus Nachfolger, Weimar.

Hukacs, A. R. (1989) Dental paleopathology: methods for reconstructing dietary patterns in 
Reconstruction of llfe from the skeleton UEds. Iscan, H. Y. and Kennedy, K. A. R. Alan Lis.s, Inc., New York, $\mathrm{p}, 26 \mathrm{H} 286$

Maat, G. ) R. (1984) The dating and rating of Harris's lines, The American Journal of Physical

Anthropology, 63, p. 291299

Maat G.). R. (1987) Practising methoids of age determination: comments on methods combining. multiple age indicators, Journal of Anthropology, 2. p. 93.99 .

Madit, G. ], R. (2003) Male stature: a parameter of health and wealth in the low countries, 50-1997 AD in Wealth, health and human remains in archaeology, Vol. 25 (Ed. Metz, W. H.) Stichting Nederlands Museum woor Anthropologilie en Praehistorie, Amsterdam, p. 57-88:.

Maat, G. I. R., Mastwilk, R. W. and wan der Velde, E. A. (1994) Skeletal distribution of degenelrative changes th vertebiral osteophytosis, wertebral osteoarthritis and DisH international journal of os teoarchaeology, 5, p. 289.298.

Maat, G. J. R., Pamhusysen, R. G. A. M. and Mastwijl K, R. W. (2000) Manual for the physica! anthropological repart, Lelden.

Maat, G. J. R., van den Eynde, G. and Mastwijk, R. W. (1997) De eerste Nassaus in Nederland: bidentificatie wan en paleopathollogische bevindingen bil de voorouders van willem wan oranje begraven in de Grote of onze Lieve Wrouwe Kerk te Breda., Nederlands Tijdschrift woor Geneskunda, 141, p. $2501-2513$.

Maat, G. J. R. and van der Velde, E. A. (1987) The Caries attrition competition, International Journal of Anthropology, 2 , 281-292

MacLaughlin, S. and Bruce, M. F. (2985) A simple univariate technique for determining sex from fragmentary femora: Its application to a scottish short cist population, The American journal of Physical Anthropology, 67, p. 413*417
Mafart, B. Y (1980) L"abbaye Saint-Wictor de Marseille: Etude anthropologique de la nécropole des Verme - Vleme siectes, Paris.

Mafart, B.-Y. (1983) Pathologie osseuse au Moyen Age en Provence, paris.

Mann, R. W. and Murphy, S. P. (1990) Regional atlas of bone disease: A guide to pathologic and nomal variation in the human skeleton, springfield.

Manouvfer, L. (1893) La détermination de la taille d'apres les grands as langs des membres,

Bulletins et Mémoires de la saciété

d"Arthropologie de Paris, 4, p. 347.402.

Mant, A. K. (1987) Knowledge acquired from post War exhumations in Death, decoy and reconstruction: Approaches to archaeology amd

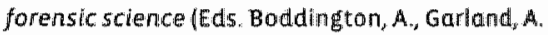
N. and Janaway, R. C. Manchester Universily Press, Manchester, p. 65-78.

Manzi, G., Salwadei, L., Vienna, A. and Passarello, (1999) Discontinuity of life conditions at the transition from the Roman imperial age to the early midile ages: Example from central Italy evaluated by pathologicall dento alveolar lesions, American Journal of Human Biolagy, 11, p. $327 \cdot 341$

Maresh, M. M. (1955) Linear growth of long bones of extremities from infancy through adolescences American Journal of Diseases in Children, 89 . p. $125-142$

Martin, R. and Saller, K. [1957), Lehrbuch der Anthropologie in systematischer Darstelung. Stuttgart.

Mays, S. (1998) The archaeology of human bones, Routledge, London

Mays, s. and Cox, M. a. (2000) Sex determination in sheletal remains in Human osteology in archaeology and forensic science (Eds. Cox M th and Mays, S.) Greenwich Medical Media Ltd. London, p. 117-13:0. 
Mcrulley. II and Roberts, C. A. (1993) Excavation whd post-xcavatian treatment of cremated and unhumed human remains, Birmingham

Mekituerick, R. (Ed) (1995) The new Cambridge medieval history, Cambridge University Press, Cambridge.

Whowirs, A. Viner, L and Wells, C (1982) RamanaBritish cemeteries at Cirencester, Cirencester Excavation Committe, Cirencester.

Wekking, A. (2000) Die Darstellung der Flucht noch Agypten und des Bethlehemitischen Kindermordes in der servatiuskirche zu Mcastricht. Eine Syrische lkonographie ouf einem Jruhmitteld terlichen Chorschrankenrelief a.ts Metz? In L'évangelisation des régions entre Metse et Moselle et la fondation de l'abbaye Winternach (VevXe siecle), Val, 117 (Ed. Polfer, M.) Luxembourg.

Wekking, A. J.) (1986) De Sint-Servaaskerk te Madstricht: Bijdragen tot de kennis wan de symboliek en de geschiedenis van de bouwrelen en de bouwsiculptuar tot circa 1200, Clawis, uitrecht.

Melzer, W. (1993) Das fräkische Gräberfeld von Saffig, Kreis Mayen Koblenz, Verlag Marie L. Leidorf, Buch am Erlbact.

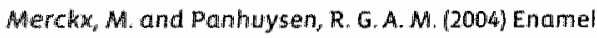
hypoplasia and health during childhood in early med leval Madricht and nineteenth century Zwolle The Netherlands), Programme and dibstracts of the 1sth European meeting of the paleopathalogy Association, Durham, U.K., P. 6 .

Merret, D. C and Pfeiffer, \$. (2000) Maxillary Sinusitis as an Indicator of Respiratory Health in Past Populations, American Journat of Physical Anthropology, 111, p. 301-318.

Martens, I. (1987) De weg Boulogne-Keulen op Be gisch grondgebied in Langs de weg (Eds. stuart, P. and de Grooth, M.E.T.) Thermenmuseum, Heerlen p. 16-21.
Mertens, 1. (1990) La destine des centres urbains gallo-romains a la hmiere de l"archélogle des textes In La gendse et les premiers sidcles des villes medievales dans les Pays-Bas méridionaux. un probleme archéologique et historique, Vol, 83 Crédit Communal, Brussels, p. 6174 .

Meschan, 1. (1975) An Atlas of Anatomy basic to Radiology, W. B. Saunders Company, Phitadelphia.

Micozzi, M. S. 199.1 Postmortem change in human and animal rematns: a systematic approach, Charles C Thomas, Springfield.

Molieson, T. 1. (1991) Demographic implications of the age structure of edrly English cemetery samples in Ville et campagne en Europe occidentaie fve. XWe siècle), Vol. 14. (Ed. Buchet, L) CNRS Editions, Paris, D, 113-122

Molleson, T. H. (1994) Can the degree of sexua dimorphism provide on insight in to the position of women in past populations? In La femme pendant le moyen age et l'epoque moderne, Vol. 17 (Ed: Buchet, L.) CNRS Editions, Pari 5, p. 51-67

Mollesom, T. ll. and Cox, M. (1993) The Spitalfields project. Wolume 2 : the anthropology The middling sort, London.

Moore Jr., T. C., Rea, D. K. and Godsey, H. (1998) Regional variation in madern radiocarbon ages and the hard-water effects in Lakes Michigan and Hurom, Journal of Paleolimnolagy 20. p. $347 \cdot 3.51$

Morris, 1. (1992) Deathvitual and social structure in ciassical anciquäty, Cambridge University Press, Camburidge.

Morrisan, K. F. and Grunthal, H. (1967) Carolingian coinage, New York.

Najjar, M. Y. E. and MicWilliams, K. R. (1978) Forensic anthropology, Charles C Thomas, springfield

Nawrocki, S, P, (1995) Taphanimic processes in historic temeteries In Bodves of evidence: Reconstructing history through skele tal a nalysis IEd. Graweir, A. L.) New York, D. 49-66. 
Welson, 1. L. (1995a) The Frankish kimgdoms; 144898 the West In The Wew Combridge Medieval History, Vol all ic. 700 G. 900 (Ed, Wickitterick, R.) Cambridge university Press, Cambrige, p. $110-14.1$

Nelson, ). L. (1995t) Kingship and royal government In The New Cambridge Mediewal History, Voll Ill c. 700.C. 900 (Ed McKitterick, R.) Cambridge University Press Cambridge, p. 383-430. Nirmeyer, D. F. (1984) Mediae latimitatis lexicon Minus, E.].Brill, Leiden.

Mithard (1907) Historiarum Libri Mil, in Manumenta Germanhae historica, Scriptores in usum scholarum, Vol. 44 (Ed Muller, E.) Hannover. Nomn, U. (1983) Pagus und Comitatus in Miederbothringen: Untersuchungen zur politischen Raungliederung im Frahen Mittelalter, Bonni.

Novak, S. (2000) Battle-related trauma in blood red rases: The archaeology of a mass grave from the battle of Towton AD 14E1 (Eds, Fiorato, $V_{\text {, }}$ Boylston, A. and Knüsel, C.) Oxbow books, Oxford p. $90-102$.

Ohler, N. (1990) sterben und Tod im Mittelalter, Artamis Verlag, München.

Olivier, G. (1963) L'estimation de la stature par les os long des membres, Bulletins et Mémoires de la Societe dianthopologie de paris, 4, p. 433-449.

OLLughlin, W. D. (2004) Effects of different kinds of cranial deformation on the incidience of Wormian bones, American lournal of physical Anthropology, 123, p. $146 \cdot 155$.

Orther, D. 1. (2003) Identification of patholagical conditions in human sketetal remains Academic Press, Amsterdam.

Ortner, D. 1. and Aujderheide, A. C. (Eds.) (1991) Human paleopathology: Current syntheses and future aptions, Washington.

Ortner, D. I. and Putschar, W. G. 1. (1985) Identification of pathological conditions in human sketetal remains, Washington.
Otten, T. (2003) Die Ausgrabungen unter St. Viktor zu Xanten: Dom und immuntät, Mainz.

Paine, R R. and Boldsem, 1. L. (2002) Linking ageath death distributions and ancient population dynamics a case study in Paleodemography oge distributions from skeletal samples vol. 31 lEds. Hoppa, R. D. and Vaupel, J. W.J Cambridge University Press, Cambridge, p. 169-180.

Panhulsen, R. G. A. M. (1989) Giselbert H wan Latharingen, een tweede Catilina?, Leiden/ Münstier.

Panhuysen , R. G. A.M. (1994) Begravingen in het: Witte Wrouwenklooster in De Theateropgraving in Madstricht (1988-1989), Vol. I (Ed. Hulst, R. A. . Madstricht, p. 61-63.

Panhuysen, R. G. A. M. (1995) Paleopathology and history: one story many sources in Proceedings. of the IXth European meeting of the paleopathology Association: Barcelona Ist - 4th September, 1992 (Eds. Batista, R., Campillio, D. and Carreras, T.) Museu d'Arquelogia de Catalunya, Barcelona, p. 263-266.

Panhuysen, R. G. A. M. (1999) La populatian maastrichtobs du We au WNe sięcle in Masa Nastra, Val. 23 (Eds. Plumier, ), Plumier-Torfs, 5. and Regnard, M.) Namur, p. 39.40.

Panhuysen, R. G. A. M. (2000) Ropportage menselike skeletrestern, Deel 2: resultoten van helt fysisch antrapollogisch onderzoek in Aarvullend Archeolagisch Onderzoek Borgharen-Pasestract lgem. Maastricht) (Eds. Hulst, R. A. and Dijkman: W.) Mansticht.

Panhuysen, R. G. A. M. (2002) Het scherp van de snede, Sparen van geweld in wroegmiddelee iws Maastricht, Archeologie in Limburg, 92, p. 27.

Panhuysen, R. G. A. M. (2005a) Human skeletal remains at the Baschstraat site (MAGM-B): $A$ catalogue of thhumations with archaeological, physical anthropological and palaeapathological data, Maastricht. 
Panhuysen, R. G. A. M. (2005b) Human skeletal remains at the Serwas church site (MAKK-3): A calatogue of inhumations with archaeologicat, physical anthropological and pallae opathological data, Naastricht

Panhuysen, R. G. A. M. (2005c) Human skeletal remauns from the Chapelle Saint Hilaire site Namur, Betgim): A catalogue of inhumations: with archaeological, physical anthropological ard palaeopathological data, Mastricht.

Panhuysen, R. G. A. M., Couenen, V. and Bruintjes, T. D. (1997) Chranic maxillary sinusitis in medieval Maastricht, The Netherlands, International Joumal of Osteoarchatology, 7. p. 610614.

Panhuysen, R. G. A. M. Walenkamp, G. H. I. M. and Maat, G. J. R. [1994] Osteolytic lesions on humerus and clowlelle, Homo, 45, p. 597 .

Panhulysen, R. G.A. M., Walenkamp, G. H. I. W. and Maat, G. J. R. (in press) Cortical "defects" in humerus and clawicle in pateopothology today. Proceedings of the Xuth European Meeting of the Pialeopathology Association, Götingen, 29th August - 3rid september 1994. (Eds. Schultz, $\mathrm{M}_{\text {* }}$ Tieegen, $W$ - $R$, and Kreut $2, K$, Verlag Marie Leidorf Rahden.

Panthuysern, T. A. S. M. (1982) 1981. MAKK. 3: Een millpaal in het onderzoek van de Sint Servaas in Campus Liber, vol. 8 Limburgs gieschled en Owdiheidkundig Genow tschap, Mastricht, 1. 21.54

Panthysen, T. S. M. (1984) Macstricht stoct op zijn verleden, Stichting Historische Re elks Maastricht, Madstricht.

Panhuysen, T. A. S. M. (1986) Wat weten we over de continuifteit van Masastricht? in Sint Servatius, bisschop yan Tongeren-Mastricht. Het vrowgste Christendom in het Maasland, Wol. 28 (Ed de Dijn, G.) Borgloon, p. 125-146.

Panthysen, T. A. S. M. (1988) Humbertus, bouwher wan de Sint-Serwaskerk te Maastricht, overleden 2 mel 1086, De Maasgouw, 107, p. 159-163.
Panhuysen, T. A. 5. M. (1990) Die Maastrichter Servatiuskirche im frothmittelater: Ein Vorbericht uber die jüngsten Grabungen des städ tischen Amtes für Bodendenkmalplege Mastricht, Kunstchronik: Manatschriftefor Kunstwissenschaft, Museumswesin und Denkmolpflege, 43. p. 541-553.

Panthuysen, T. A. S. M. (1991) De Sint-Serwaaskerk te Maastrichtin de wroegie middeleeuwen. Voorlopig eindverstag wan de opjrawingen door de dienst Stadsontwikkeling Maastricht in de periode 1981-1989, Bulletin van de koninklijke Nederlandse Oudheldkundige Bond, 90, p. 15.24.

Panhuysen, T. A. S. M. (19920) Die Euregho Macs. Rhein, 300 bus 1250. Von der Peripherie lins Zentrum der europulschem Geschichte in Spurensicherung: archöologische Denkmalpflege in der Euregio Maas-Rhein, Vol, 136 IEds. Bauch hen B, G. and von Prittwitz U. Gaffrom, H.H. Verlag Phitup von Zabern, Mainz an khein, P. 115-144.

Panhuysen, T. A. S. M. (1992b) Techniseth verslag van het archeologisch bodemonderzoek in de sintSienvaskerk te Mastricht, Mastricht, p. 14.

Panhuysen, T. A. S. M. (1996a) Barbarische ader römische Barbarel? In Akten des 3. internationalen Kolloquíms aber Prableme des provinziatrom ischen Kunstschafrens fed. Bauchien $\beta_{n}$ G.j Dr. Rudoly Habelt GmbH, Bonn. p. 121-126.

Ponhuysen, T. A. 5. M. (1996b) Romeln.s Maastricht en zijr beelden, Van Gorcum, Mastricht.

Panhuysen, T.A. S. M. and de la Haye, R. (2002) 2 . Madstrichtin Province ecclésiastique de cologne (Germanic Secunda), Vol. XII (Eds. Gauthier, $N$, Beoujard, D. and Fr, P.j De Goccord, Paris, p. $91 \div 115$.

Panhuysen, T. A. S. M, Dljkman, $W_{s}$ Hulst, R. A. and Panhuysen, R. G. A. M. (1991) Opgravingen door het Gemeentelijlk oudheidkundig Bodiemonderzoek Madiricht (GOBM) in het jaar 
2990 from: Stoepker, (Ed.) Archeologische kroniek yan Limburg over 1990 , Publications de la Socter Hishorique et furcheloginge dans le Limbourg, 127 , p. $237 \times 251$.

Panhuyseri, T. A. S. M., Dikman; W. Hulist, R. A. and Panthuysen, F. A. M. (2992) Opgravingen door hest Gernentelijk Oudheidkundig Bodemonderzok Madstricht (GOBM) in het jaar 1991 From" Stoepker, H. (Ed) Archeologische kroniek van Limbuig over 1991, Publications de la societe Historigue et Archéloginge dans le Limbourg, 128, p. 259288.

Pankulysen, T. A. S. M. and Leupen, P. H. D. (1990) Marstricht in het eerste millenildm: De wroegste sticudsontwikkeling in Nederland, in La genèse et les premiers siecles des villes mediévales dans les Pays-Bas méridionaux Un probleme archéologiqua et historique, vol 83 Brussels, p. $411 \cdot 455$

Parkin, T. G. (1992) Demography and Roman soclety. The Johns Hopkins University Press, Baltimore. Paxton, F. S. (1996) Christianizing death: the creation of a ritual process in early medieval Europe, Comell University Press, New York.

Pearson, K. (1898) On the Reconstruction of the Stature of Prehistoric Races, Philosophical Transactions of the Rayal Saciety 1924, p. $169-244$.

Pearson, K. L. (1997) Nutrition and the early-medieval diet $.5 p$ eculum, 72, p. 1.32.

Ferizonilus, W: R. K. (1982) Excavation data of skeletal remains for the human osteologist; questionmaire for the archaeologist, Journal of Human Evolution, 11, p. 461.479

Pfäfgen, B. (1992) Die Ausgrabungen in St Severin zu Koin Tell 1, Verlag Phillpp won Zaberm, Mainz cam Rhein.

Pfdffgen, B. and Ristow S. (1996a) Die Religion der Franken im Spiegel der archiologischer Zeugnisse In Die Franken - Wegbereiter Europas, Vol 2 (Eds. Wieczorek, A, Pérn̈m, $\mathrm{P}$, won Weltek, K. and Menghin, W.) Philipp von Zabern, Hain, p. 7388744.

Pfaffigen, B. and Ristow, 5. (1996b) Die Romerstodt Köln zar Merowingerzeit In Die Franken. Wegberëter Europas, Vol. 1 Lds. Wieczorek, As Perin, Pi, won Welck, K and Menghin, W. Philipp vion Zabern, Mainz, p. 145-159.

Pilet, C. (Ed.) (1994) La nécropole de Saint-Martin-déFontenay, Calvados, Editions du CNRS, Paris:

Pilet, C. (1996) Chrono-typolagie des combes de Normandie in Archeologle du cimetière chrétien FERACF / La Simarre, Tours, p. 251-255.

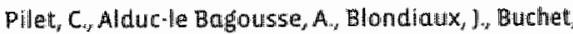
L. Grewin, G. and Pilet-Lemière, ], (1990) Les nécropolles de Giberville (calwados) fin du ve stecle - fin du vile siécle ap. 1,C, Archéologie Médiévale, $\times \times(1990)$, p. 3-140.

Pol, A. [1995) Les monetaires d Huy et Marastricht. Production et distribution des monnales merovingiennes moscunes, Buthetirn de l'institut Archélogique Liegeois, 107, 185.200.

polet ${ }^{C}$. and Katzenterg. M. A. (2003) Reconstriction of the diet in a mediaeval monastic commumity from the coast of Bellgium, lournal of Archaeological science, 30, p. 525-533.

Polet, C., Orban, R. and Herbosch, A. (1994) Différences sexullles des teneurs en zimc et en strontium dans les ossements humains de quelques echantillons medievoux de Belgique (résultats préliminaires) in La femme pendant le moyen age lepoque moderni, vol 17 CNAS Editions, Paris, p. 173-187.

Pontal, 0. (1989) Histoire des canciles merovingiens. Editions du Cerf, Paris.

prowell, M. L. [1988] Status and hed th in prehistory, Washington.

Pycke, (1990) "Urbs fuerat quandam, quod adhuc vestigia monstrant" Reflexions sur l'histohe de Toumai piendant le Haut Moyen Age We-Xe siecled, in La genése et les premiers siecles des villes mudiévales dans les Pays-Bas meridionaw 
Un probleme archeologique et historique, vol. 83 Brussels, p. 212.233 .

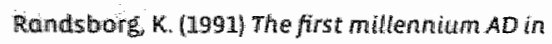
Europe and the Mediterranean: an archaeological essay, Cambridge.

Reich: K. I. (Ed) (1986) Forensic osteology: Advances in the identification of human remairs,

Springfield.

Renes, 1. (1988) De geschiedenis van het zaidhmburgse cultuurlandschap, Van Gorcam. Assen.

Resnick, D. (1996) Bone and joint imaging, W.B. Saunders Company, Philadelphia.

Reynolds, S. (1994) Fiefs and vassials: The medieval evidence reinterpreted, oxford.

Riche; P. (1983) Les Carolinglens; Une famille qui fait Purope, Hachette, Paris.

Richer (1930) Histoire de France, Vol. 1 (8848-954) (Ed. Latouche, R.) Paris.

Rididle, $1 . M$. (1994) Contraception and abortion from the ancient world to the Renaissance, Harvard Unversity Press, Cambridge.

Rivet, L. (Ed) (1992) Actes du congrès de Tournai 28 31 mai 1992, société Françailse d'tetude de la Ceramique Antique en Gaule.

Rabb, 1., Btgazzi, R., Lazzarini, L., Scarsimi, $C$ and Sorrega, F. (2001) social "status" and biological "status": a comparis on of grave goods and skeletal indicators from Pontecaghario, American Journal of physical Anthropology, 115, p. $213-222$.

Hobuts, C. and Cox, M. (2003) Health and disease in Britain, from prehistory to the present day. sutton Publishing.

Roberts, C. Lee, Fand Bintliff l. (Eds ) (1989) Burial archaeolagy: Current research, methods and developments.

Roberts, C. and Manchester, K. (1995) The archoeology of disease, Alom sutton Publishing Mever York.
Rouriguez; W. C. (1997) Diecomposition of buried and submerged bodles in fortensic taphonomy: the postmortem fate of human remains $\mathrm{EdS}$. Haglund w. D and Sorg M. H. CRC Press, Boca Raton, p. 459-467.

Roebroeks, W. (1992) Won "Umenschern". Landschajtszerstorung und archalogischer Forschung in der Grube Mastricht-Belvédere in Spurensicherung: archalogische Denkmalpflege in der Euregio Maas Rhein, Vol. 136 /Eds. BauchhenB, G. and won Prittwitz u. Gaffron, H.H.) Veriag Philipp wan Zaberm, Mainz am Rheil, p. $413-420$

Roemen, H.C. W. (1947) Macstricht: Een geografische - Hoofdzakelijk ecanomisch-geografische. beschriving en verklaring der agglomeraties in de gemeente Mastricht, p. 345.

Rogers, J. and Waldron, T. (1995) A field guide to joint disease in archeology, John Whey Sons Chichester.

Rogers, J: and Waldron, T. (2001) DISH and the monastic way of life, International journal of Ositeoarchaeology; 11 , p. 357.365 .

Rogers, J. Waldron, T, Dieppe, P. and Watt, I. [1987] Arthropathies in paialopathology: the basis of: classification according to mast probable cause, journal of Archabological Science, 14, p. 179-193. Roosens, H. (1973) Siedlung whd Bewolkerungsstruktur im splegel merowlingischeir Graberfelder in siedlung, sprache und Bevökerungsstruktur tim Frankenreich, Vol. 49 (Ed. Petri, F) Wissenschaftliche Buchesellschaf, Darmstadt, p. 383-399.

Roosens, H. (1989) De Merovingische vondsten op het grondgebied van Groot Bilizen in Bodemschatter: Archeologisch onderzoek in Groot Blzen wan de Bandceramlek tot de Merovingers (Eds. Gorissen, M. and Roosens, B.) Stadsbestutur von Btzen, Bilzer, p. 50.59 . 
Roosens, H, De Boe, G. and De Mevlemeester, D. 1976) Het Merowhisch grafveld van Rosmeer, Nationale Dlenst voor Opgravingen, Brussel. Roth, H. (1986) kunst und Handwerk im frihen Mitcelolter: Archalologische Zeugntse von Chllderich f. bis zu Karl dem Grossen, Konrad Theiss Verlag, stuttgart.

Rouche, M (1973) La folm a l'époque carolingienne, Revue Historique, 250, p. 295-320.

Russell, W. M. 5. (1983) The palaeodemographic view un Disease in ancient man (Ed. Hart, G. D.) Clarke Irwirn, Ontario, p. 217-253:

Sablerolles, $Y_{\text {, Henderson; }}$, and Dikman, W. (1997) Early medieval glass bead making in Mastricht (Jodenstraat 30); The Netherlands An archaealogical and sciemtific investigation in Perlen: Archäologile Jechniken, Analysen, vol. I (Eds. von Freeden, U. and Wieczarek, A.) Dr. Rudolf Habelt GmbH, Bonn; P. 293-313

Sallin, E. (1952) La civilisation Mérovinglenne: d"après les sepultures, les textes et le laboratoine, Editions Picard, Paris.

Sapin, C. (1996) Dans l'église ou horsil'église, quel choix pour linhume? In Aschéologie du cimetière chretien (Eds. Gatinie, H. and Zadora.Rio, E) FERACF/LA SIMARRE, Tours, p. 65-78.

Saunders; 5. R. (1992) 5ubadult skeletons and growth related studies in skeletal biology of past peoples: research methods (Eds. Sounders, S. R and Katzenberg, $M$. A. New York, p. 120.

Saunders, S, R. and Barrans, L, (1999) What can be done about the infant categary in skelletal samples? in Human growth in the past (Eds. Hoppa, R. D. and Fitzgerald, C. M.) Cambindge Universtry Press, Cambridge, p. 183.209.

saunders, 5. R, and Herring A. (Eds.) (1995) Grawe Reflections: Portraying the Past through Cemetery Studies, Canadian Stholars' Press Inc., Toronte.

Saunders, S. R., Herring, D. A, and Boyce, G. (1995) Can skelletal samples accurately rapresent the living population they come from? The St. Thomas cernetery site, Bellewille, ontario In Bodies of evidence: Reconstructing history through s.keletal analysis (Ed, Grauer, A. L.) New Yark, D. $69-89$

Saunders; 5. R. and Katzenberg, A. IEds.) (1992] Skeletal biology of past peoples: research methods, New York.

Schaeffer, U (1963) Anthropologische Untersuchung der Sketatte von Haithabu, Kanl Wachholtz Verlag Neuminster.

Scheser, L. and Black, S. (2000) Dewelopmental Jumenile Osteology Acadenic Presis, san Dïego.

Schuta, R. 1. (1990) The language of fractures. Williams Wikins, Baltimore.

Schutkowski, H. Hermann, B., Wiedemann, $F$. Bocherens, H. and Grupe, G. (1999) Diet, status and decomposition at Weingarten: trace element and isotope analyses on early mediaeval siketetal material, Journal of Archaeological science, 26 , p. 675-685.

Schwartz, ). H. (1995) Skeleton keys, oxford University Press, oxford.

Shauffer, I. A, and Collins, W. V. (1966) The deep clawicular thombold jossa journal of the American Medical Association, 195, f. 778.779.

simon, C. and Leemans, E. (1991, Probleme pose par une population moyendgeuse de la campagne genevoise (Satigny-Genéve) In ville et camplagne en Europe occidentale (ve - Xwe sidede) Wol 1 it (Ed. Buchet, L) CMRS Editions, Paris, p. 135-154.

Siraisi, N. G. (1990) Medieval and early Renassonce medicine: an introduction to knowledge and practice, the University of Chicago Press, Chicago.

Sithanni, I. E. and Högins, R. L. (1995) A comparison of death records from the Monroe county almishouse with skeletal remains from the associated Highland Park cemetery In Grave reflections: Portraying the past through cemetery studies (Eds. Saunders, S. R. and 
Herming, A.) Canadiart Scholars Press, Toronto, p. 71-89:

Skĭmer, M, and Goodman, A. H. (1992)

Anthopological uses of developmental defects of enamel in skeletal biology of past peoples: research methods (Eds. SaunderS, S.R. and Katzenberg, M. A I Wiley Liss, New Yark, p. $153-174$.

Silaus, Mol, Kollmann, D, Nowak, 5. A. and Novak, M. (2002) Temporal trends in demogiaphic profiles and stress levels in medieval (6th-13th ventury) population samples from continental croatia, Croatian Medical Journal, 43, p. 598-605.

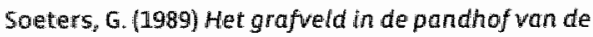
St Servaaskerk te Mastricht, Maastricht, p. 115. Sprenger, 1. (1956) Fundamentresten, een tweetal sarcophagen en een 17e eeuwse grafsteen gevonden te sint Pheter, te Maastricht; De Maasgoum, 70, p. 141-150.

Sprenger ]. (1958) Herkamst der sarcophagen in de crypten der St. Serwas-kerken in het Bonnefantenmuseum te Madstricht, De Matsgoww, 72, p. 1-12.

5it. Hoyme, L. E. and liscan, M. Y. (1989) Determination of sex and race: coccuracy and assumptions in Reconstruction of life from the skeleton (Eds. Iscan, M. Y. and Kennedy, K. A. R. J New York, p. 53-94.

Staab, f (1996a) Die Franken - Wegberehter Europas In Die Franken - Wegbereiter Europas, Vol. 1 IEds Wéczoriek; A., Pểrin, P. won Welck, $K$ and Menghin, W.) Phillipp von Zabern, Mainz, p. $10-22$. Staab, F. (1996b) Die Gesellschaft des Merowingerreichs In Die Franken "Wegbereiter" Furapas, Vol. 1 leds. Wieczoreh, A. Perin, P., won Welck, $K$ and Mernghin, W.j Werlag Phillipp won Zaberm, Mainz, p. 479-484:

Steckel R. H. and Rosie, ]. C (2002) The Backbone of Mistory: Health and Nutrition in the Western Hemisphere, Cambridge University Press, cambridge.
Stedman, T. L. (1990) Stedman's medical dictionary, Willitams e Wilkins, baltimore.

Steinbach, E. (1926) Studien zur Westdeutschen Stammes-und votks geschichte, stuttgart.

Stever, H. (1982) Frahgeschichtliche Sozialstrukturen in Mitteleuropa, Vandenhoeck e Ruprecht, Gottingen.

Stirhand, A. J (2000) Raising the dead: the skeleton crew of Henry WIIs great ship, the Mary Rose, JohnWiley Sons, Cichester.

Stoodley, (1999) The spindle and the spear. A critical enquiry into the construction and meaning of gender in the early Anglo Saxon burial rite, Archoeopress, oxford.

Stork, 1. (1997) Friedhof und Dorf, Herrenhof und Adelsgrab: der einmallige Befund Latheim un Die Alamannen (Eds. Fuchs, K. Kempa, M., Redies, R., Theune-Girosskopf, B. and Wais, A. Konrad Theiss Verlag, stuttgart, p. 290-310.

Stroud, G. and Kemp, R. L. $(1993)$ Cemeteries of the church dud priory of 5 t Andrew, Fishergate, Council for British Archaeology, Yark.

Sulivan, A. (2004) Reconstructing relationships among mortallity, status, and gender att the Medieval Gllbertine Priory of 5t. Andrew, Fishergate, York, American Journal of Physical Anthropology, 124, p. 330.345 .

Tanner, 1. M. (1978) Faetus trito man, Harvard University Piress, Cambridge.

Theis, L. (1990) Lheritage des Charles: De la mort de Charlemagne aux environs de lan mil, edition's du Seull, Paris.

Theuws, F. C. W. ) (1988) De archeologie van de perfferie: Studies naar de ontwikkeling van bewoning en samenlewing in het Maas DernerSchelde gebled in de wroege middeleouwen, in Faculteit der Ruimtelijke wetenschappenAmsterdam, p. 351.

Theuw 5, F, C W I. (1998) Changlig settement patterns, burial grounds and the symbolic construction of ancestors and communities in 
the lote Nerowingian southern Netherlonds, In Settemerit and Landscape (Eds. Fabech, $\mathrm{C}$ and Ringtwed, I) Arhus, P. 337-349.

Theuws, C. W.). (2001) Mastricht as a centre of power in the early Middle Ages in Topographies of power in the early Mtadale Ages Vol. GlEds. de Jong, M. and Theuws, F. C. W. I. Brill, Leiden, p. 155216 .

Theuws, F. C. W. J. (2003) De sleutel van Sint Servads: vitwlsselling, relighe, identiteit en centrale plaatsen in de Vroege Middele euwen, Vossluspers UVA, Ansterdam.

Theuws, F. C. W. l. and Hudink, H. A. (1996) Der Kontakt zu Rom In Die Franken-Wegberehter Europas, Vol 1 IEds. Wieczorek, A., Perin, P.; von Welck, Kand Menghin, W.J Philipp won Zabeirn, Mainz, p.66-80.

Thirion, E. (1985) L'origine des sarcophages et leur Wiffusion dans la wallee de la Meuse; in la civilisation mérovingienne dans le bassin mosane, Vol. 22 (Eds. Willems, y. and otte. M.) Amcy-Liege, p. 171 - 180 .

Timmers, 1. ). M. (1955) Twee vroege grafschriften uit de pandtuin der Maastrichtse $5 t$. Servaas, Bulletin wan de Kaninklike Nederlandse Oudheidkundige Bond, 8, p. 77.84 .

Toussaint-5amat, M. (1994) A history of food, - lackwell, cambridge.

Trancho, 6. 1., Campillo, D. and Sanjose, N (1995) Thbial periostitis in several individuals of the Vallisoletana thecropolis at Wamba [Spainu (15th. 17th century a d. In Procedings of the $x$ th European meeting of the pateopathology Association: Barcelona 1 st - Ath September 1992 (Eds. Batista, R., Compillo, D. and Carreras, T.) Museu di' Arquelogia de Catalunya, Barcelona, p. $407 \times 4.15$

Treffort, C (1996) L' eglise carolingivenne et la mort. Christionisme, rites fundraines et pratigues commenoratives, Presses universitatres de Lyon, Lyon.
Tratter, M. (1970) Estimation of stature from intact limb bones in Personal identification in mass disasters (Ed. Stewart; T. D) Smithsonilam Unstitution, Washington, p. $7 \mathrm{i} \cdot 83$.

Trotter, A. and Gleser, G. C. (1958) A re-ewaluation of estimation of stature based on mecsurements of stature taken during life and of llongtoomes after death, American lournal of Physical Anthropology, (n.s.) 16, p. 794.123.

Tyrell, A. (2000) Skeletal non-metric traits and the assessment of inter-and intrapopulation diversity: past problems and future potentid in Human osteology in archa eology and forensic siclence (Eds. Cox, M. a. and Mays, S.) Greenwich Medical Media, London, p. 289-306.

Ubelaker, D. H. (1989) Human skeletal remains. Excavation, analysis, interpretation, Taraxcum, Washington.

Uligaszek, 5. J. (1994) Growth monitoring and growth cyclicities in developed countries in Anthroponetry: the individual and the population (Eds. Uijaszek, 5. J. and Mascie-Toylor, C. G. N.) Cambridge Unversity Press, Cambridge, p. $99 \cdot 107$

Ulrith Eochster, 5. (1997) Anthropologische Befunde zar stellung von Frau und kind in Mittelatter und Neuzeit. soziobiologische und soziokuture the Aspekte im Lichte von Archaologie, Geschichte. Volkskunde und Medizingeschuchte, Haupt Verlag Bern.

Walenzuela, C. Y. (1983) Pubertal origin of the larger sex dimorphism for adult stature of a Chilear population, Amenican yournal of Physical Anthropology, 60, p. 53060 .

Wan Dam, R. (1988) Gregory of Tours: Glory of the confessors, In Translated Texts for Historians: Latin Sertes, Vol. IV Liverpool, p. 127.

Van Impe, L., Huyge, D., Van Laere, R. and Vynckier, $G$. (1992) Archdolog ische butersuchungen im Demertal und seiner vimgebung in spurensicherumg: archäologische Derkmalpfege 
In der Eunegio Mas Rhein, Vol. 136 lEds.

Bauch hen 18 , G. and won Prittwitz U. Gaffron, H. H.)

verlag: Phillipp von Zabern, Mainz am Rheir.

p. $5,50-572$

Wan Lith, 5. M. E. (1987) Late Roman and early

Merovingian glass from a setlement site at

Manstricht (Dutch sauth Limburg) Part 1 , Journal

of Glass studies, 29 , p. 47-59.

Wan Lith, 5. M. E. (1988) Late Roman and early

Merovingian flass from a settlement site at

Maastricht, (Duteh south Limburg) Part ll, journal

of Glass studies, $30, p .6276$

Wan Ommeten, H.R. (1991) Bronnen woor de (geschiedenis yan Marasticht (359-1204): Deell: Bronmen betreffende het tijdvak vanaf het jaar 359 tot en met 923 , publications de la societé Historique et. Archeologique dars le Limbourg, $127, \mathrm{p} .5-48$.

Van Ossel, $\mathbb{P}_{n}(1992)$ Etablissements ruraux de Antiquite tardive dans le nord de la Gaule, Editions du CNRS, Paris.

Vamderhoeven, A. (2002) 1. Tongres In Province ecclesiastique de Calogne (Germania Secunda) Wol. XII (Eds. Gauthuer, N., Beaujard, B. and F $\pi_{\text {. }}$ P.) De Boccard Paru.s, p. 75-89.

Vanderthoeven, A, Nouwen, R. and Vynckier, G. (1992) Tongen In Spurensicherung: archăologische Denkmalphege in der Eureglo Mads-Rhein, Vol.

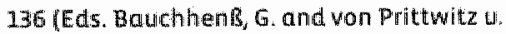
Gaffron; H-H4) Veriag Philpp von Zabern, Manrz art Rhein, p. 387.402

Verthulst, A. (1995) Economic organisation In The New Cambridge Mediewal History, Vol. II c. 700-c.900

(Ed. Mckitterick, R.j Cambridge University Press, Combridge, P. 48:509.

Verhulst, A. (1999) The rise of cities in north-west Europe, Cambridge University Press, Cambridge. Werwers, "W. J. H. (1986) Her grafveld in de Pandhof wan de Sint toServaas te Macistricht: een voortopig verslag In Munsters in de Masgouw, vol. 9
Limburgs Geschied-en Outheldlkundig

Genootschap, Manstricht, p. 56.71

Wos. A. D. (2002) Resten wan Romeinse bruggen te Maastricht in de Maas, Lelystad

Wahl 1 . (1985) Graber der Vorzeit: Knochen erzahlen von Leben, Kronkheil und Tod In Der Keltenfurst von Hochdarf, Hethoden und Ergebnisse der Landesarchaologie [Eds. Planck, D, Btel, i, Süsskind, G. and Wais, A.) Konrnd Theiss Verlag $\mathrm{GmbH}_{*}$ 5tuttgart, p. 288.913.

Waldion, T. (1985) DHSH ac Merton Priory: evidence for a "new" occupational disease?, Eritish Medical Journal, 291, p. 176:2-1763.

Waldron, T. (1987) The relative surwival of the human skeletorr: implications for palaeopathology In Death, decay and reconstruction: Approaches to archaeology and forensic sclerke (Eds. Boddington, A., Garliand, A. N and Janaway, R. C.) Manchester University Press, Manchester, p. $55+64_{\text {t. }}$

Walidron, T. (1994) Counting the dead, John Whey e Sons, Chichester.

Walker, P. L. (1995) problems of preservation and sexism in sexing: some lessons from historical collections for pallaeodemographers in Grave reflections: portraying the past through cemetery situdies lEds. Saunders, S. R. and Herring, A. Conadian Scholars press, Toronto, p. 31.47.

Walker, P. L., Johnson, ) R. and Lambert, P. M. (1988) Age and sex bias in the preserwation of human skeletol remains, Amarican Journal of Physhical Anthropology, 76, p. 183-188.

Wampach, C. (1935) Urkunden-und Quellenbuch zur Geschühte der altuxemburgischen Territorien bis zur burgundischen Zeit, Vol. ILkemburg. p. 160.

Weaver, D. S (1986) Forensic aspects of fetal and neonatal skeletons in Forensic asteology. advances in the idertificotion of human remains 


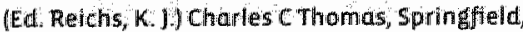
p. $90-100$

Weber, 1 and Czarnet $k$, A. (2001) Brie Communication Ne rotratmatologicat aspeds of Head Injures Resuhing From Sharp and Blunt Force in the Early Medieval Perlod of Southwestern Germany, American lournat of Physicat Anthropology 174 , P. 352-356.

Weidemann, M. (1990) Dle krehliche Organisation der Provinzen Belgica una Germania vom 4 bis zum 7 , Johrhundert in Whbrord, ziln werelden ziln werk Voordrachten gehouden thdens het Will briordcongres Nijmegen, $28-30$ september 7989, Vol.6 (Eds. Bange, $P$, and Weller, $A, G$ G) Mijmegen, p. 286.

Weinfeld, R. N, Olsen, P. N, Maki, D. D and Grifffths, H. 1: (1997) The prevalence of diffuse idiopathic skefetal hyperastosis (DISH) in two lare Aimericam Midwest metropolitamhospital populations, skeletal Radiology, 26, p. 222225 .

Weis5, E. (2003) Understanding Muscle Markers: Aggregation and construct Validity American journal of Physical Anthropology, 121, p. 230240

Weiss, K. M. (1972) On the systematic bias in skeleta sexing, American Journal af Physical Anthropotogy, 37, 2 239-250.

Wells, $c$ and Green, $C$ (1973) sumrise datime of death and burlal, Norfolt Archiaeology, 35, p: 435-442.

Wisner, J. (1973) Zur Entstehung der Reltheng biberzivilisation In steduing, sprache und Bevolkerungsstruktur in Frankenrelch, Wol. IL (Ed Petri, H) Wissenschaftiche Buchgeselischoft, Darmstadt, p. 285-325.

Werner, M. (1980) Der Latticher Raum in Frihkorolinglscher zeit Untersuchungen zur Geschichte elner karolinglschen stammlandschaft, Vandenmoeck exprecht. Gotting ext.

Wieczorek, $A_{3}$, Perin, $P_{\text {, w }}$ won Welck, $K$, and Menghin, W: (Eds.) 1996) Die Franken - Wegbereiter Europas, Philipp won Zabern, Mainz.
Wieger, A. (1992) Die Naturgeographischen Voraussetzwngen der Euregilo Maas Rheir in Spurensicherung archaologische Denkmalpflege In der Euregio Maas-Rhein, Vol. 136 IEds.

Eauchihen B, G, and won Prittwitz u. Gaffron, $\mathrm{H}$ H Verlag Philip von Zabern, Mainz am Rhein, p. 1.15

Wieringen, , C. v. (1972) Seculaire groelverschuiving Lengte en gewicht surveys 1964-1966 in Nederland in thistarisch perspectief, Nederlands Instituut voor Praeventieve Geneeskunde TNO. Leiden.

Willems; W. 1. H. (1983) Archeologische kroniek wan Limburg over de jaren 1980-1982, Publications de la Saciété Historique et Archéologique dans le Limbourg, 119, p, 197-291.

Willems, W. J. H. (1992) Die koisierzeitliche villa von Voerendal In Spurensicherung: archidologische Denkmalpflege in der Eureglo Maas-Rhein, Vol. 136 (Eds: BauchhenB, G and van Prittwitz U. Gaffron, H.-H.) Verlag Philipp von Zabern, Mainz am Rhein, p. 526534 .

Wiltschke-Schrottia, $K$. and Teschter-Nicola, M. (1991) Das spätantike Gräberfeld von Lentia/Linz, Tiefer Graben/Flähelhofgasse Stadtmuseum Linz. Nordico, Linz:

Wood, (1994) The Merovingiankingdoms, 450-751, Longman, Lontion

Wood, W. Winer, G. R, Harpending, H. C and Weiss, K. M. (1992) The osteologlcal paradow: problems of inferting prehistoric health from skeletal samples, Current Anthropology, 33, ph 343-370:

Workshop of European Anthropologists (2980) Recommendations for age and sex diagnoses of skeletons, loumal of Human Evolution, 9 , p. $517-5.49$

Wright, $\mathrm{L}_{\mathrm{x}} \mathrm{E}$ and Yoder, C. I. (2003) Recent progress in bioarchaeology: approaches to the asteological paradox, Journal of Archaeological Research, 11 , p. 4370 . 
Wurm, 1 H. (1985) Über die durschnittlichen Korperhöhen der sozialen Mittel- und Uinterschichten im mitteleuropäischen germanischen Siedluingsraum vom Frühmittelalter bis zur Neuzeit, Anthropologischen Anzeiger $r_{n} 43$, p. 11-30.

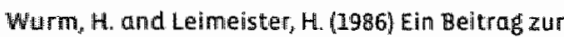
speziffischen Auswahl von vorschlagen zur Körperhöhenschatzung nach Skeletfunden, zur Wergleichbarkeit won Schätzergebnissen und zur allgemeinen Problematik realistischer Lebendhöhenschadtzungen, Gegenbauers morpholog isches jahrbuch, 132, p. 69-110.

Young, B. K. (1999) The myth of the pagan cemetery In spaces of the living and the dead: an archaeological dialogue, Vol. 3 (Eds. Karkov, C. E., Wickham-Crowley, K. M. and Young, B. K.l oxbow Books, Oxford, p. 61-85.

Ypey. J. (1985) Enkele 5 de-eeuwse vondster uit Zuiden Noord-Nederland, Westerheem, XXXIV, p. 2-10. Zeeman, \}, (1861) Rapport van de commissie voor statistiek over de lotelingen wan de provincie Groningen 1836-1861, Nederlands Tijdschrift voor Geneeskunde, 5, p. 691.

Zink, A. (1999) Kindersterblichkeit in fruhen Mittelalter: Marpholagische und paldopetholagische Ergebnisse an der Skeletserie von Altenerding, Ldkr. Erding, Bayern, Cuvillier verlag Göttingen.

Zoepf, L. (1908) Das Heiligen-Leben im 10. Jahrhundert, B.G. Teubner, Leipzig. 


\section{Samenvatting}

Acknowledgements

Curriculum Vitae

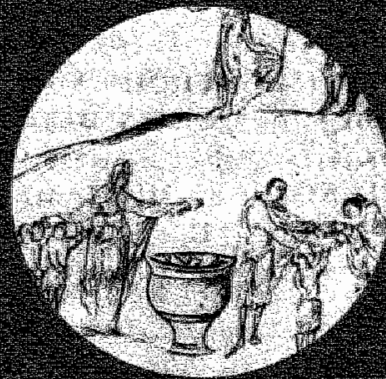




\section{Samenvatting}

Over de levensomstandigheden in de vroege middeleeuwen weten we in het algemeen weinig. De spaarzame schriftelijke bronmen leveren doorgaans nauwelijks informatie over dat onderwerp. Een mogelikheid om meer te weten te kamen over ziekte en gezondheid in het verledien is door bestudering van menselijke skeletresten gevonden bij opgravingen. Voor deze studie zijn de menselijke resten van twee begraafplaatsen uit Maasticht onderzocht. Bij opgravingen in het Boschstrautkwartier zijn menselijke skeletresten van 54 individuen verzameld, deze dateren uit het einde van de zevende en het begin van de achtste eeuw. De graven uit het Boschstraat kwartier lagen voor een deel bijeen in een klein grafveld en een tientall graven lag verspreid over een nederzettingsterrein. Deze nederzetting lijkt vooral gebruikt te ziln voor bewaning en productie-activiteiten van een kleine groep handwerkslieden. Tijdens de opgravingen in de Servaaskerk werden 184 skeletten uit de periode tussen 350 en 950 na Christus gevonden. Voor een belangrijk deel waren de graven uit de Sint Serwaaskerk "ad sanctos" begravingen, dit zijn graven die dicht bij de vermoedde locatie van het gebeente van Sint Servaas lagen. In ieder geval vertegenwoordigen de graven uit de kerk slechts een klein deel wan een veel grotere begraajplaats die zich met naar het noorden naar de Pandhof uitstrekte.

De skeletten uit de sint 5ervaaskerk zijn in drie graepen ingedeeld op grond wan hun datering: een groep skeletten uit de periode van circa 350-480 na Christus (de cella fase), een groep uit de periode tussen circa 480 en 700 na Christsus (de templum fase) en een groep vari circa $700-950$ na Christus (de basilica fase). Hierdoor is het mogelijk om te onderzoeken of er veranderingen optreden in de gezondheidssituatie vanaf de laat-Romeinse tijd tot het einde wan de Karolingische tijd. Verder werden drie groepen onderscheiden aan de hand van de status van het graf. Parameters voor het bepalen van de status wan het graf waren de begraafplaats, het graftype, de positie van het graf binnen de begraafplaats en eventuele grafgiften. De graven van het Boschstraatkwartier werden op grond van de vondsten uit de bijbehorende nederzetting en uit de graven gecategoriseerd als graven met een lage status. De graven uit de Sint Servaaskerk werden zo mogelijk in twee groepen ingedeeld. Een groep van gemiddelde status, bestaande uit graven dile doorgaans wat verder weg lagen van de vermoede locatile van het graf van sint Servaas. In deze groep werden geen grafgiften gevonden en de graftypen waren ook eenvoudig. meestal kist- of kuilgraven. De groep van graven van hoge status bestond uit graven dicht tegen de toenmalige kerk aan of zelfs daarin. Bovendien betrof het vaak sarcofagen of gemetselde grafkelders. Tot deze categorie behoorden ook graven met kostbare bijgiften.

De skeletten werden onderzocht met behulp wan gestandaardiseerde methoden. Eventuele patholagische aandoeningen werden besproken tijdens bijeenkomsten van een team van medisch specialisten. in totaal werden 238 skeletten onderzocht. Niet alle skeletten bleken even compleet te zijn. Hiervoor konden twee factoren als barzaak worden aangewezen. Ten eerste was het duidelijk dat de intensieve verstoringen van de bodem, bijvoorbeeld tijdens de bouw en de sloop van een kerkgebouw, de graven uit de voorafgaande fase ernstig hadden verstoord. De 
tweede factor was het graftype. Begravingen in kullgraven, dus direct in de grond zonder kist, bleken in het algemeen demeest complete skeletten op te leveren.

De skeletten uit de laat-Romeinse cella fase lagen oorspronkelijk aan de rand wan de begrafplaats. Ongeveer evenveel mannen als vrouwen werden aangetroffen in deze populatie. ook waren er relatief veel onvolwassenen in deze groep. Be gemiddelde leeftijd bij overlijden en de lengte waren relatief hoog. Er was geen sprake van opvallende pathologiscthe aandoeningen. Well had verhoudingsgewijs een groot aantal skeletten verschijnselen van DISH (diffuse idiopathische skelet hyperostose). DISH is een aaridoening die doorgaans geassocieerd wordt met een overmatig rijke voeding.

In de graven uit de templum fase werden meer vrouwen dan mannen aangetroffen. Mat name de vrouwen werden gemiddeld ouder dan hun tijdgenoten en met name hun lengte was bovengemiddeld. Qua algemene gezondheid lijkt deze groep daarom niet onder te doen voor die in de voorafgaande periode. Wel zijn er in deze groep twee mannen met zwaardverwondingen aan de schedel.

De graven uit de basilica fase werden aangelegd in en om een grote nieuwe kerk. In deze groep werden er meer mannen gevonden. Voor zover kon worden vastgesteld, wareh alle individuen die in de kerk begraven zijh wan het mannelijk geslacht. Mogelijk waren dit geestelijken, die als kanunnik of monnnik aan het sint Servaas klooster waren verbonden. De gemiddelde lichaamslengte van de mannen in deze groep is hoog, net als de gemiddelde leeftijd bij overlijden. Voor de vrouwen werden jets lagere waarden woor leeftijd en lengte gevonden dan in de voorafgaande fase. De meeste indicatoren woor de algemene gezondheid wezen in deze groep op een goede gezondheid. DISH kwam relatief veelvuldig voor in deze groep. Ook in deze fase werden er mannen met zwaardverwondingen aan de schedel gevonden. Drile van deze mannen lagen dicht bij elkaar pal ten zuiden van het koor, hetgeen doet vermoeden dat ze mogelijk aan el kaar gerelateerd waren.

De begravingen uit het Boschstraatkwartier gaven een volstrekt afwijkend beeld van de graven uit de Servaaskerk. In het Boschstraat grafveld kwamen veel meer jonge kinderen vaor en er werden ongeveer vilf maal zoveel vrouwen als mannen begraven. Hoewel de lengte van deze individuen gemiddeld iets achterbleef, is de algemene indruk toch dat ook in deze populatie geen grote gezondheidsproblemen optraden.

Met name het antbreken van een deel van de mannen op het Boschstraat grafueld, maar ook een aantal afwijkende leeftijdsverdelingen in de begrafplaatsen wijzen er op dat er in Matastricht in de Meravingische tijd een constellatie van complementaire begraafplaatsen bestond. op dit moment zijn angeveer negen begraafplaatsen in en om Maastricht bekend. Kennelijk werd een aantall mensen niet begraven op de aanpalende begraafplaats. In het Boschstraat grafveld lijkt dit vooral bij mannen op grote schaal te zijn gebeurd. De vergelijking van de fasen in de Servaaskerk laat qua gezondheidsindicatoren weinig verschil zien tussen de laat-Rameinse cella fase en de Meroving ische templum fase. Dit pleit dus tegen de algemeen veronderstelde verslechtering in levensomstandigheden tijdens de overgang van de laatRomeinse tijd naar de Merovingische thjd. De analyse van de verschillen tuissen de skeletten uilt verschillende status groepen toont verwaarloosbare verschillen tussen de graven van lage en 
gemiddelde status. De graven van hoge status vertonen well een afwijkend pation. Met name mannen uit graveri van hoge status grawen bereikten gemiddeld een significant hogere leeftijd. Als gevolg daarvan vertoonden ze ook meer aan een hoge leeftijd gerelateerde pathologie is. Op grond van dit onderzoek kunnen we is vastgesteld dat er in de onderzochte begraafplaatsen graepen aanwijsbaar zijn die van elkaar verschilen in levensomstandigheden. In de templum fase zlen we gen groep vrouwen ut rijke graven, wier grote gemiddelde lichaamslengte wilst op gunstige levensomstandigheden tijdens de groeli. Hetzelfde geldt voor een groep mannen uit de basillca fase Het is verleidelijk om in die groepen respectievelijk adelijke vrouwen en kanunniken te herkennen. Maar verder onderzoek moet uitwijzen of er overeenkomsten zijn qua verwantschap (ancient DNA) of herkomst (isotopen). De bevolking van vroegmiddeleeuws Maastricht kende in het algemeen gunstige levensomstandigheden en lijkt niet structureel te hebben gelleden onder ernstige ziekten. 


\section{Acknowledgements}

This book is the result of a project that materialised in the second half of the eighties. In a way it even started long before that with my grand parents. Both the parents of my mother and father had strong ties with Maastricht. The father of my mother, Ferdinand Rondagh, came from a familly with a long history in the region and Maastricht in particular. My father's father, Gerard: Panhuysen, was the first in the family two write a Ph.D. thesils on the history of Maastricht in 1933. His youngest son, Titus Panhuysen was in 1996 the second to write a Pho thesis discussing the meaning of fragments of Raman sculpture from Maastricht. With this background it is not surprising that this thesis also addresses aspects of the history of Mcastricht. My first involvement with the history of Maastricht was when I participated in several excavations in Maastricht; among these were the Boschstraat and the Servaas church excavations I have good memories of the field work at the various sites with Breur Emmenes, Jules Lebon, Maurice Roufflart, Henk Siebels $(t)$, Jean Zwakhalen, and Piet Boyens.

Actual work on skeletal remains from Manstricht started with a project with Tjasse Bruintjes. Together, we studied the "tall man" of Maostricht, a skeleton found during excavations in the Servaas church. Tjasse had examined the bories, and I had searched the written sources looking for possibilities to identify this individual We spent days and nights discussing and writing a paper on now obscure computer systems of friends. After Lucas wan Beeck capably edited the Englishtext of the paper it was accepted for publication, but we decided to withdraw it when the dating of the grave became unclear. Still, this project convinced me of the possibilitles of combining osteo-archaeological data with historical and archaeological information. After following a short course in physical anthropology with George Maat, I seized the opportunity to study twelve skeletons from the Servaas church excavation. During this project I was familiarised with physical anthropalogical methods by Herman Lonnee and Wim Mulder.

The next step was witing a progliamme for what was called the Saint Servaasproject. For the development of a plan to study human skeletal remains from several early medieval cemeteries. in Maastricht I received much support from Tjasse Bruintjes. The project started even before funding was found. Together with Ronny Dassen the bones were cleaned and packed. And thanks to the support of Hans Beijer the first skeletons were examined at an unused attic of one of the buildings of Maastricht University. At the same time attempts were made to acquire financial support for the project by professor wan Engellshoven, Titus Panhuysen and Geert Walenkamp with the support of the members of the board of the Willem Goossens foundation: Messrs. Jamar, Gehlen, Poesen, and Versteeg. Thanks to their effort the City of Maastricht and the Stichting Wetenschappeiljk Onderwijs Limburg the Foundation for Scientific Education Limburgl both subsidised the Saint Servaasproject for four years. The department of radiology of the Madstricht University Hospital provided the institutional setting and facilities for the project.

The co-workers of the archaeological service of the City of Maastricht, Wim Veldman, Greetje Flaton ( + ), Paul Rossel, and John Delnoy were most helpful by making available drawings, 
photographs, and written documentation. Carlien Zjlstra and Ron Hulst assisted in particular with the digitising of excavation drawings. As a curator Wim Dijkman was of assistance with the dating of grave finds and he provided valuable information on sites in Marstricht as well in the region.

While working in the radiology department Paul Hofman soon was a strong supporter of the project and a friend lenjoyed the time we spiend making $x$-rays and CT-scans and discussing various diseases of the skeleton. The department of radiology prowided a pleasant working environment, not at the least due to the support of the secretariat and Mrs Mordant. After George Maat had returned to the Netherlands he became strongly involved in the project and we spent a lot of time looking at the bones from the two cemeteries and discussing methodollogical issues and pathology. What made the project special were the pathology sessions, which were attended by TJasse Bruintjes, professor van Engelshoven, Paul Hofman, Hein Janssen, Ed van der Linden, Riël Snoep, Ton Vermeulen, and Geert Walenkamp. During: these meetings all individuals with pathology were presented, if necessary together with $x$ rays: These meetings generally evolved into an animated debate.

Four students participated in he project and contributed to the results of the study: namely Wincent Coenen, Mariëlle van Gijn; Johannes van der Heidle, and Ralph Huits. Three trial studies were carried out using the skeletal remains of this study. Peter Frederiks, Paul Bomans, and Bas Verhoef analysed trace elements in bone samples with Proton Induced X-ray Emission (PIXE). Jarn Talmon designed an interface and database for the recording of physical anthropological data and Floris Wiesman experimented with a computer application designed to aid in the diagnosis of pathological conditions. Marielle van Gijn studied ancient DNA from the Servaas church cemetery under the supervision of Henk Meyer and professor Geraedts. A word of thanks goes to my subsequent working environments, since without a proper research context it is difficult to carry out and complete a project like this. It was a pleasure to work within the department of radiology in Maastricht as well as the laboratory for anatomy in Leiden. At present $I$ am privileged to work in Amsterdam in a team that takes the andysis of the cemeteries af the Serwas complex a step further. The open discussions and the multidisciplinary approach is stimulating and also has had an effect on this dissertation. Simllarly stimulating is my work in the Mobility and Exchange project in Leiden, which offers the possibility to apply promising new techriques and to study osteo archaeological data within a well studied archaeological context.

A considerable number of people were involved in the production of this book. Paul Rutten was responsible for the photographs of the excavations. Jan lens edited all photographs: the photographs of the excavation, and the photographs of pathollogical changes made by the author. Fons kessels patiently introduced me into the world of statistics with effective advice and ample supplies of chupa chups: Alice Samson corrected the English text. Sappho Panhuysen designed the layout of this book, which $\|$ think is very clear and still has character. Dieuwertie Smal adapted and created the numerous illustrations and tables in this dissertation. She also skilfully and passionately processed the text. I cordially thank all of the persons mentioned above for their contribution to this dissertation. 
I am especially grateful to the quadrumvirate that was inwolved in this project from the beginning to the end: professor van Engelshoven, George Maat, Titus Panhuysen and Geer: Walenkamp. Each of you had his own role in the project and neither could be missed or it would have lacked in quality or in scientific thoroughness.

Writing a dissertation in the way I have done it has a price. And I realise that it has lead to neglect of family and friends at times. The support and continuing lnterest in the project was heart-warming. I would like to thank in particular Martin Koopmans, Mabelvan Esch, and Dik van der Meulen. Welcome support in various forms I received from my family my father paul and his wife Hélène, my sisters Sappho and Elleke. There is one person who through the years has stimulated me to finish my dissertation with incredible perseverance. Thank you Gerrti, with the publication of this dissertation you have fulfilled a mission; I am sure she would have liked the book.

Dear let it was not easy two dissertations in one family almast within a year. Now the time has come for that party you already announced in your thesis. Wonderful years lay ahead of us. Dear Tijmen and Cailus you are the best thing that happened to me and although you two were sometimes a distraction you were also a source of motivation. Maybe one day you will read this book, and maybe one of you will even consider writing a dissertation on the history of Marastricht.

This study was supported by:

De Gemeente Maastricht

Stichting Wetenschappelijk Onderwijs Limburs

Academisch Ziekenhuis Mastricht

Universiteit Maastricht

Stichting Willem Goossens

Stichting Nederlands Museum voar Anthropologie en Praehistorie

Stichting voor Anthropobiologle

Kodak Nederland B.V.

Entermed B.V. 


\section{Curriculum vitae}

The author was born in 1963 in Leeuwarden and attended secondary school at the Jeanne D'Arc College, in Maastricht from 1975 to 1981 . From 1981 to 1989 he studied history at Leiden University. In the year 1988-1989 he studied in Manster with professor Althoff at the institutfur Fruhmittelalterforschung of the Westfallsche Wilhelms Universitat. During his studies he participated in warious excavations in Maastricht. In 1989 he finished his studies (Doctoraalexamen oude still) in medileval history with prehistory and physical anthropology as subsidiary subjects. Between 1990 and 1992 he worked with the archaeological service of the City of Maastricht From 1992 to 1996 the warked as a research fellow at the department of radiology of the Academisch Ziekenhuis Masastricht. November 1996 the author worked as a physical anthropologist in a team of Physicians for Human Rights (Boston, USA) in a project aimed at the determination of the identity and the cause of death of victims found in the mass grave of Vukovar (Craatia). During 1997 author worked as a contract physical anthropologist. From 1998 to 2002 the author worked as an assistant professor in physical anthropology with Biarge's Anthropologica the centre for physical anthropology of the medical faculty of Leiden University. In 1999 he spend a month in Kosovo as a member of the British Forensic Team, working as a forensic anthropologist examining mass graves in the area around Prizren. During the summer of 2000 the author participated in an excavation of the faculty of archaeology of Leiden University at Anse a la Gourde, Guadeloupe. In 2002 the author started working as a research fellow for the Saint Servatiusproject (NWO-funded) at the Amsterdam Archaeological Centre of the University of Amsterdam. Recently he also started working in Leiden as a Postdoc in physical anthropology for the Mobility and Exchange project (NWO-funded) in the Faculty of Archaealogy of Leiden University. The author is married with Jet Panhuysen van den Akker and they have two sons: Tijmen and Cailus. 


\section{ISBN 90-810283-1-6}

Raphäl Panhuysen, 2005

Graphic design Studio Vrijdag

Imagery and DTP Dieuwertje Sinal

Printing Datawyse Maastricht

Publisher Anthro.nl

Illustrations taken from the Utrecht PSalter (E.T. DeWald 1932)

No part of this book may be reproduced in any form, by print, photocopy, microfilm, electronic data transfer or any other means, without prior permission of the author 